\title{
The five song cycles for voice and piano by Benjamin Britten written specifically for Peter Pears: The effect of their relationship
}

Robert Strauss

West Virginia University

Follow this and additional works at: https://researchrepository.wvu.edu/etd

\section{Recommended Citation}

Strauss, Robert, "The five song cycles for voice and piano by Benjamin Britten written specifically for Peter Pears: The effect of their relationship" (2006). Graduate Theses, Dissertations, and Problem Reports.

3451.

https://researchrepository.wvu.edu/etd/3451

This Dissertation is protected by copyright and/or related rights. It has been brought to you by the The Research Repository @ WVU with permission from the rights-holder(s). You are free to use this Dissertation in any way that is permitted by the copyright and related rights legislation that applies to your use. For other uses you must obtain permission from the rights-holder(s) directly, unless additional rights are indicated by a Creative Commons license in the record and/ or on the work itself. This Dissertation has been accepted for inclusion in WVU Graduate Theses, Dissertations, and Problem Reports collection by an authorized administrator of The Research Repository @ WVU.

For more information, please contact researchrepository@mail.wvu.edu. 
The Five Song Cycles for Voice and Piano by Benjamin Britten written specifically for Peter Pears: The Effect of Their Relationship

\section{Robert Strauss}

Dissertation submitted to the

College of Creative Arts

at West Virginia University

in partial fulfillment of the requirements

for the degree of

Doctor of Musical Arts

in

Vocal Performance and Literature

Keith Jackson, D.M.A.

Byron Nelson, Ph.D.

Janis Rozena-Peri, M.M.

Robert Thieme, M.M.

Christopher Wilkinson, Ph.D., Chair

Department of Music

Morgantown, West Virginia
2006

Keywords: Benjamin Britten, Peter Pears, British Art Song

Copyright 2006 Robert Strauss 


\section{ABSTRACT \\ The Five Song Cycles for Voice and Piano by Benjamin Britten written specifically for Peter Pears: The Effect of Their Relationship}

\section{Robert Strauss}

Benjamin Britten composed five song cycles for voice and piano to be performed by his partner, tenor Peter Pears: Seven Sonnets of Michelangelo, opus 22 (1940), The Holy Sonnets of John Donne, opus 35 (1945), Winter Words, opus 52 (1953), Sechs Hölderlin-Fragmente, opus 61 (1958), and Who Are These Children?, opus 84 (1969). These five cycles span almost the entire length of their personal relationship, the first having been composed the year they consummated their relationship in the United States, and the last seven years before the composer's death. These compositions give insight into the way that Britten wrote for the man with whom he shared his life, especially in terms of the texts he chose to set, the way he organized those texts into a narrative, and the way he used his partner's voice to express these texts.

This paper includes a brief biography of the two men, a discussion of the five cycles within the context of Britten's compositional output, and examines each of the five cycles in terms of the selection of the text, the dramatic construction of each cycle, as well as the use of the voice in each song. When relevant to the discussion, matters of accompaniment, key, form, and other musical aspects of the songs are also discussed. The paper also includes a comprehensive bibliography of sources about Britten and Pears. 


\section{ACKNOWLEDGMENTS}

First and foremost, I am indebted to my committee, Dr. Keith Jackson, Dr. Byron Nelson, Ms. Janis Rozena-Peri, Mr. Robert Thieme, and especially Dr. Christopher Wilkinson, for their help and wisdom. I would like to thank Robyn Card, Matthew Smedal, and Amy Strauss for proofreading the many drafts of this paper. I need also like to thank Scott Paeplow and Michael Roddy for helping with the creation and formatting of the music examples. Above all, I would like to thank Benton Hess for all his guidance and support, and Brian Davis for being a sounding board throughout the entire process. 


\section{CONTENTS}

List of Music Examples . . . . . . . . . . . . . . . . . . . . v

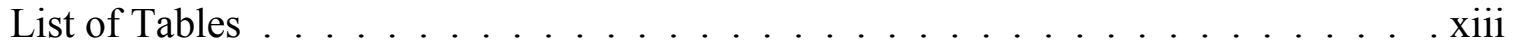

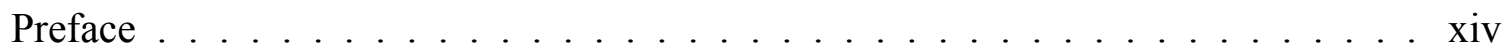

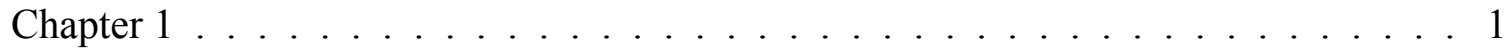

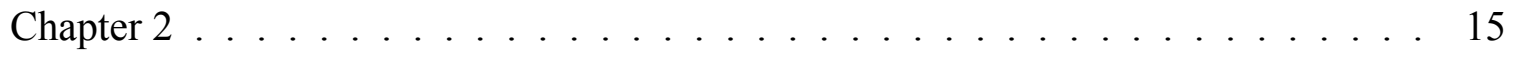

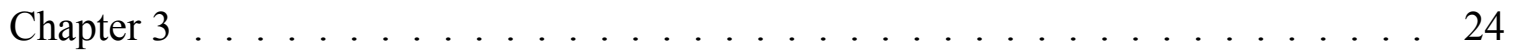

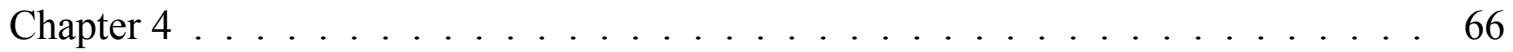

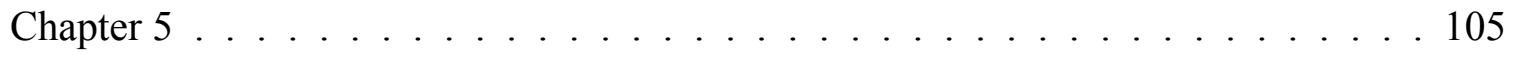

Chapter $6 \ldots \ldots \ldots \ldots \ldots \ldots \ldots$

Chapter $7 \ldots \ldots \ldots \ldots \ldots \ldots \ldots$

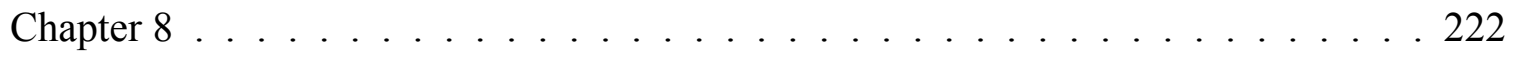

Comprehensive Bibliography . . . . . . . . . . . . . . . . . . . 229

Additional Works Consulted . . . . . . . . . . . . . . . . . . . 280

Scores Consulted . . . . . . . . . . . . . . . . . . . 281

Selected Discography . . . . . . . . . . . . . . . . . . . . . 282

Curriculum Vitae . . . . . . . . . . . . . . . . . . . . . . . . . . . . . . 


\section{LIST OF MUSIC EXAMPLES}

Seven Sonnets of Michelangelo, opus 22

Copyright 1943 in U.S.A by Boosey \& Co., Ltd.

Reproduced with kind permission by Boosey \& Hawkes, Inc.

"The Ash Grove" from Folksong Arrangements: Volume 1 - British Isles

Copyright 1943 in U.S.A. by Boosey \& Co., Ltd.

Reproduced with kind permission by Boosey \& Hawkes, Inc.

The Holy Sonnets of John Donne, opus 35

Copyright 1946 by Boosey \& Co., Ltd.

Reproduced with kind permission by Boosey \& Hawkes, Inc.

Winter Words, opus 52

Copyright 1954 by Boosey \& Co., Ltd.

Reproduced with kind permission by Boosey \& Hawkes, Inc.

Sechs Hölderlin-Fragmente, opus 61

Copyright 1962 by Boosey \& Hawkes Music Publishers, Ltd.

Reproduced with kind permission by Boosey \& Hawkes, Inc.

Who Are These Children?, opus 84

Copyright 1972 by Faber Music Ltd.

Reproduced with kind permission by Faber Music Ltd, London

Example 3-1, (a.) W.A. Mozart, "Un aura amorosa" from Così fan tutte, mm. 63-66, (b.) mm. 70-73, (c.) "Sonetto XVI," mm. 4-5 . . . . . . . . . . . 27

Example 3-2, (a.) Giuseppe Verdi, "Questa o quella," mm. 36-39, (b.) "Sonetto XXXI," mm. 59-61 . . . . . . . . . . . . . . . . . 28

Example 3-3, (a..) Giacomo Puccini, "Che gelida manina," from La Boheme, mm. 65-66, (b.) "Sonetto XXX," m. 57 . . . . . . . . . . . 29

Example 3-4, (a.) “Che gelida manina," mm. 53-55, (b.) “Sonetto XXIV," m.8 . . . . 30

Example 3-5, "Sonetto XXXVIII," mm. 21-24 . . . . . . . . . . . . . . . . 32

Example 3-6, "Sonetto LV," mm. 14-15 . . . . . . . . . . . . . . . . . . 33

Example 3-7, "Sonetto XXIV," mm. 7-15 . . . . . . . . . . . . . . . . 34 


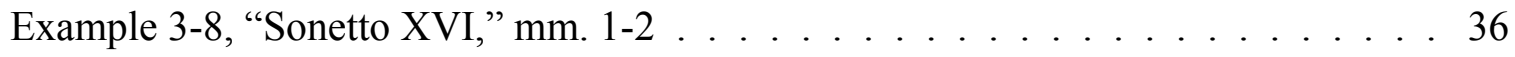

Example 3-9, "Sonetto XVI," mm.2-5 . . . . . . . . . . . . . . . 37

Example 3-10, "Sonetto XVI," mm. 16-24 . . . . . . . . . . . . . . . 38

Example 3-11, "Sonetto XVI," mm.29-38 . . . . . . . . . . . . . . . . . . . 39

Example 3-12, Alessandro Parisotti (attr. Pergolesi)

"Se tu m'ami, se tu sospiri," mm. 1-4 . . . . . . . . . . . . . . . 4 41

Example 3-13, "Sonetto XXXI," mm. 37-48 . . . . . . . . . . . . . . . . . . 42

Example 3-14, "Sonetto XXXI," mm. 58-66 . . . . . . . . . . . . . . . . 43

Example 3-15, "Sonetto XXX," mm. 1-7 . . . . . . . . . . . . . . . . 45

Example 3-16, "Sonetto XXX," mm. 25-27 . . . . . . . . . . . . . . . 45

Example 3-17, "Sonetto XXX," mm. 39-50 . . . . . . . . . . . . . . . 47

Example 3-18, "Sonetto XXX," m.57 . . . . . . . . . . . . . . . . . 48

Example 3-19, "Sonetto LV," mm. 1-2 . . . . . . . . . . . . . . . . . . . . 49

Example 3-20, "Sonetto LV," mm. 19-34 . . . . . . . . . . . . . . . 50

Example 3-21, "Sonetto XXXVIII," mm. 1-4 . . . . . . . . . . . . . . . 52

Example 3-22, "Sonetto XXXVIII," mm. 5-8 . . . . . . . . . . . . . 53

Example 3-23, "Sonetto XXXVIII," mm. 46-65 . . . . . . . . . . . . . . . 54

Example 3-24, "Sonetto XXXVIII," mm. 43-44 . . . . . . . . . . . . . . 55

Example 3-25, "Sonetto XXXII," (a.) mm. 5-8, (b.) 11-14, (c.) 17-20 . . . . . . . 57

Example 3-26, "Sonetto XXXII," mm. 1-4 . . . . . . . . . . . . . . . . 60

Example 3-27, "Sonetto XXIV," mm. 1-8 . . . . . . . . . . . . . . . 62

Example 3-28, "Sonetto XXIV", mm. 21-28 . . . . . . . . . . . . . . 63

Example 3-29, "Sonetto XXIV," mm. 35-40 . . . . . . . . . . . . . . . 64

Example 4-1, "O My Blacke Soule!," mm. 1-2 . . . . . . . . . . . . . . . 68 
Example 4-2, "O My Blacke Soule!," mm. 3-5 . . . . . . . . . . . . . . . . . . . . 69

Example 4-3, “O My Blacke Soule!," (a.) mm. 14, (b.) 19-20, (c.) 40-42 . . . . . . . 70

Example 4-4, "O My Blacke Soule!" mm. 31-33 . . . . . . . . . . . . . . . 71

Example 4-5, "Batter My Heart," mm. 1-4 . . . . . . . . . . . . . . . . . . 72

Example 4-6, "Sonetto XXXVII" from Seven Sonnets of Michelangelo, mm. 5-8 . 73

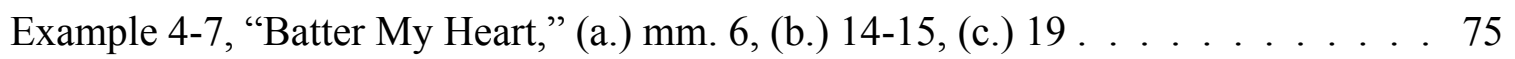

Example 4-8, "Batter My Heart," m. 31 . . . . . . . . . . . . . . . . 76

Example 4-9, "O Might Those Sighes and Teares," (a.) mm. 4-6, (b.) 13-16 . . . . . 77

Example 4-10, "O Might Those Sighes and Teares," mm. 1-2 . . . . . . . . . . . . 78

Example 4-11, "O Might Those Sighes and Teares,"

(a.) $\mathrm{mm} .7-10$, (b.) $17-19$, (c.) $27-28 \ldots \ldots \ldots \ldots \ldots$

Example 4-12, "O Might Those Sighes and Teares," m. 25 . . . . . . . . . . . . 80

Example 4-13, "Oh, To Vex Me," mm. 1-2 . . . . . . . . . . . . . . .81

Example 4-14, “Oh, To Vex Me,” (a.) mm. 5-6, (b.) 9-10, (c.) 23-24, (d.) 55-57 . . 82

Example 4-15, "Oh, To Vex Me," mm. 63-71 . . . . . . . . . . . . . . 83

Example 4-16, Henry Purcell, "Sweeter Than Roses," mm. 41-51 . . . . . . . . . . . 84

Example 4-17, Franz Schubert, "Die Wetterfahne," mm. 1-5 . . . . . . . . . . 85

Example 4-18, "What If This Present," mm. 1-2 . . . . . . . . . . . . . 85

Example 4-19, "What If This Present," mm. 3-4 . . . . . . . . . . . . 86

Example 4-20, "What If This Present," mm. 9-10 . . . . . . . . . . . . . . 87

Example 4-21, "What If This Present," mm. 19-20 . . . . . . . . . . . . 88

Example 4-22, "What If This Present," mm. 22-24 . . . . . . . . . . . . 88

Example 4-23, Franz Schubert, "Nacht und Träume," mm. 1-4 _ . . . . . . . . . . . 90 
Example 4-24, "Since She Whom I Loved," mm. 1-2 _ . . . . . . . . . . . . . 90

Example 4-25, "Since She Whom I Loved," mm. 17-26 . . . . . . . . . . . . . . . 91

Example 4-26, "Since She Whom I Loved," mm. 6-7 . . . . . . . . . . . . . . 92

Example 4-27, "Since She Whom I Loved," mm. 8-10 . . . . . . . . . . . . . 92

Example 4-28, "Since She Whom I Loved," mm. 36-38 . . . . . . . . . . . . . . . 93

Example 4-29, "At The Round Earth's Imagined Corners,"

(a.) $\mathrm{mm} .2$, (b.) 8 , (c.) 21 , (d.) $24-25$, (e.) $31 \ldots$. . . . . . . . . . . 94

Example 4-30, "At The Round Earth's Imagined Corners," mm. 1-2 . . . . . . . . 95

Example 4-31, "Thou Hast Made Me," mm. 16-19 . . . . . . . . . . . . . . . . . . 96

Example 4-32, "Thou Hast Made Me," mm. 36-44 . . . . . . . . . . . . . . . . . . 97

Example 4-33, "Thou Hast Made Me," (a.) mm. 45-47, (b.) 51-53 . . . . . . . . . . 98

Example 4-34, "Thou Hast Made Me," mm. 64-73 . . . . . . . . . . . . . . . . . . . 99

Example 4-35, "Death, Be Not Proud," mm. 1-6 . . . . . . . . . . . . . . . 101

Example 4-36, "Death, Be Not Proud," mm. 32-35 . . . . . . . . . . . . . . . . 102

Example 4-37, "Death, Be Not Proud," mm. 55-63 . . . . . . . . . . . . . . 103

Example 5-1, "Midnight on the Great Western," mm. 1-3 . . . . . . . . . . . 110

Example 5-2, "Midnight on the Great Western," mm. 12-14 . . . . . . . . . . . 110

Example 5-3, "The Little Old Table," mm. 56-59 . . . . . . . . . . . . . . . 111

Example 5-4, "At Day Close in November," (a.) mm. 10-18, (b.) 20-29, (c.) 45-54 . 112

Example 5-5, "At Day Close in November," mm. 69-74 . . . . . . . . . . . . 113

Example 5-6, "Midnight on the Great Western," mm. 64-78 . . . . . . . . . . . 115

Example 5-7, "Midnight on the Great Western," mm. 98-102 . . . . . . . . . . 116

Example 5-8, Franz Schubert, "Auf dem Wasser zu Singen," mm. 1-8 . . . . . . . 117

Example 5-9, "Wagtail and Baby," mm. 1-3 . . . . . . . . . . . . . . 118 
Example 5-10, "Wagtail and Baby," mm. 45-47 . . . . . . . . . . . . . . . . . . 119

Example 5-11, "The Little Old Table," mm. 1-2 . . . . . . . . . . . . . . 120

Example 5-12, “The Little Old Table," (a.) mm. 16-20, (b.) 37-41 . . . . . . . . 120

Example 5-13, "The Little Old Table," mm. 16-20 . . . . . . . . . . . . . . . . . 121

Example 5-14, "The Choirmaster's Burial," mm. 1-4 . . . . . . . . . . . . . 123

Example 5-15, "The Choirmaster's Burial," mm. 26-33 . . . . . . . . . . . . 123

Example 5-16, "The Choirmaster's Burial," mm. 44-51 . . . . . . . . . . . . 124

Example 5-17, "The Choirmaster's Burial," mm. 54-58 . . . . . . . . . . . . 125

Example 5-18, "The Choirmaster's Burial," mm. 67-71 . . . . . . . . . . . . 125

Example 5-19, Henry Purcell, "Strike the Viol," mm. 32-39 . . . . . . . . . . . . 127

Example 5-20, "The Choirmaster's Burial," (a.) mm. 16-19, (b.) 71-77 . . . . . . 128

Example 5-21, "Proud Songsters," mm. 1-2 . . . . . . . . . . . . . . 130

Example 5-22, "Proud Songsters," mm.29-34 . . . . . . . . . . . . . . . . 130

Example 5-23, "At the Railway Station, Upway," mm. 1-4 . . . . . . . . . . . . . 132

Example 5-24, Franz Schubert, "Erlkönig," mm. 72-85 . . . . . . . . . . . . 133

Example 5-25, "At the Railway Station, Upway," (a.) mm. 5-8, (b.)13-18 . . . . 134

Example 5-26, "At the Railway Station, Upway," mm. 21-23 . . . . . . . . . . 135

Example 5-27, "At the Railway Station, Upway," mm. 24-27 . . . . . . . . . . 136

Example 5-28, "Before Life and After," m. $1 \ldots \ldots$. . . . . . . . . 137

Example 5-29, "Before Life and After," (a.) mm. 1-2, (b.) 7-8 . . . . . . . . . 138

Example 5-30, "Before Life and After," mm. 25-28 . . . . . . . . . . . . . . 139

Example 5-31, "Before Life and After," mm. 29-32 . . . . . . . . . . . . . . 139

Example 6-1, "Menschenbeifall," mm. 1-8 . . . . . . . . . . . . . . . . . . . 144 
Example 6-2, "Die Linien des Lebens," mm. 18-20 . . . . . . . . . . . . . . . . 145

Example 6-3, "Die Heimat," mm. 1-6 . . . . . . . . . . . . . . . . . . . 146

Example 6-4, "Hälfte des Lebens," mm. 1-10 . . . . . . . . . . . . . . . . . . 146

Example 6-5, "Sokrates und Alcibiades," (a.) mm. 1-10, (b.) 25-35 . . . . . . . . 148

Example 6-6, "Die Jugend," (a.) mm. 12-15, (b.) 44-47 . . . . . . . . . . . . . . 149

Example 6-7, "Menschenbeifall," mm. 9-15 . . . . . . . . . . . . . . 150

Example 6-8, "Menschenbeifall," mm. 25-32 . . . . . . . . . . . . . . 151

Example 6-9, "Menschenbeifall," mm. 46-59 . . . . . . . . . . . . . . . . . 152

Example 6-10, "Die Heimat," (a.) mm. 7-11, (b.) 26-28 . . . . . . . . . . . 154

Example 6-11, "Die Heimat," mm. 16-20 . . . . . . . . . . . . . . . 155

Example 6-12, "Die Heimat," mm. 30-37 . . . . . . . . . . . . . . . . 156

Example 6-13, "Die Heimat," mm. 39-46 . . . . . . . . . . . . . . . . . 157

Example 6-14, "Sokrates und Alcibiades," mm. 9-20 . . . . . . . . . . . . . . 159

Example 6-15, "Sokrates und Alcibiades," mm. 30-49 . . . . . . . . . . . . . 160

Example 6-16, "Sonetto XXX," mm 1-7 . . . . . . . . . . . . . . . . . 161

Example 6-17, "Sokrates und Alcibiades," m. 46-48 . . . . . . . . . . . . . . 162

Example 6-18, "Die Jugend," mm. 2-5 . . . . . . . . . . . . . . . . . . 163

Example 6-19, "Die Jugend," mm. 16-22 . . . . . . . . . . . . . . . . . . . . 164

Example 6-20, "Die Jugend," mm. 46-63 . . . . . . . . . . . . . . . . . 165

Example 6-21, "Die Jugend," mm. 77-82 . . . . . . . . . . . . . . . . . . 166

Example 6-22, "Die Jugend," mm. 108-113 . . . . . . . . . . . . . . . . 166

Example 6-23, "Sonetto XXXI," mm. 58-61 . . . . . . . . . . . . . . . . . 167

Example 6-24, "Hälfte des Lebens," mm. 1-10 . . . . . . . . . . . . . . . . 168 
Example 6-25, "O Might Those Sighes and Teares," mm. 4-6 . . . . . . . . . . . . 169

Example 6-26, "Hälfte des Lebens," mm. 11-21 . . . . . . . . . . . . . . . . 170

Example 6-27, "Hälfte des Lebens," mm. 25-37 . . . . . . . . . . . . . . . . 172

Example 6-28, "Hälfte des Lebens," mm. 39-47 . . . . . . . . . . . . . . . . . . 174

Example 6-29, "Die Linien des Lebens," (a.) mm. 6-9, (b.) 14-18 . . . . . . . . . 177

Example 6-30, "Die Linien des Lebens," (a.) mm. 2-5, (b.)10-13 . . . . . . . . . 179

Example 7-1, "The Ash Grove," (a.) mm. 40-44, (b.) 50-54 . . . . . . . . . . 186

Example 7-2, “A Riddle (The Earth)," (a.) mm. 12, (b.) 16, (c.) 31, (d.) $35 \ldots .$.

Example 7-3, “A Riddle (The Earth)," (a.) mm. 14, (b.) 18, (c.) 33, (d.) 37 . . . . 190

Example 7-4, “A Laddie's Sang,” (a.) mm. 1-2, (b.) 5-6, (c.) 9-10 . . . . . . . . . 191

Example 7-5, "Nightmare," m. $1 \ldots \ldots$. . . . . . . . . . . . . . . . 193

Example 7-6, "Nightmare," mm. 2-7/1 . . . . . . . . . . . . . . . . . 193

Example 7-7, "Nightmare," m. 12 . . . . . . . . . . . . . . . . . . . . . 194

Example 7-8, "Nightmare," m. 17 . . . . . . . . . . . . . . . . . . . 195

Example 7-9, "Nightmare," mm. 18-20 . . . . . . . . . . . . . . . . . . 195

Example 7-10, "Black Day," (a.) mm. 2, (b.) 6, (c.) 10, (d.) $14 \ldots \ldots$. . . . . . 197

Example 7-11, "Bed-time," mm. 8-10 . . . . . . . . . . . . . . . . . 198

Example 7-12, (a.) “Thou Hast Made Me," mm. 1-9, (b.) “Slaughter," mm. 1-6 . . . 200

Example 7-13, "Slaughter," (a.) mm. 12-14, (b.) 25-26, (c.) 37-39 _ . . . . . . . 202

Example 7-14, "Slaughter," mm. 34-36 . . . . . . . . . . . . . . . . 203

Example 7-15, "Slaughter," mm. 55-58 . . . . . . . . . . . . . . . 203

Example 7-16, "Riddle (The Child You Were)," mm. 4-5 . . . . . . . . . . . . . 204

Example 7-17, "The Larky Lad," mm. 1-3 . . . . . . . . . . . . . . . . . 205 
Example 7-18, "The Larky Lad," mm. 7-15 . . . . . . . . . . . . . . . . . 206

Example 7-19, "Who Are These Children?," mm. 35-39 _ . . . . . . . . . . . . 208

Example 7-20, "Who Are These Children?," mm. 59-63 . . . . . . . . . . . . . . 208

Example 7-21, "Who Are These Children?," mm. 75-77 . . . . . . . . . . . . . . 209

Example 7-22, "Who Are These Children?," m. 84 . . . . . . . . . . . . . . 210

Example 7-23, "Supper," mm. 19-24 . . . . . . . . . . . . . . . . . . . 212

Example 7-24, "Supper," mm. 26-29 . . . . . . . . . . . . . . . . . . 212

Example 7-25, "The Children," (a.) mm. 17, (b.) $21 \ldots$. . . . . . . . . . . . . 214

Example 7-26, "The Children," mm. 42-45 . . . . . . . . . . . . . . . 215

Example 7-27, "The Children," mm. 49-59 . . . . . . . . . . . . . . . 216

Example 7-28, "The Children," (a.) mm 65-68, (b.) 71-73 . . . . . . . . . . . . 217

Example 7-29, "The Auld Aik," mm. 2-4 . . . . . . . . . . . . . . . . . . . . 219

Example 7-30, "The Auld Aik," mm. 11-15 . . . . . . . . . . . . . . . . . . . 219

Example 7-31, "The Auld Aik," mm. 17-22 . . . . . . . . . . . . . . . . 220 


\section{LIST OF TABLES}

Table 7-1: Organization of Poems as a Cycle (Who Are These Children?) . . . . . . 183 


\section{PREFACE}

Introduction and Intent.

Via the voice, and other people's talents - above all that of Peter Pears - he was able to commit himself to the emotional revelations that eluded him when he was alone at the keyboard and under public scrutiny. ${ }^{1}$

Composer Benjamin Britten (1913-1976) and tenor Peter Pears (1910-1986) were lovers and collaborators for almost forty years. The influence of this relationship upon Britten's vocal compositions for his partner is apparent in many ways, including his choice of texts, his setting of these texts, the type and uses of accompaniments, and his overall musical style. These compositions include numerous operas with roles written for Pears, realizations of Purcell songs from the figured bass for voice and piano, folk-song arrangements, and works for voice with orchestra, voice with accompanying instruments other than piano, and voice with other voices. The focus of this paper shall be the five song cycles with piano accompaniment that the composer wrote specifically for his partner.

In narrowing the scope to these five cycles, the development of the composer's skill at using Pears's voice to express the meaning of the texts and the development of the artistic partnership between the two men from early in their relationship until the latter part of the composer's life will be apparent. These cycles, Seven Sonnets of Michelangelo (1940), The Holy Sonnets of John Donne (1945), Winter Words (1953), Sechs Hölderlin-Fragmente (1958), and Who Are These Children?(1969), encompass not only Britten's setting of different languages (Italian, German, and a Scottish dialect) but span almost the entire length of Britten and Pears's relationship. These works have been chosen to the exclusion of others not only because they represent works from throughout the composer's career, but also because they use the same

\footnotetext{
${ }^{1}$ Graham Johnson, Britten, Voice \& Piano: Lectures on the Vocal Music of Benjamin Britten (Burlington, VT: Ashgate Publishing Company, 2003), 27.
} 
performing forces, and therefore may be easily compared. Also, although much has been discussed about Britten's operas in the scholarly literature, comparatively less has been written about the song cycles and in particular about the way that the composer used the voice. These works, nevertheless, will also be discussed in the larger context of his compositional output.

The body of the paper includes a short examination of the two men's lives together, focusing mainly upon their working relationship. This is followed by a general discussion of the song cycles, including the selection of texts, their underlying themes, and their place within Britten's canon. I will then examine each song separately, focusing upon the use of the tenor's voice to express the poetic ideas of the texts.

The evidence of the impact of the relationship of the two men upon the compositions will be discussed primarily as inferred from the compositions themselves. Britten accepted Pears's selection of poetry, both for compositions written for the tenor and for others. Since they lived together for almost forty years, it was undoubtedly easy for him to suggest poets to Britten whose texts he felt were suitable for song texts. It would have been just as easy for the composer, when writing for Pears, to have the singer attempt passages to see if they in fact did work for his voice in the way that the composer had intended. Their shared interests and experiences influenced the compositions of these cycles as well. Lastly, because of the composer's intimate knowledge of the singer, he could choose texts with which the tenor was sympathetic to the extent that he could give an appropriately expressive performance as indicated by the emotional depth of those texts.

An important precursor to this discussion is knowledge of the quality and characteristics of the tenor's voice. In his biography of Pears, Christopher Headington states:

This particular voice and the artistry with which it was produced were at once recognizable. Those who did not like it called it variously too white in tone, 
insufficiently heroic and virile, and too mannered, but the critic Alan Blyth praised its "clear, reedy, almost instrumental quality."

Michael Kennedy, in his biography of the composer, notes: "Like many composers, Britten had strong likes, dislikes and prejudices where other people's music was concerned (just as, among singers, he disliked a 'beautiful voice' for its own sake)." ${ }^{3}$ Likewise, it is acknowledged by those who knew him, including his partner, that he considered the specific voice for which he composed when he was writing music. ${ }^{4}$

Britten knew the limits of his partner's voice to the extent that, while he often challenged his partner's abilities, the singer was always able to carry off the intended effect with solid technique and artistry. The composer set the texts of these cycles in a way that exploited the voice of his partner in order to express the meanings of the texts; he was not interested in composing merely beautiful melodies which, while vehicles for vocal beauty, were unrelated to those meanings. Therefore, the compositions for the tenor's voice included the use of the different colors available to the singer by exploring different registration and range and also by exploiting the weight and size of Pears's voice. I have also examined qualities of the texts themselves, bringing to light certain themes, such as death or the loss of innocence, to which both men were drawn.

The scores of all five cycles are readily available, as are recordings made by Pears with Britten at the piano. I have included a bibliography of works from which I found information relevant to this particular topic, and I have included a detailed bibliography of scholarly

\footnotetext{
${ }^{2}$ Christopher Headington, Peter Pears: A Biography (London: Faber and Faber Limited, 1992), 188.

${ }^{3}$ Michael Kennedy, Britten, The Master Musicians, ed. Stanley Sadie (New York: Oxford University Press, 1981), 114.

${ }^{4}$ Robert Gene Brewster, "The Relationship Between Poetry and Music in the Original Solo Vocal Works of Benjamin Britten through 1965" (PhD diss., Washington University, 1967): 115-116.
} 
materials about both men - not just relating to these compositions, but to all aspects of their lives. 


\section{CHAPTER 1}

The Nature of the Relationship between Peter Pears and Benjamin Britten

What would Britten's music have been like without Pears? How would Pears's voice have developed without Britten? ${ }^{1}$

It is not at all uncommon to discover that a vocal composition was written with a specific singer in mind. The instance of singer and composer sharing a close personal bond is perhaps less common, but we need only look at the example of Richard Strauss and his wife Pauline de Ahna to find an example. However, it seems more unusual to find a homosexual couple in these roles. Even so, the relationship that Britten had with Pears continued to affect his compositions throughout their lives whether the nature of the relationship and its impact was stated outright or whether it can be inferred in the music that was written.

The two shared many commonalities in terms of biography, besides their both having been born in England. Both men were the youngest children in their families, born to older parents. Both studied music at an early age and went on to study music at the Royal College of Music in London. Both men abhorred violence and became pacifists in their adult lives and conscientious objectors during World War II. ${ }^{2}$ And certainly, of course, both men were homosexual in a country that vilified homosexuality to the point of imprisoning anyone convicted of such a "crime."3

Peter Neville Luard Pears was the seventh child born to Jessie and Arthur Pears in the town of Farnham, Surrey on June 22, 1910. ${ }^{4}$ As a boy, Pears studied piano (later organ, bassoon, and some viola), but although he was very musical it was said that he was not gifted technically

\footnotetext{
${ }^{1}$ Michael Wilcox, Benjamin Britten's Operas (Bath, England: Absolute Press, 1997), 9.

${ }^{2}$ Michael Oliver, Benjamin Britten (London: Phaidon Press Limited, 1996), 96.

${ }^{3}$ Ibid., 105.

${ }^{4}$ Christopher Headington, Peter Pears: A Biography (London: Faber and Faber Limited, 1992), 1.
} 
at the piano. ${ }^{5}$ In his adolescence, he became aware of his homosexuality and seemed to come to terms with it fairly quickly. ${ }^{6}$ He went on to study music at Oxford but only for a short time; he dropped out lacking both financial resources and an interest in studying the nuts and bolts of music - theory and history. ${ }^{7}$ He returned to his prep school, The Grange in Crowborough near Tunbridge Wells, where he taught Latin, French, Mathematics, and Music, as well as private piano. ${ }^{8}$ He taught there for four years (1929-1933) but during that period was encouraged by friends to pursue his dream of a singing career, and so he attended the Royal College of Music as a student of singing and opera for a short time until he was hired to be a member of the British Broadcasting Company (BBC) Singers. ${ }^{9}$

Edward Benjamin Britten was the fourth child of Robert Victor and Edith Britten of Lowestoft, on the North Sea in Suffolk County, born on November 22, 1913. ${ }^{10} \mathrm{He}$ was named Benjamin after the last child of the biblical Jacob and Rachel since he was the youngest of their children. ${ }^{11}$ Although his father was rather stern, Britten's mother doted on him, and, being something of an amateur singer and pianist herself, she encouraged the development of his musical ability. ${ }^{12}$ Britten studied piano and viola as a youth and in his teens began studying composition with Frank Bridge. ${ }^{13}$

Bridge was the first major influence on Britten's compositional style. Their lessons began in 1927 and were often quite rigorous and notoriously long, during which the older man challenged his pupil above all to find his own personal style and be true to it while maintaining

\footnotetext{
${ }_{6}^{5}$ Ibid., 6.

${ }^{6}$ Ibid., $15-16$.

${ }^{7}$ Ibid., 26, 29.

${ }^{8}$ Ibid., 33.

${ }^{9}$ Ibid., 39-40, 42.

${ }^{10}$ Oliver, 15.

${ }^{11}$ Humphrey Carpenter, Benjamin Britten: A Biography (New York: Macmillan Publishing Company, 1992), 5.

${ }^{12}$ Ibid., 5.

${ }^{13}$ Ibid., $8,16$.
} 
attention to good, solid technique. ${ }^{14}$ Bridge continued to be an influence upon Britten until his death in $1941 .{ }^{15}$ Meanwhile, Britten attended the Royal College of Music, studying piano with Arthur Benjamin and composition with John Ireland, but he did not meet his future partner there since he graduated in December 1933, the year before Pears matriculated there. ${ }^{16}$ During this time, Britten began acquiring a national reputation as certain of his early works were being performed, including his A Boy was Born, opus 3, which is a set of choral variations, and Simple Symphony, opus $4 .{ }^{17}$

In 1935, at the age of 21, he started working for John Grierson's General Post Office Film Unit, composing music for film scores. ${ }^{18}$ This job led to associations with other film companies affiliated with the BBC. It also brought him into contact with a new circle of friends, including Wystan Hugh Auden and Christopher Isherwood who helped him to accept his homosexuality of which he was becoming increasingly aware. ${ }^{19}$ However, Britten may not have explored a physical relationship until after the death of his mother in January of $1937 .^{20}$

W. H. Auden was the next great influence upon Britten as a composer. The writer introduced him to new literature and taught him to appreciate that which he already knew in a different way, including especially the works of homosexual poets and writers. These included poems of Arthur Rimbaud, which he would later set in his orchestrated song cycle Les Illuminations, opus 18. Auden also wrote poems intended to be set by the composer, including the erotic text "To Lie Flat on the Back with Knees Flexed," a setting of which was not published until after the composer's death.

\footnotetext{
${ }^{14}$ Ibid., 17.

${ }^{15}$ Peter A. Evans, The Music of Benjamin Britten (Oxford: Clarenden Press, 1995), 2.

${ }^{16}$ Carpenter, 35, 51.

${ }^{17}$ Ibid., 53-54.

${ }^{18}$ Ibid., 64.

${ }^{19}$ Oliver, 48.

${ }^{20}$ Ibid., 61.
} 
Although it seems likely that the writer was attracted to the younger composer, most of their friends of the time did not believe that it was reciprocated or that there was any sort of physical consummation. ${ }^{21}$ There was, however, a consummation of sorts of the professional relationship. Aside from the songs written for singer Hedli Anderson to Auden's texts, four of which are included in Cabaret Songs, published after the composer's death, Britten used the writer's words for his orchestrated song cycle Our Hunting Fathers, opus 8 (1936) and for the song cycle for voice and piano On This Island, opus 11 (1937), as well as for a host of other songs, many of which were published posthumously. They also collaborated on the operetta Paul Bunyan, opus 17, while they were both living in the United States.

In April 1937, a friend of both Pears and Britten's, Peter Burra, was tragically killed in an airplane accident. ${ }^{22}$ The two men, who had met by that point but had not established a close relationship, got to know each other better as they sorted through Burra's belongings, putting his affairs in order. ${ }^{23}$ Although they did not become lovers at this point, they did become close friends who felt comfortable sharing intimate details of their lives. ${ }^{24}$ The two men ultimately decided to share an apartment in London beginning in $1938 .{ }^{25}$ During this time they also began concertizing in Great Britain, although the exact date is not known. ${ }^{26}$ It was not until they emigrated to the United States, however, that the two entered into a romantic relationship.

In 1939, as Europe was becoming more and more involved in what would ultimately become World War II, their relationship and careers continued to develop. The two men, who were confirmed pacifists, decided to follow Auden and Isherwood, who had emigrated to the

\footnotetext{
${ }^{21}$ Graham Johnson, Britten, Voice \& Piano: Lectures on the Vocal Music of Benjamin Britten (Burlington, VT: Ashgate Publishing Limited, 2003), 145.

${ }^{22}$ Headington, 63.

${ }^{23}$ Ibid., 65-66.

${ }^{24}$ Ibid., 80-82.

${ }^{25}$ Ibid., 79.

${ }^{26}$ Ibid., 75.
} 
United States. ${ }^{27}$ At this point, Pears had intended to stay only a short time, hoping to have some voice lessons in the States, whereas the composer was unsure that he would ever return to Britain, thinking that a change of locality might be good for his career. Frank Bridge, his former teacher, had experienced greater success in the United States than in the United Kingdom, and Britten hoped that the same might be true for him. ${ }^{28}$ They arrived first into Canada and remained there for almost a month as plans were made for their performances in the United States. ${ }^{29}$ The two men arrived into the United States on June 12. According to their letters, it was upon their arrival in Grand Rapids, Michigan that the two consummated their relationship, which had turned from friendship into love. ${ }^{30}$

It was during this time that Britten first dedicated a composition to Peter Pears: the song "Being Beauteous" from Les Illuminations, opus 18 (1939), to texts of Arthur Rimbaud (the English title is the poet's own ${ }^{31}$ ), although this piece was not written for Pears's voice, but rather for the Swiss soprano Sophie Wyss. The song mentioned above uses feminine pronouns but might otherwise be considered an expression of the composer's newfound love especially in passages such as "Devant une neige, un Etre de beauté de haute taille (Against a background of snow is a beautiful Being of majestic stature)" and "Oh! Nos os sont revêtus d'un nouveau corps amoureux (Oh rapture! Our bones are covered anew with a body of love). ${ }^{32}$

As war broke out in Europe, the British government advised that British citizens living or staying in the United States should remain there, and so Pears and Britten did. ${ }^{33}$ The pair was fortunate enough to have a friend, mentor, and surrogate mother in Elizabeth Mayer during their

\footnotetext{
${ }^{27}$ Carpenter, 126.

${ }^{28}$ Oliver, 71.

${ }^{29}$ Headington, 86-87.

${ }^{30}$ Ibid., 87.

${ }^{31}$ Edward Sackville-West, preface to Les Illuminations, Benjamin Britten (London: Boosey \& Hawkes, 1944).

${ }^{32}$ Boris Ford, ed. Benjamin Britten's Poets: An Anthology of the Poems He Set to Music (Manchester: Carcanet Press, 1994), 79.

${ }^{33}$ Carpenter, 134.
} 
visit. She was an amateur musician who had emigrated to the United States from Germany.

Pears had met her previously while touring in the United States, and he renewed his acquaintance with her on this visit. ${ }^{34}$ Ultimately, the couple was invited to stay with Mayer and her family in Amityville, New York in August 1939, and they stayed with them sporadically for their entire visit, leaving for good in March 1942. ${ }^{35}$ Mrs. Mayer encouraged music-making in the house, often participating with Britten and Pears. Being fluent in German, she helped the men with their interpretations of German lieder, and being something of a linguist she aided in the translation of texts, including that of Britten's setting of the Michelangelo Sonnets which she prepared with Pears and which accompanied the published version of that cycle.

While staying in the Mayer home, Britten completed the first of his cycles written specifically for his lover. Seven Sonnets of Michelangelo, opus 22, was completed in Amityville in October 1940. The idea of setting sonnets of Michelangelo Buonarroti (1475-1564) may have occurred to the composer before he fell in love with the tenor, but the cycle itself was written with Pears and his voice in mind. Michelangelo had written most of these sonnets about a man with whom he was in love, the subject matter of which clearly appealed to the young composer. There is a youthful quality to these songs which is indicative of the age of the two men: Britten at the time was 26, and Pears was 30. Pears had continued to take voice lessons during this time, and Britten was able to gauge the improvements to his technique and put it to good use in these songs. ${ }^{36}$

\footnotetext{
${ }^{34}$ Headington, 55 .

${ }^{35}$ Ibid., 90 .

${ }^{36}$ It is of interest to note that in 1940 , at the age of 29 , Peter Pears had his tonsils removed. Although not much is made of this, particularly since the concern was for ill effects rather than benefits, from this point the voice that had once been considered small was now considered viable for the operatic world. This is certainly due in part to the continued vocal study and coaching, but it is possible as well that the extra space in the pharynx afforded by the removal of the tonsils could also have been a benefit to the singer. (Headington, 98.)
} 
In November 1940, Britten and Pears moved into a house occupied also by their friends Auden and Isherwood in New York City. ${ }^{37}$ However, in spite of the creative atmosphere - aside from the two poets, the house was occupied by other artists - and the fun the two men may have had in this bohemian atmosphere, the composer did not necessarily find it the perfect environment for composition because of all the distractions. Furthermore, neither man enjoyed the less than pristine conditions of the house and ultimately returned to stay with the Mayer family. ${ }^{38}$ While in New York City, however, Auden and Britten completed the operetta Paul Bunyan, opus 17. Pears served as a copyist for his partner, as he had for many of the compositions during the United States trip. This would be the last collaboration of the composer and poet in such close proximity, although Britten did set the words of Auden a few more times. The main influence in Britten's life had become his lover.

The two men made their living in the United States by performing, teaching, and directing. ${ }^{39}$ The couple performed recitals in the United States (featuring works by Purcell and Bach, among others). ${ }^{40}$ Although Britten was achieving some degree of fame as a composer, they did not make an extraordinary living. They were also tremendously worried about their families and started to feel homesick, beginning to doubt whether they should continue to reside in the United States.

In the summer of 1941, the two men traveled to California to visit their friends, the pianists Rae Robertson and Ethel Bartlett. ${ }^{41}$ During this visit they found an article about the works of poet George Crabbe in The Listener, a magazine published by the BBC. They

\footnotetext{
${ }^{37}$ Oliver, 85 .

${ }^{38}$ Headington, 107.

${ }^{39}$ Ibid., 108-109.

${ }^{40}$ Ibid., 94.

${ }^{41}$ Oliver, 84-85.
} 
subsequently found a collection of Crabbe's poems in an antique bookshop. ${ }^{42}$ Among the works that caught their attention was his poem "The Borough," set in Britten's home county of Suffolk in England. The pair was at this point rather homesick, and this poem reminded them of many things that they missed about England, and so they began to make plans to return. They sailed in March 1942, and both began to work out the details of an opera to be based on the poem "The Borough" that Britten would spend the next several years composing. The result of this work would be his first full-scale opera (and the tenor's first role in a Britten opera), Peter Grimes, opus $33 .^{43}$

Upon returning to Great Britain in the spring of 1942, both men were exempted from combat duties in part due to their work with the Council for the Encouragement of Music and the Arts, considered to be "a contribution to public morale in wartime." 44 They gave several concerts throughout 1942 and 1943, ${ }^{45}$ including the debut of Seven Sonnets of Michelangelo, opus 18, Schubert's Die schöne Müllerin, Schumann's Dichterliebe, Poulenc's Tel jour telle nuit, as well as Britten's arrangements of folk songs and realizations of Purcell songs from the figured bass. ${ }^{46}$ Peter Grimes, opus 33, to a libretto by Montagu Slater, another writer with whom Britten had worked during his employment as a composer of film scores, had its premiere in 1945. Pears had continued to help with the opera, offering suggestions, critiquing the excerpts that the composer played for him, and revising the libretto when Britten needed some last minute changes. $^{47}$ This showed the level of partnership that the two men had already developed. Pears continued to be an influence for his partner on the literary side of his work, not only

\footnotetext{
42 Ibid., 90.

${ }^{43}$ Carpenter, 164-166.

${ }^{44}$ Ibid., 96.

${ }^{45}$ Headington, 118-119.

${ }^{46}$ Ibid., 121-122.

${ }^{47}$ Oliver, 105.
} 
recommending poets but also assisting with opera librettos and translating foreign language texts, as he had already done with the Michelangelo Sonnets.

Pears was at this time engaged to sing Hoffman in Jacques Offenbach's Les Contes d'Hoffmann with the Sadler's Wells Opera Company, ${ }^{48}$ a touring opera group, with which he subsequently sang the roles of Tamino in Die Zauberflöte, Rodolfo in La Bohème, the Duke in Rigoletto, Alfredo in La Traviata, Almaviva in Il barbiere di Siviglia, Ferrando in Così fan tutte, and Vašek in Smetana's The Bartered Bride. ${ }^{49}$ It was through his involvement with this opera company that he and Britten became acquainted with Joan Cross, Eric Crozier, John Piper, Erwin Stein and Anne Wood, with whom, in 1946, they founded the English Opera Group, the mission of which was "to mount operas cheaply and to tour them widely, in the hope of building a new audience. ${ }^{50}$ It was ultimately from this group that the Aldeburgh Festival developed, which consumed much of the two men's creative energies in their later lives.

Britten also did some performing apart from his partner, including as accompanist for violinist Yehudi Menuhin on a tour of recently liberated concentration camps. The horrors that he saw combined with the amazing hopefulness of the survivors inspired him to set selected sonnets of John Donne (1572-1631) that were full of images of death, spiritual crisis, and ultimately a renewed hope through adversity. The Holy Sonnets of John Donne was written at a feverish pace, in part quite literally since at the time Britten was ill with fever from a reaction to an inoculation he had received for the trip, and was again dedicated to and written for his partner. Britten found impressive the dramatic skill that Pears had shown on stage as detailed in his letters addressed respectively to Elizabeth Mayer and her husband William:

\footnotetext{
${ }^{48}$ Ibid., 116-117.

${ }^{49}$ Ibid., 124.

${ }^{50}$ Ibid., 138.
} 
Peter sang so well, acted so delightfully, \& was such a ravishing personality on the stage, in Hoffmann, that everyone was delighted and more than surprised. ${ }^{51}$

I wish you could see Peter on the operatic stage - he is really staggering! Looks very good, \& acts wonderfully, \& his voice is really sounding grand. ${ }^{5}$

The composer gave the tenor opportunity to use this growing dramatic finesse and his growing technical prowess in this cycle.

The first production by the English Opera Group was Britten's Albert Herring, opus 39, in $1947 .{ }^{53}$ While touring the opera throughout Europe, Pears had the idea to establish a festival in Great Britain. The two men were moving into a house in the Suffolk town of Aldeburgh, which seemed like an ideal location for such a festival. ${ }^{54}$ The other collaborators in the group agreed, and so in 1948 the first festival featured performances of Britten's Albert Herring, opus 39, and Saint Nicholas, opus 42, a cantata for chorus and orchestra, as well as recitals by Britten and Pears. Other performances included works by Lennox Berkeley, a contemporary British composer, and Henry Purcell. ${ }^{55}$ The festival, which has continued annually since its inception, was a large part of the lives of the two men both as performers and as managers. The Aldeburgh Festival also brought the pair into contact with other musicians who would become lifetime friends and collaborators, including guitarist Julian Bream, cellist Mstislav Rostropovich, soprano Galina Vishnevskaya, baritone Dietrich Fischer-Dieskau, mezzo-soprano Janet Baker, and harpist Osian Ellis. ${ }^{56}$

Britten continued writing for his partner, but the tenor performed other composers' works as well - in the early 1950s he sang Tamino and Vašek again, and in 1951 he sang the title role

\footnotetext{
${ }^{51}$ Benjamin Britten, Letter 376 to Elizabeth Mayer, in Letters from a Life: The Selected Letters and Diaries of Benjamin Britten, 1913-1976: Volume Two (1939-1945), ed. Donald Mitchell (Berkeley: University of California Press, 1991), 1050.

${ }^{52}$ Benjamin Britten, Letter 386 to William Mayer, in Mitchell, 1066.

${ }^{53}$ Headington, 139.

${ }^{54}$ Ibid., 150.

${ }^{55}$ Oliver, 134.

${ }^{56}$ Headington, 173.
} 
in Stravinsky's Oedipus Rex. ${ }^{57}$ His interpretation of the Evangelist in the Matthauspassion and Johannespassion of J.S. Bach became famous during the mid-1950s as well. ${ }^{58}$ Because the composer preferred to work at home on his composition, he did not always accompany Pears on his travels, and as a result the two were apart frequently during the 1950s. The letters that passed between them show that the two men remained devoted to each other.

The cycle that many consider to be Britten's crowning achievement, Winter Words, opus 52, was completed in 1953, setting poems of Thomas Hardy (1840-1928). When compared to the first two cycles written for the tenor, this composition shows a more mature musical style and more varied material for the singer, both technically and dramatically as will be discussed in Chapter 5. By this time, the composer had written several operatic roles for his partner: the title role in Peter Grimes, opus 33 (1945), the Male Chorus in The Rape of Lucretia, opus 37 (1946), Albert Herring in the opera of the same name, opus 39 (1947), and Captain Vere in Billy Budd, opus 50 (1950), and so he had been constantly able to see the growth in the tenor's artistry and therefore was able to write music that showed him to increasing advantage.

By the mid-1950s, both men had become quite successful in their careers. Britten continued composing prolifically, taking time off only to travel with his partner. Pears sang frequently, performing not only roles in Britten's operas but also in those of other composers. The two strove to be the best in their respective fields, so even their vacations were occasions for them to continue to develop as artists. The two men took an extended vacation from October 1955 to March 1956, visiting Holland, Germany, Switzerland, Yugoslavia, Turkey, India, Singapore, Indonesia, Bali, Japan, and Russia. ${ }^{59}$ The duo performed occasional recitals on this trip but also made a point to experience the local culture, including the gamelan music of

\footnotetext{
${ }^{57}$ Ibid., 160-162.

${ }_{59}^{58}$ Ibid., 174.

${ }^{59}$ Ibid., 181.
} 
Indonesia, and Nô theatre in Japan. ${ }^{60}$ The influence of both can be seen in his ballet The Prince of the Pagodas, opus 57 (1956). ${ }^{61}$

Throughout the 1950s and 1960s, the two men continued to travel for pleasure and for health reasons and also continued to hone their craft and cultivate friendships with fellow artists and patrons of the arts. Pears took lessons for a time again, and Britten continued to study the music of different cultures. Aside from performing together on recitals, they continued to work together in choosing texts for the composer to set, and they worked together on the libretto for $A$ Midsummer Night's Dream, opus 64, in 1960. ${ }^{62}$ The two men also continued their involvement with the Aldeburgh Festival by presenting new works and giving annual recitals to raise money for the event.

Two dear friends of Pears and Britten, the Prince and Princess of Hesse, with whom they frequently traveled, had recommended the poetry of Friedrich Hölderlin (1770-1843) to the pair. The composer had such empathy for the poems that he was inspired to set several of them, and the subsequent collection of settings became the first song cycle for voice and piano written for his partner in over a decade. Although the poet was heterosexual, one of the poems deals with the love of Alcibiades and Socrates and bears a resemblance to one of the Michelangelo Sonnets. The continued development of both the composer's skill and that of the tenor are evident in this cycle, written when both were at the top of their own fields.

By the end of the 1960s, both men were having some serious health problems. In 1968, Pears had a hernia operation, and was told by doctors to reduce his hectic performing schedule -

\footnotetext{
${ }^{60}$ Ibid., 184-186.

${ }^{61}$ Evans, 226; and Carpenter, 372.

62 "The work on A Midsummer Night's Dream was one of several literary projects that occupied Pears then. He had always loved the English language, whether in poetry, literature or drama, and it had been he who had helped Elizabeth Mayer to translate the Michelangelo Sonnets and sketched out the first Peter Grimes synopsis. It was sometimes he who suggested a poet or a text to Britten, and it was with his help that the composer outlined his artistic credo for a speech in 1964 that was later published as On Receiving the First Aspen Award." (Headington, 201.)
} 
advice he did not heed. ${ }^{63}$ Britten's problems were of a more serious nature: during this time he was beginning to experience the heart trouble that would eventually lead to surgery and ultimately to his death. ${ }^{64}$

The last of Britten's cycles for voice and piano specifically for the tenor, Who Are These Children?, opus 84, written was written in 1969, although it was not performed in full until 1971. The poems were written by William Soutar (1898-1943), a pacifist. The texts appealed to both men for their stark depiction of cruelty to humanity, especially to children. The music accommodates the slight shift downward in range of the tenor, now nearing the age of 60 , but shows an increase in the dramatic challenge for him, both in individual poems and in the shift between seemingly careless Scottish rhymes and deeply emotional English texts.

During this period, the two men still lived and worked together, including ventures into the world of television. Some of Britten's operas had been televised, but Owen Wingrave, opus 85, was written specifically for the medium and was first broadcast in March 1971. There was also a performance by the two men of Schubert's Winterreise televised in November $1970 .{ }^{65}$ The duo gave their last recital in Britain in September 1972, and their final recital together in Germany in January $1973 .^{66}$

Britten had open-heart surgery in May 1973, during which he suffered a slight stroke that rendered his right arm partially paralyzed. ${ }^{67}$ Since he was unable to play piano, the recital duo of Britten and Pears was ended. The tenor, with his partner's blessing, gave recitals with harpist Osian Ellis, and the composer, once well enough, began writing music specifically for this pairing. Pears also still performed occasionally with guitarist Julian Bream, but it was some time

\footnotetext{
${ }^{63}$ Ibid., 235.

${ }^{64}$ Carpenter, 539-540.

${ }^{65}$ Headington, 238-239.

${ }^{66}$ Ibid., 244

${ }^{67}$ Ibid., 547.
} 
before he started performing with another pianist. ${ }^{68}$ He made his Metropolitan Opera debut in New York City at the age of 64 as Aschenbach in Death in Venice, opus 88, in October 1974, however, he began to spend more of his time teaching. ${ }^{69}$ Although he had started teaching voice occasionally as early as in 1951 , he did not do so regularly until the early 1970 s. $^{70}$ He and Britten decided to open a school to help young performers bridge the gap between the conservatory and the professional world, and so by 1974 the Britten-Pears School for Advanced Musical Studies had a permanent home in Aldeburgh. ${ }^{71}$

Britten composed a few more works for his partner, and the tenor continued to perform at the Aldeburgh Festival as he taught at the school they had opened. However, the composer never fully recovered from his heart surgery. Benjamin Britten died in the arms of his lover in December, 1976 at their home. ${ }^{72}$

... and honestly you are the greatest artist that ever was - every nuance, subtle $\&$ never over-done - those great words, so sad \& wise, painted for one, that heavenly sound you make, full but always coloured for words \& music. What have I done to deserve such an artist and $\underline{\text { man }}$ to write for? (Britten, in a letter to Pears, November 17, 1974.) ${ }^{73}$

\footnotetext{
${ }^{68}$ Headington, 245.

${ }^{69}$ Ibid., 248.

${ }^{70}$ Ibid., 171.

${ }^{71}$ Ibid., 263.

72 Ibid., 274.

${ }^{73}$ Ibid., 257.
} 


\section{CHAPTER 2}

\section{The Five Song Cycles Within Britten's Canon}

Benjamin Britten composed in a wide variety of genres, but he is perhaps most famous for his vocal works: operas, orchestrated song cycles, folk-song arrangements, realizations of Baroque works by composers including Purcell and Bach, compositions for voice with other instruments (including guitar and harp), and cycles for voice and piano. The five cycles for voice and piano written for Pears are representative of his entire solo vocal canon not only because of their chronology but also because they show his constantly developing musical style, his taste in texts, his ability to use Peter Pears's voice to express the meaning of those texts, and how the relationship of the two men affected all of the above.

In this chapter, I will discuss the circumstances that led to the composition of the five cycles themselves, the influences upon Britten during composition including his travels, his personal values, and people he had met, the reasons for the choice of these texts and the themes represented within them, and the cycles' place within Britten's entire output. The subsequent five chapters will address the way Britten used Pears's voice in each of the five works in terms of the choice of texts and dramatic themes, the composer's developing compositional style especially in terms of text setting, and the effect of the relationship upon the entire process.

The Seven Sonnets of Michelangelo, opus 22, from 1940, was the first song cycle to be composed by Britten specifically for the man who by this time was his companion in life as well as in art. ${ }^{1}$ He had already composed for the voice - in fact he had just completed the orchestrated song cycle Les Illuminations, opus 18, for soprano Sophie Wyss. ${ }^{2} \mathrm{He}$ had previously completed a variety of other vocal works, including the songs to texts of W. H.

\footnotetext{
${ }^{1}$ Christopher Headington, Peter Pears: A Biography (London: Faber and Faber, 1992), 98-99.

2 Graham Johnson, Britten, Voice \& Piano: Lectures on the Vocal Music of Benjamin Britten (Burlington, VT: Ashgate Publishing Limited, 2003), 40-41.
} 
Auden, later to constitute Cabaret Songs, published posthumously, for Hedli Anderson, an untrained theatre singer, ${ }^{3}$ other settings of texts by W.H. Auden including "To Lie Flat on the Back with Knees Flexed" and "Fish in the Unruffled Lakes," and those that comprise the composer's first song cycle for voice and piano, On this Island, opus $11 .^{4}$ The texts he chose were in so many ways non-traditional for song settings in terms of rhythmic construction and thematic material, especially when compared to songs composed by his contemporaries. ${ }^{5}$ Few of the texts were about love in a traditional sense; in fact, the most numerous texts about love between two people from these five sets is to be found in the Michelangelo settings, in which the unrequited love is between two men.

During the time Britten and Pears spent in the United States from 1939 to 1942, they came to know each other better personally and professionally, eventually becoming both lovers and recital partners. ${ }^{6}$ This growing knowledge and trust is evident in the Michelangelo Sonnets. In the work, the singer was required to sing difficult rhythms and intervals, and the technical and expressive demands on him were great.

Many of the sonnets chosen by the composer to be set have homoerotic texts - these sonnets were written unambiguously by Michelangelo about a much younger (and presumably heterosexual) man who was the object of his affection. ${ }^{7}$ It was certainly a daring choice for Britten and Pears in light of the fact that homosexuality was illegal in their home country. ${ }^{8}$ The Italian language helped to mask the meaning of the texts, and the translations given, done in part by Pears, were vague in many respects as to the nature of the relationship between the two men

\footnotetext{
${ }^{3}$ Ibid., 168.

${ }^{4}$ Ibid., 147, 156-157.

5 Robert Gene Brewster, "The Relationship Between Poetry and Music in the Original Solo Vocal Works of Benjamin Britten through 1965” (Ph.D. diss., Washington University, 1967): 226-7.

${ }^{6}$ Headington, 87-89.

7 Johnson, 42.

${ }^{8}$ Michael Wilcox, Benjamin Britten's Operas (Bath, England: Absolute Press, 1997), 39.
} 
depicted in the sonnets. The choice of the Italian texts following the French of Les Illuminations is also explained by Donald Mitchell and Peter Pears in Mark Alexander Whitmire's discussion of Britten's compositions for solo voice:

For the next two cycles, the orchestral cycle Les Illuminations, Op. 18 (1939) and Seven Sonnets of Michelangelo Op. 22 (1940), Britten turned to languages other than English, a move which, according to Donald Mitchell, was a part of "a conscious abandonment of the English tradition." According to Pears, "it was the excursion to Italy (the Seven Sonnets) which liberated Britten, just as the Italians had helped Purcell 250 years before."

The liberation to which the tenor refers is from the heritage of British vocal music including that of Ralph Vaughan Williams and John Ireland, both of whom were much more conservative musically and in their choice of texts. ${ }^{10}$

The setting of the Michelangelo Sonnets was composed in 1940 but did not receive its first public performance until the couple returned to Great Britain in 1942, in part due to the fact that Pears wanted to be certain that he was up to the vocal challenge of the pieces. "Caution at the Sonnets' overt homosexuality may have been one reason for this delay [of the premiere performance ] ..., but Pears did not feel ready for a public performance of such taxing music. In the United States he worked hard with vocal coaches to increase the range and power of his voice ..."11 The set was enormously successful in Britain, and was recorded almost immediately. ${ }^{12}$

Following its appearance, Britten composed many other popular works including the first two volumes of published folk-song arrangements (1941), A Ceremony of Carols, opus 28 for

\footnotetext{
${ }^{9}$ Mark Alexander Whitmire, "Songs by John Ireland and Benjamin Britten to Poems by Thomas Hardy" (D.M.A. diss., University of Maryland, College Park, 1991): 75-76.

${ }^{10}$ Ibid., 74-75.

${ }^{11}$ Michael Oliver, Benjamin Britten (London: Phaidon Press Limited, 1996), 84.

${ }^{12}$ Headington, 121.
} 
treble voice and harp (1942), Serenade for Tenor, Horn, and Strings, opus 31 (1943), Peter Grimes, opus 33 (1945), on which Britten spent much of his compositional energy, and The Young Person's Guide to the Orchestra: Variations and Fugue on a Theme of Henry Purcell, opus 34 (1945). ${ }^{13}$ In the same year as the setting of the John Donne sonnets, 1945, he also published two sets of realizations of Purcell songs for high voice and piano. ${ }^{14}$ The realizations of the Purcell songs, as well as the use of a theme by Purcell in The Young Person's Guide informed the compositional style in the next song cycle. ${ }^{15}$

The Holy Sonnets of John Donne, opus 35, was composed in 1945 upon Britten's return from abroad. ${ }^{16}$ The purpose of his journey had been to serve as an accompanist for violinist Yehudi Menuhin as they gave recitals for survivors at Nazi concentration camps. Britten had already intended to set the poetry of Donne, but these visits served as an impetus to set these particular texts, which deal with death, spiritual crisis, and the final triumph of the spirit in life everlasting. $^{17}$

"The Holy Sonnets of John Donne are [sic] a masterful example of a man fearing death, and it is most probably this very thought which was foremost in Britten's mind at the time he wrote them [sic]. Surely the aspect of death which he had just witnessed could not be better expressed than by Donne." 18

As will be discussed in Chapter 4, the influence of Purcell's compositional style both harmonically as well as vocally is evident throughout the work, which was given its premiere in London in November of $1945 .{ }^{19}$

\footnotetext{
${ }^{13}$ Peter Evans, The Music of Benjamin Britten (Oxford: Clarenden Press, 1995), 575-576.

${ }^{14}$ Humphrey Carpenter, Benjamin Britten: A Biography (New York: Macmillan Publishing Company, 1992), 229.

${ }^{15}$ Evans, 349-350.

${ }^{16}$ Oliver, 120.

${ }^{17}$ Johnson, 135.

${ }^{18}$ Ann Rebekah Lewin, "Text Settings in the Songs of Benjamin Britten" (M.A. thesis, University of California, Los Angeles, 1964): 15.

${ }^{19}$ Carpenter, 228-229.
} 
Britten composed in a number of genres before he wrote Winter Words, opus 52. The Rape of Lucretia, opus 37, had its premiere in 1946, and Albert Herring, opus 39, followed the next year. ${ }^{20}$ The composer published another set of folk-song settings in 1946 and in 1947 composed the first of his canticles, "My Beloved is Mine," opus 40, written for Pears. ${ }^{21}$ Also in 1947, he composed the song cycle for voice and piano A Charm of Lullabies, opus 41, for mezzo-soprano Nancy Evans. ${ }^{22}$ For the Aldeburgh Festival, Britten realized The Beggar's Opera of John Gay in 1948. Billy Budd, opus 50, followed in 1950, another full-scale opera. The second canticle, "Abraham and Isaac," opus 51, written for Pears and Kathleen Ferrier, was completed in 1952. ${ }^{23}$ Britten finished a new performing edition of Purcell's Dido and Aeneas in 1951, once again attesting to the composer's admiration of his predecessor. ${ }^{24}$ In 1952 , the same year as the composition of the next cycle, Winter Words: Lyrics and Ballads of Thomas Hardy, opus 52, he completed his opera Gloriana, opus 53, an opera about Queen Elizabeth I which was commissioned for the coronation of Queen Elizabeth II. ${ }^{25}$ The style of recitative that he had developed in his operas during this time is evident in Winter Words, and the influence of folk songs is apparent in the work as well in terms of melodic contour, range, and rhythm.

Winter Words is comprised of settings of poetry by Thomas Hardy (1840-1928). The poems chosen are about the loss of innocence and ignorance associated with childhood that occurs with the onset of adulthood and its increased responsibility to society. "The similarities of Britten's and Hardy's views of life are apparent in this set .... The songs appeal for a return to innocence, to youth, and for an escape from the complexities and tainted mind set of

\footnotetext{
${ }^{20}$ Evans, 575-576.

${ }^{21}$ Jennifer Doctor, Judity LeGrove, and Paul Banks (works), "Benjamin Britten," Grove Music Online. L. Macy, ed. [online]; available from http://www.grovemusic.com; Internet: accessed 27 August 2005.

${ }_{22}^{22}$ Carpenter, 262.

${ }^{23}$ Johnson, 248.

${ }^{24}$ Evans, 579-580.

${ }^{25}$ Ibid., 577.
} 
maturity." ${ }^{26}$ This theme was evident in many of the composer's works throughout his career, notably in the operas The Turn of the Screw, opus 54 (1954) and Death in Venice, opus 88 (1973). ${ }^{27}$ It is said that he lamented the loss of innocence he experienced in his early adulthood in part because of the death of both of his parents, and in part because of the realization that his own sexuality (of which he became aware about the same time he became orphaned) could alienate him from society with its lack of acceptance of homosexuality. ${ }^{28}$ Although the texts themselves do not deal with homosexuality at all (Hardy was heterosexual), the theme was one with which the composer could identify psychologically. This work, which some consider to be Britten's greatest, was premiered in conjunction with the Leeds Triennial Festival in October $19533^{29}$

From 1953 to 1958, before the composition of Sechs Hölderlin-Fragmente, opus 61, Britten composed comparatively less. The composer and his lover took some time away from Great Britain, touring Europe and Asia, including Japan and Indonesia in particular, vacationing, concertizing, and experiencing music indigenous to the different areas visited, which gave the composer less time to focus on composition. ${ }^{30}$ Realizations of six Purcell duets were published in 1954, which indicates that the Baroque composer was still of interest to Britten. ${ }^{31}$ The Turn of the Screw, opus 54, was completed in 1954, followed the next year by the third canticle "Still Falls the Rain - the Raids, 1940, Night and Dawn,” opus 55, for tenor, horn, and piano. ${ }^{32}$ Britten's ballet, The Prince of the Pagodas, opus 57, was composed following his visit to Bali

\footnotetext{
${ }^{26}$ Georgia Ypma Bonney, “A Study of the Music and Text of Benjamin Britten's Winter Words, op.52: Lyrics and Ballads of Thomas Hardy" NATS Journal 49 (November/ December 1992): 6.

${ }^{27}$ Ann Brashear, "Winter Words, op. 52, by Benjamin Britten: An analysis" (M.M. thesis, Northern Illinois University, 1986): 21-22.

${ }^{28}$ Johnson, 245-246.

${ }^{29}$ Brashear, 3.

${ }^{30}$ Headington, 206.

${ }^{31}$ Doctor, LeGrove, and Banks.

${ }^{32}$ Evans, 577.
} 
(part of a vacation in 1955 to 1956) and was influenced by the music of Balinese culture. ${ }^{33} \mathrm{~A}$ fourth volume of folk-song arrangements was published in 1957. During this period, he also composed another orchestrated song cycle for his partner, Nocturne, opus 60, for tenor, seven obbligato instruments and string orchestra, which was completed in $1958 .{ }^{34}$ Songs from the Chinese, opus 61, for tenor and guitar (1958) reflected the influence of music the composer heard during his travels in the mid-1950s. ${ }^{35}$

Pears and Britten traveled during the mid-1950s with their friends Prince Ludwig and Princess Margaret of Hesse, who acquainted them with the poetry of Friedrich Hölderlin (17701843). ${ }^{36}$ Hölderlin was not only obsessed with a loss of innocence, but also plagued by a sense of estrangement from society as a whole: themes that had attracted the composer before. "It appears that Hölderlin, like Britten, was obsessed with memories of childhood. A.M. Whittall mentioned the contrast between '. . . the vanished peace of childhood and the cold reality of maturity ...' as a comparison between Sechs Hölderlin-Fragmente and Winter Words." 38 Britten composed Sechs Hölderlin-Fragmente for himself and Pears in 1958 and the set was premiered in November of that same year on the BBC. ${ }^{39}$

Over a decade passed between this and the next song cycle for voice and piano written for the tenor, but these were productive years for the composer as he continued to write vocal music in other genres, and for other performers. He continued to publish both arrangements of folk songs (in 1958 and 1959) and figured-bass realizations of the works of Purcell (five songs in

\footnotetext{
${ }^{33}$ Ibid., 225.

${ }^{34}$ Ibid., 577.

35 Ibid., 362.

36 Johnson, 57.

${ }^{37}$ Brewster, 58-59.

38 A.M. Whittall, "Benjamin Britten" The Music Review XXIII (Nov 1962): 315; quoted in Lewin, 15.

${ }^{39}$ Carpenter, 386.
} 
1959). ${ }^{40}$ Pears and Britten collaborated on the libretto of A Midsummer Night's Dream, opus 64, which was composed in $1960 .^{41}$ In May 1962, War Requiem, opus 66, was premiered in Coventry Cathedral to great acclaim. ${ }^{42}$ The composer published three more realizations of songs by Purcell in 1963. During the same period, he wrote many smaller scale dramatic works (church parables and the like) which included Curlew River, opus 71 (1964). The composer did not avoid cycles for voice and piano during this interval, indeed he wrote two in 1965, but they were composed for other singers both of whom were friends of the two men: Songs and Proverbs of William Blake, opus 74, for baritone Dietrich Fischer-Dieskau and The Poet's Echo, opus 76 (in Russian), for the soprano Galina Vishnevskaya. ${ }^{43}$ The Burning Fiery Furnace, opus 77, and The Golden Vanity, opus 78, two church parables, were composed in 1966. On the larger scale, Britten completed new performing editions of both The Fairy Queen of Purcell and Johannespassion of J.S. Bach in $1967 .{ }^{44}$ The Prodigal Son, opus 81 , another church parable, was completed in 1968, and was followed by the publication of realizations of three more songs of Purcell in 1968 and of five spiritual songs of Johann Sebastian Bach in 1969. ${ }^{45}$

Who Are These Children?, opus 84, the last song cycle for voice and piano for Pears, was written in $1969 .{ }^{46}$ By William Soutar (1898-1943), the texts of this set are a collection of children's rhymes (in a Scottish dialect) and adult musings upon the loss of innocence and even more about the high cost of war upon both the individual and society. ${ }^{47}$ Soutar's pacifism is one of the things that drew the composer to these texts, as well as the opportunity to juxtapose the

\footnotetext{
${ }^{40}$ Doctor, LeGrove, and Banks.

${ }^{41}$ Wilcox, 75.

${ }^{42}$ Evans, 450.

${ }^{43}$ Ibid., 376, 382.

${ }^{44}$ Doctor, LeGrove, and Banks.

${ }^{45}$ Ibid.

${ }^{46}$ Alan Gasser, "Performing Benjamin Britten's Who Are These Children?, opus 84” NATS bulletin, 42 (May/June 1987): 5.

${ }^{47}$ Evans, 385.
} 
rhymes - told from a child's perspective - with the bitter, angry poems from the adult perspective. ${ }^{48}$ Who Are These Children? was premiered in May of 1971, in Edinburgh. ${ }^{49}$

Owen Wingrave, opus 85 , written specifically for television, was composed in $1970 .{ }^{50}$ Britten returned to the canticle, composing his fourth "The Journey of the Magi," opus 86 in 1971, for counter-tenor, tenor, baritone, and piano, and also published more realizations of Purcell songs. ${ }^{51}$ Britten had heart surgery in 1973, a complication of which was partial paralysis of his right hand which left him unable to play piano. ${ }^{52}$ He had his surgery after the completion of his last opera, Death in Venice, opus 88 (which again deals with the loss of innocence and isolation from society as a whole) which had its premiere in $1973 .{ }^{53} \mathrm{He}$ found other performance media so that he could continue to compose recital repertoire for his lover, writing the fifth canticle, "The Death of Saint Narcissus," opus 89 (1974), and A Birthday Hansel, opus 92 (1975), as well as arranging more folk songs (published in 1976) all with harp accompaniment. These were the last works that Britten wrote for his partner before he died. ${ }^{54}$

It was heaven to hear your voice, \& to know you're feeling better. Practise [sic] hard \& get the golden box back in its proper working order again. Something goes wrong with my life when that's not functioning properly. (Britten to Pears in a letter from November 1943. $)^{55}$

\footnotetext{
${ }^{48}$ Gasser, 5 .

${ }^{49}$ Evans, 385.

${ }^{50}$ Ibid., 579.

${ }^{51}$ Doctor, LeGrove, and Banks.

${ }^{52}$ Carpenter, 546.

${ }^{53}$ Evans, 579.

${ }^{54}$ Doctor, LeGrove, and Banks.

${ }^{55}$ Benjamin Britten, Letter 438 to Peter Pears, in Letters From a Life: The Selected Letters and Diaries of Benjamin Britten 1913-1976, Volume Two, (1939-1945) ed. Donald Mitchell (Berkeley, University of California Press, 1991), 1165.
} 


\section{CHAPTER 3}

Seven Sonnets of Michelangelo, opus 22

(1940)

In the late 1930's and early 1940's, the time of the composition of the Seven Sonnets of Michelangelo, Benjamin Britten was just learning how to use Peter Pears's voice to express the texts he set, while at the same time the tenor continued studying voice with the intention of solidifying his technique. The fact that the composer was involved in his partner's artistic development explains why from the beginning of their relationship he developed a facility for setting texts for his partner's voice. ${ }^{1}$ The pairing of Pears's voice with Britten's music in these pieces, according to writer and musicologist Edward Sackville-West (the dedicatee of the Serenade for Tenor, Horn, and Strings, opus 31, written three years later in 1943, and friend to the two men), resulted in "the finest [songs] that had been written in England since Purcell and anywhere in the world since the death of Hugo Wolf."

Britten selected these seven sonnets from the seventy-six that were published in the late nineteenth century with translations by John Addington Symonds (1840-1893). ${ }^{3}$ Other composers have chosen to set some of Michelangelo's poetry, including Richard Strauss (1886), Hugo Wolf (1897), Luigi Dallapiccola (1949), and Dmitry Shostakovich (1974) ${ }^{4}$, but Britten’s treatment was different from the other composers' in his presentation of the works and in the choice of theme. All seven of these sonnets have to do with love, most unrequited, and at least

\footnotetext{
${ }^{1}$ Although there is no evidence that Britten attended any of Pears's lessons, it is at least reasonable to assume that he would have heard Pears practicing and/or that the two would discuss problems as well as progress in these lessons.

${ }^{2}$ Michael Oliver, Benjamin Britten (London: Phaidon Press Limited, 1996), 96.

${ }^{3}$ Donald Mitchell, ed., Letters From a Life: The Selected Letters and Diaries of Benjamin Britten 1913-1976, Volume Two, (1939-1945) (Berkeley, University of California Press, 1991), 930.

${ }^{4}$ Emily Esuzt, The Lied and Arts Song Text Page [online]; available from http://www.recmusic.org/lieder/; Internet; accessed 14 August 2005.
} 
four were written about Tomasso Cavalieri, a younger man whom Michelangelo desired, ${ }^{5}$ but these sonnets were not considered by the poet to be part of a cycle or a unit of any kind.

The arrangement of the seven sonnets is cyclical: throughout the course of the work conflict is introduced and ultimately resolved. The numbering of the sonnets is Symonds', although scholars do not believe that it represents the chronological order of their creation. Regardless, Britten's order is his own: XIV, XXXI, XXX, LV, XXXVIII, XXXII and XXIV, ${ }^{6}$ creating this cyclical narrative character. The narrative begins with the lover presenting his feelings for his beloved in the first setting, expressing confusion and anger at himself about the unreciprocated feelings in the second, defining and accepting the nature of his feelings in the third, addressing his fear about having these feelings in the fourth, momentarily succumbing once again to self-doubt in the fifth, accepting the inevitability of his feelings and accusing society of being the cause of his self-doubt in the sixth, and finally proclaiming his love without apology in the seventh setting.

There are certainly aspects of the texts which would have been autobiographical for the composer and his lover. The third, quoted in a letter from Pears to Britten much later in their lives, and the seventh certainly seem to express their relationship, and the sixth may be construed as the two men defying society to find fault with their love. However, there is no evidence to support the idea that the cycle as a whole is in any way an allegory of their coming together as a couple other than the fact that the texts are full of homosexual references. The cycle could be seen as a representation of the feelings of each man separately, or related to experiences that one or the other of the two men had up to that point.

\footnotetext{
${ }^{5}$ Christopher Leo Goeke, "A Discussion of the Relationship between the Words and Music in Benjamin Britten's Seven Sonnets of Michelangelo" (D.M.A. diss., University of Iowa, 1994): 50.

${ }^{6}$ Ibid., 8-9.
} 
The vocal lines in the Michelangelo set are broad and lyrical, yet aggressive, youthful, passionate, and energetic. Almost every one of these sonnets has a climactic high note at or near the end of the piece, a practice that Britten did not continue in the subsequent sets. However, the use of the high voice is appropriate for the style of the work, which mimics the Italian operatic style (See Examples 3-1, 3-2, 3-3, 3-4). 
Example 3-1, (a.) W.A. Mozart, "Un aura amorosa" from Così fan tutte, mm. 63-66, (b.)

$$
70-73,{ }^{7} \text { (c.) "Sonetto XVI," mm. } 4-5 .^{8}
$$

(a.)

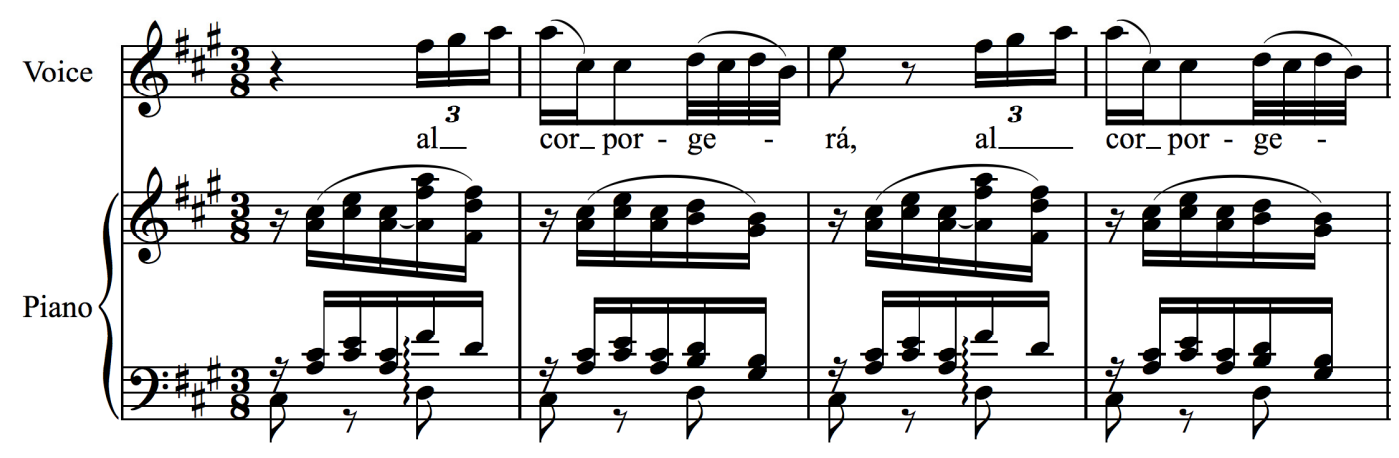

(b.)

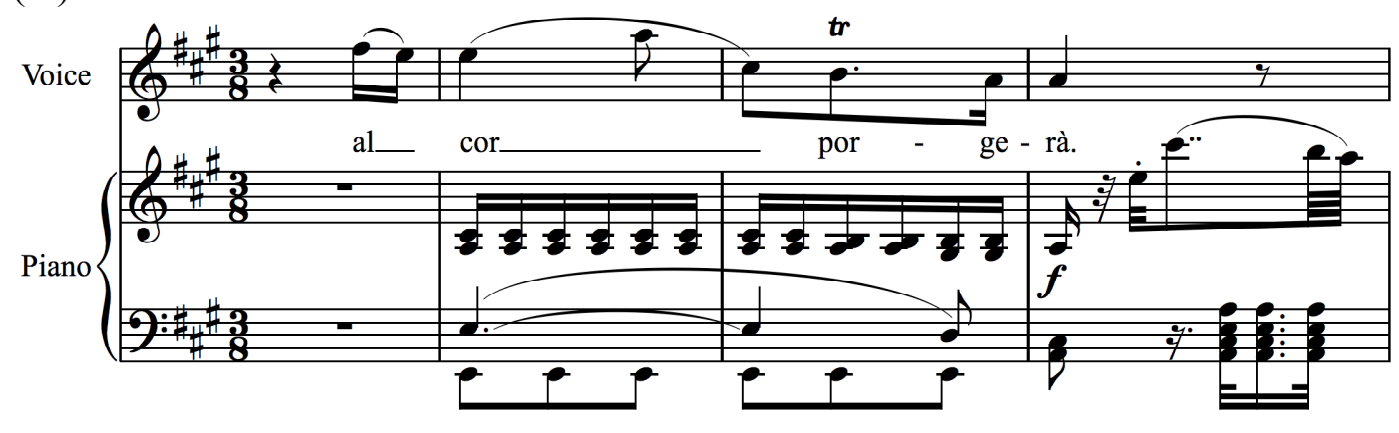

(c.)

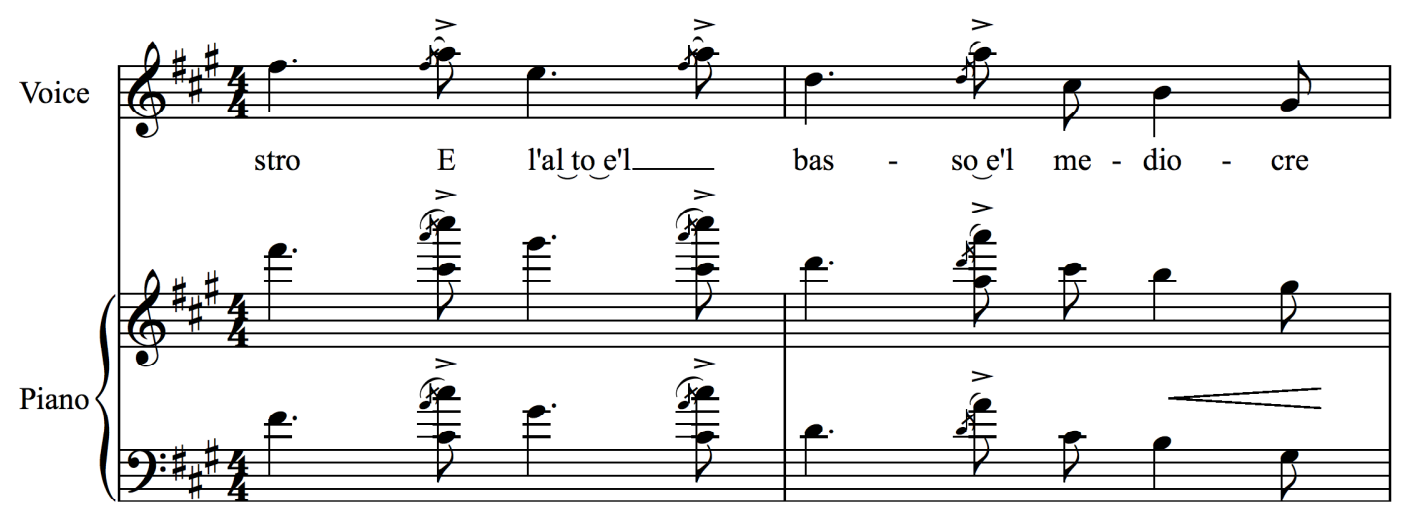

\footnotetext{
${ }^{7}$ Robert L. Larsen, ed. Arias for Tenor (New York: G. Schirmer, 1991), 60.

${ }^{8}$ Britten, Seven Sonnets of Michelangelo, opus 22 (New York: Boosey \& Hawkes, 1943), 2. Examples from "Sonetto XVI" reproduced with kind permission of Boosey \& Hawkes, Inc.
} 
Example 3-2, (a.) Giuseppe Verdi, "Questa o quella," mm. 36-39, (b.) "Sonetto XXXI," mm. 59-61. ${ }^{10}$

(a.)

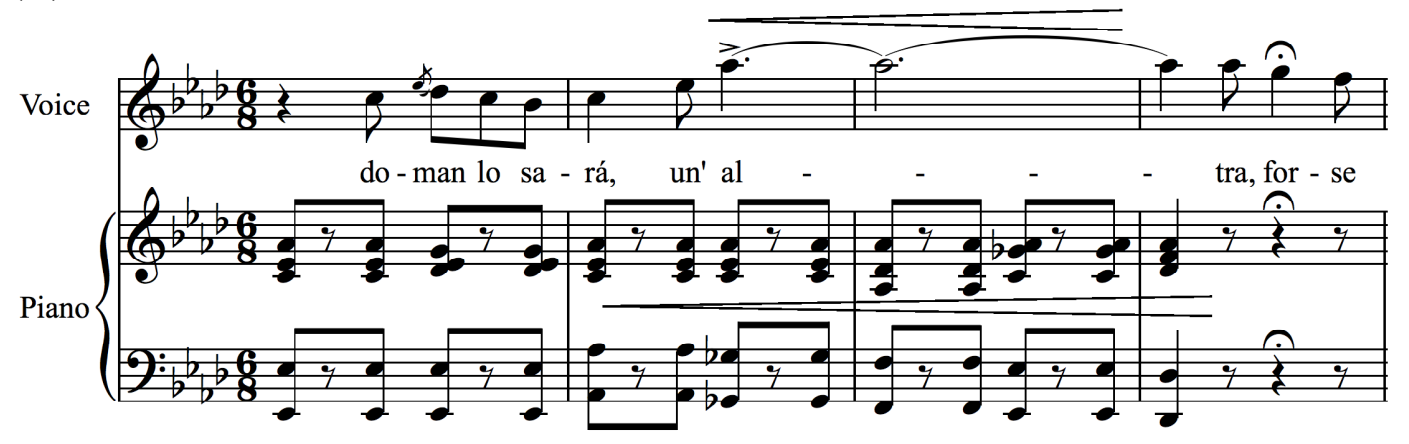

(b.)

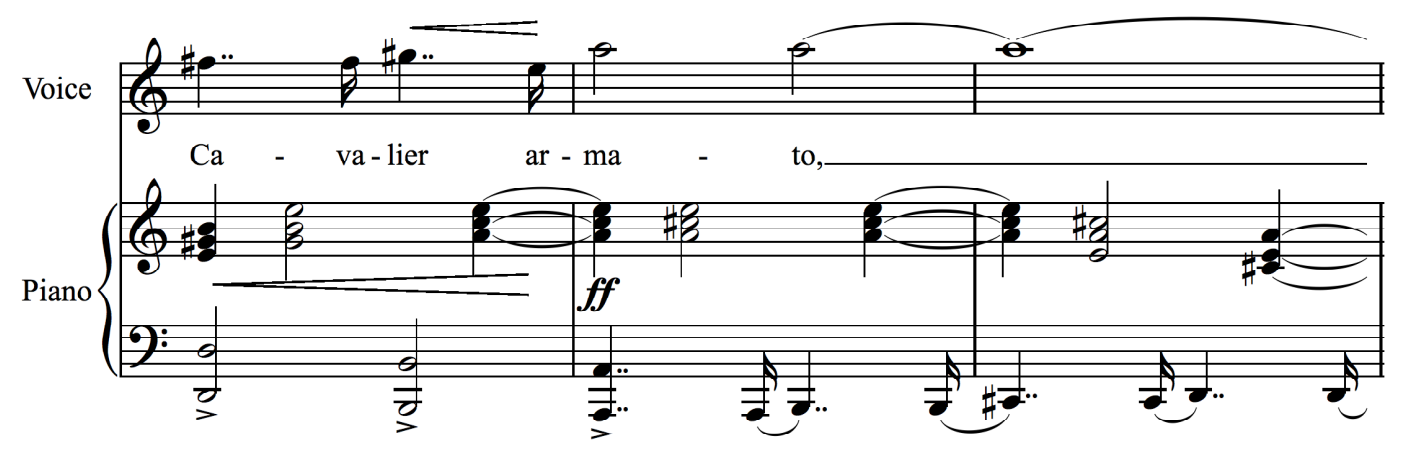

${ }^{9}$ Larsen, 104.

${ }^{10}$ Britten, 9. Examples from "Sonetto XXXI" reproduced with kind permission of Boosey \& Hawkes, Inc. 
Example 3-3, (a.)Giacomo Puccini, "Che gelida manina," from La Boheme, mm. 65-66, (b.) "Sonetto XXX," m. 57. ${ }^{12}$

(a.)
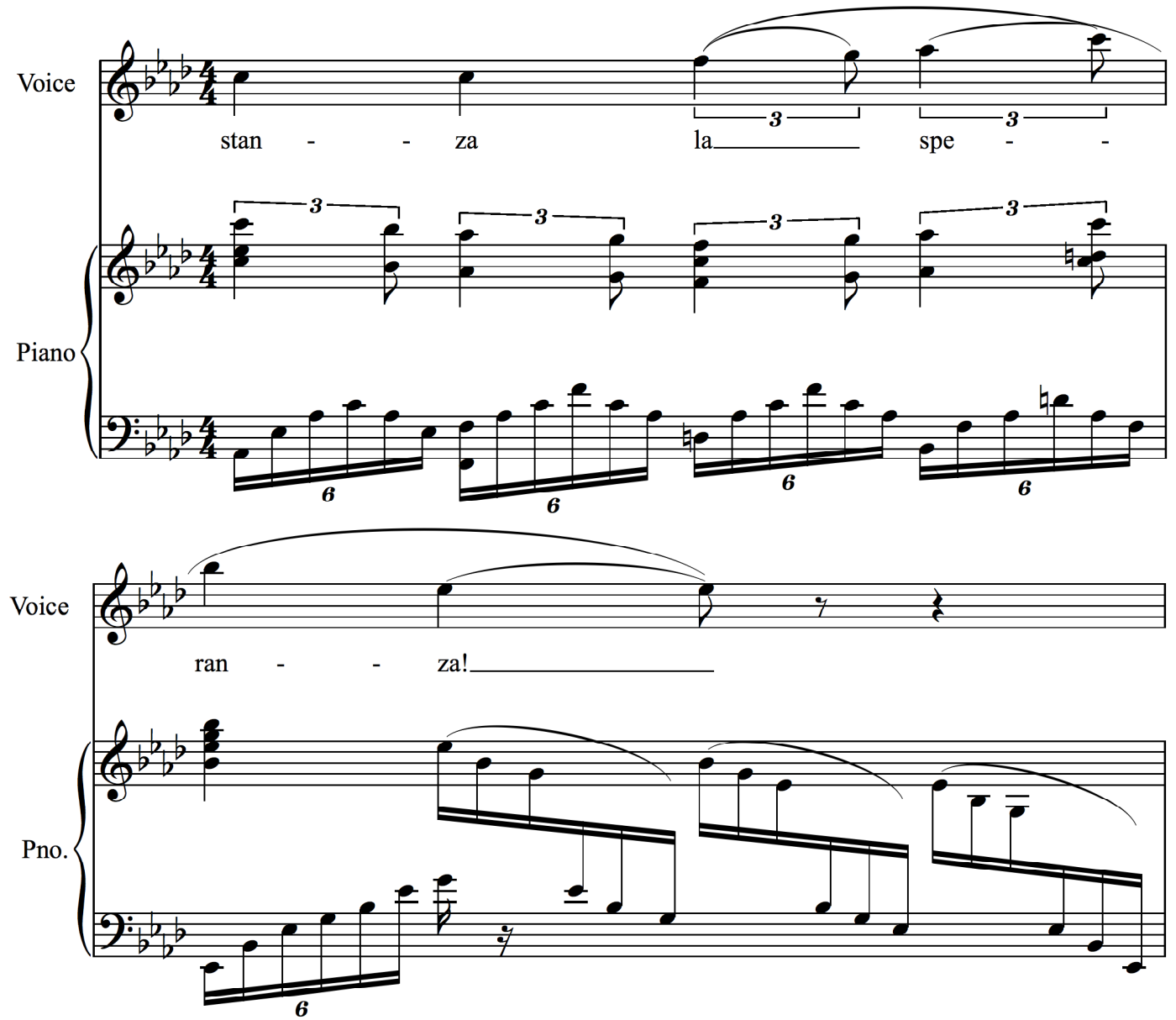

(b)

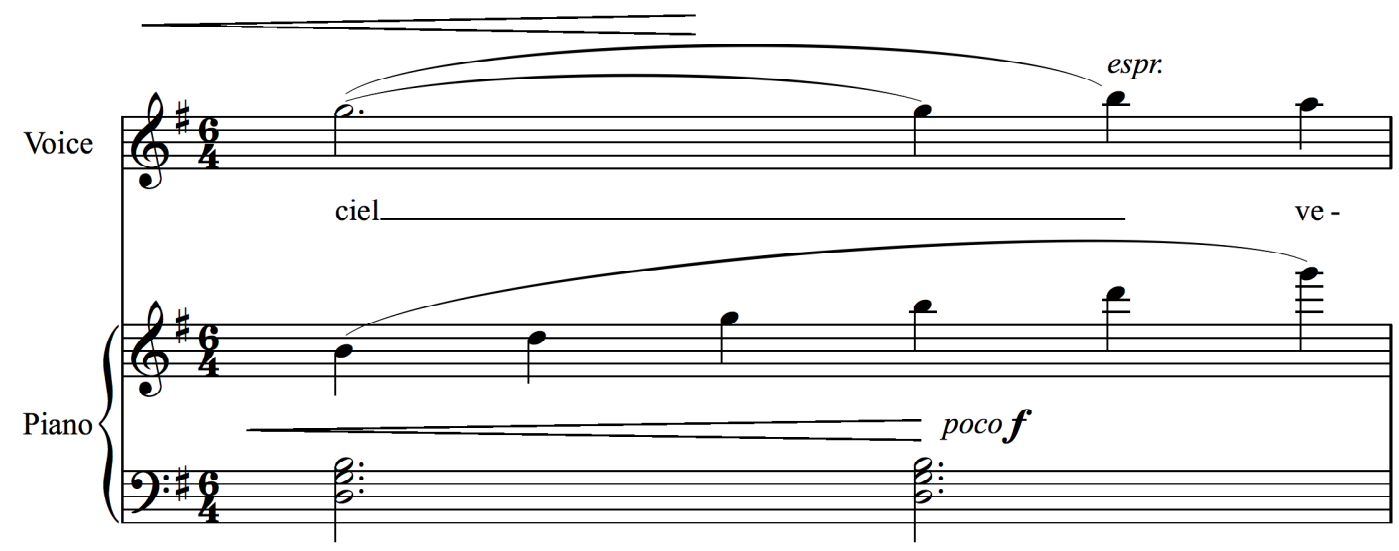

${ }^{11}$ Larsen, 167.

${ }^{12}$ Benjamin Britten, 13. Examples from "Sonetto XXX" reproduced with kind permission of Boosey \& Hawkes, Inc. 
Example 3-4, (a.) "Che gelida manina," mm. 53-55, ${ }^{13}$ (b.) "Sonetto XXIV," m.8. ${ }^{14}$

(a.)

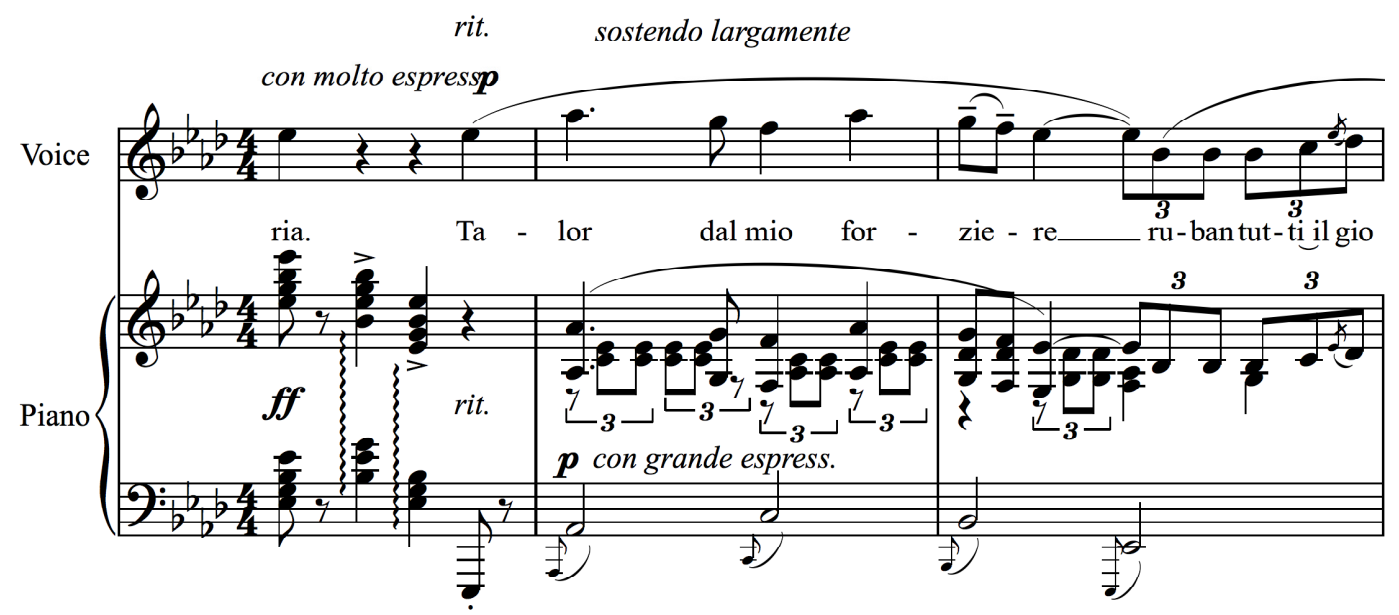

(b.)

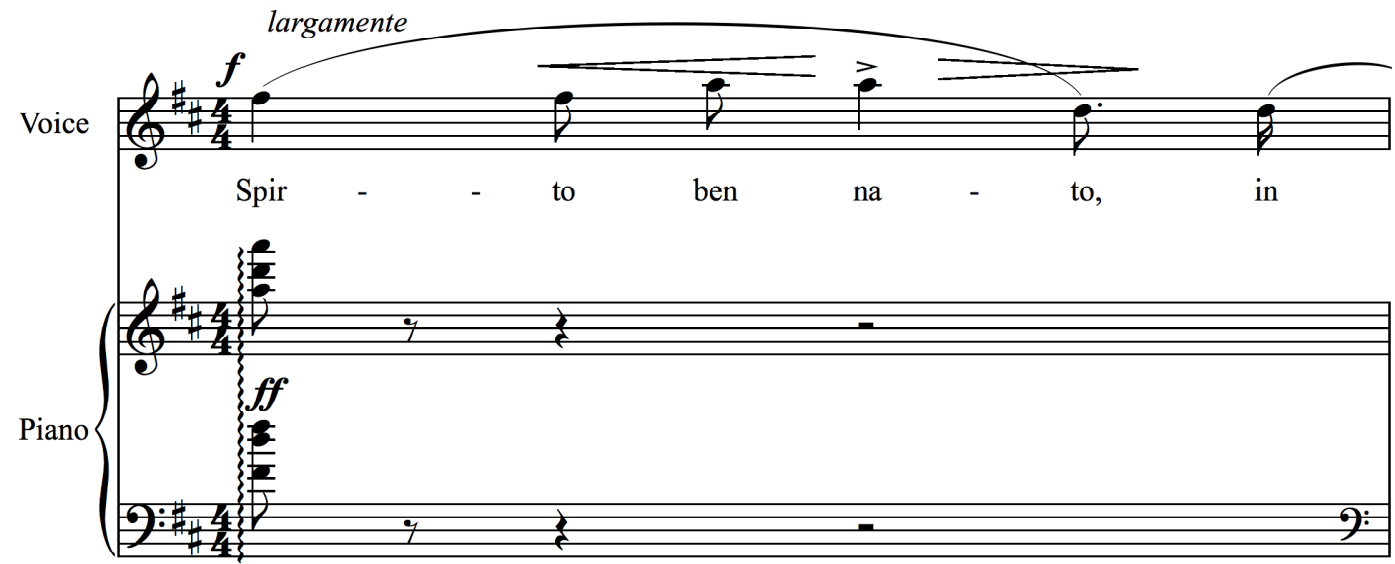

Although the tessitura of this cycle is quite high, the highest of the five to be studied in fact, this was not a problem for Pears in most cases. Britten's ability to use the tenor's upper middle voice for dramatic effect even at this early stage was quite remarkable. This part of the tenor's voice, especially E-natural to G-natural, could sound fragile and innocent, often having a somewhat mournful quality. Pears's voice was not heroic, but there is a powerfully bright and energetic

\footnotetext{
${ }^{13}$ Larsen, 165.

${ }^{14}$ Britten, 26. Examples from "Sonetto XXIV" reproduced with kind permission of Boosey \& Hawkes, Inc.
} 
quality to it, especially evident in recordings from this time, that reinforces the high sweeping statements in the sonnets. Pears was also capable of creating an innocent or naïve vocal quality; these declarations of love would not work as well with a heavier voice. The transparency of the tenor's tone quality in this register allowed the singer to express fully the fragility and weakness of the lover and his inability to control his emotions. In this way, the communicativeness and emotive power of this part of Pears's voice was exploited by the composer throughout his partnership with the singer, and clearly this started immediately from this first set.

The overall range of the Michelangelo Sonnets is nearly two octaves: from C-natural an octave below middle C to the B-natural a major seventh above it. This tested Pears's voice in both extremes, although generally he was comfortable using the lower part of his range, which is atypical among tenors. In point of fact, the composer immediately seemed to know how to use the tenor's low range for more introspective or intimate moments. Regarding the vocal range of this set, it has been said that Pears was loath to attempt these pieces too early in his development, knowing that he would have to work to get them into his voice. ${ }^{15}$ According to Graham Johnson, the high B-natural in Sonetto XXX always remained a concern of the tenor's. ${ }^{16}$ Although most of the higher lying passages seem to have been very comfortable for him, for example the beginning and end of Sonetto XVI and the beginning of each verse in Sonetto XXIV. The high A-naturals in mm. 60-61 of the second sonnet seem to have been problematic, a function of Britten's still learning about his partner's voice and how to bring it through the passaggio, the area of transition between chest and head registers typically found between the Dnatural above middle $\mathrm{C}$ to the G-natural above that, and into the high voice.

\footnotetext{
${ }^{15}$ Graham Johnson, Britten, Voice \& Piano: Lectures on the Vocal Music of Benjamin Britten (Burlington, VT: Ashgate Publishing Limited, 2003), 84.

${ }^{16}$ Ibid., 48.
} 
Although he lacked the heroic sound of a heavier tenor voice, Pears was able to float effortlessly within the passaggio and his partner was aware of this ability. The singer was capable of a very intimate sound in this region of his voice, and Britten gave him many opportunities to show this off. Britten also seemed confident in Pears's musicianship and did not hesitate to use difficult musical material to express the text more clearly. The set has very wide melodic leaps, for example the descending major seventh leaps in the fifth piece which express the singer's frustration at his inability to control his feelings and love instead someone who could return this love (See Example 3-5).

Example 3-5, "Sonetto XXXVIII," mm. 21-24. ${ }^{17}$

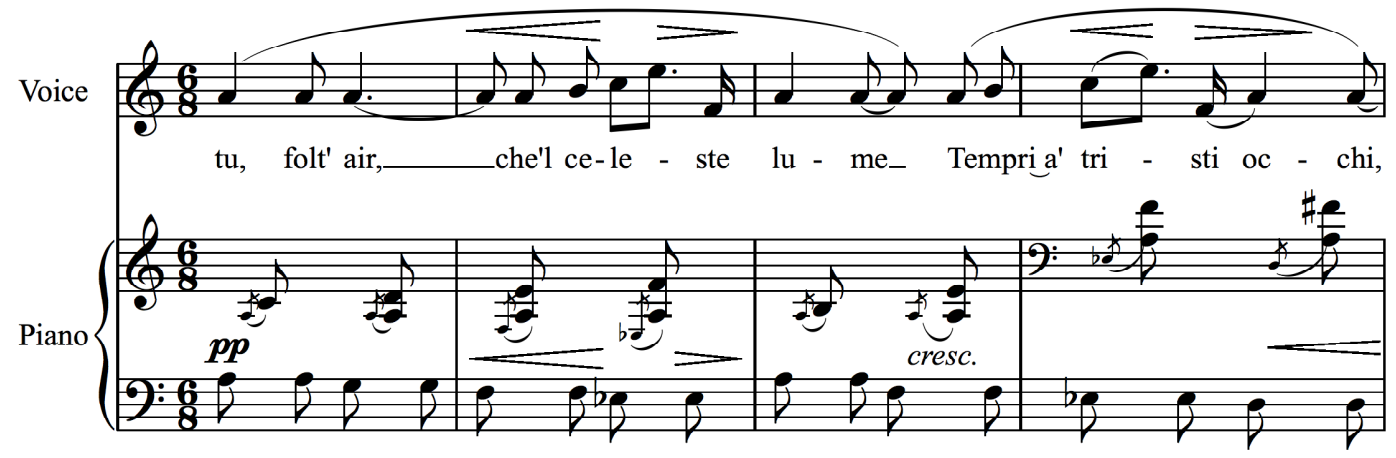

It has great dissonances with the accompaniment including the dissonant G-sharps against the strong E minor harmony in the fourth sonnet, a musical representation of the anger expressed by the poet at the man who is unable or unwilling to return his love (See Example 3-6).

${ }^{17}$ Ibid., 19. Examples from "Sonetto XXXVIII" reproduced with kind permission of Boosey \& Hawkes, Inc. 
Example 3-6, "Sonetto LV," mm. 14-15. ${ }^{18}$

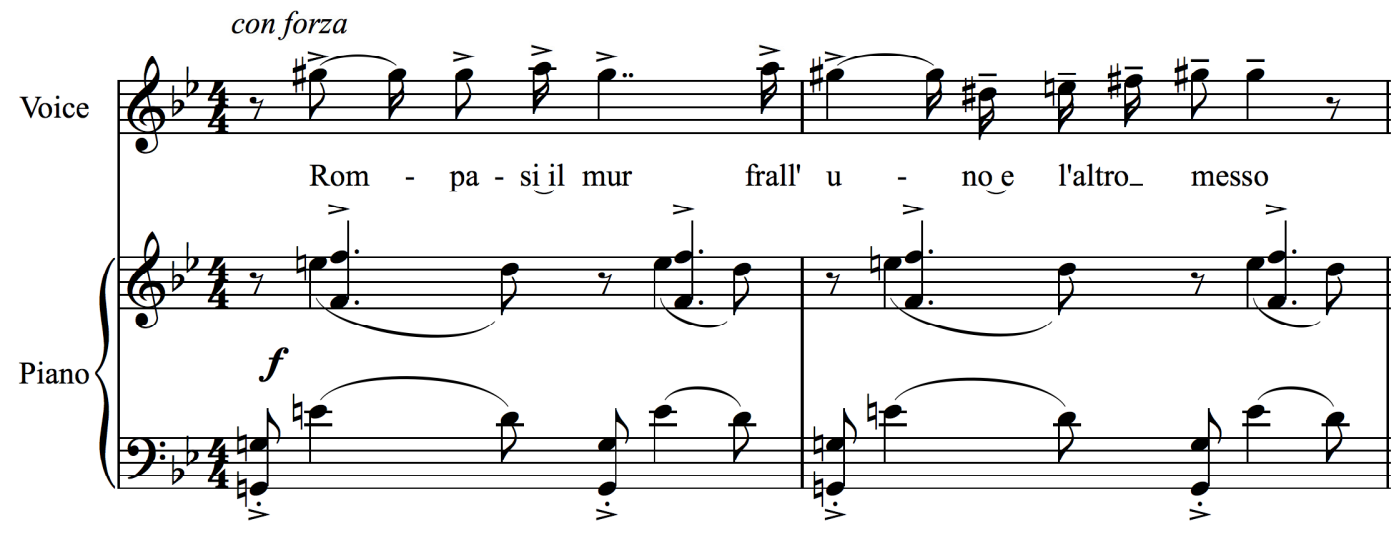

It also has moments of incredible independence from the accompaniment, especially in the seventh sonnet where the voice is unaccompanied for an entire verse as he expresses his devotion to his beloved (See Example 3-7).

${ }^{18}$ Ibid., 15. Examples from "Sonetto LV” reproduced with kind permission of Boosey \& Hawkes, Inc. 
Example 3-7, "Sonetto XXIV," mm. 7-15. ${ }^{19}$
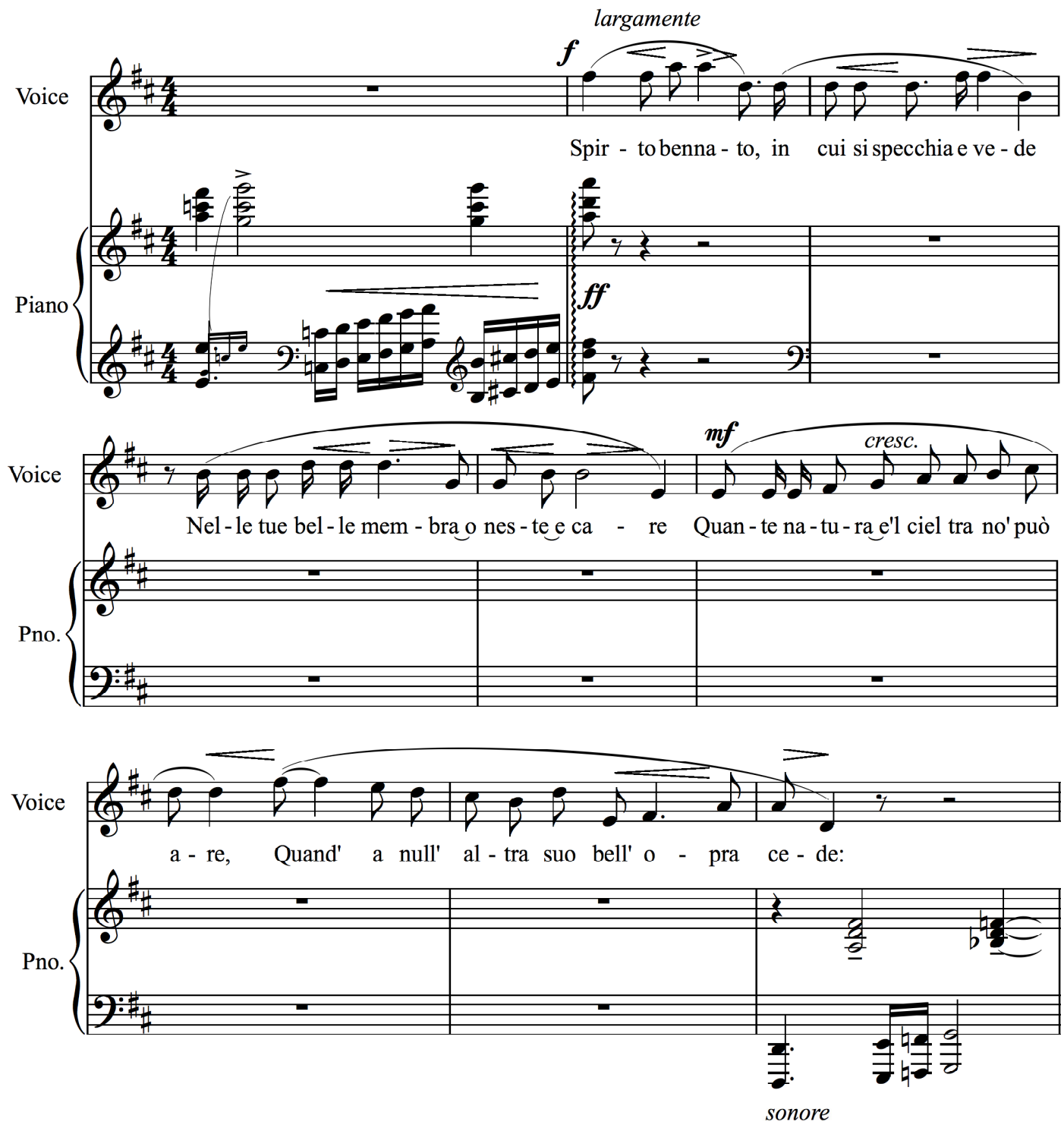

Michelangelo was not a young man when he wrote these poems of unrequited love, but there is an innocence and an energy in the raw emotion of these texts that was skillfully captured by Britten. ${ }^{20}$ There is a youthfulness in the way the voice is used throughout all these settings: bursts of emotion poured out on high notes, the musical athleticism of certain movements in the

\footnotetext{
19 Ibid., 26-27.
}

${ }^{20}$ Goeke, 9. 
use of quick accompaniment figures with rapid text declamation, the bold leaps up and down, and this mirrors the youth of both the performers and of their burgeoning relationship.

\section{Sonetto XVI}

Sì come nella penna e nell' inchiostro e l'alto e'l basso e'l mediocre stile, e ne' marmi l'imagin ricca e vile, secondo che'l sa trar l'ingegnio nostro;

così, signior mie car, nel petto vostro, quante l'orgoglio, è forse ogni atto umile: ma io sol quel c'a me propio è e simile ne traggo, come fuor nel viso mostro.

chi semina sospir, lacrime e doglie, (l'umor dal ciel terreste, schietto e solo, a’ vari semi vario si converte), però pianto e dolor ne miete coglie; chi mira alta beltà con sì gran duolo, dubbie speranze, e pene acerbe e certe.

\section{Sonnet $\mathrm{XVI}^{21}$}

Just as there is a high, a low, and a middle style in pen and ink, and as within the marble are images rich and poor, according as our fancy knows how to draw them forth:

So within your heart, dear love, there are perhaps, as well as pride, some humble feelings: but I draw thence only what is my desert and like to what I show outside on my face.

Whoever sows sighs, tears and lamentations (Heaven's moisture on earth, simple and pure, adapts itself differently to different seeds)

reaps and gathers grief and sadness: whoever looks on high beauty with so great a grief reaps doubtful hopes and sure and bitter pain.

This kind of energy is exemplified right away in the first sonnet of the set, Sonetto XVI.

The text is a grand expression of love, albeit it unrequited. There is a devil-may-care attitude to the sonnet, and an acceptance of the pain that comes from the love felt by the narrator. The setting of the text therefore is aggressive, using Pears's full range to color phrases. Britten used

\footnotetext{
${ }^{21}$ All translations in this chapter were prepared by Peter Pears and Elizabeth Mayer and are published in Benjamin Britten, Seven Sonnets of Michelangelo, opus 22 (New York: Boosey \& Hawkes, 1943).
} 
a single motive in the accompaniment throughout this song which serves both to set the mood of the piece, both angry and confused, and to unify it (See Example 3-8).

$$
\text { Example 3-8, "Sonetto XVI," mm. 1-2. }{ }^{22}
$$

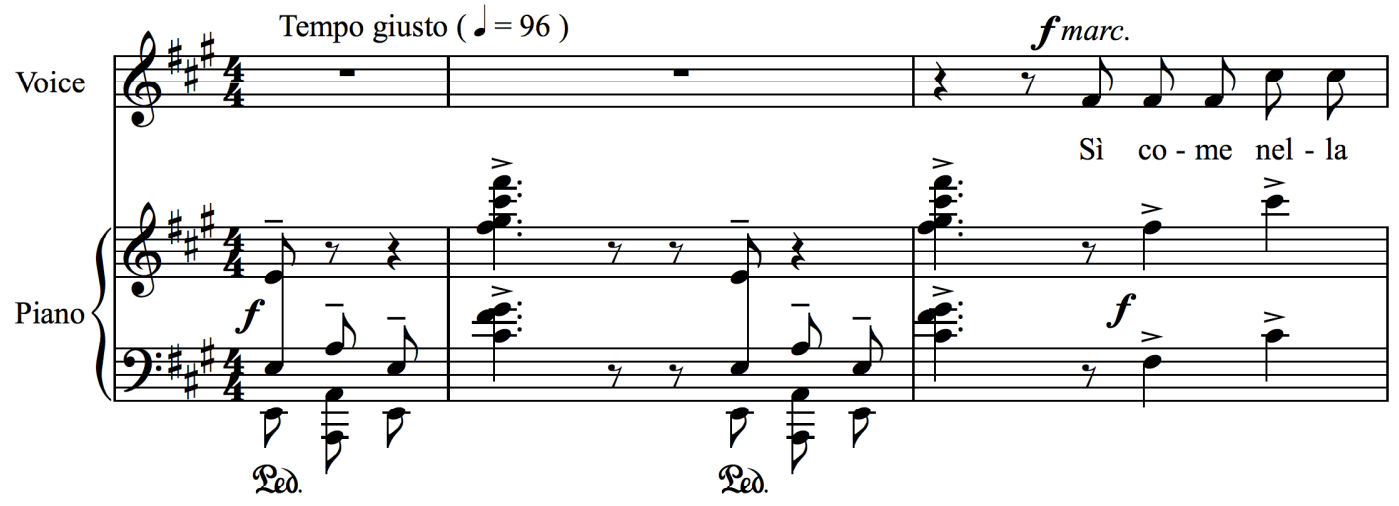

After the bold opening of the piano and voice in setting, "Sì come nella penna e nell' inchiostro e l'alto e'l basso e'l mediocre stile [Just as there is a high, a low, and a middle style in pen and ink]," with its repeated high A-naturals (See Example 3-9), Britten set the vocal line into the passaggio on a string of sustained E-naturals, for the more intimate, introspective, yearning text as the narrator hopes for some return of the love, "Così signior mie car, nel petto vostro, Quante l'orgoglio è forse ogni atto umile; Ma io sol quel c'a me propio è e simile [So within your heart, dear love, there are perhaps, as well as pride, some humble feelings: but I draw thence only what is my desert and like]" (See Example 3-10).

\footnotetext{
${ }^{22}$ Britten, 2.
} 
Example 3-9, "Sonetto XVI," mm.2-5. ${ }^{23}$

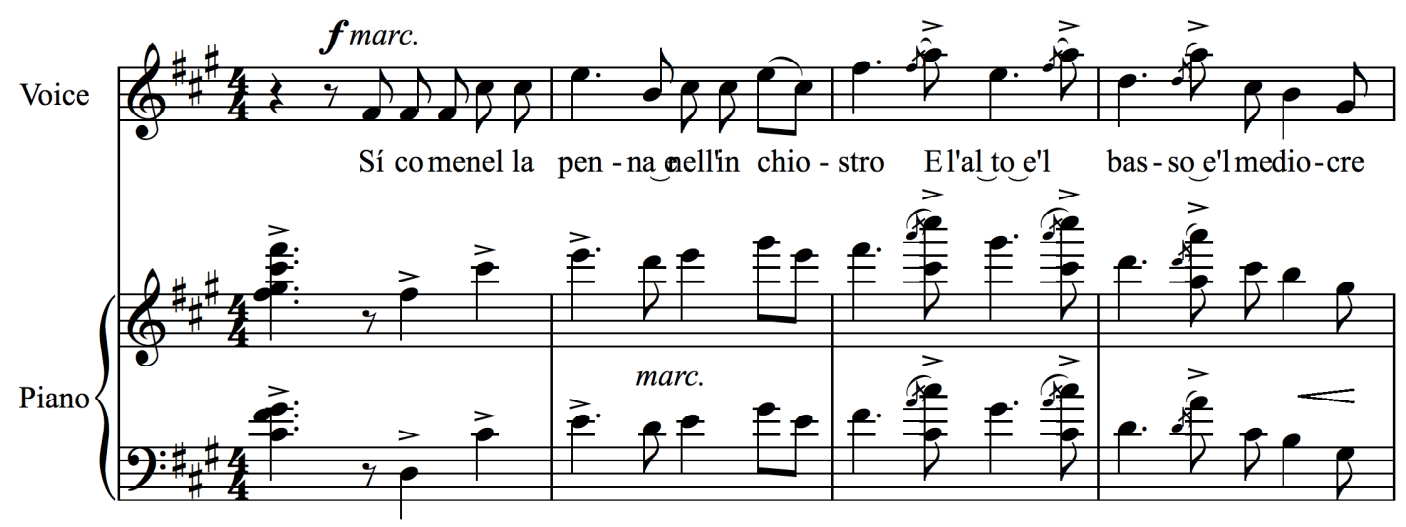

${ }^{23}$ Ibid., 2.

Strauss

37 
Example 3-10, “Sonetto XVI," mm. 16-24. ${ }^{24}$
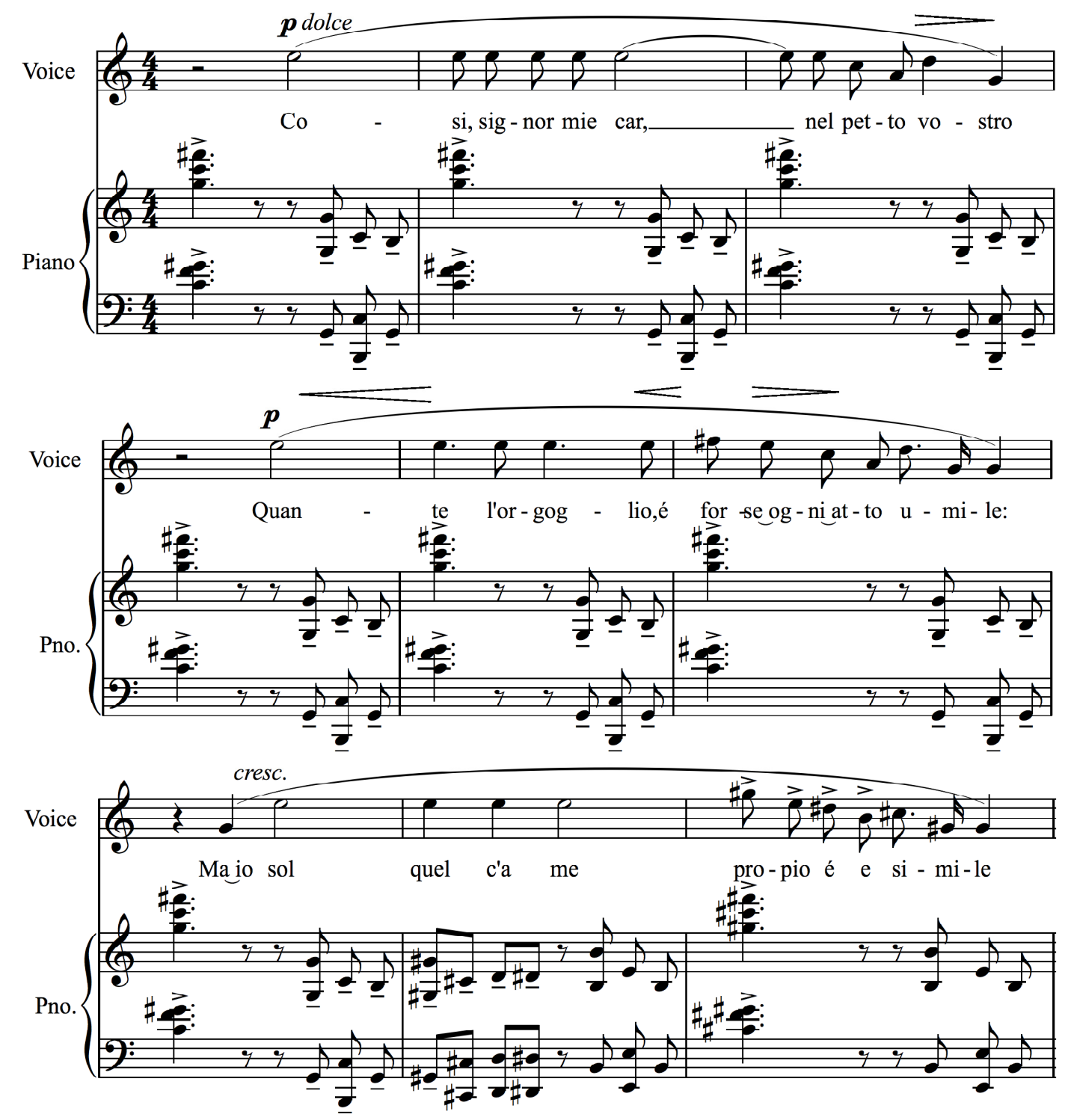

A sense of self-pity is evident is the lower-lying passages in mm. 29-30 of the first sonnet ("Chi semina sospir, lacrime e doglie, (l'umor dal ciel terreste, schietto e solo, a' vari semi vario si converte), Però pianto e dolor ne miete coglie [Whoever sows sighs, tears and lamentations heaven's moisture on earth, simple and pure, adapts itself differently to different seeds - reaps and gathers grief and sadness]" (See Example 3-11).

\footnotetext{
${ }^{24}$ Ibid., 3-4.
} 
Example 3-11, “Sonetto XVI," mm.29-38. ${ }^{25}$
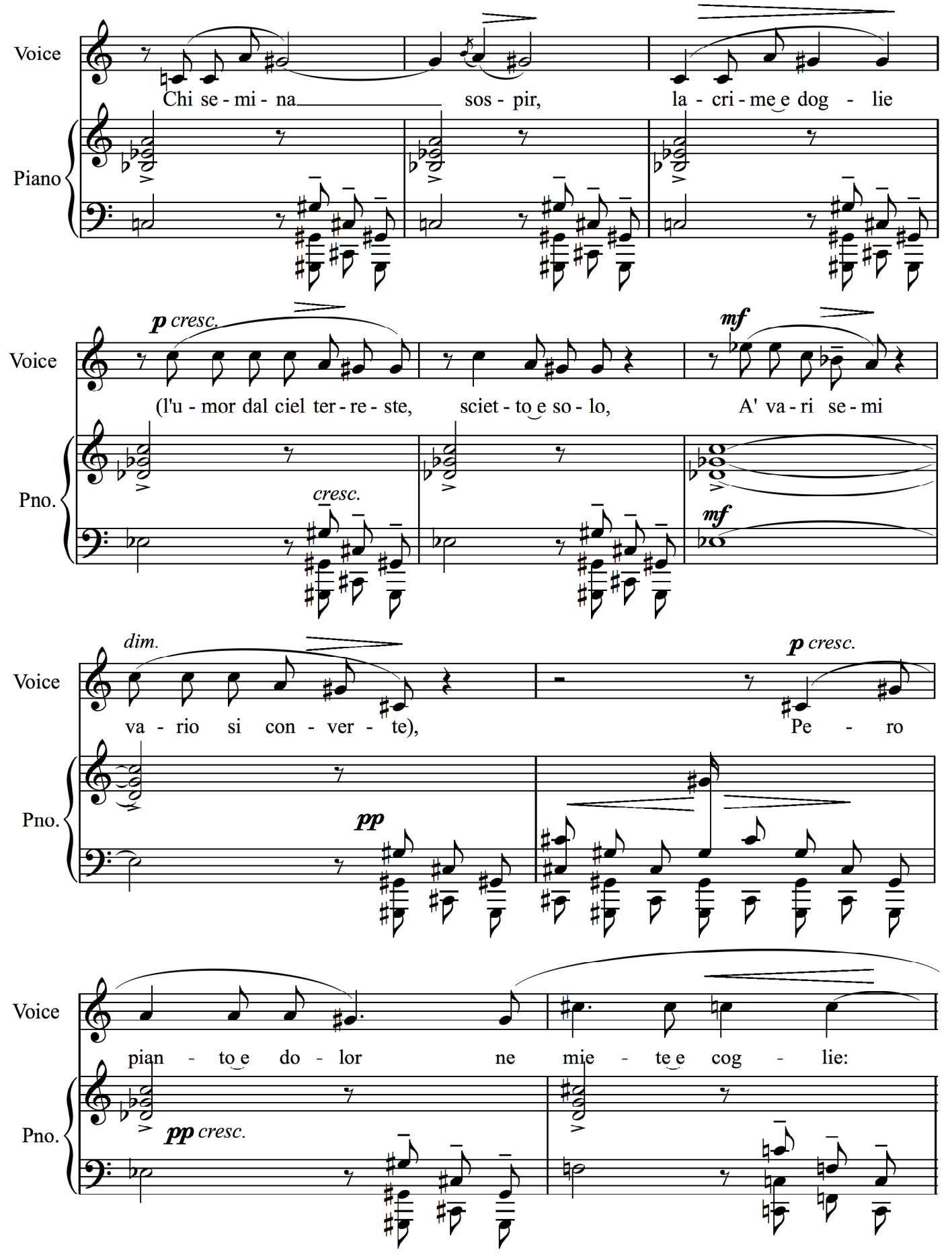

${ }^{25}$ Ibid., 4-5. 
The piece closes with a return to the same high, bold statement of the vocal line that opens the piece.

\section{Sonetto XXXI}

A che più debb'io mai l'intensa voglia sfogar con pianti o con parole meste, se di tal sorte ' 1 ciel, che l'alma veste, tard' o per tempo alcun mai non ne spoglia?

A che'l cor lass' a più morir m'invoglia, s'altri pur dee morir? Dunque per queste luci l'ore del fin fian men moleste; ch'ogn' altro ben val men ch'ogni mia doglia.

però se'l colpo ch'io ne rub'e 'nvolo schifar non poss', almen, s'è destinato, chi entreràn fra la dolcezza e'l duolo?

Se vint' e pres' I' debb' esser beato, maraviglia non è se nud' e solo resto prigion d'un cavalier armato.

\section{Sonnet XXXI}

Why must I go on venting my ardent desire in tears and melancholy words, if Heaven that dresses the soul in grief, never, soon or late, allows relief?

Why should my weary heart long for death since all must die? So to these eyes my last hours will be less painful, all my grief being greater than any joy.

If, therefore, I cannot avoid these blows nay, even seek them, since it is my fate, who is the one that stands always between joy and grief?

If to be happy I must be conquered and held captive, no wonder then that I, unarmed and alone, remain the prisoner of a Cavalier in arms.

The text of the second song, Sonetto XXXI, expresses more anger, and this anger is represented in the music by the strong rhythms of the vocal line, echoed at times in the fairly simplistic accompaniment, which pays homage to the Italian song tradition (See Example 3-12). 
Example 3-12, (a.) Alessandro Parisotti (attr. Pergolesi) "Se tu m'ami, se tu sospiri," mm. $1-4,{ }^{26}$ (b.) "Sonetto XXXI," mm. 1-4. ${ }^{27}$

(a.)

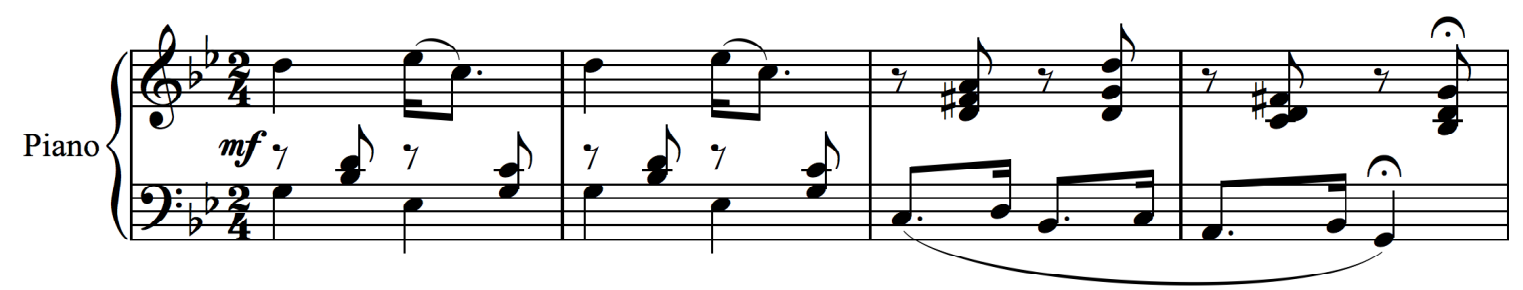

(b.)

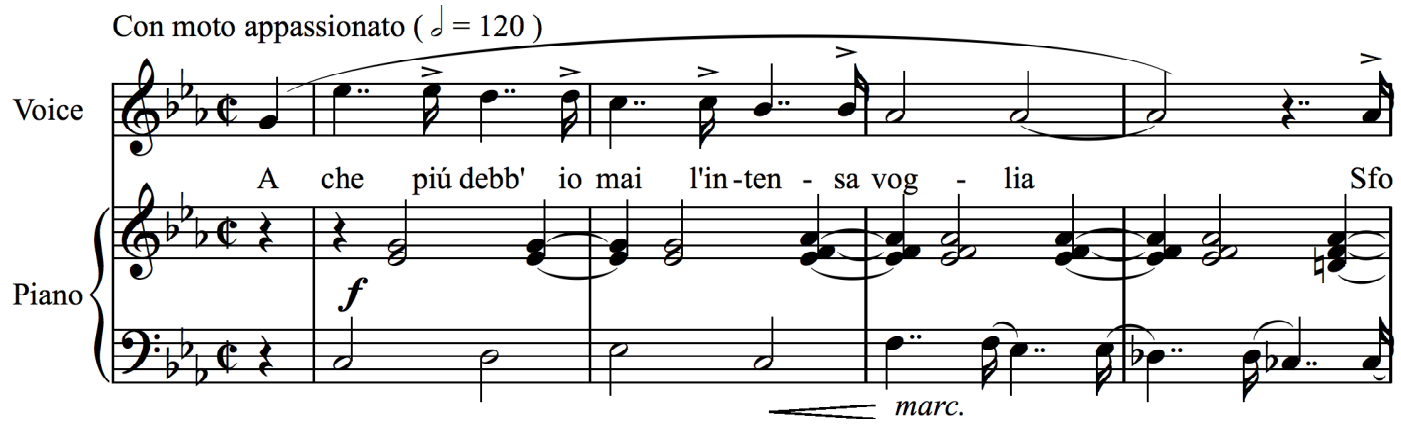

The rhythmic interest is especially intense in mm. 37-48 with an aggressive double-dotted quarter-sixteenth pattern. The repetition of the one pitch (D-natural) in this rhythm helps to focus the attention upon the text itself and also exemplifies Britten's use of Pears's upper middle voice, the region that roughly includes his passaggio, at a piano dynamic for moments of highly charged emotional intensity ('Però se'l colpo ch'io ne rub'e 'nvolo schifar non posso, almen, s'è destinato, chi entrerà 'nfra la dolcezza e'l duolo? [If, therefore, I cannot avoid these blows, nay, even seek them, since it is my fate, who is the one that stands always between joy and grief?]”) (See Example 3-13).

\footnotetext{
${ }^{26}$ Alessandro Parisotti, ed. Italian Songs and Arias of the Seventeenth and Eighteenth Centuries (New York: G. Schirmer, 1926), 68.

${ }^{27}$ Britten, 6.
} 
Example 3-13, "Sonetto XXXI," mm. 37-48. ${ }^{28}$
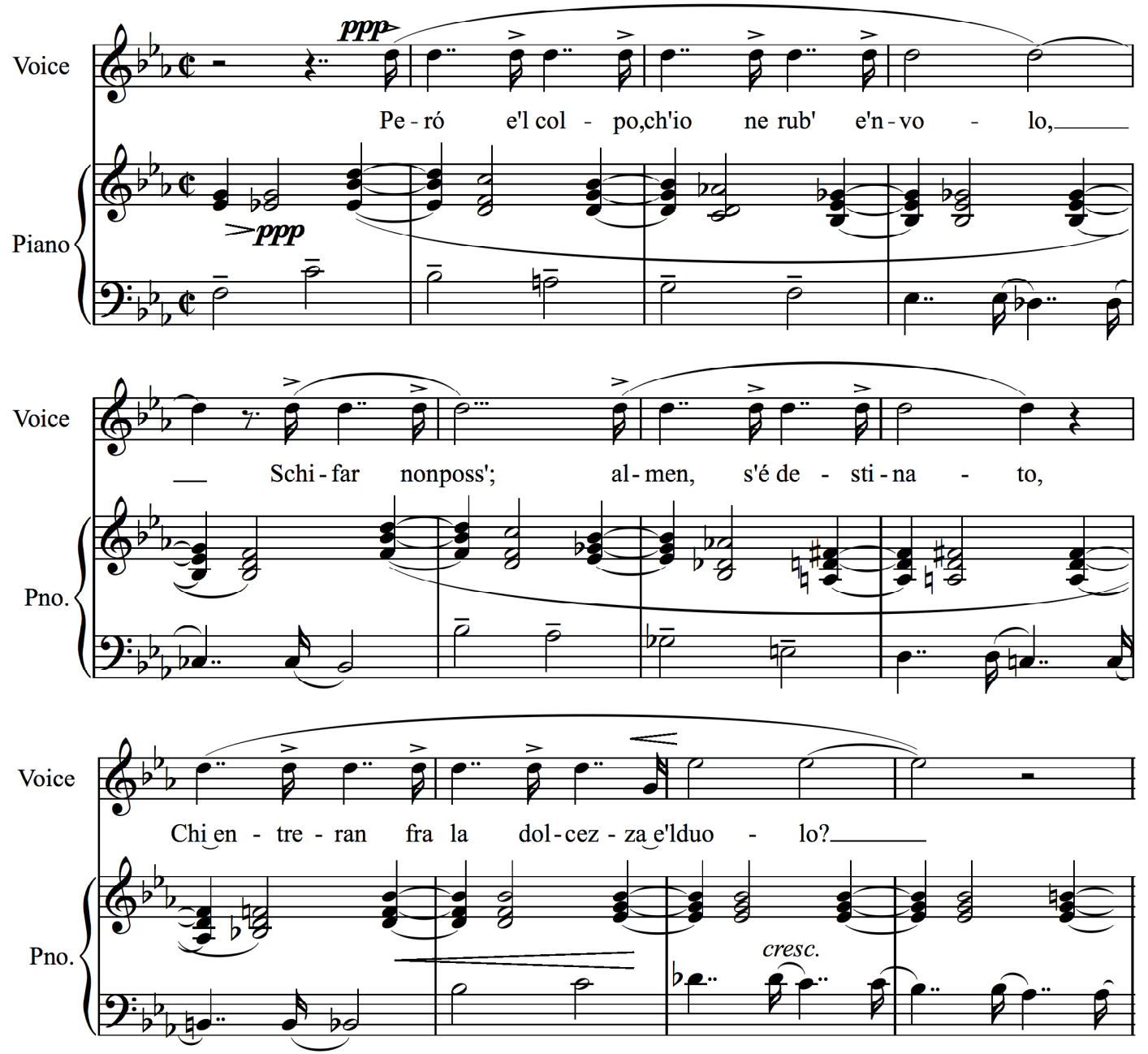

The aforementioned problematic high A-naturals occur in the passage set to the text

"Resto prigion d'un cavalier armato [Remain the prisoner of a cavalier in arms]." Even though the passage is difficult in its approach to the high note, it expresses the poet's pent-up emotion being released in a moment of anger, confusion, and lust. The subsequent repetition of the text at a lower pitch level shows the poet's resolution to accept the consequences of his desires and puts Pears in his upper middle voice, with all the possible coloristic effects he had at his disposal (See Example 3-14).

${ }^{28}$ Ibid., 8 . 
Example 3-14, “Sonetto XXXI," mm. 58-66. ${ }^{29}$

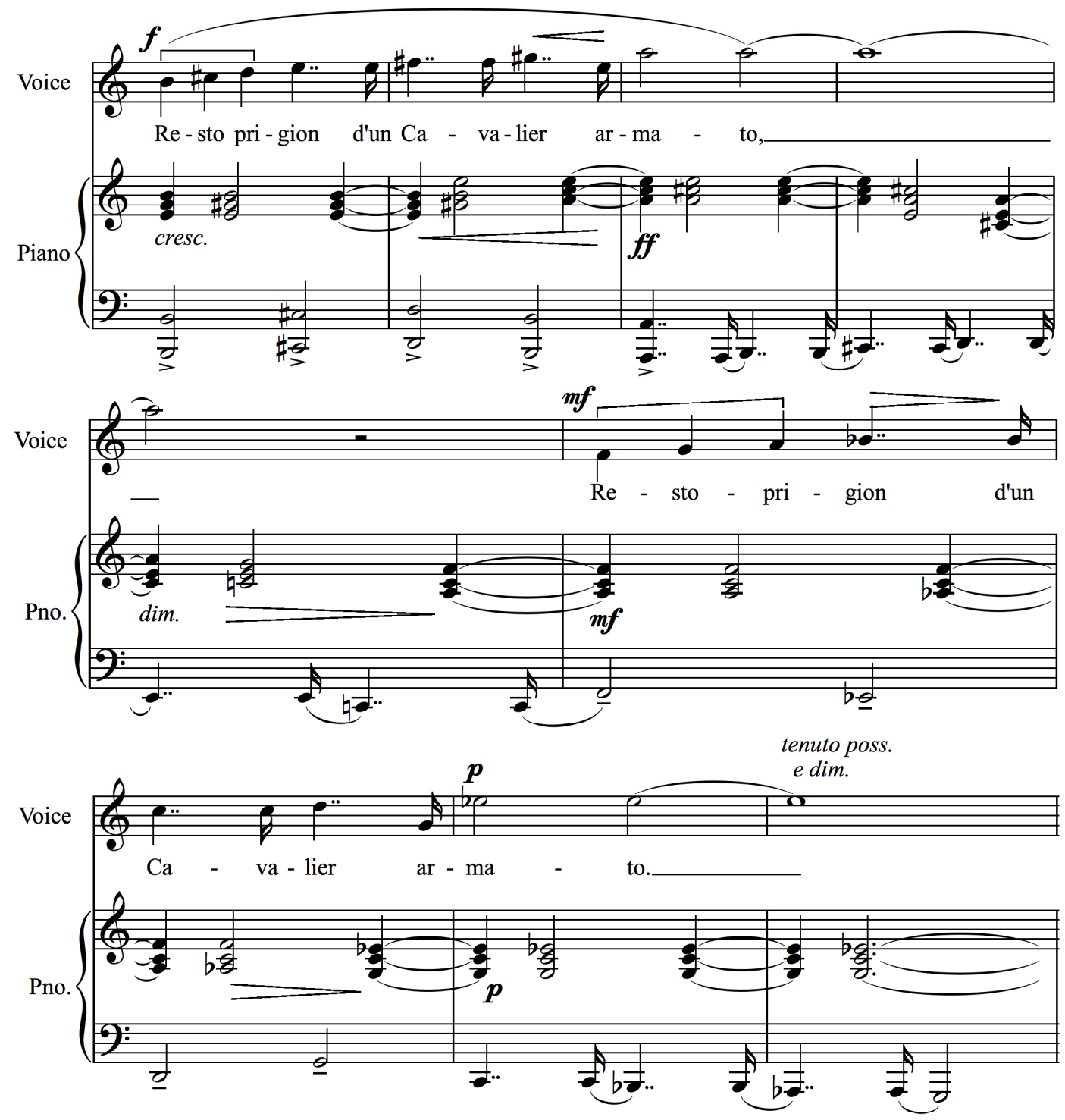

\section{Sonetto XXX}

Veggio co' be' vostri occhi un dolce lume che co' miei ciechi già veder non posso; porto co' vostri piedi un pondo a dosso, che de' mie' zoppi non è già costume.

Volo con le vostr'ale senza piume; col vostr' ingegno al ciel sempre son mosso;

\section{Sonnet XXX}

With your lovely eyes I see a sweet light that yet with my blind ones I cannot see; with your feet I carry a weight on my back which with my lame ones I cannot;

With your wings I, wingless, fly; with your spirit I move forever heavenward;

${ }^{29}$ Ibid., 9. 
dal vostr' arbitrio son pallido e rosso, freddo al sol, caldo alle più fredde brume.

Nel voler vostro è sol la voglia mia, i mie' pensier nel vostro cor si fanno, nel vostro fiato son le mie parole.

Come luna da sé sol par ch'io sia, ché gli occhi nostri in ciel veder non sanno se non quel tanto che n'accende il sole. at your wish I blush or turn pale, cold in the sunshine, or hot in the coldest midwinter.

My will is in your will alone, my thoughts are born in your heart, my words are on your breath.

Alone, I am like the moon in the sky which our eyes cannot see save that part which the sun illumines.

The third setting, Sonetto XXX, is of interest both for the text itself, a beautiful expression of love without anger or remorse, and for its musical setting. Britten used Pears's voice to great effect throughout the song, suggesting the connection between the two men in a melody that moves gracefully from high to low and back again effortlessly (or seemingly so) through different tonalities. The accompaniment, just as in the first two settings, develops a simple motive to serve as a basis for the vocal line, which then expands upon the mood set by the piano part. In this case, the left hand of the piano plays triads while the right arpeggiates chords in the differing tonalities (See Example 3-15). 


\section{Example 3-15, "Sonetto XXX," mm. 1-7. ${ }^{30}$}
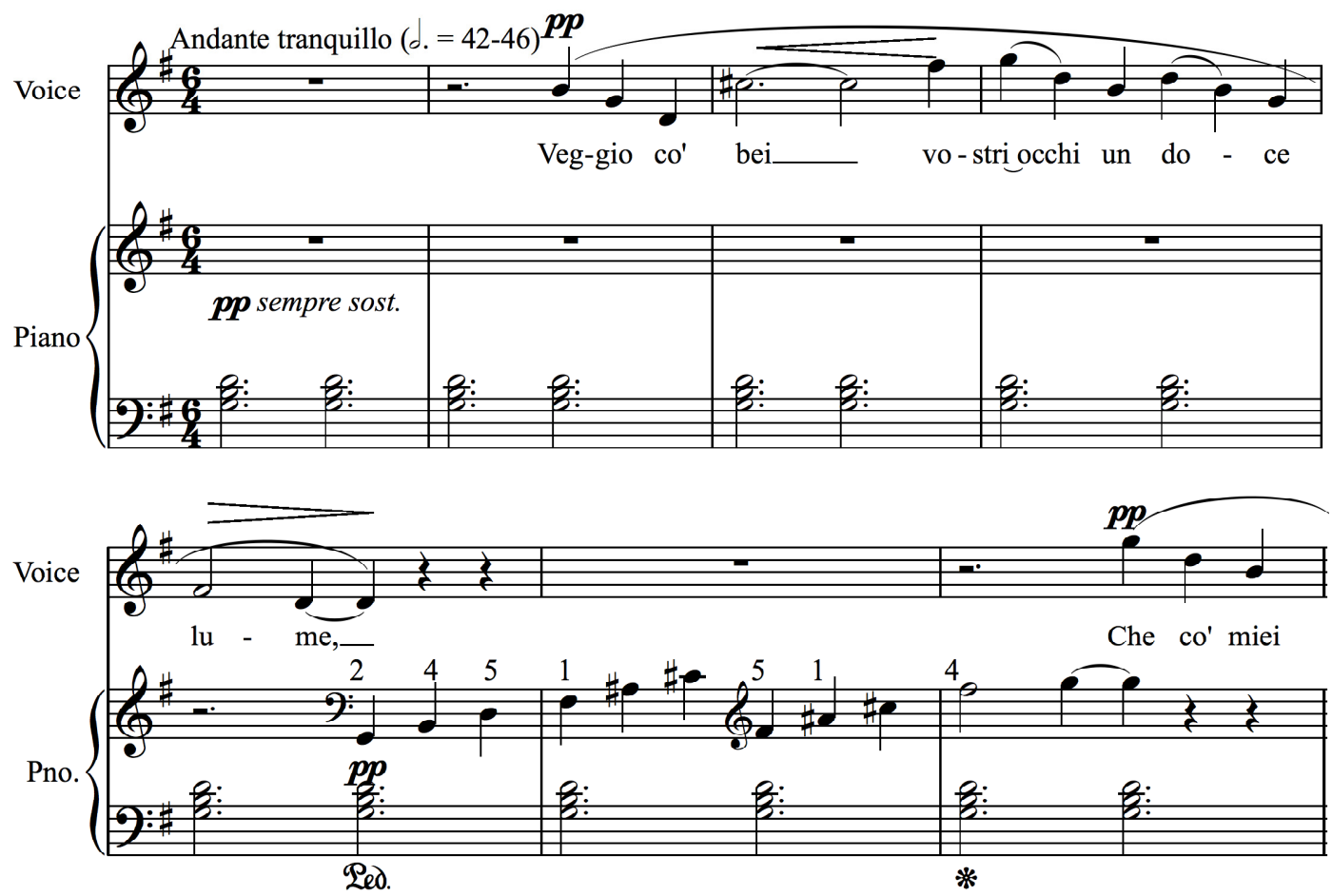

The word painting in mm.25-27 is obvious (the melody ascends setting the text "Col vostro ingegno al ciel sempre son mosso [With your spirit I move forever heavenward]") (See Example 3-16), but also took the singer above the passaggio for an impassioned, joyful expression of his indebtedness to the beloved.

Example 3-16, "Sonetto XXX," mm. 25-27. ${ }^{31}$

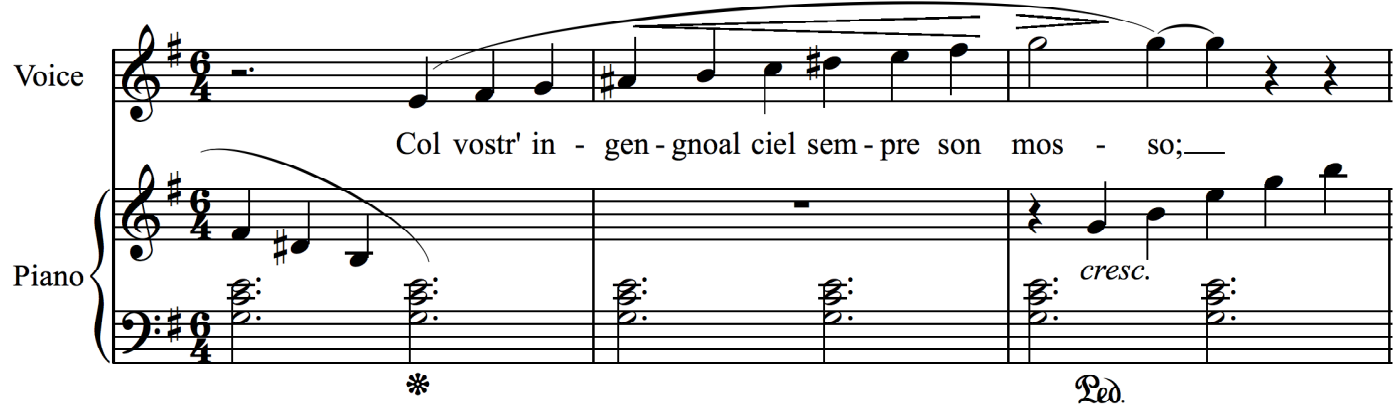

\footnotetext{
${ }^{30}$ Ibid., 10 .
}

${ }^{31}$ Ibid., 11. 
In mm. 39-50, Pears was to sing very softly in his passaggio, and in this way he was able to express the innocence and almost submissiveness of the text as he floated the voice ("Nel voler vostro è sol la voglia mia, i miei pensier nel vostro cor si fanno, nel vostro fiato son le mie parole. [My will is your will alone, my thoughts are born in your heart, my words are on your breath.]") (See Example 3-17). 
Example 3-17, “Sonetto XXX,” mm. 39-50. ${ }^{32}$
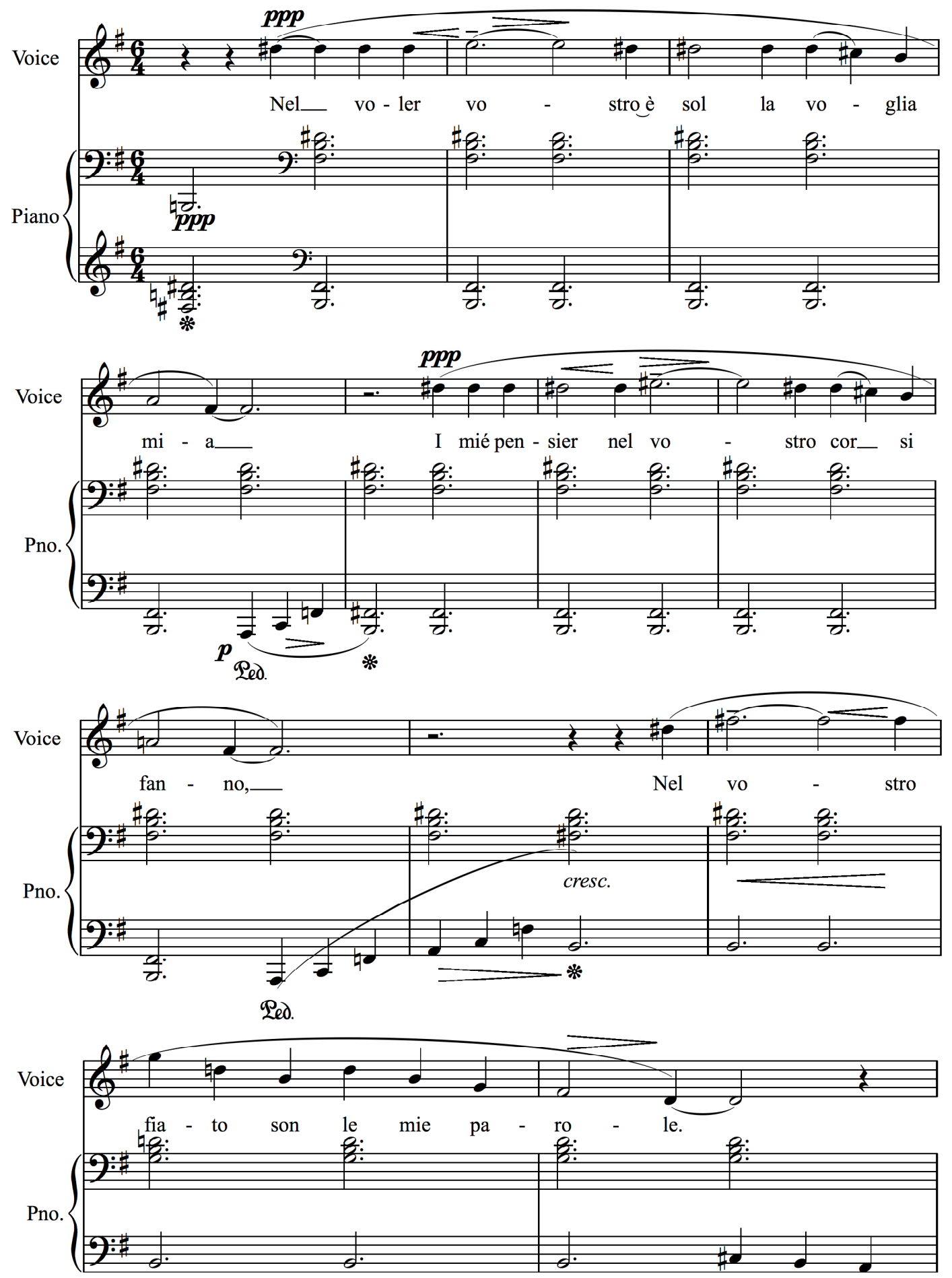

${ }^{32}$ Ibid., 12. 
The high B-natural on the word "ciel [heaven]," sometimes problematic for Pears as it lay at the top of his range, is another example of word-painting, as the singer's voice "moved heavenward" passionately, yearning for the completion that only his lover could bring to him (See Example 3$18)$.

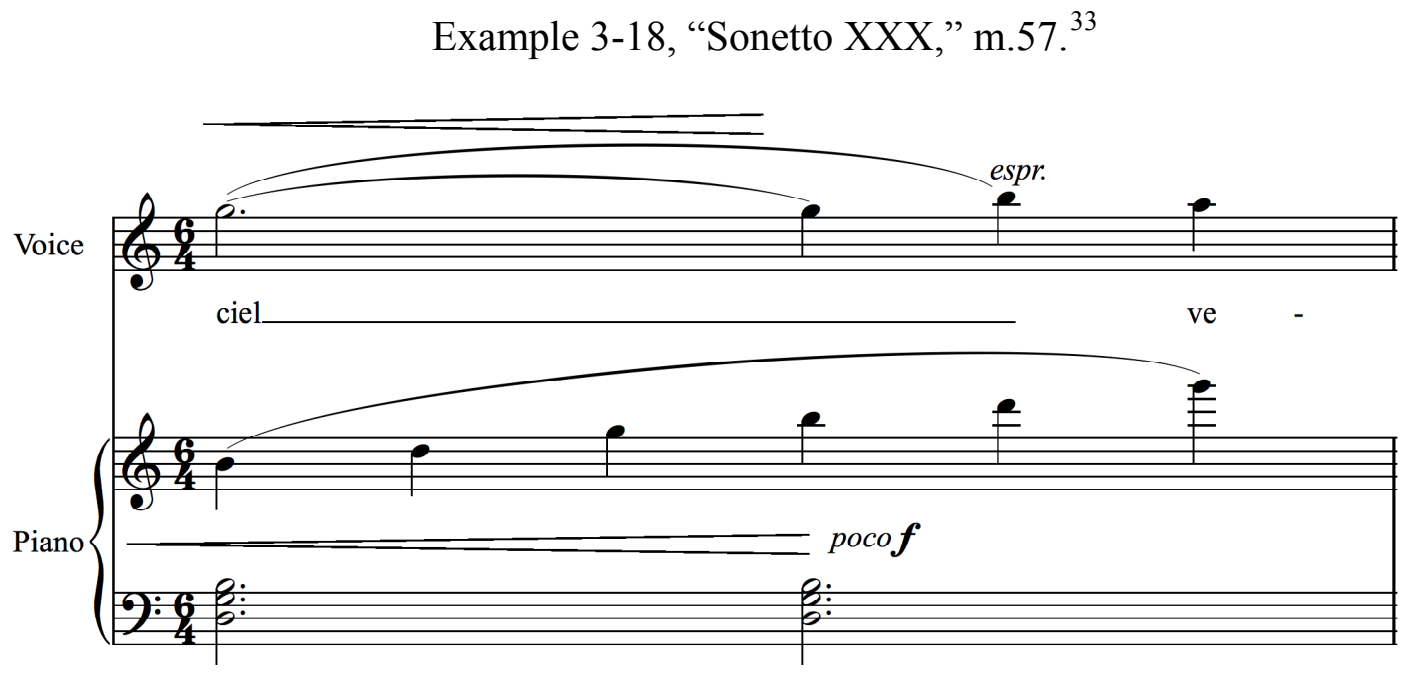

Sonetto LV

Tu sa' ch'io so, signior mie, che tu sai

ch'i' venni per goderti più da presso; e sai ch'i' so, che tu sa' ch'i' son desso:

a che più indugio a salutarci omai?

Se vera è la speranza che mi dài, se vero è'l buon desio che m'è concesso, rompasi il mur fra l'uno e l'altro messo, ché doppia forza hann'i celati guai.

S'i'amo sol di te, signior mie caro, quel che di te più ami, non ti sdegni, ché l'un dell'altro spirto s'innamora.

Quel che nel tuo bel volto bramo e 'mparo, That which in they lovely face I yearn for

\section{Sonnet LV}

Thou know'st, beloved, that I know thou know'st

that I am come nearer to enjoy thee more; and thou know'st that I know thou know'st that I am still the same.

why, then, do I hesitate to greet thee?

If the hope thou givest me is true, if true the strong desire that is granted me, the wall between us crumbles, for secret griefs have double force.

If I love in thee, beloved, only what thou lovest most, do not be angry; for so one spirit is enamoured of another.

\section{and seek to grasp,}

${ }^{33}$ Ibid., 13. 
e mal compress' è degli umani ingegni, is but ill understood by human kind, chi'l vuol veder convien che prima mora. and he that would see it, first must die.

The fourth song, Sonetto LV, perhaps the angriest of the set, is full of dotted rhythms and large disjunct intervals in the vocal line to express this anger, set above an angry motive in the accompaniment (See Example 3-19).

Example 3-19, "Sonetto LV," mm. 1-2. ${ }^{34}$

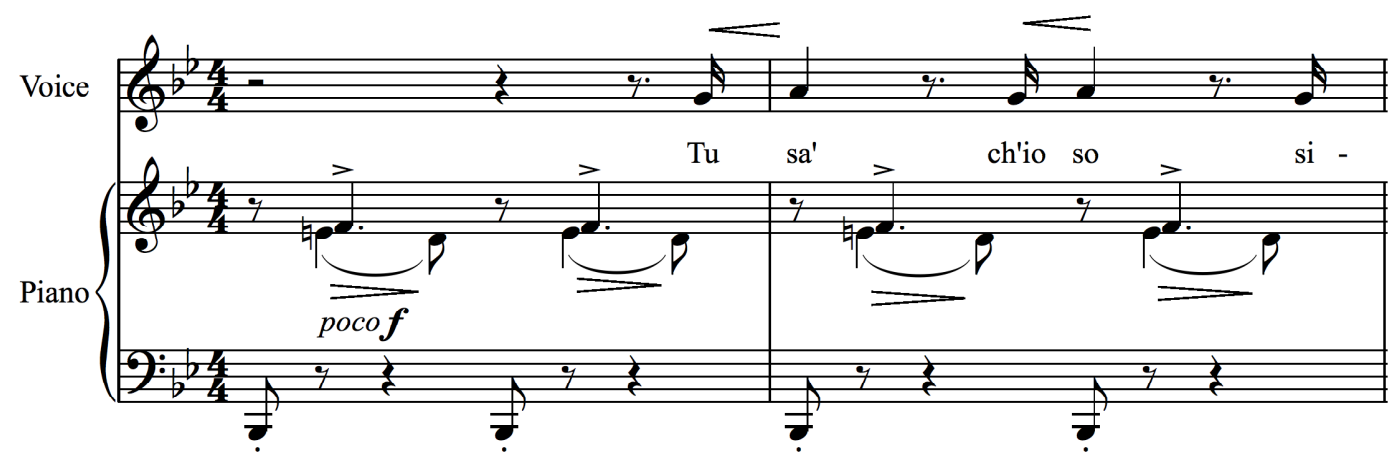

The composer again used the tenor's low range for more introspective or intimate moments such as at the end of this sonnet ("Chi'l vuol veder convien che prima mora [And he that would see it, first must die].") Pears was called upon to sing in his passaggio again in the recitative section found in $\mathrm{mm}$. 26-30, where the highly-charged energy of the preceding text gives way to gentler feelings of love, as the angry accompaniment figure dissolves into chords, before returning to a more forceful and almost desperate plea (up to an A-flat) that dissolves into despair as the melody descends to the bottom of the tenor's range ('S'i'amo sol di te, signior mie caro, quel che di te più ami, non ti sdegni; ché l'un dell' altro spirto s'innamora. Quel che nel tuo bel volto bramo e 'mparo e mal compress' è degli umani ingegni, chi'l vuol veder convien che prima mora [If I love in thee, beloved, only what thou lovest most, do not be angry; for so one spirit is

\footnotetext{
${ }^{34}$ Ibid., 14.
} 
enamoured of another. That which is thy lovely face I yearn for and seek to grasp - is but ill understood by human kind, and he that would see it, first must die]") (See Example 3-20).

$$
\text { Example 3-20, "Sonetto LV," mm. 19-34. }{ }^{35}
$$
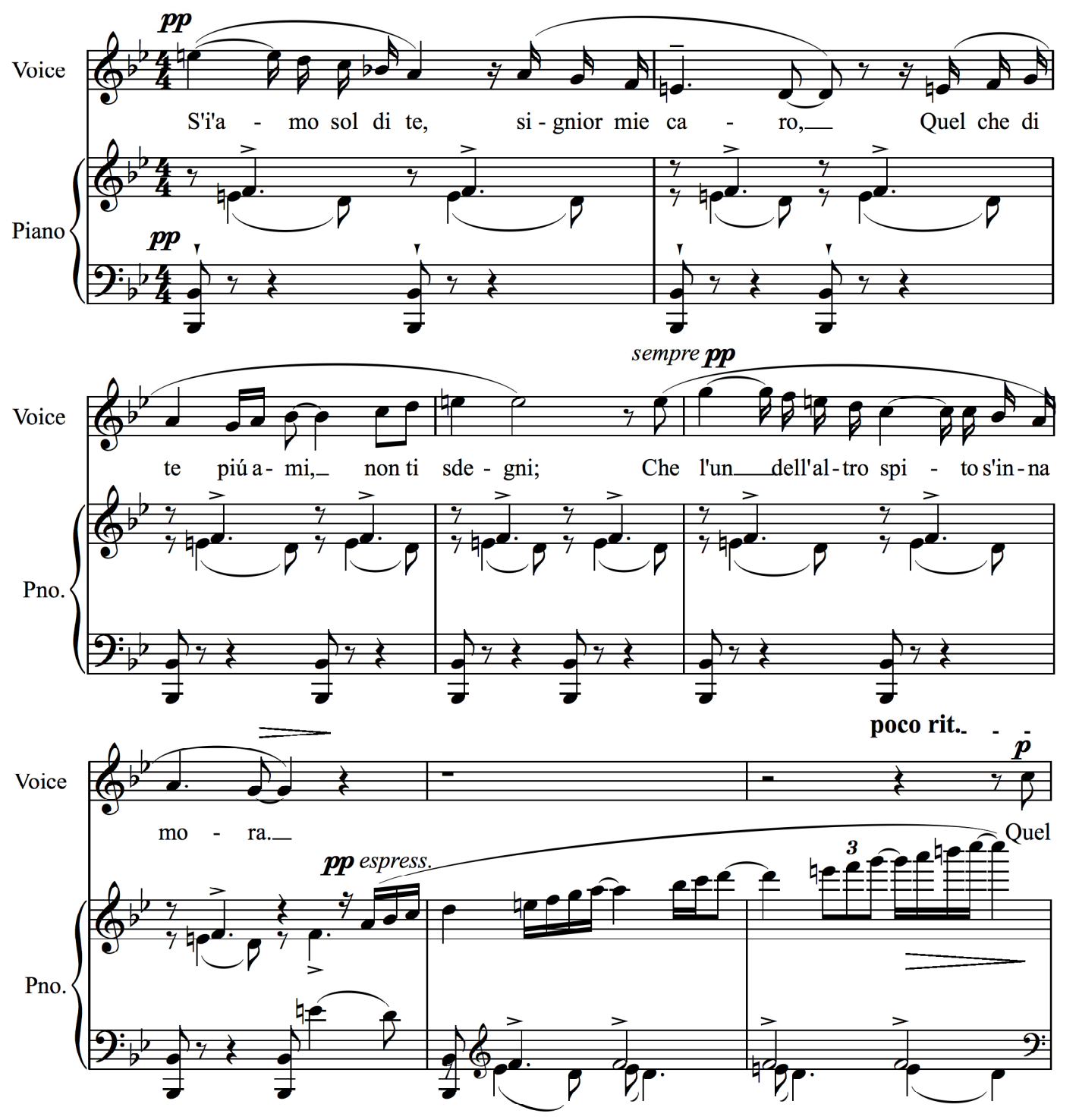

${ }^{35}$ Ibid., 16-17. 

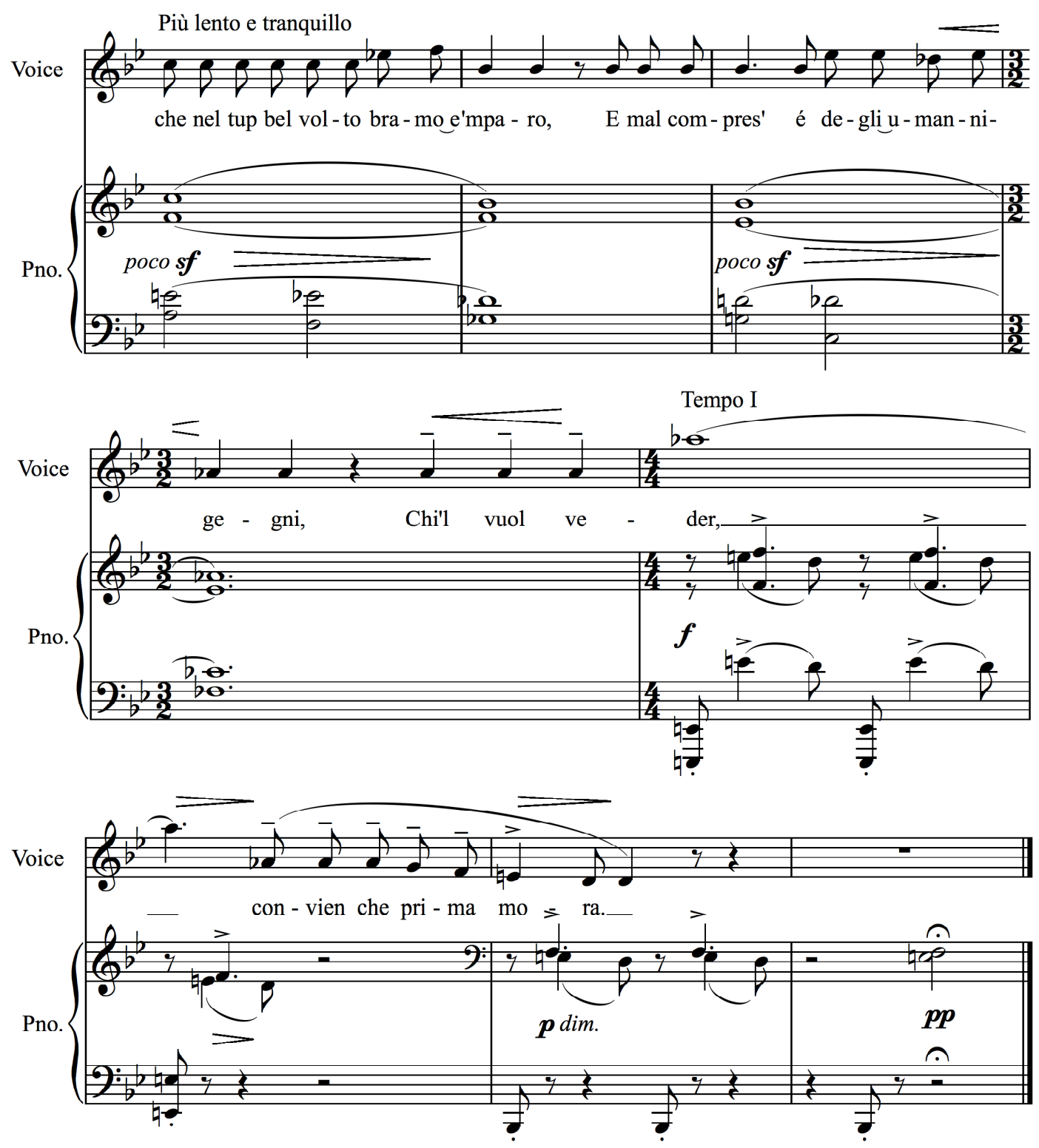

Sonetto XXXVIII

Rendete a gli occhi miei, o fonte o fiume,

l'onde della non vostra e salda vena,

che più v'innalza e cresce, e con più lena

che non è'l vostro natural costume.
Sonnet XXXVIII

Give back to my eyes, you fountains and rivers, the waves of those strong currents that are not yours,

which make you swell and grow with greater power

than is your natural way. 
E tu, folt'aír, che'l celeste lume

tempri a' tristi occhi, de' sospir mie piena, rendigli al cor mio lasso e rasserena

tua scura faccia al mio visivo acume.

Renda la terra i passi a le mie piante, ch'ancor l'erba germogli che gli è tolta,

e'l suono Ecco, già sorda a mie lamenti;

Gli sguardi a gli occhi mie' tue luci sante, ch'io possa altra bellezza un'altra volta amar, po' che di me non ti contenti.
And thou, heavy air, that dims the heavenly light

to my sad eyes, so full of my sighs art thou, give them back to my weary heart and lighten

thy dark face to my eye's keen sight.

Earth, give me back my footsteps that the grass may sprout again where it was trod; and Echo, yet deaf to my laments, give back thy sound;

and you blest pupils give back to my eyes their glances; that I another time may love another beauty, since with me you are not satisfied.

The text of the fifth setting, Sonetto XXXVIII, describes a man who wants to be returned to the days before this unrequited love took hold, and with the increasing intensity of the emotion the pitch rises. Over an accompaniment which is meant to represent that of a lute (See Example 3-21), a dotted rhythm in the vocal line seems to disrupt the $6 / 8$ meter and keep the listener on edge (See Example 3-22).

Example 3-21, "Sonetto XXXVIII," mm. 1-4. ${ }^{36}$

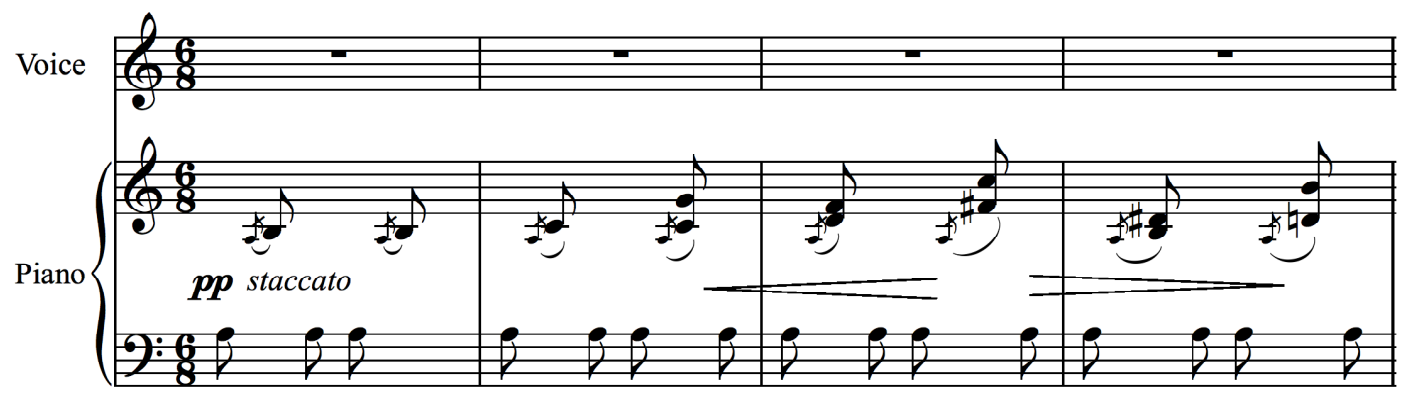

una corda sempre, senza 2 ed.

${ }^{36}$ Ibid., 18. 


\section{Example 3-22, "Sonetto XXXVIII," mm. 5-8. ${ }^{37}$}

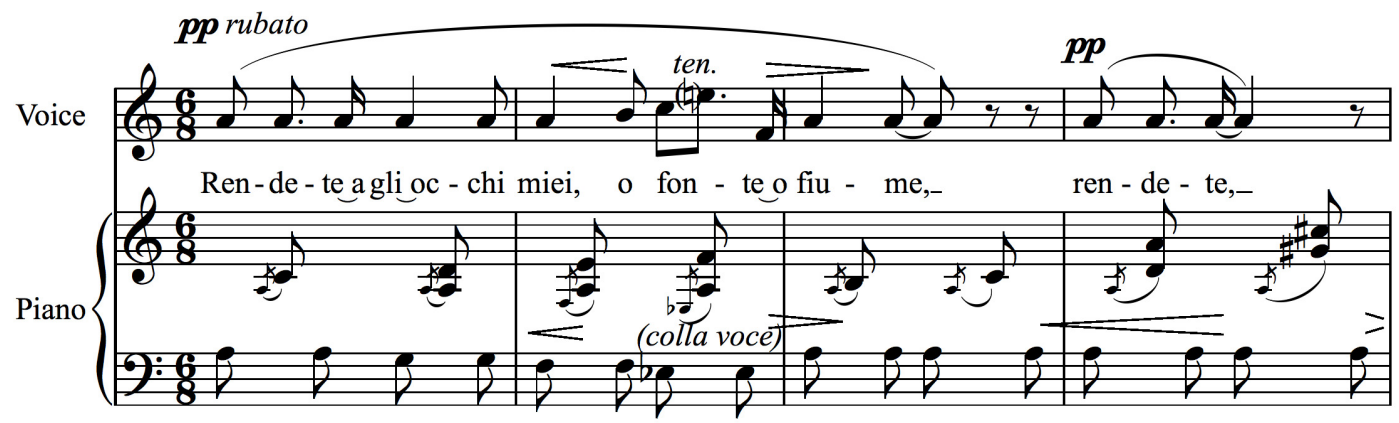

This setting ends in the lower middle voice, where Pears could draw on a heavy, mournful sound to express the despair at the end of this sonnet. ("Gli sguardi agli occhi miei tue luci sante, ch'i' possa altra bellezza un'altra volta amar, po' che di me non ti contenti. [And you blest pupils give back to my eyes their glances; that I another time may love another beauty, since with me you are not satisfied]" (See Example 3-23).

${ }^{37}$ Ibid., 18. 
Example 3-23, "Sonetto XXXVIII," mm. 46-65. ${ }^{38}$
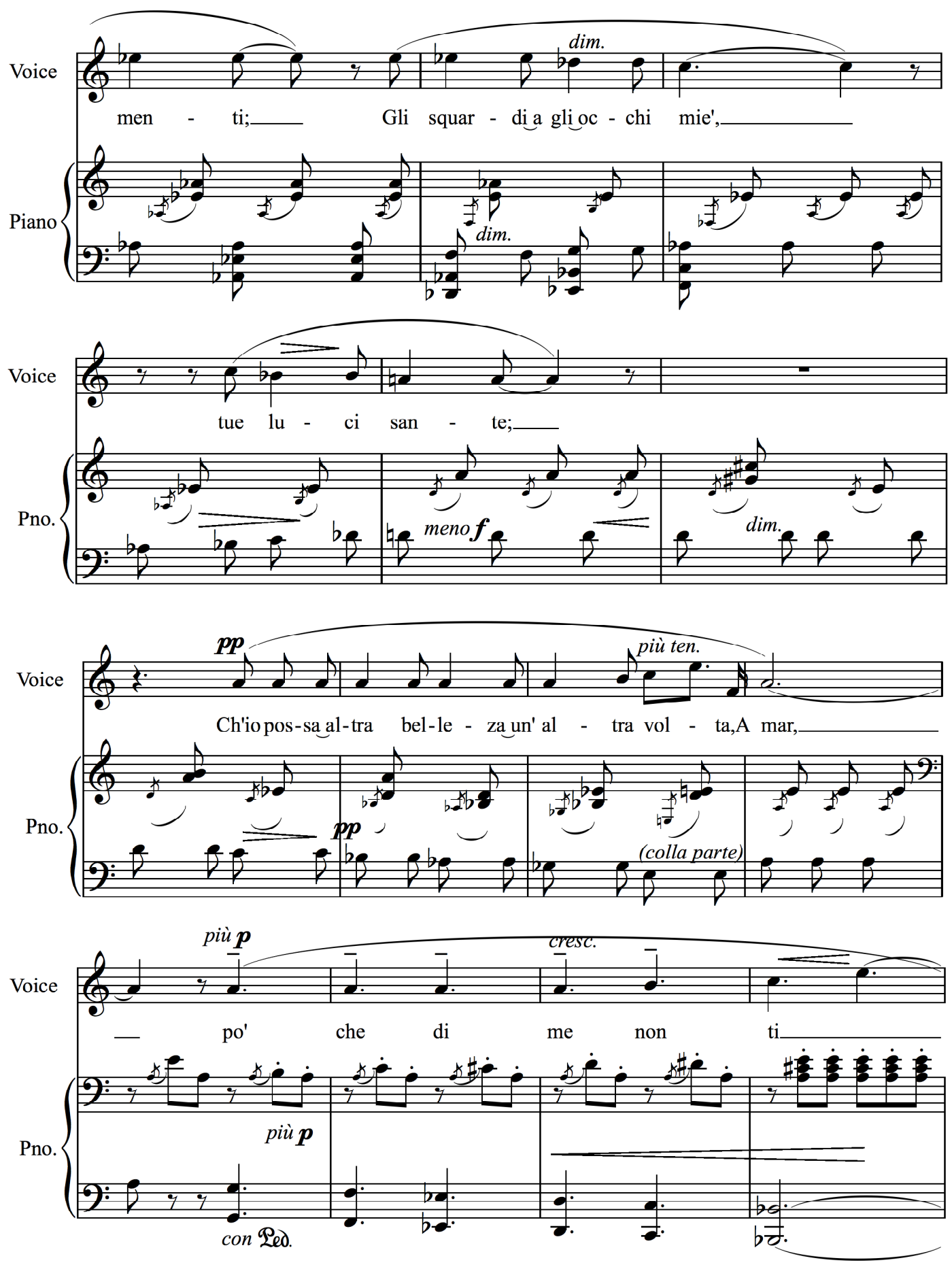

${ }^{38}$ Ibid., 20-21. 

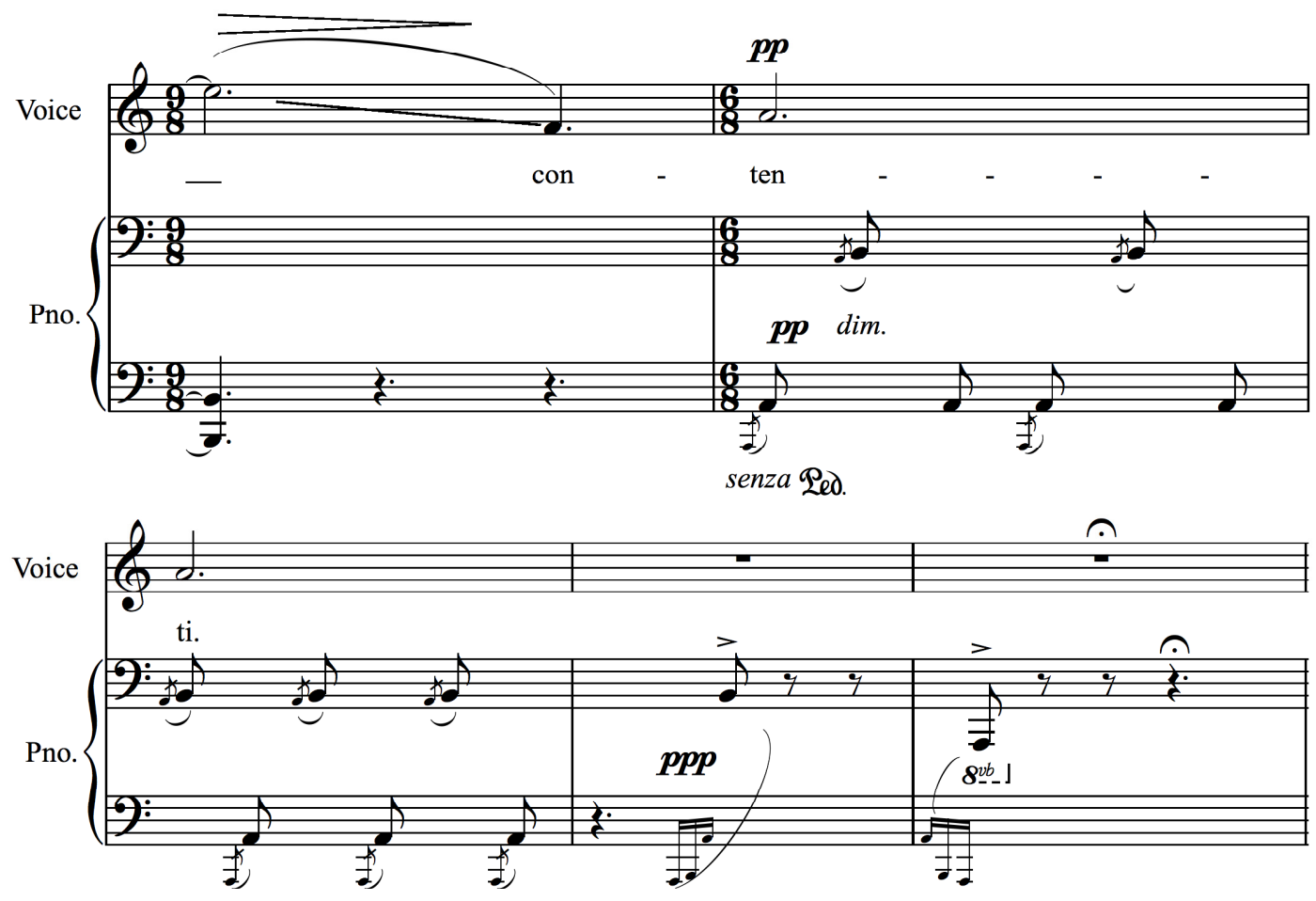

This setting is indicative of the way the composer would write for his lover's voice in the future. It has a climax to a high A-flat in the middle of the piece (See Example 3-24), but much of the drama of the text was set for the middle voice, because it was in this register that Pears could bring more color to his voice to heighten the meaning of the text.

Example 3-24, “Sonetto XXXVIII,” mm. 43-44. ${ }^{39}$

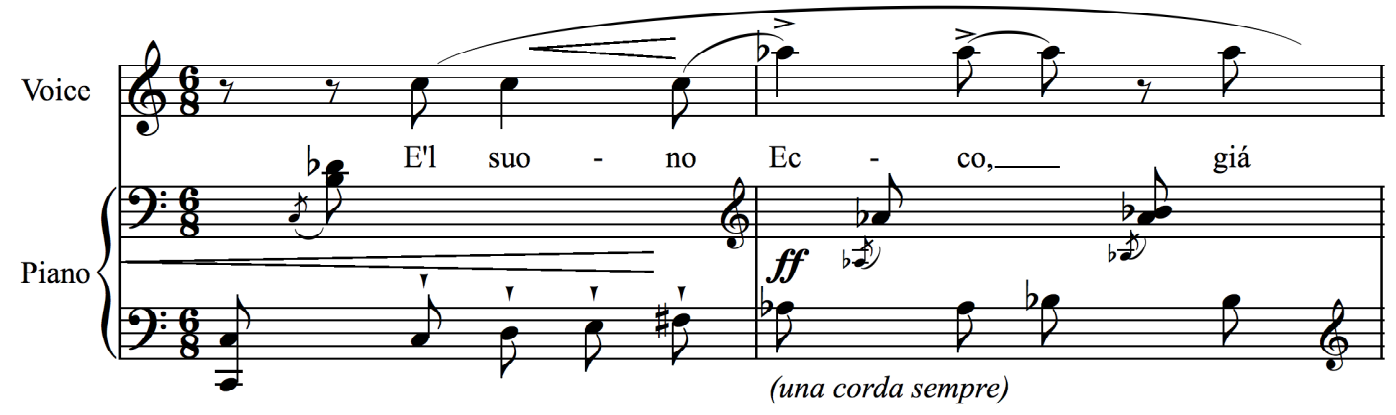

${ }^{39}$ Ibid., 20 
Although Britten's later works for Pears certainly contained pitches above the passaggio, the composer did not always reserve the high notes for the final climax of the piece; he instead found other ways to utilize Pears's voice for dramatic effect including large melodic skips, great dynamic contrast, or the use of the mournful and fragile sound of notes slightly lower in his range, in his passaggio as opposed to above it.

\section{Sonetto XXXII}

S'un casto amor, s'una pietà superna, S'una fortuna infra dua amanti eguale, S'un' aspra sorte all'un dell'altro cale, S'un spirto, s'un voler duo cor governa;

S'un'anima in duo corpi è fatta eterna, Ambo levando al cielo e con pari ale; S'Amor d'un colpo e d'un dorato strale Le viscier di duo petti arda e discierna;

S'amar l'un l'altro e nessun se medesmo,

D'un gusto e d'un diletto, a tal mercede

C'a un fin voglia l'uno e l'altro porre:

Se mille e mille, non sarien centesmo

A tal nodo d'amore, a tanta fede; E sol l'isdegnio il può rompere e sciorre.

\section{Sonnet XXXII}

If love be chaste, if pity heavenly, If fortune equal between two lovers; If a bitter fate is shared by both, And if one spirit, one will rules two hearts;

If in two bodies one soul is made eternal, Raising both to heaven on the same wings; If at one stroke and with a gilded arrow Love burns and pierces two hearts to the core;

If in loving one another, forgetting one's self,

With one pleasure and one delight there is such reward that both wills strive for the same end;

If thousands and thousands do not make one hundredth part

To such a bond of love, to such constancy, Can, then, mere anger break and dissolve it?

The youthfulness of the voice at this time allowed for the aggressive passage of patter in the sixth sonnet, Sonetto XXXII, which an older Pears would certainly have been capable of singing but not with the same degree of vigor (See Example 3-25). 
Example 3-25, "Sonetto XXXII," (a.) mm. 5-8, (b.) 11-14, (c.) 17-20. ${ }^{40}$

(a.)
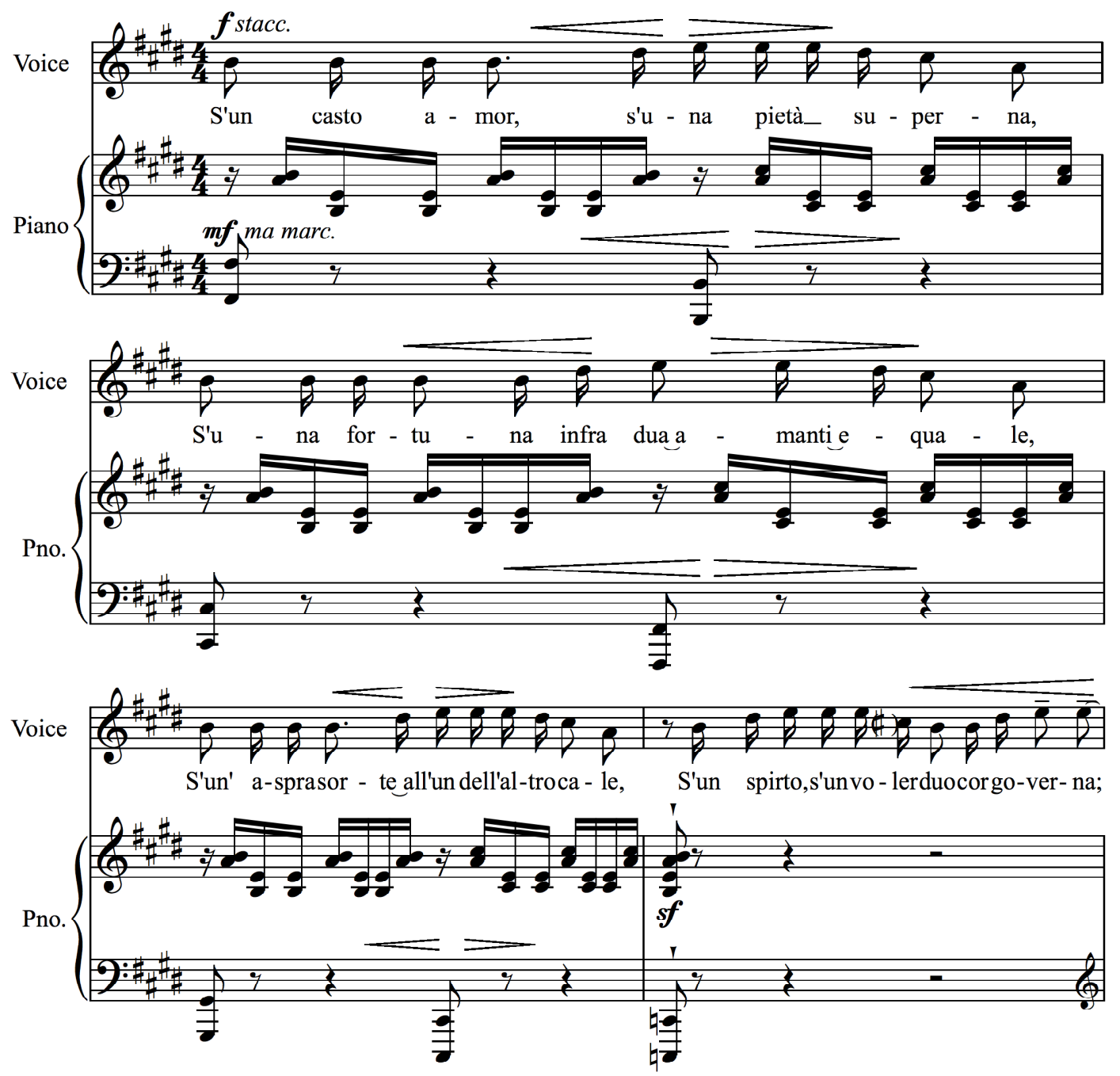

${ }^{40}$ Ibid., 22, 23, 24. Examples from "Sonetto XXXII" reproduced with kind permission of Boosey \& Hawkes, Inc. 
(b.)
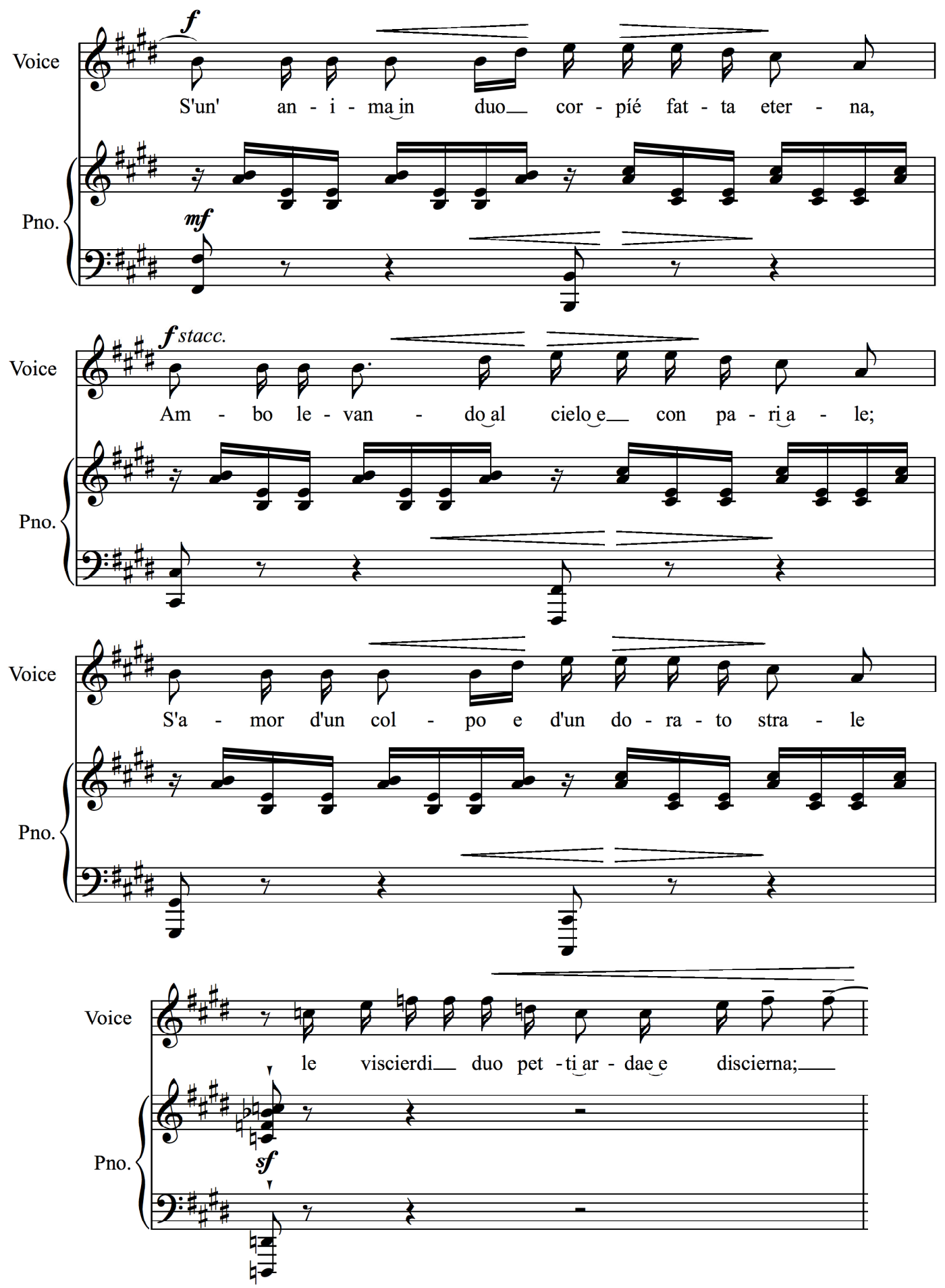
(c.)
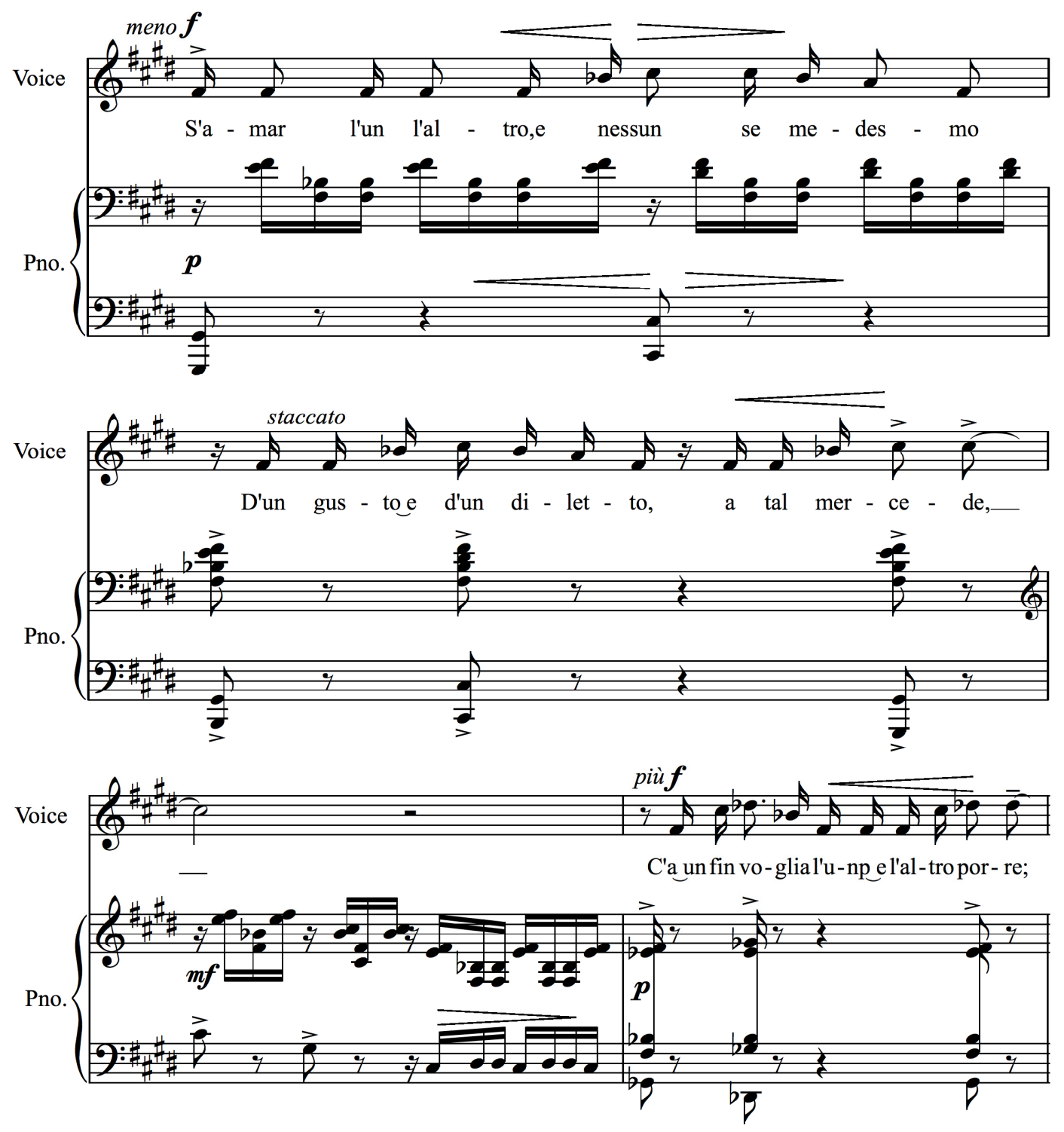

The accompaniment is just as aggressive, if not more so, again developing a motive throughout the setting which supports the affect of the text (See Example 3-26). 


\section{Example 3-26, “Sonetto XXXII," mm. 1-4. ${ }^{41}$}
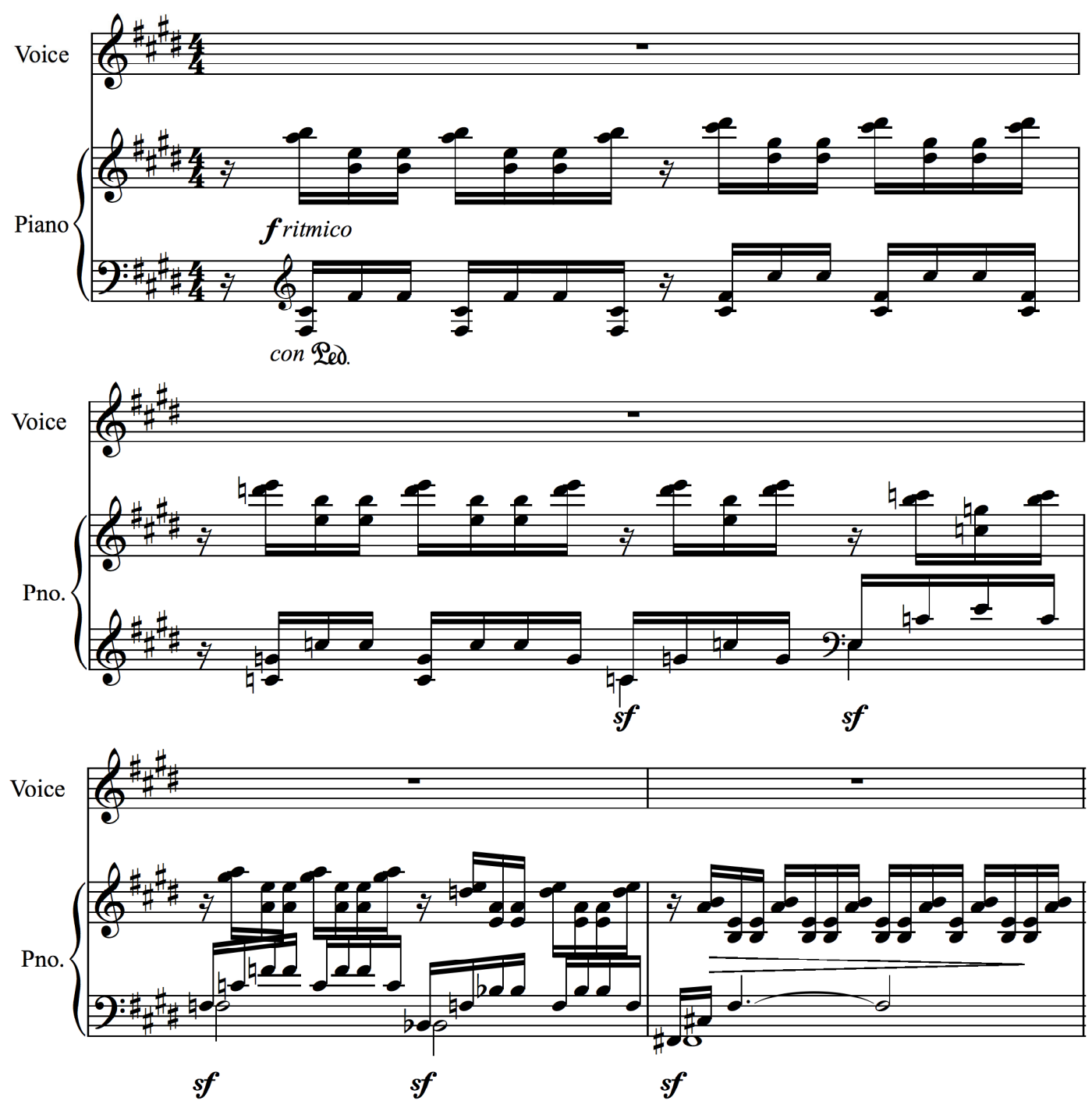

This sonnet also sits fairly high in the tenor's range: this was a good range for the tenor to get the text out and to be fairly intelligible. The poet clearly defies anyone to find fault with the love between the two men, ("Se mille e mille, non sarien centesmo a tal nodo d'amore, a tanta fede; e sol l'isdegnio il può rompere e sciorre. [If thousands and thousands do not make one hundredth part to such a bond of love, to such constancy, can, then, mere anger break and dissolve it?]”) which was clearly a very assertive statement for Britten to be making in the homophobic

\footnotetext{
${ }^{41}$ Ibid., 22.
} 
atmosphere of the United Kingdom at this time, and the athleticism of both parts clearly

expresses this idea of an unbreakable love, although as mentioned before, the Italian language did help to mute the statement.

\section{Sonetto XXIV}

Spirto ben nato, in cui si spechia e vede Nelle tue belle membra oneste e care Quante natura e'l ciel tra no' può fare, Quand'a null' altra suo bell'opra cede:

Spirto leggiadro, in cu' si spera e crede

Dentro, come di fuor nel viso appare, Amor, pietà, mercé, cose si rare, Che ma' furn'in beltà con tanta fede;

L'amor mi prende e la beltà mi lega;

La pietà, la mercé con dolci sguardi

Ferma speranz'al cor par che ne doni.

Qual uso o qual governo al mondo niega, Qual crudeltà per tempo o qual più tardi, C'a si bel viso morte non perdoni?

\section{Sonnet XXIV}

Noble soul, in whose chaste and dear limbs Are reflected all that nature and heaven can achieve with us, The paragon of their works:

Graceful soul, within whom one hopes and believes

Love, Pity and Mercy are dwelling, As they appear in your face;

Things so rare and never found in beauty so truly:

Love takes me captive, and Beauty binds me;

Pity and Mercy with sweet glances fill my heart

With a strong hope.

What law or earthly government, What cruelty now or to come, Could forbid Death to spare such a lovely face?

The text of the last sonnet, Sonetto XXIV, is a grand expression of love with less anger bubbling under the surface; consequently the vocal line is much more lyrical. After an extended piano solo, grand and noble mirroring the affect of the text (See Example 3-27), the vocal line is just as grand in its own respect, extending an octave and a fifth in the first lengthy statement of the voice and an octave and a sixth in the second. 
Example 3-27, “Sonetto XXIV,” mm. 1-8. ${ }^{42}$
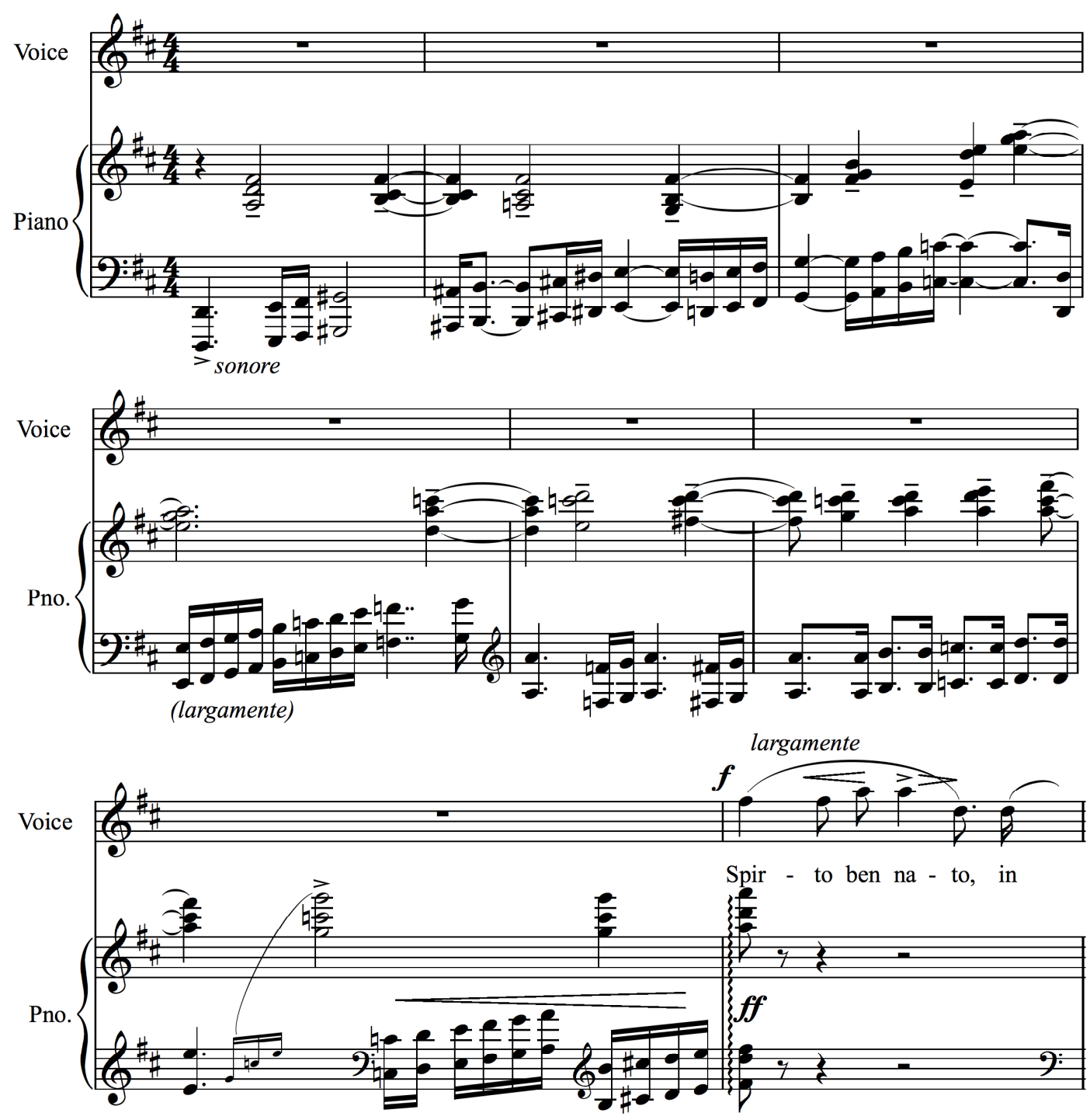

Throughout this sonnet, the composer gave his partner the opportunity to use different colors of his voice: bold high A-naturals at the beginning of the first two verses which seem to dare the listener to challenge this love, and use of the full expanse of the tenor's range as if to show the extent of the love (See Example 3-28).

\footnotetext{
${ }^{42}$ Ibid., 26.
} 
Example 3-28, "Sonetto XXIV," mm. 21-28. ${ }^{43}$
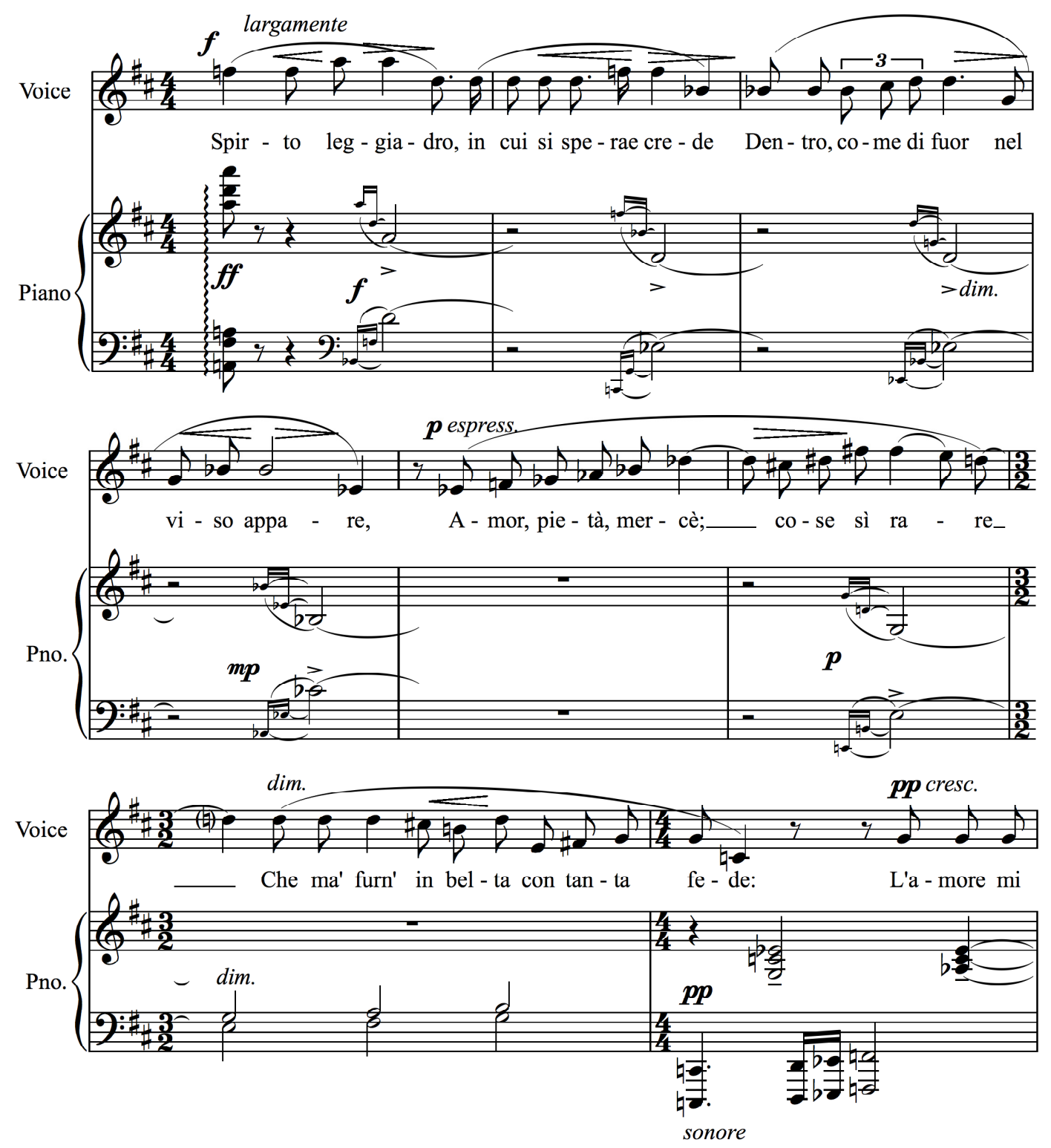

Britten once again used Pears's lower voice to express the intimacy of the last statements of this sonnet (“Qual uso o qual governo al mondo niega, qual crudeltà per tempo o qual più tardi, c’a si bel viso morte non perdoni? [What law or earthly government, what cruelty now or to come, could forbid Death to spare such a lovely face?]" (See Example 3-29).

\footnotetext{
${ }^{43}$ Ibid., 27-28.
} 
Example 3-29, “Sonetto XXIV," mm. 35-40. ${ }^{44}$
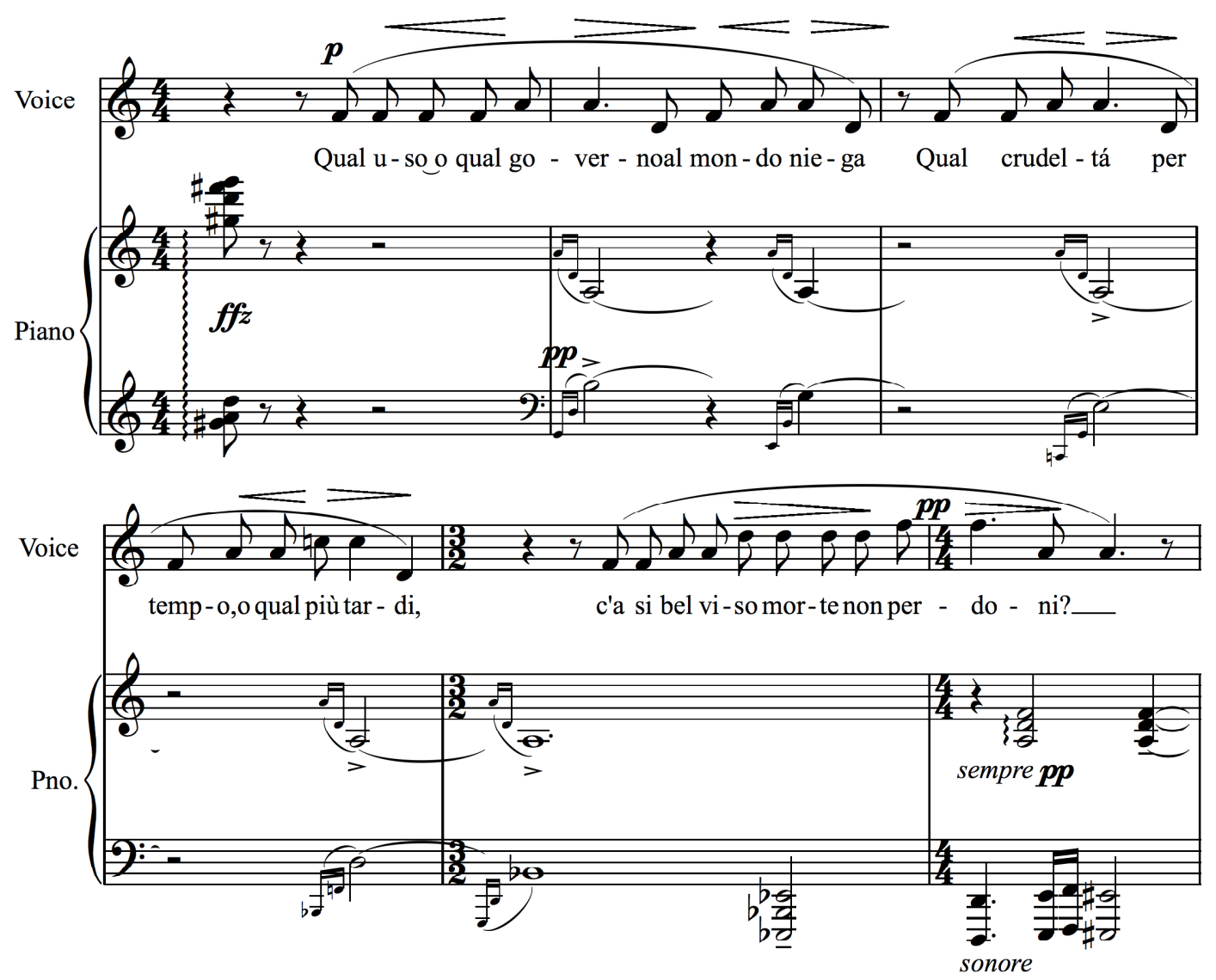

The accompaniment is sparse here, so as to allow the singer to be heard, and the effect of the quiet, almost weak sound of the tenor's low voice indicates an awe at the beauty of the narrator's object of affection.

With this first cycle, we see the two men engaged in the early stages of an ongoing artistic collaboration. In Seven Sonnets of Michelangelo, we are able to discern the composer's approach to text-setting and the tenor's ability to communicate those ideas to an audience.

Although Pears was reluctant to attempt these songs before he felt vocally ready for them, ${ }^{45}$ the pieces were very well-written for him to express the meanings of the texts dramatically. The composer already was able to use Pears's voice to express the texts just as the tenor was able to

\footnotetext{
${ }^{44}$ Ibid., 29.

${ }^{45}$ Goeke, 16.
} 
understand and communicate Britten's intentions, and they only continued to improve these skills in the compositions that followed.

The texts of this cycle are those of a man who is at first confused and upset by his feelings of love (for another man) but slowly comes to terms with his anger, the unrequited nature of the love, and society's treatment of his feelings. The extent to which these texts are autobiographical is debatable, other than the fact that they deal with homosexuality. That is to say, the songs in the cycle do not represent the story of the relationship between Britten and Pears. However, it is reasonable to assume that the feelings expressed in the sonnets chosen by the composer were those experienced by either or both of the men in their lives to that point in relationships with others, if not with each other. In this way, the composer chose texts with subject matter with which both performers could identify psychologically and arranged them in such a manner as to form a cohesive narrative which he knew the singer could communicate well. The musical style of the composition is at times grand and operatic in the Italian tradition, specifically in the use of the tenor's high notes for climactic passages. The accompaniments develop short motives which helped to set the mood for each poem and allowed the tenor to further express the meaning of each poem.

These traits, the ability to infuse the poems with a style appropriate to their own composition and creating accompaniments which support the emotions of the poetry, are apparent in the following works as well, giving each cycle its own identity. The composer's careful selection of texts and consideration of interest from both performers continues to be found in the subsequent cycles as well. 


\section{CHAPTER 4}

The Holy Sonnets of John Donne, opus 35

(1945)

Five years elapsed between the composition of Seven Sonnets of Michelangelo and The Holy Sonnets of John Donne. During the interval, Britten and Pears returned to the United Kingdom, and as part of their service as conscientious objectors gave recitals across the country. ${ }^{1}$ Their performances included not only the composer's own works, among these being the setting of the Michelangelo Sonnets, but Franz Schubert's lieder and airs by Henry Purcell as well. The influence of these composers on the way that Britten set the text of the Holy Sonnets is apparent almost immediately, as is the composer's developing musical style and the confidence he had in his partner's abilities both technically and expressively exemplified by the setting of the texts in this cycle.

Just as in the Michelangelo Sonnets, the composer carefully chose and ordered John Donne's sonnets in such a way as to create a psychological journey from the beginning to the end. The order in which the nineteen sonnets were published by Donne is not known, ${ }^{2}$ and the sonnets in their entirety form no particular narrative on their own: the narrative of the cycle therefore was of Britten's own imagination. The journey begins as the poet expresses despair over his own brokenness (“Oh My Blacke Soule!”) followed by self-pitying anger towards his maker in the second ("Batter My Heart"). This emotion gives way in the third setting ("O Might Those Sighes and Teares”) to feelings of brokenness and self-pity in the midst of more sorrowful questioning. This is followed in the fourth by more panicked feelings ("Oh, To Vex Me") and then in the fifth by the realization of his guilt ("What If This Present"). The sixth setting is the

\footnotetext{
${ }^{1}$ Christopher Headington, Peter Pears: A Biography (London: Faber and Faber, 1992), 118-119.

${ }^{2}$ Rembert Bryce Herbert, Jr, “An Analysis of Nine Holy Sonnets of John Donne Set to Music by Benjamin Britten." (Ph.D. diss., American University, 1974): 10.
} 
clearest statement of the cause of this spiritual crisis, from which point the poet can begin to heal ("Since She Whom I Loved"). The seventh setting (“At the Round Earth's Imagined Corners") is a more hopeful representation of the Judgment Day (as compared to the poet's representation of it in the fifth song), as he asks for guidance. The eighth is a passionate challenge to God to teach the poet salvation ("Thou Hast Made Me"), and the final setting ("Death, Be Not Proud") is the resolution of all this crisis, a realization that the poet can in fact triumph over adversity and that death has no power over him.

In The Holy Sonnets of John Donne, Britten used the tenor's upper middle voice for more heroic, steadfast statements since, when he covered the sound in this region of his voice, Pears was able to produce a very warm, rich tone. The range of the cycle is similar to that of the Michelangelo songs although not as consistently high: it spans from the $\mathrm{C}$ below middle $\mathrm{C}$ to the B-flat above it, but there is a greater range within phrases in comparison to that of the previous cycle. The angularity of phrases in certain of these settings was meant to express the tormented nature of the texts. The singer was required to stay in a lower range at times, which is something Pears could do to great effect either to express anger, as if through clenched teeth, a passive acceptance, or even a sneering defiance. At the other extreme, throughout the cycle there is urgency to the high notes. These high notes are meant to be neither heroic nor steadfast, but instead they express feelings that are emotionally unstable and highly charged.

\section{Oh My Blacke Soule!}

Oh my blacke Soule! Now thou art summoned

By sicknesse, death's herald, and champion; Thou art like a pilgrim, which abroad hath done Treason, and durst not turne to whence hee is fled, Or like a thiefe, which till death's doome be read,

Wisheth himselfe deliver'd from prison; 
But damn'd and hal'd to execution, Wisheth that still he might be imprisoned.

Yet grace, if thou repent, thou canst not lacke;

But who shall give thee that grace to beginne?

Oh make thy selfe with holy mourning blacke,

And red with blushing, as thou art with sinne;

Or wash thee in Christ's blood, which hath this might

That being red, it dyes red soules to white.

The first setting in the cycle, "Oh My Blacke Soule," begins with a dotted figure in the accompaniment, a single pitch in four octaves, which establishes the heavy mood of the piece (See Example 4-1).

Example 4-1, “O My Blacke Soule!,” mm. 1-2. ${ }^{3}$

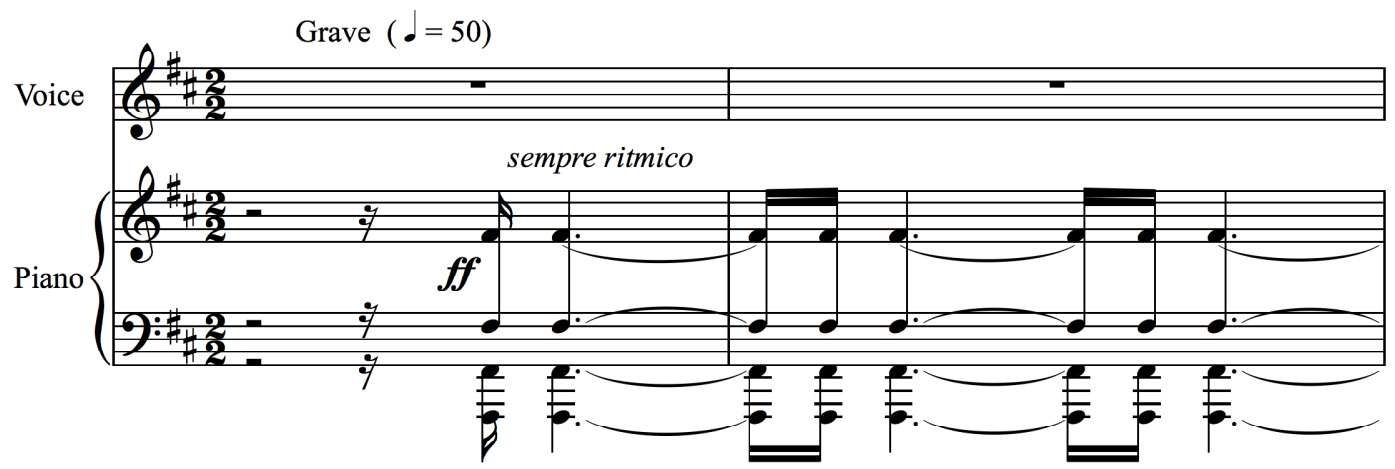

This motive in the accompaniment is repeated throughout the piece. The opening is followed by a very angular melody traversing just over an octave in four notes (See Example 4-2).

\footnotetext{
${ }^{3}$ Benjamin Britten, The Holy Sonnets of John Donne, opus 35 (New York: Boosey \& Hawkes, 1946), 3. Examples from "Oh My Blacke Soule" reproduced with kind permission of Boosey \& Hawkes, Inc.
} 
Example 4-2, "O My Blacke Soule!," mm. 3-5.

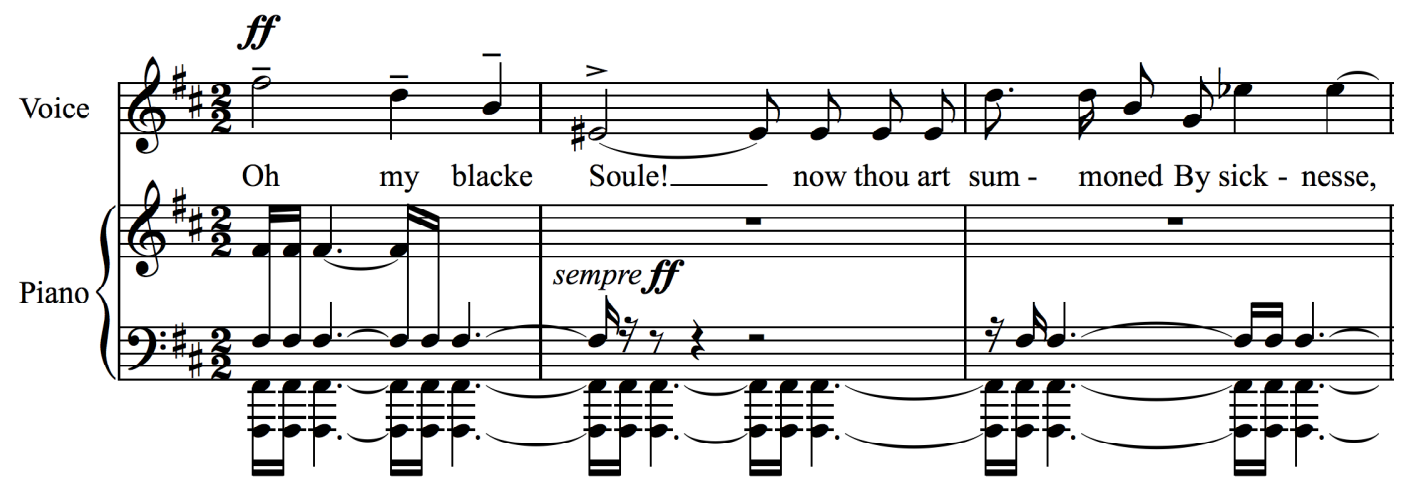

Throughout these settings of the Holy Sonnets this kind of angularity can be found, attesting to the composer's knowledge that the singer, capable of negotiating such leaps, would be able to use the colors of his voice to express the angularity of emotion expressed in a particular passage. This setting in particular is full of examples of very disjunct melodic ideas, for example at the text "Or like a thiefe," "damn'd and hal'd to execution," and “... it dyes red soules to white ..." (See Example 4-3).

${ }^{4}$ Ibid., 3. 
Example 4-3, “O My Blacke Soule!,” (a.) mm. 14, (b.) 19-20, (c.) 40-42.

(a.)

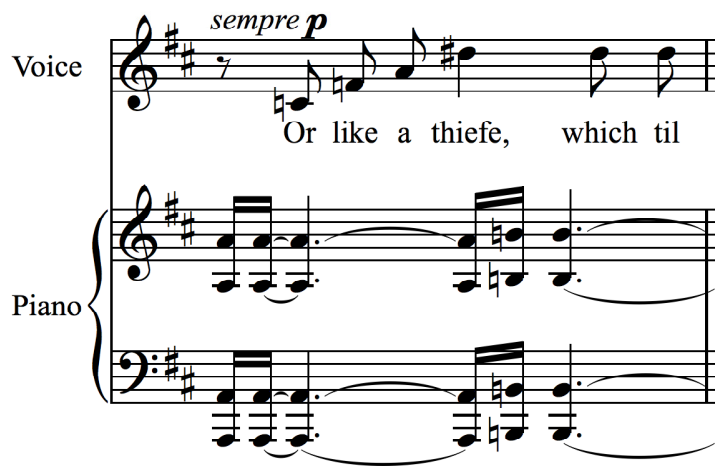

(b.)

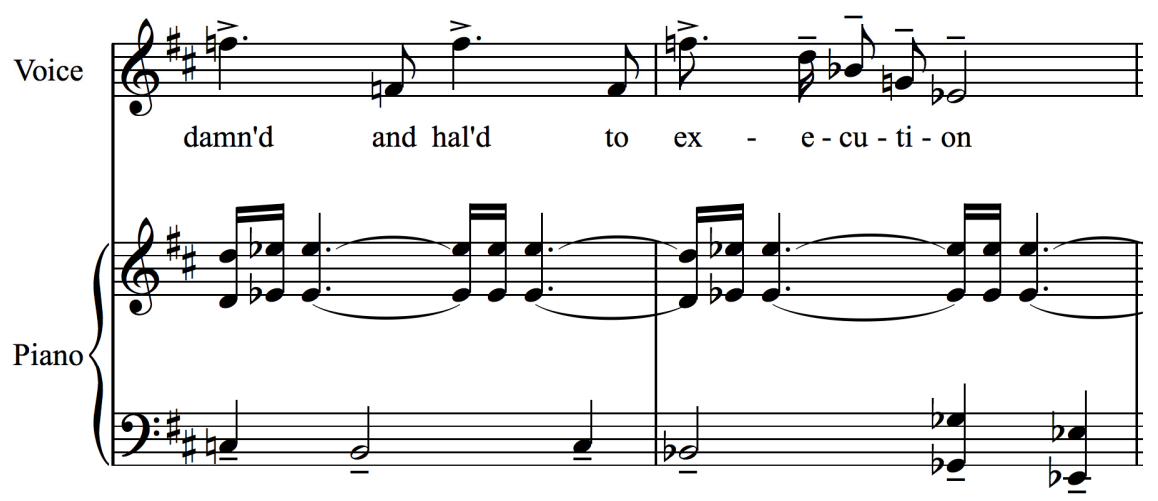

(c.)

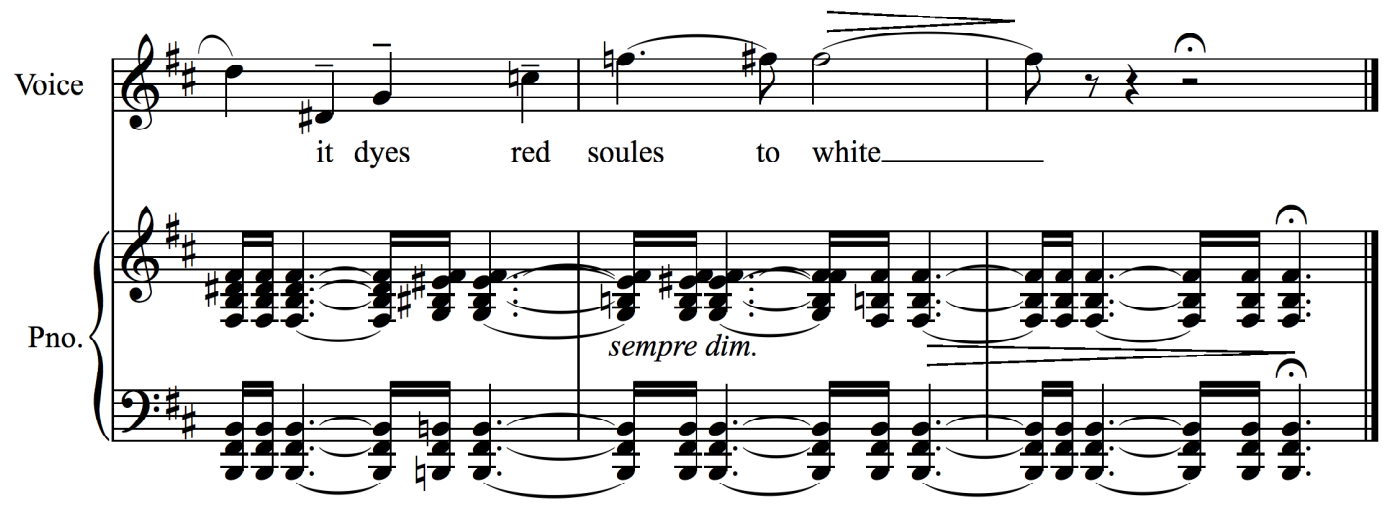

The opening melodic idea returns in m. 31 as the narrator turns to God for guidance in his time of suffering and confusion (See Example 4-4).

\footnotetext{
${ }^{5}$ Ibid., 4, 5, 6 .
} 
Example 4-4, “O My Blacke Soule!” mm. 31-33. 6

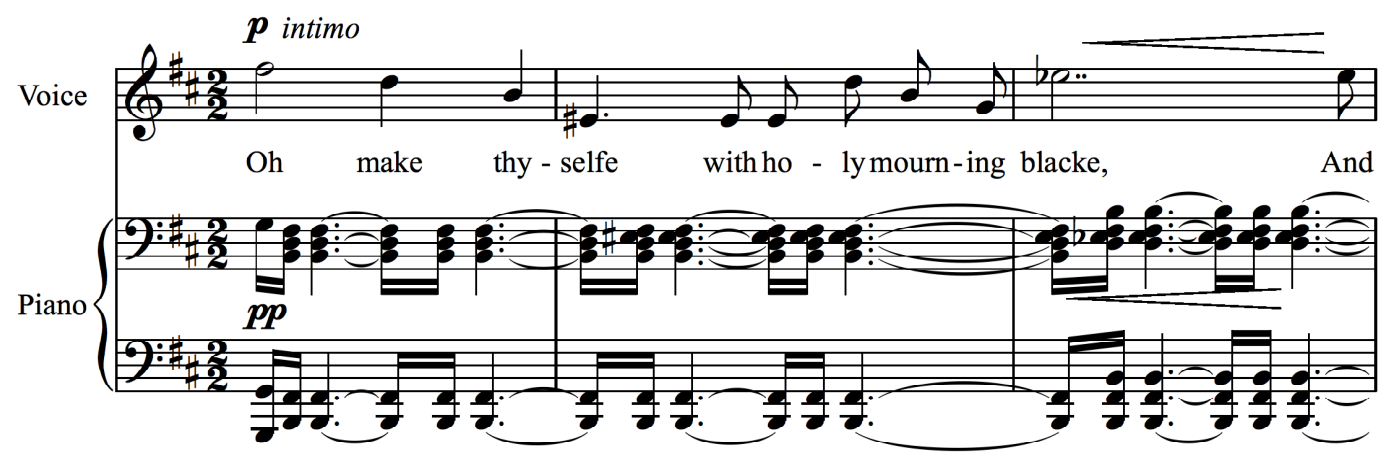

To express more intensely the anger and confusion of the text, the singer is not taken very high in his range which allowed the tenor to use a heavier tone quality and thereby helped him to portray a man weighed down by his spiritual dilemma. Throughout the cycle, the composer used this technique to express anger, whereas he was inclined to reserve pitches above the passaggio for moments of greater defiance.

\section{Batter My Heart}

Batter my heart, three person'd God; for you As yet but knocke, breathe, shine, and seeke to mend; That I may rise, and stand, o'erthrow mee, and bend

Your force, to breake, blowe, burn and make me new.

I, like an usurpt towne, to'another due,

Labour to'admit you, but Oh, to no end, Resaon your viceroy in mee, mee should defend,

But is captiv'd, and proves weake or untrue.

Yet dearely I love you, and would be loved faine,

But am bethroth'd unto your enemie:

Divorce mee, untie, or breake that knot againe,

Take mee to you, imprison mee, for I

Except you enthrall mee, never shall be free,

Nor ever chaste, except you ravish mee.

\footnotetext{
${ }^{6}$ Ibid., 5.
} 
"Batter My Heart," the second setting, could be compared to the sixth of the Michelangelo settings because of its quick accompaniment figures and quick text declamation, but the overall musical effect is quite different than that of the earlier piece (See Examples 4-5 and 4-6).

\section{Example 4-5, "Batter My Heart," mm. 1-4.}

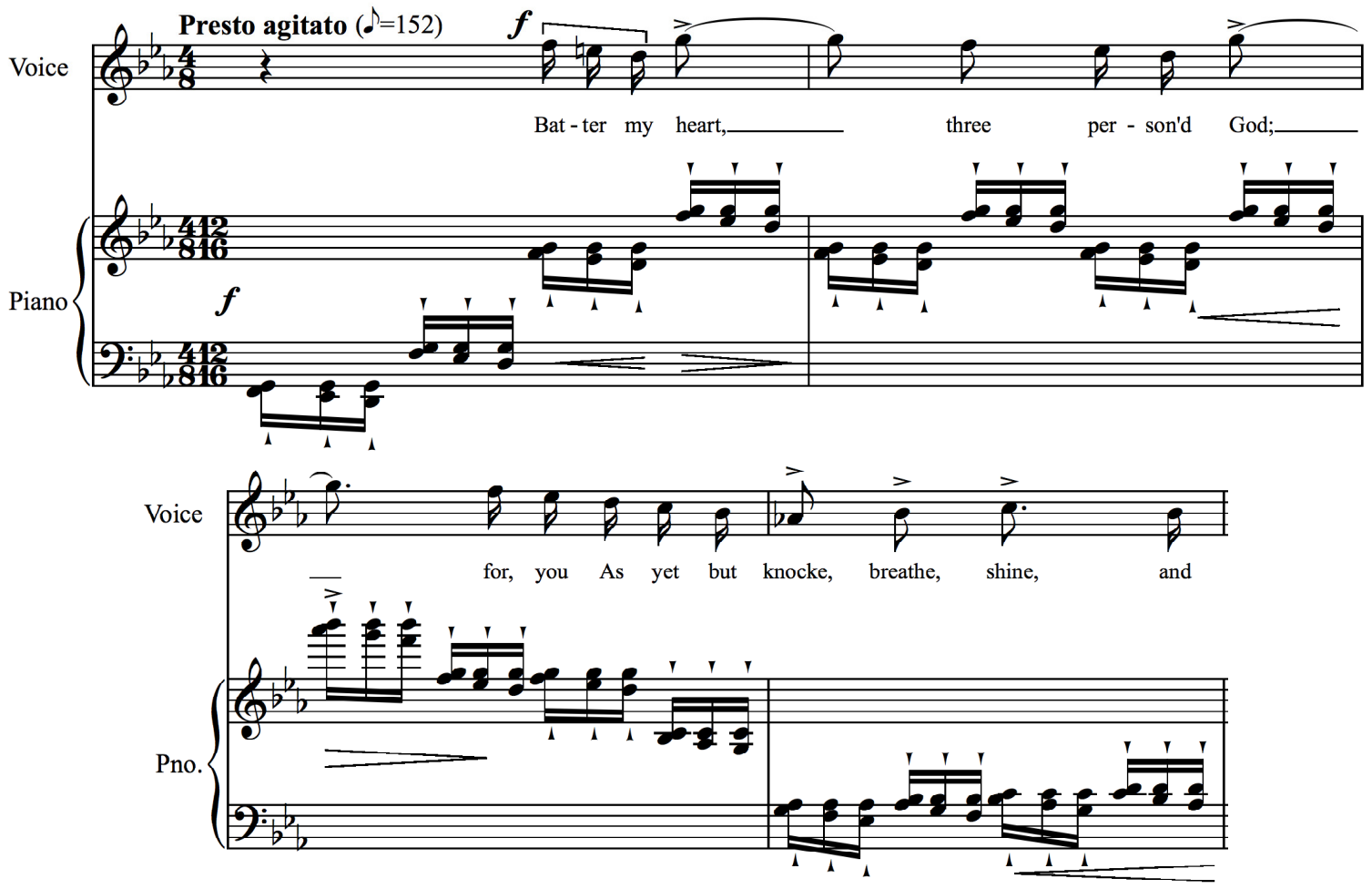

\footnotetext{
${ }^{7}$ Ibid., 7. Examples from "Batter My Heart" reproduced with kind permission of Boosey \& Hawkes, Inc.
} 
Example 4-6, "Sonetto XXXII" from Seven Sonnets of Michelangelo, mm. 5-8. ${ }^{8}$

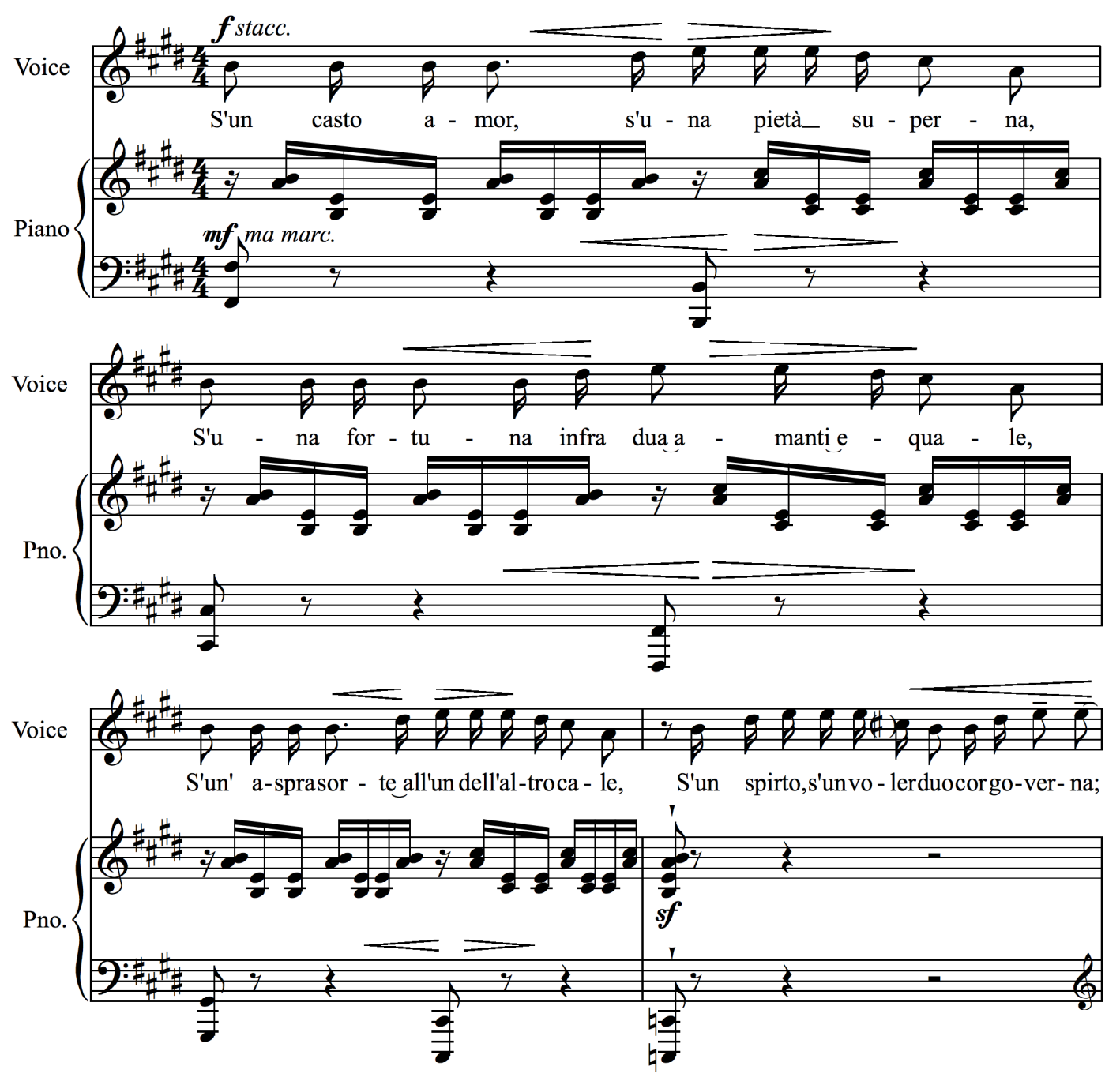

This setting does not have the same aggressiveness equally in both the accompaniment and the vocal line, more of it is to be found in the accompaniment. In this way, the anger expressed in the John Donne setting is heavier, more weighed down, and the poet seems less near to a resolution of his torment, whereas in the Michelangelo Sonnets the poet expressed his anger as a resolution of his problem.

\footnotetext{
${ }^{8}$ Benjamin Britten, Seven Sonnets of Michelangelo, opus 22 (New York: Boosey \& Hawkes, 1943), 22.
} 
This second setting in the cycle lies higher in range than the first, and it expresses more uncontrolled rage and recklessness. The tenor's sound in this slightly higher range could be mournful and almost pitiful, unstable and certainly fragile. The steadfastness of the first sonnet, expressed in a slightly lower range, has been superceded by emotional instability: the vocal line seems tossed about by the quicker triplet figures in the accompaniment just as the poet felt tossed about by God. The rhythmic motive which, as in the first, is repeated throughout the setting, is echoed by the vocal line throughout, ("that I may rise," "Labour to admit you," "Reason your viceroy in mee") (See Example 4-7), but as the poet becomes more distressed the rhythm of the vocal line is slowed down slightly, at the text "Divorce mee, untie" (See Example 4-8) putting it in conflict with the rhythm of the accompaniment. 
Example 4-7, "Batter My Heart," (a.) mm. 6, (b.) 14-15, (c.) $19 .{ }^{9}$

(a.)

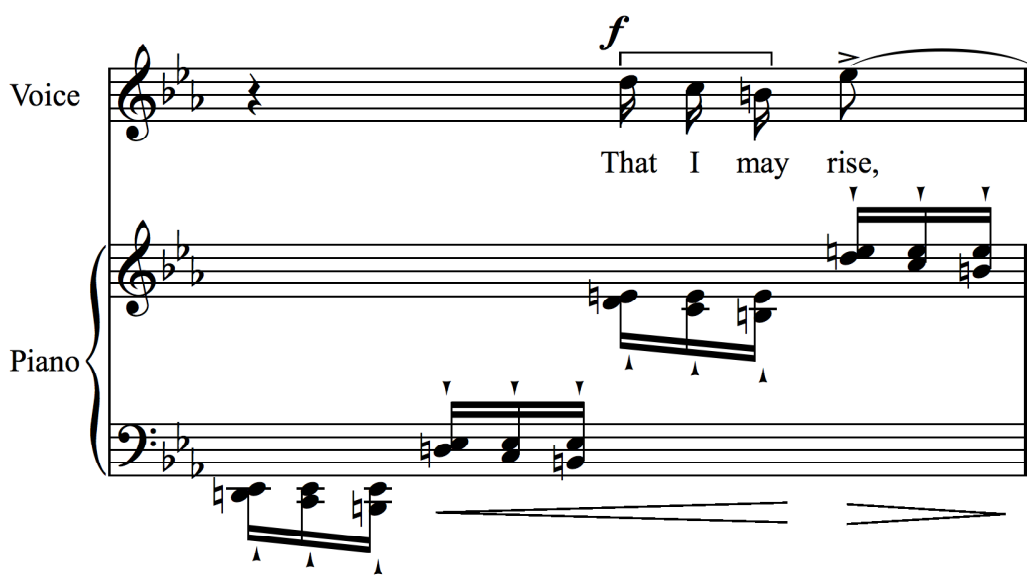

(b.)

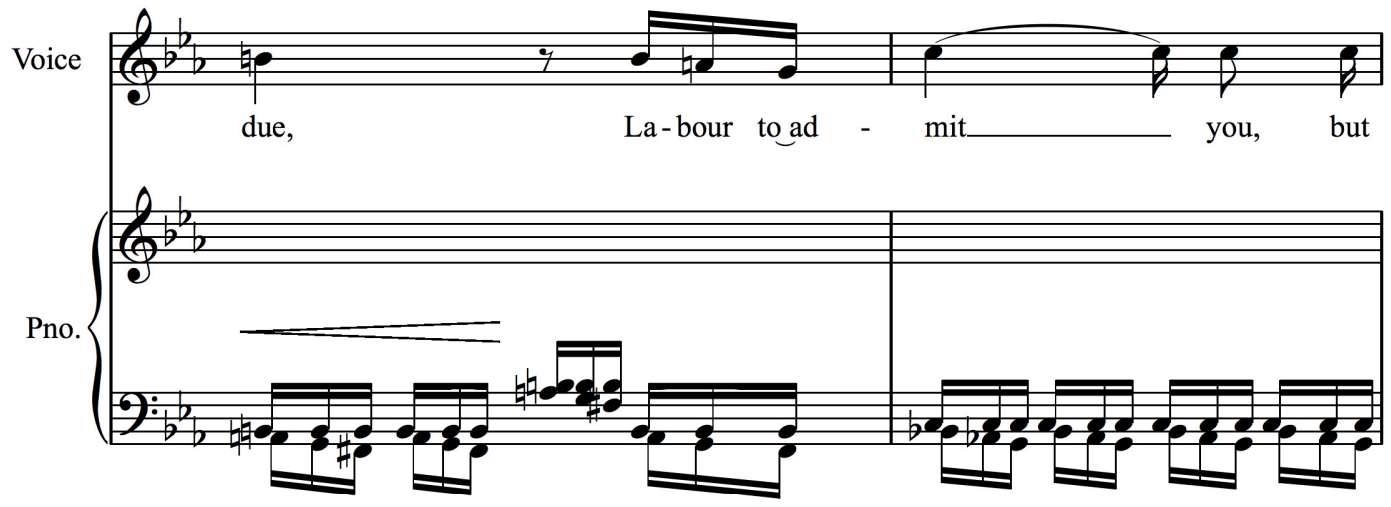

(c.)

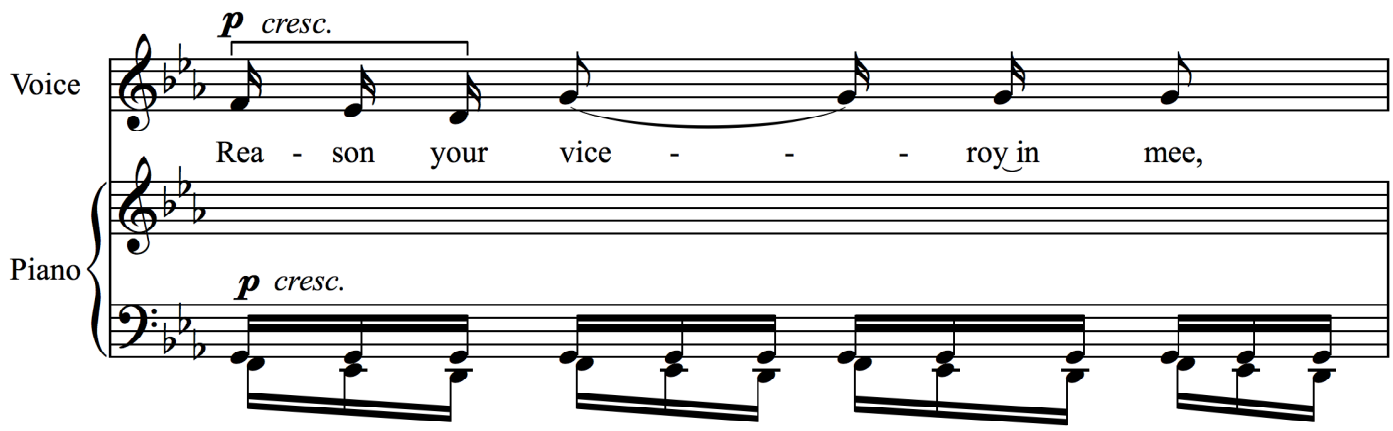

${ }^{9}$ Britten, The Holy Sonnets of John Donne, 7, 8, 9. 
Example 4-8, “Batter My Heart,” m. 31. ${ }^{10}$

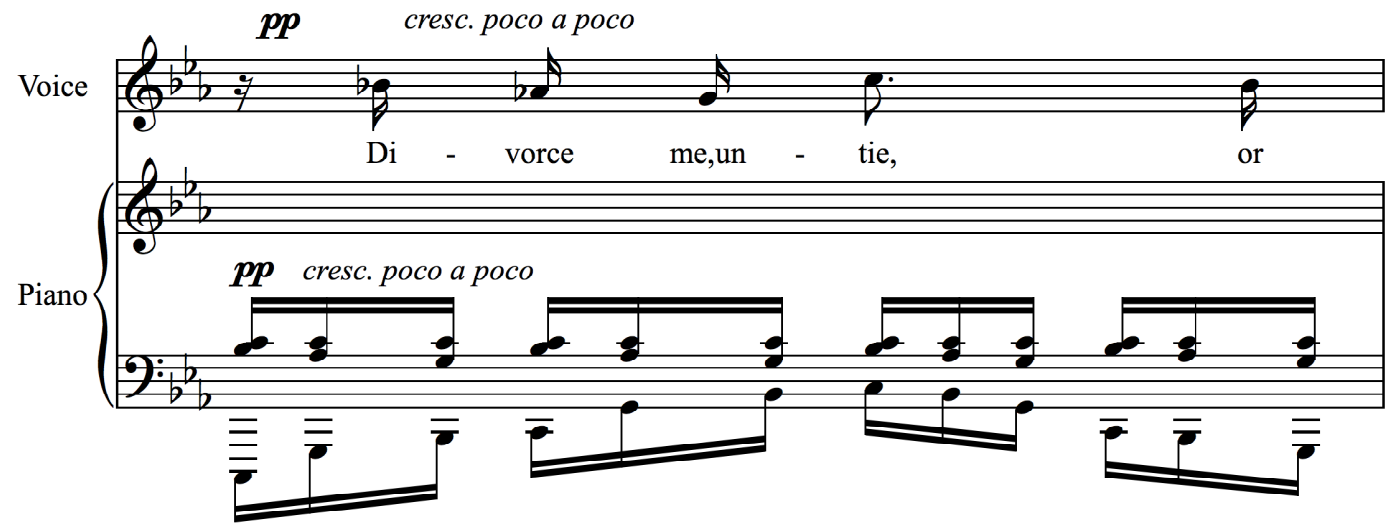

This conflict adds weight to the vocal line, and in this way the singer was able to express more strongly the increasing internal conflict.

\section{O Might Those Sighes and Teares}

O might those sighes and teares returne againe

Into my breast and eyes, which I have spent,

That I might in this holy discontent

Mourne with some fruit, as I have mourn'd in vaine;

In mine Idolatry what show'rs of rain

Mine eyes did waste? What griefs my heart did rent?

That sufferance was my sinne; now I repent;

'cause I did suffer I must suffer paine.

Th'hydroptique drunkard, and night-scouting thiefe,

The itchy Lecher, and self tickling proud

Have the remembrance of past joyes, for reliefe

Of coming ills. To poore me is allow'd

No ease; for, long, yet vehement griefe hath been

Th'effect and cause, the punishment and sinne.

The third of the Holy Sonnets, "O Might Those Sighes and Teares," requires perfect intonation, especially with the half-steps which the composer used to sound like weeping and moaning (See Example 4-9).

\footnotetext{
${ }^{10}$ Ibid., 10.
} 
Example 4-9, “O Might Those Sighes and Teares,” (a.) mm. 4-6, (b.) 13-16. ${ }^{11}$

(a.)

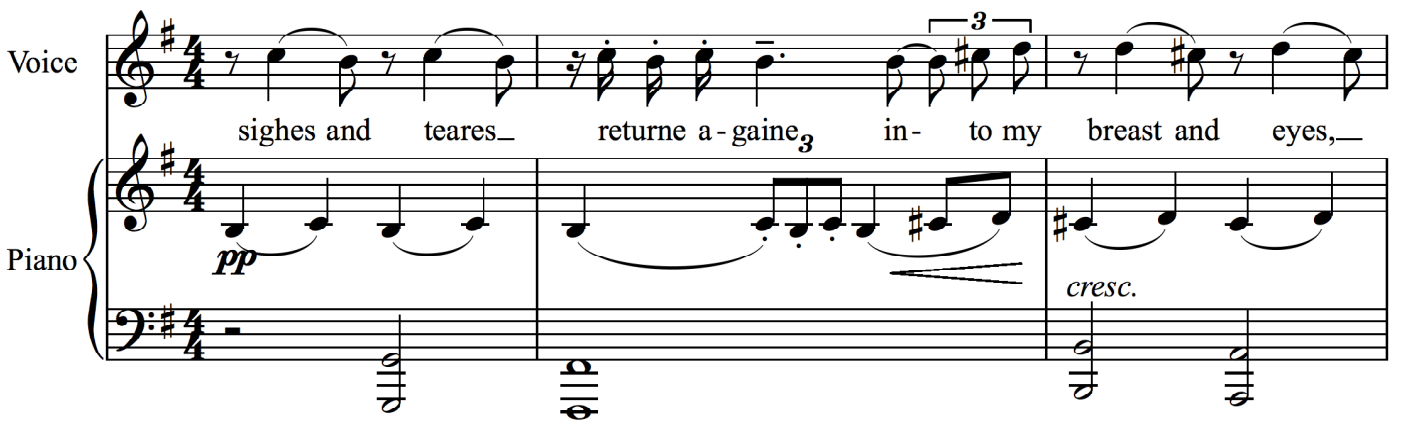

(b.)
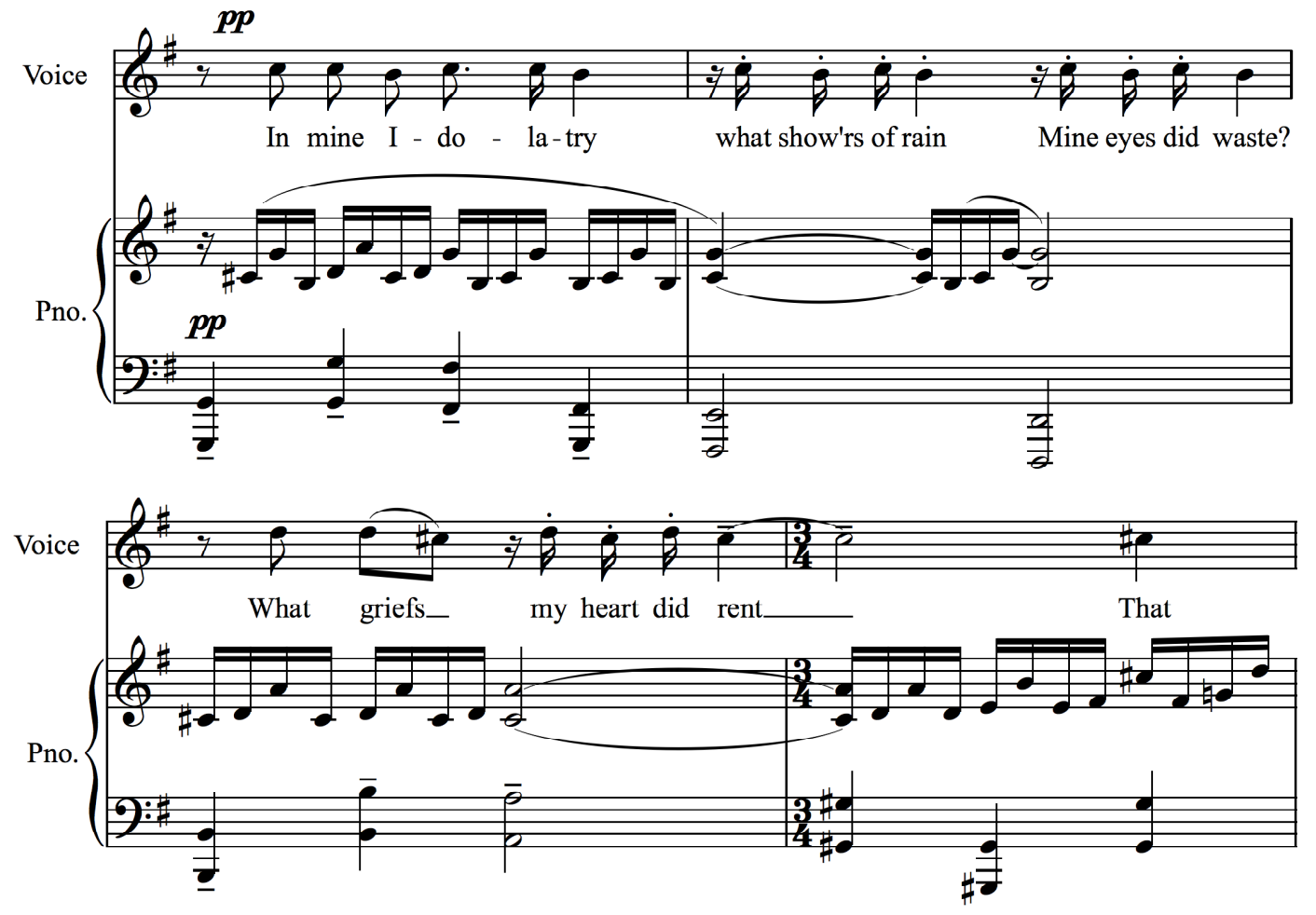

The accompaniment, as it had in the previous two sonnets, sets up this motive in the introduction and continues to develop it throughout, helping both to set the tone for the piece, and to unify it (See Example 4-10).

\footnotetext{
${ }^{11}$ Ibid.,12, 13. Examples from "O Might Those Sighes and Teares" reproduced with kind permission of Boosey \& Hawkes, Inc.
} 
Example 4-10, “O Might Those Sighes and Teares," mm. 1-2. ${ }^{12}$

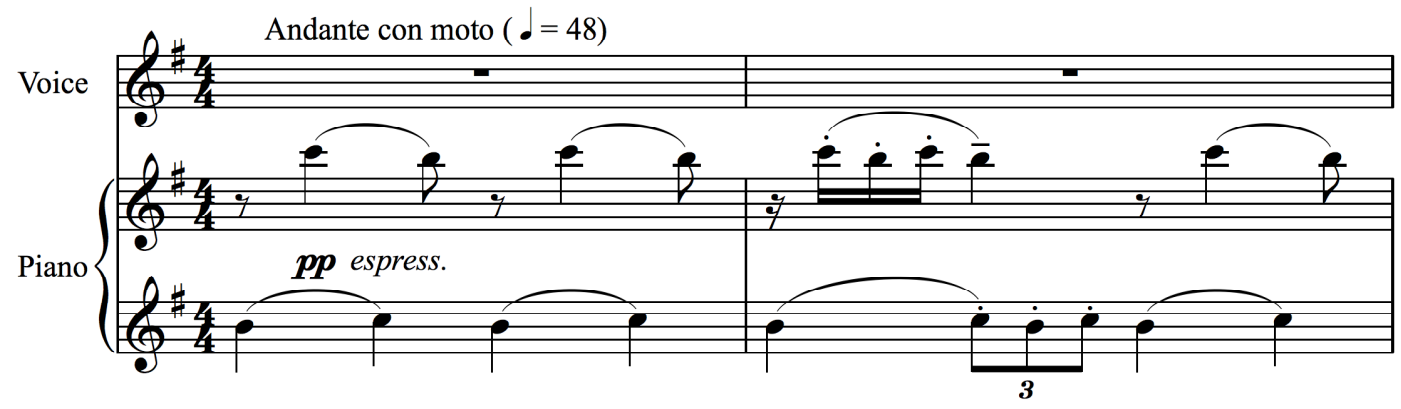

The vocal line is chromatic, lying primarily in the tenor's passaggio, which allowed the tenor to sing the text in an almost whiny, broken sound, showing the emotional state of the text, especially on climactic phrases such as "That I might in this holy discontent mourne," "That sufferance was my sinne, now I repent," and "Have the remembrance of past joyes for reliefe of coming ills" (See Example 4-11).

${ }^{12}$ Ibid., 12. 
Example 4-11, “O Might Those Sighes and Teares,” (a.) mm. 7-9, (b.) 17-19, (c.) 27-28. ${ }^{13}$

(a.)

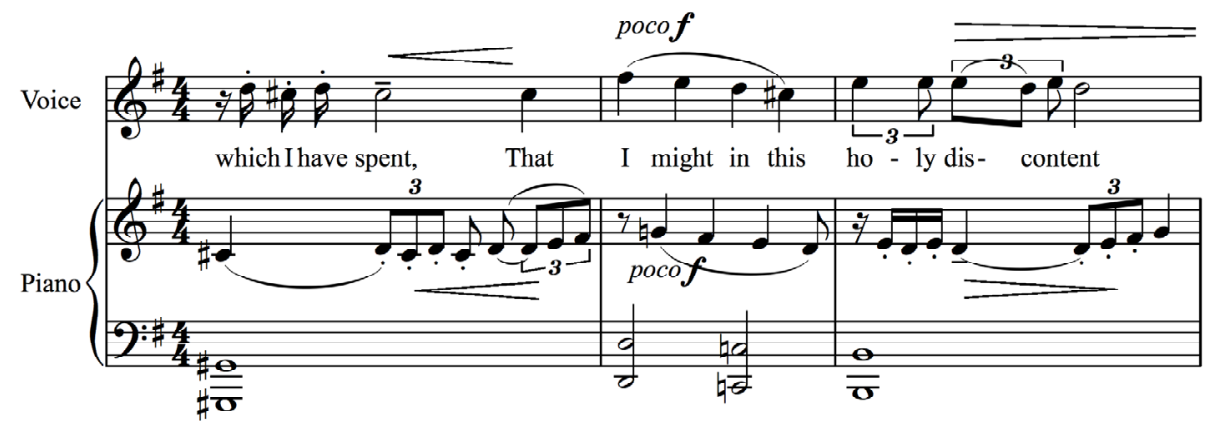

(b.)

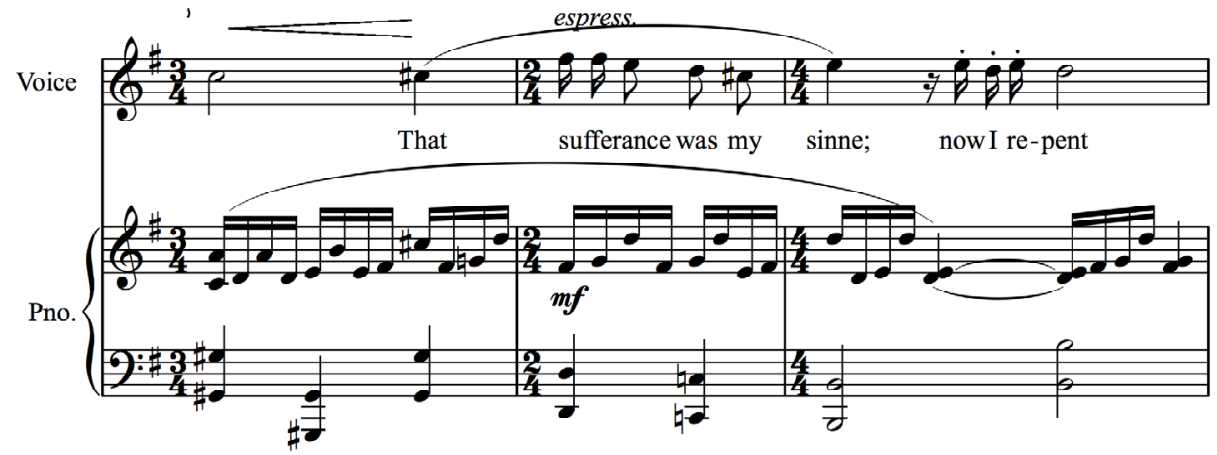

(c.)
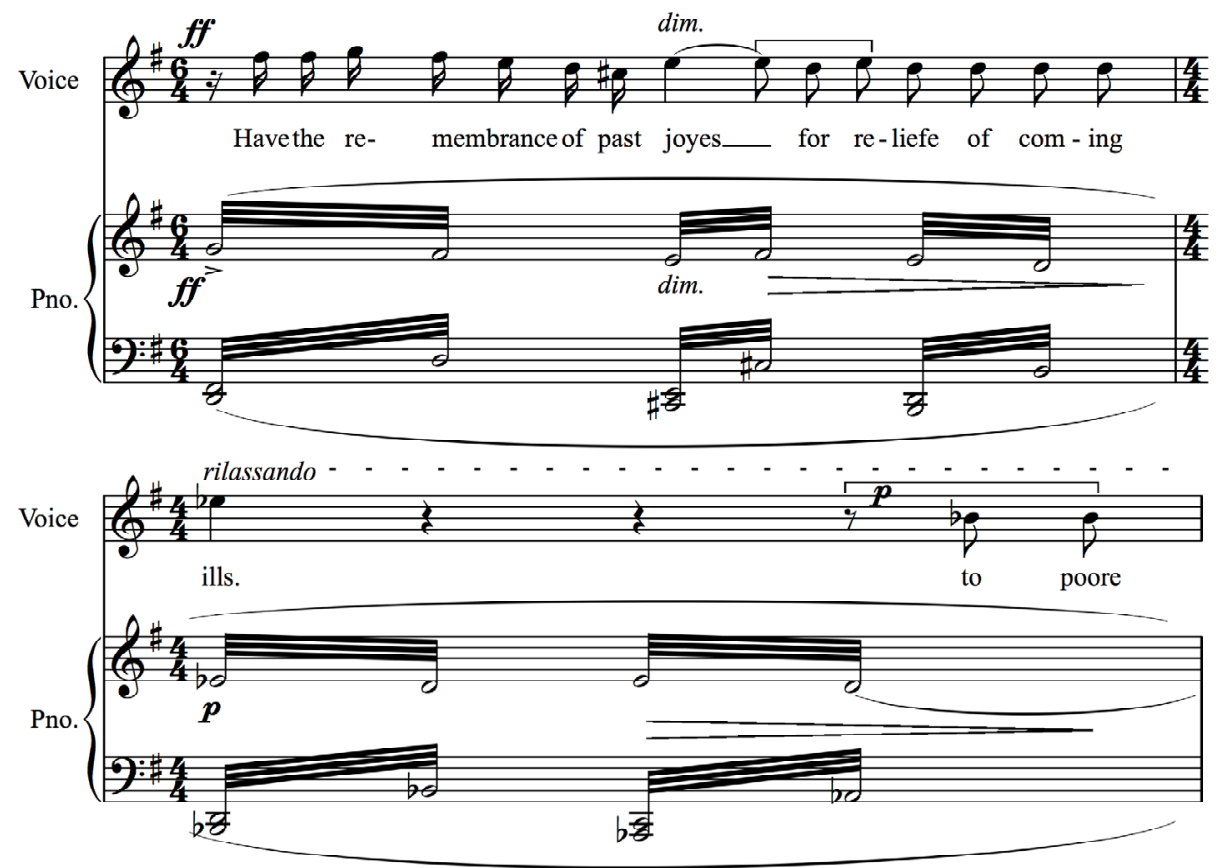

${ }^{13}$ Ibid., 12, 13, 14. 
The composer set the vocal line progressively higher throughout the setting, finally up to a high A-natural, on the text "The itchy lecher and self tickling proud" (See Example 4-12), continuing to use the tone-painting of the minor seconds, showing the increasing fragility of the contents of the text.

Example 4-12, "O Might Those Sighes and Teares," m. $25 .{ }^{14}$

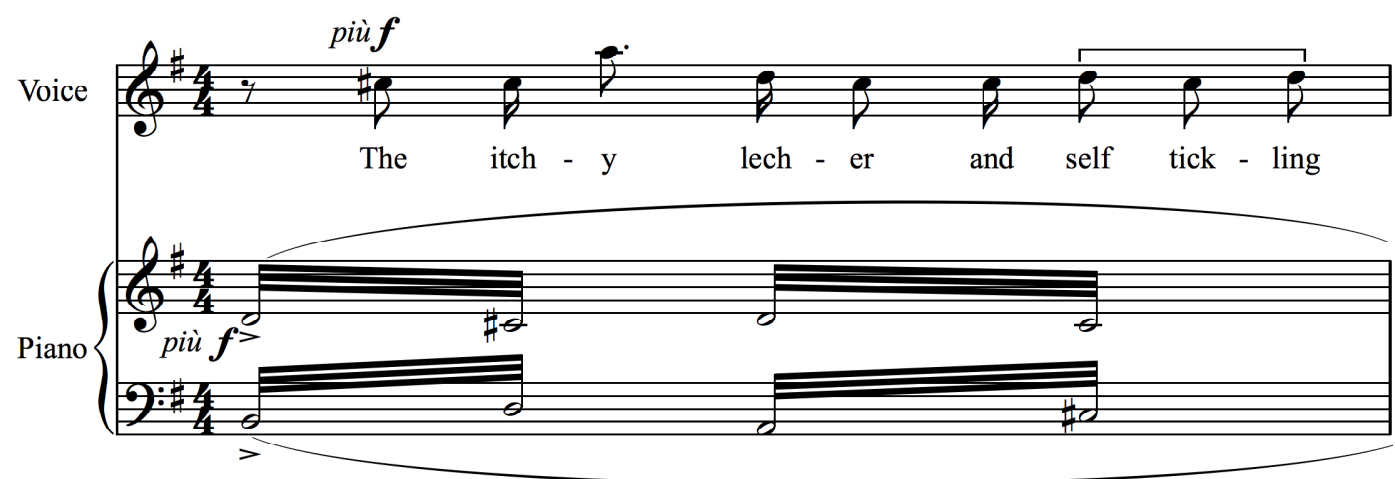

\section{Oh, To Vex Me}

Oh, to vex me, contraryes meet in one:

Inconstancy unnaturally hath begott

A constant habit; that when I would not

I change in vowes, and in devotione.

As humorous is my contritione

As my profane Love, and as soone forgott:

As ridlingly distemper'd, cold and hott,

As praying, as mute; as infinite, as none.

I durst not view Heav'n yesterday; and to day In prayers, and flatt'ring speaches I court God:

To morrow I quake with true feare of his rod.

So my devout fitts come and go away

Like a fantastique Ague: save that here

Those are my best dayes, when I shake with feare.

\footnotetext{
${ }^{14}$ Ibid., 14.
} 
In the fourth setting, “Oh, To Vex Me," Britten used a broken accompaniment figure motive (See Example 4-13), reappearing throughout the setting, underneath a more broken, recitative-like vocal style to express the inconstancy described in the text.

Example 4-13, “Oh, To Vex Me,” mm. 1-2. ${ }^{15}$

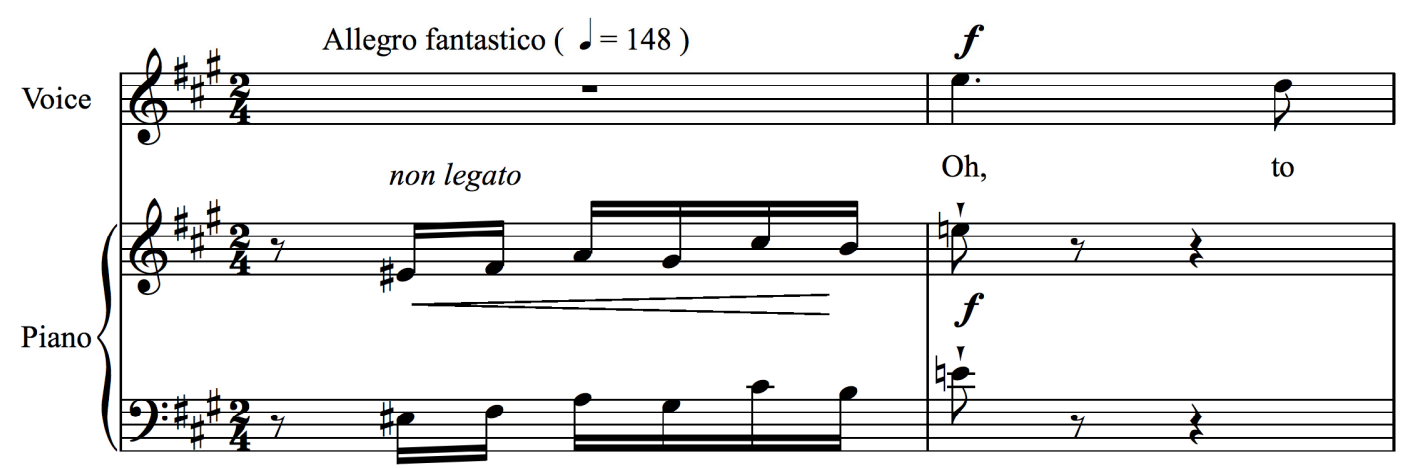

The composer also used large skips in most phrases to accent the disjointed quality of the text, knowing that his partner would be able to use the disjunct melody to his advantage by using different tone colors within the phrases to express further the disjointed emotional quality of the text at moment like "contraryes meet in one," "unnaturally hath begott," "and as soon forgott," and "come and go away" (See Example 4-14).

${ }^{15}$ Ibid., 15. Examples from “Oh, To Vex Me” reproduced with kind permission of Boosey \& Hawkes, Inc. 
Example 4-14, “Oh, To Vex Me,” (a.) mm. 5-6, (b.) 9-10, (c.) 23-24, (d.) 55-57. ${ }^{16}$

(a.)

(b.)
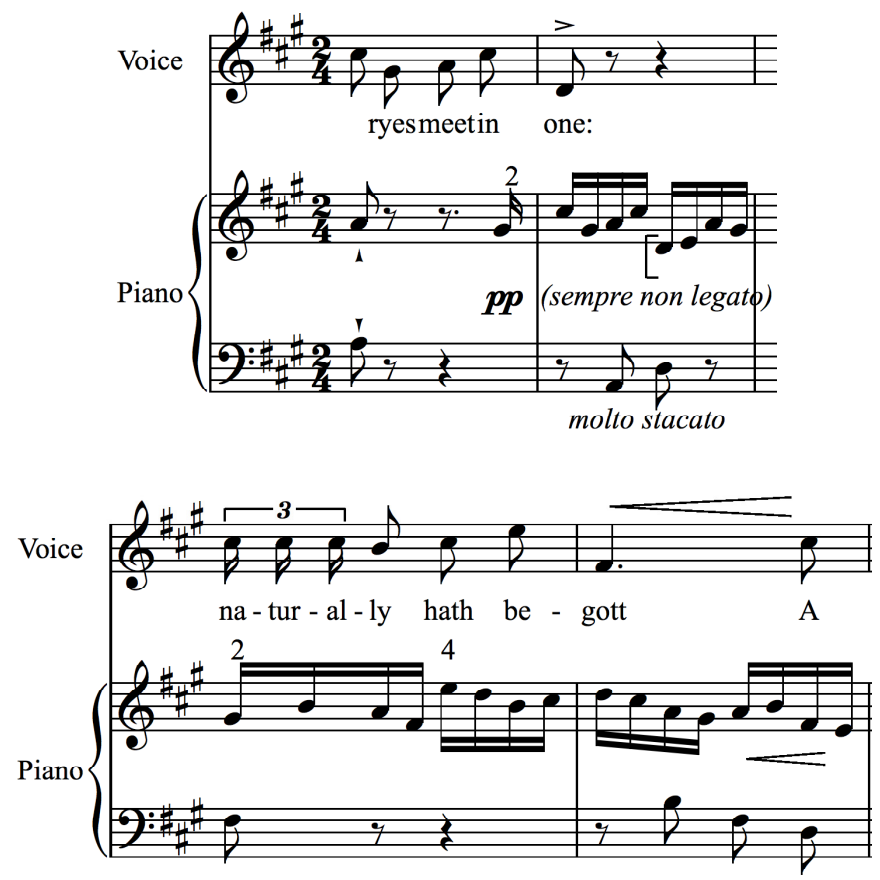

(c.)

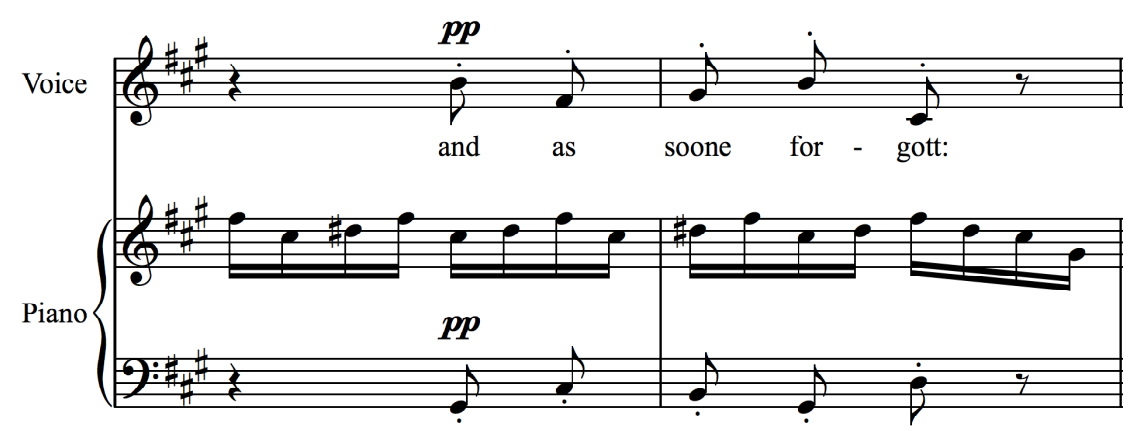

(d.)

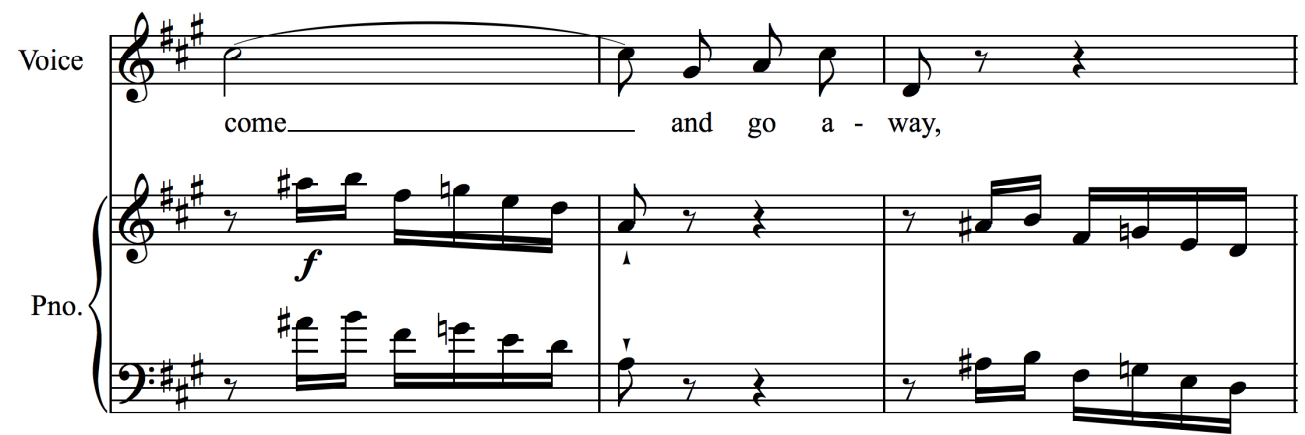

${ }^{16}$ Ibid., 15, 16, 18. 
One of the most remarkable vocal events in this setting, however, is the thirty-seven note melisma used as word-painting on the text "shake" (See Example 4-15), which owes to the influence of Henry Purcell, as seen in his song "Sweeter than Roses" (Example 4-16).

Example 4-15, “Oh, To Vex Me,” mm. 63-71. ${ }^{17}$
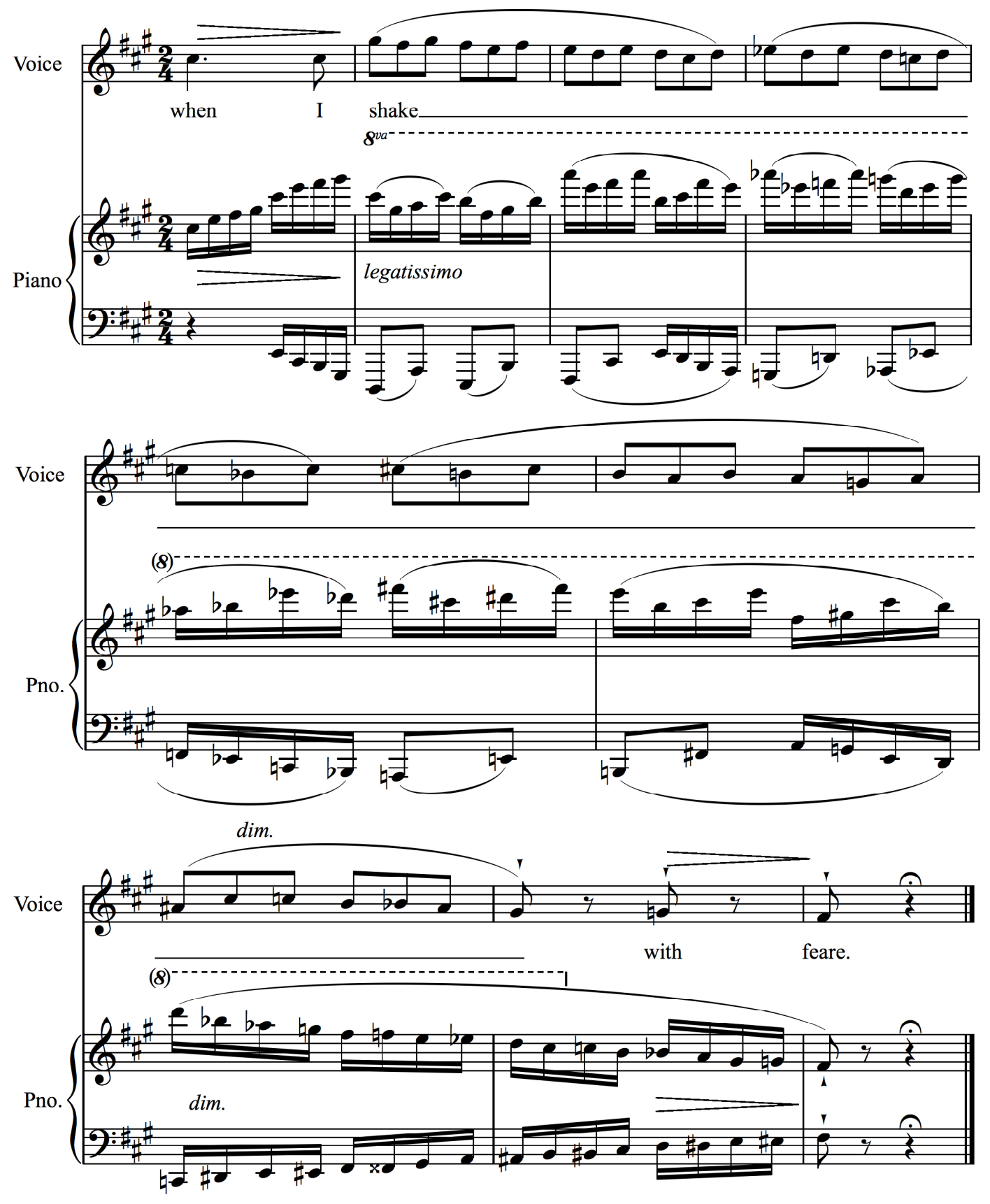

\footnotetext{
${ }^{17}$ Ibid., 19.
} 
Example 4-16, Henry Purcell, "Sweeter Than Roses,” mm. 41-51. ${ }^{18}$

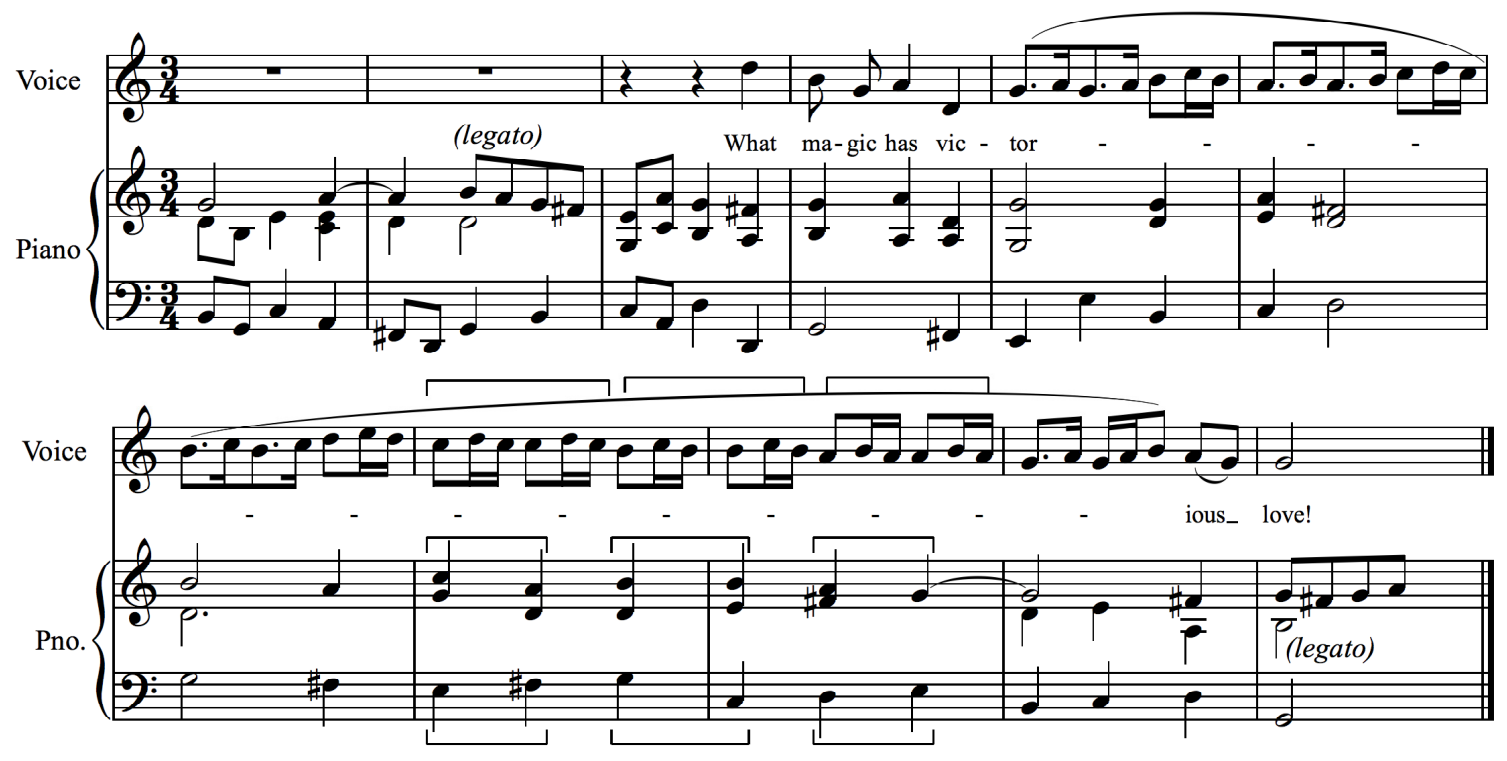

What If This Present

What if this present were the world's last night?

Marke in my heart, O Soule, where thou dost dwell,

The picture of Christ crucified, and tell

Whether that countenance can thee affright,

Teares in his eyes quench the amazing light,

Blood fills his frownes, which from his pierc'd head fell.

And can that tongue adjudge thee into hell,

Which pray'd forgivenesse for his foes fierce spight?

No, no; but as in my idolatrie

I said to all my profane mistresses,

Beauty, of pity, foulnesse onely is

A signe of rigour: so I say to thee,

To wicked spirits are horrid shapes assign'd,

This beauteous forme assures a piteous minde.

Comparisons have been made between the setting of "What If This Present" and the second song in Schubert's Die Winterreise, "Die Wetterfahne," because of the use of the

\footnotetext{
${ }^{18}$ Henry Purcell, 40 Songs for Voice and Piano (New York: International Music Company, 1958), 16-17.
} 
accompaniment to express a windy, stormy day: John Donne's representation is of the Judgment Day (See Examples 4-17 and 4-18). ${ }^{19}$

Example 4-17, Franz Schubert, "Die Wetterfahne," mm. 1-5. ${ }^{20}$

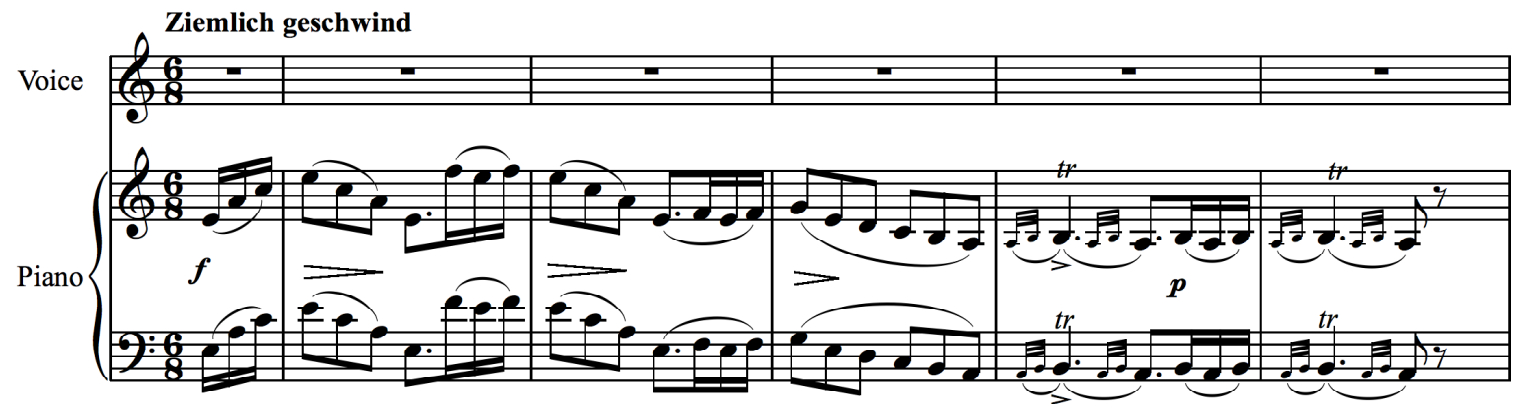

Example 4-18, “What If This Present," mm. 1-2. ${ }^{21}$

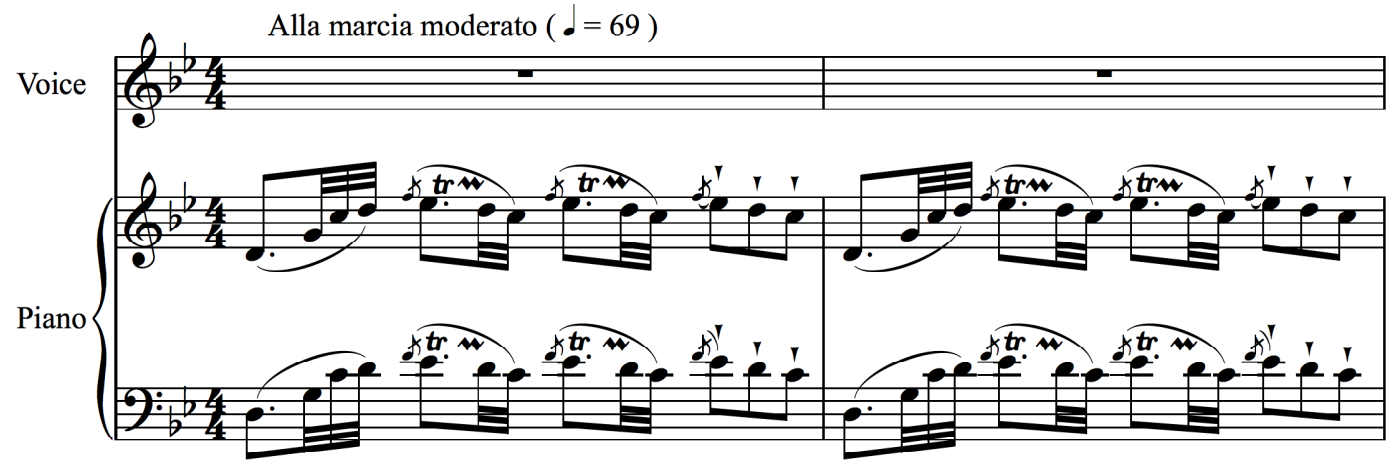

In both accompaniments, the use of the quick ascending notes and the trills is notable. The vocal line in the Donne setting imitates the contour of the opening melodic idea of the accompaniment (See Example 4-19), giving emphasis to the idea of a stormy day, an idea of Britten's not necessarily present in the poem itself.

\footnotetext{
${ }^{19}$ Graham Johnson, Britten, Voice \& Piano: Lectures on the Vocal Music of Benjamin Britten (Burlington, VT: Ashgate Publishing Limited, 2003), 131.

${ }^{20}$ Franz Schubert, 200 Songs in Three Volumes, Volume 1: 100 Songs (New York: International Music Company, 1961), 56.

${ }^{21}$ Britten, The Holy Sonnets of John Donne, 20. Examples from "What If This Present" reproduced with kind permission of Boosey \& Hawkes, Inc.
} 
Example 4-19, "What If This Present," mm. 3-4. ${ }^{22}$
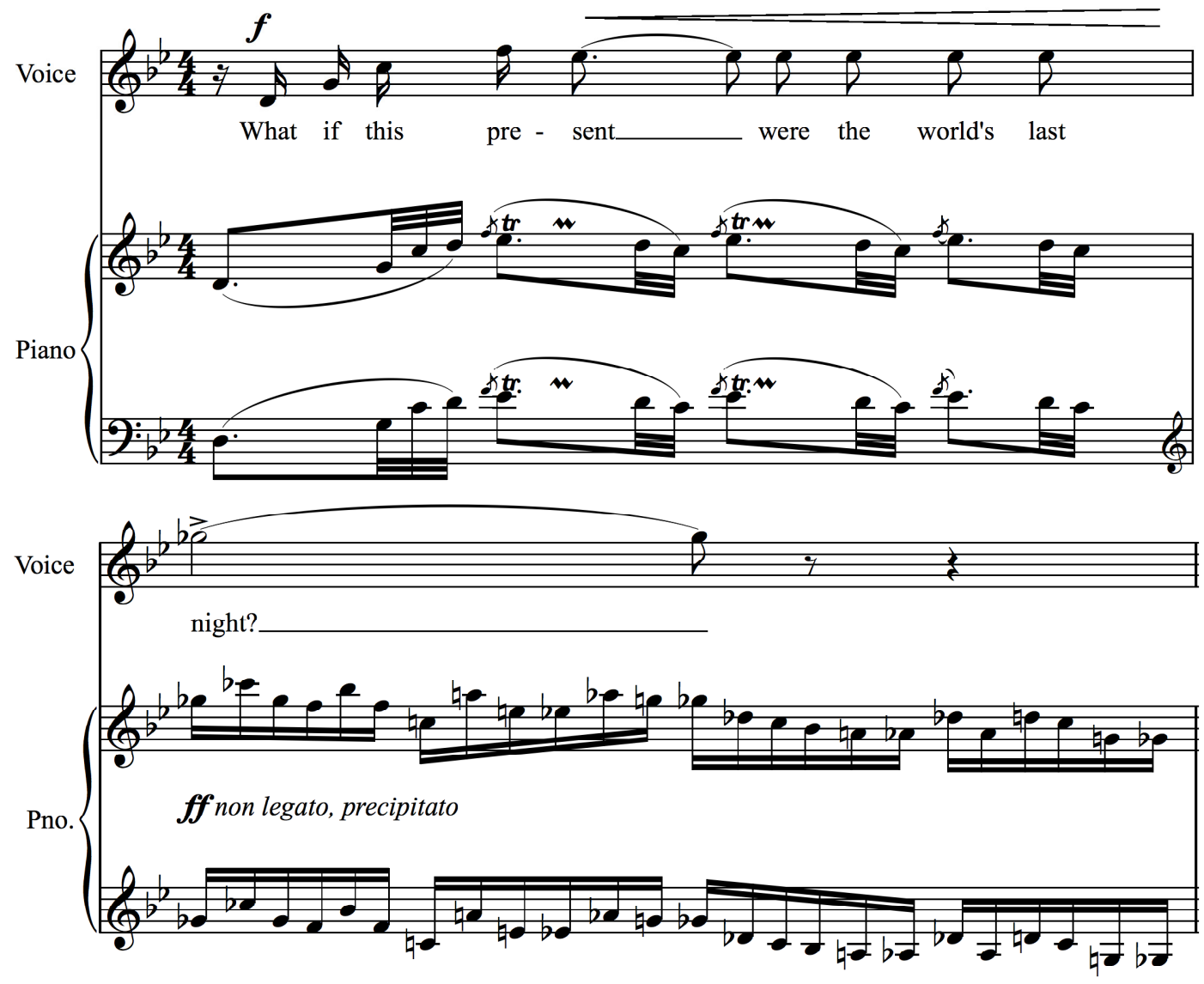

Throughout his setting there are examples of word-painting, including especially the chromatic melisma on the word "crucified," set in Pears's passaggio, where he could add a little weight to the sound while still sounding shocked (See Example 4-20).

${ }^{22}$ Ibid., 20. 
Example 4-20, “What If This Present," mm. 9-10. ${ }^{23}$
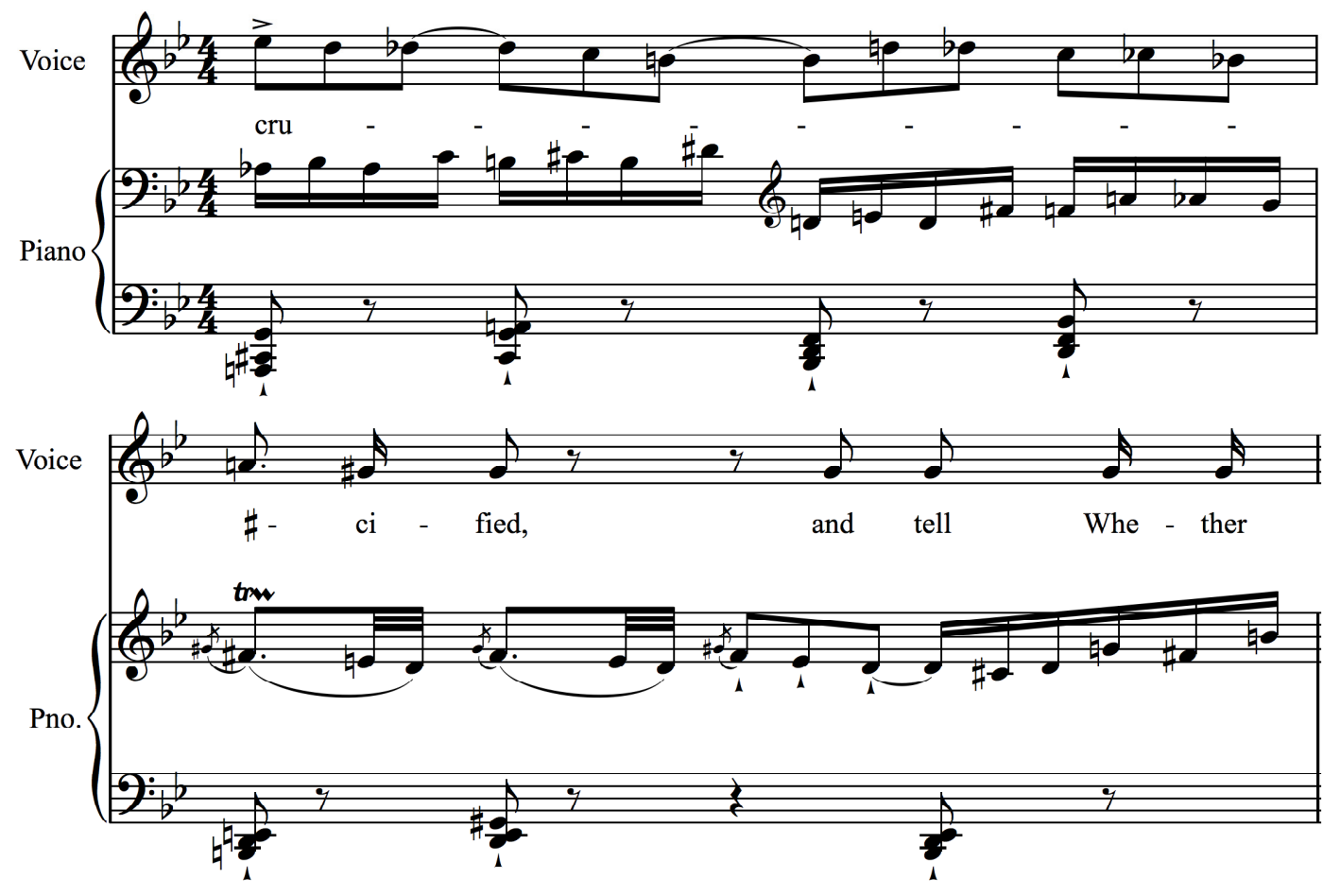

The panic infused by Britten into the text is expressed in the higher tessitura of the first half of the song. This includes the highest note of the cycle, a desperate plea for “forgivenesse" (See Example 4-21) and by the yearning screams "No!" (See Example 4-22).

${ }^{23}$ Ibid., 21. 
Example 4-21, "What If This Present," mm. 19-20. ${ }^{24}$

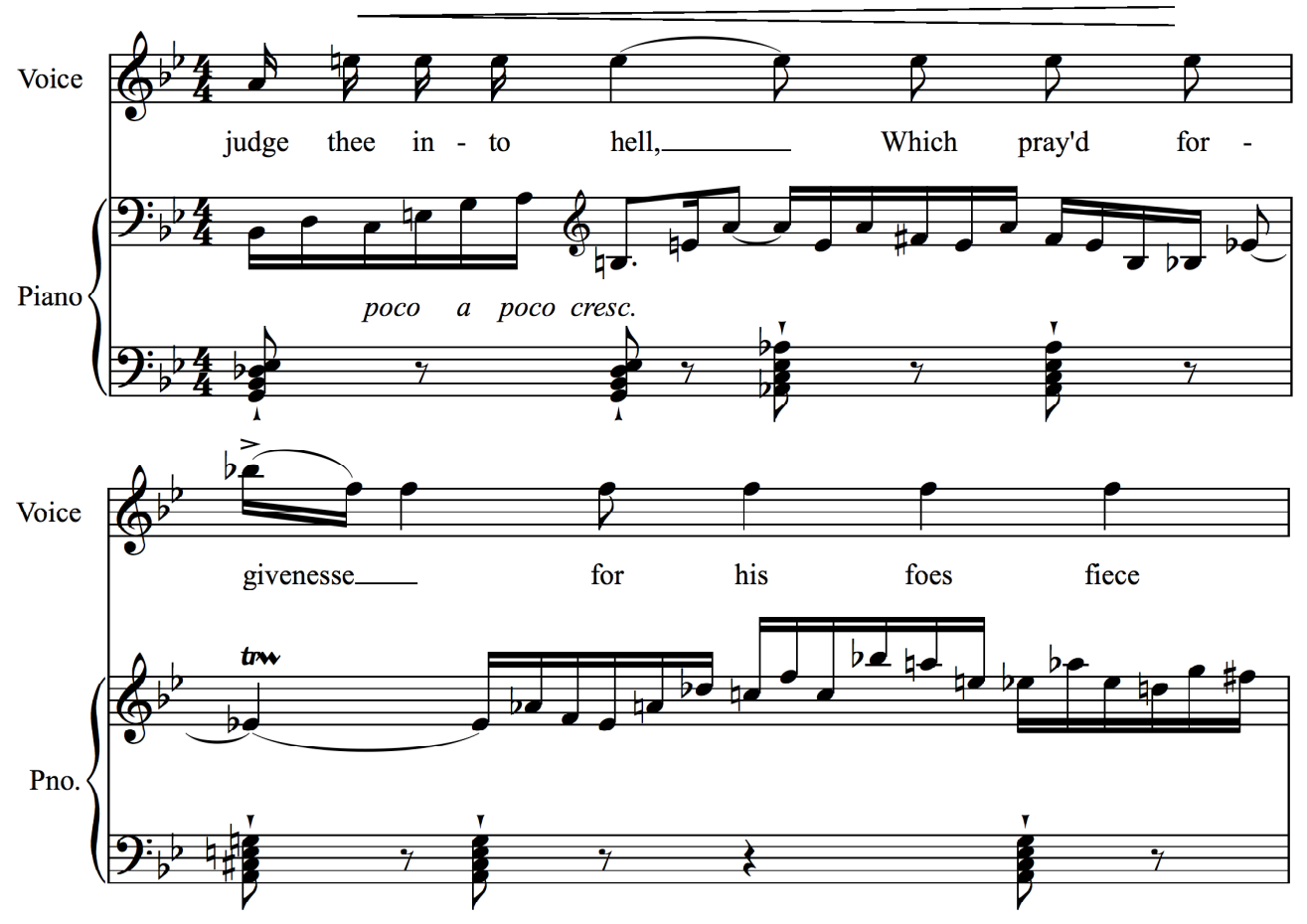

Example 4-22, “What If This Present," mm. 22-24. ${ }^{25}$

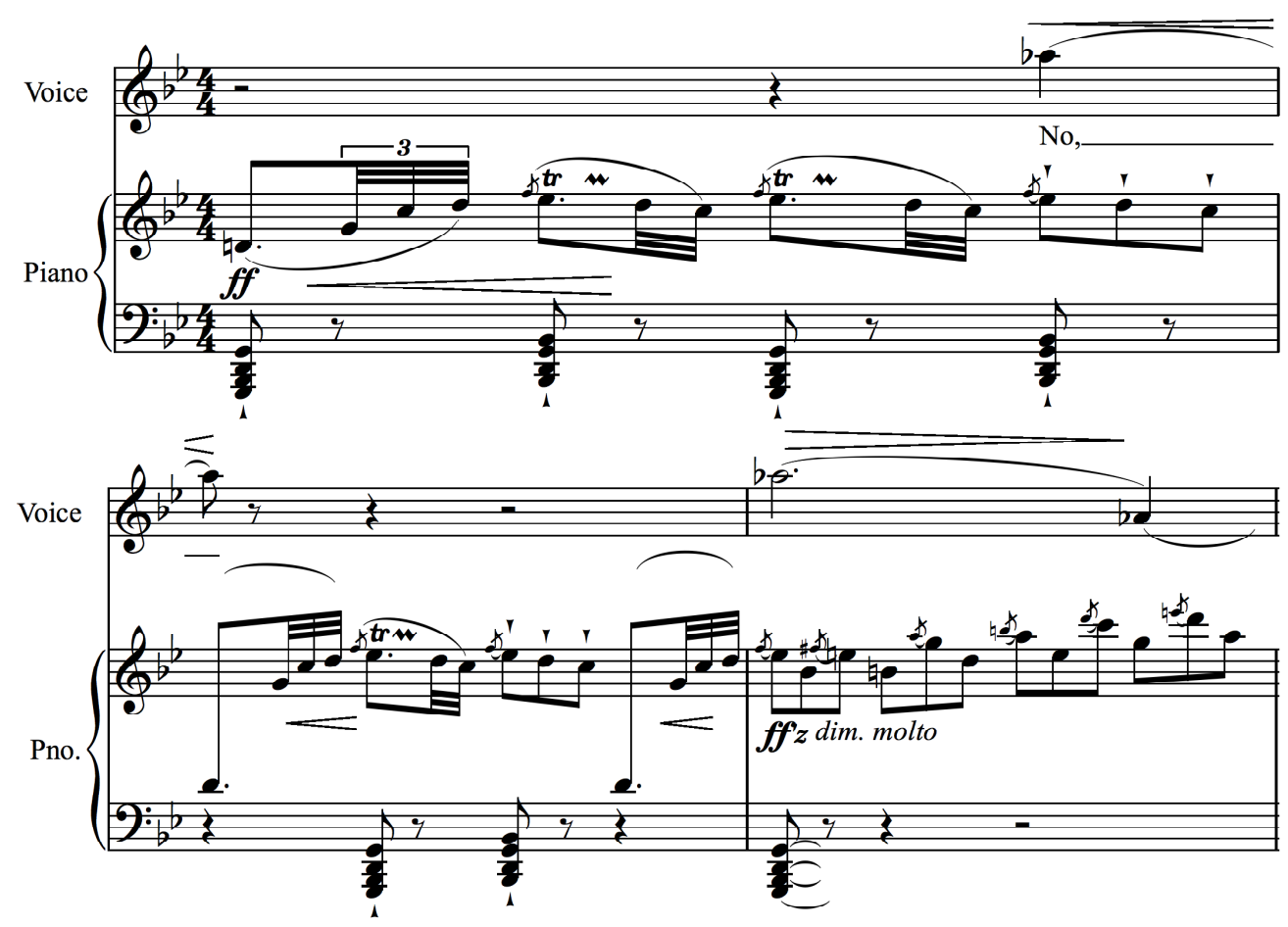

${ }^{24}$ Ibid., 22.

${ }^{25}$ Ibid., 22-23. 
After that point, the tessitura of the vocal line drops, which allowed Pears to use the richer quality of his lower middle voice to express the utter despair and guilt of the poet.

\section{Since She Whom I Lov'd}

Since she whom I lov'd hath payd her last debt

To Nature, and to hers, and my good is dead, And her soule early into heaven ravished, Wholly on heavenly things my mind is sett.

Here the admyring her my mind did whett To seeke thee God; so streames do shew their head; But though I have found thee, and thou my thirst hast fed, A holy thirsty dropsy melts mee yett.

But why should I begg more Love, when as thou

Dost wooe my soul for hers; off'ring all thine:

And dost not only feare least I allow

My love to Saints and Angels things divine,

But in thy tender jealousy dost doubt

Least the World, Fleshe, yea Devill putt thee out.

The sixth setting, "Since She Whom I Loved," could also be compared to Lieder of Schubert such as "Nacht und Träume" in his use of rocking chords in the accompaniment and in the lyric melodic line (See Examples 4-23 and 4-24). 
Example 4-23, Franz Schubert, "Nacht und Träume," mm. 1-4. ${ }^{26}$
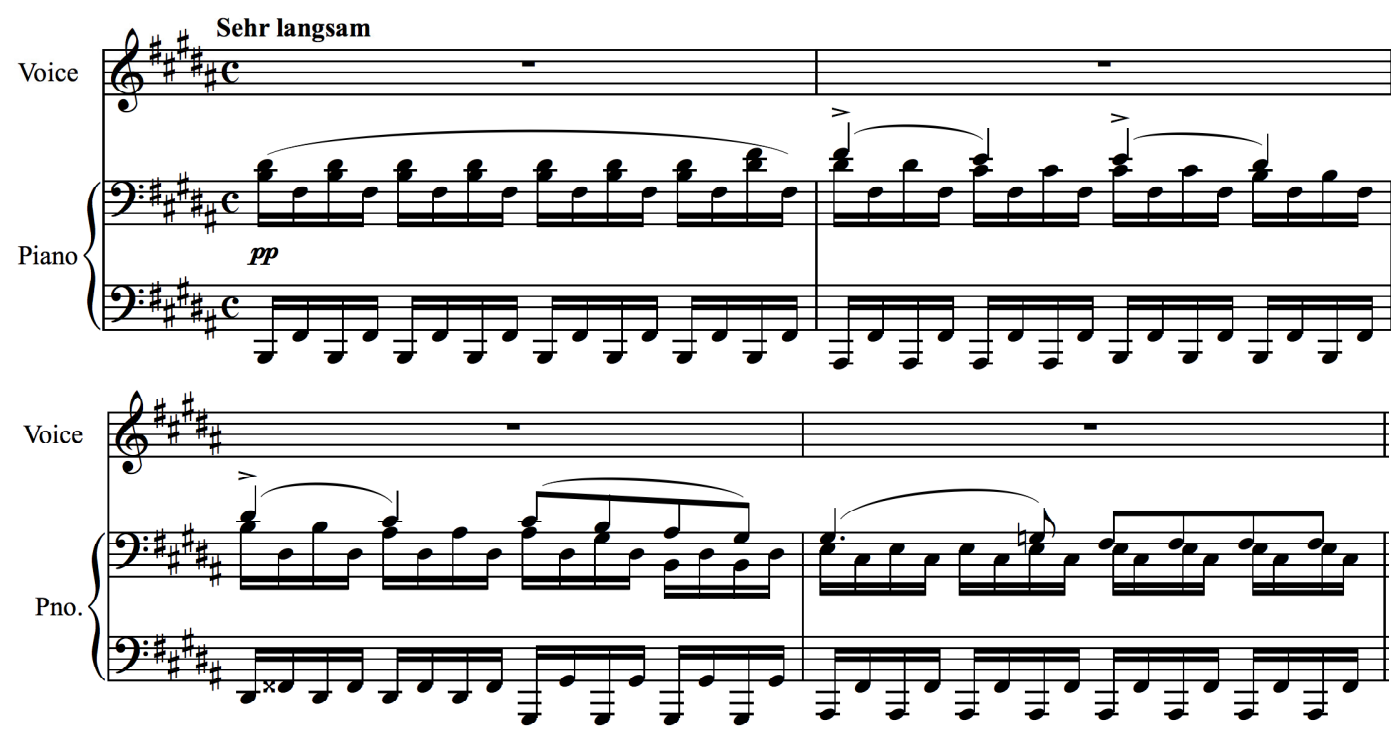

Example 4-24, "Since She Whom I Loved," mm. 1-2. ${ }^{27}$

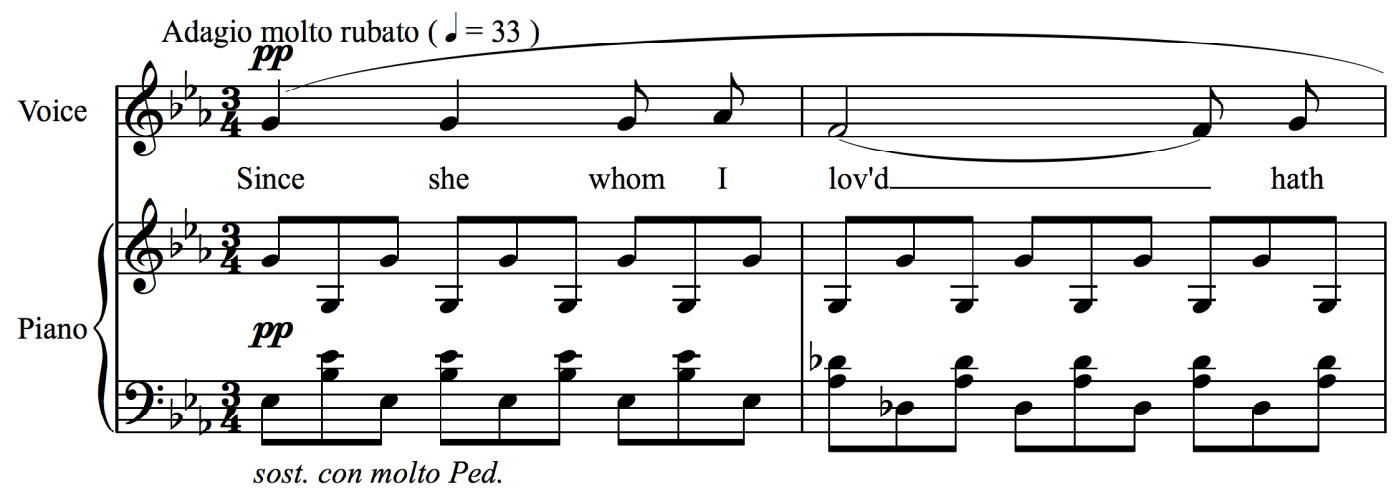

The use of the simple meter in the vocal line against the compound meter in the accompaniment helped to express the desperation of this man, who has suffered the greatest loss he can imagine: the effect is that the singer cannot keep up with the accompaniment throughout the piece, including at the text "Here the admyring her my mind . . . a holy thirsty dropsy melts mee yet" (See Example 4-25).

\footnotetext{
${ }^{26}$ Schubert, 238.

${ }^{27}$ Britten, The Holy Sonnets of John Donne, 25. Examples from "Since She Whom I Loved" reproduced with kind permission of Boosey \& Hawkes, Inc.
} 
Example 4-25, "Since She Whom I Loved," mm. 17-26. ${ }^{28}$
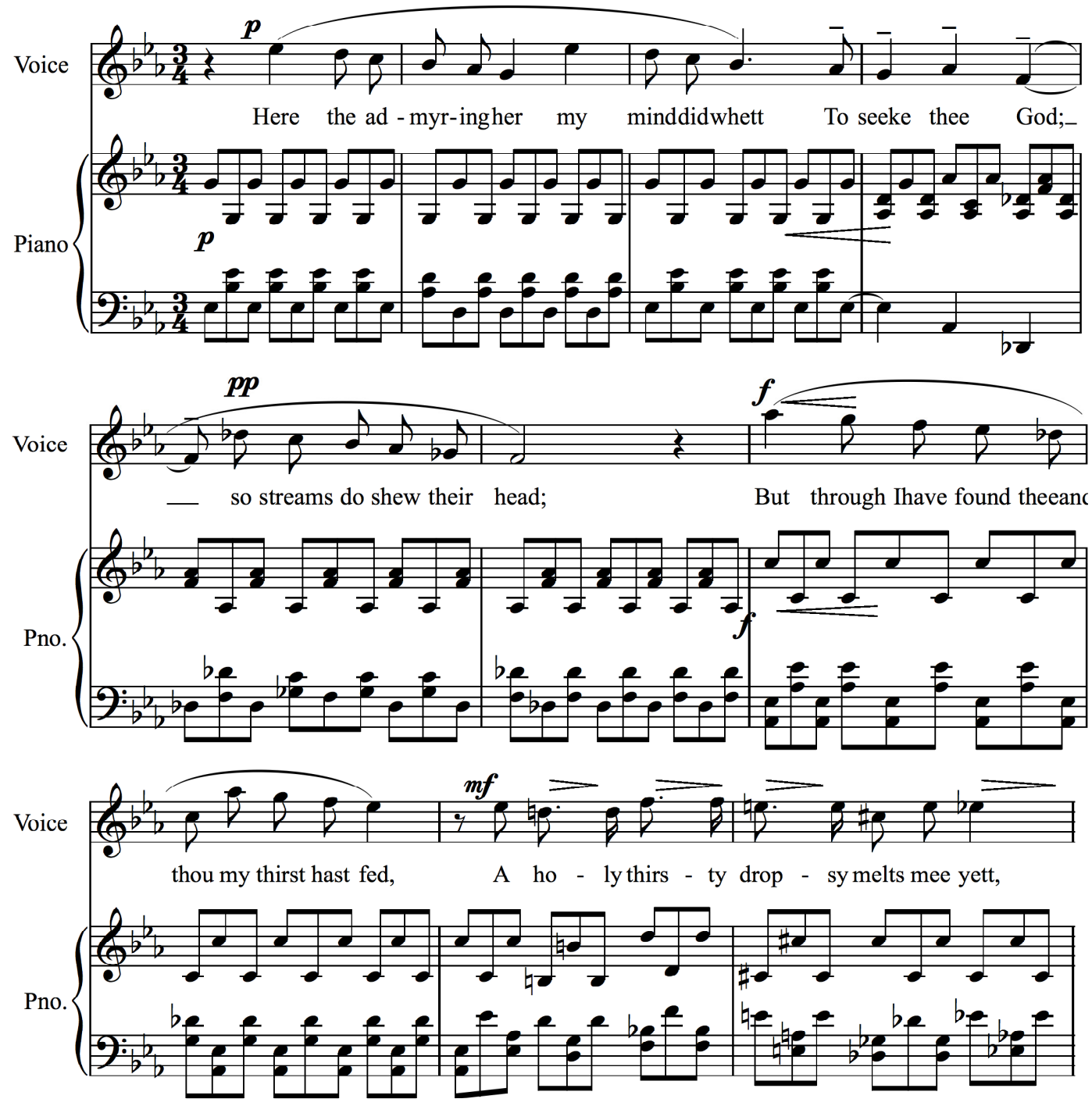

The vocal line of this setting starts relatively low so that the tenor could express the emotions of the stunned poet ("Since she whom I loved hath payd her last debt"). The melody then ascends into the passaggio where the tenor could show more overt emotion by adding more color to his voice at the text "and my good is dead" (See Example 4-26).

\footnotetext{
${ }^{28}$ Ibid., 25.
} 
Example 4-26, "Since She Whom I Loved," mm. 6-7. ${ }^{29}$

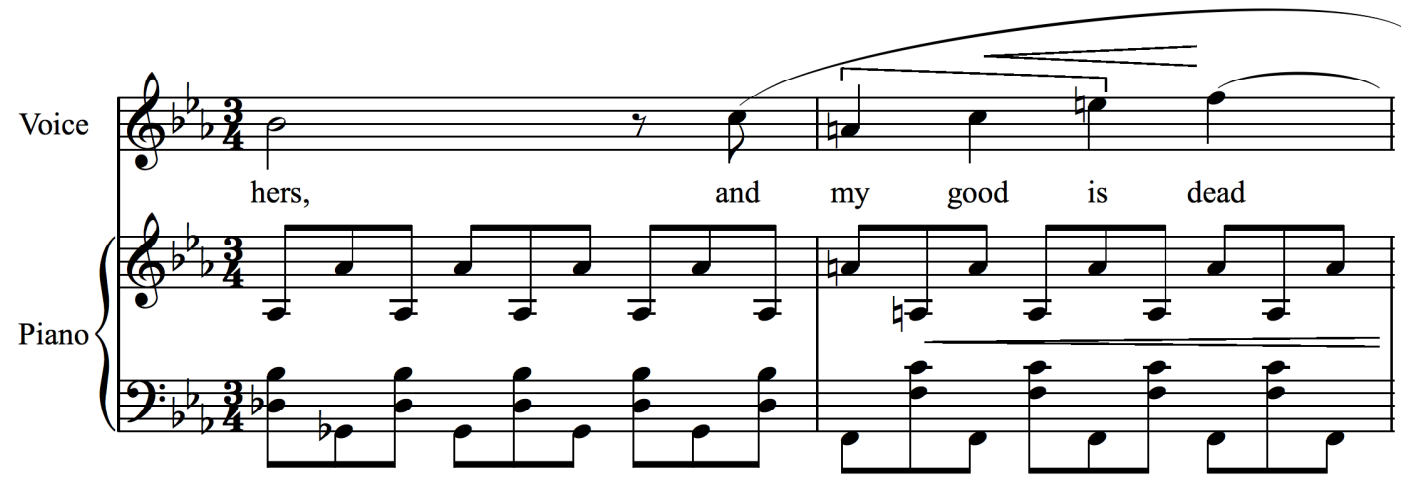

It then moves into the top voice briefly at the text "And her Soule early into Heaven" (See

Example 4-27), which allowed the tenor to express the effect of bitter weeping followed by the restoration of control over his emotions, and the vocal line descended in pitch.

Example 4-27, "Since She Whom I Loved," mm. 8-10. ${ }^{30}$

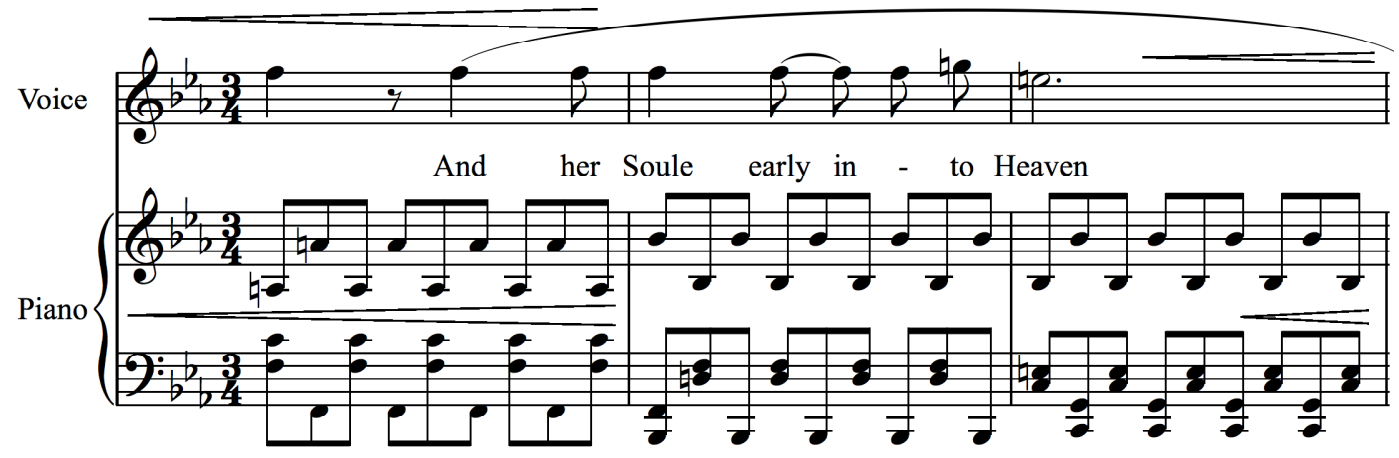

The ascent begins again, this time climbing higher more quickly, and the use of the high voice allowed the singer to express the pity and raw emotion to an even greater degree ("But in thy tender jealousy") (See Example 4-28).

\footnotetext{
${ }^{29}$ Ibid., 25.

${ }^{30}$ Ibid., 25.
} 
Example 4-28, “Since She Whom I Loved,” mm. 36-38. ${ }^{31}$

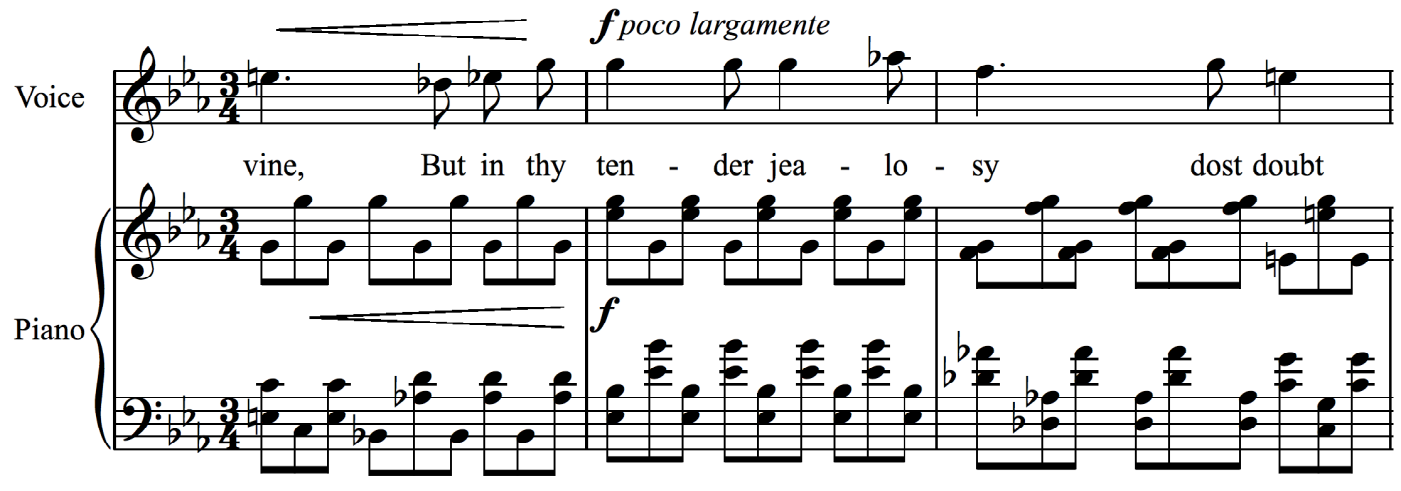

At The Round Earth's Imagin'd Corners

At the round earth's imagin'd corners, blow

Your trumpets, Angels, and arise, arise

From death, you numberless infinities

Of soules, and to your scattr'd bodies goe, All whom the flood did, and fire shall o'erthrow,

All whom warre, dearth, age, agues, tyrannies, Despaire, law, chance, hath slaine, and you whose eyes,

Shall behold God, and never taste death's woe.

But let them sleepe, Lord, and mee mourne aspace,

For, if above all these, my sinnes abound,

'Tis late to ask abundance of thy grace,

When we are there; here on this lowly ground,

Teach me how to repent; for that's as good

As if thou hadst seal'd my pardon, with thy blood.

The quintuplet vocal melismas used throughout the seventh sonnet, "At the Earth's Imagined Corners," are repeated throughout the piece at different pitch levels, primarily in the middle to high voice (See Example 4-29).

\footnotetext{
${ }^{31}$ Ibid., 28.
} 
Example 4-29, “At The Round Earth's Imagined Corners,” (a.) mm. 2, (b.) 8, (c.) 21, (d.) $24-25$, (e.) $31 .^{32}$

(a.)

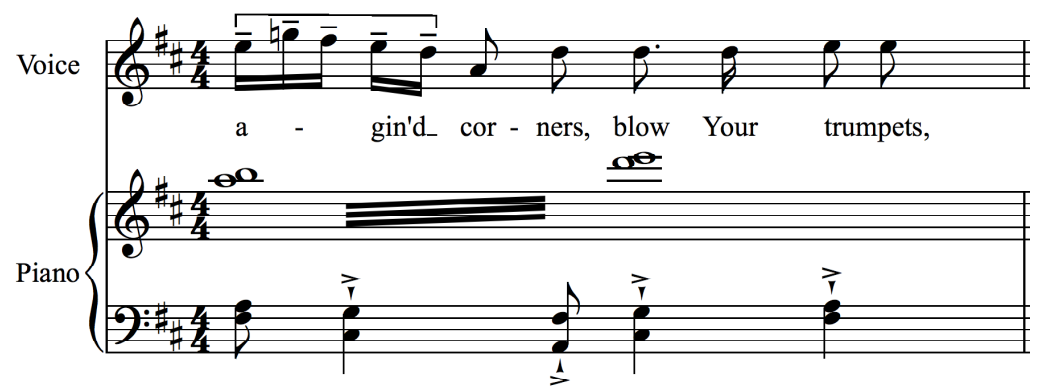

(b.)

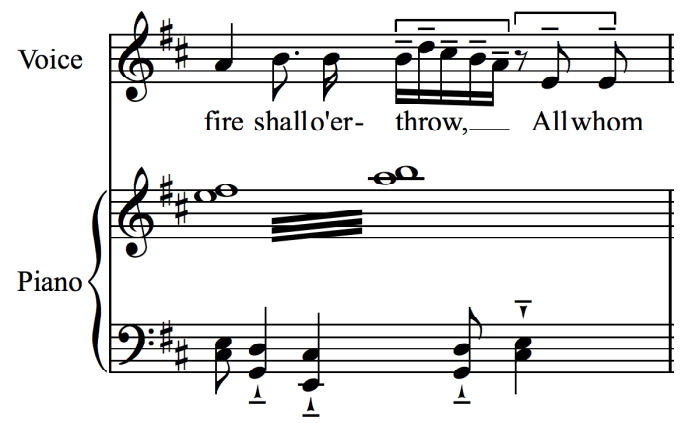

(c.)

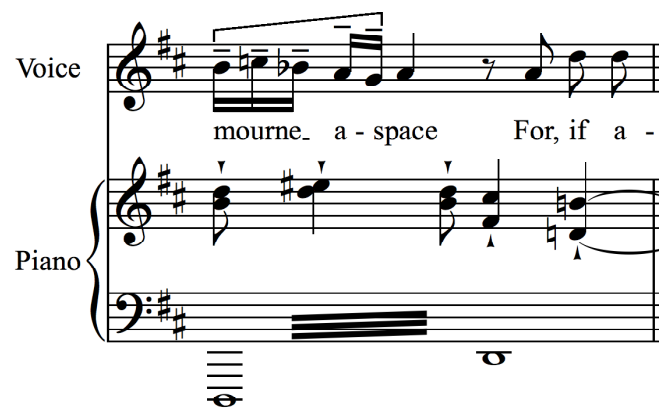

(d.)

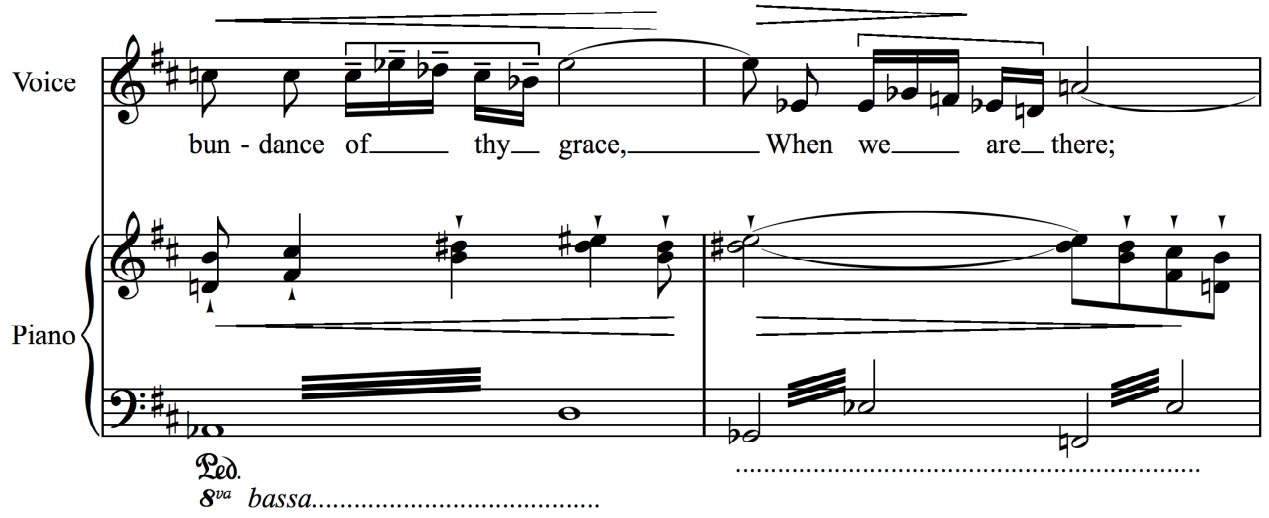

(e.)

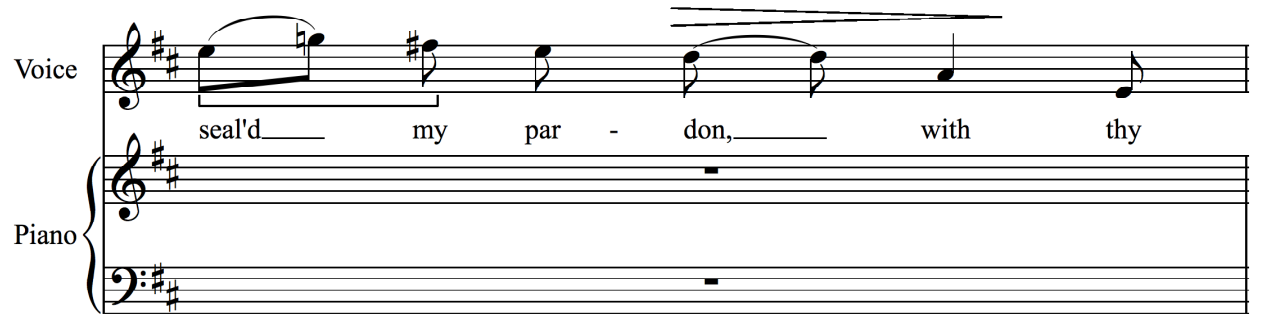

${ }^{32}$ Ibid., 29-32. Examples from “At the Round Earth's Imagined Corners” reproduced with kind permission of Boosey \& Hawkes, Inc. 
These melismas, along with the D major tonality which predominates throughout the piece, give the vocal line a certain graceful energy and helped the tenor to express the text's emotions, more positive than those as yet expressed. Pears was excellent at performing these melismas cleanly and using them for the expressive purpose for which they were intended.

At this point in the cycle as Britten has organized it, the narrator has identified the problem and seeks to solve it. Although there is still a pleading quality in the text, it is neither desperate nor deprecating. Instead, the narrator seems to expect to get the answers he needs. The accompaniment, which repeats a horn call (Judgment Day) and tremolo figure throughout the setting (See Example 4-30), and the energy of the vocal line, in part due to the repeated melismas, combine to represent this more positive outlook.

Example 4-30, “At The Round Earth's Imagined Corners,” mm. 1-2. ${ }^{33}$

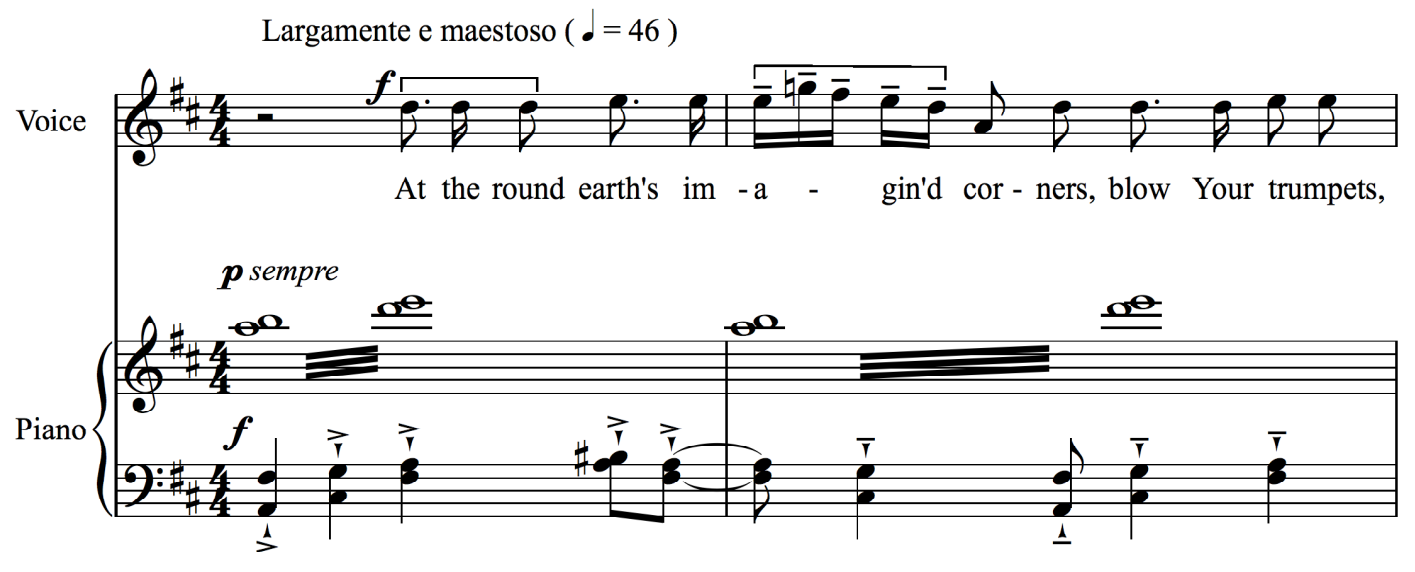

Thou Hast Made Me

Thou hast made me, And shall thy work decay? Repaire me now, for now mine end doth haste, I runne to death, and death meets me as fast, And all my pleasures are like yesterday; I dare not move my dim eyes any way,

\footnotetext{
${ }^{33}$ Ibid., 29.
} 
Despaire behind, and death before doth cast

Such terror, and my feeble flesh doth waste By sinne in it, which it t'wards hell doth weigh;

Onely thou art above, and when t'wards thee

By thy leave I can looke, I rise againe;

But our old subtle foe so tempteth me,

That not one houre my selfe I can sustaine;

Thy Grace may wing me to prevent his art, And thou like Adamant draw mine iron heart.

The raw emotion found in the second setting ("Batter My Heart") returns in the eighth, "Thou Hast Made Me," however this time it seems that the narrator's faith has returned. The accompaniment again is vigorous, but the vocal line is less so (See Example 4-31).

Example 4-31, “Thou Hast Made Me,” mm. 16-19. ${ }^{34}$
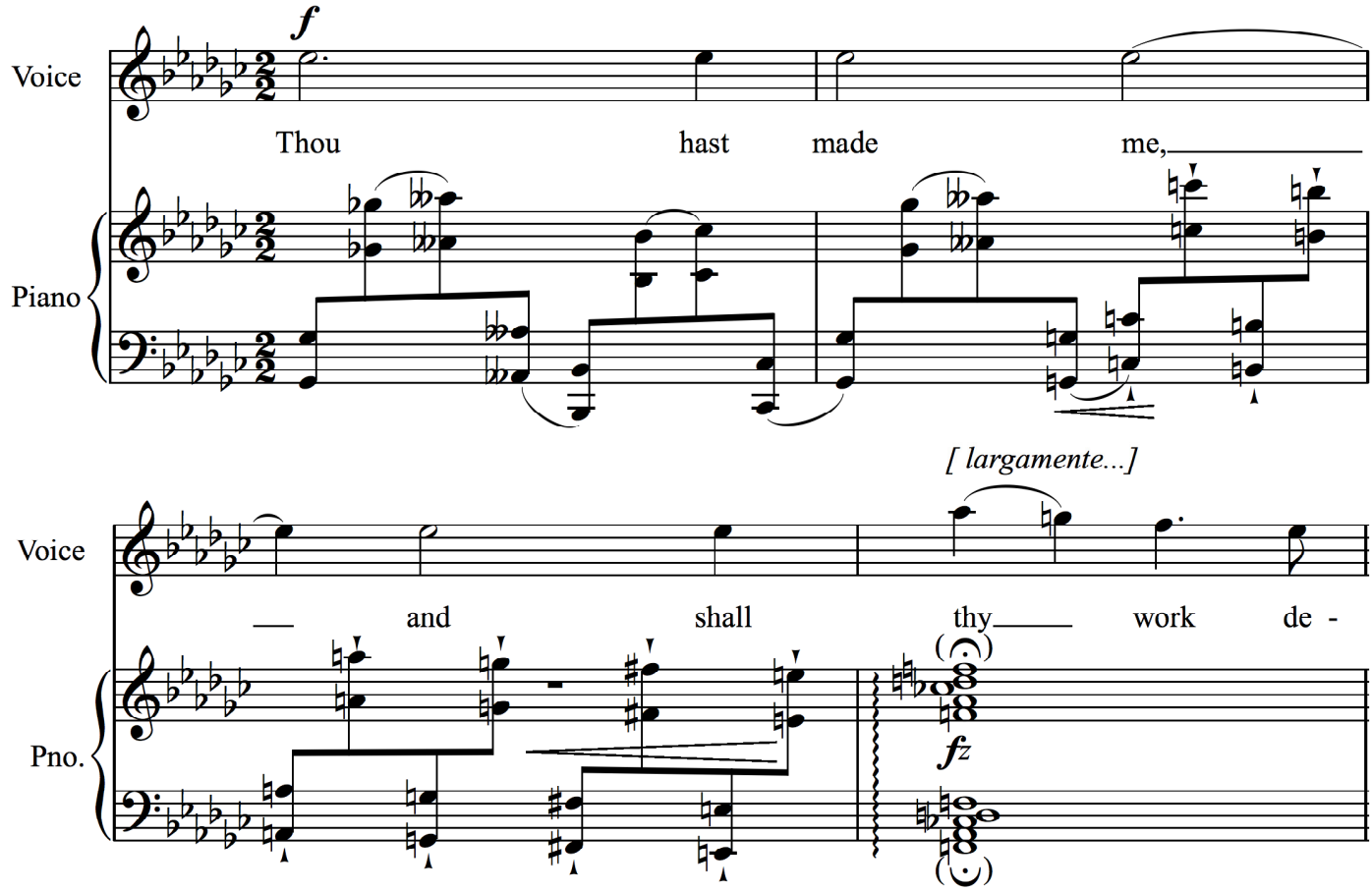

${ }^{34}$ Ibid., 33. Examples from "Thou Hast Made Me" reproduced with kind permission of Boosey \& Hawkes, Inc. 
The resoluteness of this text, as opposed to the panicked, confused statements of the second song, is shown through the more stable vocal line, which has more conjunct motion or skips within chords.

The angularity of the melody in mm. 36-44 ("Despaire behind, and death before ... towards Hell doth weigh") is replaced by a very tonal statement in mm. 45-47 (an E-flat major arpeggio up to a high $\mathrm{G}$ ) which is repeated in $\mathrm{mm}$. 51-54, to the text "Onely thou art above" and "I rise againe" (See Example 4-32 and 4-33).

Example 4-32, “Thou Hast Made Me," mm. 36-44. ${ }^{35}$
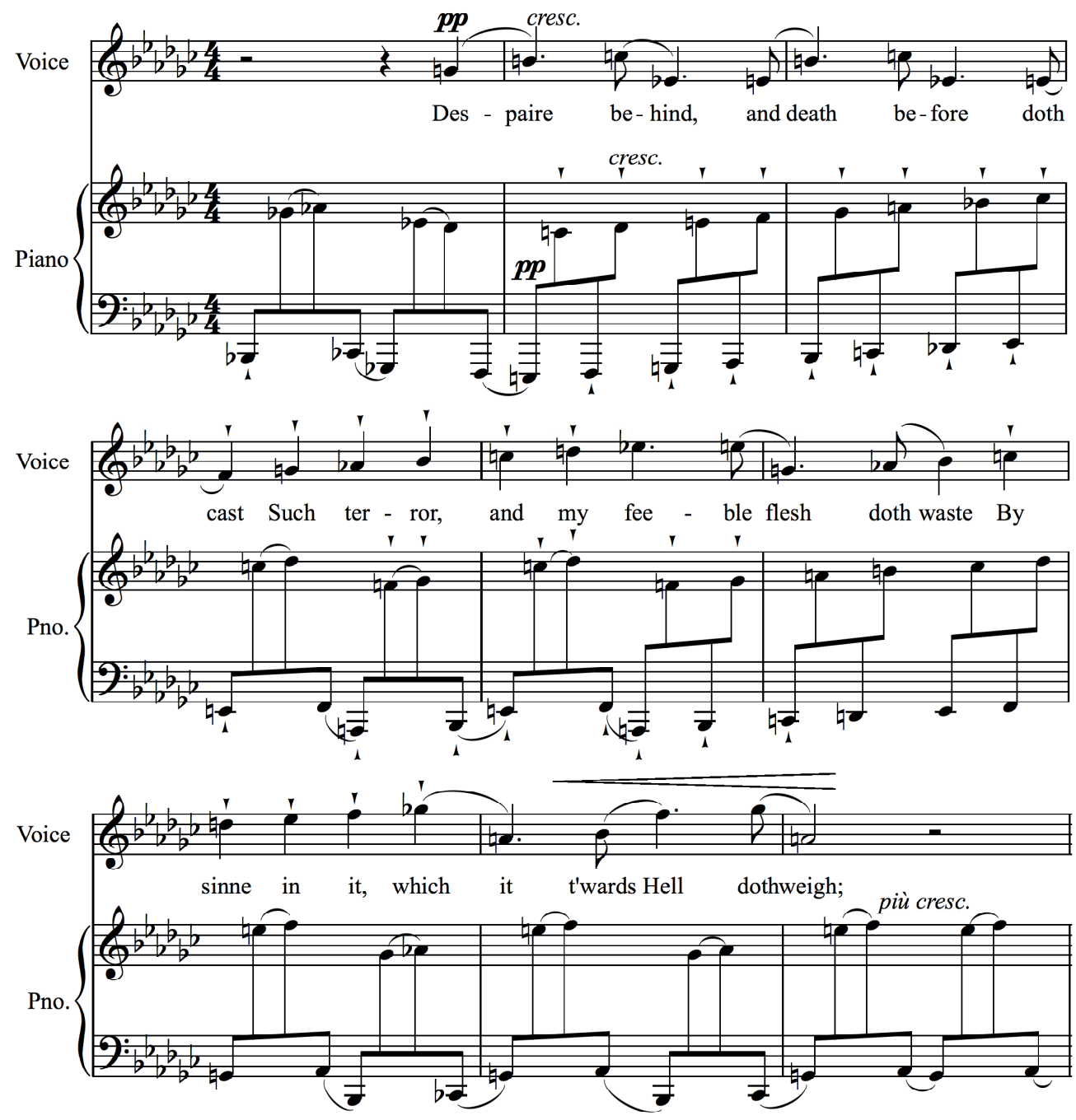

${ }^{35}$ Ibid., 34-35. 
Example 4-33, “Thou Hast Made Me,” (a.) mm. 45-47, (b.) 51-53. ${ }^{36}$

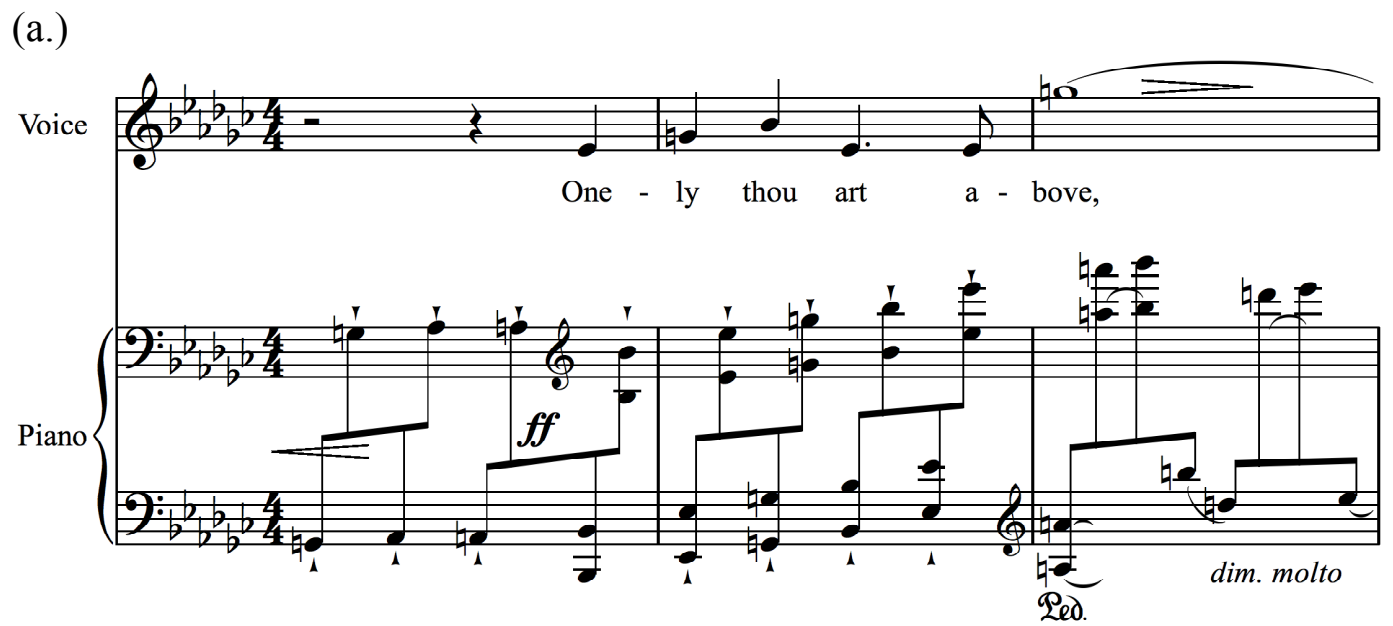

(b.)

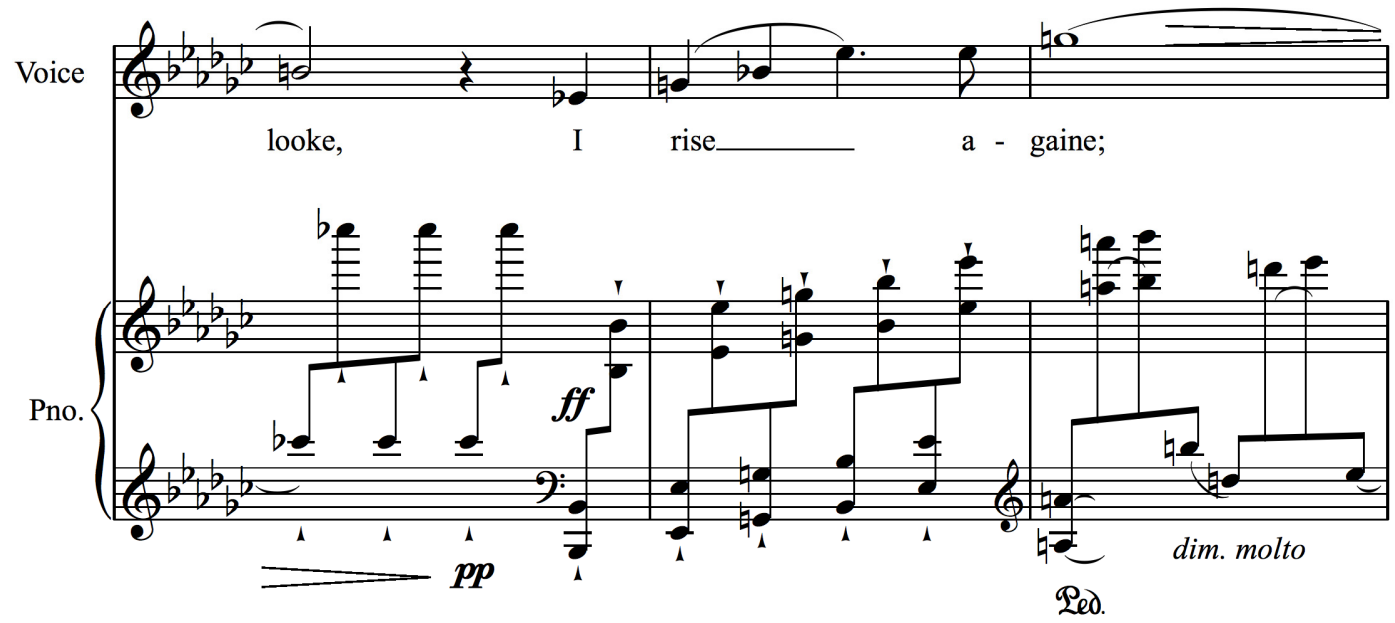

The defiance expressed by the singer in a tonally unambiguous arpeggio against the unstable tonality of the previous phrases, and the use of the sustained high G's at the end of those phrases show that the emotional state of the text is more stable and less tormented than he was in the second sonnet. This stability is further accentuated at the text "Thy Grace may wing me to prevent his art, and thou like adamant" by the seventeen repeated E-flats (eight measures worth) that lead to the final vocal flourish ("draw mine iron heart”) (See Example 4-34).

\footnotetext{
${ }^{36}$ Ibid., 35.
} 
Example 4-34, “Thou Hast Made Me," mm. 64-73. ${ }^{37}$
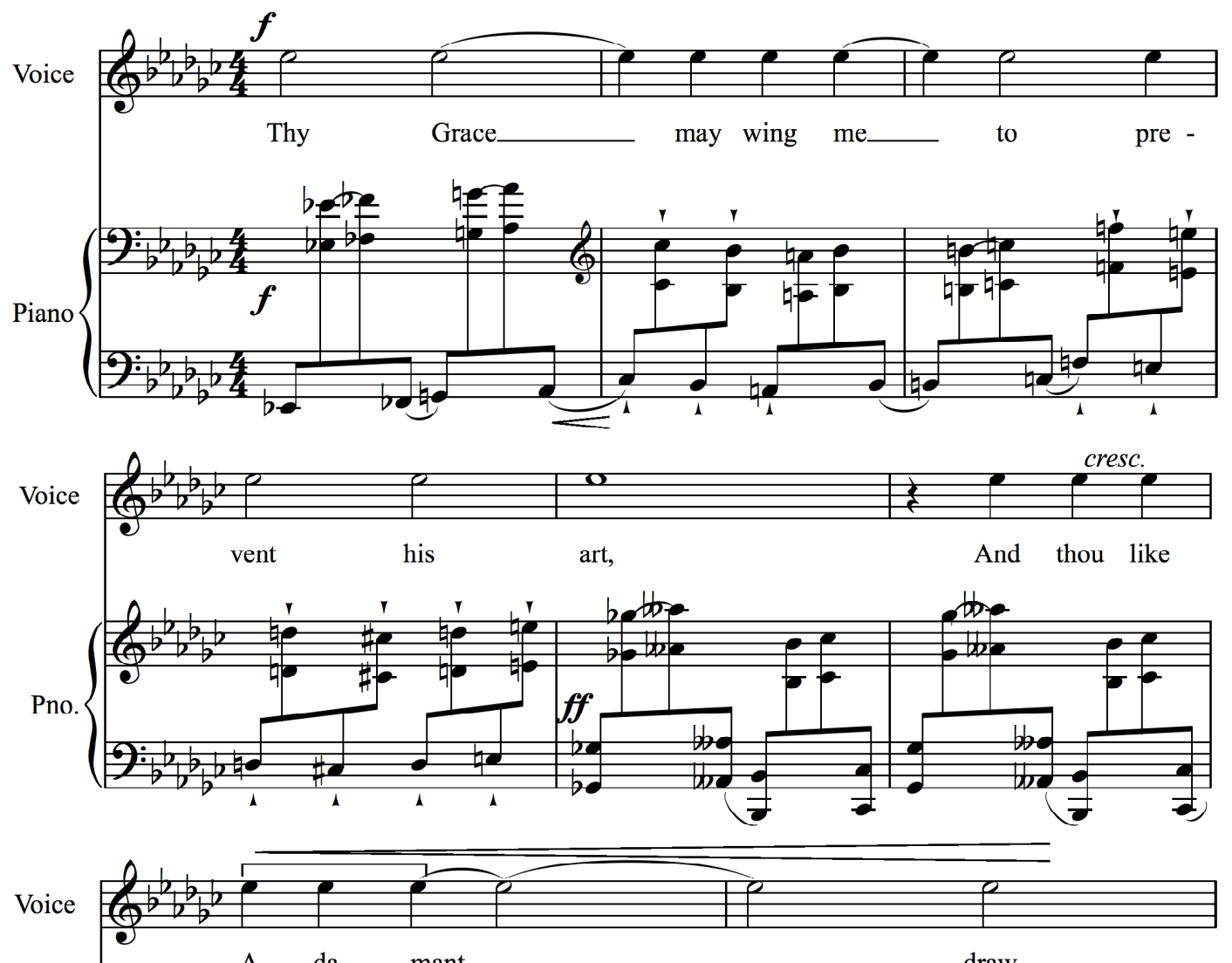
A - da - mant
draw

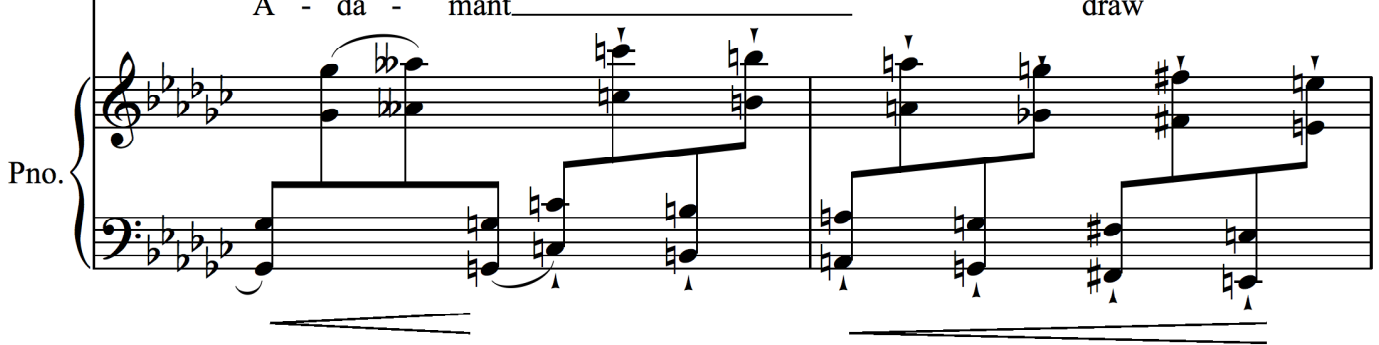

[largamente...]

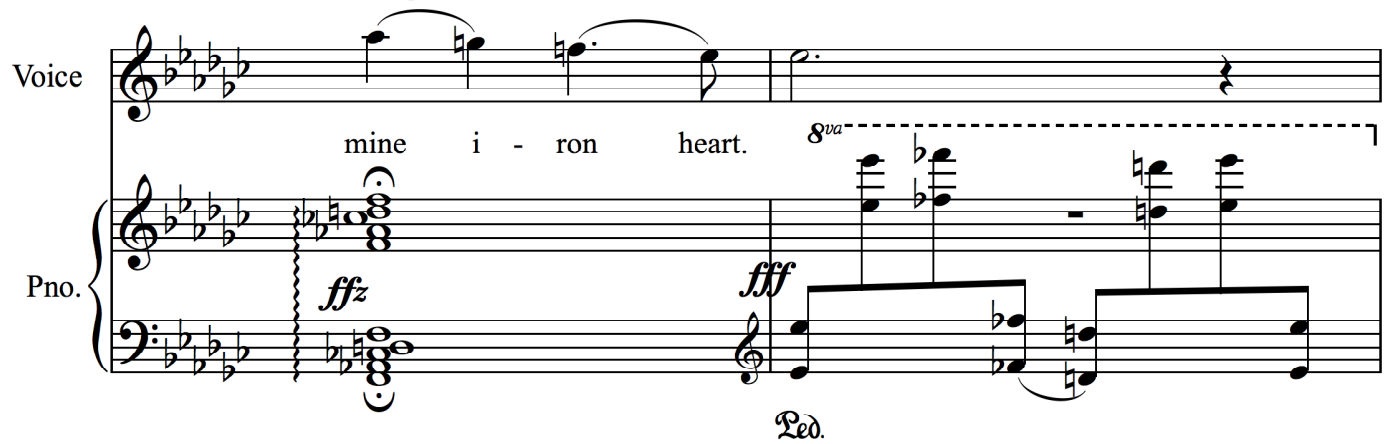

${ }^{37}$ Ibid., 36 


\section{Death, Be Not Proud}

Death be not proud, though some have called thee Mighty and dreadfull, for, thou are not soe, For, those, whom thou think'st, thou dost overthrow, Die not, poore death, nor yet canst thou kill mee.

From rest and sleepe, which but thy pictures bee, Much pleasure, then from thee, much more must flow, And soonest our best men with thee do goe, Rest of their bones, and soules deliverie. Thou art slave to Fate, Chance, kings, and desperate men, And dost with poyson, warre, and sickness dwell, And poppie, or charmes, can make us sleepe as well, And better than thy stroake; why swell'st thou then?

One short sleepe past, wee wake eternally, And death shall be no more; death, thou shalt die.

Another Purcellian device used in the cycle is the ground bass passacaglia in the final

piece, "Death, Be Not Proud." The composer used this device to express the triumph over death indicated in the sonnet: the text suggests that there is in fact no end to life, and the repeated bass line despite the harmonic changes above it seems to affirm this belief (See Example 4-35). 
Example 4-35, "Death, Be Not Proud," mm. 1-6.
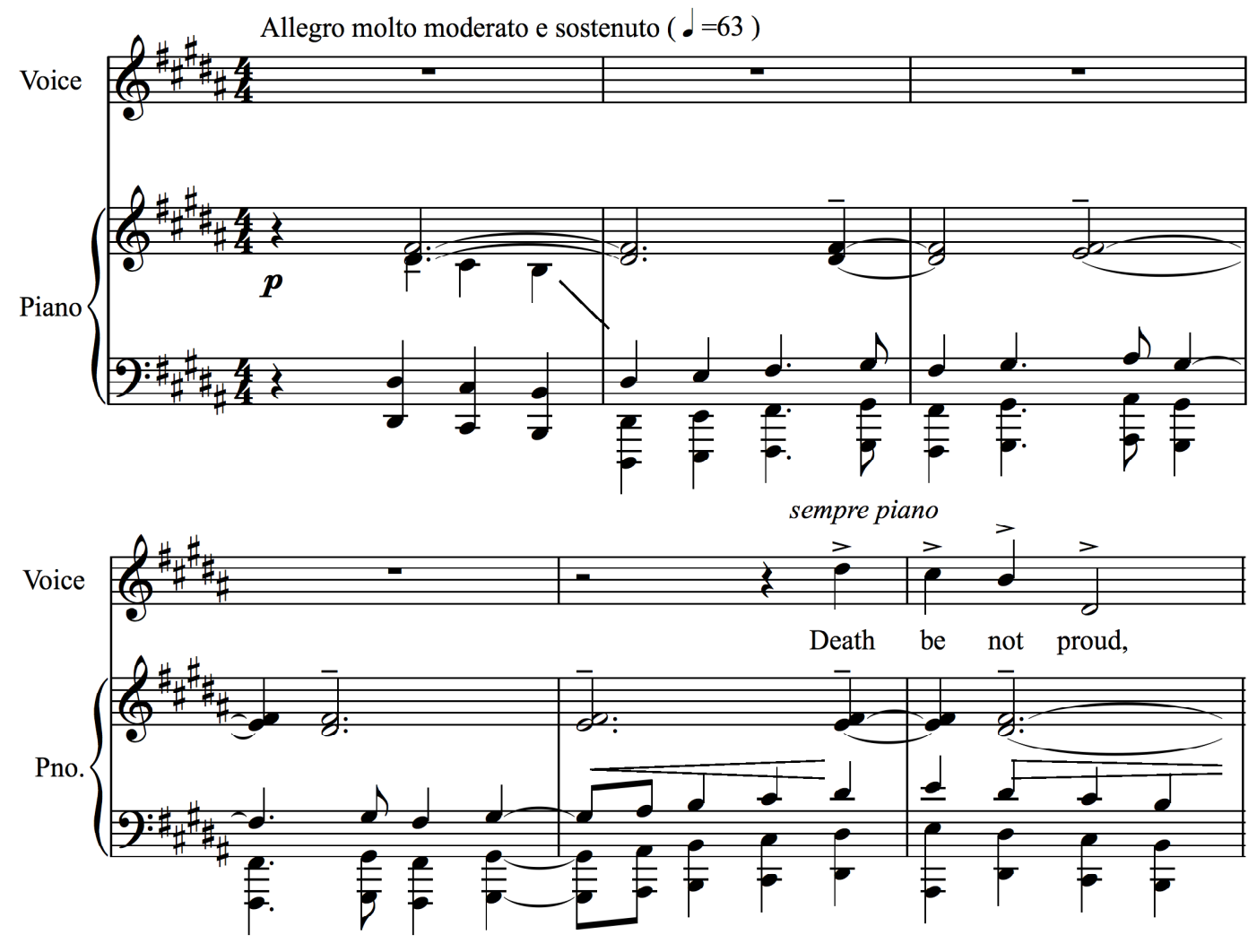

The steadfastness found in the first sonnet returns in the text of the ninth, albeit without the torment, and accordingly the tessitura is lower.

Britten set this text in this manner so that Pears again could use a more covered tone to his sound, in this case more mature, more stable emotionally, and more confident vocal quality. The vocal line lingers just below the staff quite a bit in this setting since the tenor was able to bring a richness to the sound in this lower range when at a softer dynamic level. The composer allowed for the softer dynamic through the economy of means in the accompaniment (See Example 4-36).

\footnotetext{
${ }^{38}$ Ibid., 37. Examples from “Death, Be Not Proud” reproduced with kind permission of Boosey \& Hawkes, Inc.
} 
Example 4-36, "Death, Be Not Proud," mm. 32-35. ${ }^{39}$
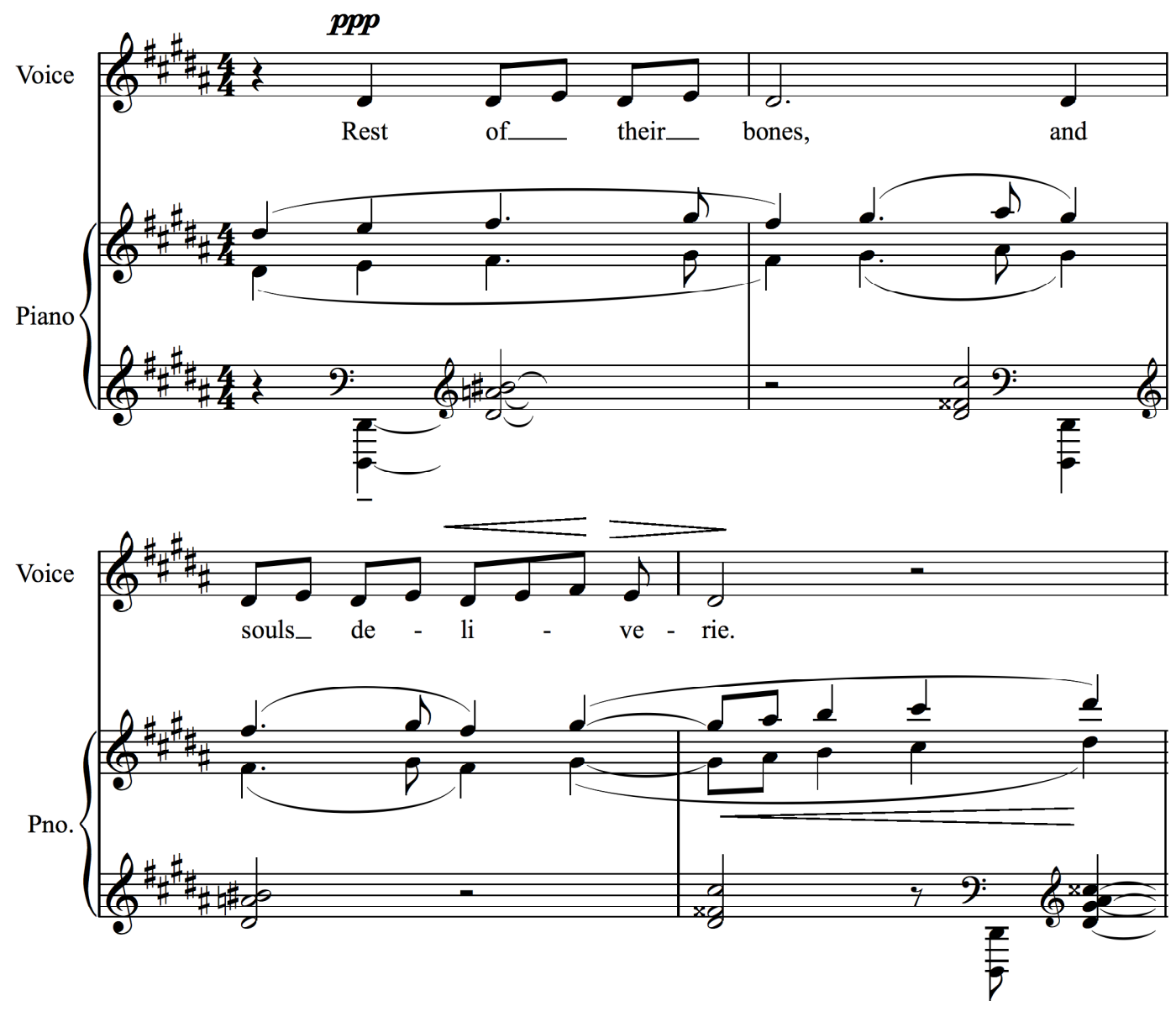

At these lower pitches the tenor could almost seem to taunt or sneer at death throughout the piece until its final statements, when the narrator reveals that he cannot be conquered even by death (See Example 4-37).

\footnotetext{
${ }^{39}$ Ibid., 39.
} 
Example 4-37, “Death, Be Not Proud,” mm. 55-63. ${ }^{40}$

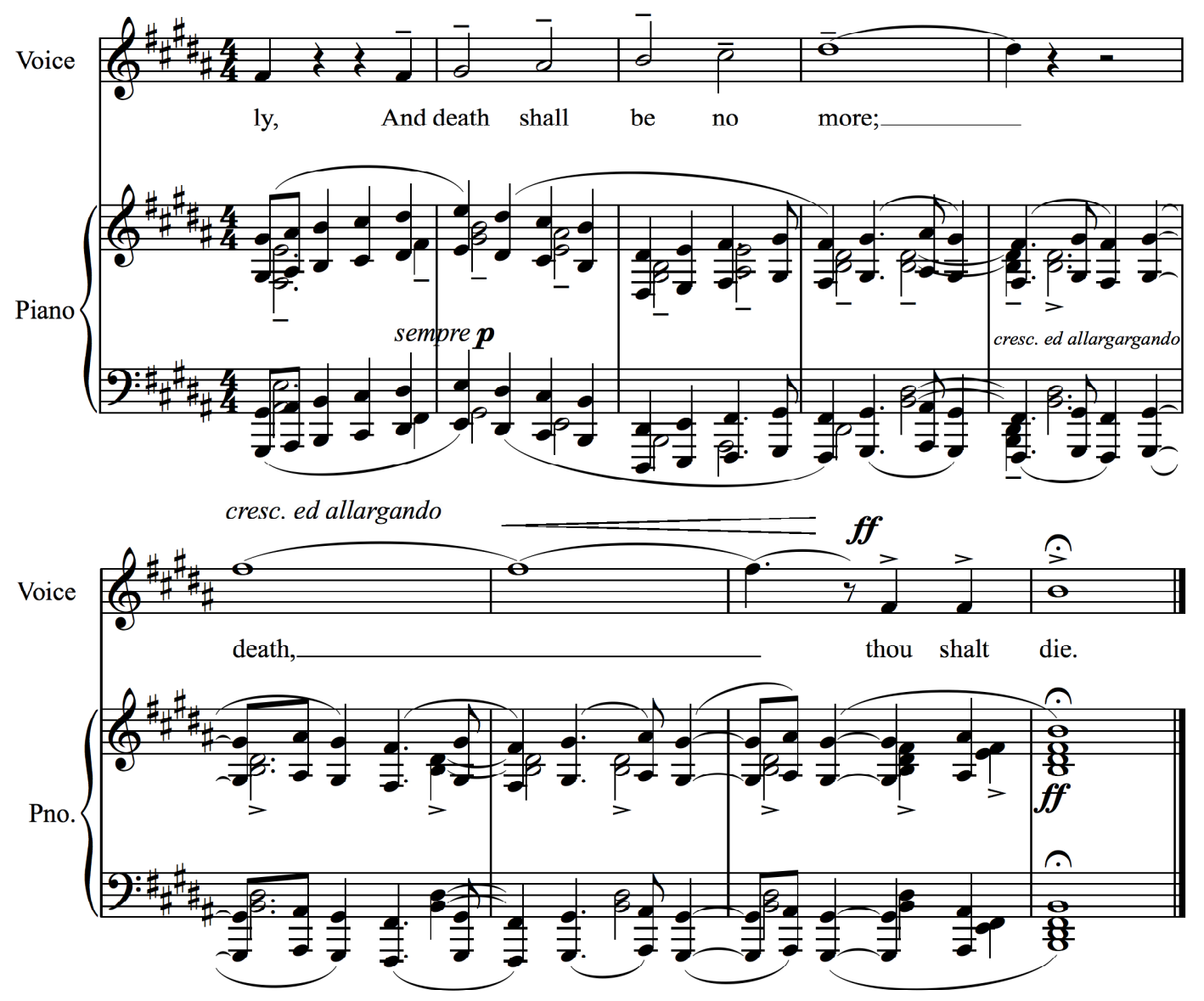

In the time between the composition of Seven Sonnets of Michelangelo and The Holy

Sonnets of John Donne, Britten and Pears had returned to England after their extended stay in the United States. While the tenor gained experience and renown on the opera stage, portraying major tenor roles in the standard repertoire, the composer was finishing up work on what would be his first operatic masterpiece, Peter Grimes. They also regularly performed art song recitals which included not only the Michelangelo cycle, but also lieder of Franz Schubert and airs by Henry Purcell. As their confidence grew so did their artistry, and this is exemplified in The Holy Sonnets of John Donne.

\footnotetext{
${ }^{40}$ Ibid., 40.
} 
The musical style of the work is not only influenced by the works of Purcell and Schubert, the works of whom were often programmed by the duo, but also by the texts themselves. The texts of The Holy Sonnets of John Donne are more dramatic and much angrier than those of the Michelangelo Sonnets, and Britten's setting shows this. This increased drama was also indicated by the tenor's developing acting ability. Compared to the earlier work, the composer used the power of his partner's upper middle voice for more stable climaxes in this cycle, reserving higher notes for less stable emotional moments.

As with the settings of the Michelangelo Sonnets, though, the composer carefully selected texts which combined to form a single narrative thread which he knew the tenor could communicate to audiences. These texts would have appealed to both men in that the poems could be seen to express some of their shared political values as both pacifists and as homosexual men. The choice and arrangement of texts and their setting in this cycle are a testament to the ongoing development of the artistry of the two men, as well as to the development of their personal relationship. The influence of their professional lives upon the composition is evident, and continued to be an influence upon the compositions yet to be discussed. 


\section{CHAPTER 5}

Winter Words: Lyrics and Ballads of Thomas Hardy, opus 52

(1953)

Britten composed Winter Words in 1953 following a number of his operas, including Albert Herring and The Rape of Lucretia. It predates The Turn of the Screw but shares with it not only a theme, the loss of innocence and the consequent regret, but also a musical language that is at times informed by the style of recitative that he had been developing in his operas. The texts of Winter Words are quite different from those of the cycles he had already composed for his partner as is the overall structure of the cycle.

The texts of the Michelangelo Sonnets were energetic, those of a man deeply in love whose love is not being returned as he would wish, and so there are moments of great agony and torment as well as moments of great passion and love. The John Donne sonnets were also highly passionate: this man was feeling that his soul was in torment and in that way he was questioning his spirituality. The text-setting in both of these cycles is indicative of these emotions. The Hardy poems do not have this kind of passion: they express a different kind of torment and quite often in a more passive way. The texts are despairing, but there is an acceptance of the despair: a wistfulness without bitter anger. This is a man looking back and seeing that the innocence and ignorance of youth have been lost and laments that loss by commenting upon it. The musical settings of the text are therefore not as aggressively passionate as the previous cycles, at least not until the last song of the cycle.

Britten chose the eight poems for his cycle from six different publications of Thomas Hardy's poetry dating from 1909 to $1928 .{ }^{1}$ Only one of the poems, "Proud Songsters," comes from the posthumous collection of Hardy poetry entitled Winter Words, the title of which Britten

\footnotetext{
${ }^{1}$ Annabelle Paetsch, "Aspects of Narrativity and Temporality in Britten's Winter Words." Music \& Letters 79 (November 1998): 538.
} 
used for the title of this cycle. The narrative that Britten created for this cycle differs from those of the two compositions already discussed in this paper in that the narrator is not always a figure in the action of the poem. This adds to the feeling of distance, the feeling of the "persona of the adult observer in his later years," that took it away. The anger and incredulousness of the narrator increases throughout the cycle as Britten has conceived of it, culminating not in a solution to the problem in the last setting, "Before Life and After," but in the clearest statement of the problem, that being the loss of innocence associated with the onset of adulthood.

Just as in the previous cycles, Britten chose poems that he felt could be combined to form a narrative. Its cyclic nature is found by looking at the thematic material of each poem, the manner in which the subject matter is presented, the time-line that is created when reading the poems in order, and by examining the key structure of the cycle as a whole. The overall form of the cycle is an arch. The first and eighth settings, "At Day-Close in November" and "Before Life and After," respectively, deal with the passage of time, the second and seventh both feature a young boy and a train, the third and sixth both have birds as central figures, and the fourth and fifth, at the center of the cycle, deal more specifically with people in the narrator's life: a love interest in the fourth and a family member in the fifth. ${ }^{3}$

Furthermore, the first and the last settings in the cycle function almost as bookends: the middle six settings are anecdotal in nature representing different aspects of the narrator's life and development retrospectively, whereas the first and last settings, both occurring at the end of his life and in the present, actually are focused upon his life without metaphor. Realizing that the

\footnotetext{
${ }^{2}$ Ibid., 540.

3 “The Little Old Table" was written about a gift from Tryphena Sparks, a former sweetheart of Hardy's, and "The Choirmaster's Burial" is about the death of Hardy's grandfather as relayed to him by his father. Georgia Ypma Bonney, “A Study of the Music and Text of Benjamin Britten's Winter Words, Op. 52: Lyrics and Ballads of Thomas Hardy," NATS Journal 49 (November/ December 1992): 5.
} 
outer settings function this way, we can look at the inner six settings separately as they reflect upon the narrator's life bringing him back to the present. The second setting, "Midnight on the Great Western (or The Journeying Boy)," reflects upon the narrator's own childhood and the naïve view he had about the reality of the adult world and all its hardship and cruelty. In the third setting, "Wagtail and Baby (A Satire)," the poet reflects upon his adolescence and all the aspects of his own life, represented by the different creatures that the wagtail encounters. The fourth setting, "The Little Old Table," represents that time in post-adolescence when he became aware of romantic love and its possibilities for loss and heartache. The fifth setting, "The Choirmaster's Burial (or The Tenor Man's Story)," deals with the narrator's first experience with the death of a loved one and the callousness of adults toward one another as well as with the realization that he was no longer a child himself. The sixth setting, "Proud Songsters (Thrushes, Finches and Nightingales)," represents the narrator's years of parenthood and grandparenthood, the birds in the setting being his children and then grandchildren who are, as the boy was in "Midnight on the Great Western," ignorant of their future. The seventh setting, "At the Railway Station, Upway (or The Convict and Boy with the Violin)," is a representation of the narrator at middle-age and beyond as he realizes that he is a prisoner of his life. This brings the narrator back to the present for his great lament in the last setting "Before Life and After."

These six settings alternate between poems which have one main character (or group in the case of the sixth, "Proud Songsters") and those which have essentially three major characters, one observer and two others in conflict. ${ }^{4}$ The second setting has for its main character a young boy traveling alone on a train. The third setting is the first with the three conflicting elements: the baby (the narrator's current self observing and reflecting), the wagtail (the narrator in the past as

\footnotetext{
${ }^{4}$ In the case of "wagtail and baby," one of the three characters being compared is in fact a group, one each for each verse of the poem. The other two characters remain constant throughout.
} 
an adolescent), and, of the other characters, the most notable is the gentleman (an adult male bound by and enforcing the rules of society), of whom the bird is afraid. The fourth setting has for its single main character the table, a gift to the narrator from his first love that reminds him of her. The fifth setting has the three characters again: the narrator of the story, who functions as the baby did in the third setting, the choirmaster who is wronged by man (as the wagtail feared), and the vicar who, like the "perfect gentleman" in the earlier setting, was supposedly respected in his community but his behavior was neither kindly nor good. The sixth setting has for its main characters the birds that remind the narrator of his lost past and his own tormented present. The seventh setting has three characters: the boy in this story is the narrator in the present, hoping to comfort his past self (and perhaps change the outcome of the story), the convict is wronged and trapped by his life, and the constable is the keeper of the rules who is ignorant of the pain he is causing.

The work functions as a cycle as well in terms of tonal centers from setting to setting. The first, although somewhat bi-tonal, primarily has D minor for a tonal center. ${ }^{5}$ The key of the second setting is a whole-step down from the first, $\mathrm{C}$ minor (the flat seven of the home key). The fairly remote relationship helps to establish the change of time and attitude that occur from the one song to the next. The key of the third setting is a minor third lower than that of the second, A major, the dominant of the home key, which helps to remind us that despite the different approach of the middle six settings in telling the narrative, there is still a relationship between their characters and the narrator of the first setting. The fourth song is primarily in $\mathrm{E}$ minor, although it has moments of $\mathrm{E}$ major which help to establish the relationship between it and the previous setting in that this one is in the dominant key of the previous (and is the

\footnotetext{
${ }^{5}$ Graham Johnson has discussed the relationship between this cycle and that of Franz Schubert's Die Winterreise in that both include "winter" in the title, but also in the shared overall tonality of D. Graham Johnson, "Voice and Piano," The Britten Companion, ed. Christopher Palmer (London: Faber and Faber, 1984), 296.
} 
submediant of the cycle as a whole). The change in the narrator from the fourth to the fifth setting is perhaps the greatest because he encounters the most profound disappointment thus far, and he realizes that his innocence has been lost. This is represented by the movement of the tonal center from $\mathrm{E}$ in the fourth song to a predominantly B-flat major tonality in the fifth (despite the fact that it seems to begin and end in A-flat major). The tritone relationship between the two settings reflects this great change in the fact that the tonal center has moved as far away as it possibly can around the circle of fifths and therefore shares as little in common as two major keys can. Just as the third and fourth settings had a tonic to dominant key relationship, the fifth and sixth do as well, this time the B-flat tonality of the fifth song serves as a dominant to the sixth, which is in E-flat major. Also, just as the third was in the dominant key of the cycle as a whole, the E-flat major can be thought of as an upper leading tone to the D tonality, which reinforces not only the key of the cycle, but the kind of perversion that happens during adulthood, especially the cruelty to nature and others, in that this is an unusual way to represent a dominant-tonic relationship. The seventh setting is a minor third away, just as the third was from the second, being primarily in $\mathrm{C}$ major. This also creates the same relationship to the home key, when it returns in the final setting, as the cycle had when it first left, that of a major second. The final setting is in the key of D major, the major tonality being a representation of the hope for a return to the innocence of youth in the afterlife.

Winter Words examines a life retrospectively, rather than as present experience. Therefore, the musical style of the cycle and the vocal line are generally more reserved, less angular, almost less direct in many ways than those of the cycles that preceded it, since the texts more often are the memories of actions rather than the actions themselves. The difference in the emotional quality or the passion of Winter Words when compared to the others is the difference 
between anger and sorrow. The innovation in this composition is the understatement of the voice, in contrast to the great passion in the Michelangelo and John Donne settings. The Hardy cycle is much more wistful, and consequently the vocal line is much more understated throughout the work.

In this cycle, the vocal line often functions in the same way that the accompaniment does: the accompaniment is used for general mood-painting, for example the train's horn expressed in the opening of "Midnight on the Great Western" (See Example 5-1).

Example 5-1, "Midnight on the Great Western," mm. 1-3. ${ }^{6}$

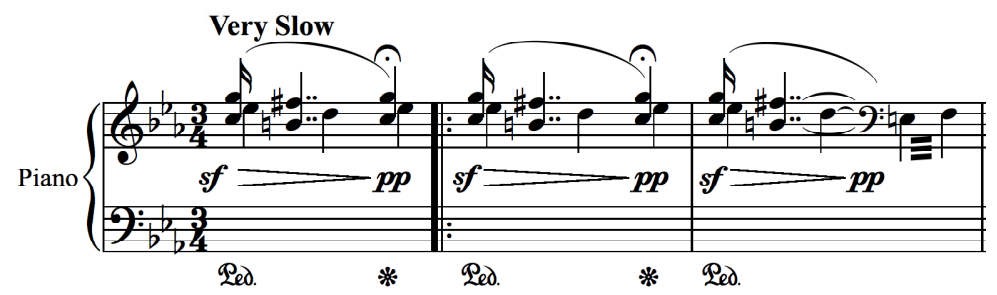

Vocally, this mood-painting is expressed in the same setting by the triads in increasing rhythm giving the effect of a train jostling down the tracks (See Example 5-2) and by the repetition of the creaks in "The Little Old Table," which help to give the impression of the table's advanced age (See Example 5-3).

Example 5-2, "Midnight on the Great Western," mm. 12-14.

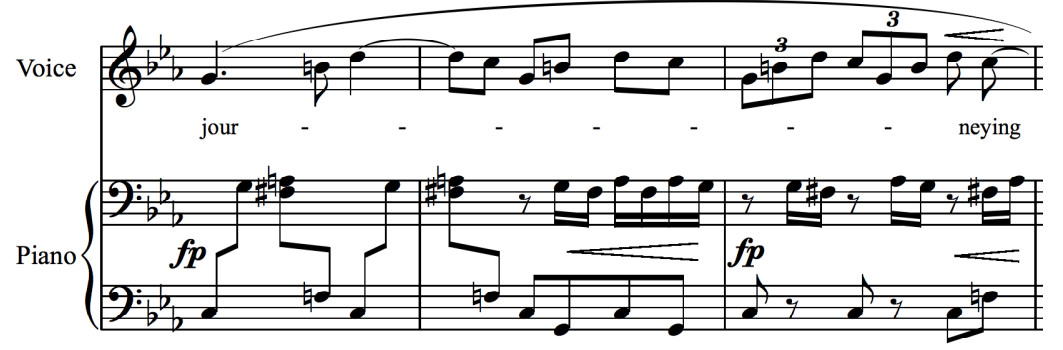

Example 5-3, "The Little Old Table," mm. 56-59. ${ }^{8}$

\footnotetext{
${ }^{6}$ Benjamin Britten, Winter Words, opus 52. (New York: Boosey \& Hawkes, 1954), 4. Examples from “Midnight on the Great Western (or The Journeying Boy)" reproduced with kind permission of Boosey \& Hawkes, Inc.

${ }^{7}$ Ibid., 4.
} 


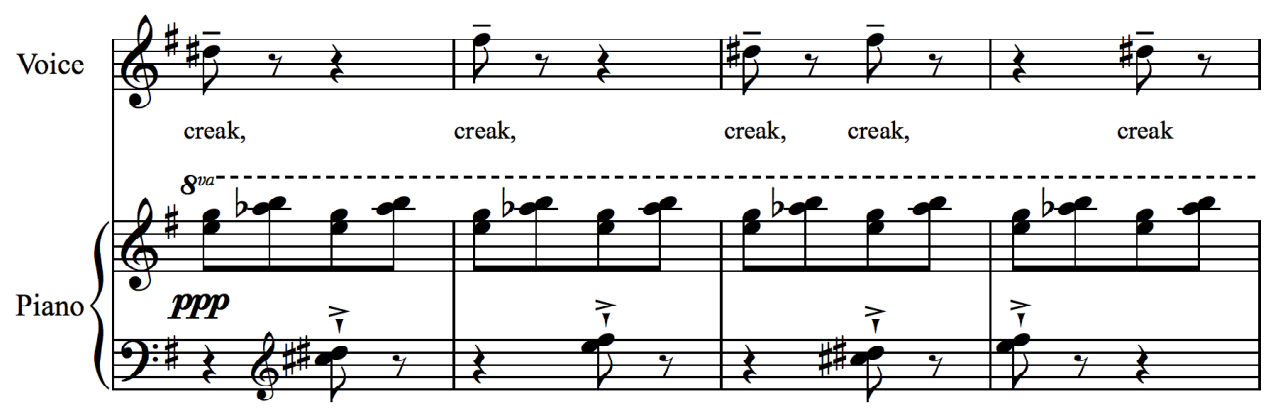

The overall range of the cycle is just a little smaller than that of the previous cycle, extending from the $\mathrm{C}$ below middle $\mathrm{C}$ to the $\mathrm{A}$-natural above it.

At Day-Close in November

The ten hours' light is abating, And a late bird wings across, Where the pines, like waltzers waiting, Give their black heads a toss.

Beech leaves, that yellow the noon-time, Float past like specks in the eye; I set every tree in my June time, And now they obscure the sky.

And the children who ramble through here

Conceive that there never has been A time when no tall trees grew here, A time when none will be seen.

The opening accompaniment figure of "At Day-Close in November," one that continues throughout this setting, sets the mood for the text. Britten's use of chromaticism in the vocal line causes it to function more as an overall musical effect to express better the detached, mournful quality of the text. The melodic line seems to drift down in each phrase, incorporating almost all

\footnotetext{
${ }^{8}$ Ibid., 17. Examples from “The Little Old Table" reproduced with kind permission of Boosey \& Hawkes, Inc.
} 
of the twelve tones of the octave, and gives the effect of diminishing youth or an increasing exhaustion (See Example 5-4).

Example 5-4, “At Day-Close in November," (a.) mm. 10-18, (b.) 20-29, (c.) 45-54. ${ }^{9}$

(a.)
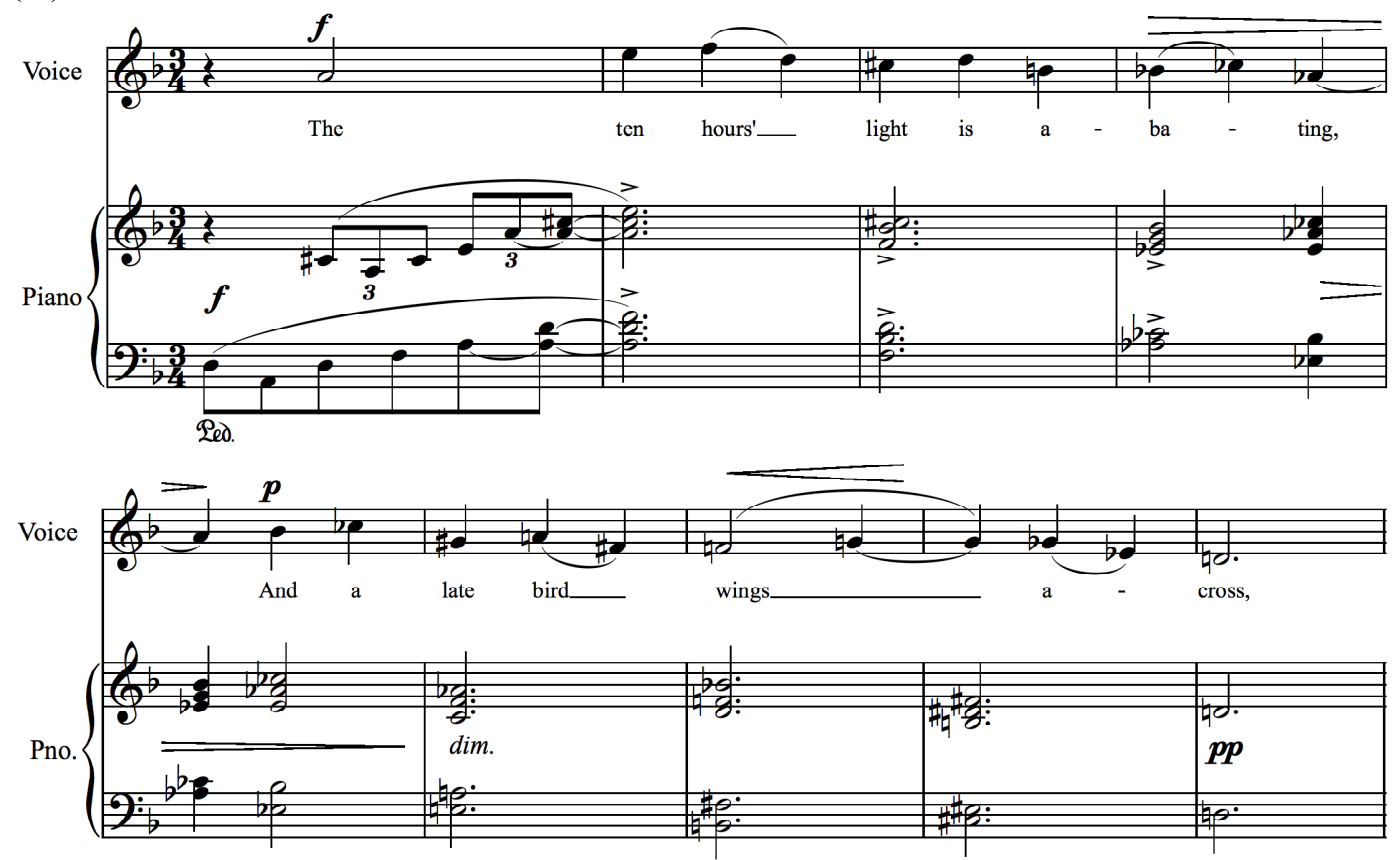

(b.)
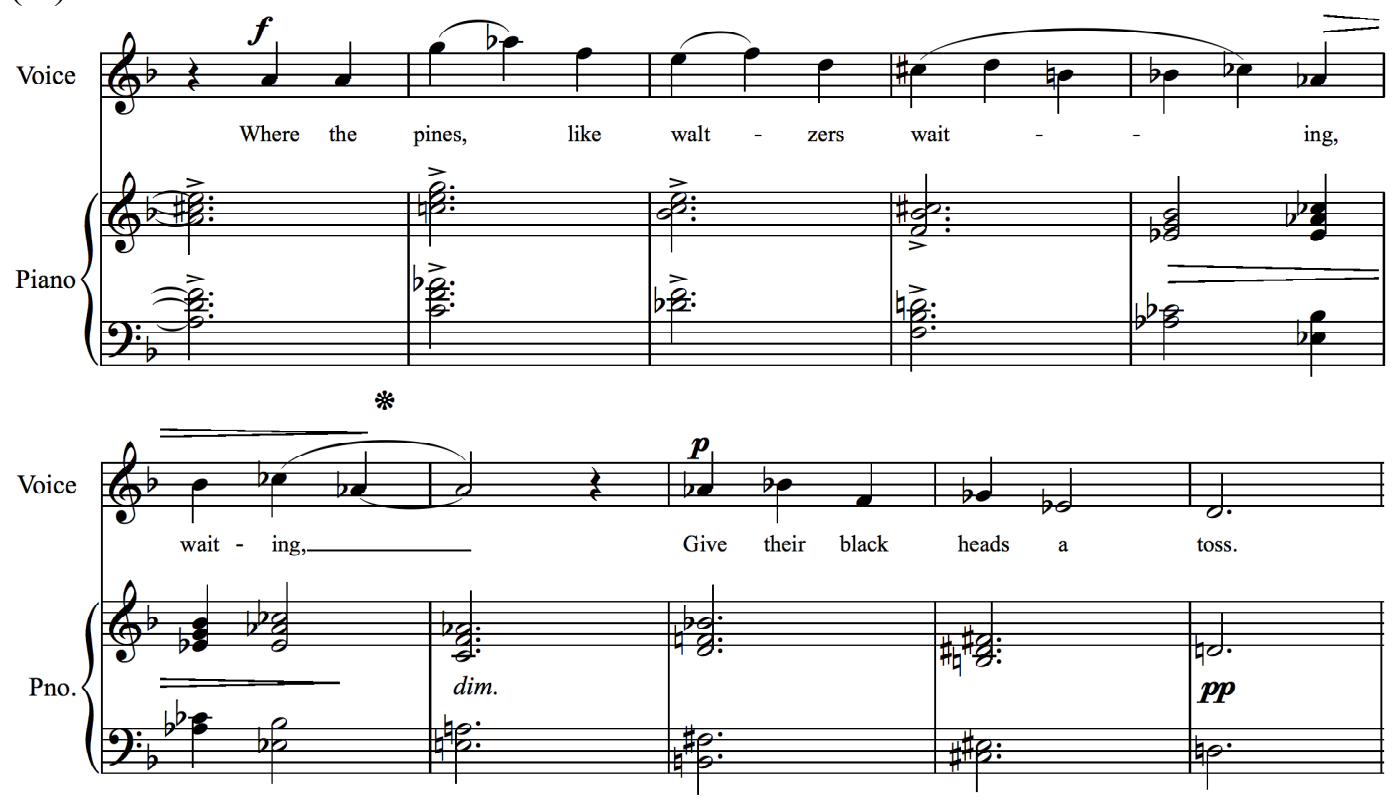

${ }^{9}$ Ibid., 1, 2, 3. Examples from "At Day-Close in November" reproduced with kind permission of Boosey \& Hawkes, Inc. 


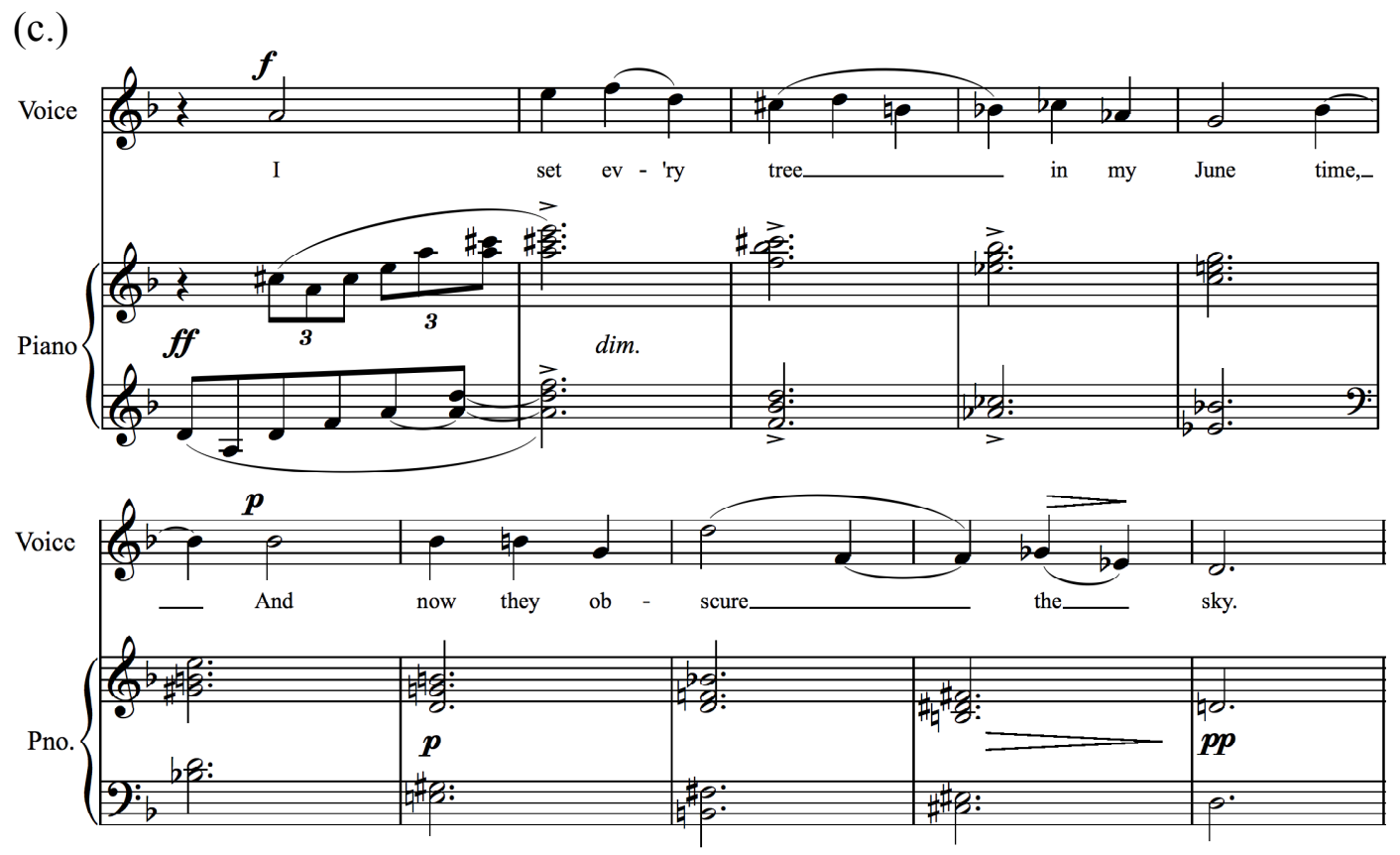

In the first several phrases of the piece, Pears was taken up above the passaggio, but with the following descent, it seems that the emotional resolution of the poem is not reached: the resolution is almost unattainable. In point of fact, the composer did not take Pears above the passaggio again in this setting, which allowed the singer to represent the narration of an old man by using the richer sounds he was afforded in his middle and lower voice (See Example 5-5).

Example 5-5, “At Day-Close in November," mm. 69-74. ${ }^{10}$

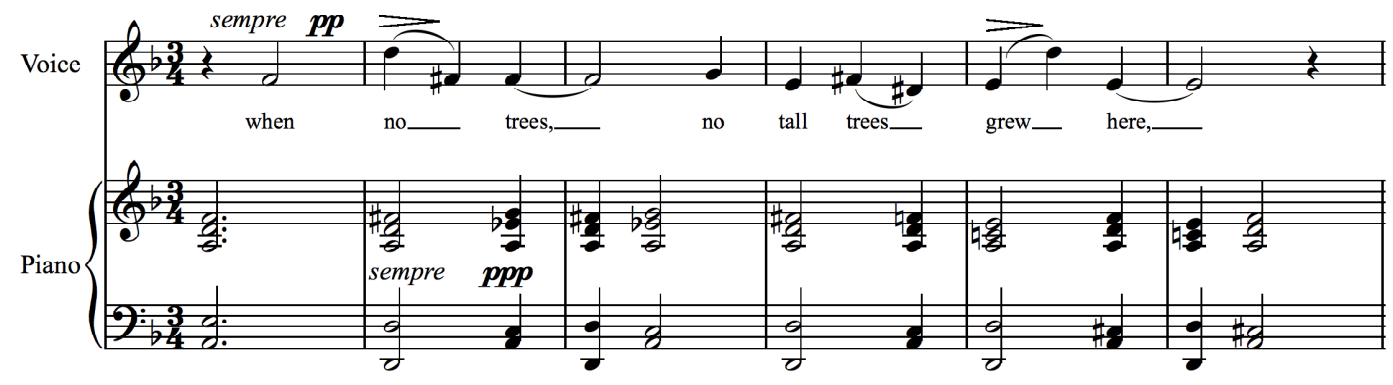

${ }^{10}$ Ibid., 3. 
The remainder of the setting alternates between conjunct melodic motion and large melodic skips, which allowed the tenor to express the thoughts of the narrator, who at this point in the cycle has not yet realized the depth of his anger and loss.

The text expresses the ignorance of the children, who are blissful because of their lack of knowledge, juxtaposed with the isolation and unhappiness of the narrator, who has outgrown this ignorance. These ideas, which are a part of the entire cycle, may have attracted Britten as a homosexual, in many ways separate from the society in which he lived, but also as a man approaching middle age, a time when it is common to evaluate one's life and become more aware of one's own mortality.

\section{Midnight on the Great Western \\ (or The Journeying Boy)}

In the third-class seat sat the journeying boy,

And the roof-lamp's oily flame

Played down on his listless form and face,

Bewrapt past knowing to what he was going,

Or whence he came.

In the band of his hat the journeying boy

Had a ticket stuck; and a string

Around his neck bore the key of his box, That twinkled gleams of the lamp's sad beams

Like a living thing.

What past can be yours, $O$ journeying boy

Towards a world unknown, Who calmly, as if incurious quite

On all at stake, can undertake

This plunge alone?

Knows your soul a sphere, O journeying boy,

Our rude realms far above,

Whence with spacious vision you mark and mete

This region of sin that you find you in,

But are not of? 
The opening of "Midnight on the Great Western" is an imitation in the accompaniment of the train whistle, as detailed earlier, and sets the scene vividly for the second of the Hardy settings. The voice continues this idea with its representation of the boy being jostled in the train, to the text "journeying boy." The middle section of the piece, starting with "What past can be yours, ...” is an example of the free recitative style that Britten had been developing in his operas, and it gave his partner the opportunity to bring the text into clear focus (See Example 5$6)$.

\section{Example 5-6, "Midnight on the Great Western," mm. 64-78. ${ }^{11}$}
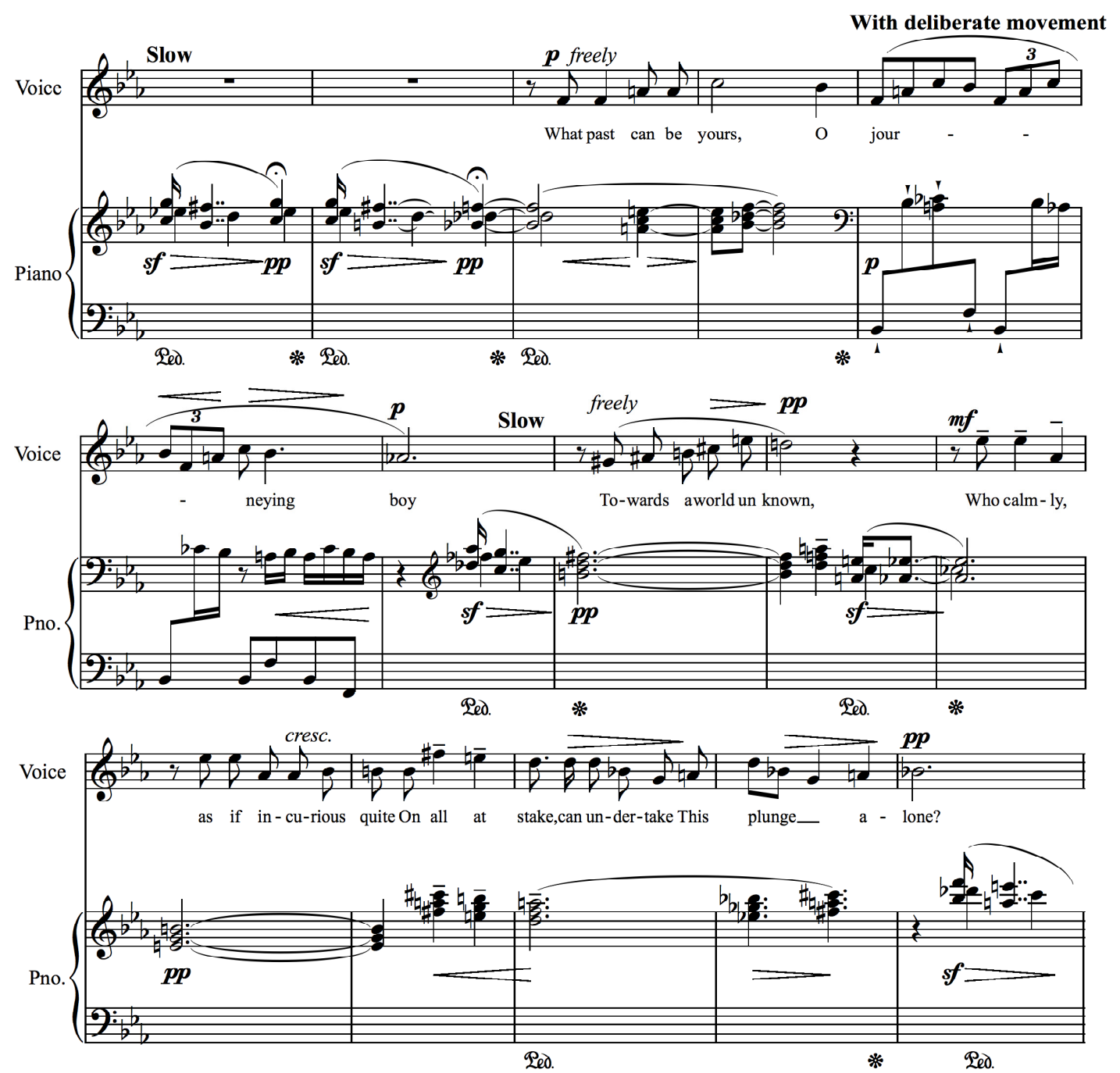

${ }^{11}$ Ibid., 6. 
The lack of stability of the tonal center of this section gives the listener less upon which to focus, calling more attention to the words. Pears was able to use the frailer, more transparent quality of his upper middle voice to express the dismay the narrator feels about the young boy. The use of the tenor's low voice at the end of this setting is both very intimate and shocked, almost disembodied, as the poet questions the fate of the poor young boy traveling on his own through an unfamiliar and dangerous world, "This region of sin that you find you in, but are not of," hoping that the boy's fate could be different than his own (See Example 5-7).

Example 5-7, "Midnight on the Great Western," mm. 98-102. ${ }^{12}$

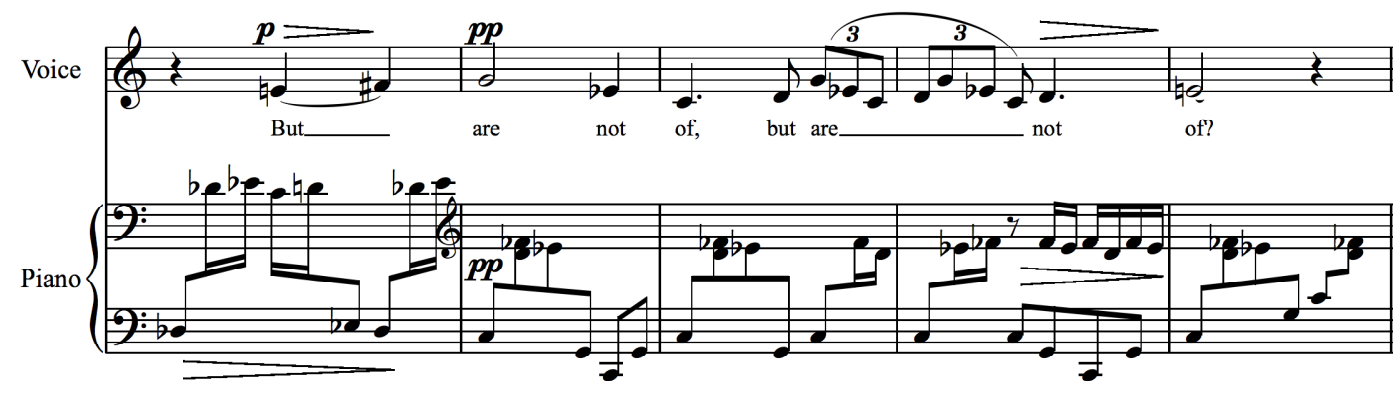

Wagtail and Baby

(A Satire)

A baby watched a ford, whereto

A wagtail came for drinking;

A blaring bull went wading through,

The wagtail showed no shrinking.

A stallion splashed his way across,

The birdie nearly sinking;

He gave his plumes a twitch and toss, And held his own unblinking.

Next saw the baby round the spot

A mongrel slowly sinking;

The wagtail gazed, but faltered not

In dip and sip and prinking.

${ }^{12}$ Ibid., 8. 
A perfect gentleman then neared;

The wagtail, in a winking,

With terror rose and disappeared;

The baby fell a-thinking.

The text of "Wagtail and Baby" has the character of a folk story in which there is a kind of lesson to be learned about the relationship of man and nature, and so the melody is accordingly more folk-like as well in its speech-like rhythms. In this way, the composer used a general musical idea to express the text rather than more specific examples or word-painting. The accompaniment, notably in the left hand, however, is reminiscent of those of a number of songs by Franz Schubert, such as in "Auf dem Wasser zu Singen" (See Examples 5-8 and 5-9).

Example 5-8, Franz Schubert, “Auf dem Wasser zu Singen,” mm. 1-8. ${ }^{13}$
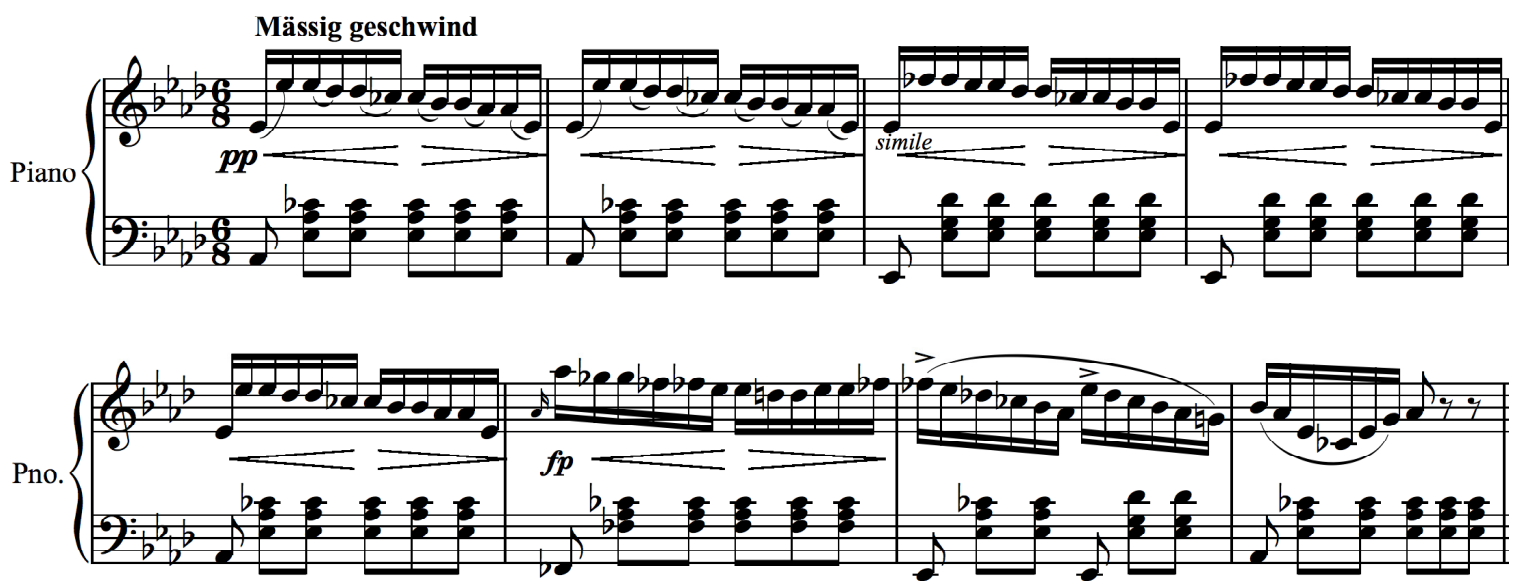

\footnotetext{
${ }^{13}$ Franz Schubert, 200 Songs in Three Volumes Volume 1: 100 Songs (New York: International Music Company, 1961), 214.
} 
Example 5-9, "Wagtail and Baby," mm. 1-3. ${ }^{14}$

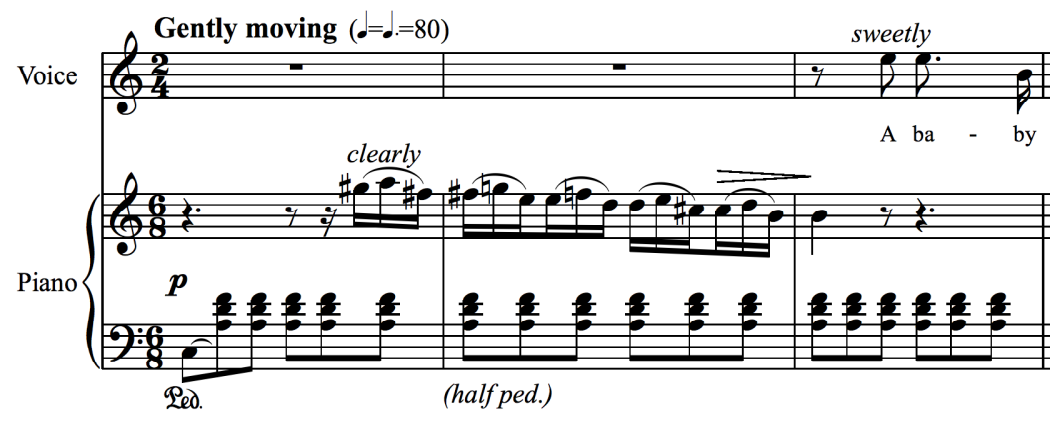

This accompaniment pattern is consistent throughout the setting, serving to set the general mood of the text, and therefore the vocal line is used to express more specifically the meaning of the words. The vocal line in this setting is somewhat high, so Pears was therefore able to use a light tone throughout to further the conversational feel afforded by the speech-like rhythms.

In telling the story, the narrator is more distanced from the action, allowing him to examine his feelings from this perspective, much as the baby does in the story, maintaining more of an emotional neutrality throughout. This distance is expressed melodically in this setting by the relatively conjunct nature of the vocal line: there are no particular extremes melodically except for a slight coloristic effect at the text "like a perfect gentleman," which serves to accent the fact that the bird is frightened away by the human and not by others in the animal kingdom, and which also expresses a certain condescension or even snootiness in the adult (See Example 5-10).

\footnotetext{
${ }^{14}$ Britten, 9. Examples from "Wagtail and Baby" reproduced with kind permission of Boosey \& Hawkes, Inc.
} 
Example 5-10, “Wagtail and Baby," mm. 45-47. ${ }^{15}$

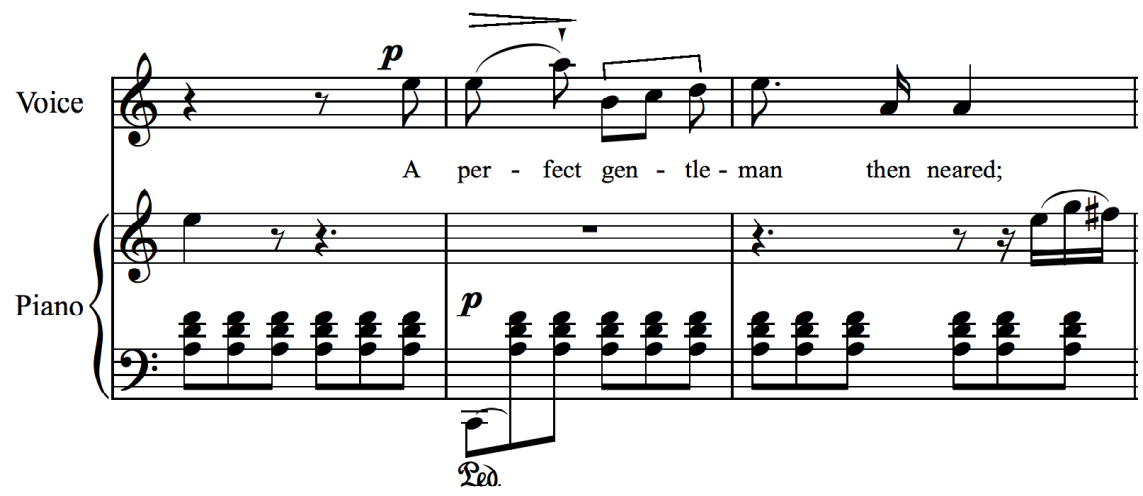

The Little Old Table

Creak, little wood thing, creak

When I touch you with elbow or knee;

That is the way you speak

Of one who gave you to me!

You, little table, she brought -

Brought me with her own hand, As she looked at me with a thought

That I did not understand.

- Whoever owns it anon, And hears it, will never know

What a history hangs upon

This creak from long ago.

The dream-like quality of the beginning of the accompaniment of "The Little Old Table" sets the mood of the piece, (See Example 5-11) and the vocal line once again follows suit.

${ }^{15}$ Ibid., 12. 
Example 5-11, “The Little Old Table," mm. 1-2. ${ }^{16}$

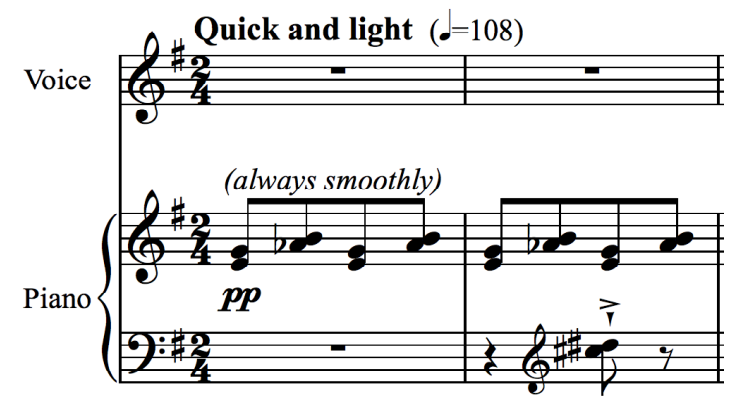

The melody has a somewhat nebulous tonality, alternating between E major and E minor, and again lingered in the tenor's upper middle voice, helping to express the detached emotion of most of the text. The setting has brief moments of stronger emotion at the end of each verse, where Britten took Pears to a high $\mathrm{G}$, but with the downward motion of the chromatic line that follows the emotion is muted almost as soon as it appears (See Example 5-12).

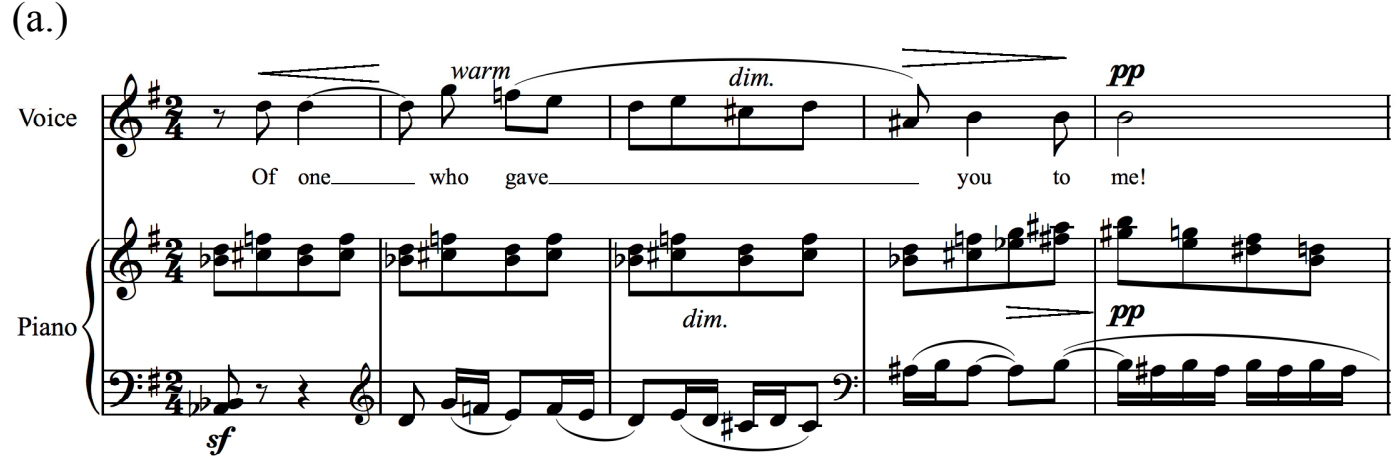

(b.)

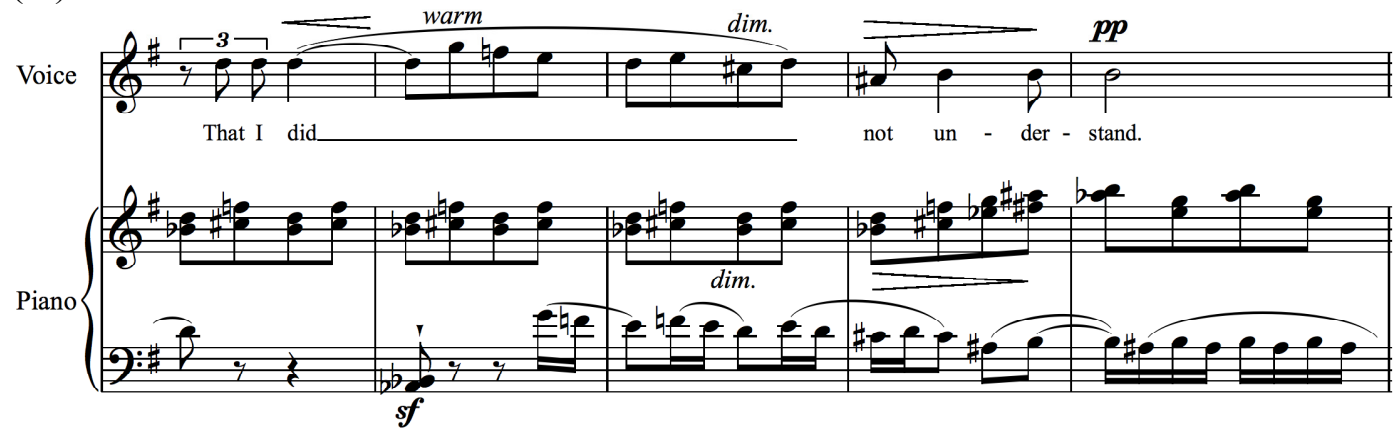

\footnotetext{
${ }^{16}$ Ibid., 14.

${ }^{17}$ Ibid., $15,16$.
} 
The simplicity of the text is matched by the composer's strophic setting, but the underlying emotions of loss and abandonment are inherent in the chromaticism of the melody itself, since it strays from the home key through tonicizations yet does not actually modulate, allowing the tenor to portray the narrator who is becoming more distraught over the loss of his first love (See Example 5-13).

Example 5-13, “The Little Old Table," mm. 16-20. ${ }^{18}$

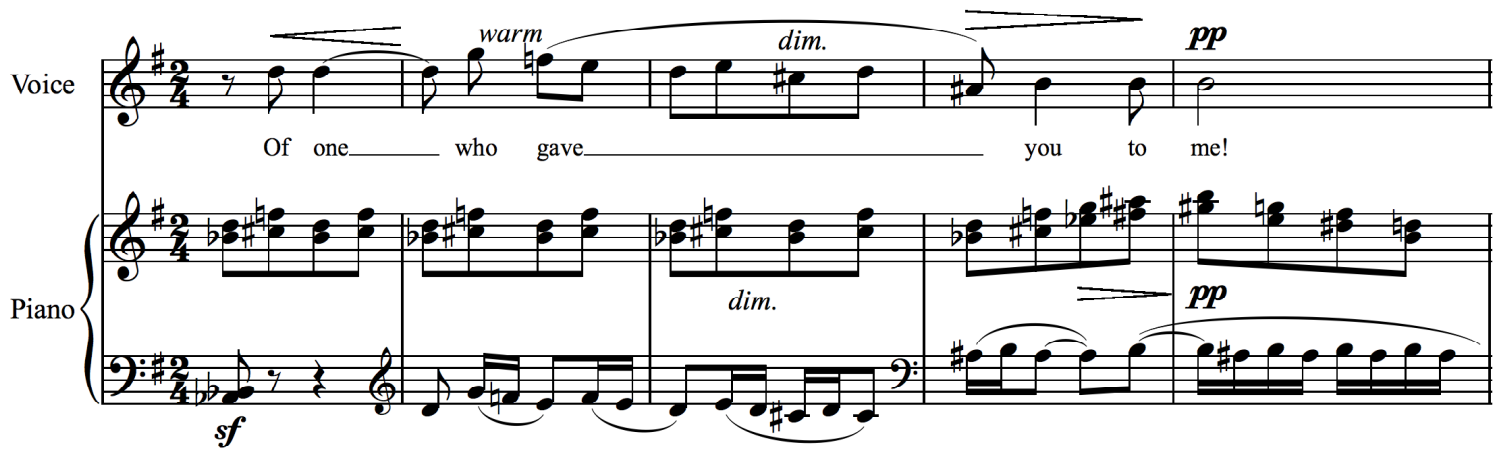

The Choirmaster's Burial

(or The Tenor Man's Story)

He often would ask us

That, when he died,

After playing so many

To their last rest,

If out of us any

Should here abide,

And it would not task us,

We would with our lutes

Play over him

By his grave-brim

The psalm he liked best -

The one whose sense suits

'Mount Ephraim' -

And perhaps we should seem

To him, in Death's dream,

Like the seraphim.

${ }^{18}$ Ibid., 15. 
As soon as I knew

That his spirit was gone

I thought this his due, And spoke thereupon.

'I think,' said the vicar, 'A read service quicker Than viols out-of-doors In these frosts and hoars. That old-fashioned way Requires a fine day, And it seems to me It had better not be.'

Hence, that afternoon, Though never knew he That his wish could not be,

To get through it faster

They buried the master

Without any tune.

But 'twas said that, when At the dead of next night The vicar looked out, There struck on his ken Thronged roundabout, Where the frost was graying

The headstoned grass,

A band all in white

Like the saints in church-glass, Singing and playing

The ancient stave

By the choirmaster's grave.

Such the tenor man told When he had grown old.

“The Choirmaster's Burial," another folk story, is a little more complex in its representation of the characters in the text and their different emotional qualities. The composer used elements of his folk-song style alongside more operatic writing, especially the use of recitative. The narrator's part in "The Choirmaster's Burial” is set in the tenor's middle range and is almost emotionless at the beginning, since in his middle voice Pears could sing with little 
color if necessary. To help differentiate the characters, Britten created a varied vocal line in terms of tessitura and also by using a more conjunct melodic line to represent the narrator and a more disjunct melody to represent the Vicar (See Examples 5-14 and 5-15).

Example 5-14, "The Choirmaster's Burial," mm. 1-4. ${ }^{19}$

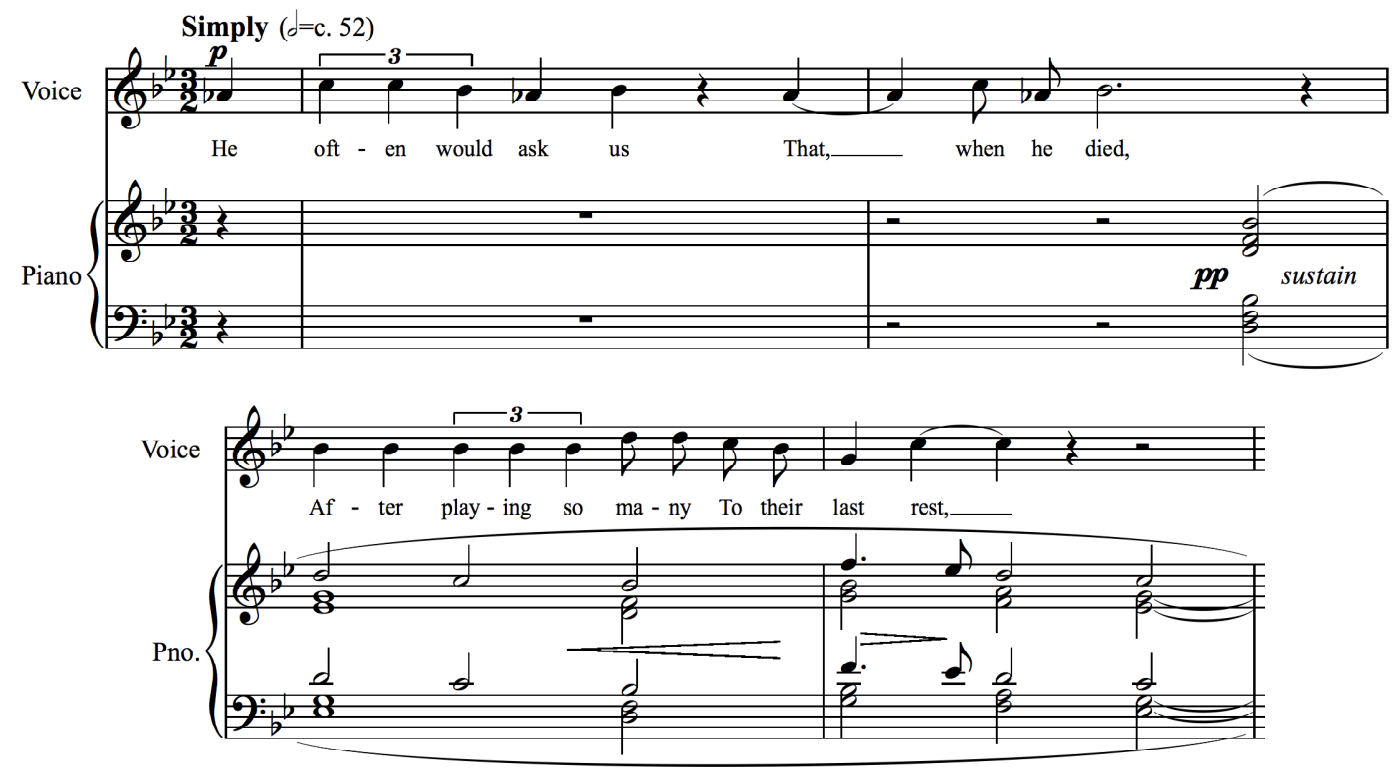

Example 5-15, "The Choirmaster's Burial," mm. 26-33. ${ }^{20}$
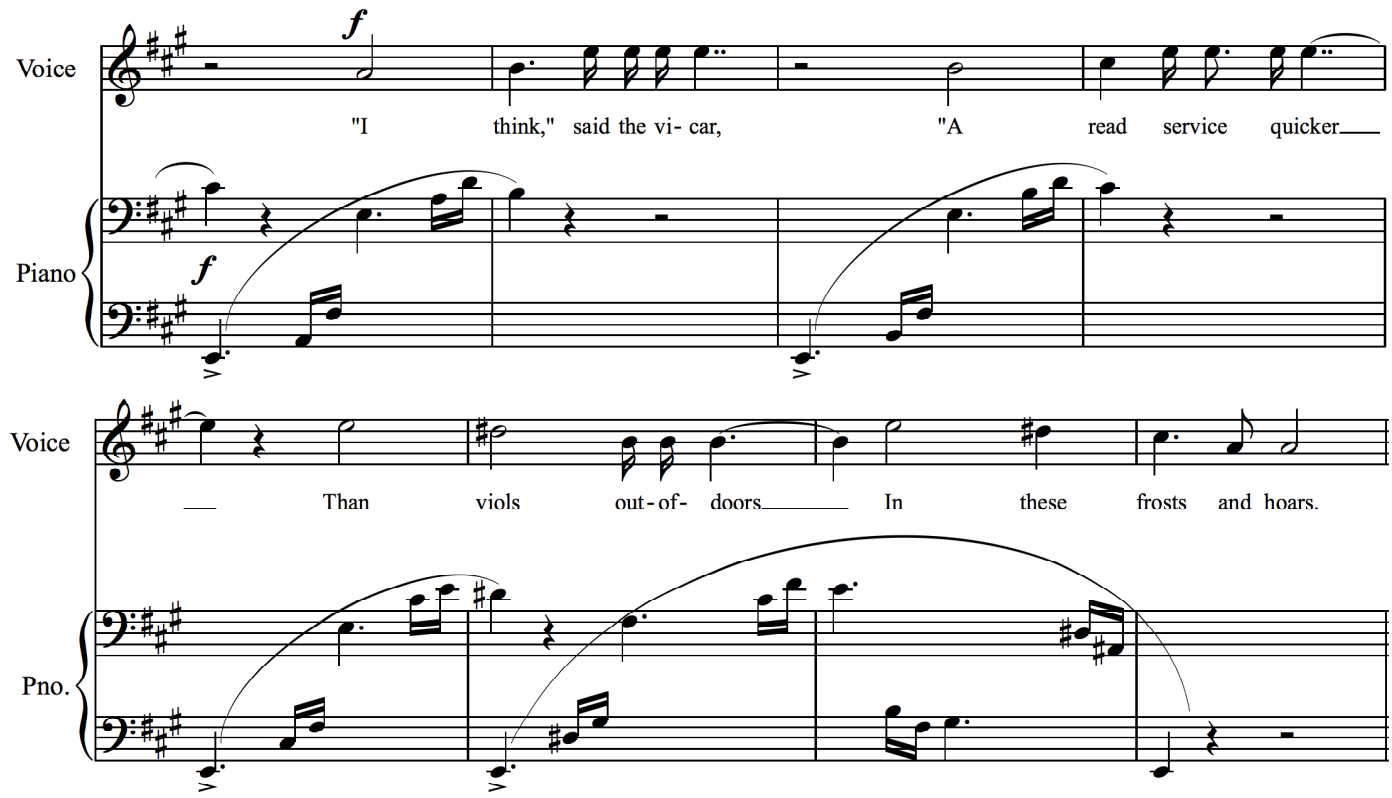

\footnotetext{
${ }^{19}$ Ibid., 18. Examples from "The Choirmaster's Burial (or The Tenor Man's Story)" reproduced with kind permission of Boosey \& Hawkes, Inc.

${ }^{20}$ Ibid., 20.
} 
The third character in the story, the choirmaster himself, is given no text and therefore has no vocal line. The melodic characteristics of the Vicar, dotted rhythms and a disjunct line, allowed the tenor to endow him with a stuffy, egotistical manner. The narrator's response to the Vicar's pronouncement (that the choirmaster will not have the kind of burial he desired) is set in a recitative with very little melodic motion at all (See Example 5-16).

\section{Example 5-16, “The Choirmaster's Burial,” mm. 44-51. ${ }^{21}$}

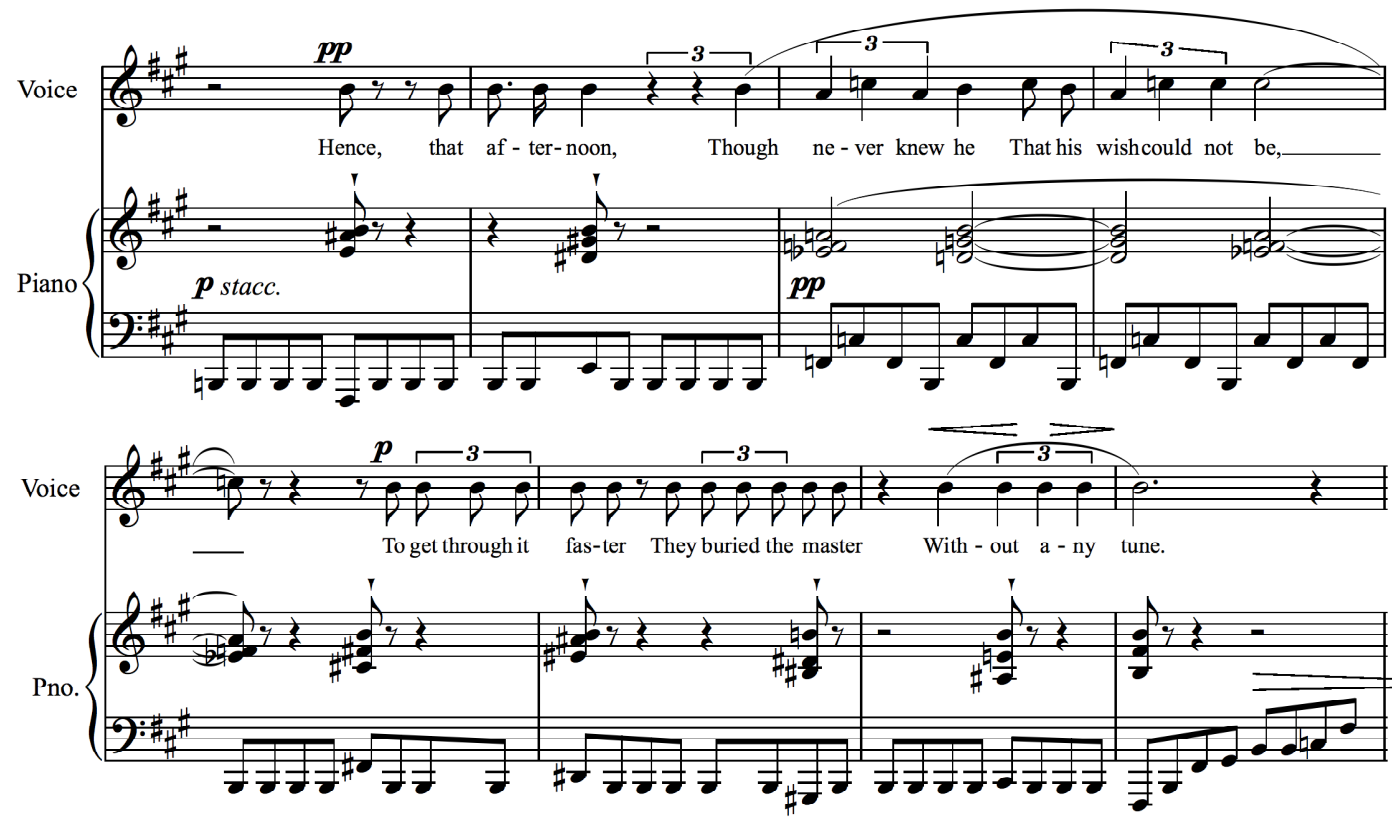

The patter-like setting of the text at this point, especially "To get through it faster they buried the master without any tune," shows the agitation of the narrator at the mistreatment of one man by another. The apparent calm of the narrator returns as does the opening melodic idea, thereby serving to unify the different sections of the piece, at the text "But "twas said that, when at the dead of next night" (See Example 5-17).

\footnotetext{
${ }^{21}$ Ibid., 21.
} 
Example 5-17, “The Choirmaster's Burial,” mm. 54-58. ${ }^{22}$

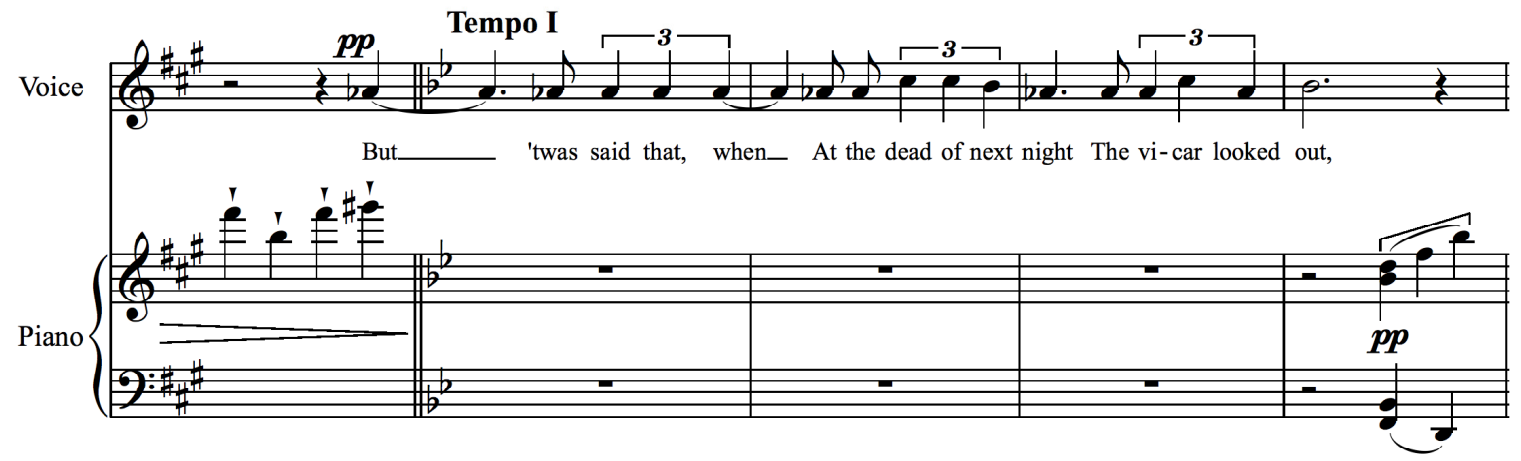

The excitement of the narrator, when he realizes that the choirmaster's wishes were respected, ostensibly by a heavenly band of angels, was expressed by the composer in a melody which repeated the text "singing and playing" as it ascended into the top of the tenor's range, where the singer could have greater exuberance in his tone (See Example 5-18). This also serves to show that the narrator has faith that his lost happiness could be returned in the afterlife.

Example 5-18, “The Choirmaster's Burial,” mm. 67-71. ${ }^{23}$

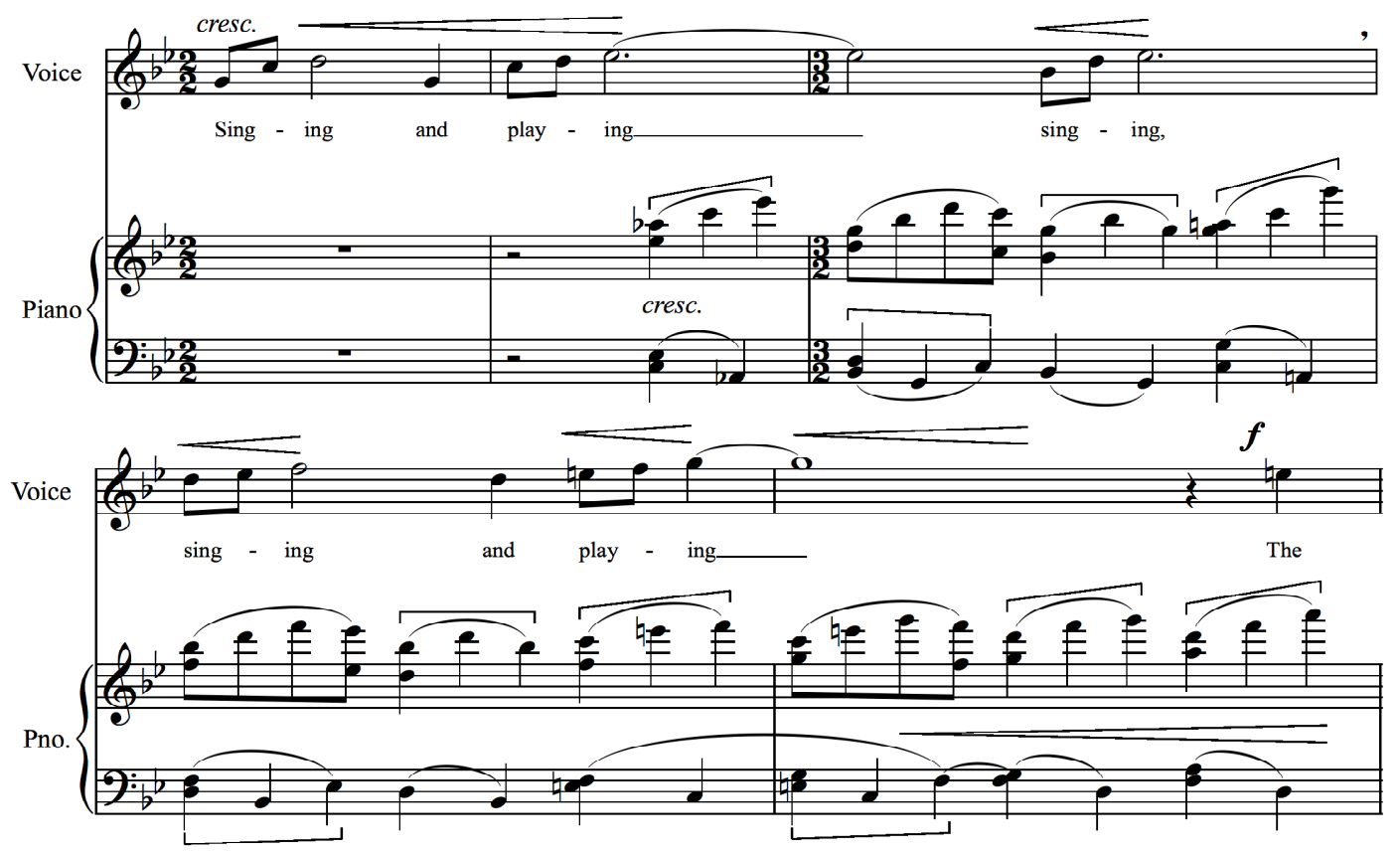

22 Ibid., 21-22.

${ }^{23}$ Ibid., 22-23. 
An important feature of the melody is the use and character of the melismas, which owe a debt to Henry Purcell, who continued to influence the later composer's style. Britten, who had realized piano accompaniments from the figured bass of a number of songs by Purcell for performance by Pears and himself, had just completed a new performing edition of Dido and Aeneas two years before the composition of this cycle, in $1951 .^{24}$ Throughout his life, Britten discussed the influence that his idol had upon him, saying: "I have always been interested in the setting of words ... and Purcell has shown me how wonderfully dramatic the sung English language can be." 25 He points out especially the earlier composer's "unfettered rhythms, boldly discordant harmonies, long soaring melodies with automatic phrases and especially the love of the virtuoso, the operatic and conscious exploration of brilliant sounds." ${ }^{26}$ It is not known that the melismas in "The Choirmaster's Burial" are influenced by any specific example from the earlier composer's works. However, by looking at one from his song "Strike the Viol" it can be seen how Purcell used melismas for expressive purpose, a practice that Britten also employed (See Example 5-19 and 5-20).

\footnotetext{
${ }^{24}$ Peter Evans, The Music of Benjamin Britten (Oxford: Clarenden Press, 1995), 580.

${ }^{25}$ Benjamin Britten, “On Writing English Opera.” Opera 12 (1961): 7.

${ }^{26}$ Eric Walter White, “Benjamin Britten.” Canon XII (January 1959): 190.
} 
Example 5-19, Henry Purcell, "Strike the Viol," mm. 32-39. ${ }^{27}$
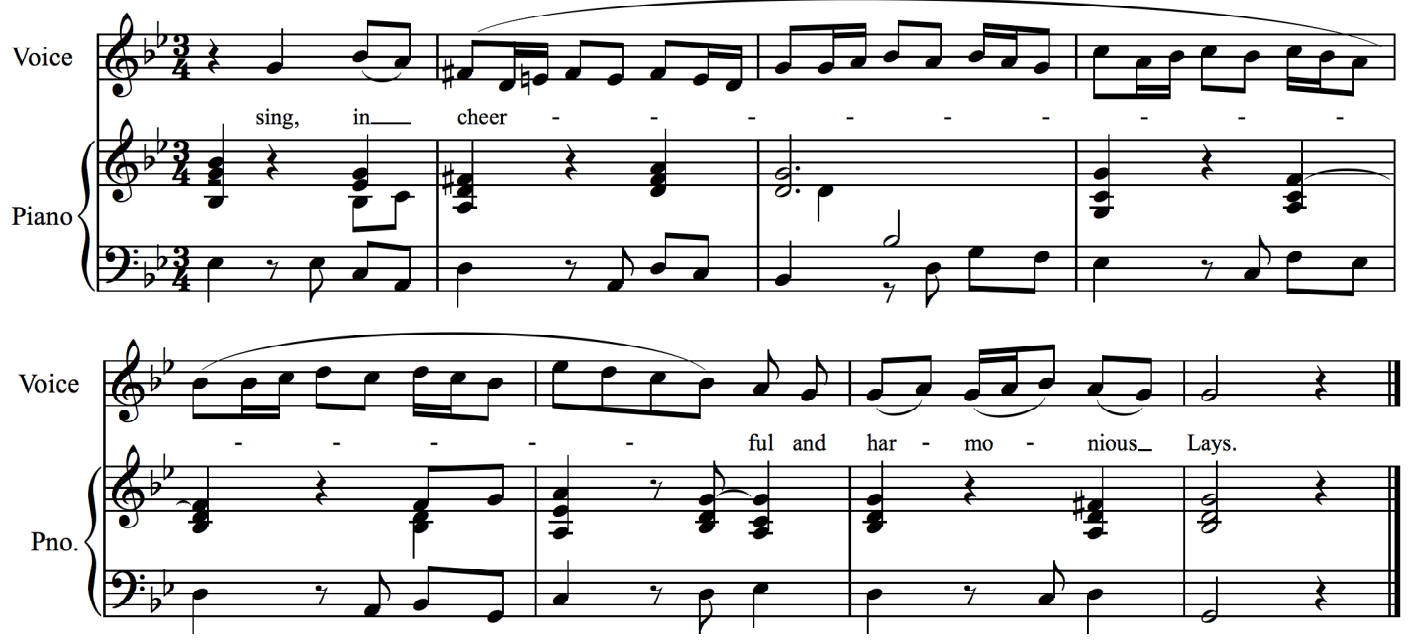

\footnotetext{
${ }^{27}$ Henry Purcell, 40 Songs for Voice and Piano (New York: International Music Company, 1958), 73.
} 
(a.)

Example 5-20, “The Choirmaster's Burial,” (a.) mm. 16-19, (b.) 71-77. ${ }^{28}$

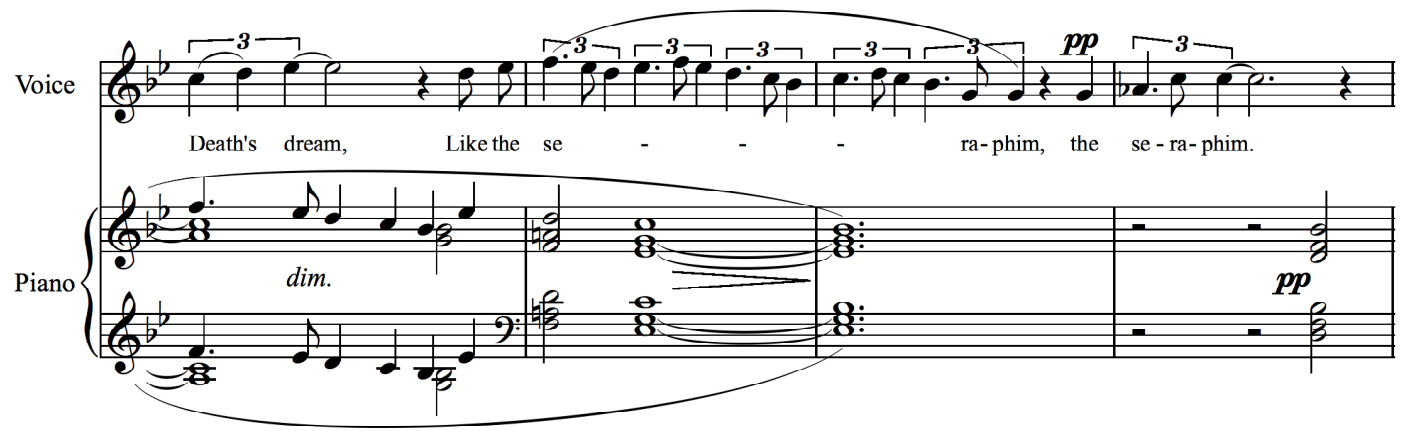

(b.)
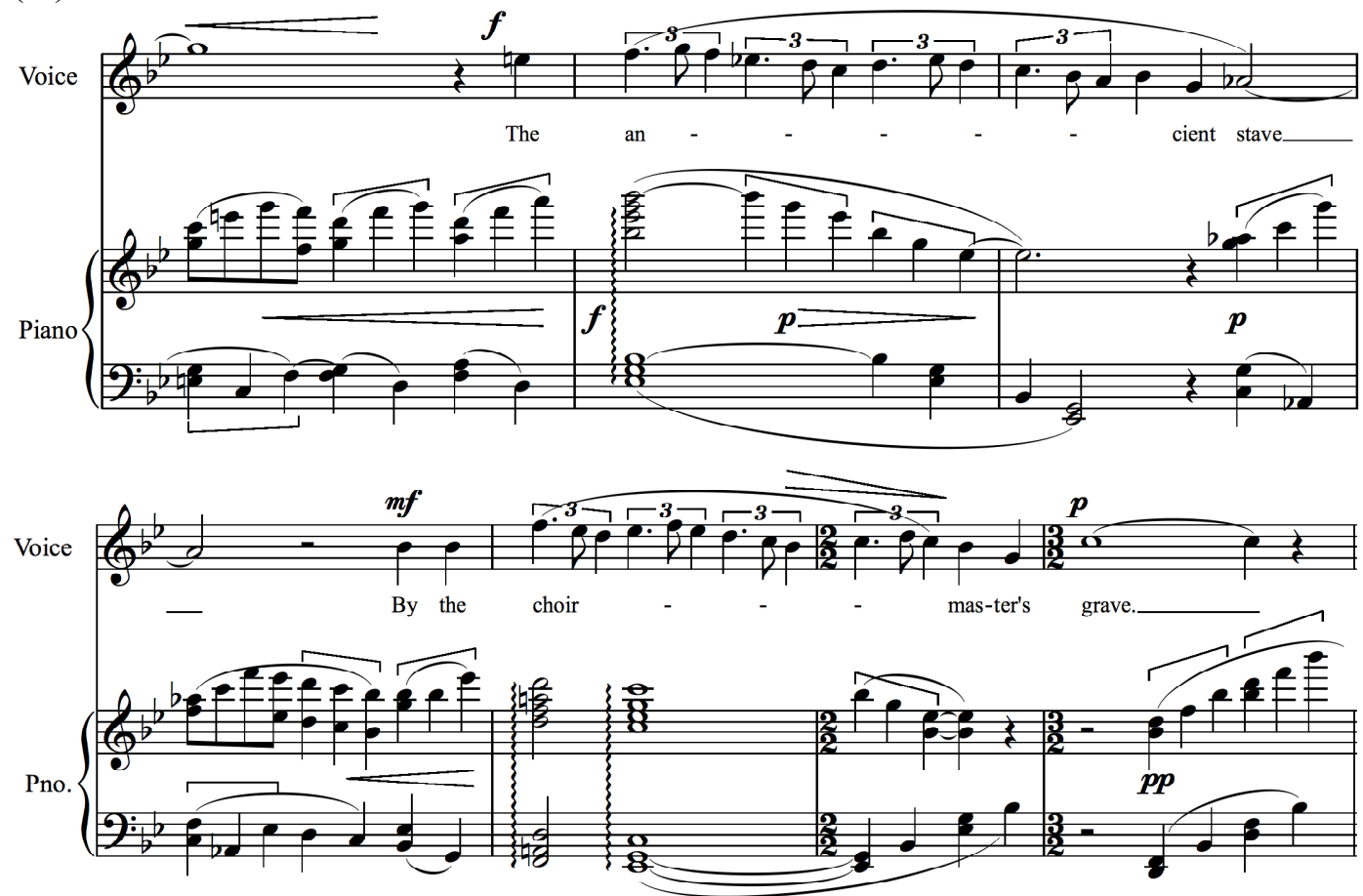

Melismas such as these in the works of Purcell are used to show an exuberance or intensity of emotion. Quite often, the rhythmic accents are at variance with the metric accents of the piece, which draws more attention to them and gives the vocal line greater energy. Britten used this kind of melisma in the same way to help to express both the joy and the mysticism of these moments by changing the rhythmic energy to dotted triplets from the straight duplets, and by slowing the speed of the text declamation.

\footnotetext{
${ }^{28}$ Britten., 19, 23.
} 


\author{
Proud Songsters \\ (Thrushes, Finches and Nightingales) \\ The thrushes sing as the sun is going, \\ And the finches whistle in ones and pairs, \\ And as it gets dark loud nightingales \\ In bushes \\ Pipe, as they can when April wears, \\ As if all Time were theirs. \\ These are brand-new birds of twelve-months' growing, \\ Which a year ago, or less than twain, \\ No finches were, nor nightingales, \\ Nor thrushes, \\ But only particles of grain, \\ And earth, and air, and rain.
}

"Proud Songsters," the sixth song, is one of the most intensely emotional settings in the cycle, as the narrator begins to realize exactly what he has lost and why. Since all of the texts in the cycle have the same underlying theme, the regret about the loss of innocence that occurs as one reaches adulthood, it is understandable that at this point the composer might start to express in his setting of the text more anger about the lost innocence in preparation for the final song in the cycle, in which this anger comes to a head. As is the case with many of Britten's accompaniments, here the piano functions to help set the mood, allowing the singer to elaborate upon the emotions found in the text. In this piece, the accompaniment mimics bird calls throughout (See Example 5-21). 
Example 5-21, "Proud Songsters," mm. 1-2. ${ }^{29}$

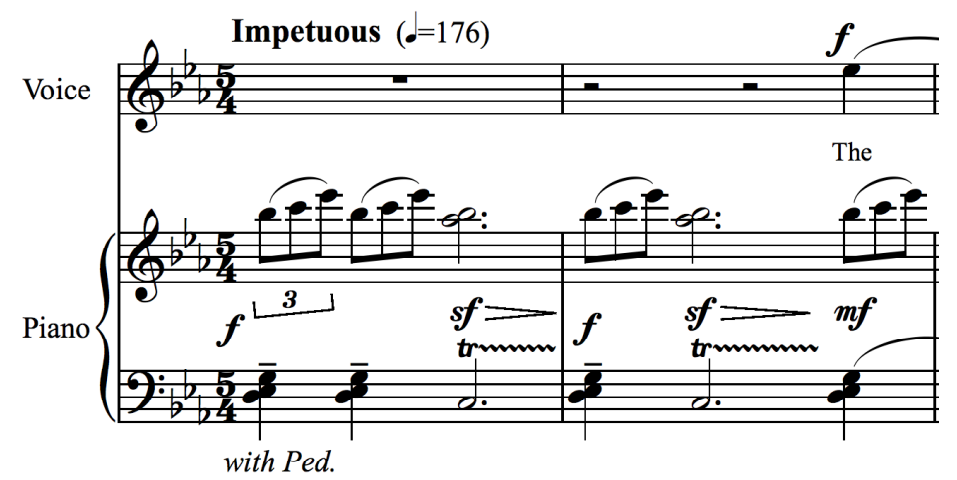

The text itself is not angry, but the composer infuses it with this emotion. The intensity is brought to the setting in part by the quick tempo and by the irregular $5 / 4$ meter, and also by the high tessitura of the melody, which allowed Pears to express the youth of the birds and the anger over the loss of that innocence (See Example 5-22).

Example 5-22, “Proud Songsters,” mm.29-34. ${ }^{30}$

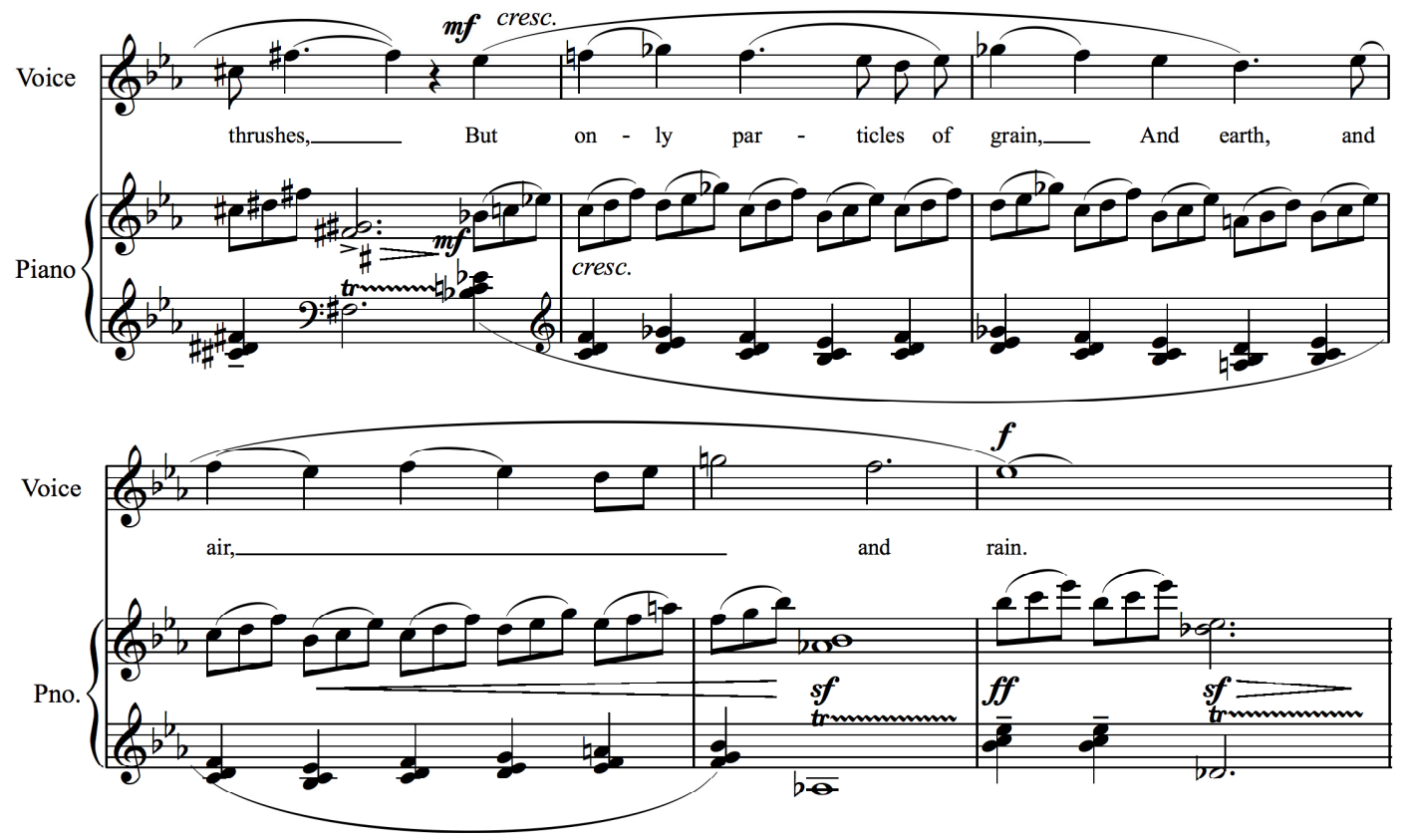

\footnotetext{
${ }^{29}$ Ibid., 24. Examples from "Proud Songsters (Thrushes, Finches and Nightingales)" reproduced with kind permission of Boosey \& Hawkes, Inc.

${ }^{30}$ Ibid., 26.
} 
At the Railway Station, Upway

(or The Convict and Boy with the Violin)

'There is not much that I can do,

For I've no money that's quite my own!'

Spoke up the pitying child -

A little boy with a violin

At the station before the train came in, -

'But I can play my fiddle to you,

And a nice one 'tis, and good in tone!'

The man in the handcuffs smiled;

The constable looked, and he smiled, too,

As the fiddle began to twang;

And the man in the handcuffs suddenly sang

With grimful glee:

'This life so free

Is the thing for me!'

And the constable smiled, and said no word,

As if unconscious of what he heard;

And so they went on till the train came in -

The convict, and boy with the violin.

The penultimate setting in the cycle, "At the Railway Station, Upway," is an anecdote in a similar vein to "The Choirmaster's Burial," although Britten used different musical styles to represent the three different characters in the story (convict, boy, and constable) as well as the narrator. In contrast to the intense emotion of the sixth setting, Britten chose to set a poem which illustrates the theme of the loss of innocence more simply to allow the listener to understand that the narrator has determined the true cause of his lament. In the accompaniment of this setting, Britten mimics the sound of a violin, beginning the setting with a passage that sounds like a violin tuning (See Example 5-23). 
Example 5-23, “At the Railway Station, Upway,” mm. 1-4. ${ }^{31}$

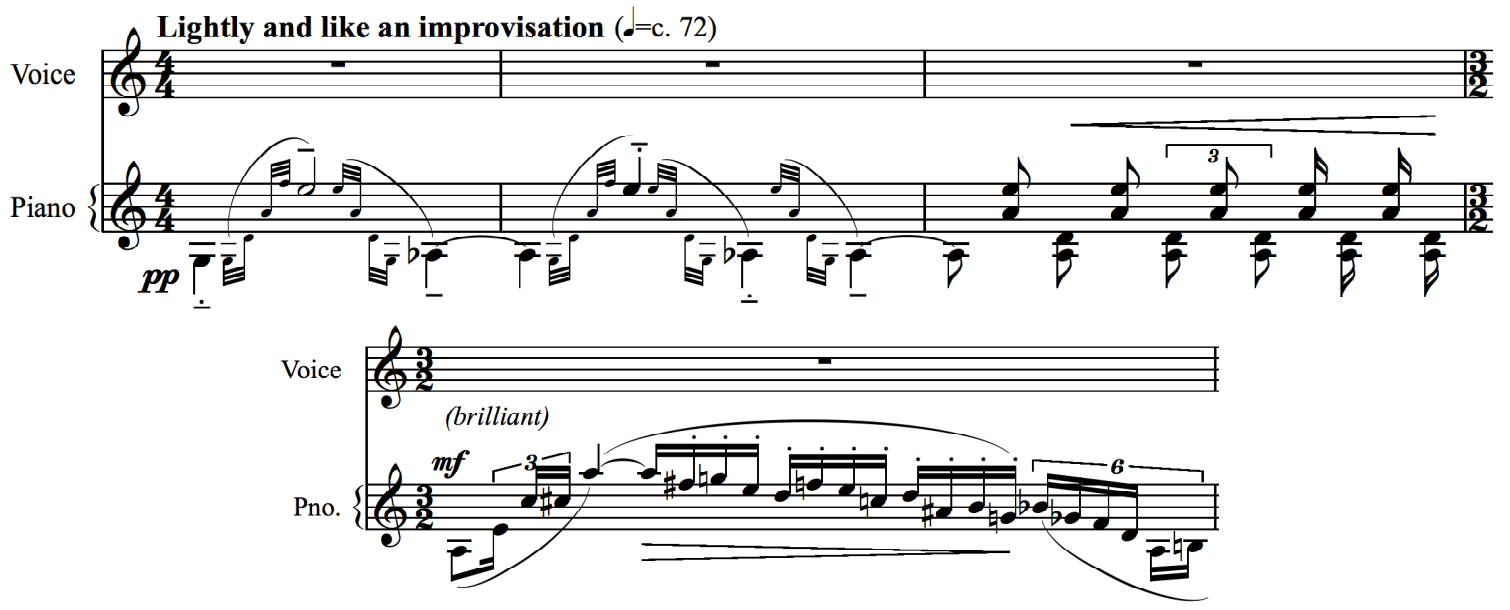

The composer's treatment of the characters, using different registers and melodic ideas to distinguish them, is reminiscent of that of Franz Scubert in his Erlkönig. This treatment helped the tenor to show what they represented to the narrator. The words of the boy are set higher in range than those of the narrator (See Examples 5-24 and 5-25).

${ }^{31}$ Ibid., 27. Examples from "At the Railway Station, Upway (or The Convict and Boy with the Violin)" reproduced with kind permission of Boosey \& Hawkes, Inc. 
Example 5-24, Franz Schubert, "Erlkönig,” mm. 72-85. ${ }^{32}$

(Child, mm. 72-79; Father 80-85)
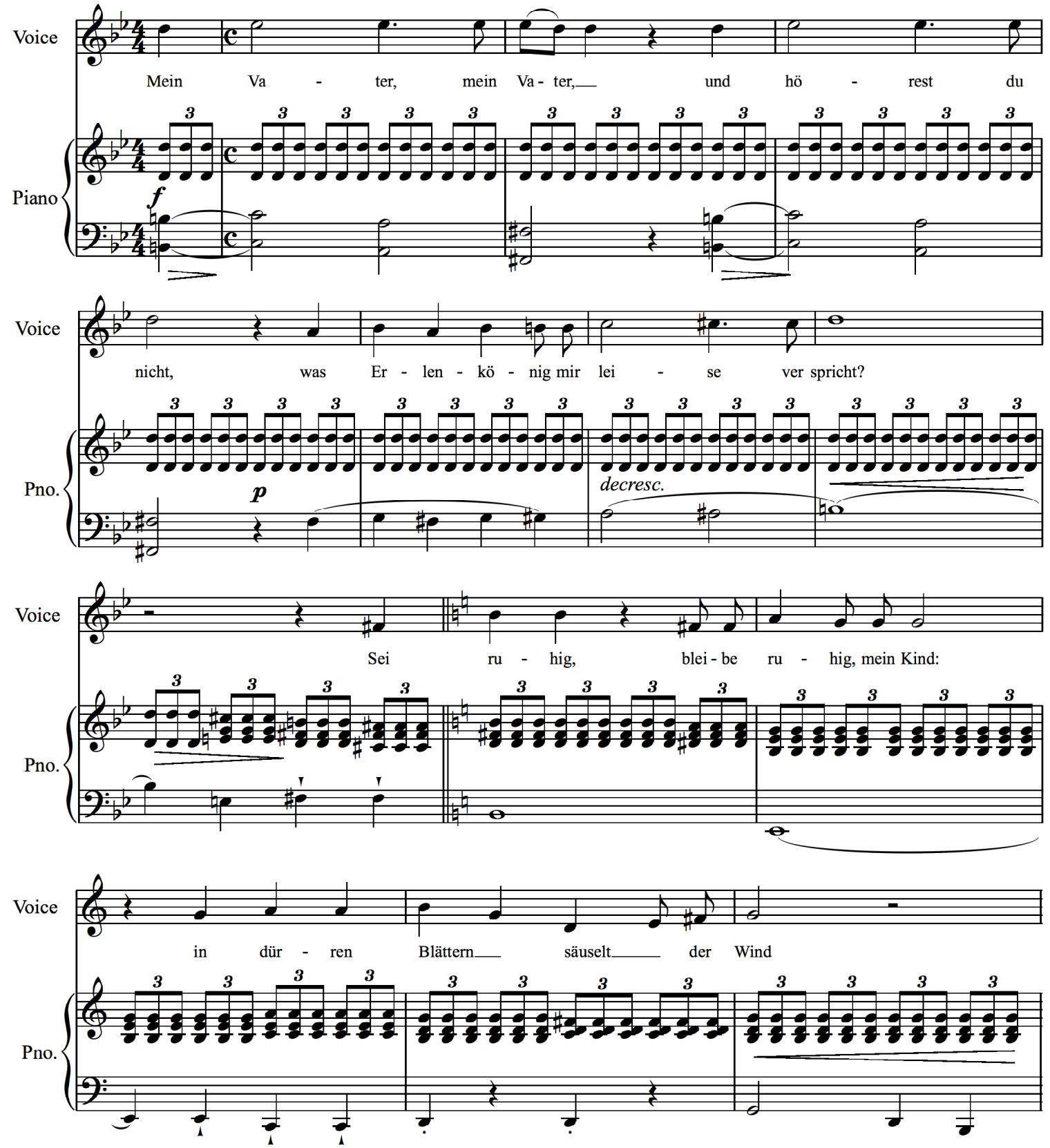

${ }^{32}$ Schubert, 171. 
Example 5-25, “At the Railway Station, Upway,” (a.) mm. 5-8, (b.)13-18. ${ }^{33}$

(a.)
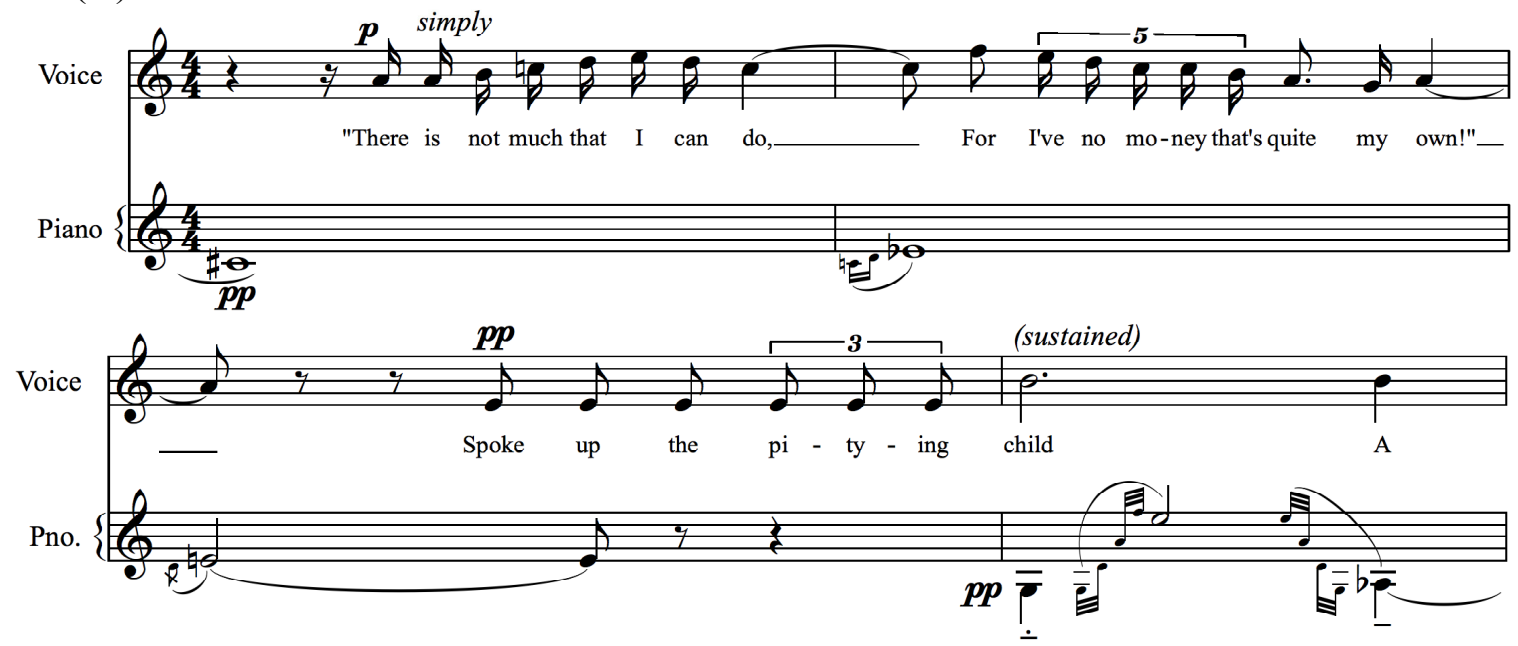

(b.)
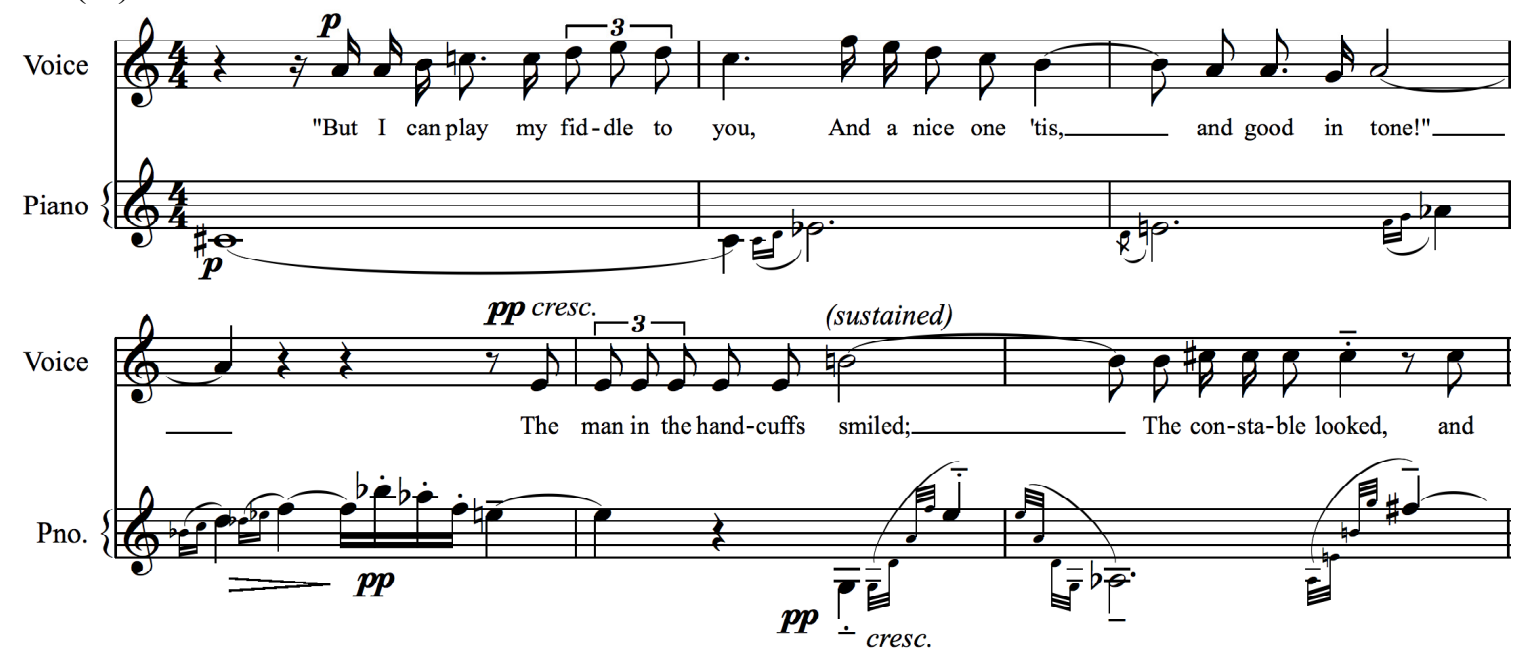

This continues until the excitement of the narrator's words builds in anticipation of the prisoner's song (See Example 5-26).

${ }^{33}$ Britten, 27, 28. 
Example 5-26, “At the Railway Station, Upway,” mm. 21-23. ${ }^{34}$

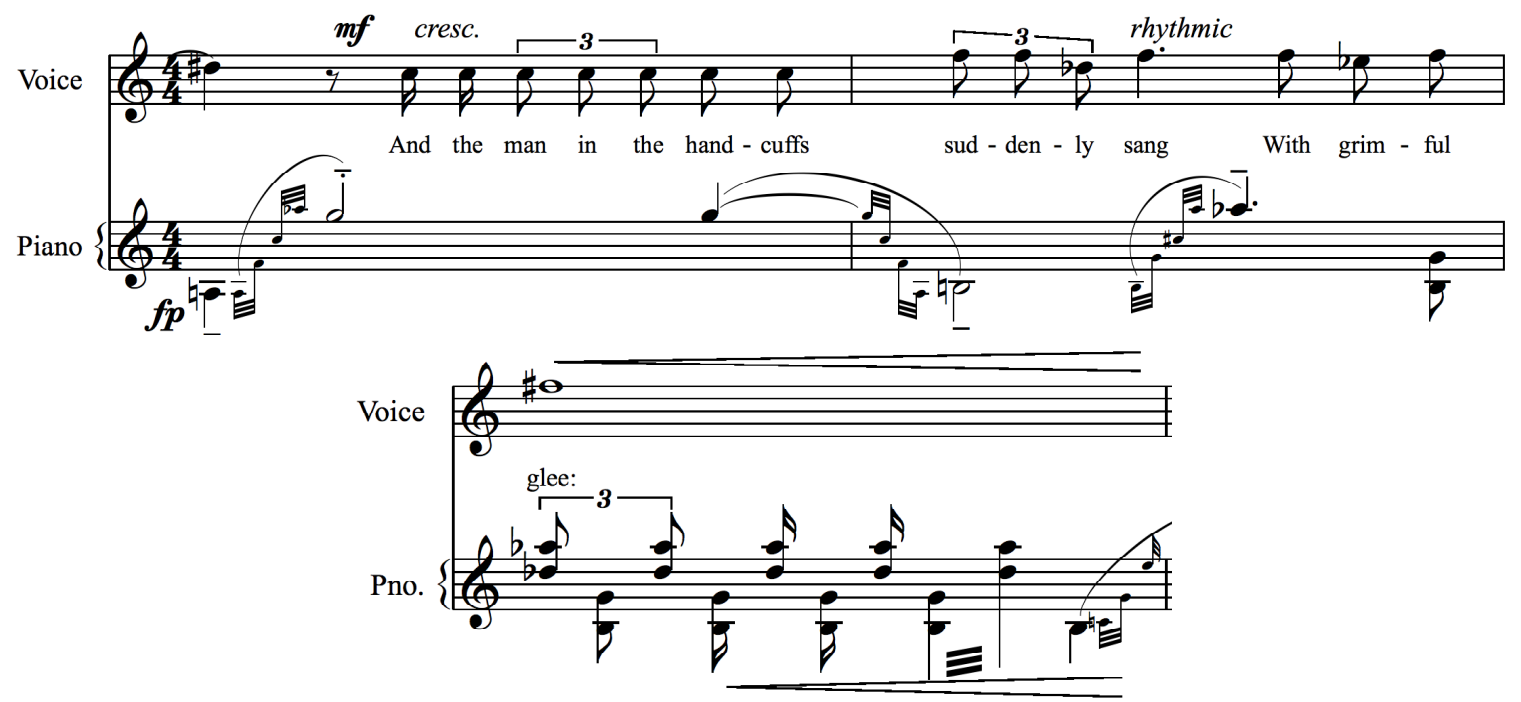

The use of different musical characterizations elaborates upon the folk-ballad character of the story and is in keeping with its simplicity.

One of the most notable features of this setting is the convict's song, accompanied by the boy's violin, which contains such joy and freedom despite the convict's obviously contrary situation (See Example 5-27).

\footnotetext{
${ }^{34}$ Ibid., 29.
} 
Example 5-27, “At the Railway Station, Upway,” mm. 24-27. ${ }^{35}$
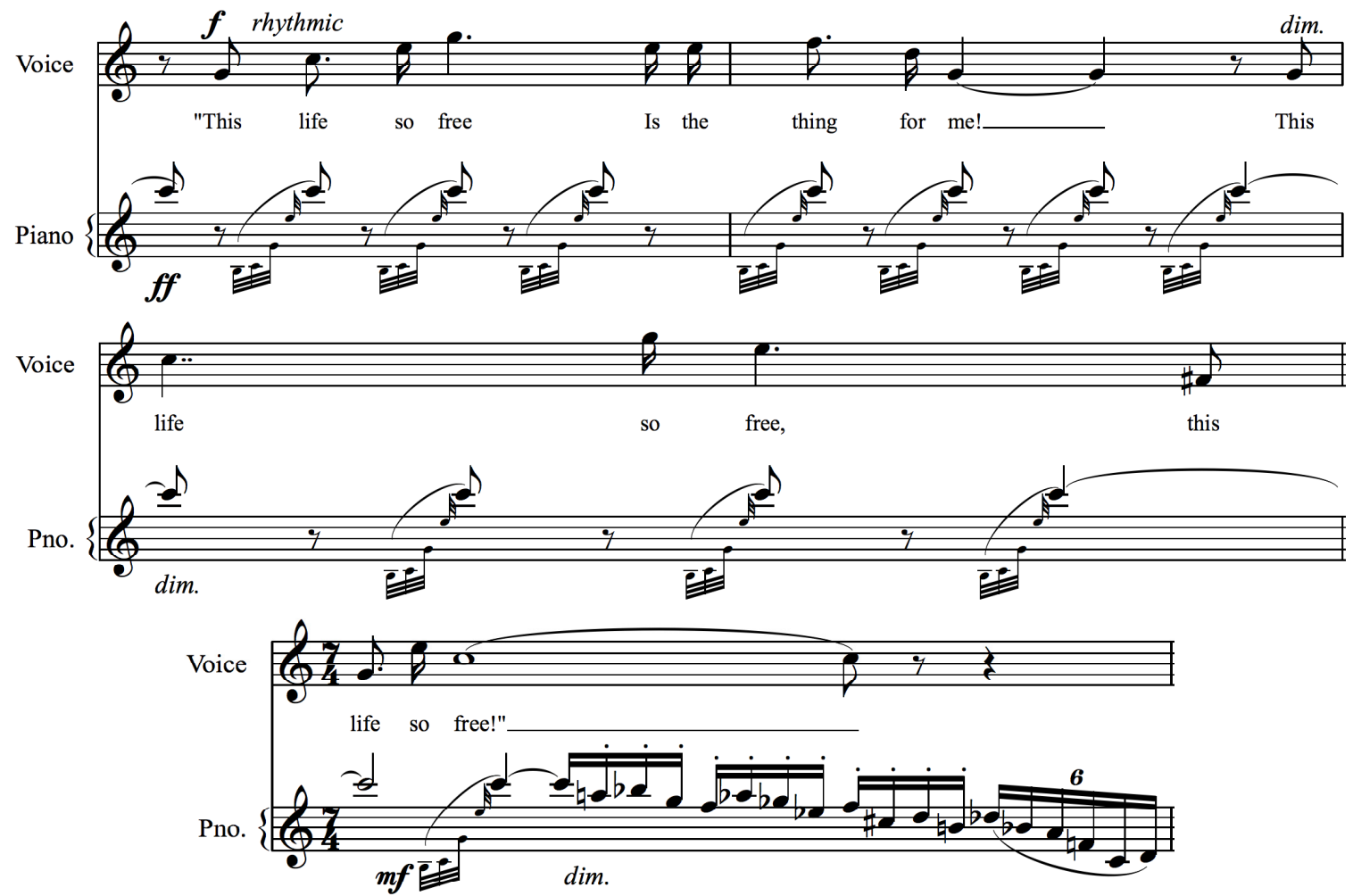

This hopefulness is reminiscent of the narrator's joy in "The Choirmaster's Burial" when he realized that heaven has succeeded where man has not.

\section{Before Life and After}

A time there was - as one may guess

And as, indeed, earth's testimonies tell -

Before the birth of consciousness,

When all went well.

None suffered sickness, love, or loss,

None knew regret, starved hope, or heart-burnings;

None cared whatever crash or cross

Brought wrack to things.

If something ceased, no tongue bewailed, If something winced and waned, no heart was wrung;

If brightness dimmed, and dark prevailed,

No sense was stung.

${ }^{35}$ Ibid., 29. 
But the disease of feeling germed, And primal rightness took the tinct of wrong;

Ere nescience shall be reaffirmed

How long, how long?

The last song of the cycle, "Before Life and After," is most similar to settings in the previous cycles because the text with its inherent passion and anger is most similar to several of the earlier texts. There is a strong yearning and definite anger here instead of the wistful, pensive or self-pitying feeling present in the other songs in this cycle because the narrator has now determined the true source of his suffering: his loss of innocence. Pears later said that both he and Britten felt this was one of the composer's best songs because of its seriousness and forcefully expressed philosophical ideas which center around the thought that a life of ignorance is a life of bliss and that it is perverted with the awakening of knowledge and maturity. ${ }^{36}$ The setting begins at the top of the passaggio over an accompaniment containing heavy chords (See Example 5-28).

Example 5-28, “Before Life and After," m. 1. ${ }^{37}$

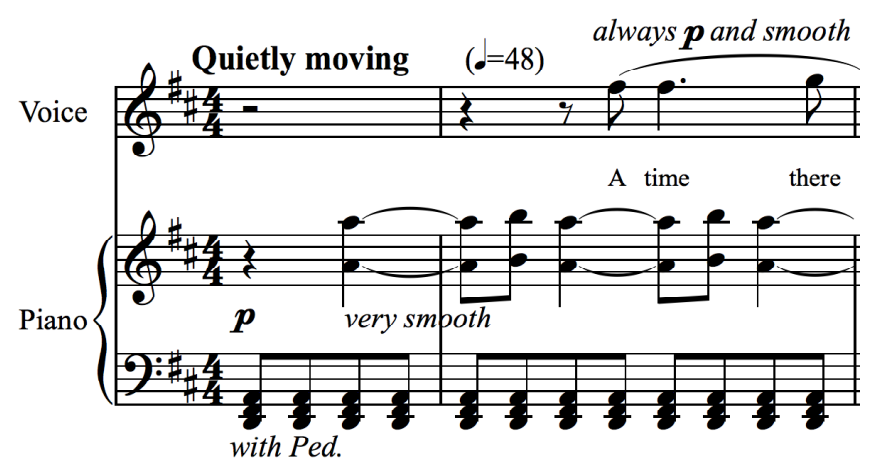

This allowed the tenor to use a yearning quality in his voice as the poet pines for the past "when all went well” (See Example 5-29).

\footnotetext{
${ }^{36}$ Christopher Headington, Peter Pears: A Biography (London: Faber and Faber, 1992), 270.

${ }^{37}$ Britten, 31. Examples from "Before Life and After" reproduced with kind permission of Boosey \& Hawkes, Inc.
} 
Example 5-29, “Before Life and After," (a.) mm. 1-2, (b.) 7-8. ${ }^{38}$

(a.)

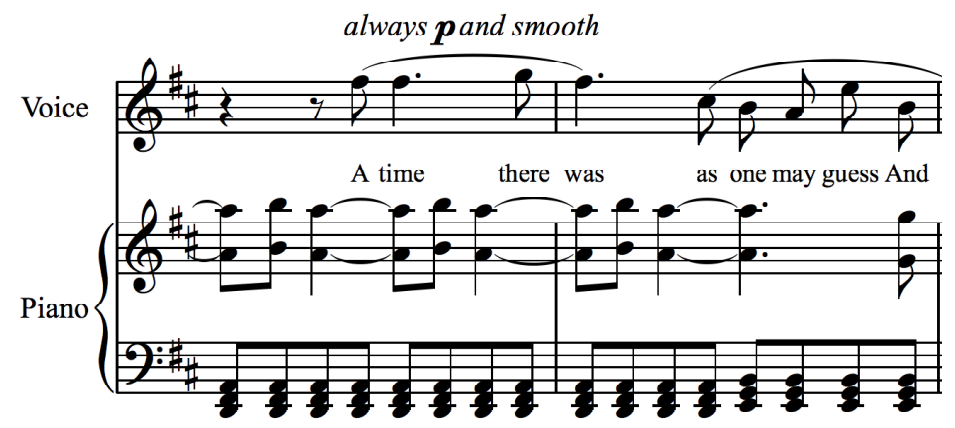

(b.)

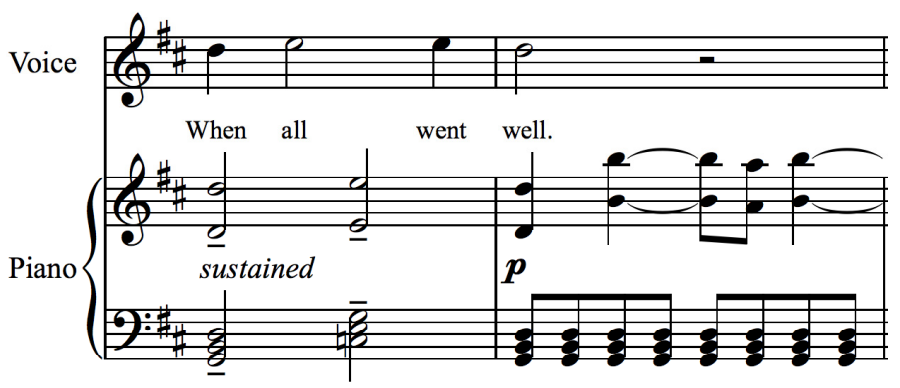

The composer had the singer tarry longer in this part of his voice in each successive verse as the poet becomes more emphatic in his anger and despair over this lost innocence. For the last verse, Britten called for the tenor to access the growl that he could get in his lower middle voice, thereby expressing both the "disease of feeling" and the "primal rightness" as the melody becomes increasingly chromatic (See Example 5-30).

\footnotetext{
${ }^{38}$ Ibid., 31.
} 
Example 5-30, "Before Life and After," mm. 25-28. ${ }^{39}$
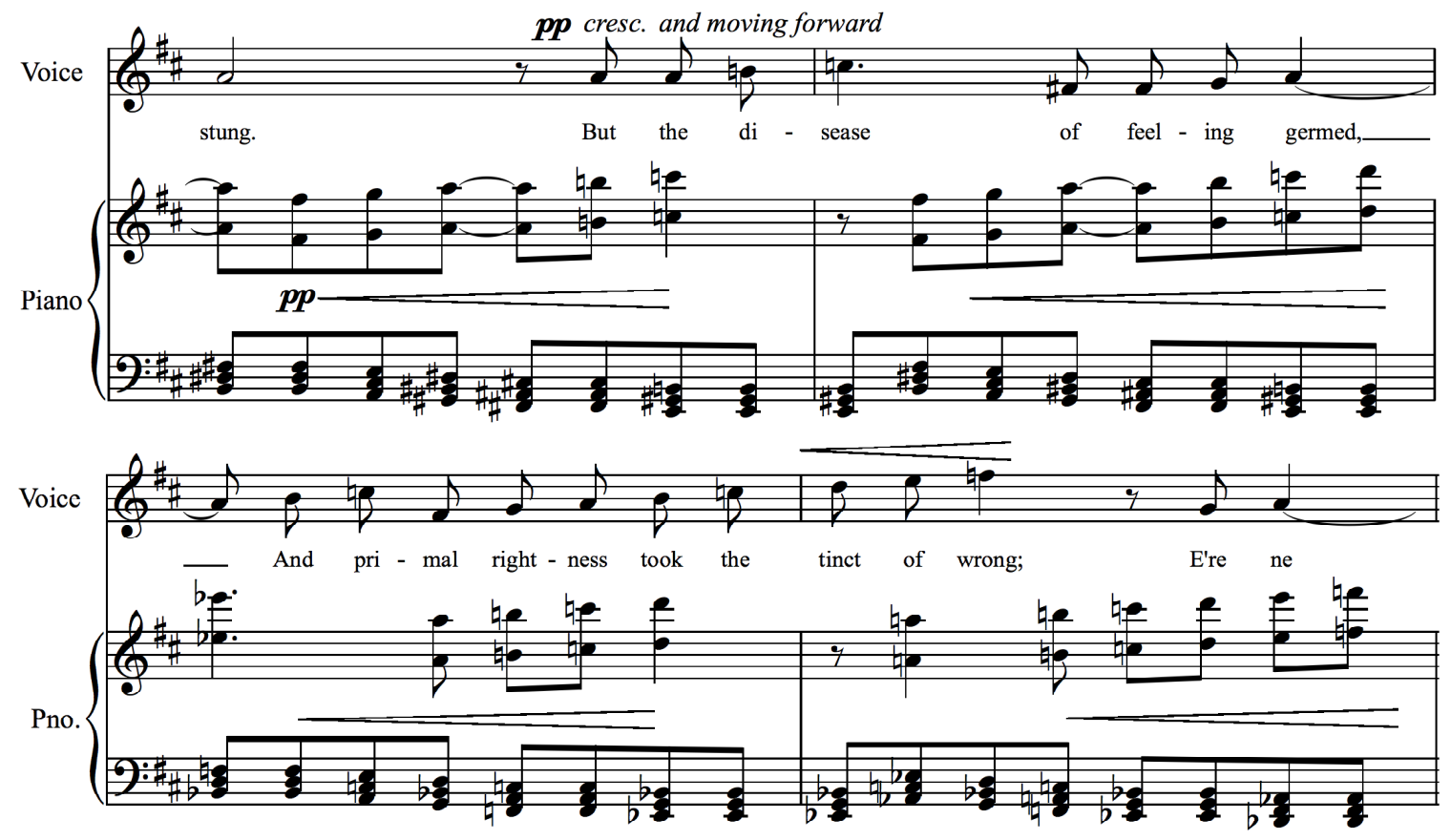

The lack of a stable tonal center at this point sets up the shock of the return to D major, as the singer reaches a high F-sharp above middle C. In mm. 30-31, the tenor was able to add a whining quality to his sound for the text "how long, how long?" because of its setting right at the top of the passaggio, and then Britten took the singer from his upper middle voice to lower middle voice on the last two repetitions of the text "how long," which allowed his partner to return to a more mature, more resigned, and almost defeated quality in mm. 31-33 (See Example 5-31).

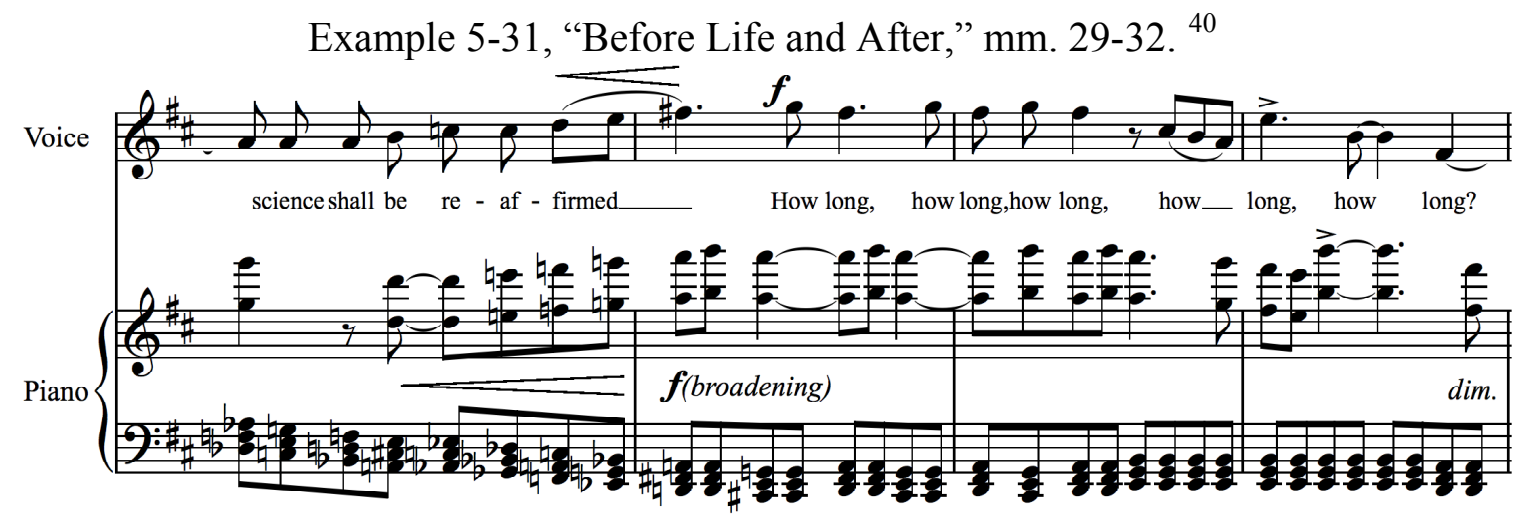

\footnotetext{
${ }^{39}$ Ibid., 33.

${ }^{40}$ Ibid., 33.
} 
Between the composition of The Holy Sonnets of John Donne and Winter Words, the two men had both continued to grow as successful artists and had begun to reap the benefit of their hard work. Britten had achieved his first major operatic triumph with Peter Grimes with Pears in the starring role. This success inspired the composer to write several more operas in the next years, all of which had starring roles for his partner: The Rape of Lucretia (1946), Albert Herring (1947), Billy Budd (1950) and Gloriana (1953). The tenor continued performing these works as well as those of other composers and so was a success in his own right as well. In all of these works, the composer found subject material which would appeal to his lover as well as himself, and so for the next cycle with voice and piano he did the same.

The texts of Winter Words are more retrospective in nature than those of the cycles previously composed for his partner. In comparison to those of the earlier works, where the text is more rooted in the present and the possible future, the musical style is also much less demonstrative. The theme of the texts was something that attracted both men: it was to be found again in the very next opera, The Turn of the Screw, as well as in later works such as Death in Venice. The arrangement of the texts chosen by the composer forms a mirror image, leading to the ultimate resolution of the conflict in that the narrator is now able to voice unambiguously his concerns even if he is unable to resolve them in any way.

This cycle could be considered to be somewhat autobiographical when it is noted that both men were approaching middle age: Britten was 40 years old and his partner was 43 at its completion. Although both were successful, Britten began to wish that he could adopt a child but was unable to do so, ${ }^{41}$ and the isolation both men felt as homosexuals in the highly charged

\footnotetext{
${ }^{41}$ Humphrey Carpenter, Benjamin Britten: A Biography (New York: Macmillan Publishing Company, 1992), 366367.
} 
atmosphere of Great Britain in the $1950 \mathrm{~s},{ }^{42}$ which will be discussed in more depth in the following chapter, was certainly represented in these texts.

Musically, the composer used characteristics of his operas, most specifically the recitative-style, in writing this work. In it we also see the influence that folk song had upon the composer, since he combined melodic and rhythmic contours of the folk song style with his own harmonic language all for expressive purpose, which allowed his partner to communicate more effectively the meaning of these texts. These elements had been used in compositions and arrangements for the tenor, and so they were not only familiar to him, but he had also achieved success with them. At times in the cycle, especially in the first and last settings, the composer used a more chromatic melodic and harmonic style, which complemented these particular angstridden texts.

42 Hyde, H. Montgomery, The Love That Dared Not Speak Its Name: A Candid History of Homosexuality in Britain (Boston: Little, Brown and Company, 1970), 214-217. 


\section{CHAPTER 6 \\ Sechs Hölderlin-Fragmente, opus 61}

(1958)

In the 1950s, Britten and Pears took time off to travel and experience other cultures.

During this period, they were introduced to the poetry of Friedrich Hölderlin (1770-1843).

Hölderlin felt alienated from society, mostly because of the state of his mental health, which today would likely be diagnosed as a form of schizophrenia, and many of his poems reflect this. ${ }^{1}$ The composer was drawn to these poems because of his own alienation from society: although he had maintained a very successful career as a composer/performer, he was often plagued by self-doubt, and his homosexuality, accepted by his close friends, was still illegal in Great Britain, and he was still ostracized because of it. Christopher Headington, in his biography of Peter Pears, points out that "hostile gossip about their presumed lifestyle was at its worst in the 1950s.",2 Humphrey Carpenter, in his biography of Britten, recounts that this homophobia existed even in the duo's inner circle, revealed in jokes about homosexuality and rumors about pedophilia. ${ }^{3}$

Consensual homosexual acts between two adult men were still illegal in Great Britain at this time, even when they occurred in private, and high profile cases, such as that of Guy Burgess and Donald McLean in 1951 involving espionage, fueled an increase in the number of arrests of allegedly homosexual men in Britain. ${ }^{4}$ In 1953 and 1954, several cases, especially that of Lord Montagu of Beaulieu, Michael Pitt-Rivers, and Peter Wildeblood, which showed the police in a

${ }^{1}$ Richard Sieburth, Friedrich Hölderlin Hymns and Fragments (Princeton, New Jersey: Princeton University Press, 1984), xv, xix, 8.

Hölderlin suffered from headaches and depression as early as age twenty and suffered a serious breakdown leading to his institutionalization at age thirty-six after the death of his married lover. According to Sieburth "most of the recent medical literature on Hölderlin has diagnosed his condition as a form of cyclothymic schizophrenia, characterized by manic depressive oscillations in mood . .."

Graham Johnson, Britten, Voice \& Piano: Lectures on the Vocal Music of Benjamin Britten (Burlington, VT:

Ashgate Publishing Limited, 2003), 57.

${ }^{2}$ Christopher Headington, Peter Pears: A Biography (London: Faber and Faber, 1992), 195.

${ }^{3}$ Humphrey Carpenter, Benjamin Britten: A Biography (New York: Macmillan Publishing Company, 1992), 384385.

${ }^{4}$ Hyde, H. Montgomery, The Love That Dared Not Speak Its Name: A Candid History of Homosexuality in Britain (Boston: Little, Brown and Company, 1970), 214. 
poor light and received much press coverage, led to enough public criticism to prompt the formation of a committee led by Sir John Wolfenden, which met from 1954 to 1957 to study the appropriateness of the legal prohibition of consensual male homosexual acts. ${ }^{5}$ The committee essentially called for a change in the law, and this, in turn, polarized people and fueled much heated discussion. ${ }^{6}$ The law was in fact not changed until $1967 .{ }^{7}$ This cycle could be thought of as Britten's response to this discussion.

Even though the themes of this song cycle and its predecessor, Winter Words, are similar, the character of the music and the consequent vocal lines are quite different in that the poems here are angrier than those of the previous work. The composer chose these six poems from the several volumes of Hölderlin's poetry and organized them into a single narrative thread. As in Winter Words, the narrator is not always an active participant in the poem. However, in Sechs Hölderlin-Fragmente, it is only in the third setting, "Sokrates und Alcibiades," that the narrator is not one of the characters, and that particular poem can be taken to relate to the narrator allegorically. The homosexual subtext was not Hölderlin's; it may be inferred from the composer's arrangement of the poems as well as the association with the other works of the composer for his lover. As in the setting of the Michelangelo Sonnets, the foreign language serves to mask the meaning of the texts resulting from Britten's arrangement of them. In the opening poem, the narrator presents his problem: he has fallen in love, and society has rejected him for it ("Menschenbeifall"). He sees that he is unable to return home, specifically to the joy and comfort it had once provided but which is no longer available ("Die Heimat"). In the third setting, he defends the choice of his object of affection allegorically, ("Sokrates und Alcibiades") and then recounts his own youth when he was protected from the judgment of society by the

\footnotetext{
${ }^{5}$ Ibid., 226-229.

${ }^{6}$ Ibid., 229-235.

${ }^{7}$ Ibid., 267-269.
} 
gods ("Die Jugend"). After once again yearning for the lost past and perhaps with an epiphany that it is important to "seize the moment" in the fifth setting ("Hälfte des Lebens"), the narrator realizes that each person has his own destiny regardless of what others might think or do ("Die Linien des Lebens").

The settings of the poems chosen for the cycle, just as those of Winter Words, are organized in such a way that they form an arch. This is further exemplified in the use of the accompaniment. The first and last settings are opposites, the first dealing with the instability and fickleness of humankind's nature and the last with the stability of life itself continuing into the afterlife. Both settings have octaves in the accompaniment, but in the first, "Menschenbeifall," they are empty octaves in short phrases of disjunct melodic motion which begin the piece (See Example 6-1), whereas in the setting of the final poem, "Die Linien des Lebens," they surround full chords in longer phrases in conjunct melodic motion which end the piece (See Example 6-2).

$$
\text { Example 6-1, "Menschenbeifall," mm. 1-8. }{ }^{8}
$$
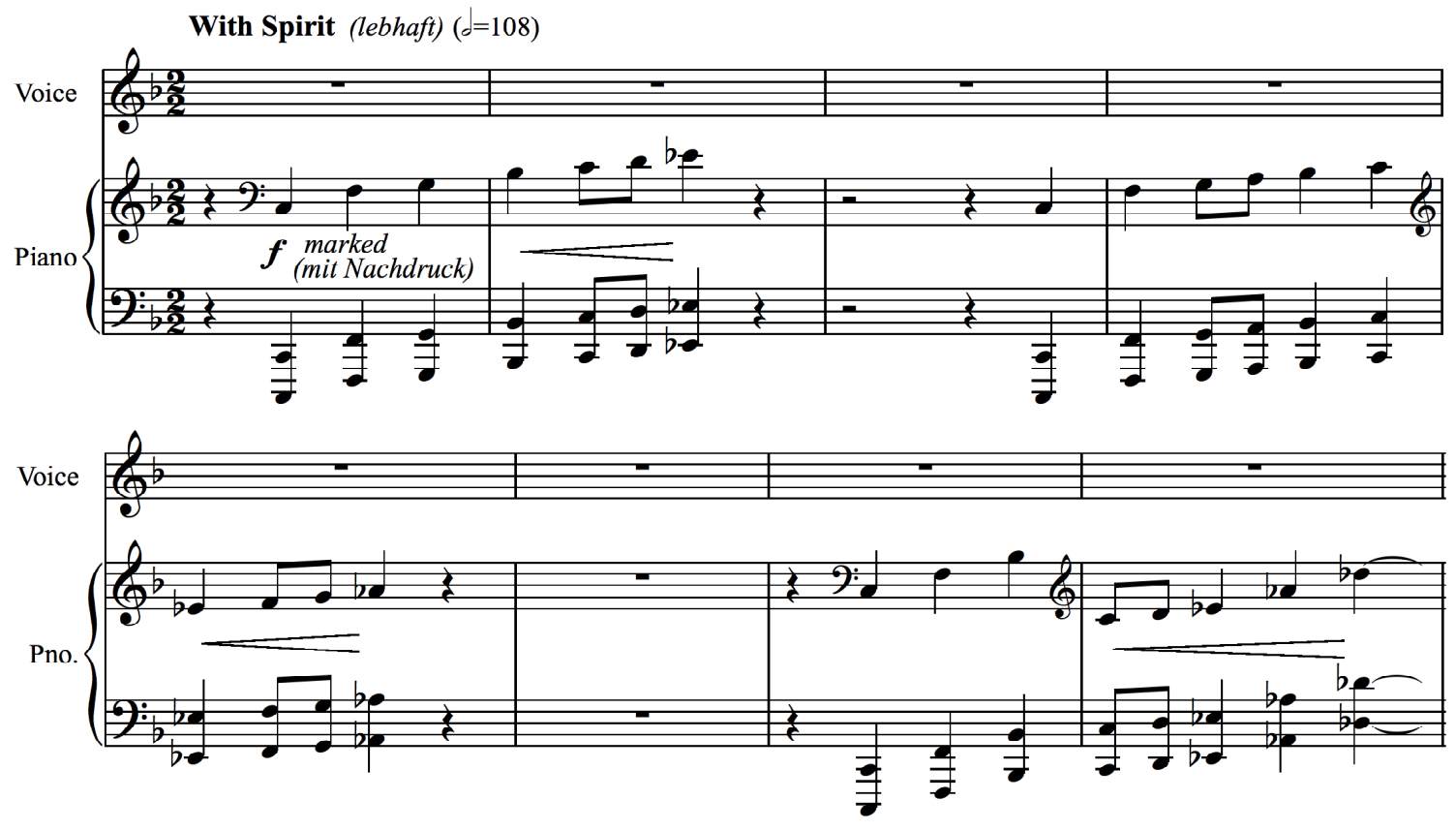

\footnotetext{
${ }^{8}$ Benjamin Britten, Sechs Hölderlin-Fragmente, opus 61 (New York: Boosey \& Hawkes, 1962), 1. Examples from "Menschenbeifall" reproduced with kind permission of Boosey \& Hawkes, Inc.
} 
Example 6-2, “Die Linien des Lebens," mm. 18-20.9

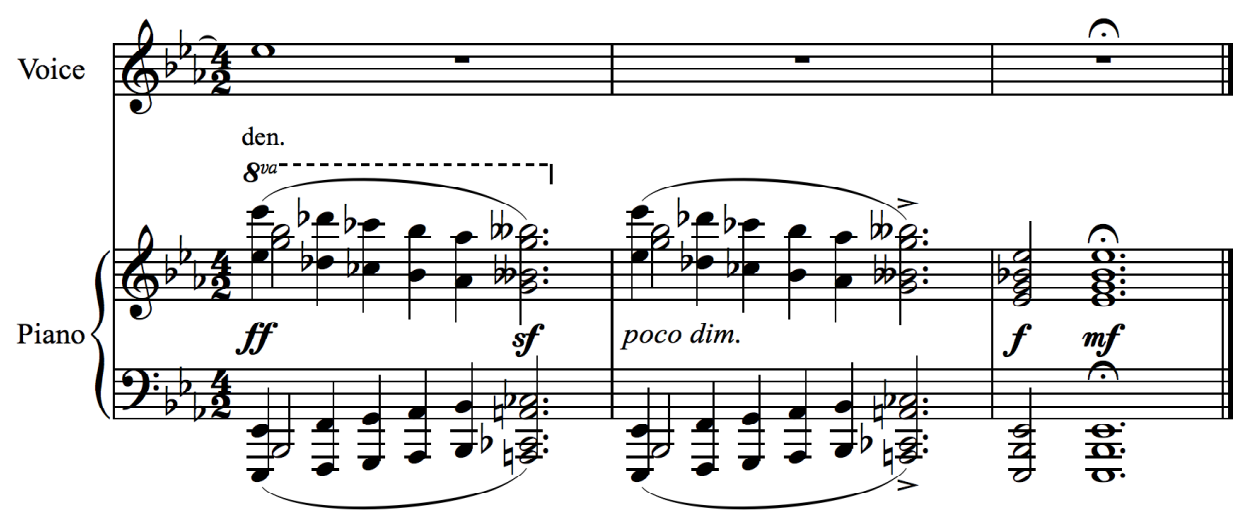

The second and fifth settings both deal with the inability to return to the past, and in both cases the accompaniment has figures which divide the beat in three which are at odds with the vocal line which has the beat divided in two, thereby representing the struggle the narrator feels. In the case of "Die Heimat," Britten accomplishes this by setting the accompaniment in $9 / 8$ against the vocal line set in 3/4, whereas in "Hälfte des Lebens," the accompaniment appears in triplets against the straight rhythms of the vocal line (See Examples 6-3 and 6-4).

\footnotetext{
${ }^{9}$ Ibid., 21. Examples from "Die Linien des Lebens" reproduced with kind permission of Boosey \& Hawkes, Inc.
} 
Example 6-3, “Die Heimat,” mm. 1-6. ${ }^{10}$
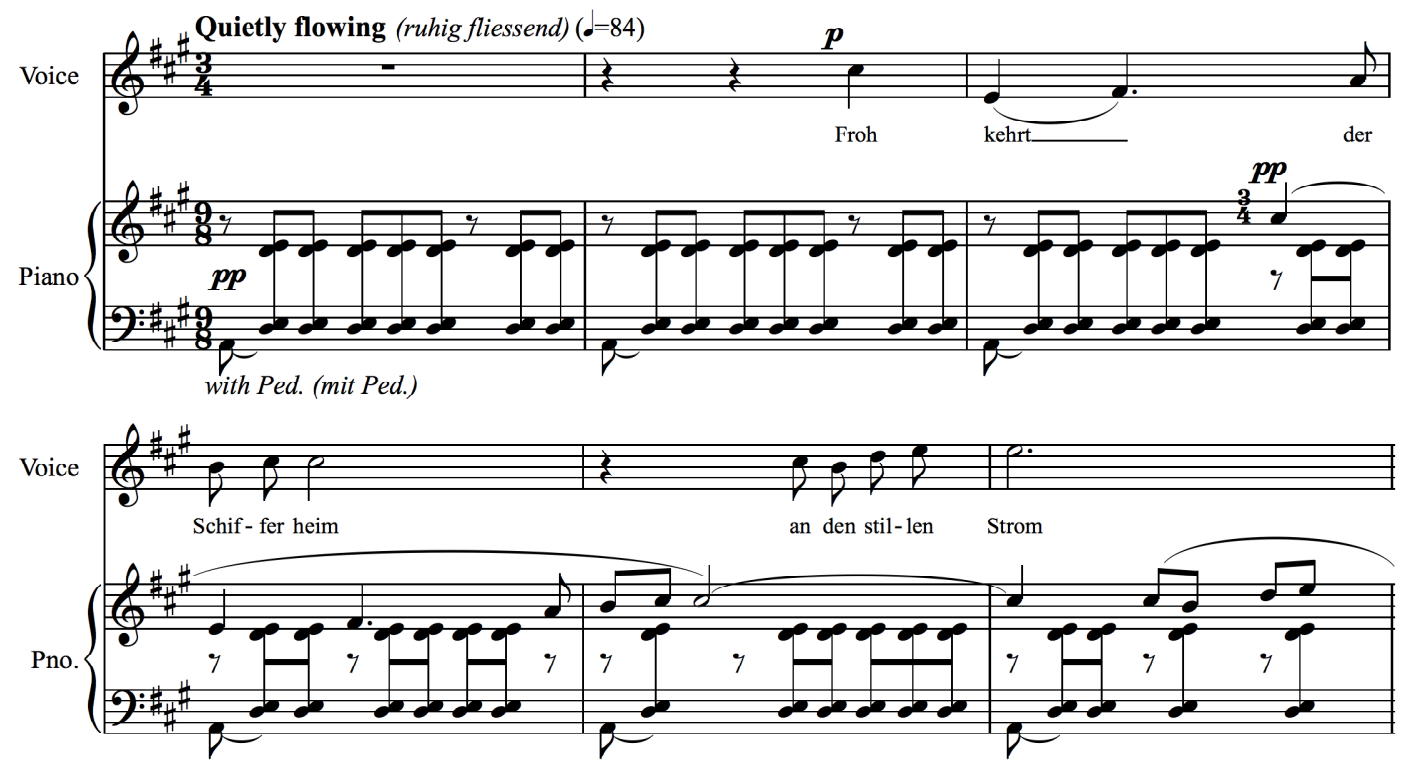

Example 6-4, "Hälfte des Lebens," mm. 1-10. ${ }^{11}$
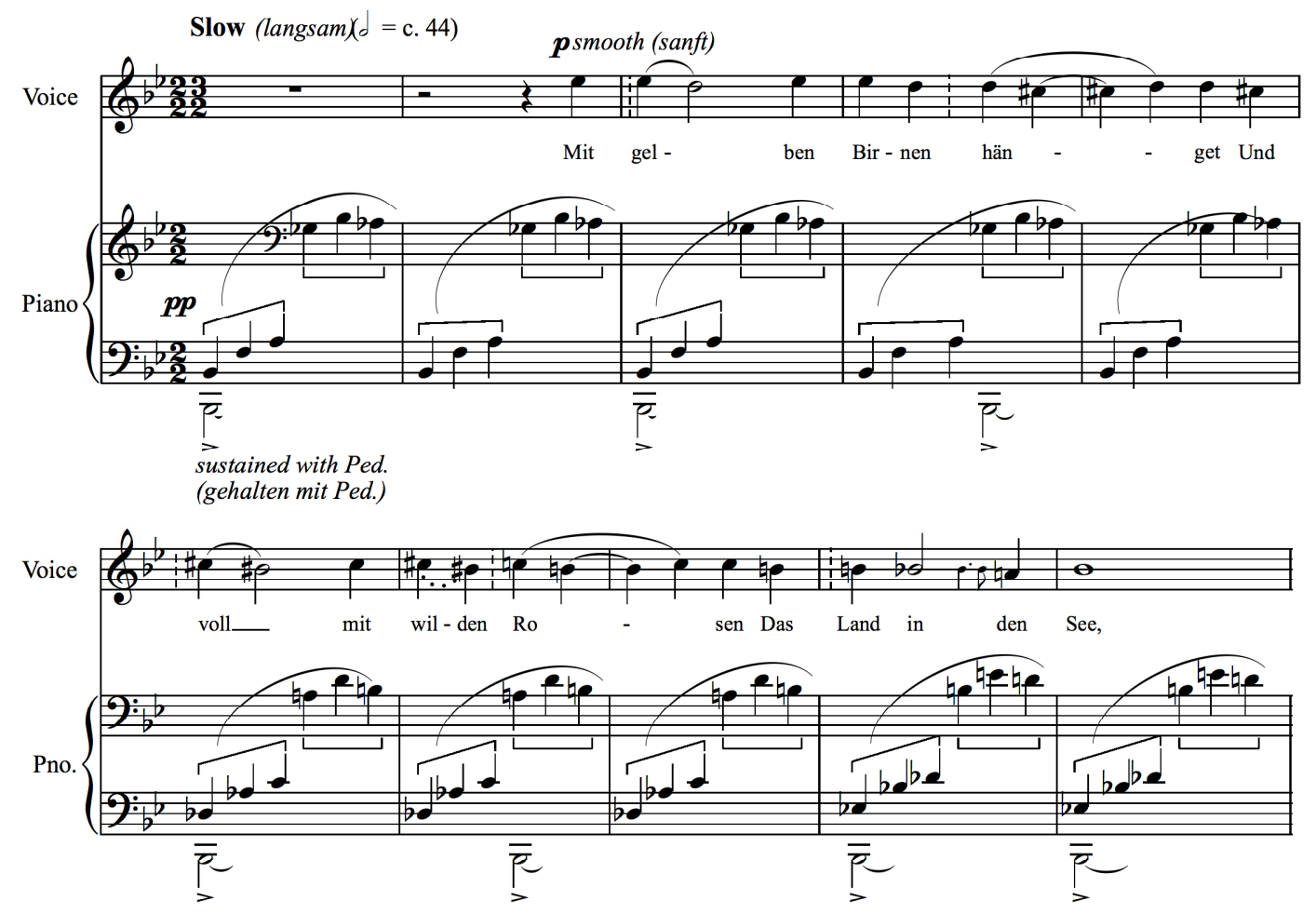

${ }^{10}$ Ibid., 5. Examples from "Die Heimat" reproduced with kind permission of Boosey \& Hawkes, Inc.

${ }^{11}$ Ibid., 16. Examples from "Hälfte des Lebens" reproduced with kind permission of Boosey \& Hawkes, Inc. 
The third and fourth settings, the center of the cycle and the dramatic turning point when the narrator begins to understand his feelings and accept his fate, are both about youth and beauty, but they are opposites: the third is more about the illogical nature and permanence of love, the fourth considers the fleeting nature of youth and the consequent loss of innocence and of ignorant bliss occurring as one must accept responsibility and appear to conform to society's rules and values, all of which are part of adulthood (implied at the end at "Im Arme der Götter wuchs ich gross [In the arms of the Gods I became a man]." ${ }^{12}$ The accompaniment of the third setting ("Sokrates und Alcibiades") includes a long drawn out melody in the right hand of the accompaniment, accentuating the searching nature of the text which ultimately becomes chordal when the questions are answered (See Example 6-5).

\footnotetext{
${ }^{12}$ All translations in this chapter are conflations of translations from three different sources: (1.) Those prepared by Peter Pears and Elizabeth Mayer and are published in Benjamin Britten, Sechs Hölderlin-Fragmente, opus 61 (New York: Boosey \& Hawkes, 1962), (2.) Those prepared by Michael hamburger for publication in Michael Hamburger, ed. Hölderlin Selected Verse. (Dover, New Hampshire: Anvil Press Poetry Limited, 1961), and (3.) Those prepared by Emily Esuzt for use on Emily Esuzt, "Sechs Hölderlin-Fragmente," The Lied and Arts Song Text Page [online]; available from http://www.recmusic.org/lieder/assemble_texts.htm?SongCycleId=148; Internet; accessed 14 August 2005 .
} 
Example 6-5, "Sokrates und Alcibiades," (a.) mm. 1-10, (b.) 25-35. ${ }^{13}$

(a.)
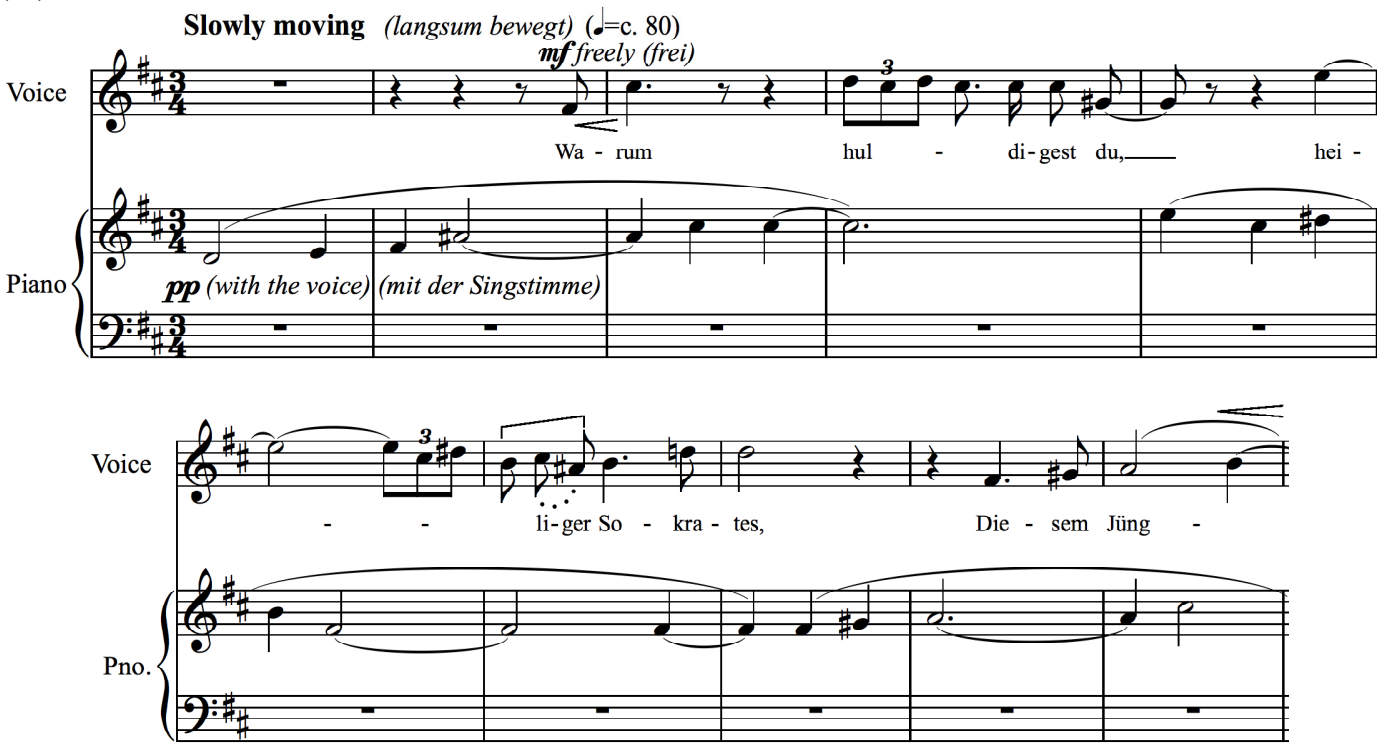

(b.)
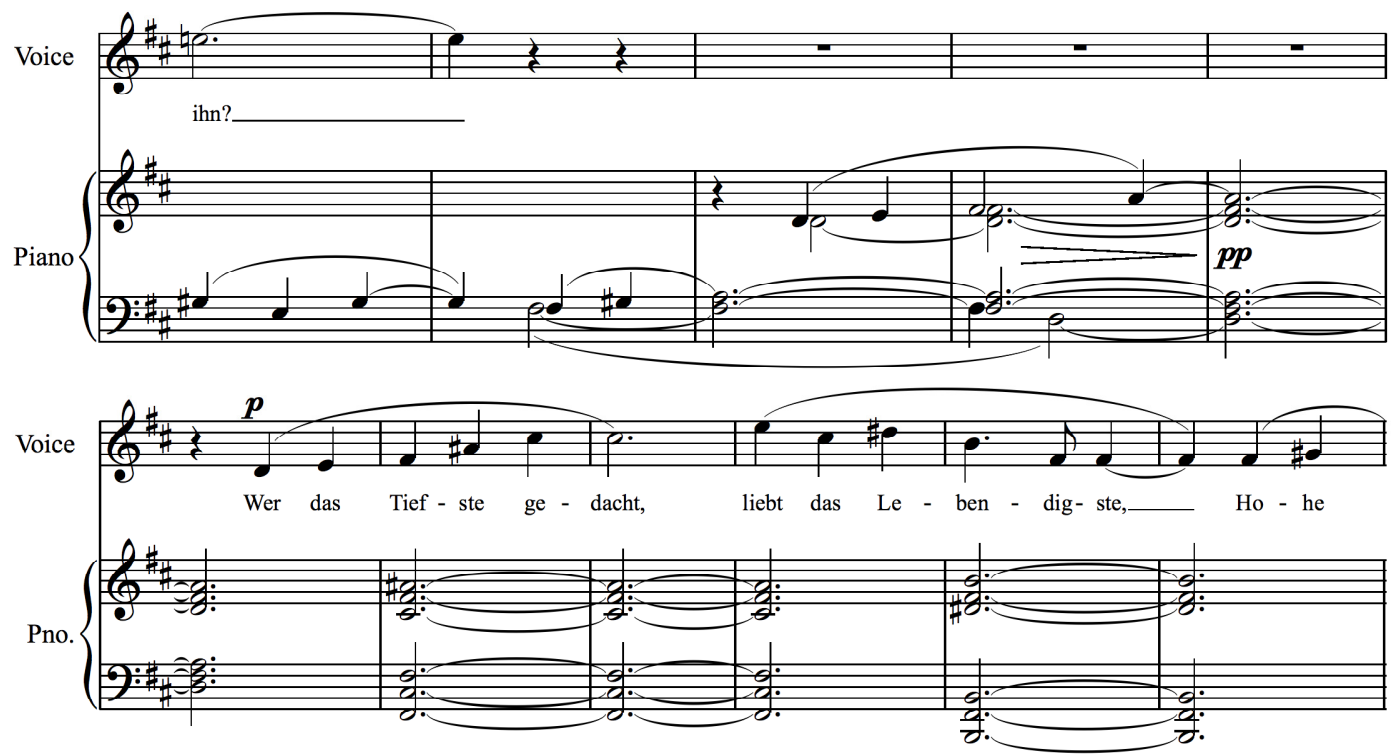

${ }^{13}$ Ibid., 9, 10. Examples from "Sokrates und Alcibiades" reproduced with kind permission of Boosey \& Hawkes, Inc. 
In contrast, the accompaniment to the fourth setting ("Die Jugend") is light and bouncy, with many staccato notes, thereby representing both the vigor of youth and its fleeting nature (See Example 6-6).

(a.)

Example 6-6, "Die Jugend," (a.) mm. 12-15, (b.) 44-47. ${ }^{14}$

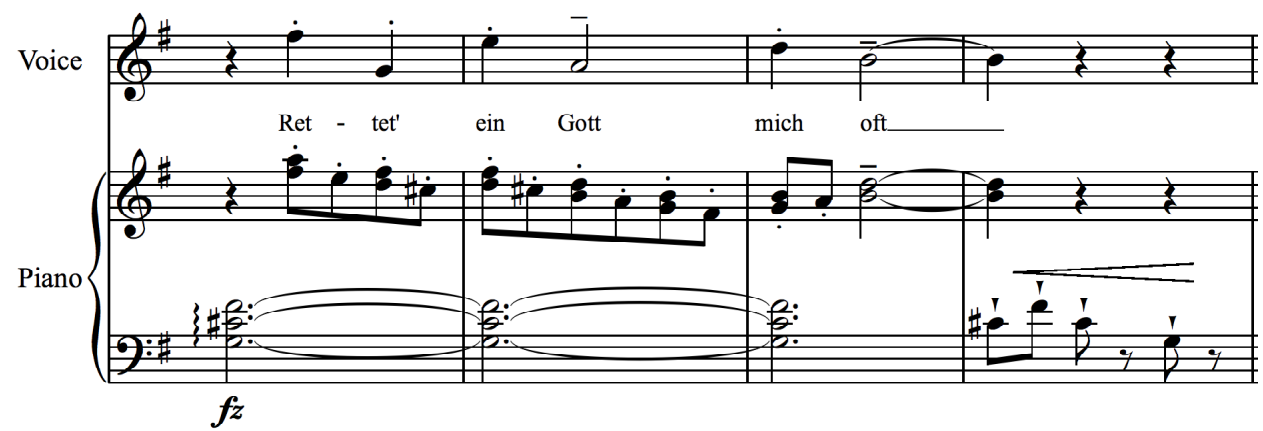

(b.)

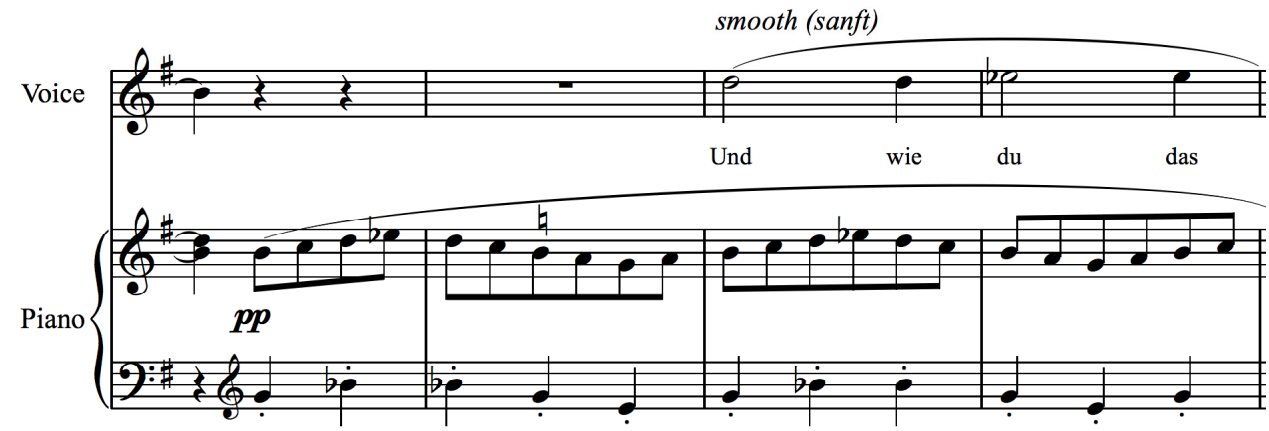

Mensschenbeifall

Ist nicht beilig mein Herz, schöneren Lebens voll,

Seit ich liebe? Warum achtet ihr mich mehr,

Da ich stolzer und wilder,

Wortreicher und leerer war?

Ach! der Menge gefällt, was auf den Marktplatz taugt,

Und es ehret der Knecht nur den Gewaltsamen;

An das Göttliche glauben

Die allein, die es selber sind.
The Applause of Men

Is my heart not holy, full of more beautiful life,

Now that I love? Why did you respect me more,

When I was prouder and wilder, More wordy and more vain?

Ah! it pleases the masses, that which sells in the marketplace, And the servant obeys only an oppressive master; Believing in God

Are only they who themselves are divine.

\footnotetext{
${ }^{14}$ Ibid., 11, 13. Examples from "Die Jugend” reproduced with kind permission of Boosey \& Hawkes, Inc.
} 
The difference in the style of the vocal line in this cycle from the last is apparent immediately. The entrance of the voice in the first setting, "Menschenbeifall," is bold and vibrant and took Pears to a sustained $\mathrm{F}$ above middle $\mathrm{C}$, near the top of his passaggio, twice within the text "Ist nicht heilig mein Herz, schöneren Lebens voll, seit ich liebe [Is my heart not holy, full of more beautiful life, Now that I love?" (See Example 6-7).

$$
\text { Example 6-7, "Menschenbeifall," mm. 9-15. }{ }^{15}
$$
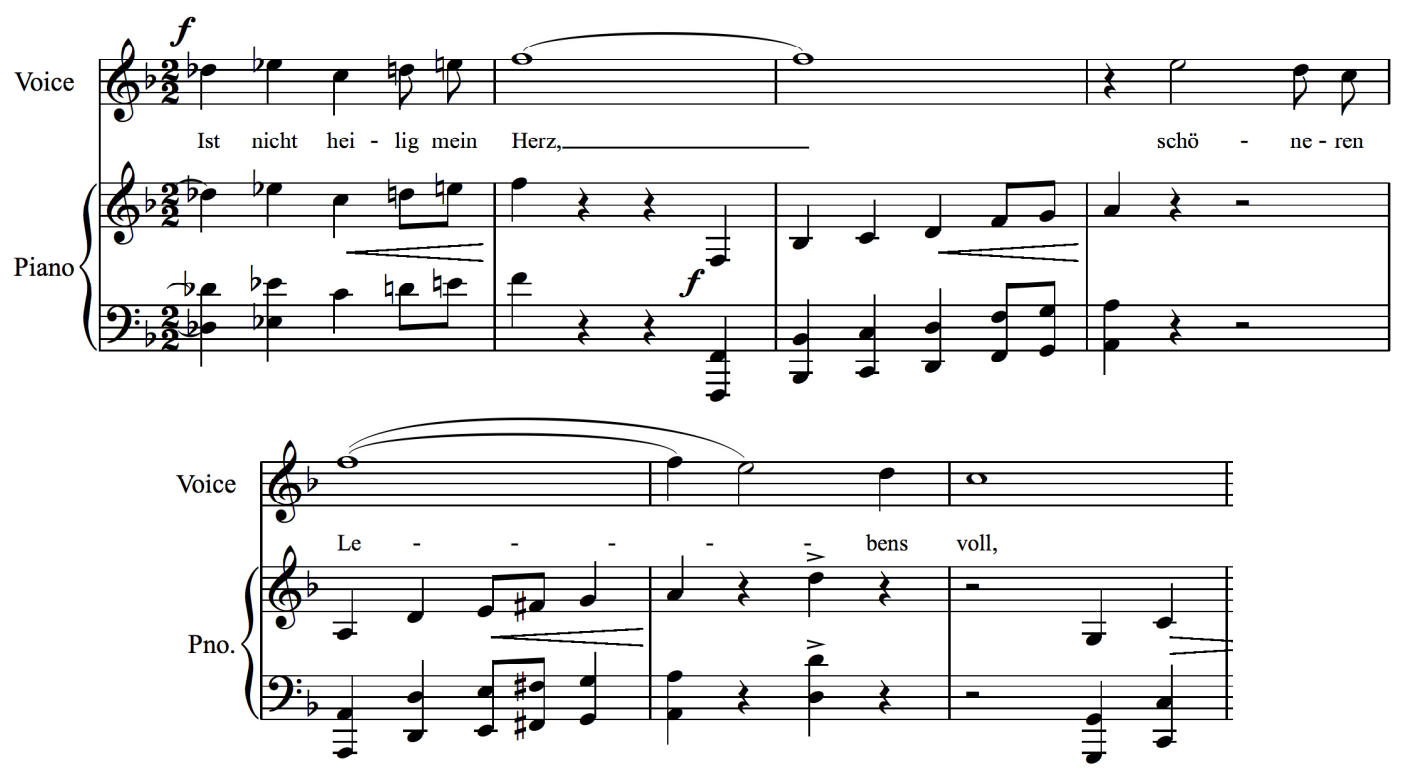

This kind of intensity is more reminiscent of the first two cycles rather than of the wistfulness of

\section{Winter Words.}

Following the opening phrase, the setting continues with a passage of recitative which lay in the tenor's middle range: "Warum achtet ihr mich mehr, Da ich stolzer und wilder, worte reicher und leerer war [Why did you respect me more, when I was prouder and wilder, more wordy and more vain?]" (See Example 6-8).

\footnotetext{
${ }^{15}$ Britten, 1-2.
} 
Example 6-8, "Menschenbeifall," mm. 25-32. ${ }^{16}$
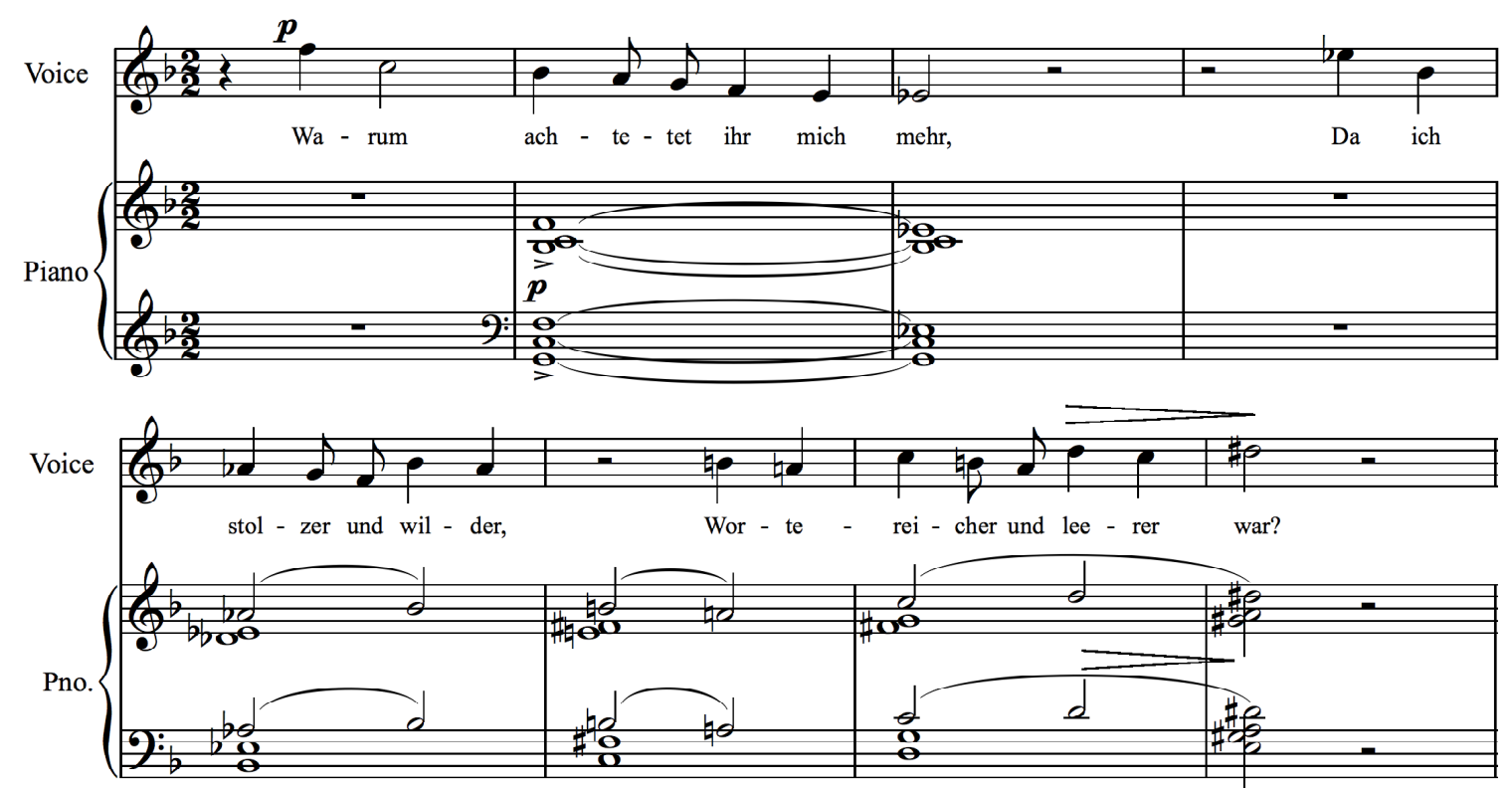

It then turns to more melodic material, which gradually ascends to a high $\mathrm{G}$ above middle C in the phrase "An das Göttliche glauben [Believing in God]." The narrator comes at last to the realization, sung softly in a lower range, that one is responsible for one's own beliefs and cannot rely on others for support or guidance: "Die allein, die es selber sind [Are only they who themselves are divine]" (See Example 6-9).

${ }^{16}$ Ibid., 2. 
Example 6-9, "Menschenbeifall," mm. 46-59. ${ }^{17}$

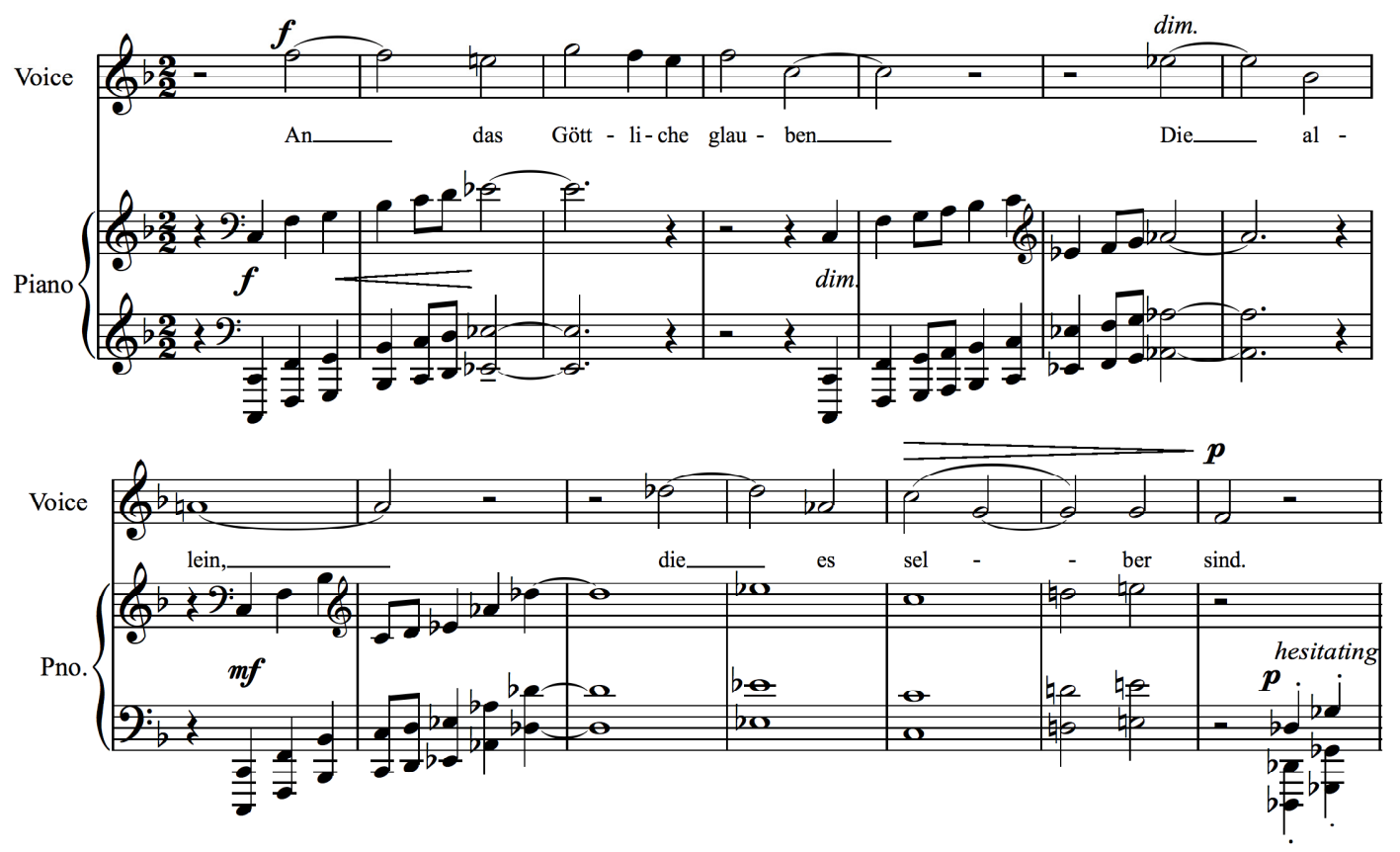

The composer's attraction to this text is fairly obvious if it is seen as a response to those people, supposedly his friends, who were making jokes and comments about his sexual orientation and his relationship with Pears. The anger over the fickleness and lack of loyalty on the part of people like this is expressed clearly in this text. Therefore, although the poet was not gay, the setting of his poetry by Britten, at this time in his life, lashes out at homophobia, something that Britten was reluctant to do by other means. ${ }^{18}$

\footnotetext{
${ }^{17}$ Ibid., 4.

${ }^{18}$ In his biography of Britten, Michael Kennedy states "Britten's silence on the matter [of the normalcy of the state of homosexuality] ... seemed to indicate an unwillingness to allow himself to be regarded as any kind of standardbearer for 'gay liberation." Michael Kennedy, Britten. The Master Musicians, ed. Stanley Sadie (New York: Oxford University Press, 1993), 115. Christopher Headington also addresses the issue: "Britten's homosexuality was never publicly discussed in his lifetime, even after the English law on the matter had changed. He was, after all, entirely un-Bohemian and even Puritan, seeming quite consciously to have sought to live 'decently' and free of scandal." Christopher Headington, Britten (New York: Holmes \& Meier, 1982), 35.
} 
Die Heimat

Froh kehrt der Schiffer heim an den stillen Strom

Von fernen Inseln, wo er geerntet hat. Wohl möcht auch ich zur Heimat wieder; Aber was hab ich, wie Leid, geerntet?

Ihr holden Ufer, die ihr mich auferzogt, Stillt ihr der Liebe Leiden? ach gebt ihr mich, Ihr Wälder meiner Kindheit! wann ich Komme, die Ruhe noch einmal wieder?
Home

Happy, the boatman turns homeward on the quiet river From distant islands, where he harvested. Gladly would I also turn toward home again; But what have I, except grief, harvested?

Ye lovely banks, which brought me up Can you soothe love's suffering? Oh, can you give me, Forests of my childhood, when I Come back, that peace once again?

The second song, "Die Heimat," is a lullaby in which the piano echoes the vocal line in canonic fashion, although never in the same octave, with the dramatic exception of the melody in mm. 38-39 where the lack of an echo serves to accentuate the text. Although some of the vocal phrases dip into the lower middle voice, most linger near the top of the staff and have conjunct melodic motion, which allowed Pears to use a mournful tone while maintaining a sound that is soothing and light (See Example 6-10). 
Example 6-10, “Die Heimat,” (a.) mm. 7-11, (b.) 26-28. ${ }^{19}$
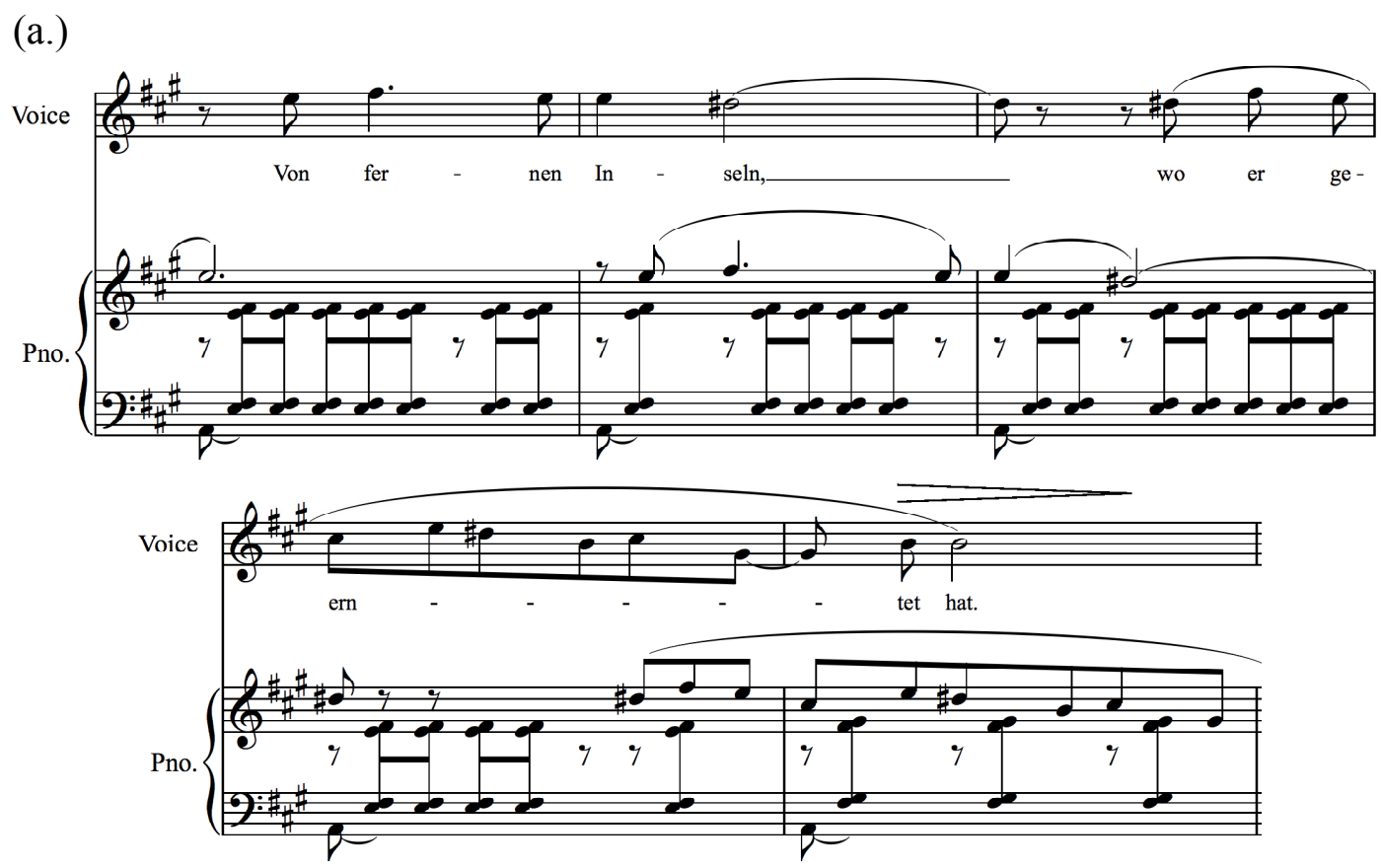

(b.)
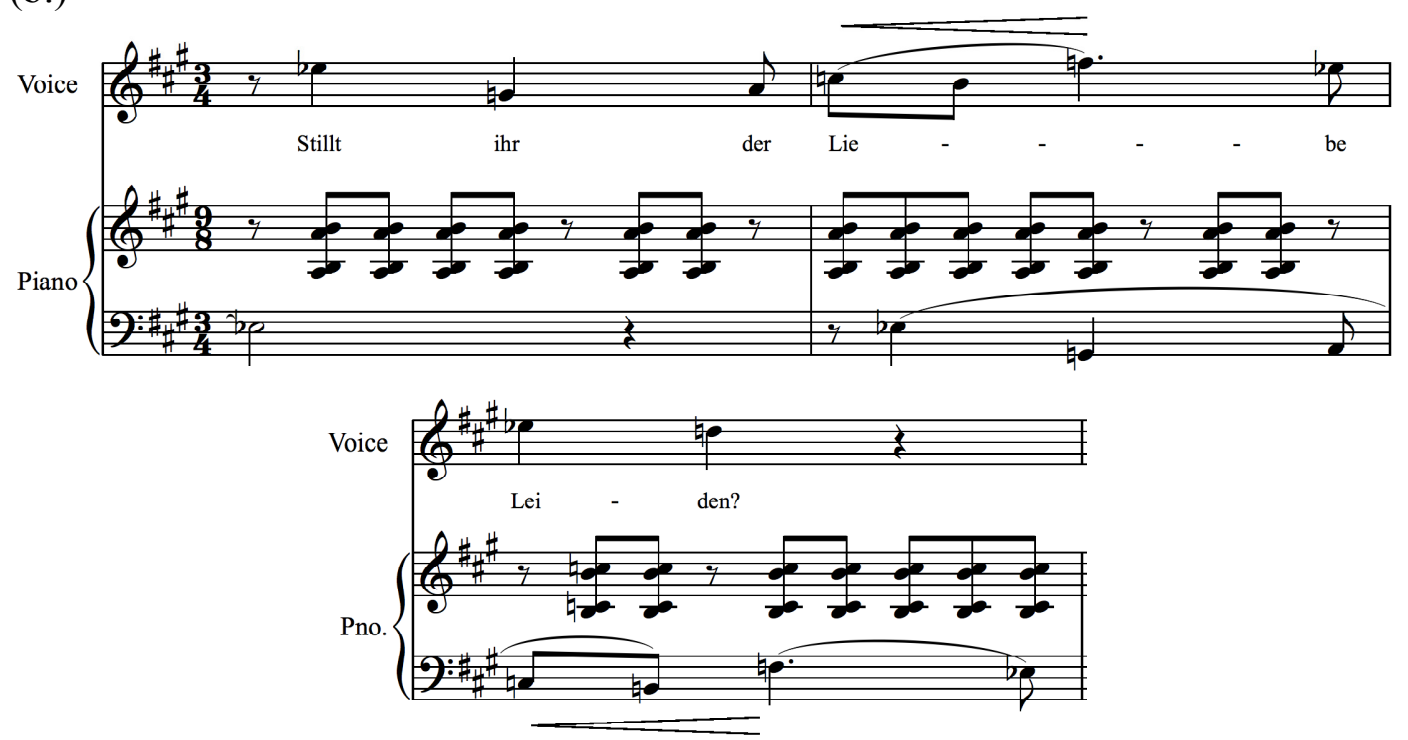

There are instances of tone-painting: the words evoke an approximation of weeping in the vocal line in the phrase "Aber was hab ich, wie Leid, geerntet? [But what have I, except grief, harvested?]" as reflected in the chromatic descent into the lower middle voice (See Example 611).

\footnotetext{
${ }^{19}$ Britten, 5-6, 7.
} 
Example 6-11, “Die Heimat," mm. 16-20. ${ }^{20}$

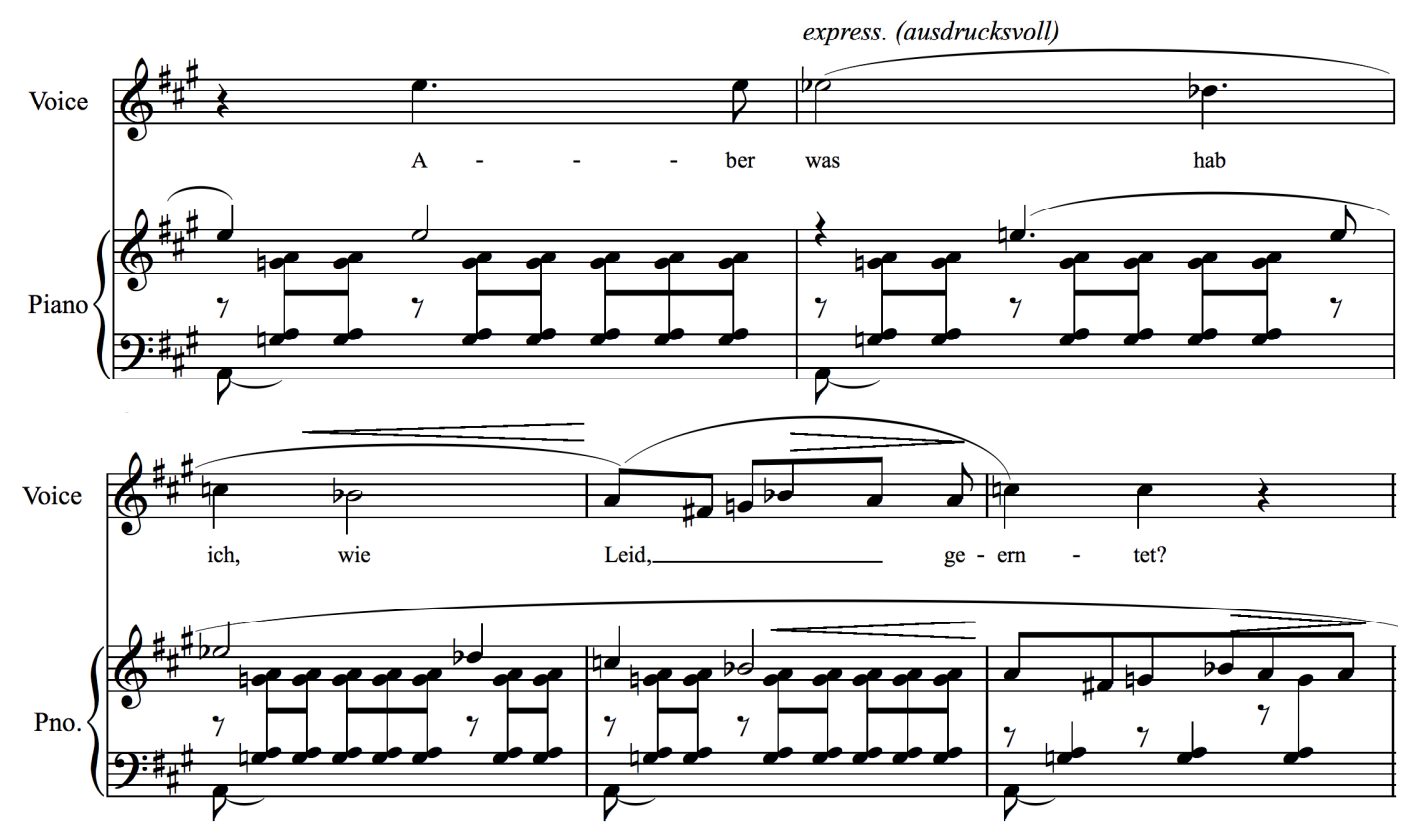

The setting becomes angrier at this point, and the composer expressed this in the vocal line by blurring the tonal center through the use of a chromatic melody (E-natural, E-flat, D-flat, Cnatural, B-flat, A-natural, F-sharp and G-natural) as well as by the deliberate increase in range from one phrase to the next culminating in a repeated F-sharp, G-natural, F-sharp throughout the phrases “Ach gebt ihr mir, Ihr Wälder meiner Kindheit [Oh, can you give me, Forests of my childhood]" (See Example 6-12).

${ }^{20}$ Ibid., 6. 


\section{Example 6-12, "Die Heimat," mm. 30-37. ${ }^{21}$}
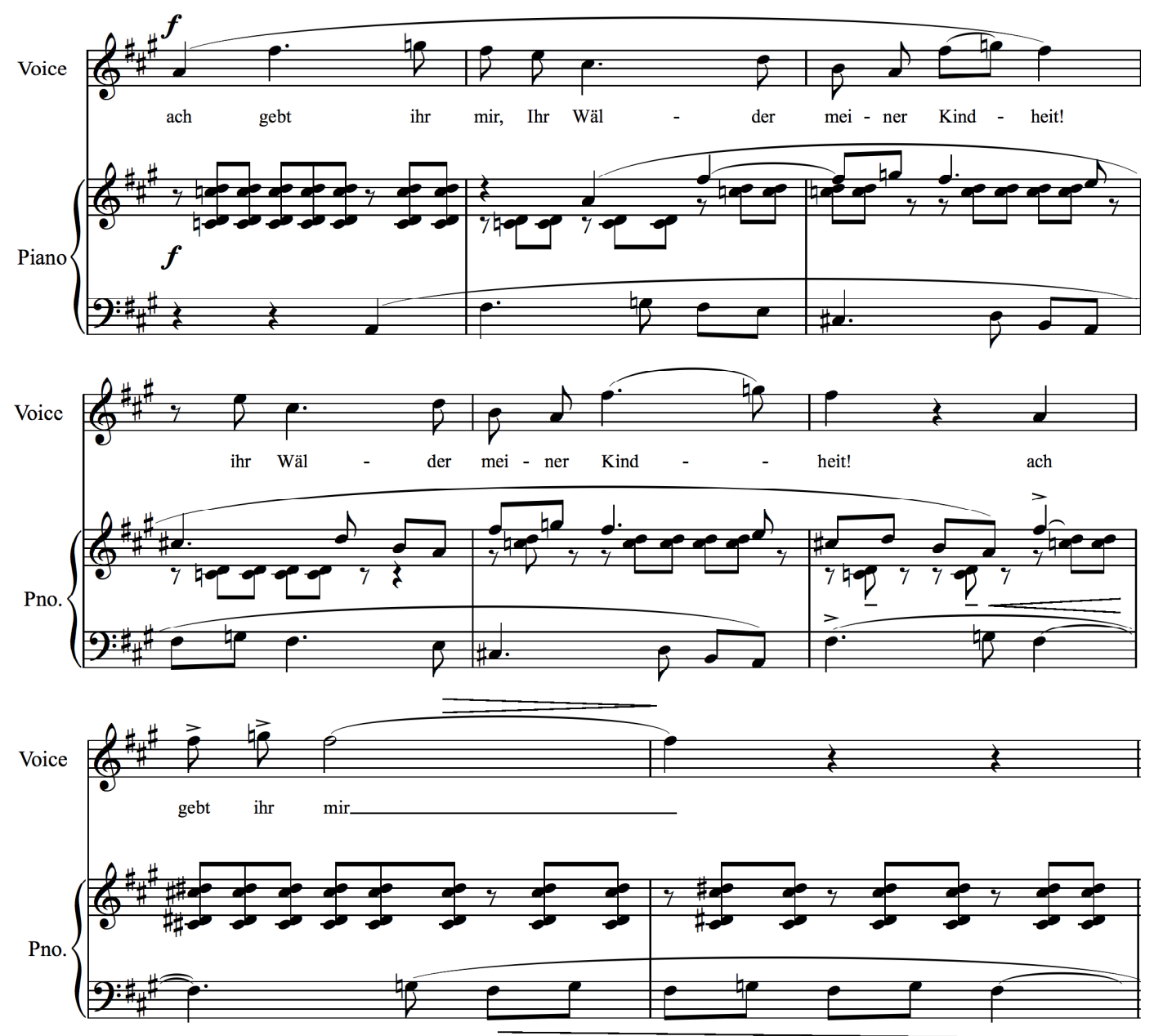

Pears's upper middle voice was exploited to great effect at the end of Winter Words, since he was able both to whine and yearn mournfully in that register, and it is used in the same way here. The "missing" accompaniment, the point where the piano does not echo the vocal melody, occurs at the text "wann ich komme [when I come back]," the climax of the text, when the narrator feels the most despondent; the emptiness is exaggerated by this device. The opening melody, which dips into the tenor's lower middle voice, is used on the repetition of the phrase

\footnotetext{
${ }^{21}$ Ibid., 7-8.
} 
“die Ruhe noch einmal wieder [that peace once again]," and this gives the effect of a more introverted, quiet sobbing than the phrases that precede it (See Example 6-13).

$$
\text { Example 6-13, "Die Heimat," mm. 39-46. }{ }^{22}
$$
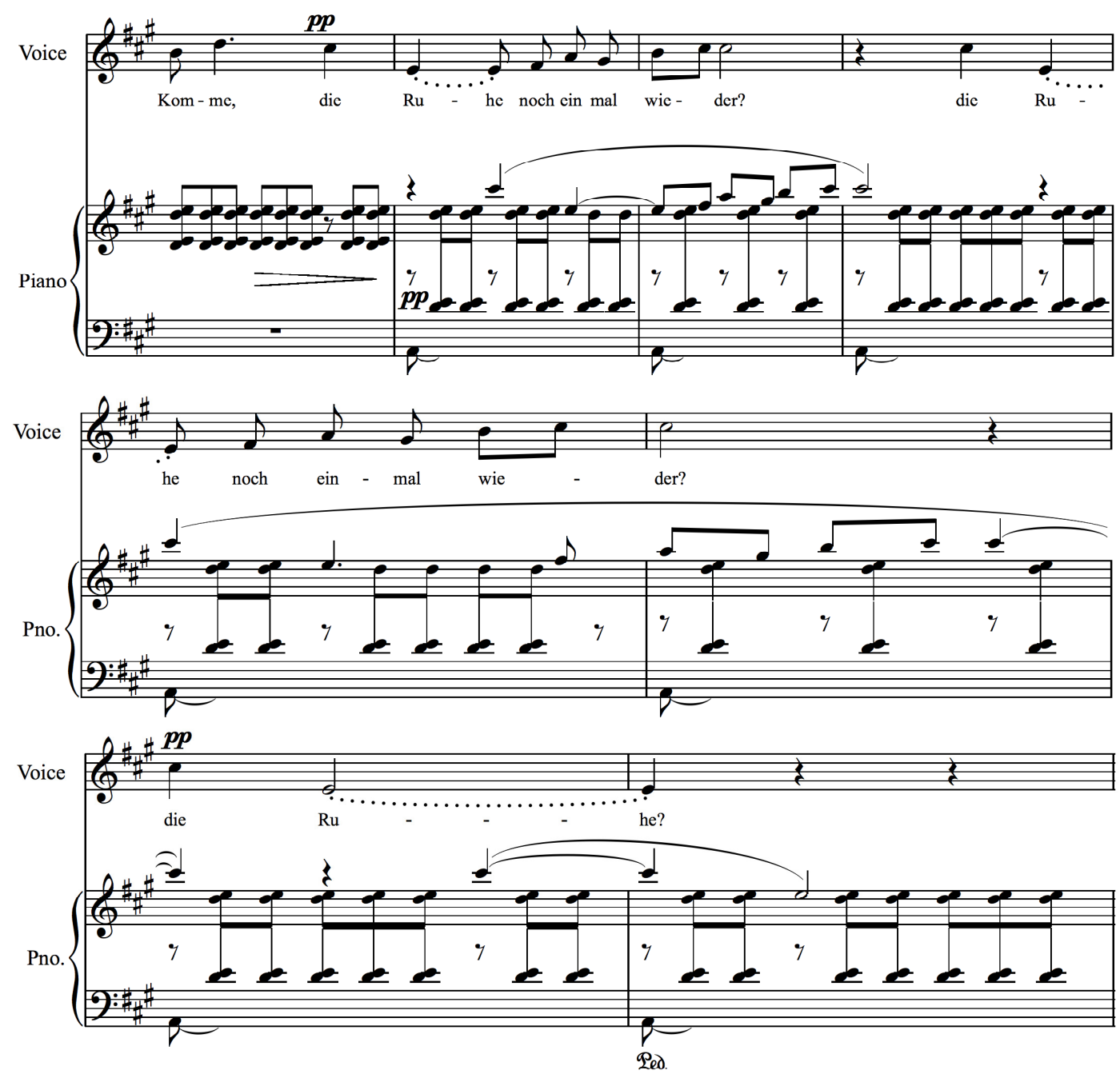

Britten grew up near the sea and was drawn to subject material dealing with it, including his first operatic masterpiece, Peter Grimes. The combination of the reference to the sea and the inability to return to the innocence and joy of youth was no doubt something that drew Britten to this particular text.

${ }^{22}$ Ibid., 8 . 
Sokrates und Alcibiades

Warum huldigest du, heiliger Sokrates,

Diesem Jünglinge stets?

kennest du Grossers nicht?

Warum siehet mit Liebe,

Wie auf Götter, dein Aug' auf ihn?

Wer das Tiefste gadacht, liebt das Lebendigste,

Hohe Tugend versteht, Wer in die Welt geblickt

Und es neigen die Weisen

Oft am Ende zu Schönem sich.
Socrates and Alcibiades

Why do you always court, holy Socrates, This youth?

Don't you know of anything greater?

Why gaze with love

As if upon the Gods, with your eyes on him?

Who ponders the deepest truths, loves the most alive, And highest Virtue understands, who has observed the world, And the wise will bow

Often in the end to that which is beautiful.

The third song of this cycle, "Sokrates und Alcibiades," tells of love between two men. Whether this love could be described as infatuation, mutual respect, or physical lust is unclear, although the poem ends with a litany of praises to the beauty of the younger man. The first half of the song is conversational in vocal style, accomplished in this section both by the rhythms, which mimic those of speech more closely, and also by the fairly low tessitura of the vocal line, which lingered predominantly in the tenor's middle range (See Example 6-14). 
Example 6-14, "Sokrates und Alcibiades," mm. 9-20. ${ }^{23}$
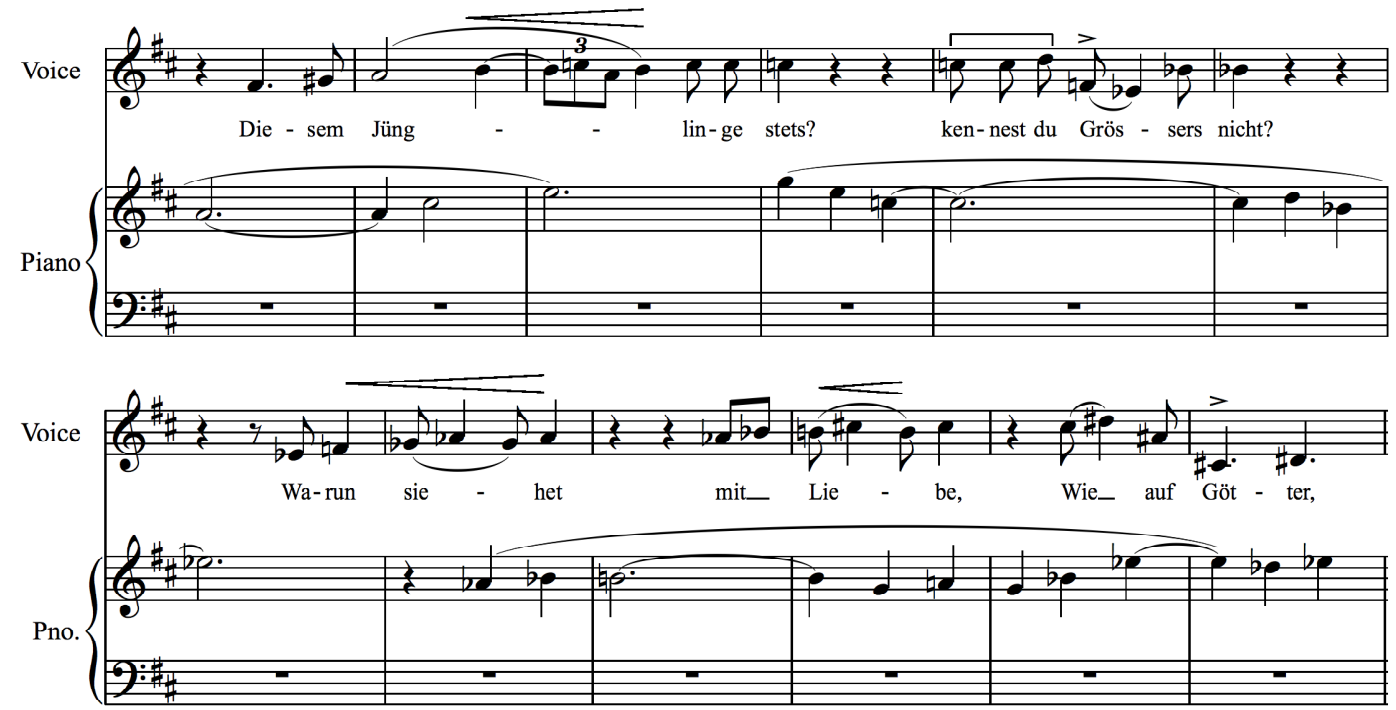

The second half of the setting, beginning in the vocal line in m. 30 with "Wer das Tiefste gedacht, liebt das Lebendigste [Who ponders the deepest truths, loves the most alive]," is reminiscent of the third setting of the Michelangelo Sonnets: the vocal lines are similar, each having long phrases with expansive ranges, and having contours consisting of arpeggiated triads juxtaposing functionally unrelated harmonies (See Examples 6-15 and 6-16).

${ }^{23}$ Ibid., 9. 
Example 6-15, "Sokrates und Alcibiades," mm. 30-49. ${ }^{24}$
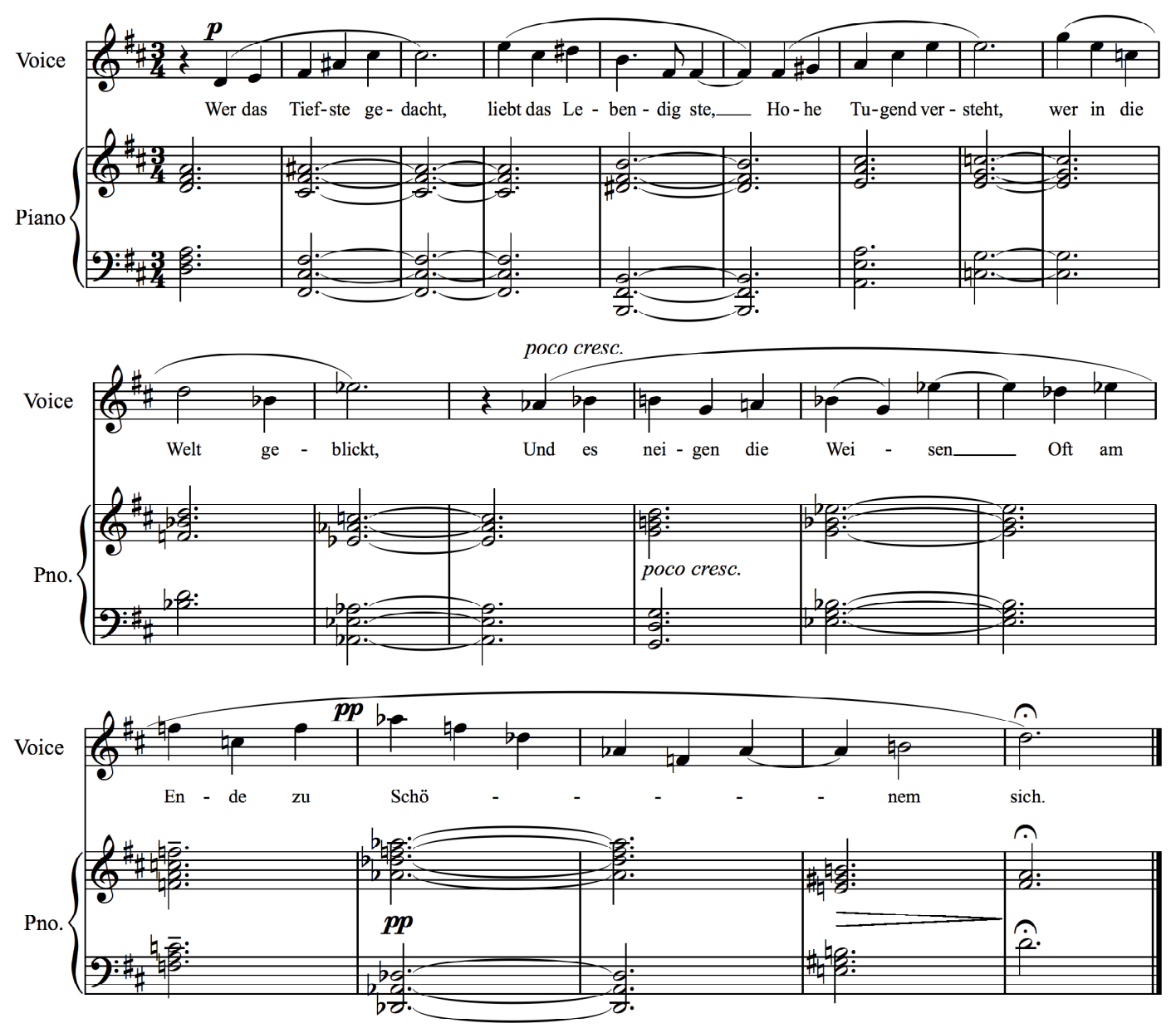

${ }^{24}$ Ibid., 10. 
Example 6-16, "Sonetto XXX," mm 1-7. ${ }^{25}$
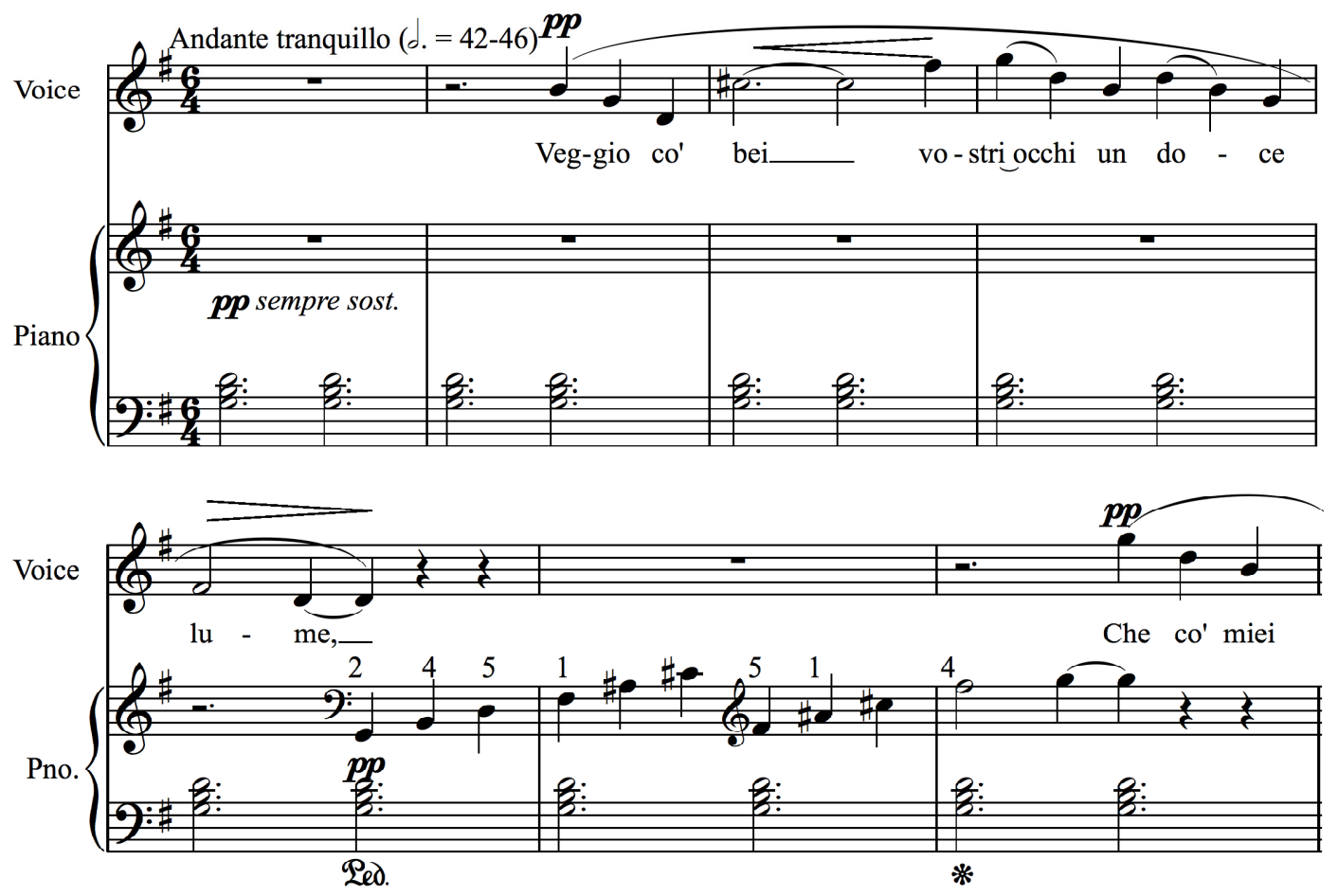

Unlike "Sokrates und Alcibiades," "Veggio co' bei vostri occhi” (Sonnetto XXX) does not touch upon all twelve major keys, but the use of the predominantly major qualities to represent the poet's explanation that the love is natural and beautiful is echoed in the setting of "Sokrates." In the later work, Britten, this time using all twelve tonal centers, achieved a similar effect.

“Sokrates und Alcibiades," along with "Veggio co' bei vostri occhi” (Sonnetto XXX) are rare examples of what might be considered a more traditional love song, in that there is no anger or bitterness due to an unrequited love. Both settings explain why the speaker loves a particular man, in the case of the Michelangelo the question is implied and the subsequent answer is directed to the man himself whereas in the Hölderlin poem the question appears in the first half of the text and the answer is directed to a third party. Musically, the answer is built on a succession of major chords.

${ }^{25}$ Benjamin Britten, Seven Sonnets of Michelangelo, opus 22 (New York: Boosey \& Hawkes, 1943 ), 10. 
The last phrase of "Sokrates und Alcibiades" took Pears up to a pianissimo high A-flat on the word "Schönem [Beautiful]" which Pears was more than capable of endowing with great emotion and tender care (See Example 6-17).

Example 6-17, "Sokrates und Alcibiades," m. 46-48. ${ }^{26}$

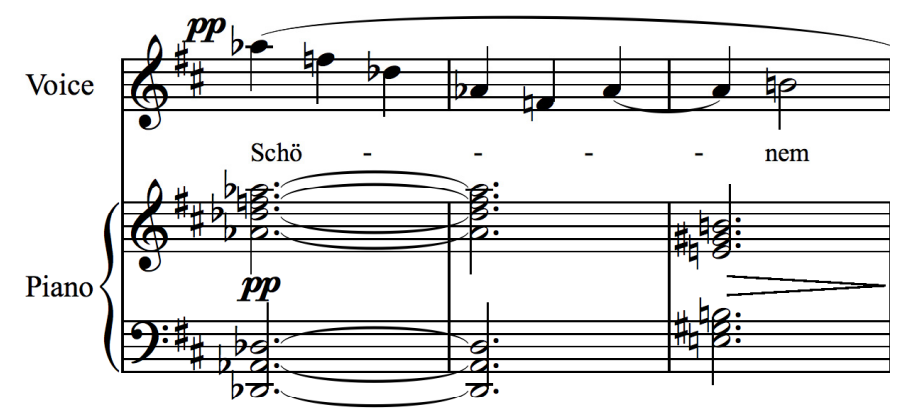

This emotion is called for in the text "Und es neigen die Weisen oft am Ende zu Schönem sich [And the wise will bow often in the end to that which is beautiful]" as Socrates explains that his love is quite natural, as all wise men would know.

After the anger of the text of the first setting, and the longing of that of the second setting, this text seems to be a justification to society of Britten's relationship with Pears, focusing upon the spirituality and inevitability of the love rather than the physical aspects. Although this was a fairly overt statement, when set by Britten, it was still masked by the use of the German language which only some, not all, would understand completely.

Die Jugend

Da ich ein Knabe war, Rettet' ein Gott mich oft Vom Geschrei und der Ruthe der Menschen,
Youth

When I was a boy

A God would often rescue me

From the shouts and rod of men.

\footnotetext{
${ }^{26}$ Britten, Sechs Hölderlin-Fragmente, 10.
} 
Da spielt' ich sicher und gut Mit dem Blumen des Hains, Und die Lüftchen des Himmels Spielten mit mir.

Und wie du das Herz

Der Pflanzen erfreust, Wenn sie entgegen dir Die zarten Arme streken, So hast du mein Herz erfreut Vater Helios! Und, wie Endymion War ich dein Liebling, Heilige Luna!

$\mathrm{O}$ all ihr treuen

Freundlichen Götter!

Dass ihr wusstet,

Wie euch meine Seele geliebt!

Mich erzog der Wohllaut

Des sa' uselnden Hains

Und lieben lernt' ich

Unter den Blumen.

Im Arme der Götter wuchs ich gross.
I played securely and good With the flowers of the grove, And the breezes of the heavens played with me.

And as you the hearts of plants cheer When they reach toward you Their tender arms, So did you please my heart, Father Helios! And, like Endymion, I was your favorite, Holy Luna!

O all you faithful

Friendly Gods!

Would that you knew

How my soul loved you!

I was educated by the pleasing sound Of the rustling grove, And I learned to love Beneath the flowers. In the arms of the Gods I became a man.

"Die Jugend" receives by far the most vigorous treatment vocally and pianistically in this cycle, full of wide melodic leaps, exemplified in the very first phrase: octave up, seventh down, sixth up, fifth down, fourth up (See Example 6-18).

Example 6-18, "Die Jugend," mm. 2-5. ${ }^{27}$

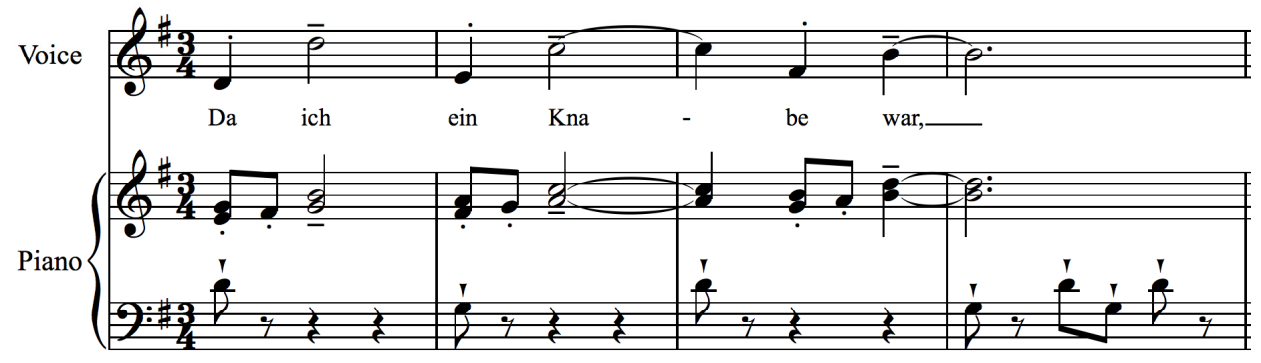

${ }^{27}$ Ibid., 11. 
This melodic idea and its inversion appear throughout the piece, representing the youthful character of the boy. The higher tessitura helped Pears to use a more youthful sound, although a lower range is used for the phrase "Rettet' ein Gott mich oft vom Geschrei und der Ruthe der Menschen [A God would often rescue me From the shouts and rod of men]" in this case so that the tenor could use a slightly more menacing tone (See Example 6-19).

Example 6-19, "Die Jugend," mm. 16-22. ${ }^{28}$

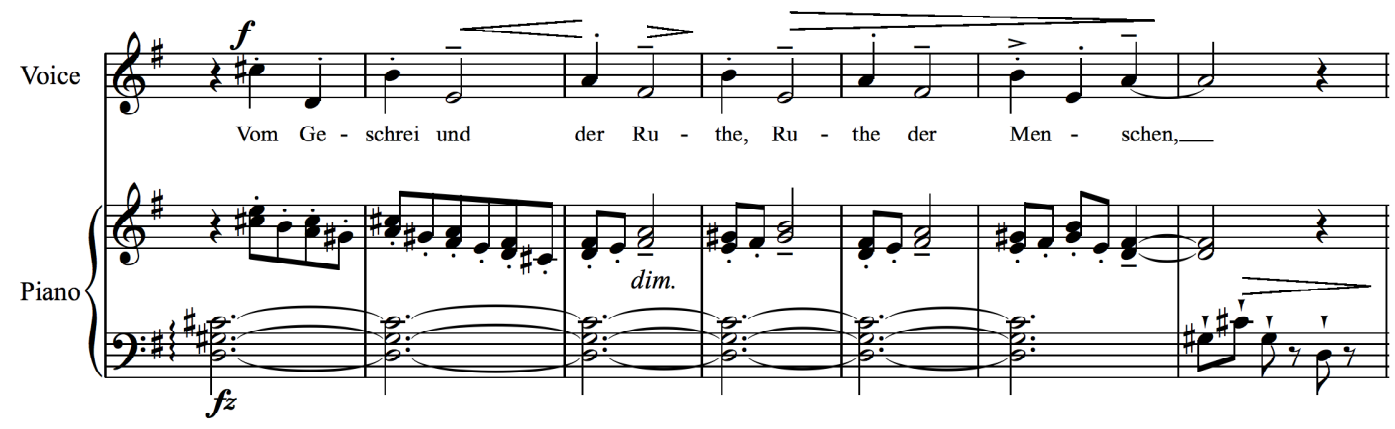

When the boy sings of the tender love and care he received, "Und wie du das Herz der Pflanzen erfreust ... So hast du mein Herz erfreut [And as you the hearts. . So did you please my heart,]" the vocal line becomes more conjunct and lingers in the upper middle voice where the singer could use a tender tone quality, until the climax of the phrase on a high A-flat (See Example 620).

${ }^{28}$ Ibid., 11-12. 
Example 6-20, "Die Jugend," mm. 46-63. ${ }^{29}$
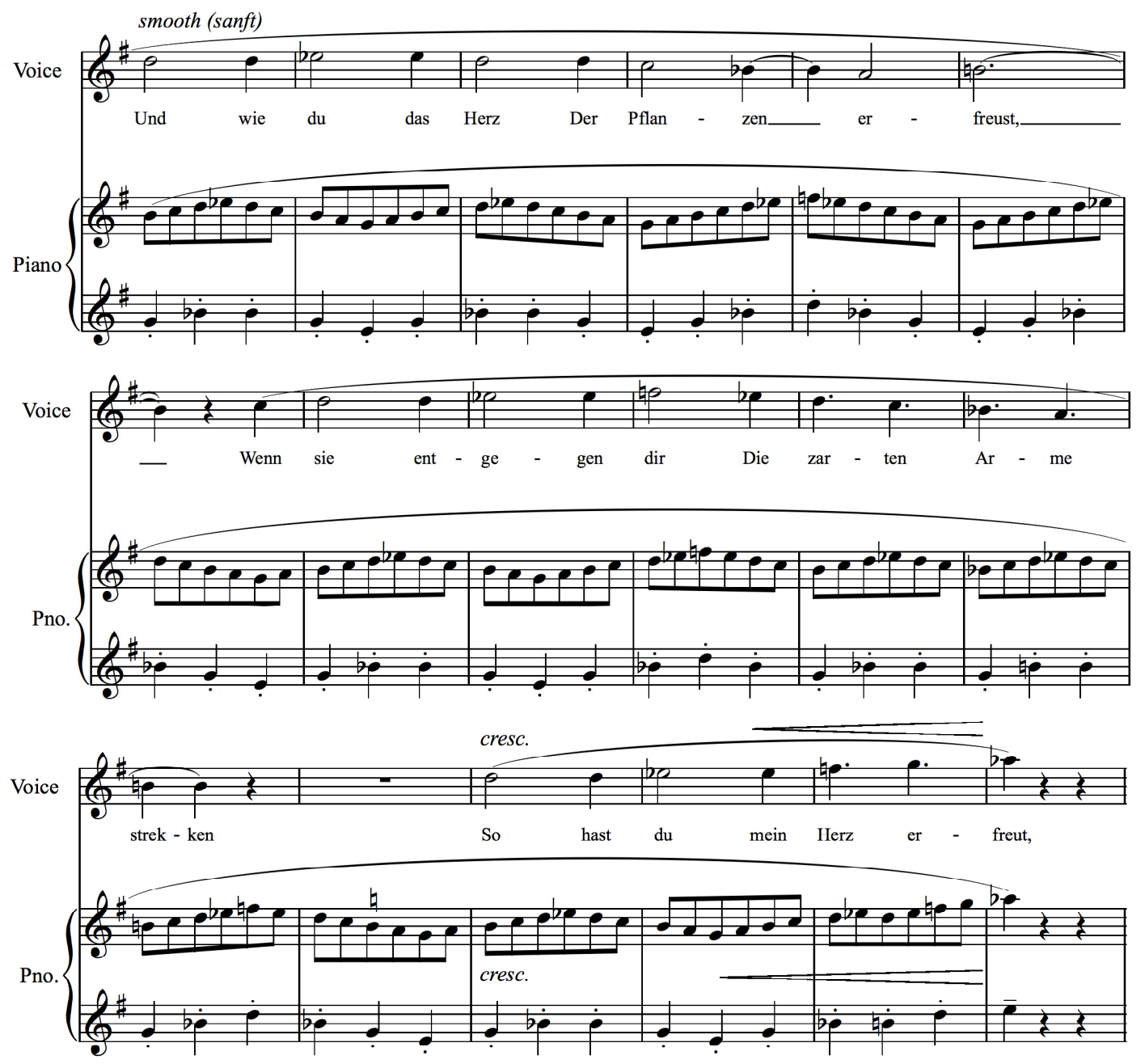

The phrases “O all ihr treuen Freundlichen Götter! Dass ihr wüsstet, Wie euch meine Seele geliebt! [O all you faithful, friendly Gods! Would that you knew how my soul loved you!]" are set first with a string of E-naturals along with the static chords of the accompaniment, indicating a persistence and dedication on the part of the narrator, followed by a slow descent into the middle-range (See Example 6-21).

${ }^{29}$ Ibid., 13. 
Example 6-21, "Die Jugend,” mm. 77-82. ${ }^{30}$

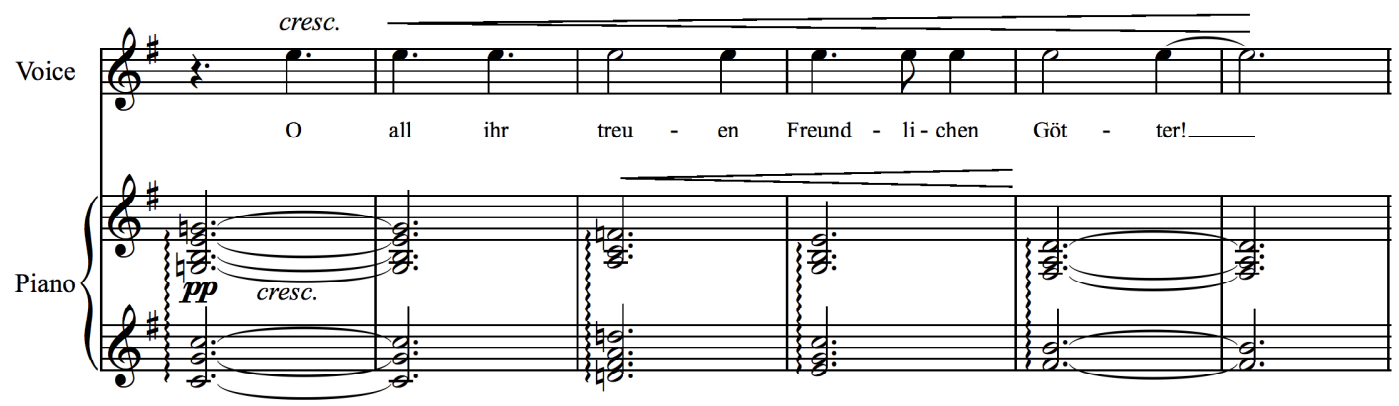

The last verse of the text, as in the first song of this cycle, displays increasing emotion towards the end, in this case a more physical passion than anger, and this is expressed in the vocal line again by the use of an increasingly high register: the piece ends on the high note, a $\mathrm{G}$ natural above middle $\mathrm{C}$, reminiscent of the use of the high voice in the Michelangelo Sonnets (See Examples 6-22 and 6-23).

Example 6-22, “Die Jugend,” mm. 108-113. ${ }^{31}$

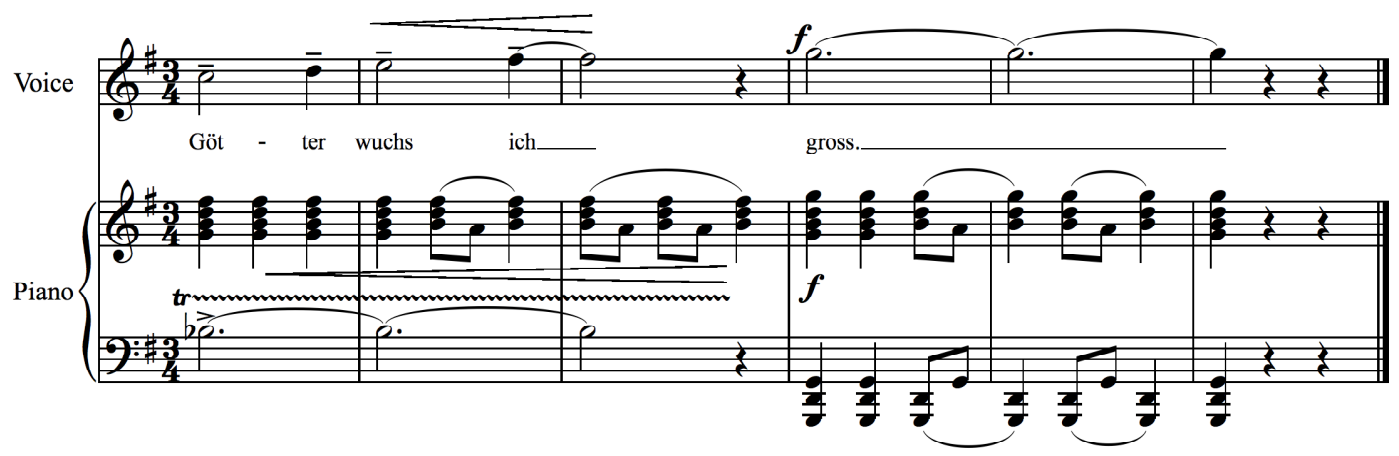

\footnotetext{
${ }^{30}$ Ibid., 14.
}

${ }^{31}$ Ibid., 15. 
Example 6-23, “Sonetto XXXI," mm. 58-61 32

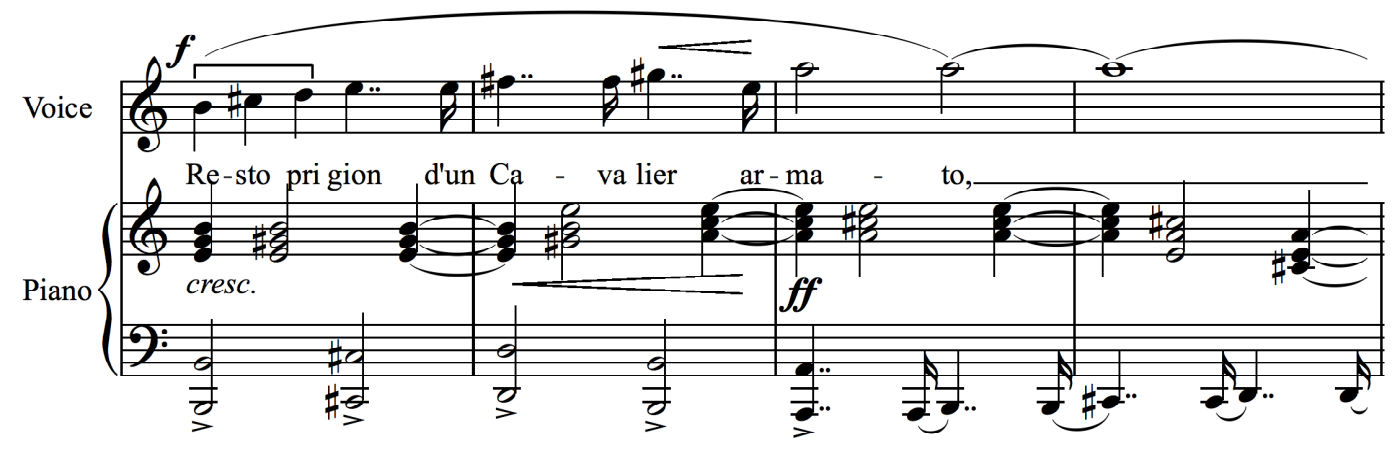

The references to Helios (God of the Sun) and Luna (Goddess of the Moon), as well as of her eternally youthful lover Endymion (in his sleep unable to age), help to emphasize the naturalness of the state of the narrator in this story as he explains why he is the way he is. It also reinforces the idea that the ignorance of childhood, in this case due to separation from humankind, is the most natural and happiest state of mind, which drew Britten to this poem.

Hälfte des Lebens

Mit gelben Birnen hänget

Und voll mit wilden Rosen

Das Land in den See,

Ihr holden Schwäne,

Und trunken von Küssen

Tunkt ihr das Haupt

Ins heilignüchterne Wasser.

Weh mir, wo nehm' ich, wenn

Es Winter ist, die Blumen, und wo

Den Sonnenschein

Und Schatten der Erde?

Die Mauern stehn

Sprachlose und kalt, im Winde

Klirren die Fahnen.

\section{The Middle of Life}

With yellow pears it hangs there

And full of wild roses

The land into the lake,

You fair swans

And drunk with kisses

You dunk your heads

In the holy, sober water.

Woe is me! where will I get,

When it is winter, the flowers, and where

The sunshine,

And the shadows of the Earth?

The walls stand

Speechless and cold; in the wind

Rattles the Weather-vanes.

\footnotetext{
${ }^{32}$ Britten, Seven Sonnets of Michelangelo, 9.
} 
The text of "Hälfte des Lebens" has a great deal of sorrow tempering the anger of alienation, and this sorrow is expressed motivically by the use of descending half-steps reminiscent of "O Might These Sighes and Teares" from the John Donne Sonnets (See Example 6-24 and 6-25), although in this case the weeping extended further in the tenor's range.

$$
\text { Example 6-24, "Hälfte des Lebens," mm. 1-10. }{ }^{33}
$$

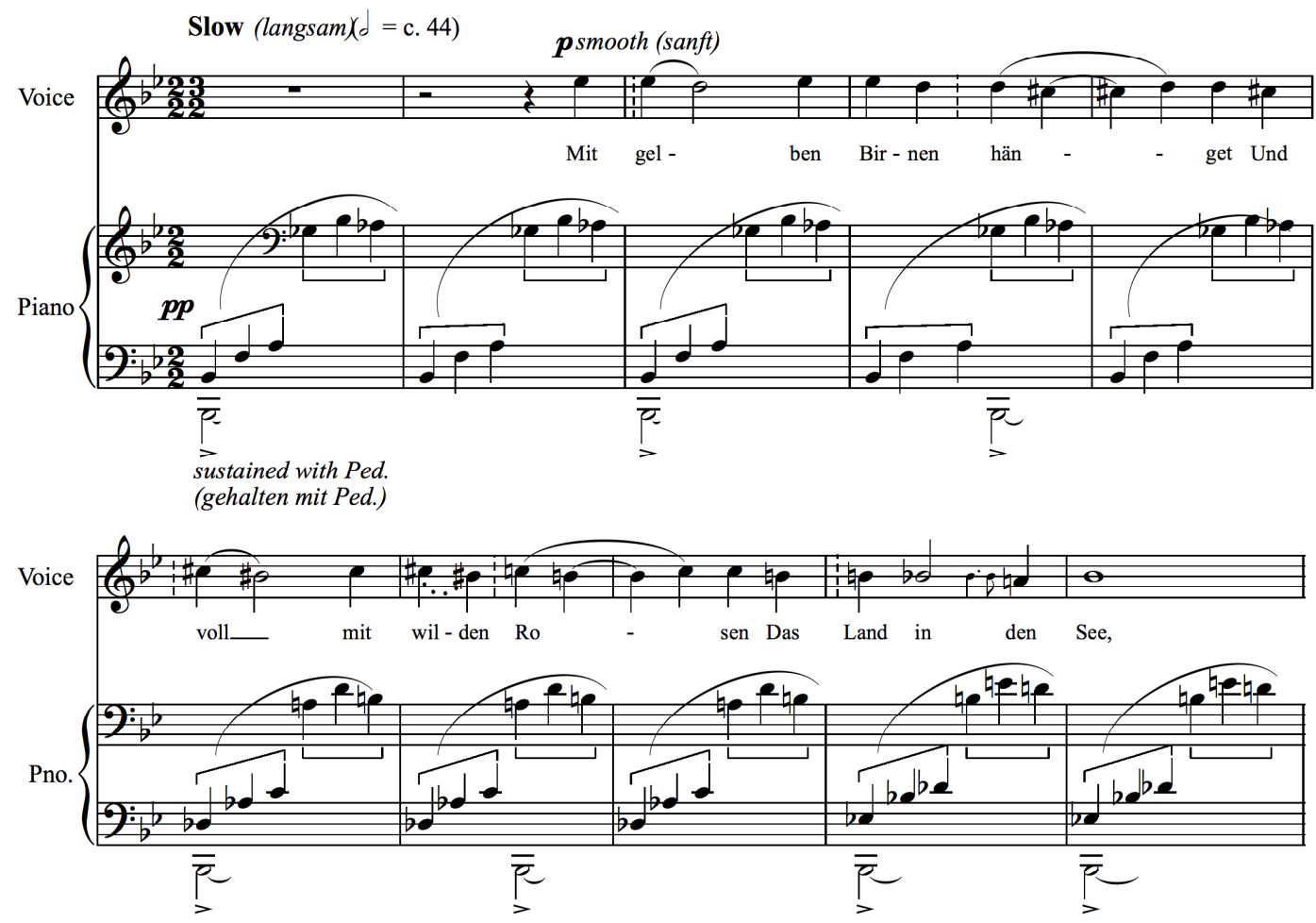

\footnotetext{
${ }^{33}$ Britten, Sechs Hölderlin-Fragmente, 16.
} 
Example 6-25, “O Might Those Sighes and Teares,” mm. 4-6. ${ }^{34}$

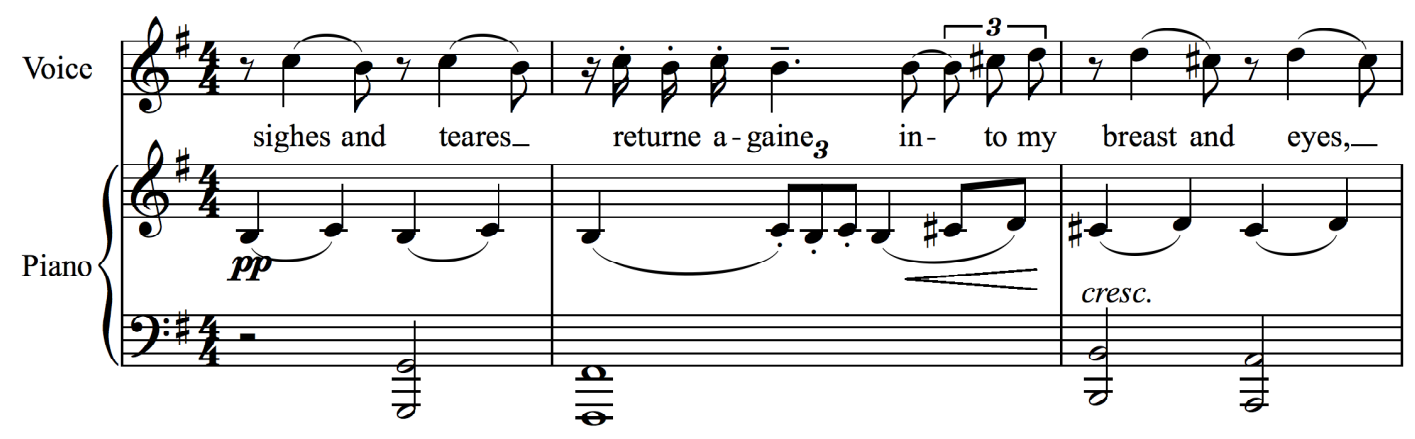

Within the phrases that contain them, the descending half-step motive, historically known as the "sigh motive," is repeated sequentially, sometimes descending the distance of a minor seventh (See Example 6-26).

${ }^{34}$ Benjamin Britten, The Holy Sonnets of John Donne, opus 35 (New York: Boosey \& Hawkes, 1946), 12. 
Example 6-26, “Hälfte des Lebens,” mm. 11-21. ${ }^{35}$
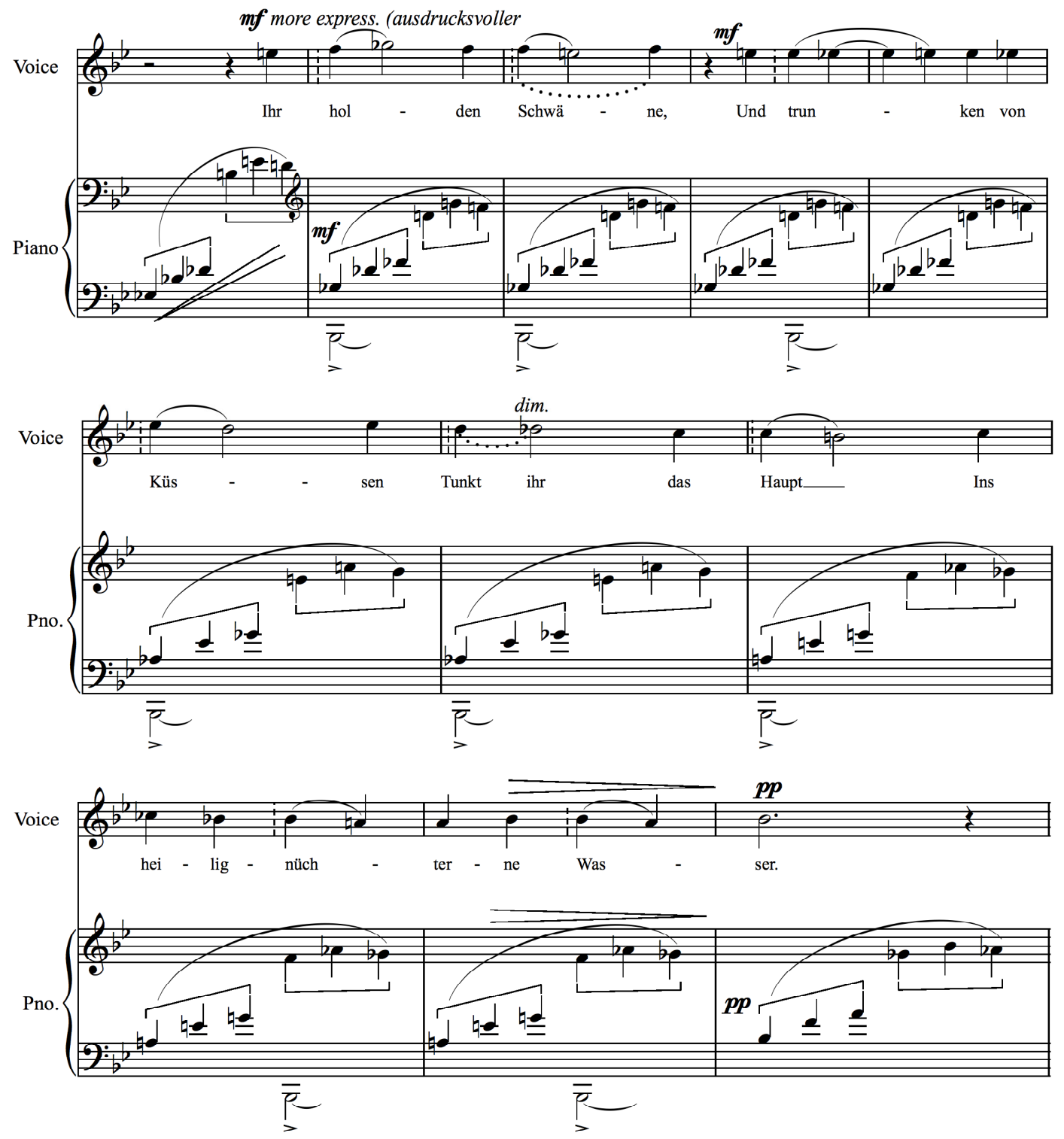

The angst was further expressed by Britten in his use of contradictory metric structures between the voice and accompaniment.

The middle section of this setting becomes angrier beginning with the text "Weh mir, wo nehm' ich, wenn es Winter ist, die Blumen, und wo Den Sonnenschein und schatten der Erde [Woe is me! where will I get, when it is winter, the flowers, and where the sunshine and the

\footnotetext{
${ }^{35}$ Britten, Sechs Hölderlin-Fragmente, 16-17.
} 
shadows of the Earth?]" with the triplets in the accompaniment coming twice as quickly, and the vocal line, set higher in the tenor's voice to allow for a more urgent tone quality, appears in shorter, almost clipped phrases (See Example 6-27). 
Example 6-27, “Hälfte des Lebens,” mm. 25-37. ${ }^{36}$
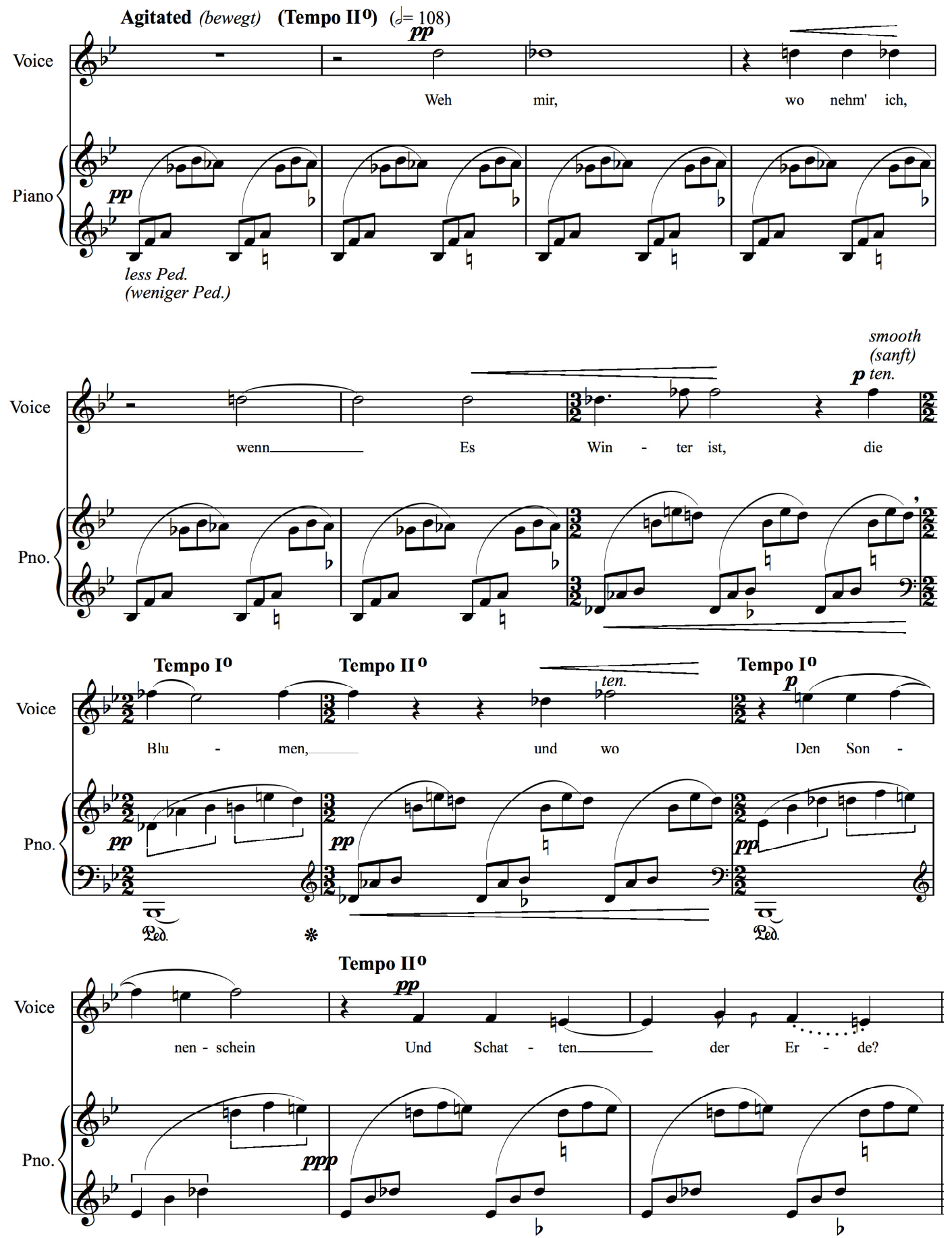

${ }^{36}$ Ibid., 17-18. 
The half-steps return as the anger is tempered with more sorrow in the subsequent phrases. The final statement of the piece ends dramatically, beginning a slow ascent from the tenor's lower middle voice at "Die Mauern stehn sprachlos und kalt [The walls stand speechless and cold]", up through his upper middle voice at "im Winde [in the wind]" and up into his top voice at "Klirren die Fahnen [Rattles the Weather-vanes]" culminating on a high A-flat (See Example 6-28). 
Example 6-28, “Hälfte des Lebens," mm. 39-47. ${ }^{37}$
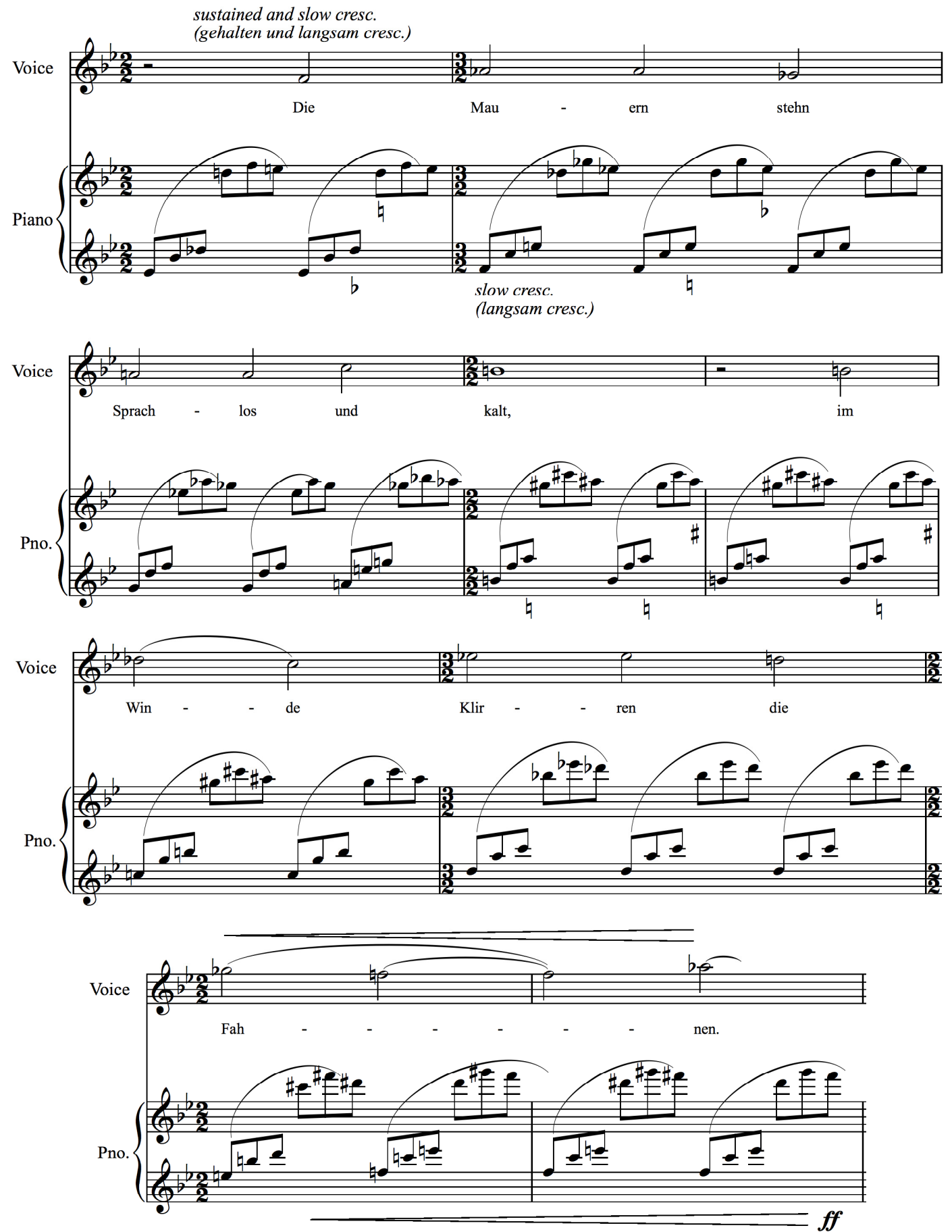

This steady climb allowed the singer to add intensity to his voice as the text acknowledges the loneliness in utter dismay. Due to its place in the cycle, immediately after the joyful setting of

\footnotetext{
${ }^{37}$ Ibid., 18-19.
} 
"Die Jugend" in which the poet relives some of the bliss he feels he no longer has, this dismay is tempered by the urgency of the love he feels.

The text expresses the inability of the narrator to have what others have: the beautiful things once thought available to him are no longer so. As a homosexual in Great Britain in the middle to late 1950s, it is likely that Britten was aware of what was not available to him, and what freedoms could be taken from his partner and himself. The sadness of the text could have also appealed to the couple, who had lost some of their homosexual friends during this period either to natural death or, in one instance, to suicide. Noel Mewton-Wood, the first performer of the revised version of Britten's Piano Concerto in 1946, was apparently unable to cope with the homophobia in his society, especially after the death of his partner, and ingested prussic acid in late 1953 at the age of $31 .^{38}$

\author{
Die Linien des Lebens \\ Die Linien des Lebens sind verschieden, \\ Wie Wege sind, \\ und wie der Berge Grenzen. \\ Was hier wir sind, \\ kann dort ein Gott ergänzen \\ Mit harmonien und ew'gem Lohn \\ und Frieden.
}

\section{Lines of Life}

The lines of life are varied,

As roads are, and as are the mountain's borders.

What we are here can there a God supplement

With harmonies and eternal reward and peace.

The final setting of the cycle, "Die Linien des Lebens," is the shortest poem of the six, in fact it is the shortest of any in the five cycles under discussion. Britten set the two verses, the second a variation of the first (the first is in minor and the second is in major), each beginning in the tenor's lower middle voice, slowly ascending up to an octave and a third away (G-flat above

\footnotetext{
${ }^{38}$ Carpenter, 365; Johnson, 221; and Cyrus Meher-Homji, "Noel Mewton-Wood," Grove Music Online. L. Macy, ed. [online]; available from http;//www.grovemusic.com; Internet: accessed 27 August 2005.
} 
middle $\mathrm{C}$ in the first verse, $\mathrm{G}$-natural above middle $\mathrm{C}$ in the second verse) and reaching a cadence on the E-flat just below it (See Example 6-29). 
(a.)

Example 6-29, “Die Linien des Lebens," (a.) mm. 6-9, (b.) 14-18. ${ }^{39}$

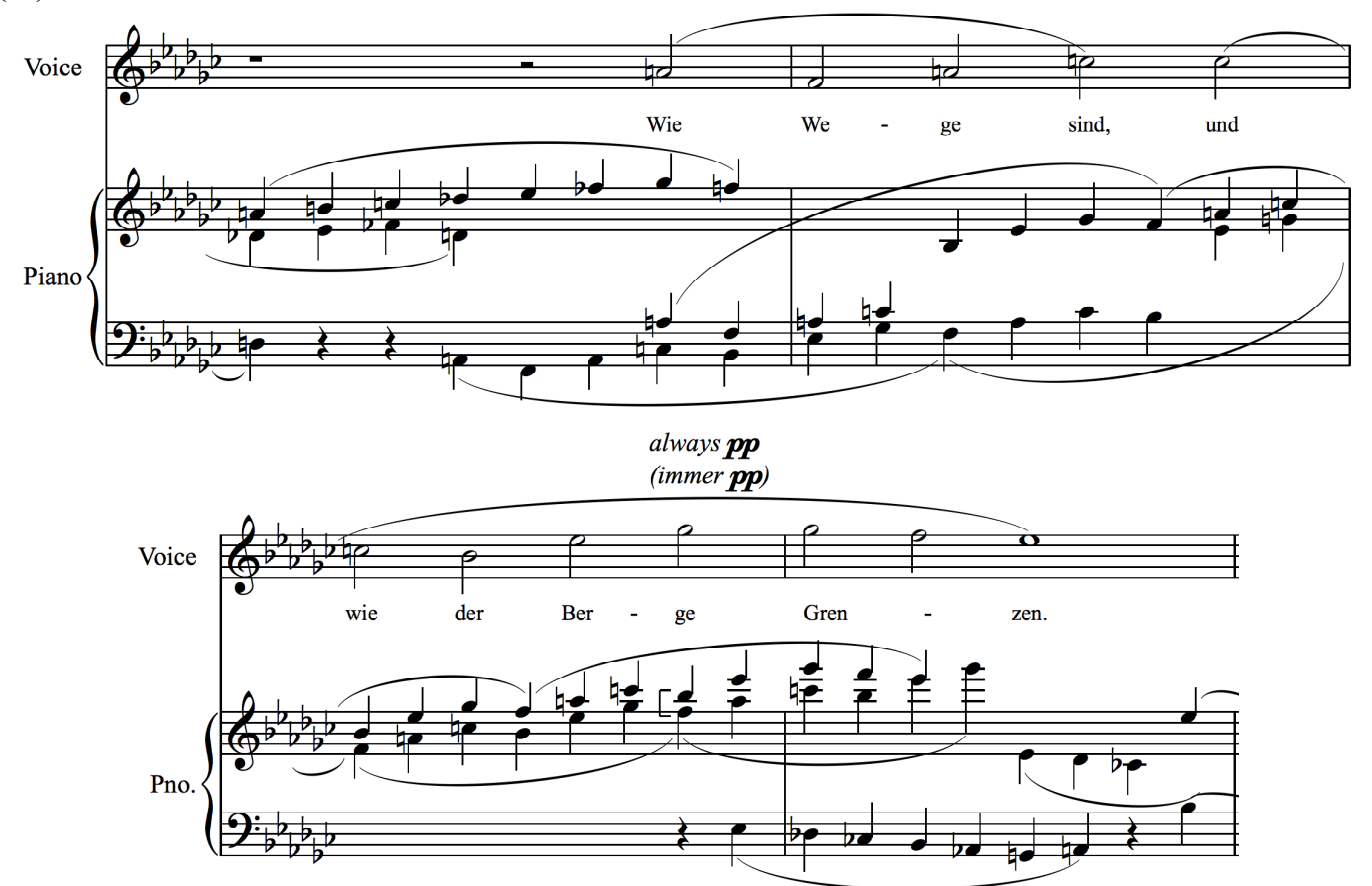

(b.)
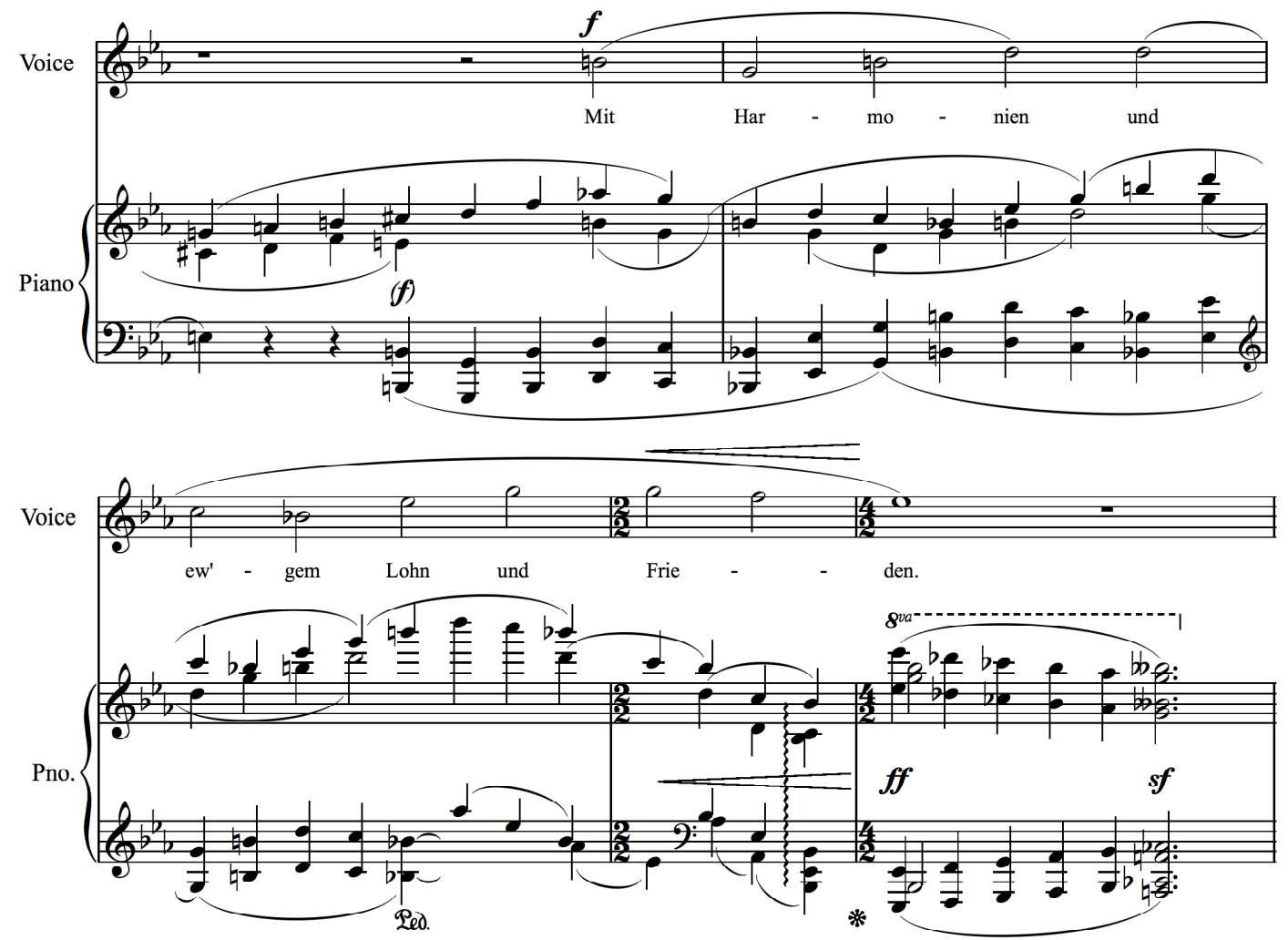

${ }^{39}$ Britten, Sechs Hölderlin-Fragmente, 20-21. 
The rise to the end of the phrase in both verses constitutes word painting of the text. The ascent depicts the height of the mountains in the first verse, to the text "und wie der Berge Grenzen [and as are the mountains' borders]" and the heavens implied by the text "und ew'gem Lohn und Frieden [and eternal reward and peace]," a hopeful and yearning statement about the afterlife, is expressed in the same way. The tempo of the piece is 66 quarter notes to the minute, and the phrases in this setting, consisting mostly of half notes, are very long at this tempo, taxing any singer's breath support, but the composer not only thought it was necessary for the expression of the meaning of this text, but also knew that his partner was more than capable of sustaining these long phrases (See Example 6-30). 
Example 6-30, "Die Linien des Lebens," (a.) mm. 2-5, (b.)10-13. ${ }^{40}$

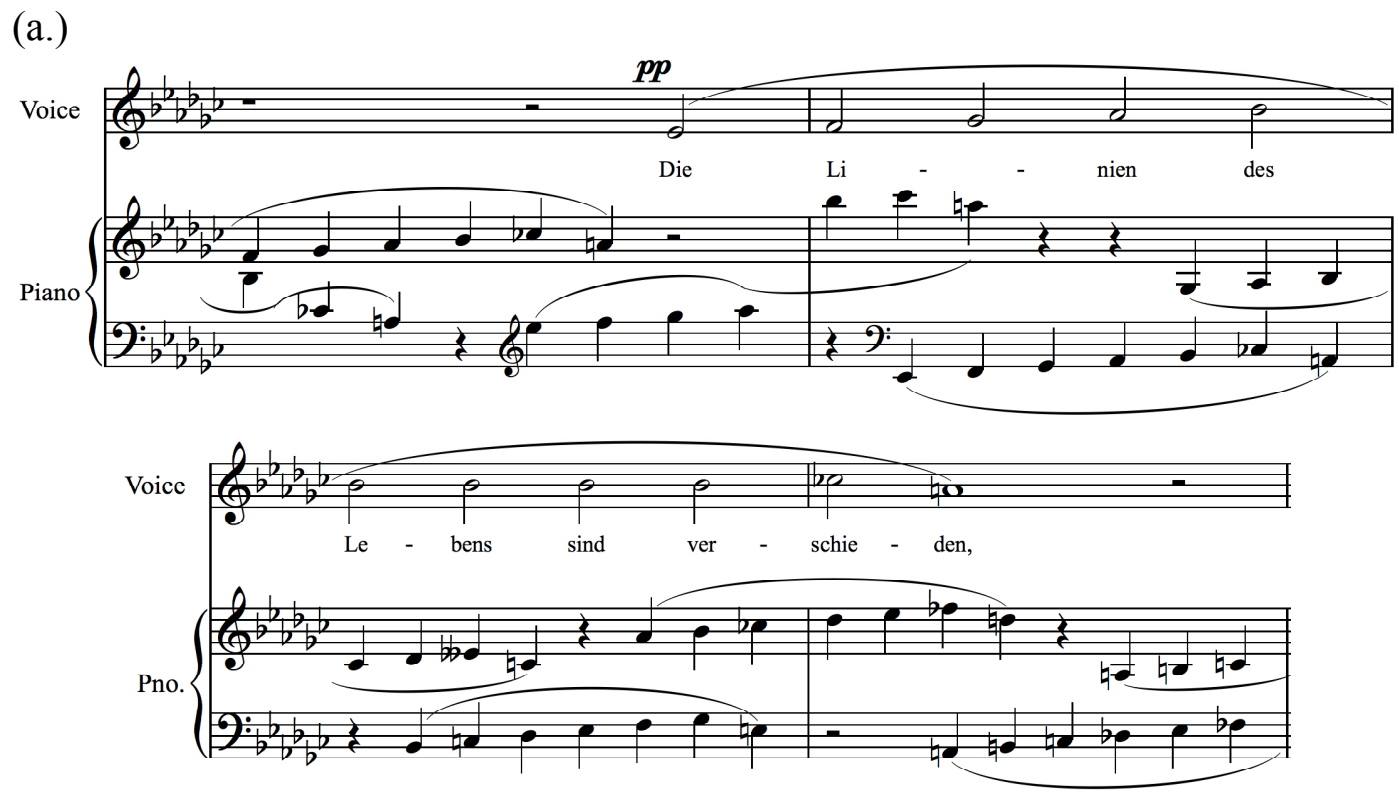

(b.)
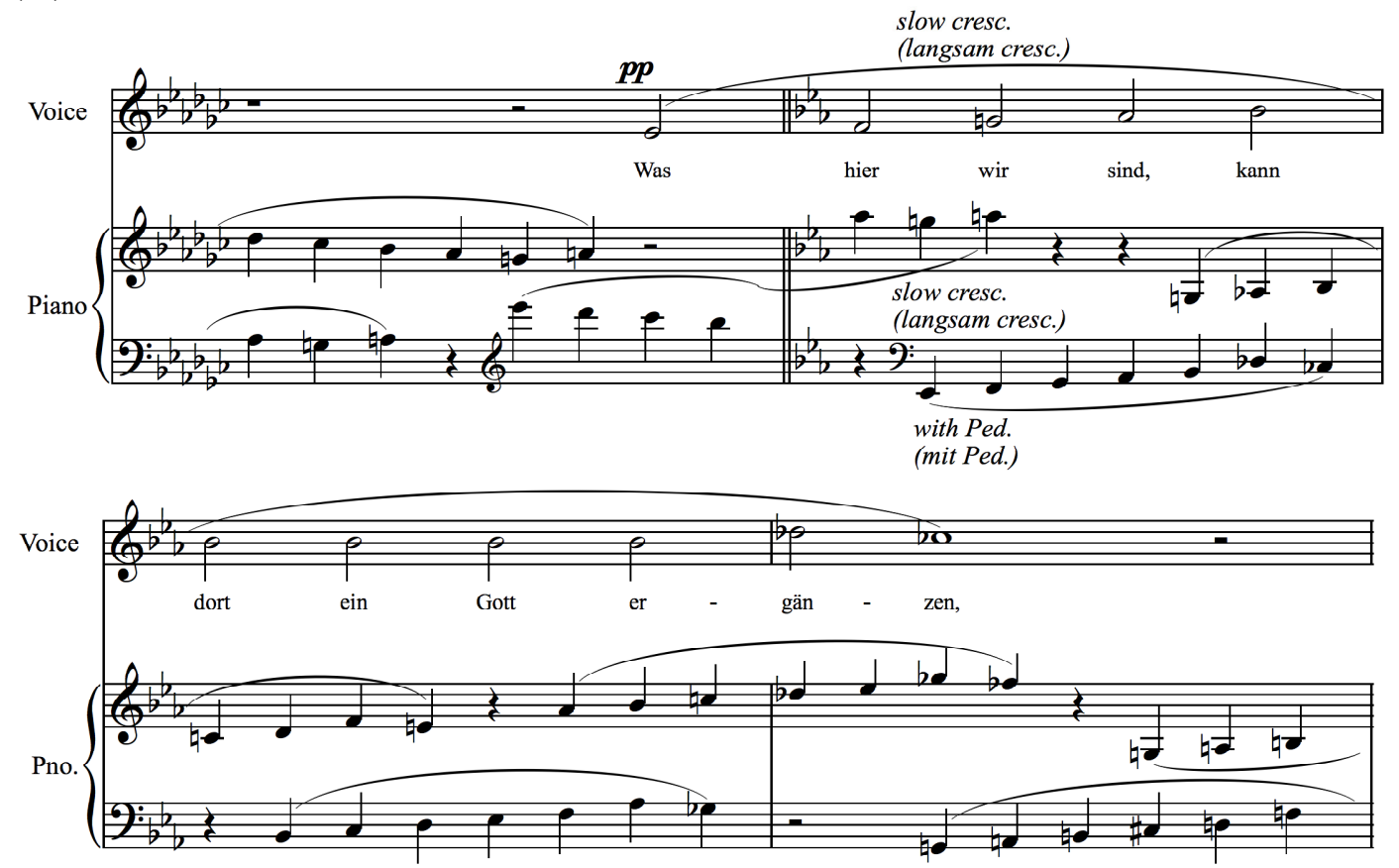

This poem promises reward to all despite the variety of different paths that each either chooses or is assigned in life. Britten, as a homosexual, would have been drawn to this kind of a statement

${ }^{40}$ Ibid., 20, 21. 
in the midst of his own turmoil, as a counterattack against those who vilified both him and all homosexual men. The setting of this poem is a powerful response to all the questions addressed in the cycle, and gives a sense of comfort and finality in its answer.

By the 1950s, both men had become very well-respected in their own fields. In the period between the composition of Winter Words and Sechs Hölderlin-Fragmente, they achieved success in Britten's The Turn of the Screw (1954), Nocturne (1958), and Songs from the Chinese (1958), the latter written for Pears and Julian Bream, guitarist. Despite his success, not only as a respected composer but as an accompanist and through his association to the Aldeburgh Festival, Britten continued to be very self-critical and to feel alienated from society. The political atmosphere in Great Britain was highly charged as the advocates of the findings of the Wolfenden Report fought against the more conservative government and its resistance to changing the laws regarding homosexuality. The law remained in place for nine more years. It is likely that for these reasons, as well as others unknown to us, the composer was inspired to set six of Hölderlin's poems for himself and his partner.

Britten again chose specific poems and arranged them to form a narrative from beginning to end. As in the preceding cycle, however, some of the poems function as an allegorical representation of the narrator's feelings (such as in "Sokrates und Alcibiades"). The choice of texts is reflective of experiences of the two homosexuals, alienated by members of their society and by their government. The compositional style of the cycle and its expectations for both performers is an indication of the level of artistry that the two men had reached at this point in their careers.

Britten carefully chose these six poems and arranged them in such a way that not only do they depict a psychological journey for the narrator, who comes to terms with his own feelings 
and those of society, but just as in Winter Words, the cycle is a mirror image of itself: the first and sixth settings are related, as are the second and fifth, as are the third and fourth. Compared to those of the previous work, these texts are both angrier and more intensely sorrowful.

Therefore the musical style is more energetic, reminiscent of his first two cycles with piano written for the tenor. 


\section{CHAPTER 7 \\ Who Are These Children?, opus 84 (1969)}

Over ten years passed between the composition of the Hölderlin cycle and that of Who Are These Children? Britten and Pears were quite busy during this time, of course, with their own separate careers and traveling with friends. In point of fact, Britten neither stopped writing for his partner, it was during this period that he created roles for the tenor in A Midsummer Night's Dream, opus 64 (1960) and War Requiem, opus 66 (1962), nor did he stop writing for voice and piano, composing Songs and Proverbs of William Blake, opus 74, for Dietrich FischerDieskau, and The Poet's Echo, opus 76, for Galina Vishnevskaya, both in 1965. It is likely, however, that since Britten was spending less time concertizing with the tenor and that he had written four cycles from which to choose for recitals with him when they did collaborate, he felt free to focus on other genres and performers.

Who Are These Children? is a setting of twelve poems by William Soutar (1898-1943), eight of which are children's rhymes in a Scottish dialect. The poet, like the composer and his partner, was a pacifist, and these poems had been written just before World War II. The contrast between the children's rhymes and the four poems about children, which are in English, is quite striking, and Britten took advantage of this in his setting of the poems. In point of fact, eleven of the twelve fit easily into three separate categories: three are lively folk-song like settings (Scottish), four are more lyrical folk-like settings akin to lullabies (Scottish), four are the English settings in a more modern style, and the remaining setting is an amalgamation of elements from the lyrical Scottish and English settings.

While the organization of the two previously discussed cycles is an arch form, this cycle is organized into two equal parts which are parallel in terms of subject material. It deals first with childhood and the loss of innocence from that perspective, and then adulthood and the loss of 
innocence from that perspective. As with the other cycles, the poems chosen by Britten were not intended by the poet to be part of a longer narrative, but the composer's ordering of the poems creates one.

The poems are organized into two parallel halves, each beginning with a riddle, the answer to which denotes the perspective of that half. A poem that describes the innocence of children is the second poem in each half, again reflecting the perspective of first a child then of an adult. The third poem in each half describes the initial wounding of innocents. The fourth is a poem about interaction between children and adults including further physical or emotional trauma to the children. The fifth poem of each half describes the end of the day as the child lies down to sleep, and is followed in the sixth by a poem about death (See Table 7-1).

Table 7-1: Organization of Poems as a Cycle

\begin{tabular}{|c|c|c|c|c|c|c|c|c|}
\hline & First Half & & & & Second Half & & & \\
\hline Theme & Title & Subject & Language & Affect & Title & Subject & Language & Affect \\
\hline Beginning & $\begin{array}{c}\text { A Riddle } \\
\text { (The Earth) }\end{array}$ & Childhood & Scottish & Quick & $\begin{array}{c}\text { A Riddle (The } \\
\text { Child You Were) }\end{array}$ & Adulthood & Scottish & Lullaby \\
\hline Youth & $\begin{array}{c}\text { A Laddie's } \\
\text { Sang }\end{array}$ & $\begin{array}{c}\text { Innocent, } \\
\text { Beautiful }\end{array}$ & Scottish & Lullaby & The Larky Lad & Rude, Ugly & Scottish & Quick \\
\hline Wounding & Nightmare & Of Nature & English & Serious & $\begin{array}{c}\text { Who Are These } \\
\text { Children? }\end{array}$ & $\begin{array}{c}\text { Of } \\
\text { Children }\end{array}$ & English & Serious \\
\hline $\begin{array}{c}\text { Adults vs. } \\
\text { Children }\end{array}$ & Black Day & $\begin{array}{c}\text { Child's } \\
\text { Perspective }\end{array}$ & Scottish & Quick & Supper & $\begin{array}{c}\text { Adult's } \\
\text { Perspective }\end{array}$ & Scottish & Lullaby \\
\hline $\begin{array}{c}\text { Child's } \\
\text { End }\end{array}$ & Bed-time & Night & Scottish & Lullaby & The Children & Death & English & Serious \\
\hline Death & Slaughter & $\begin{array}{c}\text { End of } \\
\text { Childhood }\end{array}$ & English & Serious & The Auld Aik & End of Life & Scottish & $\begin{array}{c}\text { Serious } \\
\text { (Amalgam) }\end{array}$ \\
\hline
\end{tabular}

The first riddle introduces the idea of the earth, and also serves as a metaphor for the beginning of life. The poem is all-encompassing, showing the diversity of the world. The second poem focuses upon the purity and innocence of nature, again a metaphor for childhood and its inherent innocence. The third sets nature against man, with the innocent trees being harmed, although not yet killed, by man, and is once again a metaphor for the harm to children 
by adults. The fourth setting is no longer metaphorical, speaking directly about the wounding of children by adults in the name of right. The fifth setting is a lullaby, referring to nature but addressed to a child falling asleep. The sixth poem deals with death, but the reference to "the phantoms of the dead," implies that the death is more an ending of a period of time than the actual end of life.

The second riddle, the seventh song, opens the second half of the cycle, confirming that the death at the end of the first half is that of childhood, and as the first riddle concerned the beginning of childhood, this riddle speaks of the end of childhood and the beginning of adulthood. As the first half of the cycle takes the perspective of the child, this second half adopts the perspective of the adult, and so the eighth setting looks back at the innocence of youth, as the second setting did, but this time casts the youth as disrespectful, rude, and in need of discipline. The ninth setting, the third poem of this half, concerns the wounding of children through the ignorance of adults, who seem more focused on conquest, war, and material gain. The tenth poem set of the cycle provides a self-righteous, hypocritical view of adults: they know what is good for children and that justifies what they do. The penultimate setting parallels the fifth since it occurs at the end of the day, but in this case, because of the adults who mistreat them, the children are lying in the streets instead of bed. The twelfth setting describes a death, this time a physical one, returning to the metaphorical use of nature to represent the eternal innocence of youth. Based on what we know about the times in which the composer lived and his own experiences as a young homosexual growing up in a homophobic society, a plausible interpretation of the cycle is that the boy is Britten, or at least a young homosexual under oppressive circumstances, experiencing the discrimination of the society in which he grew up. 
The overall vocal range of this cycle is not much different from those which were composed earlier: it extends from B-natural a minor ninth below middle $\mathrm{C}$ to the A-flat above it, but the tessitura throughout is lower. The tenor was approaching sixty at this point and, as often happens with age, his comfortable range had dropped slightly and his voice had gained a little bit of weight. Britten used this to his advantage, especially in the English poems, which have a deeper emotional quality. All eight settings of the children's rhymes bear a striking resemblance to Britten's folk-song arrangements, especially in the relationship of the accompaniment to the vocal line. Britten's accompaniments in his folk-song arrangements are not "traditional" harmonizations of the melodies but use dissonances and tonalities other than that implied by the melody to help set the mood of the piece (See Example 7-1). 
Example 7-1, “The Ash Grove,” (a.) mm. 40-44, (b.) 50-54 ${ }^{1}$

(a.)
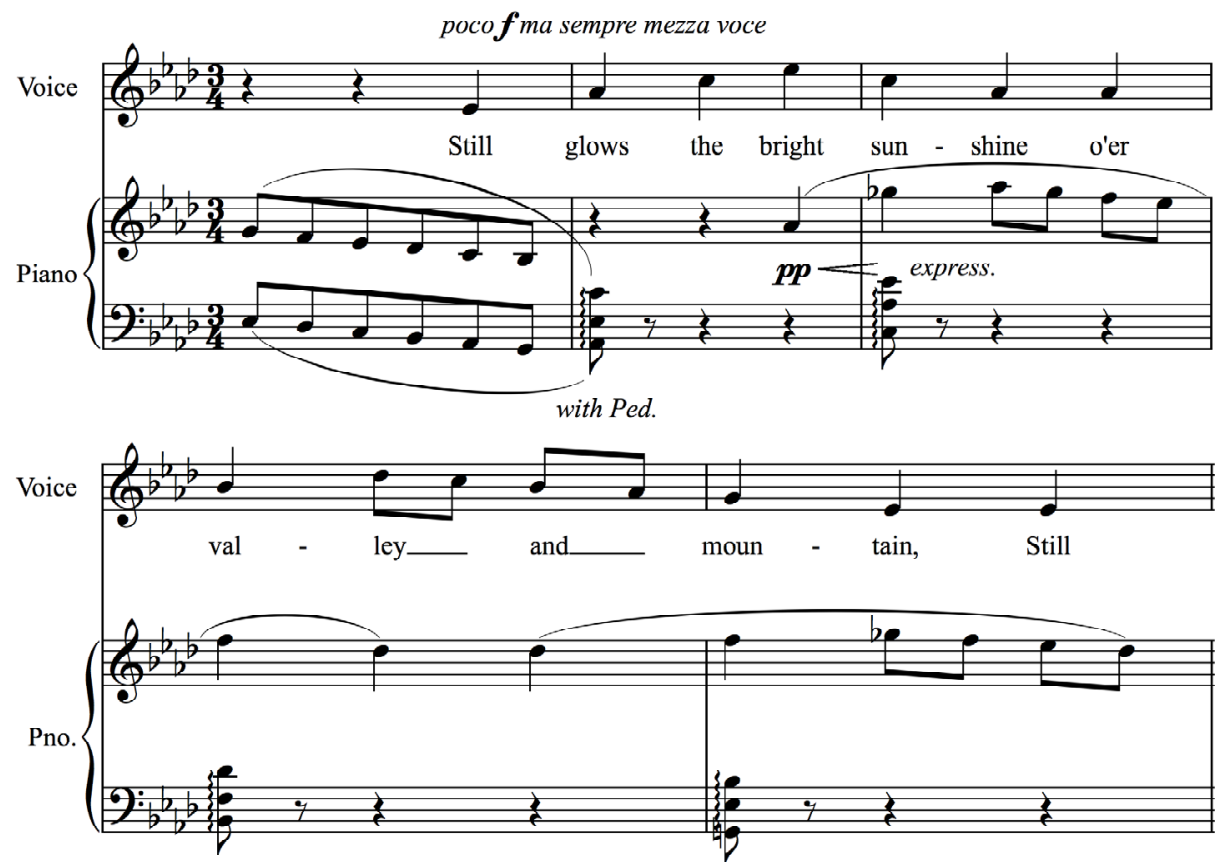

(b.)
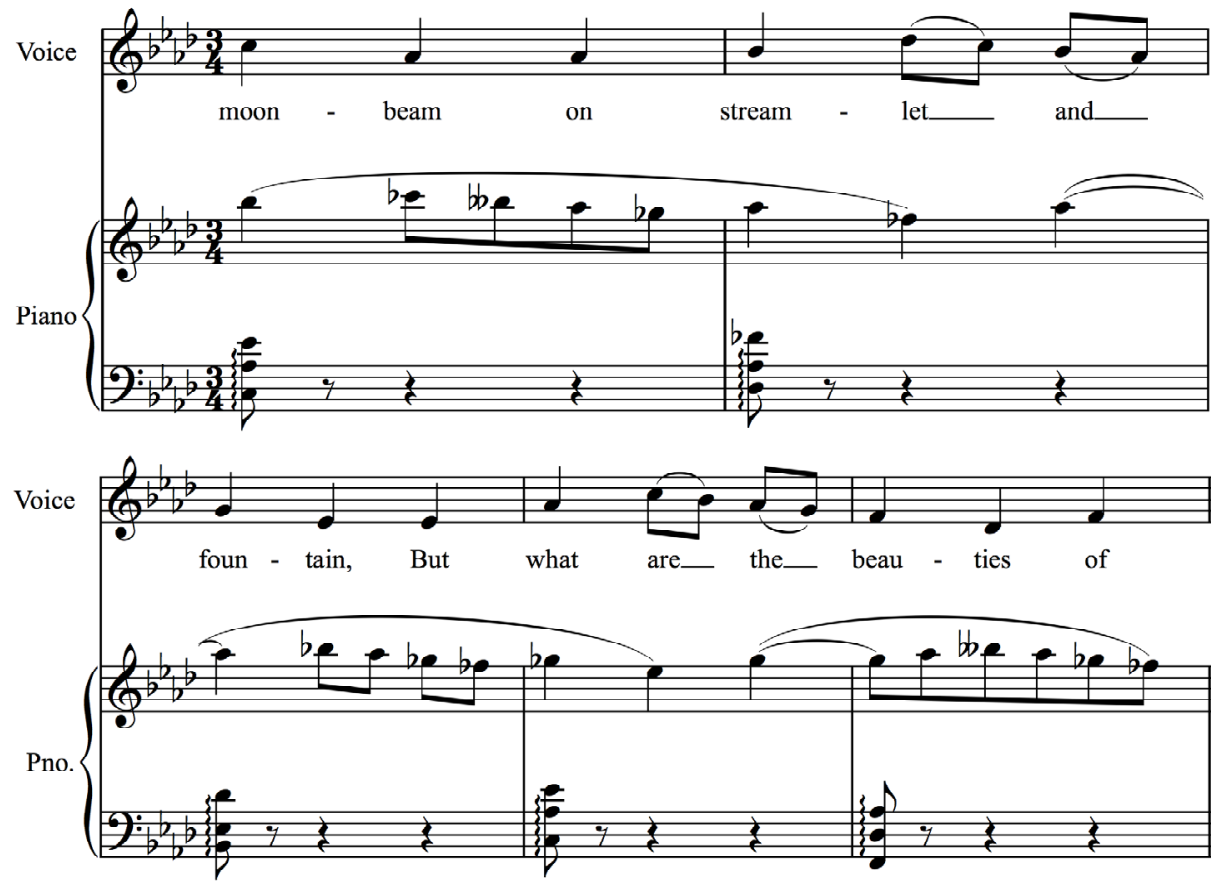

${ }^{1}$ Benjamin Britten, arranger, Folksong Arrangements, Volume 1: British Isles (London: Boosey \& Hawkes, 1943), 17, 18. Examples from "The Ash Grove" reproduced with kind permission of Boosey \& Hawkes, Inc. 
This is also true in most of these eight settings ("The Auld Aik" being a special exception). The melodies of these eight can not necessarily be considered akin to those of folk songs - there are often unusual melodic skips that one would not expect to find in a folk song - but the use of rhythmic and melodic ideas within the melodies give the effect of a folk tune.

The lively settings of the children's rhymes include the first, fourth, and eighth of the cycle, “A Riddle (The Earth)," "Black Day,” and "The Larky Lad." The accompaniments of "A Riddle (The Earth)" and "The Larky Lad" double the melodic line, which helps give the effect of the folk song because typically the treatment of a folk song does include a doubled melodic line in the accompaniment. As in Winter Words, these songs are not particularly remarkable in the way that the voice is used, other than the fact that the vocal line is meant to sound like that of a folk song. The more lyrical settings of the Scottish poems are the second, fifth, seventh, and tenth: "A Laddie's Sang," "Bed-Time," "Riddle (The Child You Were)," and "Supper." Again, these are meant to be folk-like in style, so the use of the voice is more limited than would be the case in a freer style of music. The English settings of the cycle are free in terms of tonality and discernable melody, as well as the use of some complex rhythms. In this way, the composer was able to write very dramatic sounding music, drawing attention to the text, allowing for his partner to be expressive in his performance of it. The tenor was well-respected for his acting and for his ability to put great emotional commitment in his interpretation of the sung word, and so it is not surprising that Britten should continue to find ways for his partner to do so, without being constrained by the music. 


\section{(1.) A Riddle (The Earth) \\ There's pairt o' it young \\ And pairt o' it auld: \\ There's pairt o' it het \\ And pairt o' it cauld: \\ There's pairt o' it bare \\ And pairt o' it claid: \\ There's pairt o' it quick \\ And pairt o' it dead.}

In the first setting of this cycle, "A Riddle (The Earth)," there is a youthfulness as well as a reference to nature expressed in the prelude: its rhythms evoke thoughts of a galloping horse. The vocal line, a very simple-sounding melody, is doubled throughout in the accompaniment, furthering the idea that this is in fact a folk song. In this fairly short setting, only 48 measures, there are numerous examples of Britten using a simple melodic line in an expressive way. "Young," "Het” (Hot), "Bare” and "Quick," words which indicate youth, energy, and freedom, are set on higher pitches (See Example 7-2). 
Example 7-2, “A Riddle (The Earth)," (a.) mm. 12, (b.) 16, (c.) 31, (d.) $35^{2}$

(a.)

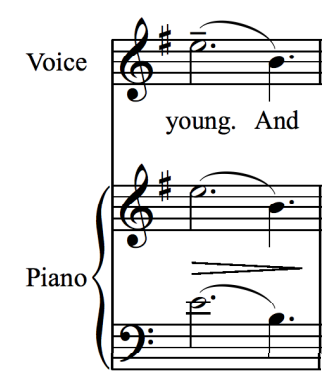

(c.)

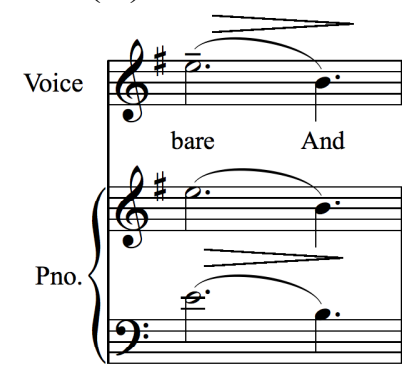

(b.)

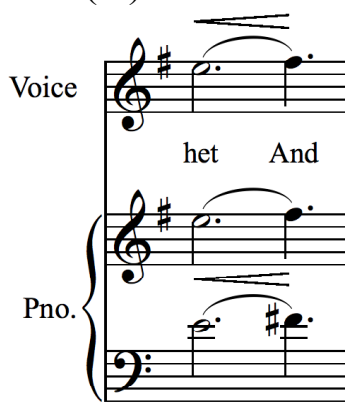

(d.)

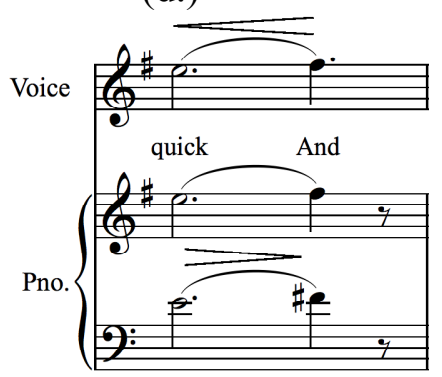

In contrast, “Auld” (Old), "Cauld" (Cold), "Claid" (Clad) and "Dead," words of old age,

lethargy, and constraint, are set on C below middle C, (See Example 7-3).

${ }^{2}$ Benjamin Britten, Who Are These Children?, opus 84 (London: Faber Music Ltd., 1972), 2-3. Examples from “A Riddle (The Earth)" reproduced with kind permission of Faber Music Ltd, London. 
Example 7-3, “A Riddle (The Earth),” (a.) mm. 14, (b.) 18, (c.) 33, (d.) $37 .^{3}$

(a.)

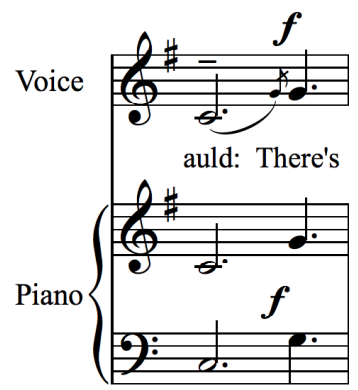

(c.)

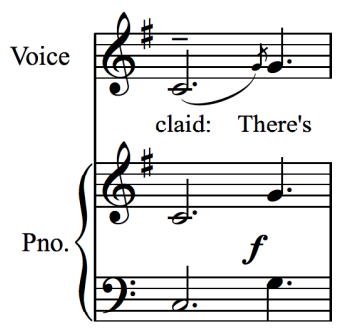

(b.)

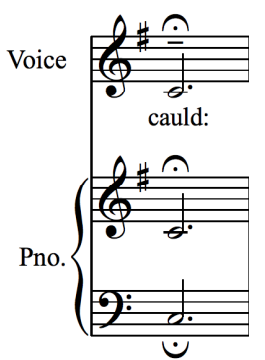

(d.)

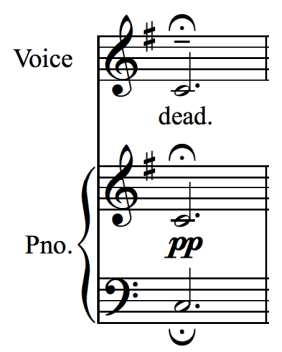

The composer's setting of this poem using folk-song characteristics helps to reflect his own sympathy for nature and youth because of its almost carefree simplicity.

\section{(2.) A Laddie's Sang}

O! it's owre the brases abüne our toun

Whan the simmer days come in'

Whaur the blue-bells grow, and the burnies row, And gowdan ${ }^{4}$ is the whin. ${ }^{5}$

The gowk ${ }^{6}$ sings frae the birken-schaw, ${ }^{7}$

And the laverock far aboon:

The bees bummer by, the peesies ${ }^{8}$ cry, And the lauchin linn ${ }^{9}$ lowps ${ }^{10}$ doun.

${ }^{3}$ Ibid., 2-3.

${ }_{5}^{4}$ golden (All translations provided are those found in the published score of Who Are These Children?)

${ }^{5}$ furze

${ }^{6}$ cuckoo

${ }^{7}$ birch copse

${ }^{8}$ peewits

9 waterfall

${ }^{10}$ leaps 
The tessitura of the first of the lyrical settings of the Scottish poems, "A Laddie's Sang," is the highest of this type in the cycle, no doubt to express the idea of the birds referenced in the text (See Example 7-4).

(a.)

Example 7-4, “A Laddie's Sang,” (a.) mm. 1-2, (b.) 5-6, (c.) 9-10. ${ }^{11}$

(b.)
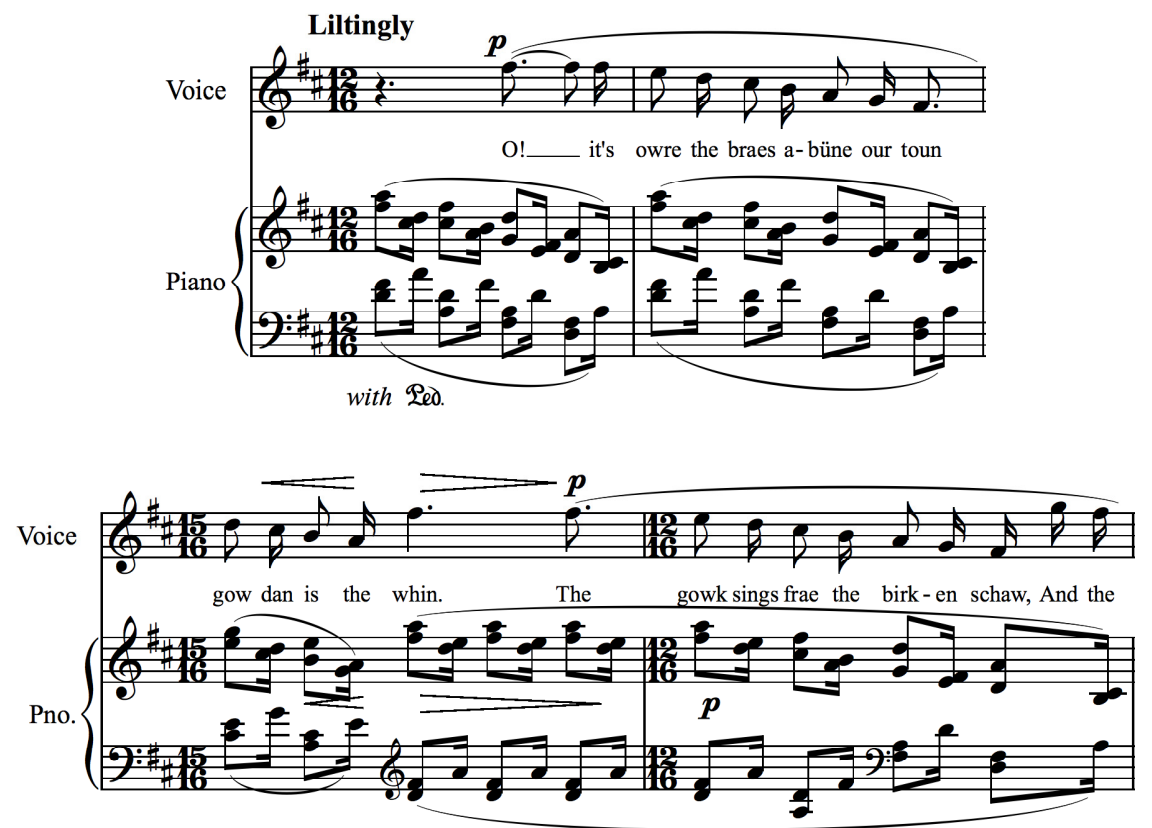

(c.)

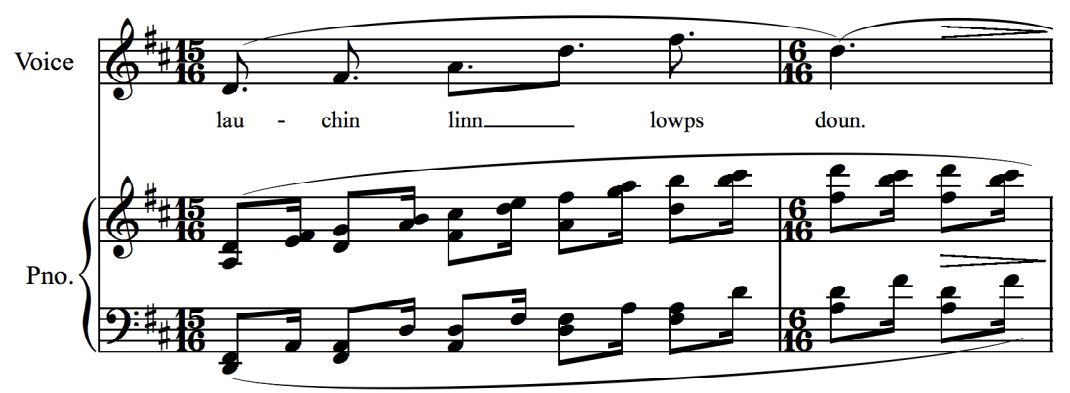

The higher range also allowed Pears to sing with a light tone, almost crooning, which added the effect of a lullaby. The setting contrasts with the previous one stylistically, but the unification of the language, as well as the theme, helps to maintain the sympathetic feelings towards nature and

\footnotetext{
${ }^{11}$ Britten, Who Are These Children?, 4. Examples from "A Laddie's Sang" reproduced with kind permission of Faber Music Ltd, London.
} 
towards children. It also provides greater contrast with the setting that follows, "A Nightmare," the first of the English poems.

The texts of the first two settings of the cycle seem to have been chosen by Britten to create the idea of an idyllic childhood, much like the one that he had. ${ }^{12}$ In this way, it is possible to suppose that Britten intends for the boy represented in the story to be a representation of his self because this is a child exposed to unjustified criticism and condemnation of his own nature. Whether this is true or not, it is not difficult to imagine as the cycle unfolds that the boy is a young homosexual.

\section{(3.) Nightmare}

The tree stood flowering in a dream: Beside the tree a dark shape bowed: As lightning glittered the axe-gleam Across the wound in the broken wood.

The tree cried out with human cries: Form its deepening hurt the blood ran: The branches flowered with children's eyes And the dark murderer was a man.

There came a fear which sighed aloud; And with its fear the dream-world woke:

Yet in the day the tree still stood Bleeding beneath the axe-man's stroke.

The third song of the cycle, "The Nightmare," the first of the settings of the poems in English, alternates between a slightly more lyric melody with a higher tessitura for the music of the tree, and a slower, lower-lying melody for the music of the man who would cut the tree down. The sections about the tree have an absence of the sense of a regular pulse, as the

\footnotetext{
${ }^{12}$ Humphrey Carpenter, Benjamin Britten: A Biography (New York: Macmillan Publishing Company, 1992), 6-9.
} 
accompaniment repeats a melody two octaves higher and faster than the vocal line which enters during the second repetition of this pattern (See Example 7-5).

$$
\text { Example 7-5, "Nightmare,” m. 1. }{ }^{13}
$$
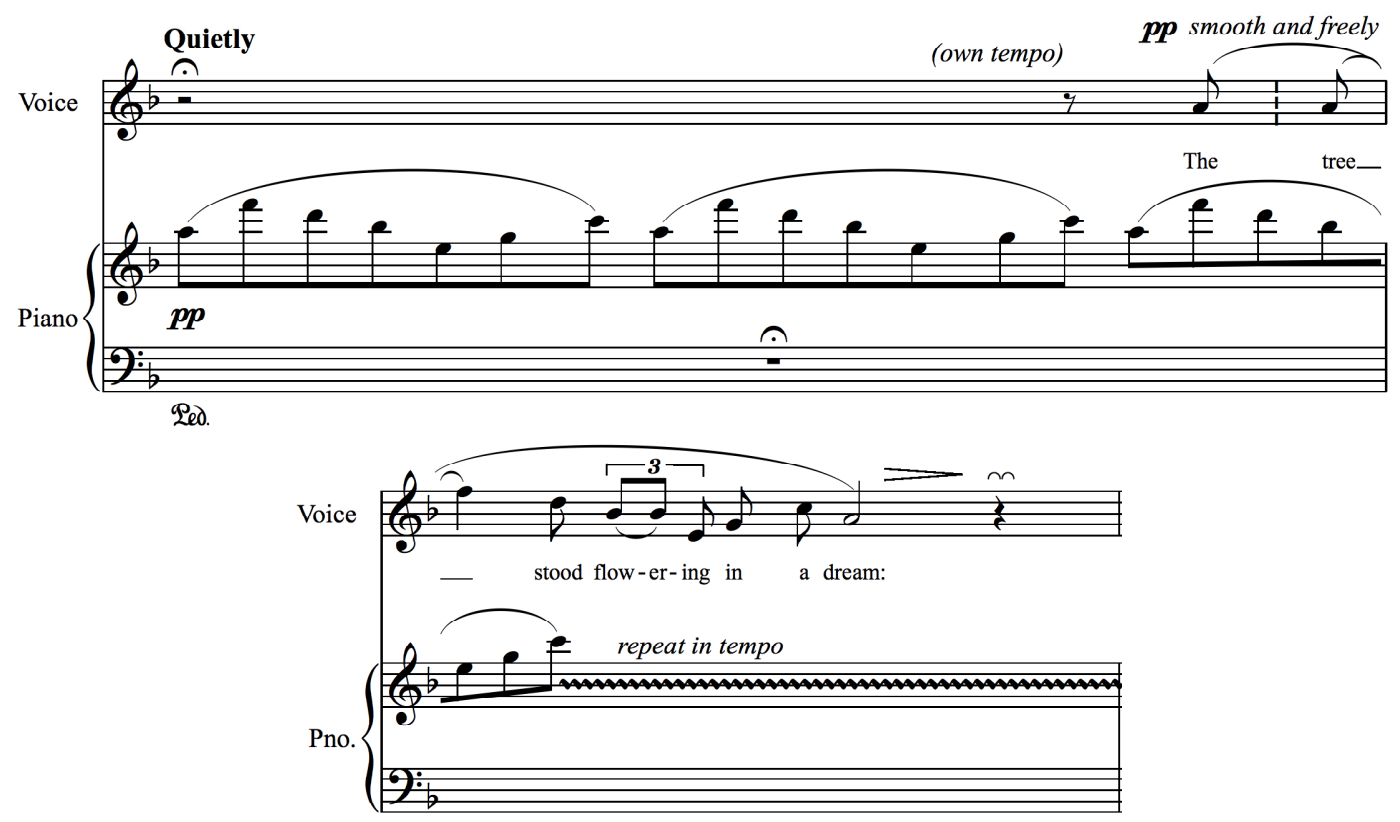

The contrasting sections about the evil "axe-man" continue the ostinato in the right hand of the accompaniment, but the vocal line and accompaniment in these sections are in the same tempo, accented by the heavy chords in the left hand of the piano which double the rhythm of the vocal melody (See Example 7-6).

\footnotetext{
${ }^{13}$ Britten, Who Are These Children?, 5. Examples from "Nightmare" reproduced with kind permission of Faber
} Music Ltd, London. 
Example 7-6, "Nightmare,” mm. 2-7/1. ${ }^{14}$

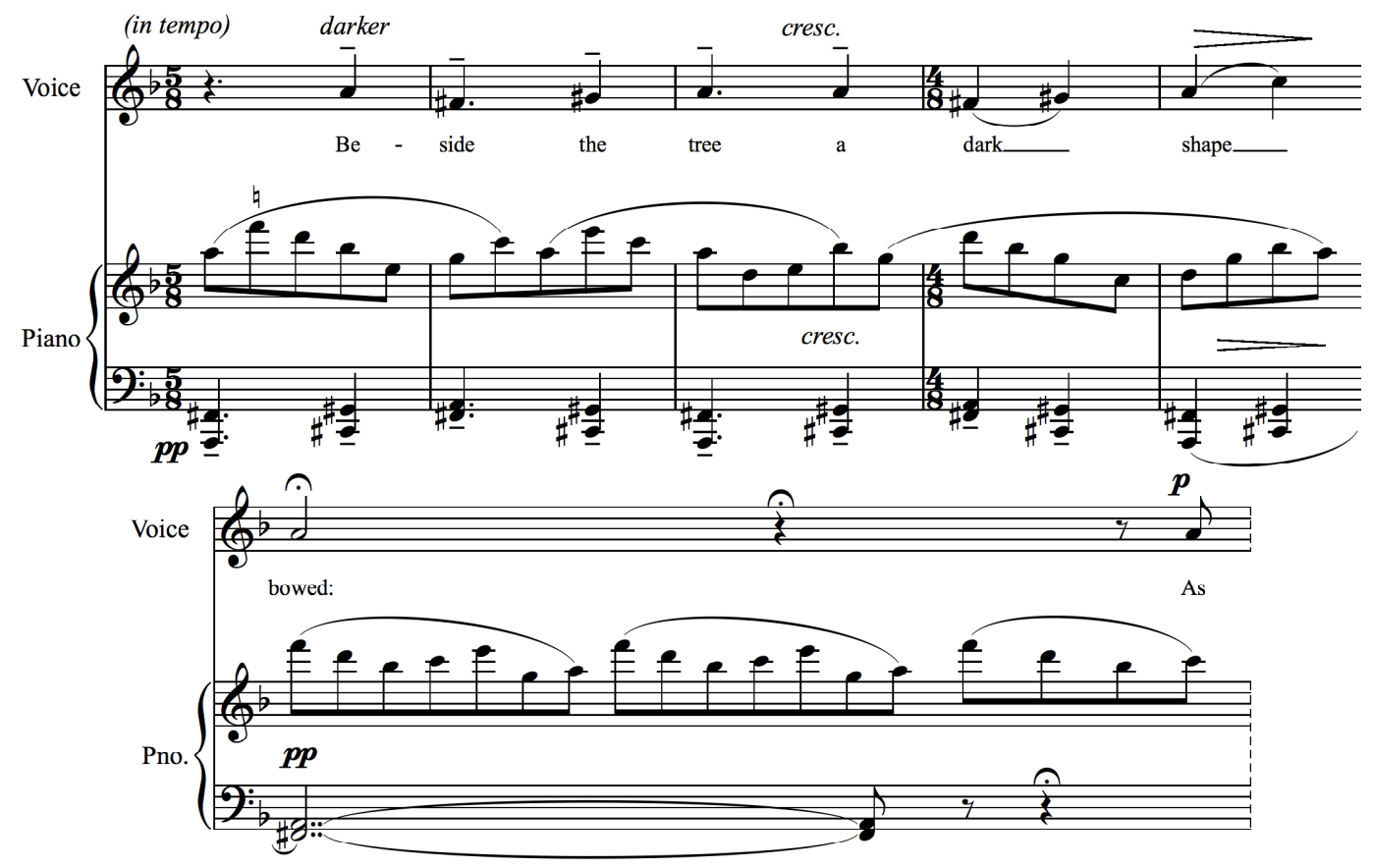

The tessitura allowed Pears the luxury of a lighter tone for the tree, which "cried out with human cries" (See Example 7-7) and has branches that are "flowered with children's eyes" (See Example 7-8), and a heavier, more ominous tone for the "dark murderer" (See Example 7-9). Example 7-7, “Nightmare," m. 12. ${ }^{15}$

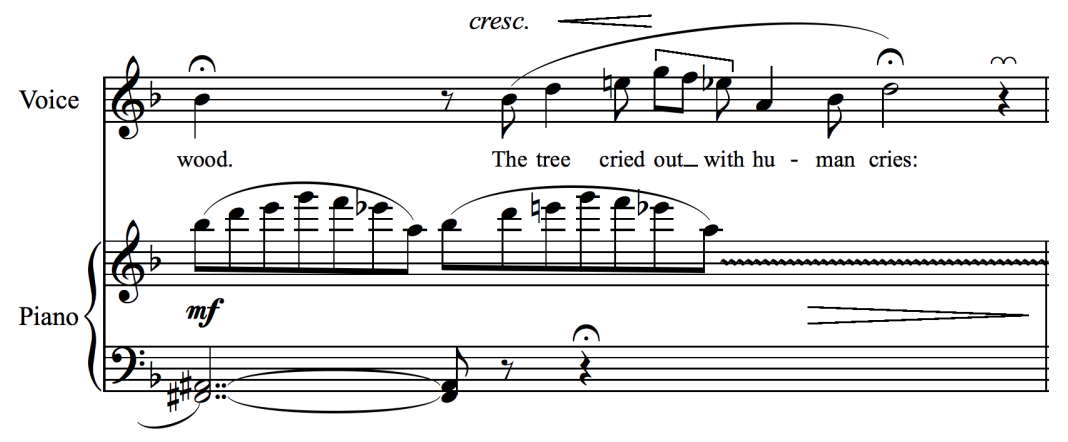

${ }^{14}$ Ibid., 5 .

${ }^{15}$ Ibid., 6 . 
Example 7-8, "Nightmare," m. 17. ${ }^{16}$

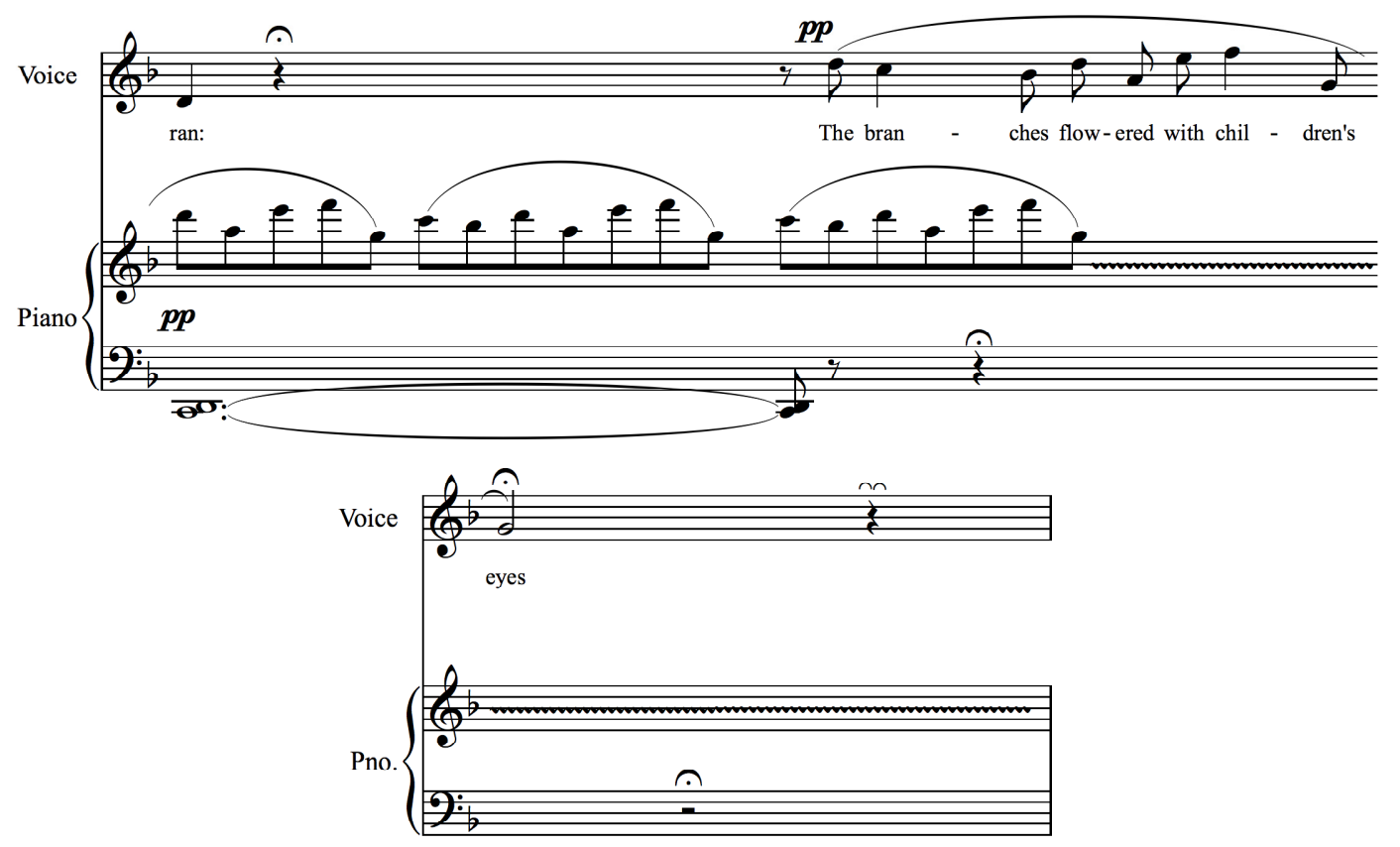

Example 7-9, “Nightmare,” mm. 18-20. ${ }^{17}$

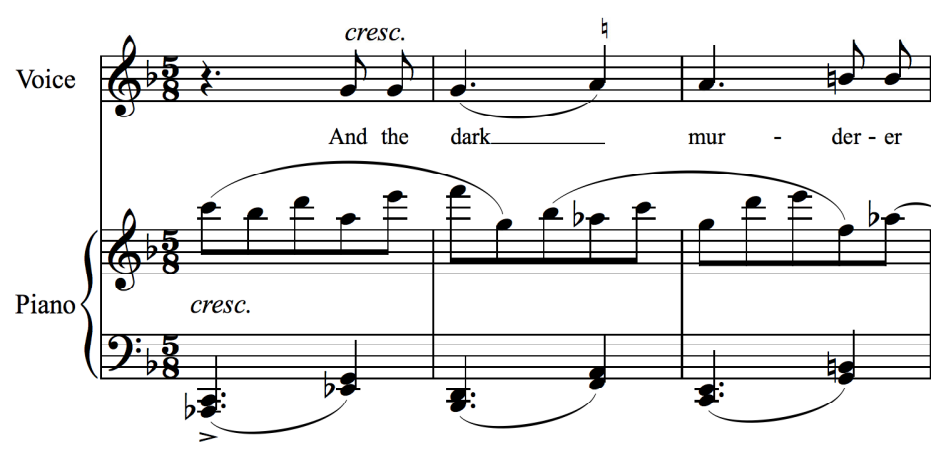

The man in this poem is doing wrong to that which is natural. Britten, in his arrangement of the texts of the cycle, has introduced two different ideas of nature: in the first text it was nature itself, and in the second it was a young boy who may represent Britten. To Britten,

${ }^{16}$ Ibid., 6 .

${ }^{17}$ Ibid., 6. 
homosexuality was natural, and is quite possibly using this poem to represent the wounds that his society inflicted upon gay men.

\section{(4.) Black Day}

A skelp ${ }^{18}$ frae his teacher For a' he cudna spell:

A skelp frae his mither For cowpin owre the kail. ${ }^{19}$

A skelp frae his brither For clourin ${ }^{20}$ his braw bat: And a skelp frae his faither For the Lord kens what.

The fourth setting of the cycle, "Black Day," is another of the lively folk-like settings.

Like that of the first, its accompaniment doubles the melodic line, helping to give it the effect of a folk song. The character of this setting is darker than the previous two Scottish settings, especially in the word painting on the beatings ("skelps") the boy receives, all set as descending tritones (See Example 7-10).

\footnotetext{
${ }^{18}$ smack

${ }^{19}$ spilling the broth

${ }^{20}$ bashing
} 
Example 7-10, “Black Day,” (a.) mm. 2, (b.) 6, (c.) 10, (d.) $14 .{ }^{21}$

(a.)

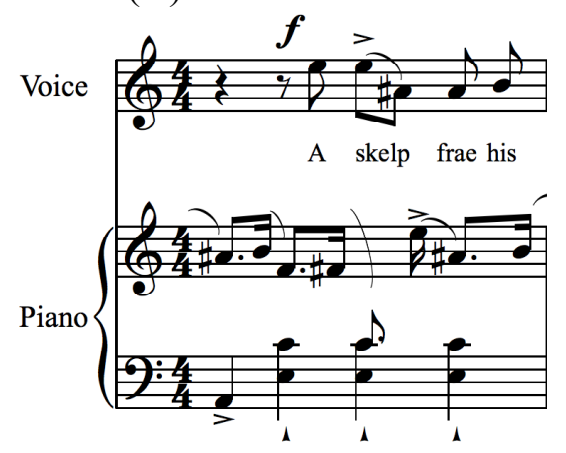

(c.)

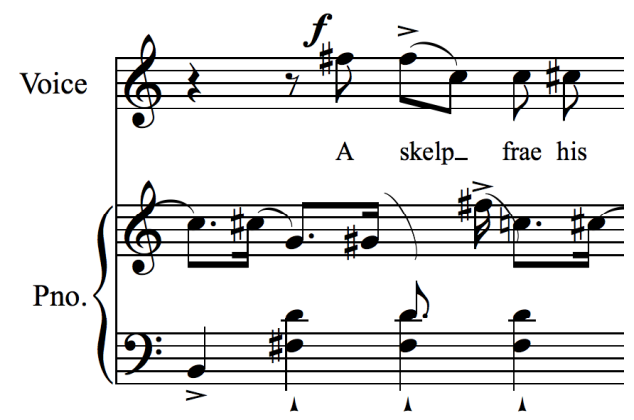

(b.)

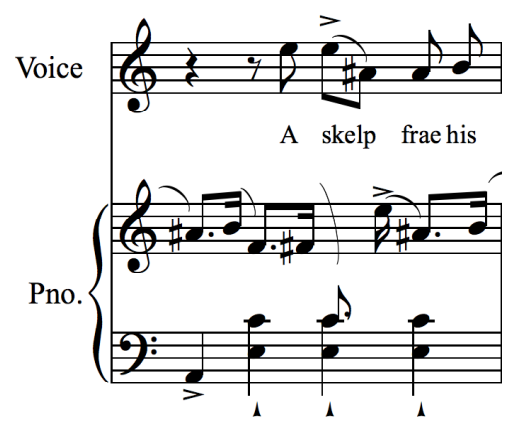

(d.)

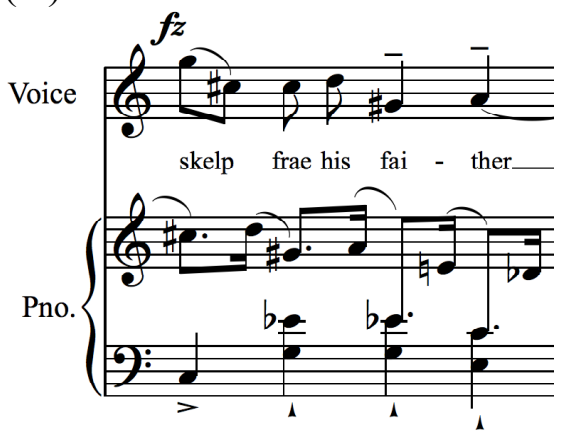

This darker quality is an effect of the setting that preceded it, with its images of violence and pain.

The sympathy that was established in the first two settings for that which is natural (especially the boy in "A Laddie's Sang") is intensified in this setting by the poor boy who does not necessarily understand what he has done to deserve so much punishment. Again, if the boy is thought of as Britten, or as a young homosexual, this would represent a coming of age and realization that what he believes to be normal is actually vilified by the society in which he lives, and that vilification will cause him pain and hardship.

\footnotetext{
${ }^{21}$ Britten, Who Are These Children?, 8-9. Examples from "Black Day" reproduced with kind permission of Faber Music Ltd, London.
} 


\section{(5.) Bed-time}

Cuddle-doun, my bairnie;

The dargie day ${ }^{22}$ is düne:

Yon's a siller sternie

Ablow the siller müne:

Like a wabster body ${ }^{23}$

Hingin on a threed,

Far abüne my laddie

And his wee creepie-bed.

Again, a lively Scottish setting is followed by a more sedate, lyric setting. "Bed-Time," a lullaby, begins somewhat low, but ascends to the top of the staff as the singer describes to the little boy the moon and a spider on its web (See Example 7-11).

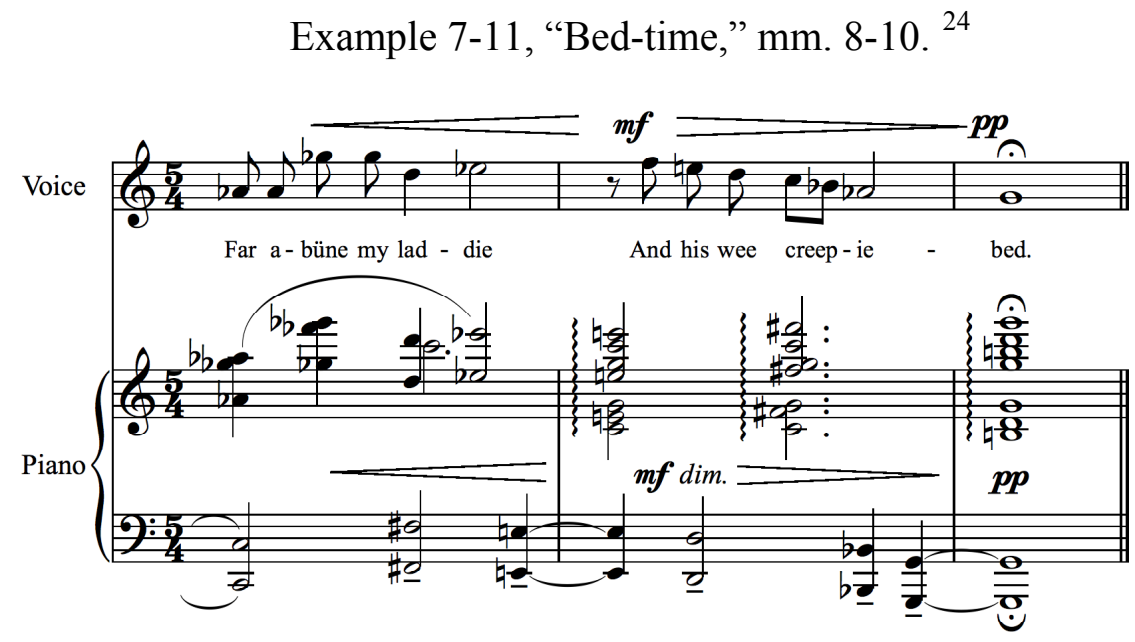

On its own, this setting is fairly serene, but by its placement in the cycle Britten seemed to acknowledge the boy's exhaustion and confusion about his treatment by society, as well as to foreshadow a darker, more sinister end to the day.

\footnotetext{
22 working day

23 spider

${ }^{24}$ Britten, Who Are These Children?, 10. Examples from "Bed-time" reproduced with kind permission of Faber Music Ltd, London.
} 


\section{(6.) Slaughter}

Within the violence of the storm

The wise men are made dumb:

Young bones are hollowed by the worm:

The babe dies in the womb.

Above the lover's mouth is pressed

The silence of a stone:

Death rides upon an iron beast

And tramples cities down.

And shall the multitudinous grave

Our enmity inter;

These dungeons of misrule enslave

Our bitterness and fear?

All are the conquered; and in vain

The laurel binds the brow:

The phantoms of the dead remain

And from our faces show.

The sixth setting, "Slaughter," has a similar accompaniment figure to that of "Thou Hast

Made Me" from the John Donne sonnets, especially in terms of the frantic energy, while the vocal line is more controlled (See Example 7-12). 
Example 7-12, (a.) “Thou Hast Made Me," mm. 1-9, ${ }^{25}$ (b.) "Slaughter," mm. 1-6. ${ }^{26}$

(a.)
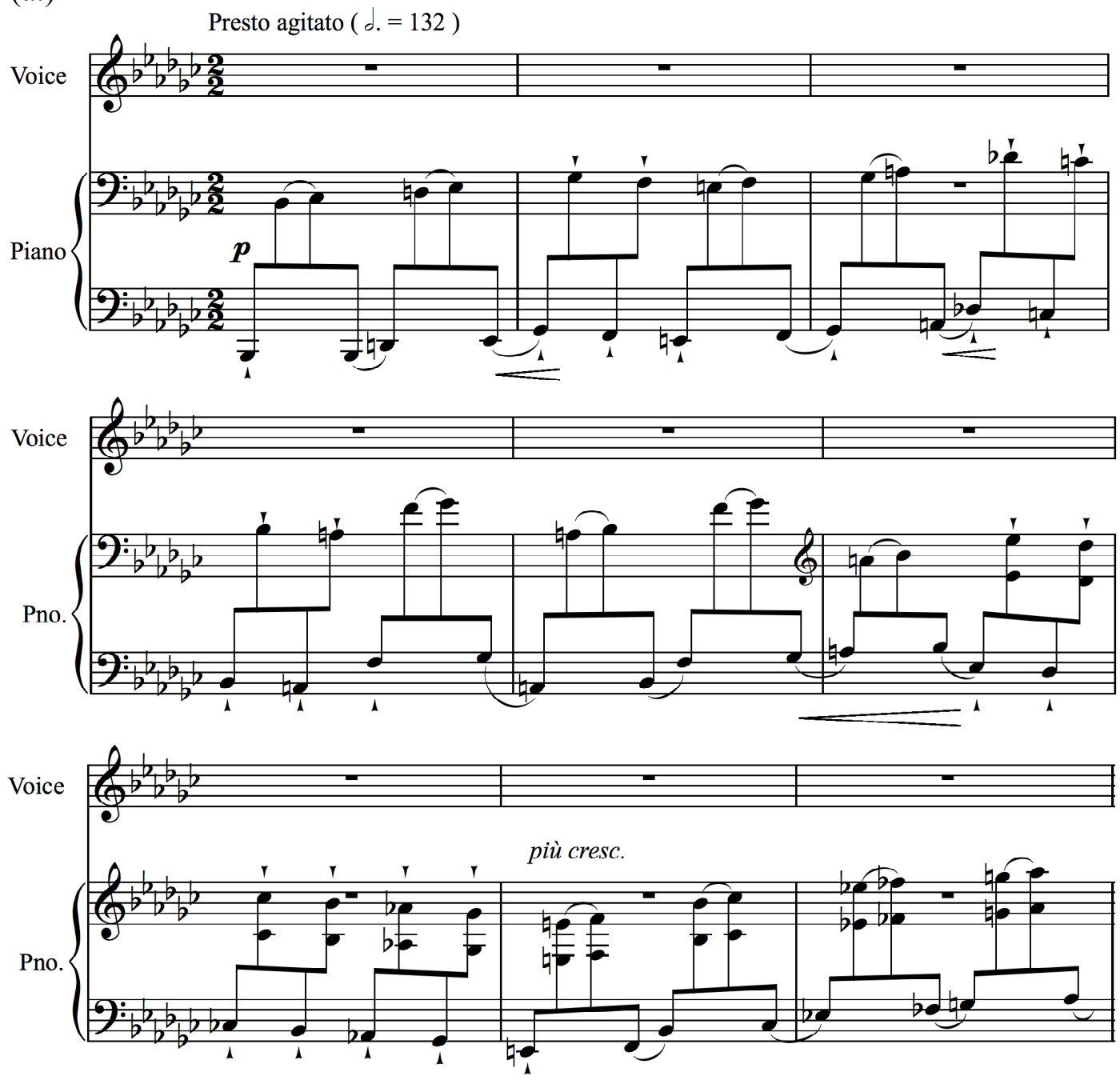

${ }^{25}$ Benjamin Britten, The Holy Sonnets of John Donne (London: Boosey \& Hawkes, 1946), 33.

${ }^{26}$ Britten, Who Are These Children?, 11. Examples from "Slaughter" reproduced with kind permission of Faber Music Ltd, London. 
(b.)
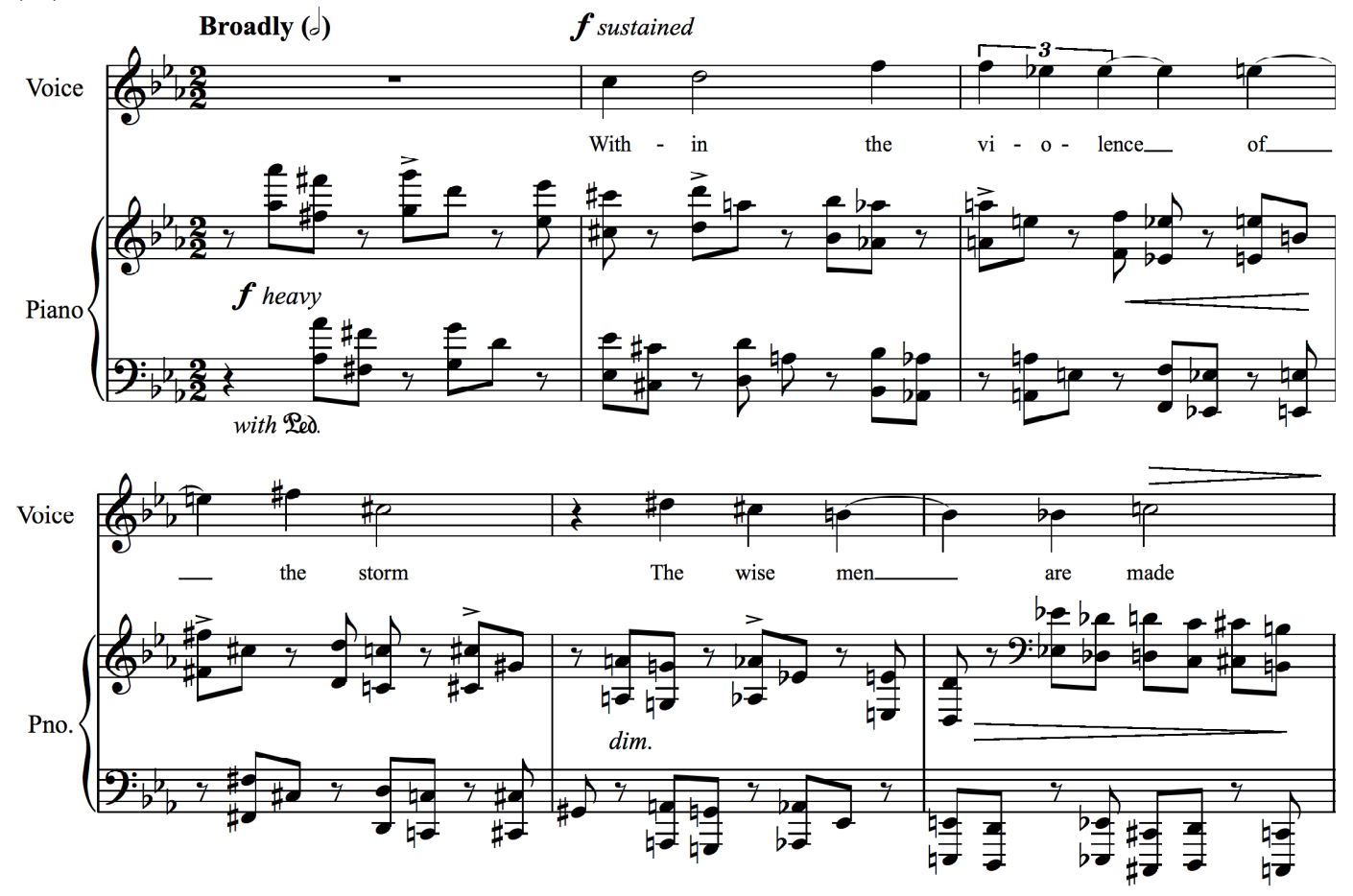

However, the tessitura of the vocal line is generally lower, not only to account for the fact that Pears's voice had settled somewhat but also because this poem does not have the same kind of youthful anger as the former setting. Many of the dark images of this poem are set to rather low pitches, "The babe dies in the womb," ". . . tramples the city down," and "our bitterness and fear" (See Example 7-13). 
Example 7-13, "Slaughter," (a.) mm. 12-14, (b.) 25-26, (c.) 37-39. ${ }^{27}$

(a.)

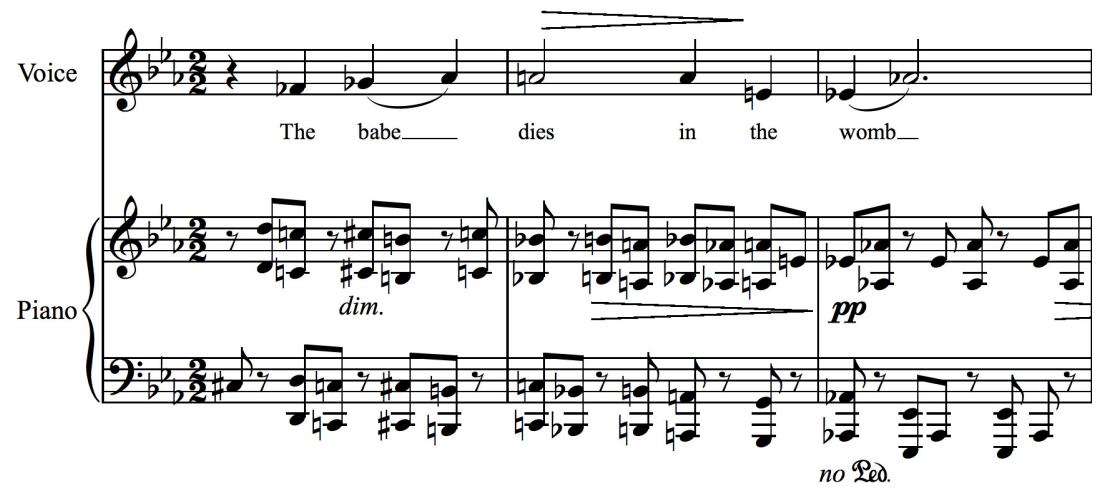

(b.)

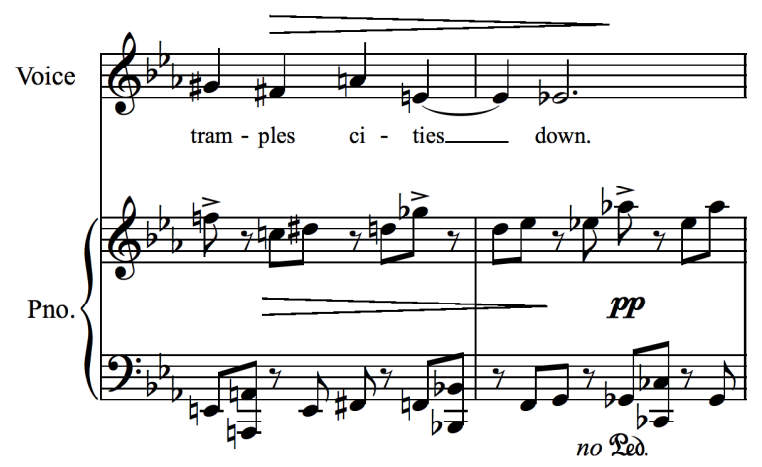

(c.)

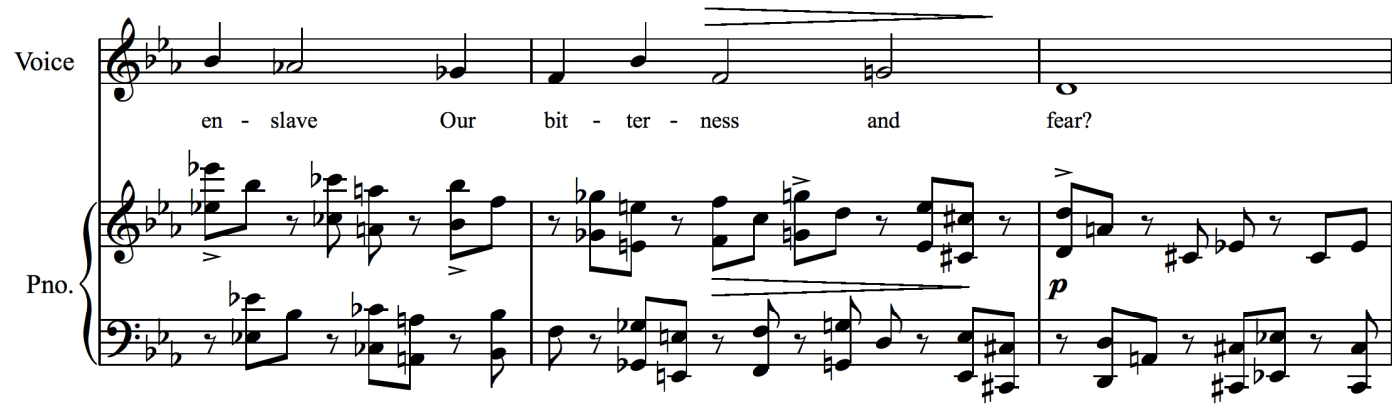

In contrast, the composer allowed the singer to express contempt for these things in a higher range, allowing for a more biting tone, especially for the highest phrase in the piece set to the text "These dungeons of misrule" (See Example 7-14).

${ }^{27}$ Ibid., 12, 13, 14. 
Example 7-14, “Slaughter,” mm. 34-36. ${ }^{28}$

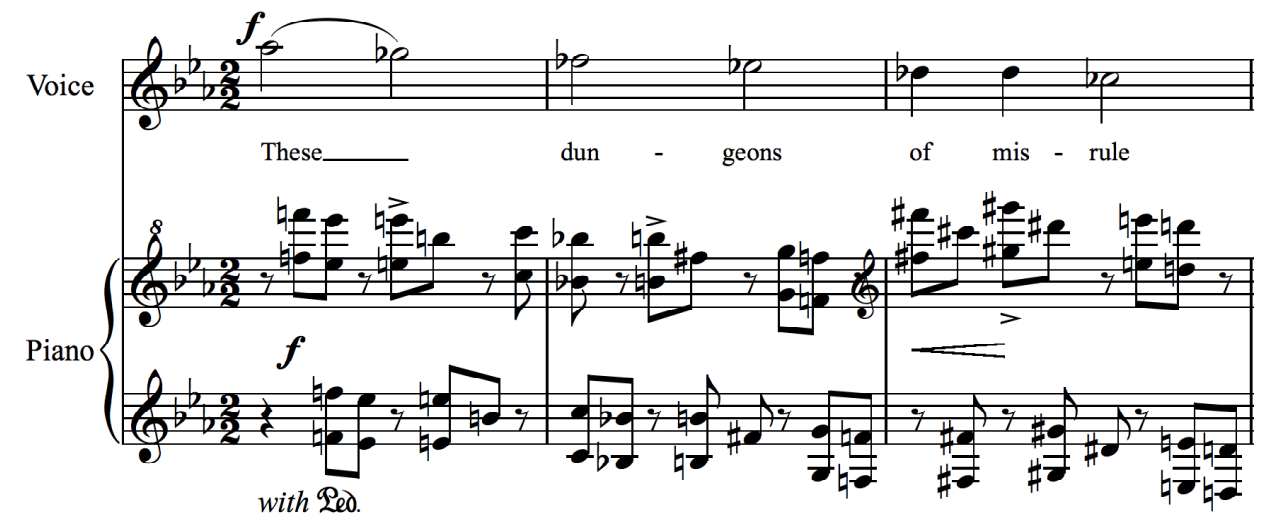

The melody of the final statement, "And from our faces show," is an ascending whole-tone scale which, with its nebulous tonality, helped the singer to express shock at the horrors that had occurred by removing from the vocal line a sense of tonality (See Example 7-15).

Example 7-15, “Slaughter,” mm. 55-58. ${ }^{29}$

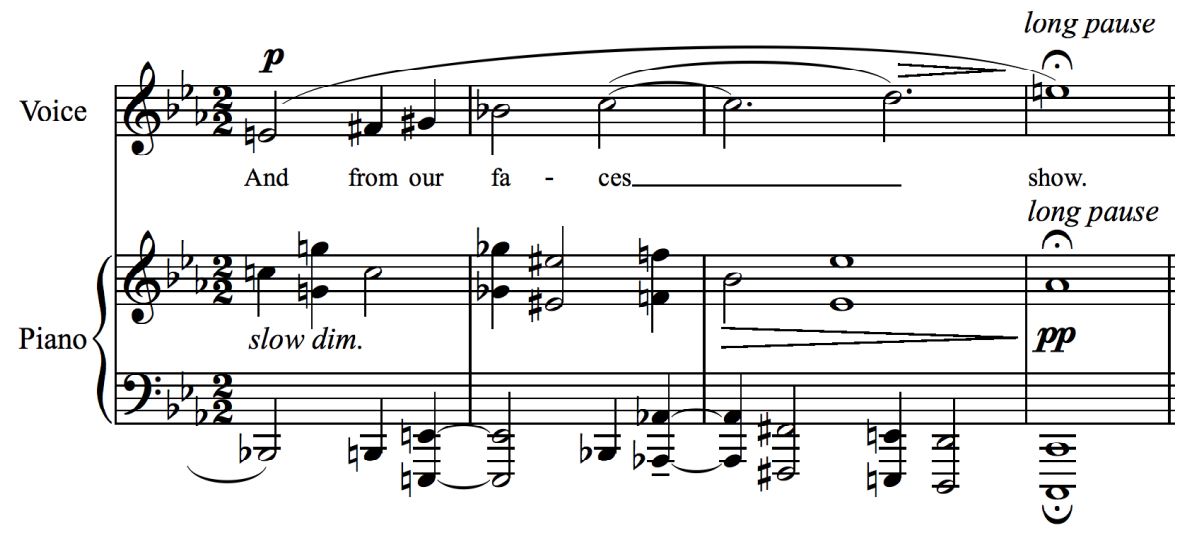

This setting marks the end of the first half of the cycle. The boy and nature, which

Britten presents as nearly identical, have suffered at the hands of adults. As has been discussed, Britten was attracted to the theme of the loss of innocence both in texts of previous cycles and of operas. At this point in the cycle, he has achieved this: all that remains of childhood thoughts and feelings are "phantoms."

\footnotetext{
${ }^{28}$ Ibid., 14 .

${ }^{29}$ Ibid., 15.
} 


\section{(7.) Riddle (The Child You Were)}

It was your faither and mither,

Yet it wasna weddit:

It was your sister or brither

Though nane were beside it.

Wit and wisdom it lent ye,

Yet it wasna lairéd:

And though it dee'd or it kent ye

It was never buried.

"Riddle (The Child You Were), begins the second half of the cycle. In contrast with the first half, which began with the lively setting "Riddle (The Earth)," this half begins with a more sober, more hushed setting. The setting gets most of its interest from the rhythmic shift between duplets and triplets (See Example 7-16).

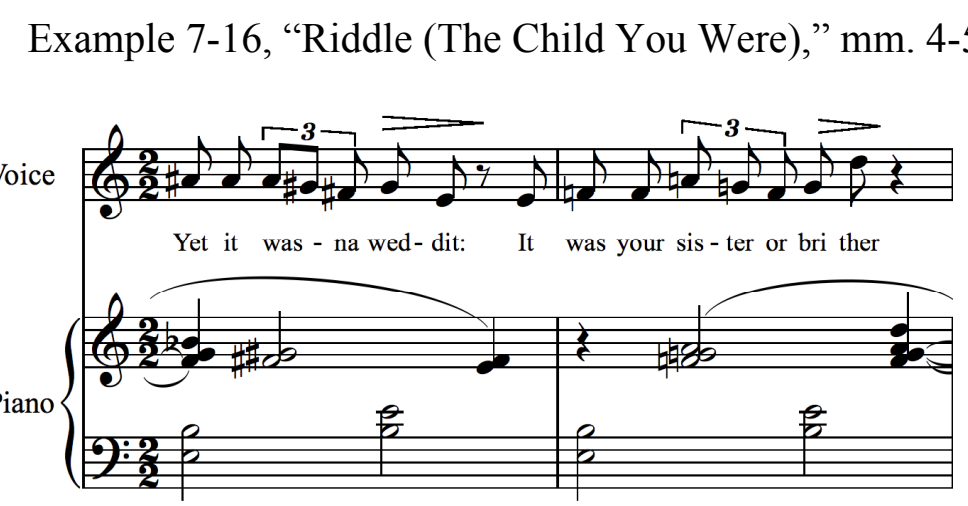

Dramatically, the hushed nature of the piece sets up the different perspective presented in this half, that of adulthood. The use of riddles to begin both halves unifies them, while the differing style sets them apart.

\footnotetext{
${ }^{30}$ Ibid., 16. Examples from “A Riddle (The Child You Were)” reproduced with kind permission of Faber Music Ltd, London.
} 


\section{(8.) The Larky Lad}

The larky lad frae the pantry

Skipp't through the muckle ${ }^{31}$ ha';

He had ma' fear o' the gentry,

And his respec' was sma'.

He cockit his face richt merry;

And as he jiggit on

His mou' was round as a cherry

Like he whistled a braw tune.

And monie a noble body

Glower'd doun frae his frame o' gowd

On the plisky ${ }^{32}$ pantry-laddie

Wha was sae merry and royd. ${ }^{33}$

The eighth setting of the cycle, "The Larky Lad," is one of the lively settings of the Scottish poems. This is a further contrast from the first half, as its counterpart, "A Laddie's Sang," was one of the more lyrical. Just as the first poems of each half are united by title, so are these in their reference to a lad. "The Larky Lad" skips through his world with a series of disjunct intervals (See Example 7-17).

Example 7-17, “The Larky Lad,” mm. 1-3. ${ }^{34}$

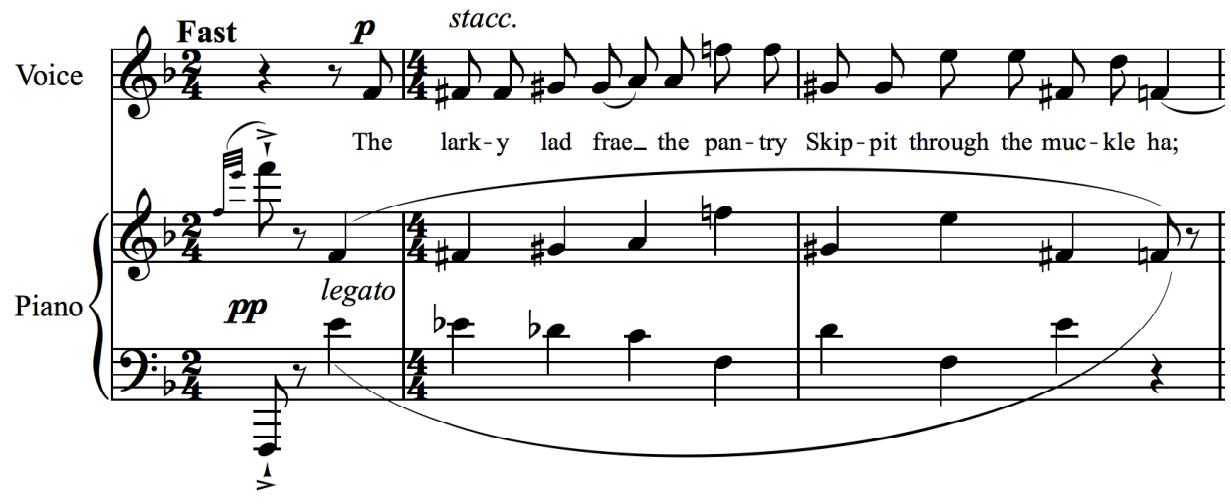

31 great

32 cheeky

33 mischievous

${ }^{34}$ Britten, Who Are These Children?, 18. Examples from "The Larky Lad" reproduced with kind permission of Faber Music Ltd, London. 
"His merry face" is set in the passaggio where Pears could add a little sweetness to his tone (See Example 7-18).

Example 7-18, "The Larky Lad,” mm. 7-15. ${ }^{35}$
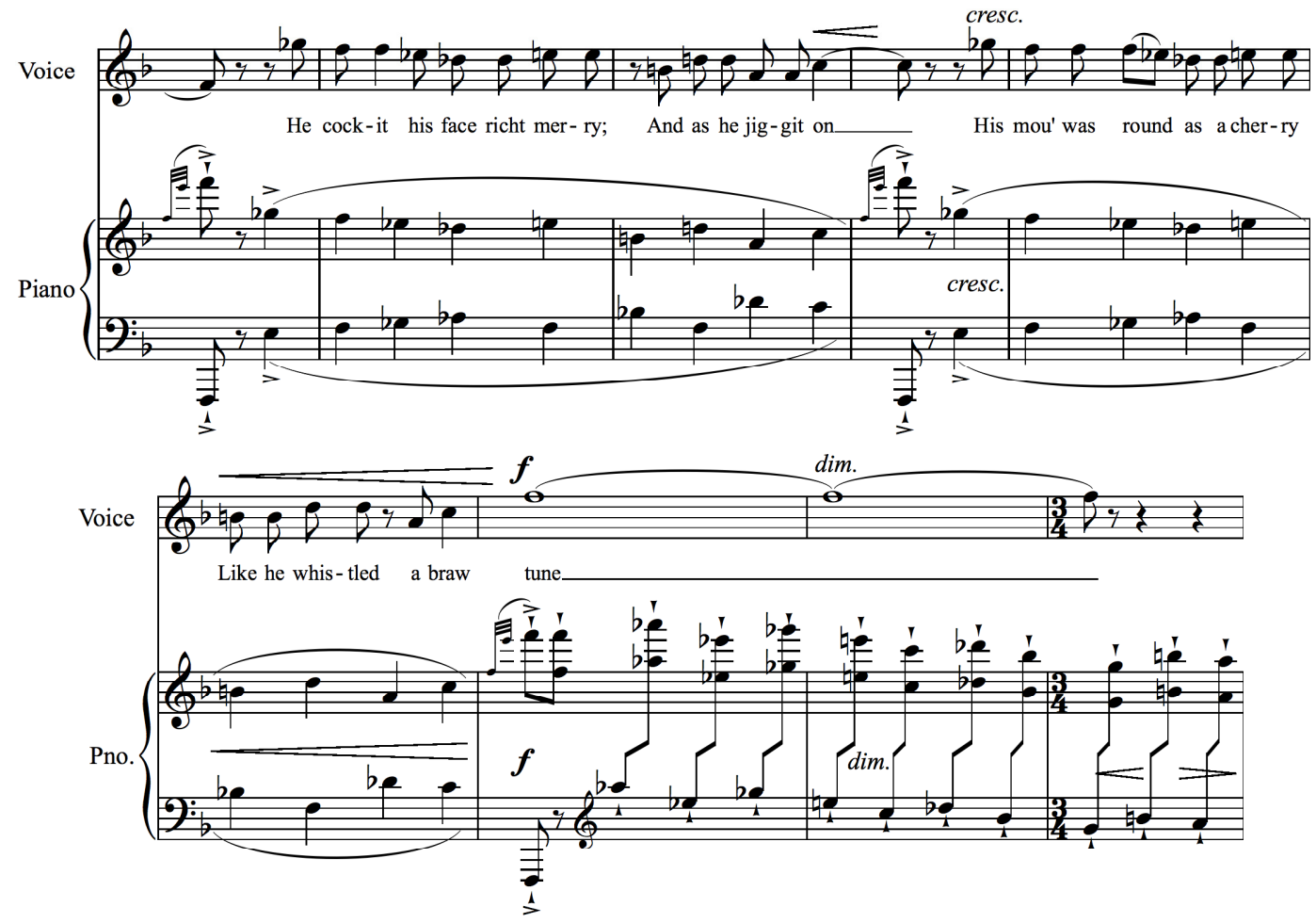

However, this sweetness can be perceived as condescending: we are now looking at children from the perspective of adulthood, and seeing them as destructive, ignorant, disrespectful, and perhaps even devious.

The organization of the cycle in this way, contrasting the two perspectives directly, offers the greatest insight into what may have been Britten's own perspective. Given the prevailing social attitudes in Great Britain at that time, casting the youth as a homosexual and the adults as homophobic shows the composer at his most overtly political. Perhaps the repeal of the law

35 Ibid., 18-19. 
banning consensual homosexual acts between adult men in 1967 made him feel less reluctant to

present these ideas more boldly, i.e. in English as opposed to the German of the previous cycle. ${ }^{36}$

(9.) Who Are These Children?

With easy hands upon the rein, And hounds at their horses' feet, The ladies and the gentlemen

Ride through the village street.

Brightness of blood upon the coats And on the women's lips:

Brightness of silver at the throats

And on the hunting whips.

Is there a dale more calm, more green

Under this morning hour;

A scene more alien than this scene

Within a world at war?

Who are these children gathered here

Out of the fire and smoke

That with remembering faces stare

Upon the foxing folk?

The title song, the ninth in the cycle, contrasts the adult world of a fox hunt with a group of young onlookers. The vocal line for the hunt is moderately high and fairly tonal which allowed the singer to express the "normalcy" of this life. The vocal line becomes a little more disjunct at "Brightness of blood upon their coats" as if to show cracks in the armor of these adults and the cruelty of the hunt itself, despite its acceptability in society (See Example 7-19).

\footnotetext{
${ }^{36}$ Hyde, H. Montgomery, The Love That Dared Not Speak Its Name: A Candid History of Homosexuality in Britain (Boston: Little, Brown and Company, 1970), 268.
} 
Example 7-19, “Who Are These Children?," mm. 35-39. ${ }^{37}$

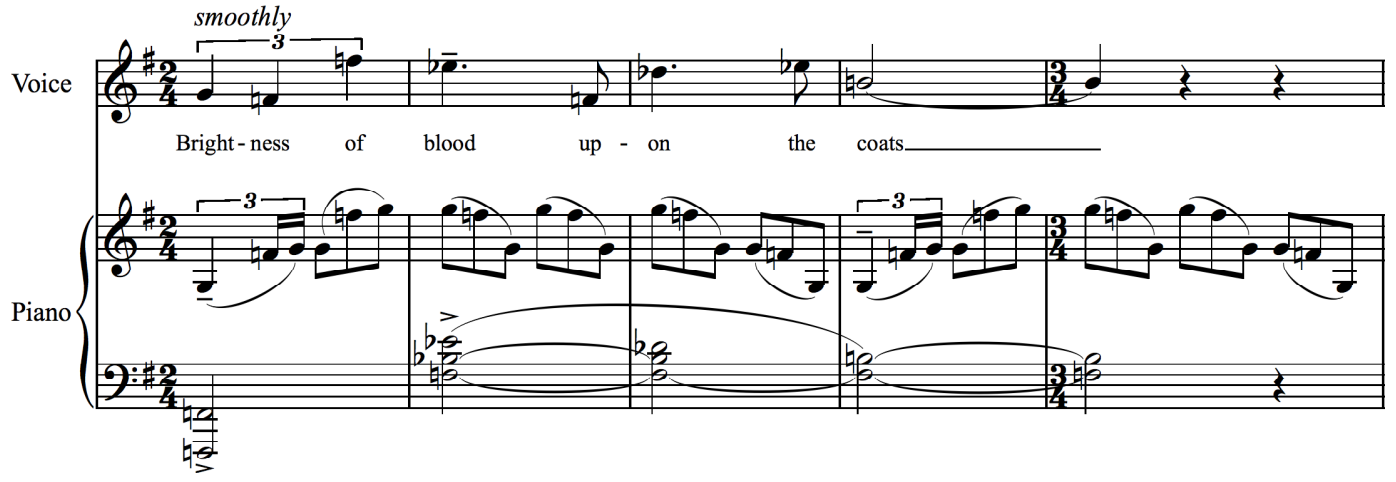

The character of the text becomes ironic at "Is there a dale more calm, more green" as the vocal line to suggest this irony consists of a sweet mid-range melody ahead of the setting of "at war" (See Example 7-20).

Example 7-20, “Who Are These Children?," mm. 59-63. ${ }^{38}$

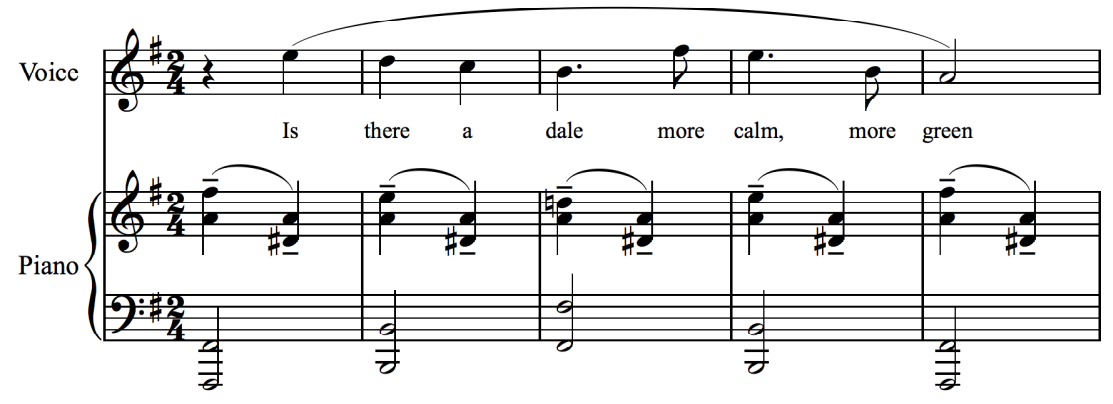

The foreboding of the low E-natural and F-natural for "at war" is striking in contrast to the higher register that precedes it (See Example 7-21).

\footnotetext{
${ }^{37}$ Britten, Who Are These Children?, 21. Examples from "Who Are These Children?" reproduced with kind permission of Faber Music Ltd, London.

${ }^{38}$ Ibid., 22.
} 
Example 7-21, “Who Are These Children?,” mm. 75-77. 39

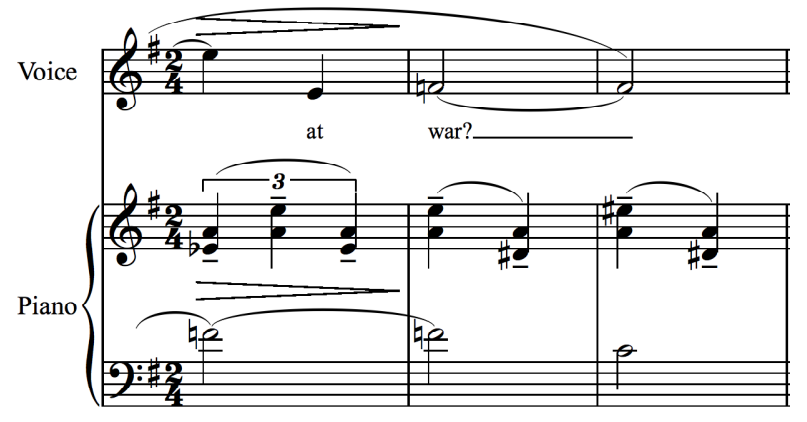

The world of the children is expressed with a disjunct melody in free recitative style (similar to the tree sections in "Nightmare") at variance with the accompaniment which in its own time continues the hunting horn calls that it has had throughout the setting (See Example 7-22).

${ }^{39}$ Ibid., 22-23. 
Example 7-22, "Who Are These Children?,” m. 84. ${ }^{40}$
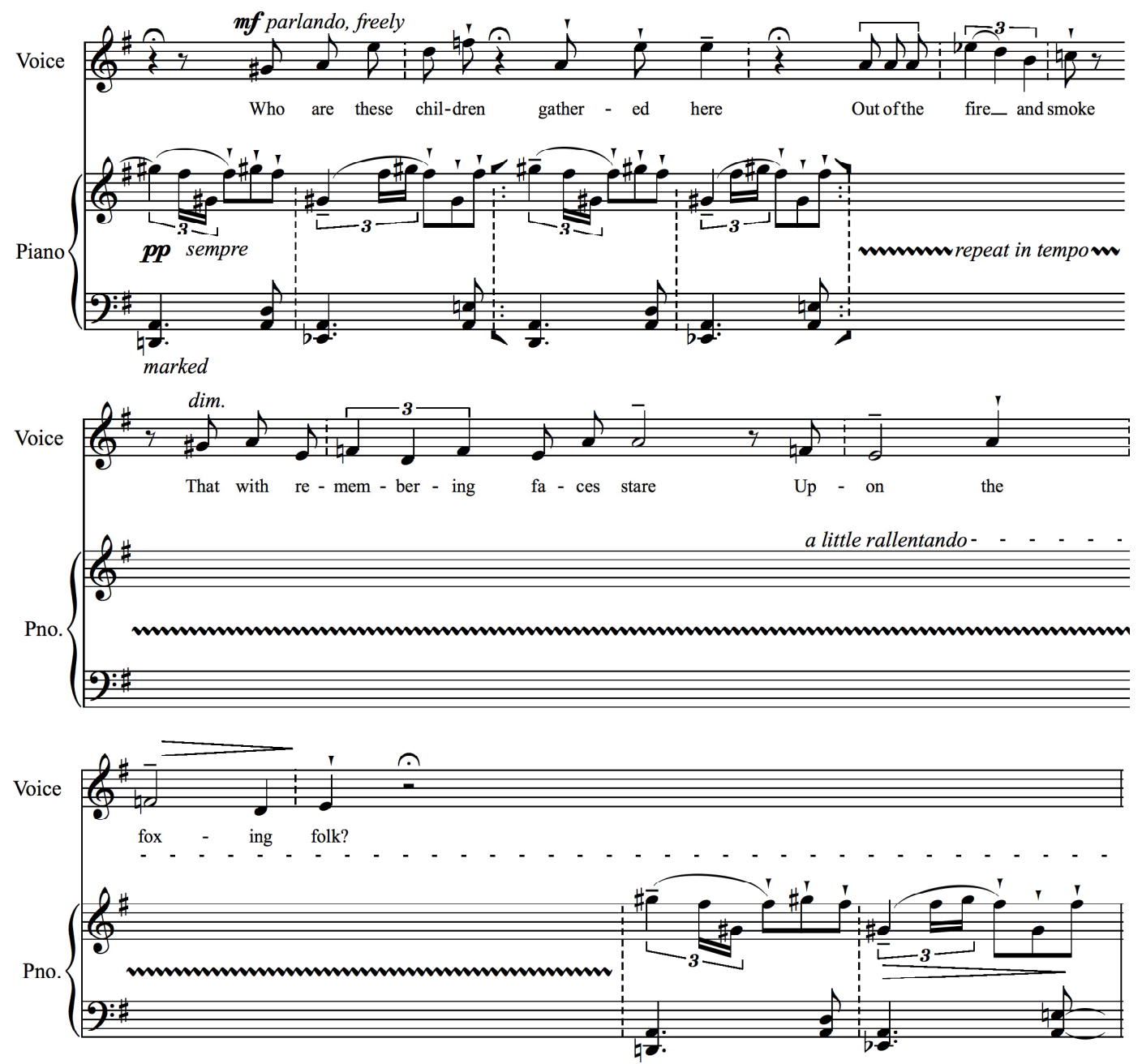

None of this melody is set in a high register; in fact it ends quite low which again allowed Pears the opportunity to add a bit of growl to the sound, which shows the narrator's pent-up anger over the mistreatment of these children.

The composer continued to contrast the world of the innocents with the society which is causing or will ultimately cause them pain. The text of this setting expresses great anger at the ignorance of those who are causing harm, in this case for the sake of mere sport. Again, this is

\footnotetext{
${ }^{40}$ Ibid., 23.
} 
not veiled in a foreign language, as it was in the Hölderlin settings, so the shock and dismay would be very apparent to the listener.

$$
\text { (10.) Supper }
$$

Steepies ${ }^{41}$ for the bairnie Sae moolie ${ }^{42}$ in the mou': Parritch for a strappan lad To make his beard grow.

Stovies ${ }^{43}$ for a muckle man To keep him stout and hale: A noggin for the auld carl To gar him sleep weel.

Bless the meat, and bless the drink, And the hand that steers the pat: ${ }^{44}$

And be guid to beggar-bodies Whan they come to your yett. ${ }^{45}$

"Supper," the tenth setting of this cycle, is actually a modified strophic song, using the same music for the first two verses but different material for the third. In the third verse, each phrase slowly ascends in pitch until "steers the pat" (stirs the pot), as the boy becomes excited about the coming meal (See Example 7-23).

\footnotetext{
${ }^{41}$ curds

42 crumbly

${ }^{43}$ potatoes

44 stirs the pot

${ }^{45}$ gate
} 
Example 7-23, "Supper," mm. 19-24. ${ }^{46}$

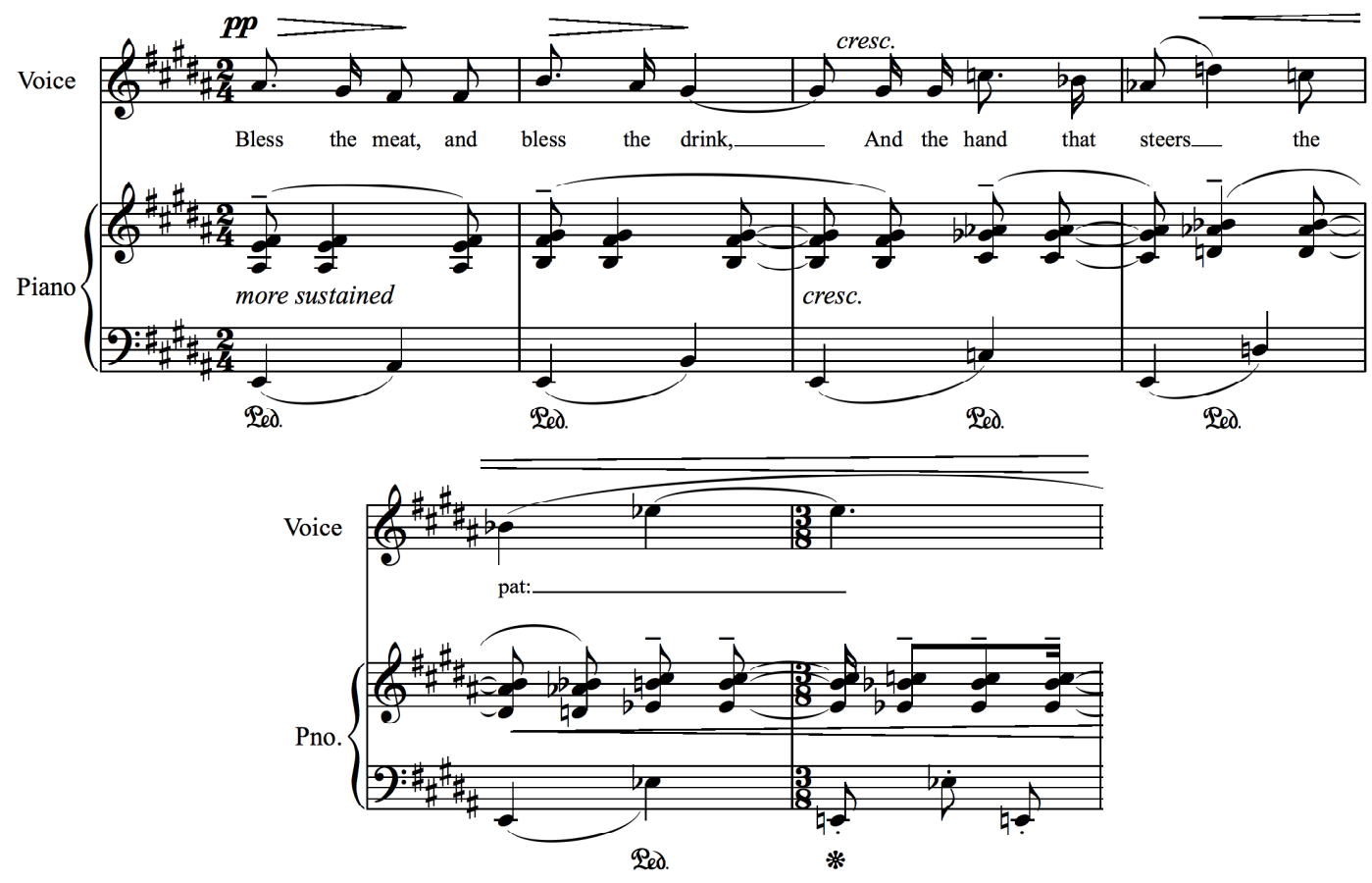

However, the line descends as he is reminded to be good to those who do not have as much as he does for dinner (See Example 7-24).

Example 7-24, “Supper,” mm. 26-29. ${ }^{47}$

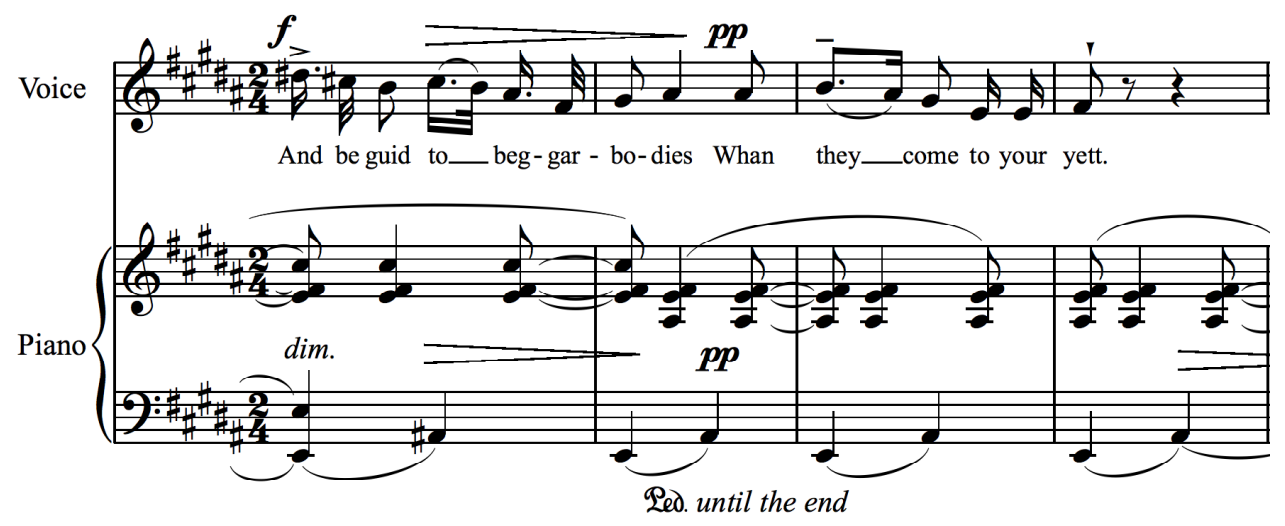

\footnotetext{
${ }^{46}$ Britten, Who Are These Children?, 25. Examples from "Supper" reproduced with kind permission of Faber Music Ltd, London.

${ }^{47}$ Ibid., 25.
} 
This is the last setting of the Scottish poetry in the more lyrical folk-like style in the cycle. Just as in "The Larky Lad," however, the sweetness of the musical setting betrays the condescending attitude of the adults who look upon children, a boy in this case, as being stupid, silly, and disrespectful creatures.

\section{(11.) The Children}

Upon the street they lie

Beside the broken stone:

The blood of children stares from the broken stone.

Death came out of the sky

In the bright afternoon:

Darkness slanted over the bright afternoon.

Again the sky is clear

But upon earth a stain:

The earth is darkened with a darkening stain:

A wound which everywhere

Corrupts the hearts of men:

The blood of children corrupts the hearts of men.

Silence is in the air:

The stars move to their places:

Silent and serene the stars move to their places:

But from earth the children stare

With blind and fearful faces:

And our charity is in the children's faces.

The eleventh setting and last of the English poems, "The Children," is perhaps the most innovative of these settings especially in terms of tonality. The lack of a stable tonality throughout and the use of many disjunct skips from one register to another helped the singer to establish the fact that the narrator was astounded by the behavior found in the poem. There are 
moments of word painting, for example a skip upwards on "sky" and a low tessitura for “darkness" (See Example 7-25).

Example 7-25, “The Children,” (a.) mm. 17, (b.) 21. ${ }^{48}$

(a.)

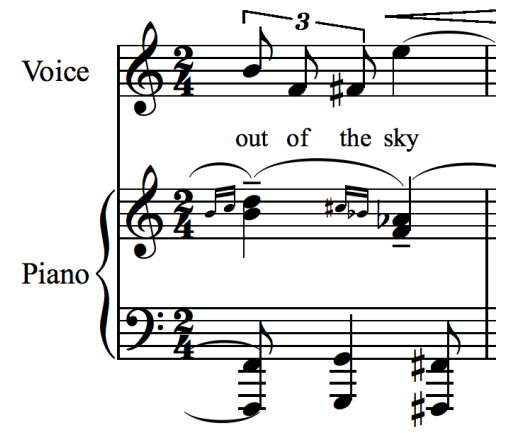

(b.)

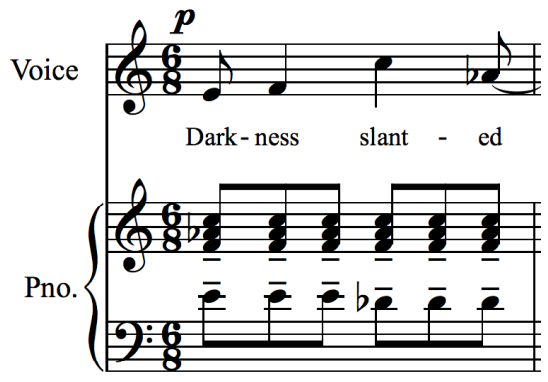

The lowest note of the cycle, the B-natural a ninth below middle $\mathrm{C}$, occurs at the end of the lowlying phrase "the blood of children corrupts the hearts of men," which again allowed Pears the chance to express a biting anger with a heavy, dark sound (See Example 7-26).

\footnotetext{
${ }^{48}$ Ibid., 27. Examples from "The Children” reproduced with kind permission of Faber Music Ltd, London.
} 
Example 7-26, “The Children,” mm. 42-45. ${ }^{49}$
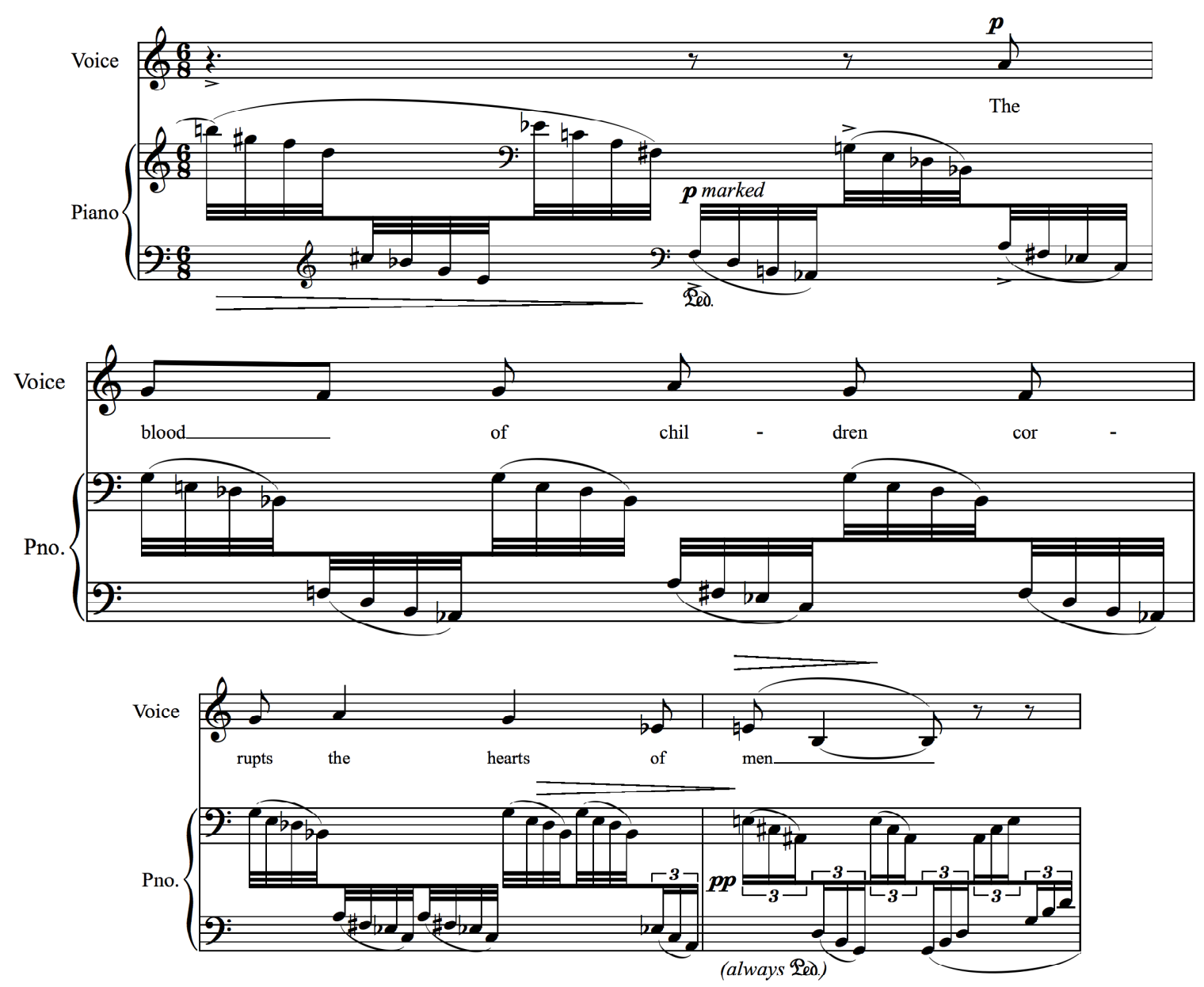

The melodic line in the subsequent phrases have a higher tessitura which descends rapidly as the narrator expresses astonishment that the world would continue unaffected by this tragedy (See Example 7-27).

${ }^{49}$ Ibid., 28-29. 


\section{Example 7-27, "The Children," mm. 49-59. ${ }^{50}$}
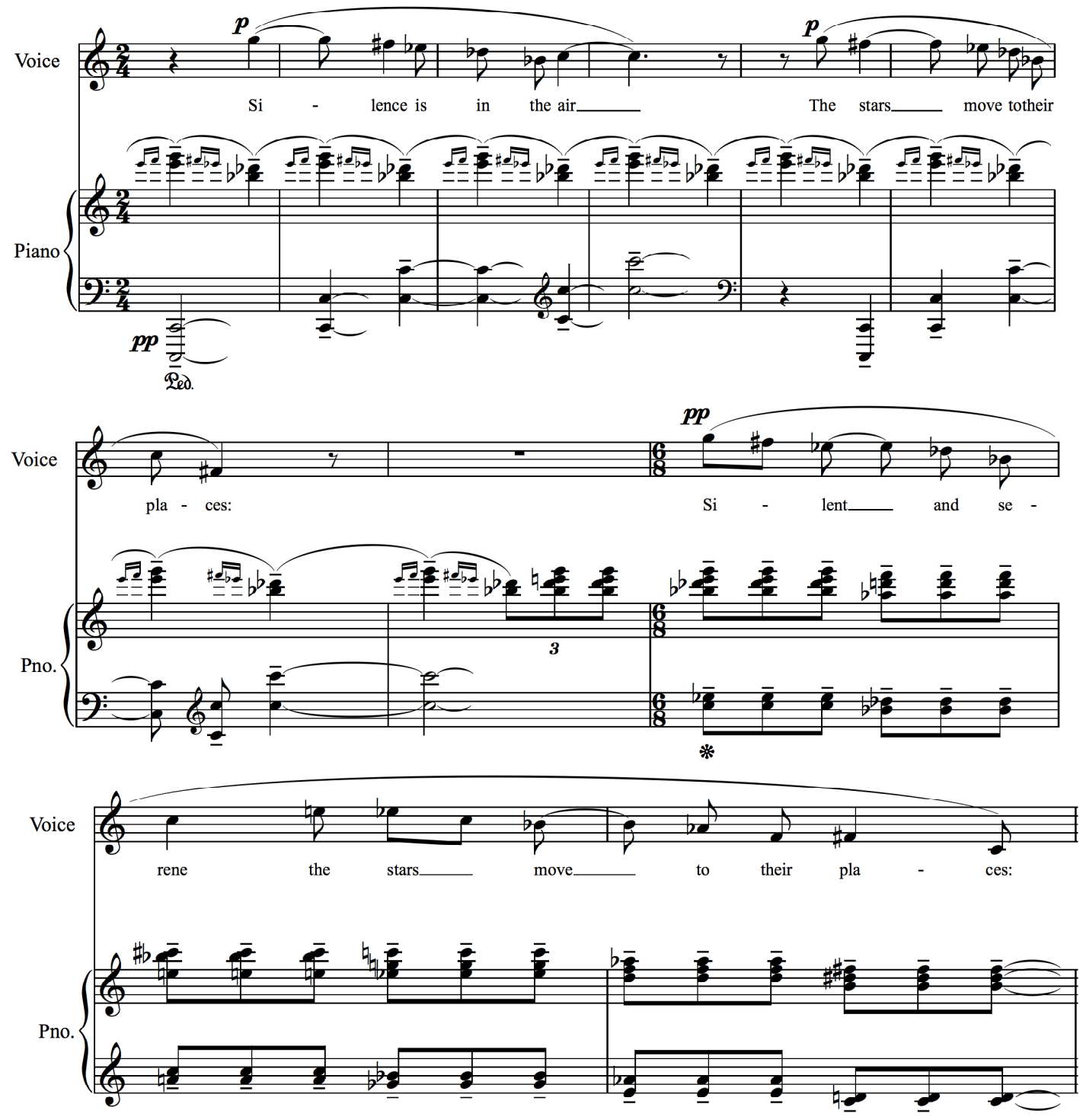

This shock turns again to anger, expressed in the vocal line by the ascent to a high A-flat, above middle $\mathrm{C}$, starting a violent sounding melisma on the word "faces" the latter part of which is echoed an octave lower on the word "children's" in the following phrase, which helped the singer to show the poet's contempt for humanity by once again using a heavy, dark sound (See Example 7-28).

\footnotetext{
${ }^{50}$ Ibid., 29-30.
} 
Example 7-28, "The Children,” (a.) mm 65-68, (b.) 71-73. ${ }^{51}$

(a.)
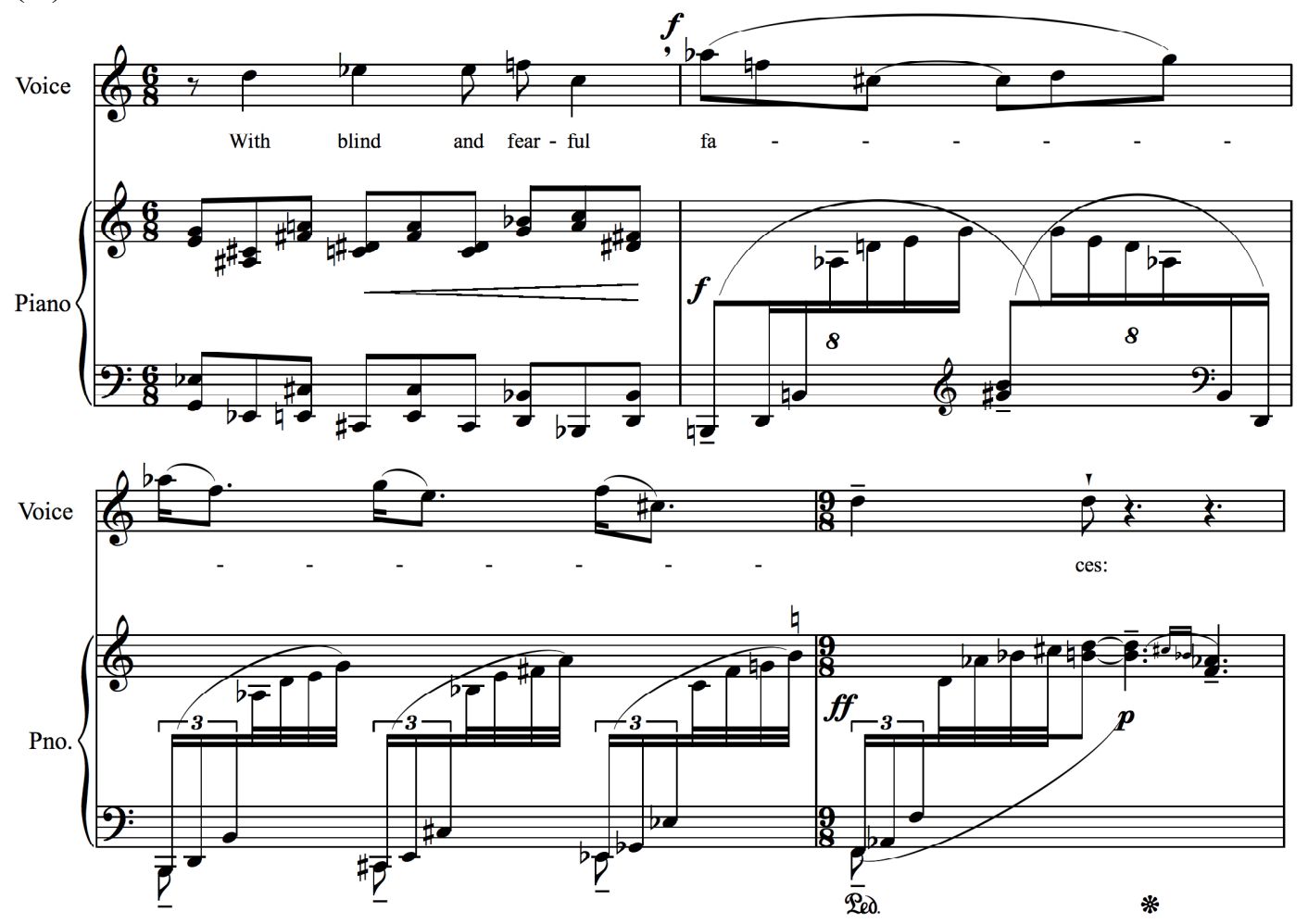

(b.)

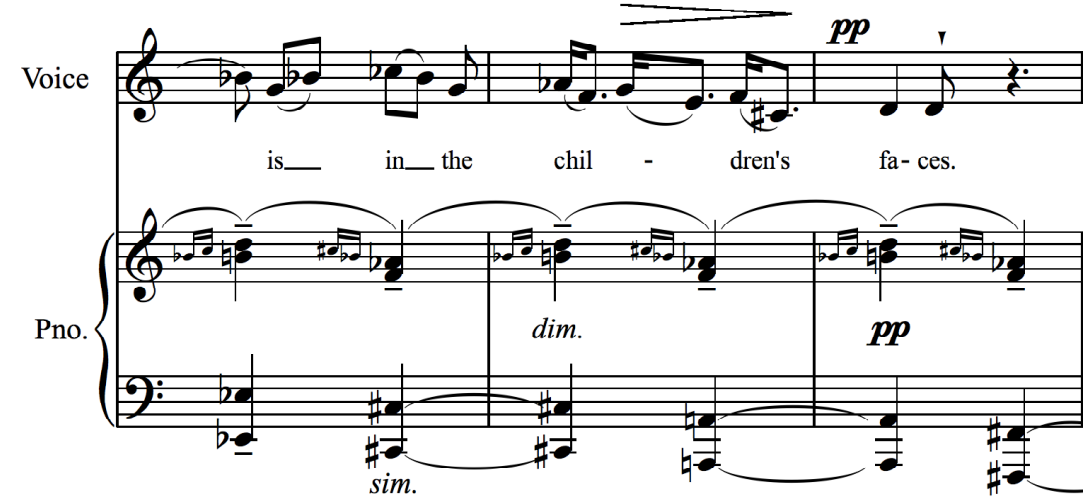

These images are arguably the darkest to be found in the five cycles discussed. Soutar was most likely describing the horrors that were seen during the Battle of Britain. The horrific damage could be taken also to represent the psychological scarring that gays suffered in the homophobic atmosphere that had predominated in Great Britain. Britten said that his first aural memory was that of an explosion near his home during World War I, and this gives further

\footnotetext{
${ }^{51}$ Ibid., 30-31.
} 
credence to the notion that the child in the story could be Britten. ${ }^{52}$ The disgust and sarcastic anger of the poem seemed to give Britten the chance to make his boldest statement of resistance to this oppression.

\section{(12.) The Auld Aik}

The auld aik's ${ }^{53}$ doun:

The auld aik's doun:

'Twa hunner year it stüde, or mair,

But noo it's doun, doun.

The auld aik's doun:

The auld aik's doun:

We were sae shair it wud aye be there,

But noo it's doun, doun.

"The Auld Aik" (The Old Oak) can be considered a postlude to the cycle in a way: although it has a slower tempo, it does not have the lullaby-like quality of the other slower settings of the children's rhymes, nor does it have the same kind of rhythmic energy of any of the other children's rhymes. Overall, because it has more of the character and emotional energy of the setting of the English poems in the vocal line, in this way it is a combination of the two vastly different elements of the cycle.

The setting is economical melodically, most phrases starting high and ending a major seventh lower, landing each time on the word "doun” (down) (See Example 7-29).

${ }^{52}$ Christoper Headington, Britten (New York: Holmes \& Meier, 1982), 17.
${ }^{53}$ oak 
Example 7-29, “The Auld Aik," mm. 2-4. ${ }^{54}$

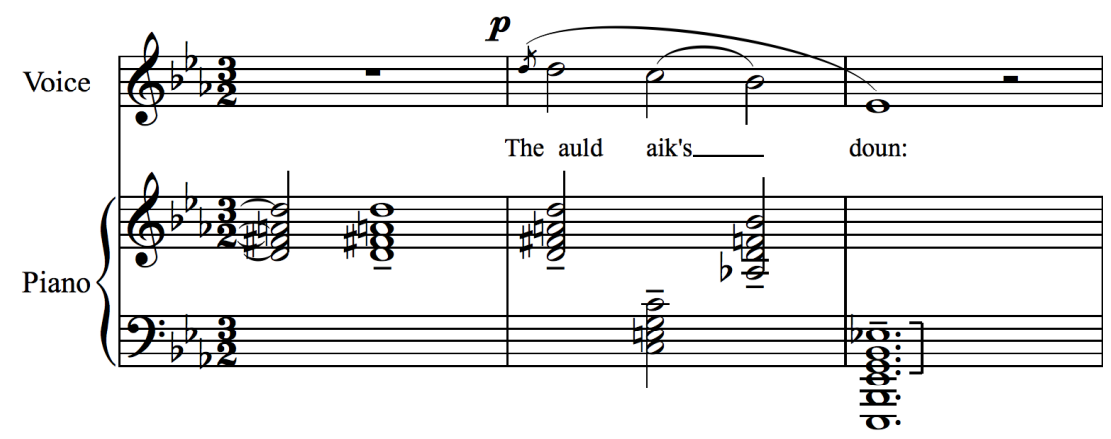

As the poet becomes more agitated about the loss of the old oak tree, the tessitura of the melody rises, ultimately climbing to a high G-flat above middle C (See Example 7-30).

\section{Example 7-30, “The Auld Aik," mm. 11-15. ${ }^{55}$}

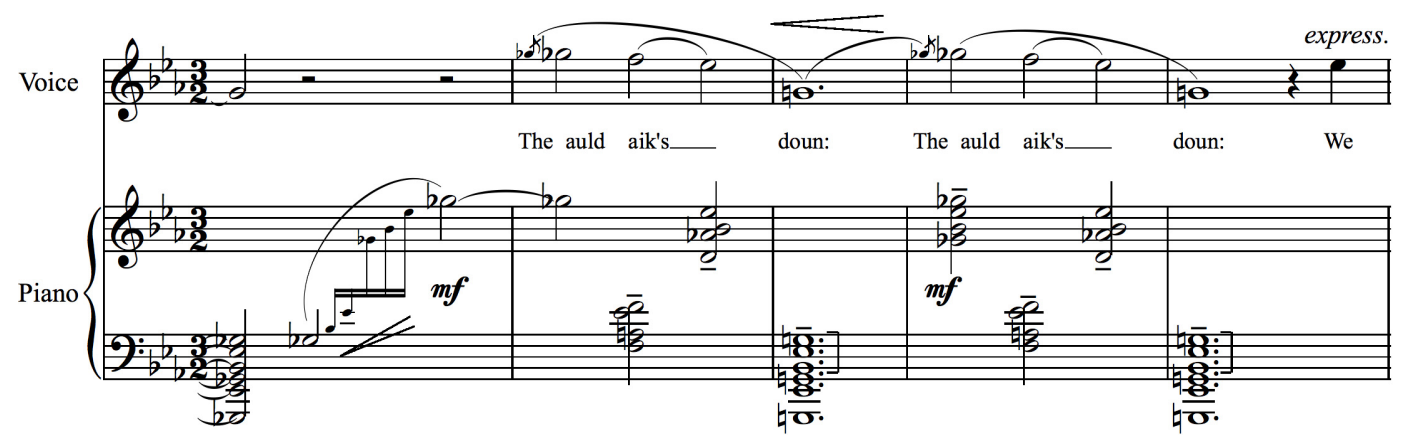

It returns then to the bottom of the staff, where the tenor was able to make a mournful sound thereby expressing the sorrow about the absolute and complete loss of that which is natural (See Example 7-31).

\footnotetext{
${ }^{54}$ Britten, Who Are These Children?, 32. Examples from "The Auld Aik" reproduced with kind permission of Faber Music Ltd, London.

${ }^{55}$ Ibid., 32-33.
} 
Example 7-31, “The Auld Aik,” mm. 17-22. ${ }^{56}$

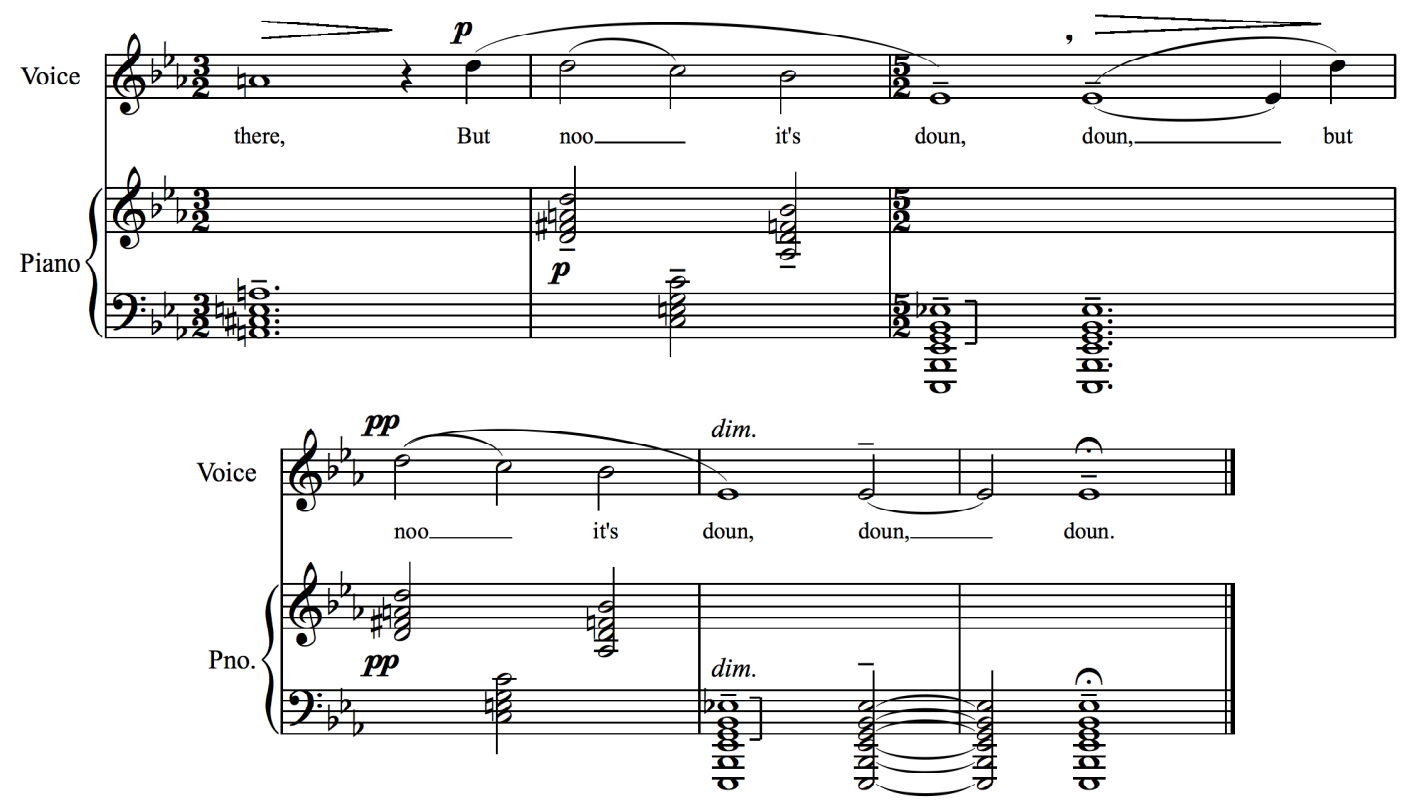

At the time this cycle was composed, both men were in their late fifties and had experienced some serious health troubles: Pears had been advised by his doctors to reduce his performing schedule following a hernia operation in 1968, and Britten was beginning to experience the heart trouble that would ultimately lead to surgery in 1973. It was perhaps these reminders of their mortality that drew the composer to these texts, and it was also the fact that the poet shared their pacifist ideals. It is also true, however, that the poems that were chosen also were unified by the theme of a loss of innocence, a theme that was seen in Winter Words (1953) and The Turn of the Screw (1954), and would be seen again in the opera Death in Venice (1974). It could be supposed that the boy in the narrative is Britten himself, especially if you consider that all the song cycles written for Pears seem to address challenges for homosexuals in a hostile British society. If this supposition were true, then this cycle would be the least veiled example of

\footnotetext{
${ }^{56}$ Ibid., 33.
} 
such statements (as opposed to the German of the Hölderlin cycle or the Italian of the Michelangelo sonnets) to be found in these five cycles.

The musical style of this work drew from not only the composer's operatic style, including the use of recitative as well as free accompaniment, but also from his arrangements of folk songs, in which he used the accompaniments not just to outline the harmony but instead as another device with which to express the meaning or mood of the texts by using countermelodies, short melodic motives, and remote harmonies. The overall vocal range of the piece takes into account the lower vocal range of the tenor at this point in his life.

This was the last song cycle for voice and piano written for the tenor by the composer. After having his heart surgery, Britten lost most of the function of his right hand and could no longer accompany his partner in performance. He continued to write for the tenor almost right up until his death, however, by composing works with harp accompaniment, including Canticle V (“The Death of St. Narcissus”) (1974) and several folk-song arrangements (1976), and of course the role of Aschenbach in Death in Venice (1973). Looking at Who Are These Children? as the final work of this genre for Britten and Pears, it is interesting to note that the composer used in its composition stylistic elements of different genres in which he composed music for his partner, his operas and folk-song arrangements most specifically, offering in this way a true culmination of an almost forty-year partnership between the tenor and composer as recital partners. 
Chapter 8

Conclusions

Benjamin Britten and Peter Pears were together as a couple from 1939 until the former's death in 1976. During this period, the composer wrote numerous works for his partner's voice. Five of these were song cycles written for solo voice and piano to be performed by the two men: Seven Sonnets of Michelangelo, opus 22, The Holy Sonnets of John Donne, opus 35, Winter Words, opus 52, Sechs Hölderlin-Fragmente, opus 61, and Who Are These Children?, opus 84. In examining these five cycles, several things seem to become apparent: the more completely Britten understood Pears's voice as he continued to compose for it, the rationales behind the choices of texts, the care that Britten took in arranging the texts to form a narrative, and the relationship that the subject material of these "cycles" had to life experiences of both men.

The original intention of this paper was to investigate how the composer wrote for his partner's voice. In examining these five cycles, it can be seen that the more he composed for the tenor, the better his understanding of how to use that instrument for expressive purposes became and as a result of that understanding, the more effective his use of it to convey nuances of the poems as Britten understood them. In the first cycle, Britten seemed to use Italian opera as one of his models. Pears, although successful in the performance of this cycle, did not have an "Italianate" voice, meaning that it was not particular large nor ringing. He was not as comfortable singing notes high in his range for extended periods of time, nor did he sound particularly heroic doing so. ${ }^{1}$ In this way, Britten had yet to understand completely how to use his partner's voice and did not use the singer's strengths to their greatest advantage, evidence of his own comparative inexperience as a composer. By the second cycle, however, the composer

\footnotetext{
${ }^{1}$ Christopher Headington, Peter Pears: A Biography (London: Faber and Faber, 1992), 192.
} 
used pitches just below the A-flat above middle $\mathrm{C}$ for moments which he intended to be more heroic in character, and used the pitches at and above for moments of extreme emotion, including the text "... which pray'd forgivenesse for his foes fierce spight? No, no" in "What if This Present” from The Holy Sonnets of John Donne and “. . . im Winde Klirren die Fahnen [in the wind clatters the weather-vane]" from "Hälfte des Lebens" from Sechs Hölderlin-Fragmente.

The vocal music he wrote in this and the subsequent cycles for his partner explored the different colors afforded the tenor, using especially his upper middle range for moments of either great strength or for texts which expressed introverted and intimate thoughts, for which Pears could use a more transparent sound. The composer also learned that the tenor was able to use his lower range to interesting effect as well: almost a growl for moments of intense shock, despair or dismay, as shown at the end of "Midnight of the Great Western" from Winter Words to the text "This region of sin that you find you in, but are not of" and in Who Are These Children? in the setting "The Children" to the text "The blood of children corrupts the hearts of men." As the tenor's voice changed as he aged, the composer made adjustments. This is apparent in the final cycle, when Britten allowed for the slight shift downward of the tenor's range.

In examining the five compositions, however, several things became apparent, most notably the way that Britten organized the texts of each cycle to form a narrative. In all five cases, the narrative that is formed by the arrangement of the poems is Britten's own and not the poet's original intention. Each narrative relates to life experiences of both composer and singer, and inasmuch as both men were gay, the five cycles could be taken to represent the perspective of homosexual men. The composer and his lover were also lifelong pacifists: neither this nor their homosexuality was ever particularly popular with the society in which they lived, and therefore both men were in many ways closeted other than in their private circle. Although the 
men kept their personal lives to themselves, the composer seemed to use these cycles to voice his views on these matters. As the relationship continued, and as society become less disapproving, especially after a change in the law - consensual homosexual acts between two men becoming legal in 1967, two years before the composition of the last cycle - the references seem to become more overt.

The first of the cycles, Seven Sonnets of Michelangelo (1940), uses poetry about Michelangelo's love for a younger man. The narrative formed by Britten in his arrangement of the texts is that of a man who realizes his love for another man, begins to come to terms with his confusion about these feelings and his anger at himself for having them, confronts his object of affection about these feelings, defends himself to society at large, and finally finds peace in the love he feels. The use of the foreign language helped to mask the meaning of the narrative from their audiences, since the translation, prepared in part by Pears, masks the fact that the object of affection is a man. For example, in Sonetto XXXII, the lines "Tu sa' ch'io so, signior mie" and "S'i'amo sol di te, signior mie caro" were translated by Pears and Elizabeth Mayer as "Thou know'st, beloved, that I know" and "If I love in thee, beloved" whereas in both cases, the "beloved" is more accurately translated as "my sir" and "my dear sir," respectively, making it clear that the object of affection is a man. ${ }^{2}$ Even those who did understand Italian may not have completely understood the implications of those texts, since the language Michelangelo used was ornate and in some ways antiquated. Therefore, although the cycle could be seen as representing thoughts and experiences shared by the two men, they were being expressed in a veiled manner.

The Holy Sonnets of John Donne (1945) was written in part as a reaction to the horrors of the Holocaust, the results of which Britten had experienced first-hand while on tour with violinist Yehudi Menuhin in 1945. The narrative of the cycle, although it can be perceived as pacifist in

\footnotetext{
${ }^{2}$ Benjamin Britten, Seven Sonnets of Michelangelo, opus 22. (New York: Boosey \& Hawkes, 1943).
} 
ideology, deals more specifically with an individual having a spiritual crisis that is resolved by the last setting in which the narrator determines that despite all he will overcome all oppression and diversity, even death.

The journey begins with self-pity, despair, and a feeling of betrayal by his maker, ultimately discovered to be over the loss of a lover. The realization in the eighth of the nine sonnets is that he is one of God's creations and that he does not believe that he would be abandoned. The subject matter in this cycle in much less overtly homosexual than that of the Michelangelo Sonnets: although it can be seen to represent the life experiences of gay men in Britain at this time, it is not the only interpretation. Even if it is taken to represent the feelings of the oppressed homosexual, the language once again helps to veil its meaning, since John Donne wrote in language that is often quite formal and allegorical. The lines "Reason your viceroy in mee, mee should defend but is captiv'd, and proves weake or untrue, yet dearely I love you and would be loved faine, but am betroth'd unto your enemie" from "Batter My Heart" and "Thou hast made me and shall thy work decay? Repaire me now, for now mine end doth haste, I runne to death, and death meets me as fast" from "Thou Hast Made Me," for example, may have homosexual subtexts derived from their placement in the cycle, including those of a gay man who has come to believe that his feelings are unnatural or wrong or that of any man who has come to terms with his feelings and lashes out against the society that oppresses him, but the language manages to mask that meaning.

The third cycle, Winter Words (1953), also lacks overtly homosexual texts, although in examining the life experiences of the two men at this time, comparisons can be drawn between them and the narrative of this cycle. The narrator of the story reflects upon his passage from childhood to adulthood, noting as he does so instances of cruelty of society toward youth. The 
narrative continues through first love, death of family members, and to the birth of younger generations and therefore is a continuation of the same process. It likens adulthood to becoming a prisoner of society's rule and ends with the narrator lamenting the loss of innocence. The narrator believes that in childhood, ignorance of society's expectations allows the child to believe that what is natural to him is natural and normal to all, whereas with the passage into adulthood he becomes aware that things that were natural to him were not perceived by society to be natural to all. In terms of language, this cycle is the most overt as yet; it is not only in English but sets poetry by an older contemporary of Britten's: Thomas Hardy, the author of the poems, lived from 1840 to 1928 .

By the late 1950s a report commissioned by the British government examined the law banning consensual homosexual acts between men. The Wolfenden report recommended changing the law, and there was public uproar on either side of the argument. ${ }^{3}$ It was during this time that Britten composed Sechs Hölderlin-Fragmente (1958). Again, his arrangement of the texts lends itself to the interpretation that the narrator of the cycle is gay. The cycle begins with the rejection by society of the narrator. He then laments the loss of innocence and his inability to return to the bliss he knew before he encountered this rejection. He defends his choice of lover and realizes that it is important to find happiness wherever possible. The cycle ends with the narrator's realization in "Die Linien des Lebens" (The Lines of Life) that life is full of diversity and that he is just on one of these possible "lines." In many ways, this narrative is the most overt in terms of the interpretation that the cycles reflect the experience of the two homosexuals, especially in the third setting of the cycle, "Sokrates und Alcibiades," which, by its very title, verifies that the love relationship alluded to in the text is between two men.

\footnotetext{
${ }^{3}$ Hyde, H. Montgomery, The Love That Dared Not Speak Its Name: A Candid History of Homosexuality in Britain (Boston: Little, Brown and Company, 1970), 229-235.
} 
The political turmoil of the day may have motivated the composer to make such a bold statement reflecting upon his life experiences and those of his partner. However, as in the past, the meaning of the cycle is masked by the language, in this case German. More than with the Italian language of the Michelangelo Sonnets however, members of the audience may have been able to understand the text and its implications. Moving from the Italian, to Donne's formal, poetic English, to Hardy's contemporary English though still having a fairly masked meaning, then to the German, with a much less veiled meaning, it seems that in these cycles, Britten not only used his lover as spokesperson for their political views but also that his meaning became less and less disguised as time goes by. This is continued in the fifth and final cycle that the composer wrote for the two men.

By 1969, when Who Are These Children? was written, the law banning consensual homosexual acts between two men had been struck down, and here we see Britten at his most overt. The coming-out process that almost reached culmination in the narrative of Sechs Hölderlin-Fragmente is fully realized here. This cycle examines society's cruelty to innocent children first from the perspective of the child and then of the adult. Each half begins with a carefree and innocent child, who is then wounded by the adults' rules and habits, and ultimately dies because of these wounds. It is plausible to assume that the child in the narrative is in fact Britten and is therefore homosexual, and if this were true, then the description of the horrors to which the young homosexual is subjected by a hostile and self-righteous society is in no way veiled, as had been the case with the previous cycle, to varying degrees.

The composition of the five song cycles spans almost the entire length of Britten and Pears's relationship. The examination of these works reveals not only the way that Britten wrote for this particular voice throughout this period, but also that he seemed to use these compositions 
to reveal thoughts and feelings that he otherwise seemed unwilling to do. Donald Mitchell, a friend of the two men and editor of the published letters of Britten, remarked ". . . they [Britten and Pears] seemed reluctant overtly to express support for causes one presumed they had at heart" and that "for him [Britten], political deeds were his works; and if we want to locate the 'social feeling' that were his politics, then we must turn to [his compositions], each of which represents commitment to a specific social belief." 4 In this way, not only did the composer write vocal music suited particularly to his partner's voice, but he chose and organized texts that then would say what he and his partner otherwise would not.

\footnotetext{
${ }^{4}$ Taken from interviews conducted by Humphrey Carpenter and found in Humphrey Carpenter, Benjamin Britten: A Biography (New York: Macmillan Publishing Company, 1992), 486.
} 


\section{COMPREHENSIVE BIBLIOGRAPHY}

* Works consulted for this paper have an asterisk.

\section{REFERENCE}

*Craggs, Stewart R. Benjamin Britten: A Bio-Bibliography. Westport, Connecticut: Greenwood Press, 2002.

Evans, John. A Britten Source Book. Aldeburgh: Britten-Pears Library, 1987.

*Hodgson, Peter John. Benjamin Britten: A Guide to Research. New York: Garland Publishing, 1996.

Parsons, Charles H. A Benjamin Britten Discography. Lewiston, NY: E. Mellen Press, 1990.

Rudnick, Tracey Esther. "Britten-related Holdings in the Harry Ransom Humanities Research Center: An Annotated Catalog." MM diss, University of Texas at Austin, 1991.

Thacker, Martin N. "The Organization of Composer Archives with Special Reference to the Britten-Pears Library, Aldeburgh, Suffolk.” Mphil thesis, University of North London, 1986.

Wilson, Paul. A Britten Source Book: Revised Bibliography. Aldeburgh, Suffolk: Britten-Pears Library, 1980. 


\section{LIFE}

Allen, S. A. "Benjamin Britten and Christianity." PhD diss., University of Oxford, 2003

Amis, John. A Miscellany: My Life, My Music. London: Faber, 1985.

Bassi, Adriano. Benjamin Britten. Milano: Targa italiana, 1989.

Bedford, Steuart. "Composer and Conductor: Annals of a Collaboration." The Opera Quarterly, USA IV, no. 3 (Fall 1986): 60-74.

Berger, Melvin. Masters of Modern Music. New York: Lothrop, 1971.

Blanco Bazan, Agustin. "Una evocacion de Benjamin Britten a una decada de su muerte.” Ritmo, Spain 577 (1987): 10-14.

Blyth, Alan, ed. Remembering Britten. London: Hutchinson, 1981.

Blythe, Ronald, ed. Aldeburgh Anthology. London: Faber \& Faber, 1972.

Bourgoin, Suzanne M. Contemporary Musicians: Profiles of the People in Music. Volume 15. Detroit, Michigan: Gale Research, Inc., 1996.

Bowen, Meirion. "Britten and Tippett: Die Erneuerung in der englischen Musik." Osterreichische Musikzeitschrift, Austria XVI, no. 3-4 (March-April 1986): 155-164.

Brauneiss, Leopold. “Zur Aktualitat Benjamin Brittens.” Musiktheorie 11, no. 2 (1996): 125-137.

Bray, Trevor. Contemporary Music: Case Studies I-II. Milton Keyes: The Open University Press, 1974.

. "Frank Bridge and His 'Quasi-adopted Son."' The Music Review, UK XLV, no. 2 (May 1984): 135-138.

Breque, Jean-Michel. "Henry James, un univers enigmatique." L'avant-scene opera 173 (September-October 1996): 138-143.

Brett, Philip. "Musicality, Essentialism, and the Closet." In Queering the Pitch: The New Gay and Lesbian Musicology, 9-26. New York: Routledge, 1994.

Britten, Benjamin. On Receving the First Aspen Award. London: Faber and Faber, 1964.

Britten (Welford), Beth. My Brother Benjamin. Abbotsbrook, Bourne End, Buckinghamshire: Kensal Press, 1986. 
Brook, Donald. Composers' Gallery: Biographical Sketches of Contemporary Composers. London: Rockcliff, 1946.

*Carpenter, Humphrey. Benjamin Britten: A Biography. London: Faber \& Faber, 1992.

Chisell, Joan. "St. Cecilia - Purcell and Britten." Monthly Musical Record LXXIII (July-August 1943): 123-127.

Christiansen, Rupert. “The Branding of Britten.” Opera, UK 54, no 3 (March 2003): 293-297.

Clark, Kenneth; Reynolds Stone. The Other Side of the Alde. London: Faber \& Faber, 1963.

Cooke, Mervyn. The Cambridge Companion to Benjamin Britten. Cambridge: Cambridge University Press, 1999.

Cowan, Thomas Dale. Gay Men and Women Who Enriched the World. Los Angeles: Alyson Publications, 1996.

Craig, John . Britten's Aldeburgh. Leominster, Herefordshire: Whittington Press, 1997.

Dickinson, Peter. "British-American Interactions: Composer and Students." The Musical Times, UK CXXIV (July 1983): 411-413, 417.

Docherty, Barbara. "We Know for Whom We Mourn: Britten, Auden and the Politics of 1936." Tетро 192 (April 1995): 22-27.

. “When Feeling Becomes Thought' Britten, Text and Biography, 1928-31.” Tempo 184 (March 1993): 24-29.

Dommett, Claire. “The Britten Evening.” Dance Europe, London, no. 44 (October 2001): 39.

Drew, David. "Britten and His Fellow Composers: Six Footnotes for a Seventieth Birthday." In On Mahler and Britten: Essays in Honour of Donald Mitchell on His Seventieth Birthday, ed. Philip Reed and Donald Mitchell, 146-166. Woodbridge, United Kingdom: Boydell \& Brewer, 1995.

Duncan, Ronald. Working with Britten: A Personal Memoir. Bideford, Devonshire: Rebel, 1981.

Egri, Peter. "A Portrait of the Artist as a Caricaturist: Picasso, Joyce, and Britten." Acta litteraria academiae scientiarum hungaricae XXIV, no. 3-4 (1982): 353-374.

Elliott, Graham John. "Benjamin Britten: The Things Spiritual." PhD diss., University of Wales, 1985.

Ermen, Reinhard. "Benjamin Britten.” In Komponisten der Gegenwart, ed. Hanns-Werner Heister, 494-507. München, Germany: Edition Text \& Kritik, 1992. 
Farrelly, Alan; Ron Morrison. Two by Two. Adelaide: Rigby, 1969.

Fielden, Jan. Composers' Letters. London: Marginalia, 1994.

Fischlin, Daniel T. "'Eros is in the word:' Music, Homoerotic Desire, and the Psychopathologies of Fascism, or the 'Strangely Fruitful Intercourse' of Thomas Mann and Benjamin Britten." In The Work of Opera: Genre, Nationhood, and Sexual Difference, ed. Richard Dellamora, 209-233. New York, NY: Columbia University Press, 1997.

Flynn, William. "Britten the Progressive.” The Music Review, UK XLIV/1 (February 1983): 4452.

Gabbard, James Henry. "Benjamin Britten: His Music, the Man, and His Times." DME diss., Colorado State College, 1969.

Garnham, Maureen. As I Saw It: Basil Douglas, Benjamin Britten and The English Opera Group 1955-1957. London: St. George's Publications, 1998.

Garvie, Peter. "Darkly Bright: Britten's Moral Imagination.” Cahiers canadiens de musique, Canada 1 (Spring-Summer 1970): 59-66.

Gaulle, Xavier de. Benjamin Britten ou l'impossible quietude. Serie musique. Arles: Actes Sud, 1996.

Gill, John. Queer Noises: Male and Female Homosexuality in Twentieth Century Music. Minneapolis: University of Minnesota, 1995.

Gishford, Anthony. "Der Aussenseiter von Aldeburgh.” Melos 35, no. 11 (November 1968): 424-429. . Tribute to Benjamin Britten on His Fiftieth Birthday. London: Faber and Faber, 1963.

Godfrey, Paul. Once in a While the Odd Thing Happens: A Play from the Life of Benjamin Britten. London: Methuen Drama, 1990.

Goodwin, Noel. "A Viewpoint on Britten." Music and Musicians XII (November 1963): 22-23.

Greenwood, Barrie L. "Britten vs. Britain, of the Differences Between Words: Discrepancies in Britten-Pears Letters and Diaries, Vols. 1 \& 2." Crescendo: Bulletin of the International Association of Music Libraries (1998): 19-23.

Gualerzi, Giorgio. “Britten in Italy.” Opera, UK 48, no. 12 (December 1997): 1418-1424. 
Gulbenkian, Fundação Calouste. Exposição Benjamin Britten :Lisboa, Galeria da Fundação Calouste Gulbenkian, 10 de maio a 5 de junho de 1967. Lisboa: Galeria da Fundação, 1967.

Hamburger, Paul. "Mainly about Britten." Music Survey III (December 1950): 98-107.

*Headington, Christopher. Britten. London: Eyre Methuen, 1981.

Hines, Robert Stephen. "Benjamin Britten.” Choral Journal, USA XI, no. 6 (February 1971): 17$19,24$.

Holst, Imogen. Britten. The Great Composers. London: Faber \& Faber, 1966.

Hunt, Rosemary. "Droga tworcza Benjamina Brittena." Ruch muzyczny, Poland 8, 9 (April 1977): 3-4, 16-18.

Hurd, Michael. Benjamin Britten. Biographies of Great Musicians. London: Novello, 1966.

Hurlimann, Martin. "Benjamin Britten (1974)." In Die Musik und ihr Preis: Die Internationale Ernst von Siemens Stiftung, 28-32. Regensburg: ConBrio, 1994.

Hylton Edwards, Stewart. Critics and Composers: Selected Articles, Lectures, and Radio Talks. New York: Vantage, 1984.

Jennings, John Wells. “The Influence of W.H. Auden on Benjamin Britten.” DMA diss, University of Illinois, Urbana-Champaign, 1979.

Kalk, Thomas; Sabine Schnieder. "Benjamin Britten (1913-1976): Ein Verzeichnis der in Offentlichen Musikbibliotheken der Bundesrepublik Deutschland vorhandenen Werke." Forum Musikbibliothek: Beitrage und Informationen aus der musikbibliothekarischen Praxis, no. 3 (1988): 229-265.

Keller, Hans Heinrich. Benjamin Britten. London: Boosey \& Hawkes, 1949.

Keller, Hans. "Britten and Mozart." Music and Letters XXIX, no. 1 (January 1948): 17-30.

Kendall, Alan. Benjamin Britten. London: Macmillan, 1973.

*Kennedy, Michael. Britten. Master Musicians Series. London: Dent, 1981.

Kildea, Paul Francis. Selling Britten: Music and the Marketplace. Oxford University Press, 2002.

Kildea, Paul Francis and Benjamin Britten. Britten on Music. Oxford: Oxford University Press, 2003. 
Kovnackaja, Ljudmila. "An Outstanding Master. On the Occasion of the 60th Anniversary of the Birth of B. Britten.” Sovetskaja muzyka, USSR 11 (November 1973): 117-123.

Kovnackaja, Ljudmila. Bendzamin Britten. Leningrad: Sovetskij kompositor, 1974.

Labie, Jean-Francois. "Une innocence ambigue." L'avant-scene opera 173 (September-October 1996): 62-67.

Law, Joe. "Linking the Past with the Present: A Conversation with Nancy Evans and Eric Crozier." The Opera Quarterly III/1 (Spring 1985): 72-79.

Law, Joe Keith. “'I Must Get a Better Composer ... But How?': The Early Letters and Diaries of Benjamin Britten." The Opera Quarterly 9, no 2 (Winter 1992): 31-51.

Lebois, Andre. "Musique, nature et litterature en Grande-Bretagne." Annales de L'universite de Toulouse-Le Mirail, France Vol. VI, no. 2 (1970): 57-67.

Lindlar, Heinrich. Benjamin Britten. Bonn: Breitkopf \& Härtel, 1954.

Manning, R.J. "Benjamin Britten.” Monthly Music Record LXXIII (June 1943): 106-111.

Mason, Colin. "Benjamin Britten.” The Musical Times LXXXIX (March 1948), 73-5; (April 1948), 107-110; (May 1948): 139-142.

Matthews, David. Britten. London: Haus, 2003.

. "The Rehabilitation of the Vernacular." In Music and the Politics of Culture, ed. Christopher Norris, 240-251. London: Lawrence and Wishart, 1989.

McVeagh, Diana, et al. The New Grove Twentieth-Century English Masters: Elgar, Delius, Vaughan Williams, Holst, Walton, Tippett, Britten. London: Macmillan, 1986.

Metzelaar, Helen. "Who Sent Benjamin Britten Hundreds of Eggs from Holland? A Somewhat One-sided Friendship." KeyNotes: Musical Life in the Netherlands 31, no. 3 (September 1997): 17-21.

Meyer, Ernst Hermann. "Benjamin Britten zum Gedenken." Handel-Jahrbuch, Germany Vol. XXIV (1978): 107.

Mitchell, Donald. Britten and Auden in the Thirties: The Year 1936. London: Faber \& Faber, 1981.

. "Outline Model for a Biography of Benjamin Britten." In Festschrift Albi Rosenthal, ed. Albi Rosenthal and Rudolf Elvers, 239-251. Tutzing: Schneider, 1984. 
. "Contemporary Chronicle: Britten and Marschner." Musical Opinion LXXVII (January 1954): 217-219.

*Mitchell, Donald, ed. Letters from a Life: The Selected Letters and Diaries of Benjamin Britten, 1913-1976: Volume One (1923-1939). Berkeley: University of California Press, 1991.

* Letters from a Life: The Selected Letters and Diaries of Benjamin Britten, 19131976: Volume Two (1939-1945). Berkeley: University of California Press, 1991.

* _ Letters from a Life: The Selected Letters and Diaries of Benjamin Britten, 19131976: Volume Three (1945-1951). Berkeley: University of California Press, 2005.

*Mitchell, Donald; Evans, John. Benjamin Britten, 1913-1976: Pictures from a Life. A Pictorial Biography. London: Faber, 1978.

Mitchell, Kathleen. "Edinburgh Diary 1968." In On Mahler and Britten: Essays in Honour of Donald Mitchell on His Seventieth Birthday, ed. Philip Reed and Donald Mitchell, 193212. Woodbridge, United Kingdom: Boydell \& Brewer, 1995.

Myers, Patricia Hoth. "Benjamin Britten: An Annotated Bibliography and Discography: A Research Paper Presented to the Faculty of the Department of Librarianship, San Jose State University, in Partial Fulfillment of the Requirements for the Degree Master of Library Science.” MLS doc., San Jose University, 1977.

Nest'eva, Marin “Ctoby prazdnik byl so mnoj.” Muzykal'naja akademija 2 (1992): 29-34.

*Oliver, Michael. Benjamin Britten. Twentieth-century Composers. London: Phaidon, 1996.

Ottaway, D.H. "A Note on Britten." Monthly Musical Record 81, no. 930 (October 1951): 207211.

*Palmer, Christopher, ed. The Britten Companion. Cambridge: Cambridge University Press, 1984.

Pears, Peter. "Britten, der Erneuerer des englischen Liedes." Musik der Zeit, no. 7 (1954): 21-30.

Piper, Myfanwy. "Venice, 1954." In On Mahler and Britten: Essays in Honour of Donald Mitchell on His Seventieth Birthday, ed. Philip Reed and Donald Mitchell, 229-230. Woodbridge, United Kingdom: Boydell \& Brewer, 1995.

Pitt, Charles. Benjamin Britten 1913-1976. Paris: Theatre nationale de l'Opera, 1981.

Reed, Philip, ed. and Donald Mitchell, ed. On Mahler and Britten: Essays in Honour of Donald Mitchell on His Seventieth Birthday. Aldeburgh Studies in Music, no. 3. Woodbridge, United Kingdom: Boydell \& Brewer, 1995. 
Robertson, Alec. Dear Alec ... A Tribute for His Eightieth Birthday from Friends Known and Unknown. Saturday 3 June 1972. Worcester: Stanbrook Abbey, 1972

Robinson, Suzanne. “'An English Composer Sees America': Benjamin Britten and the North American Press, 1939-42." American Music: A Quarterly Journal Devoted to All Aspects of American Music and Music in America 15, no. 3 (Fall 1997): 321-351.

Robinson, Suzanne. "'You Absolutely Owe It to England to Stay Here': Copland as Mentor to Britten, 1939-1942." Context: A Journal of Music Research 8 (Summer 1994): 3-11.

Saremba, Meinhard. Elgar, Britten \& Co.: Eine Geschichte der britischen Musik in zwolf Portraits. Zurich: M\&T, 1994.

Schafer, Murray. "Britten in Interview." Music and Musicians XII (November 1963): 14-20.

Schreiber, Ulrich. "Pathos und Liberlitat. Zum Tod des Komponisten Benjamin Britten." HiFiStereophonie, Germany XVI, no. 2 (1977): 149.

Searle, Humphrey; Layton, Robert. Twentieth-century Composers. III: Britain, Scandinavia, and the Netherlands. New York: Holt, Rinehart and Winston, 1973.

Smith, Patrick J. "Vec Britten: A Non-British view.” Opera, UK 47, no. 9 (September 1996): 1016-1020.

Stansky, Peter; William Abrahams. London's Burning: Life, Death, and Art in the Second World War. Stanford: Stanford University, 1994.

Sutcliffe, James Helme. "A Life for Music: Benjamin Britten - A Biographical Sketch.” The Opera Quarterly, USA IV, no. 3 (Fall 1986): 4-10.

. "Der Komponist Benjamin Britten: Versuch einer Wurdigung." Oper Heute: Ein Almanach der Musikbuhne (1978): 81-106.

Tauragis, Adeodatas. Bendzhamin Britten. Moskva: Izd-vo "Muzyka," 1965.

Teachout, Terry. “England's Greatest Composer.” Commentary 109, no. 6 (June 2000): 58-62.

Thompson, Leonard. "Skies Turned Black.” The Opera Quarterly 12, no. 1 (1995): 71-77.

Tranchell, Peter. "Britten and Brittenites." Music \& Letters XXXIV, no. 2 (April 1953): 124-132.

Trend, Michael. The Music Makers: Heirs and Rebels of the English Musical Renaissance, Edward Elgar to Benjamin Britten. London: Weidenfeld \& Nicolson, 1985. 
Tuchowski, Andrzej. “Artystyczne credo Benjamina Britenna.” Ruch muzyczny, Poland 19 (September 1979): 4-5. . Benjamin Britten: twórca, dzielo, epoka. Krakow: Musica Iagellonica, 1994.

Valencia, Mark. "Written for Britten." The Musical Times 132, no. 1784 (October 1991): 499.

Visnevskaja, Galina. Galina: Istorija zizni. Moskva: Novosti, 1991.

Warrack, John. "Britten - Musician of the Year; In Conversation with Benjamin Britten." Musical America LXXXIV, no. 10 (December 1964): 20, 272-274.

Weber, J.F. Benjamin Britten. Utica, NY: Weber, 1975.

White, Eric Walter. Benjamin Britten, A Sketch of His Life and Works. London: Boosey \& Hawkes, 1954.

. "Benjamin Britten." Canon XII (January 1959), 189-190.

*Whitall, Arnold. "Benjamin Britten." The Music Review XXIII (November 1962): 314-316. . "Cross-currents and Convergencies: Britten, Maxwell Davies, and the Sense of Place.” Tempo 204 (April 1998): 5-11.

Widdicombe, Gillian. "Aldeburgh: Straining into the Wind." Opera, UK 47, no. 9 (September 1996): 1012-1016.

Wright, Basil. "Britten and Documentary." The Musical Times CIV (November 1963): 779-780.

Young, Percy M. Britten. London: E. Benn, 1966. 


\section{PETER PEARS}

*Headington, Christopher. Peter Pears: A Biography. London: Faber \& Faber, 1993.

*Pears, Peter. The Travel Diaries of Peter Pears, 1936-1978. Aldeburgh Studies in Music, no. 2. Woodbridge, United Kingdom: Boydell \& Brewer, 1995.

*Thorpe, Marion, editor. "Peter Pears: A Tribute on His 75th Birthday.” London: Faber, 1985. 


\section{WORKS}

\section{GENERAL CRITICISM AND ANALYSIS}

Aguilar, Helene J.F. de. A Dangerous Faith: Benjamin Britten's Language. New York: Poetry in Review Foundation, 1982

Atterfors, Goran. "Musikdramatisk forstlingsverk.” Musikrevy 44 (1989): 19-20.

Banks, Paul. Benjamin Britten: A Catalogue of the Published Works. Aldeburgh, Suffolk: Britten-Pears Library, 1999.

. "Encompassing a Plenitude: Cataloguing the Works of Benjamin Britten." Studia musicologica Academiae Scientarum Hungaricae 34, no. 3-4 (1992): 317-343.

Barbieri, Stefania. "Le voci bianche nella musica di Benjamin Britten." Tesi di laurea, Universita degli Studi di Torino, 1991.

Batchelor, Stephen. "Benjamin Britten and His Works for the Guitar." Journal of the British Music Society 18 (1996): 35-49.

Boonin, Joseph. Benjamin Britten: A Catalogue of the Published Works. South Hackensack, NJ: J. Boonin, 1972.

Brill, Hans Gerd. "Die Gitarre in der Musik des 20. Jahrhunderts." Phd diss., Universitat Munster, 1993.

Briner, Andres. "Benjamin Britten und sein Werk fur die zeitgenossische Musik." Universitas, Germany XXXII/2 (1977): 129-132.

Brown, David. "Stimulus and Form in Britten's Work." Music \& Letters XXXIX (July 1958): 218-26.

Bryce, Michael E. "A Conductor's Analysis of Selected Works by Andrea Gabrieli, Jacob Handl, W.A. Mozart, Anton Bruckner, Benjamin Britten, Daniel Pinkham, and Vincent Persichetti." MM thesis, Southwestern Baptist Theological Seminary, 1982.

Burgess, Sharon. “A Study of Benjamin Britten's and W.H. Auden's Collaborative Compositions, 1932-1939." MA thesis, Ball State University, 1980.

Chase, Mary Fran. “'Guide to Britten's ...' A Reference Guide to Benjamin Britten's Friday Afternoons - Missa Brevis - Psalm 150." MA thesis, Trenton State College, 1989. 
Cimini, Gabriele. Radici dell'arte musicale contemporanea europea: B. Britten, F. Martin, B.A. Zimmerman. Roma: Sovera, 1999.

Cooke, Mervyn. "Britten and Bali." The Journal of Musicological Research, UK VII/4 (1988): 307-340.

. Britten and the Far East: Asian Influences in the Music of Benjamin Britten.

Woodbridge, Suffolk: Boydell Press, 1998.

. "Britten and the Sho." The Musical Times 129, no. 1743 (May 1988): 231-233.

. "Oriental Influences in the Music of Benjamin Britten." PhD diss., Cambridge

University King's College, 1989.

Coroniti, Joseph A. Poetry as Text in Twentieth-century Vocal Music: From Stravinsky to Reich. Studies in the History and Interpretation of Music, no. 35. Lewiston, NY: E. Mellen Press, 1992.

Couderc, Gilles. "Fils prodigues et peres assassins." L'avant-scene opera 173 (SeptemberOctober 1996): 144-150.

Craig, John William. "Thematic Construction and Development in the Chamber Music of Benjamin Britten.” MA diss: University of North Carolina, 1976.

Cusin, Michel; Adolphe Haberer; Josiane Paccaud-Huguet. De la littérature à la lettre: poésie, fiction, arts: domaine anglophone. Lyon: Presses universitaires de Lyon, 1997.

Dame, Frederick William. "The Part(ed) Song: A Subtle, Erotic View of the Bawdy and Victorian Society." Jahrbuch fur Volksliedforschung 41 (1996): 40-53.

Docherty, Barbara. "Sentence into Cadence: The Word-setting of Tippett and Britten." Tempo 166 (September 1988): 2-11.

. "Syllogism and Symbol: Britten, Tippett and English Text." Contemporary Music Review 5 (1989): 37-63.

Douglas, John R. "The Composer and His Music on Record." Library Journal 92, no. 6 (March 1967): 1117-1121.

Eschment, Ulrich-Alexander. Benjamin Britten: Die Kammermusik fur Streicher. Deutsche Hochschulschriften, no. 2281. Egelsbach: Hansel-Hohenhausen, 1995.

Evans, Peter. "Sonata Structures in Early Britten." Tempo 82 (Fall 1967): 2-13.

*__ . The Music of Benjamin Britten. Minneapolis: University of Minnesota Press, 1979. 
Foreman, Lewis. "Benjamin Britten and The Rescue." Tempo 166 (September 1988): 28-33.

Frame, M.B. "The Development of the Nocturnal Music of Benjamin Britten from Serenade to Nocturne." MA thesis, Queen's University of Belfast, 1990.

Gilardino, Angelo. "Aspetti della music per chitarra del secolo XX.” Il Fronimo, Italy I/2 (January 1973): 7-10.

. "La musica contemporanea per chitarra in Gran Bretagna." Il Fronimo, Italy I, no. 5 (October 1973): 8-14.

. "La musica per chitarra nel secolo XX - (III) Gran Bretagna." Il Fronimo, Italy VIII, no. 33 (October 1980): 25-29.

Goehr, Alexander. "The Fusion of Sacred and Secular Elements in Benjamin Britten's Vocal and Choral Literature.” DMA diss, University. of Rochester, 1973.

. The Songs We Love to Sing: (Variations on a Theme by Benjamin Britten). Aldeburgh: Britten-Pears Library, 1998.

Goluses, Nicholas. "British Guitar Music: The Composers and Their Works." Guitar Review 106 (Summer 1996): 30-36.

Handel, Darrell. "Britten's Use of the Passacaglia.” Tempo, UK 94 (Fall 1970): 2-6.

Hardwick, Peter. "The Influence of Old English Music on Four Contemporary English Composers." Canadian Association of University Schools of Music Journal, Canada III/1 (Fall 1973): 19-40.

. "The Revival of Interest in Old English Music in Victorian England, and the Impact of this Revival on Music Composed in the Twentieth Century." PhD diss, University of Washington, 1973.

Headington, Christopher. "Britten's Music and Its Significance Today." The Chesterian 34 (Spring 1960): 129-132.

Hladky, Keyte Marie. "Benjamin Britten's Settings of English Sonnets." MA thesis, University of Oregon, 1986.

Holst, Imogen. "Purcell Made Practicable." Music and Musicians XVII, no. 10 (June 1969): 48.

Hsu, Ti-fei. "Chinese Influence in Four Twentieth Century Song Cycles by Rouseel, Carpenter, Griffes and Britten." DMA doc, American Conservatory of Music, 1988. 
Isaac-Hufstader, LeAnn. "Conducting Considerations for Selected Compositions by Tchaikovsky, Britten, and Mendelssohn.” MM thesis, University of Texas at El Paso, 1994.

Keller, Hans. "Resistances to Britten's Music: Their Psychology." Music Survey II, no. 4 (Spring 1950): 227-236.

Keller, Hans; Gerold W. Gruber; Susan Bradshaw; Michael Meixner. Functional Analysis: The Unity of Contrasting Themes; Complete Edition of the Analytical Scores. Frankfurt: Lang, 2001.

Kermol, Enzo; Mariselda Tessarolo. La musica del cinema. Roma: Bulzoni, 1996.

Kovnackaja, Ljudmila. “The New English Musical Renaissance.” Sovetskaja muzyka, USSR 7 (July 1973): 118-125.

Krannich, Sabine. "Benjamin Britten und seine Verwen-dung fur den Musikunterricht." MA diss, Hochschule fur Musik und darstellende Kunst, Salzburg, 1983.

Kremin, Matthias. “'Happy were he..' Benjamin Brittens Werke fur Gitarre und Gesang. Ein Uberblick zum 75. Geburtstag des Komponisten.” Gitarre \& Laute X/6 (1988): 49-56.

Kyle, James Dewey. "The Recitative in the Dramatic Vocal Works of Benjamin Britten.” MCM thesis, Southwestern Theological Seminary, 1961.

Labie, Jean-Francois. "La Musique de la langue anglaise.” L'avant-scene opera 146 (May-June 1992): 4-9.

Lalo, Mari. “Kak vozrozdalas' anglijskaja opera.” Muzykal'naja akademija, no. 3 (1994): 36-39.

Landau, Anneliese. The Lied: The Unfolding of Its Style. Washington, D.C., University Press of America, 1980.

Libbert, Jurgen. "Benjamin Britten und die Gitarre: Eine Wurdigung anlasslich seines 10. Todestages.” Musikblatt 13, no. 6 (1986): 51-59.

Loisy, Jane. "Ecoute musicale et developpement de l'expressivite." Bulletin de psychologie 46, no. 411 (May-August 1992): 440-448.

Malm, William. Six Hidden Views of Japanese Music. The Ernest Bloch Lectures. Berkeley: University of California Press, 1986.

Mark, Christopher. "Britten and the Circle of Fifths." Journal of the Royal Musical Association 119, no. 2 (1994): 268-297.

. "Contextually Transformed Tonality in Britten." Music Analysis, UK IV, no. 3

(October 1985): 265-287. 
. Early Benjamin Britten: A Study of Stylistic and Technical Evolution. New York:

Garland, 1995.

. "Simplicity in Early Britten.” Tempo, UK 147 (December 1983): 8-14.

. "Stylistic and Technical Evolution in the Early Music of Britten." PhD diss., University of Southampton, 1989.

Martin, A. Lewis. "A Musico-dramatic Study of the Church Choral Dramas of Benjamin Britten.” MA diss., University of North Carolina, 1975.

Matthews, Colin. “Britten's Indian Summer.” Soundings, UK VI (1977): 42-50.

Maust, Wilbur R. Benjamin Britten's Music of Conscience and Compassion. Waterloo, Ontario: Conrad Grebel College, 1987.

McDonald, Ellen. "Women in Benjamin Britten's Operas.” The Opera Quarterly, USA IV, no. 3 (Fall 1986): 83-101.

Mertl, Monika. "Neuer Sinn aus alten Formen: Musikalisch-dramatische Darstellung im Kirchenraum.” Parnass, Austria 2 (March-April 1985): 62-67.

Michon, Jacques. "Relations dialectiquies entre parole et musique dans la musique vocale: Essai de semiologie comparee.” In Poetique(s), 355-372. Lyon: Université de Lyon, 1983.

Mies, Paul. "Trauermusiken von Heinrich Schutz bis Benjamin Britten.” Musica sacra, Germany XCIII, no. 4 (1973): 206-214.

Mitchell, Donald. “Britten's Revisionary Practice: Practical and Creative.” Tempo 66/67 (Autumn/Winter 1963): 15-22.

. “An Afterword on Britten's Pagodas: The Balinese Sources.” Tempo, UK 152 (March 1985): 7-11.

. "Catching on to the Technique in Pagoda-land." Tempo, UK 146 (September 1983): 13-24.

. "The Later Development of Benjamin Britten." The Chesterian XXVII (July 1953): 1-7; (October 1952): 35-40.

*Mitchell, Donald, ed. and Hans Keller, ed. Benjamin Britten: A Commentary on His Works from a Group of Specialists. London: Rockcliff, 1952.

Mosley, Michael. "Twentieth-century Guitar Idiom as Reflected in Compositions by Berkeley, Britten, and Martin." MM thesis, Indiana University, 1969. 
Nadeau, Roland. "The Crisis of Tonality: What is Avant-garde?" Music Educators Journal, USA LXVII/7 (March 1981): 37-41.

Nears, Colin. "Bridging a Distance: Television and Dance." In Parallel Lines: Media Representations of Dance, ed. Stephanie Jordan and David Allen, 147-159. London, England: Arts Council of Great Britain, 1993.

Northcote, S. Byrd to Britten: A Survey of English Song. London: Baker, 1966.

Ottobre, Alfonso. "Il coro di voci bianche e la music del Novecento." Nuova rivista musicale italiana 29, no. 2 (April-June 1995): 297-305.

Pettit, Jane R. "Paradigmatic Analysis: A Reconsideration." MA thesis, University of Leeds, 1987.

Pouncy, Siân Lynette. "The Variation Concept in the Works of Benjamin Britten." MA Thesis, University of Wales, 1976.

Raynor, Henry. "Influence and Achievement: Some Thoughts on Twentieth Century English Song." The Chesterian XXX (Winter 1956): 66-75.

Rhoads, Mary Ruth Schneyer. "Influences of Japanese Hogaku Manifest in Selected Compositions by Peter Mennin and Benjamin Britten.” PhD diss, Michigan State University, 1969.

Rigaud, N.J.; Paul Denizot. La Violence dans la littérature et la pensée anglaises. Aix-enProvence: Publications Université de Provence Aix-Marseille 1, 1989.

Rio, Marie-Noel. "Rencontre avec Pierre Barrat, metteur en scene et pedagogue." L'avant-scene opera 173 (September-October 1996): 68-77.

Royal School of Church Music. English Church Music. London, England: The Royal School of Church Music, 1977.

Ruggirello, Marywynne. "Special Orchestral Effects in the Operas of Benjamin Britten.” MA thesis, California State University, Northridge, 1980.

Rupprecht, Philip. Britten's Musical Language. Cambridge: Cambridge University Press, 2001.

. "Tonal Stratification and Conflict in the Music of Benjamin Britten." PhD diss, Yale University, 1993.

Samson, Jim T. "Nowe tendencje w angielskiej muzyce orkiestrowej." Muzyka, Poland Vol. XXXVI, no. 2 (1981): 3-21. 
Scherr, Suzanne Colette. "Non-determined Temporal Devices in Post-1960 Britten: An Analytical Investigation.” MA thesis, University of California, Los Angeles, 1981.

Schiff, David. "Learning from Britten.” Opera News 62, no. 8 (January 3, 1998): 18-21.

Schoffman, Nachum. "Persistent Notes and Proximity Harmonization." Indiana Theory Review 14, no. 1 (Spring 1993): 95-131.

Schwartz, Elliott; Childs, Barney, eds. Contemporary Composers on Contemporary Music. New York: Holt, Rinehart a Winston, 1967.

Sheppard, W. Anthony. "Modernist Music Theater: Exotic Influences and Ritualized Performance.” PhD diss., Princeton University, 1996.

Sinclair, Frances Teresa. "Benjamin Britten's Music for Children: Reflections on Youth and Innocence.” DMA diss., University of North Carolina at Greensboro, 1997.

Speranza, Ennio. "Britten e le Metamorfosi di Ovidio." I fiati 1, no. 2 (October-November 1994): 46-51.

Strode, Rosamund. "Writing and Copying: A Superficial Survey of Benjamin Britten's Music." In On Mahler and Britten: Essays in Honour of Donald Mitchell on His Seventieth Birthday ed. Philip Reed and Donald Mitchell, 280-289. Woodbridge, United Kingdom: Boydell \& Brewer, 1995.

Stuart, Charles. "Britten 'The Eclectic."' Music Survey II (Spring 1950): 247-50.

Stuckenschmidt, Hans. "Benjamin Britten's Werk und sein Beitrag zur heutigen.” Universitas, Germany XXIX (1974): 641-664.

Sutcliffe, James Helme. Die Bühnenwerke Benjamin Brittens. S.1.: J.H. Sutcliffe, 1983.

Tarasti, Eero; ed. Paul Forsell and Richard Littlefield. Musical semiotics in growth. Acta semiotica fennica, no. 4. Imatra: International Semiotics Institute, 1996.

Whitesell, Lloyd. "Men With a Past: Music and the "Anxiety of Influence." Nineteenth-Century Music 18, no. 2 (Fall 1994): 152-167.

. "Images of Self in the Music of Benjamin Britten." PhD diss., State University of New York at Stony Brook, 1993.

Whittall, Arnold. "Along the Knife-edge: The Topic of Transcendence in Britten's Musical Aesthetic." In On Mahler and Britten: Essays in Honour of Donald Mitchell on His Seventieth Birthday, ed. Philip Reed and Donald Mitchell, 290-298. Woodbridge, United Kingdom: Boydell \& Brewer, 1995. 
. Music since the First World War. London: Dent, 1977.

. The Music of Britten and Tippett: Studies in Themes and Techniques. Cambridge: Cambridge University, 1982.

. "The Signs of Genre; Britten's Version of Pastoral." In Sundry Sorts of Music Books: Essays on the British Library Collections, ed. C.A. Banks, Arthur Searle, Malcolm Turner and O.W. Neighhbour, 363-374. London: British Library, 1993.

. "The Study of Britten: Triadic Harmony and Tonal Structure." Proceedings of the Royal Musical Association CVI (1979-1980): 27-41.

Woolridge, David. "Some Performance Problems in Contemporary Music." Tempo 79 (Winter 1967): 9-14.

Yen, Ruey Shyang. "Exoticism in Modern Guitar Music: Works of Carlo Domnioni, Ravi Shankar, Benjamin Britten, Dusan Bodganovic." DMA diss., Arizona State University, 1996.

Young, Jack Donald. "World War II and its Affects on Selected English, French, and Russian Composers.” MM thesis, Baylor University, 1986 


\section{SOLO VOCAL WORKS}

\section{GENERAL}

Berlin, Myrna Genevieve. "Vowel Intelligibility Problems in Selected Solo Vocal Works of Benjamin Britten.” DMA diss., University of Iowa, 1986.

*Brewster, Robert Gene. "The Relationship Between Poetry and Music in the Original Solo Vocal Works of Benjamin Britten Through 1965.” PhD diss., Washington University, 1967.

Dauer, Robin Lee. "Three Works for Voice and French Horn with Accompaniment." DMA diss., University of Cincinnati, 1994. (General)

*Ford, Boris. Benjamin Britten's Poets: The Poetry He Set to Music. Manchester: Carcanet, 1994.

Houghland, Lynda Gay. "Unity in the Solo Song Cycles of Benjamin Britten." MA diss., University of North Carolina at Chapel Hill, 1969.

*Johnson, Graham. Britten, Voice \& Piano: Lectures on the Vocal Music of Benjamin Britten. Aldershot: Ashgate, 2004.

*Lewin, Ann Rebekah. "Text Settings in the Songs of Benjamin Britten.” MA thesis, University of California, Los Angeles, 1964.

Litten, Jack Dane. “Three Song Cycles of Benjamin Britten.” EdD diss., Columbia University, 1969.

Mitchell, Donald. "Now Sleeps the Crimson Petal, Now the White:' Britten's Other Serenade.” Tempo no. 169 (June 1989): 22-27.

Pilant, Julia. "Turning Point, the Four Featured Horn Works Benjamin Britten Wrote for Dennis Brain: Serenade, op. 31, 'Now Sleeps the Crimson Petal,' Canticle III: Still Falls the Rain, and 'The Heart of the Matter."' DMA diss., The Julliard School, 2000.

Powell Davies, Jolyon. "Issues of Analysis in the Solo Vocal and Choral Music of Britten, 193945.” Mphil thesis, University of Sheffield, 1992.

Ramirez, Marshall Victor. "Word Painting and Textual Treatment in Selected Songs of Benjamin Britten.” MA thesis, California State University, Long Beach, 1979.

*Reiser, David A. "The Solo Vocal Music of Benjamin Britten: The Effect of the Text Upon the Music.” MA thesis, University of North Dakota, 1965. 
Roseberry, Eric. "Britten's Purcell Realizations and Folksong Arrangements." Tempo 57 (Spring 1961): 7-28.

*Slowik, Gregory J. "Benjamin Britten's Song Cycles for Voice and Piano: Performance Considerations for On This Island, The Holy Sonnets of John Donne, Songs and Proverbs of William Blake." DMA diss., Boston University, 2000.

Smith, Perry D. "A Survey of the Five Orchestrated Solo Vocal Works of Benjamin Britten." DMA diss.,University of Kentucky, 1993.

Stidham, Lisa Louise. "Benjamin Britten's Solo Vocal Settings of Poems by W.H. Auden.” MA thesis, University of California, Santa Barbara, 1983.

Stilgebaurer, Marilyn Kaye. "An Analysis of the Vocal Problems of Selected Works by Benjamin Britten.” MS thesis, Eastern Illinois University, 1961.

*Stroeher, Vicki Pierce. "Form and Meaning in Benjamin Britten's Sonnet Cycles." PhD diss., University of North Texas, 1994.

*Tibbetts, George Richard. "An Analysis of the Text-Music Relationship in Selected Songs of Benjamin Britten and Its Implications for the Interpretation of His Solo Song Literature." EdD diss., Columbia University Teachers College, 1984.

Upton, Leone Suydam. "The Solo Song Cycles of Benjamin Britten with Piano Accompaniment through 1965." MA thesis, Tulane University of Louisiana, 1968.

Whittall, Arnold. “Tonality in Britten's Songs Cycles with Piano.” Tempo, UK 96 (Spring 1971): $2-11$.

\section{CANTICLES}

Arfstein, Glen Delbert. "An Analytical Study for the Performance of Canticle V: The Death of St. Narcissus by Benjamin Britten.” DMA diss., University of Alabama, 1990.

Bennett, Glenn Mackenzie. "A Performer's Analysis and Discussion of the Five Canticles of Benjamin Britten.” DMA diss., Southwestern Baptist Theological Seminary, 1988.

Brown, D. "Britten's Three Canticles.” The Music Review XX, no. 1 (February 1960): 55-65.

Delmore, John Patrick. "Benjamin Britten's Canticles and Their Literary Thematic and Musical Unity with His Operas." DMA diss., University of Arizona, 1991.

Diether, Jack. "Britten's Canticles: A Masterly Evocation" American Record Guide XXIX (January 1963): 361-365. 
Goleeke, Thomas. "The Canticles of Benjamin Britten: A Consideration of the Texts." NATS Journal 49, no. 4 (March-April 1993): 4-8.

Gordon, Samuel Sherman. "Benjamin Britten's Canticles I, II, and III: A Structural and Stylistic Analysis.” DM diss., Indiana University, 1974.

John, Evan. "Canticle II: Abraham and Isaac" Music and Letters XXXIV, no. 4 (October 1953): 349-350.

Mason, Colin. "Canticle III: Still Falls the Rain, Op. 55" Music and Letters XXXVIII, no. 1 (January 1957): 104-105.

Redlich, Hans F. "Canticle II, Abraham and Isaac, Op. 51." The Music Review 16, No. 3 (August 1955): 266-270.

Roseberry, Eric. "Abraham and Isaac Revisited: Reflections on a Theme and Its Inversion.” In On Mahler and Britten: Essays in Honour of Donald Mitchell on His Seventieth Birthday, ed. Philip Reed and Donald Mitchell, 253-266. Woodbridge, United Kingdom: Boydell \& Brewer, 1995.

Scott, Elizabeth Barrett. "The Canticles of Benjamin Britten.” MA thesis, McGill University, 1983.

Sevdayan, Victoria Agobian. "A Vocal-Performance Analysis of Benjamin Britten's Canticles I, II, and III." MM thesis, California State University, Long Beach, 1997.

\section{A CHARM OF LULLABIES}

Elam, Charlotte Mary. "Text and Musical Style in Benjamin Britten's A Charm of Lullabies, Op. 41." MM thesis, University of London, King's College, 1978.

Hwang, Der-Shin. "Performance Practice Problems in Benjamin Britten's Song Cycle $A$ Charm of Lullabies, op. 41, for Mezzo-soprano." MFA thesis, Unversity of California, Los Angeles, 1988.

Nicolai, Annette. "Benjamin Britten's A Charm of Lullabies: Historical Survey, Analysis and Performance." MM thesis, California State University, Long Beach, 1992.

HOLY SONNETS OF JOHN DONNE

*Di Rocco, Theresa. "A Literary and Musical Analysis of Benjamin Britten's The Holy Sonnets of John Donne." DMA diss., Indiana University, 1972.

*Herbert, Rembert Bryce, Jr. “An Analysis of Nine Holy Sonnets of John Donne Set to Music by Benjamin Britten.” PhD diss., American University, 1974. 
Kim, Jung-Jin. "A Barthenesian Analysis of Britten's The Holy Sonnets of John Donne, op. 35." PhD diss., University of Wisconsin-Madison, 1996.

McNeff, Paul A. "Vocal Registers: A Functional Analysis Relating to the Singing Performance of Selected Songs from The Holy Sonnets of John Donne by Benjamin Britten." MA thesis, California State University, Fullerton, 1980.

Ryan, Christopher Winfree, Jr. "English Consonants in Song: A Spectographic Analysis of Peter Pears's Diction in Britten's 'Death, be no proud."” DMA diss., University of Oregon, 1981.

White, William Robert. "A Performer's Analysis of Benjamin Britten's The Holy Sonnets of John Donne.” DMA diss., University of Texas at Austin, 1988.

\section{LES ILLUMINATIONS}

Phillips, Betty Lou. "Relationships Between Text and Music in Benjamin Britten's Song Cycle Les Illuminations, opus 18." DMA diss., University of Texas at Austin, 1989.

Simeon, Ennio. "Arthur Rimbaud e Benjamin Britten: Villes II ovvero las nostalgia della forma chiusa." Rimbaud: Le poeme en porse et la traduction poetique, ed. Sergio Scacchi, 123131. Tüubingen: G. Narr, 1988.

. "Les Illuminations de Benjamin Britten." Revue d'etudes rimbaldiennes IV (1986): 102-110.

. "Rimbaud in musica: tre versioni di Depart." Confronto letterario VII (1990): 271282.

NOCTURNE

Eyer, Ronald. "Britten Nocturne Introduced by Little Orchestra." The Musical Courier LXXX (March 1960): 25.

Holst, Imogen. “Britten's Nocturne.” Tempo 50 (Winter 1959): 14-22.

Whitesell, Lloyd. "Translated Identities in Britten's Nocturne." Repercussions 6, no. 1 (Spring 1997): 109-134.

NOCTURNE/SERENADE FOR TENOR, HORN AND STRINGS

Lewis, Gail Diane. "Benjamin Britten's Writing for Horn with Tenor Voice: Serenade, Op. 31, 'The Heart of the Matter', Nocturne, Op. 60." DMA diss., University of WisconsinMadison, 1995. 
ON THIS ISLAND

Boaz, Virginia Lile. “A Performer's Guide to Benjamin Britten's On This Island, opus 11.” DMA diss., Southwestern Baptist Theological Seminary, 2000.

Ortman, Mory Scott. "Benjamin Britten and W.H. Auden's On This Island: An Analysis and Interpretive Guide." PhD diss., Arizona State University, 2002.

OUR HUNTING FATHERS

Emmons, Celeste Mildred. "Our Hunting Fathers by Benjamin Britten and W.H. Auden: A Musical and Textual Analysis." DMA diss., University of North Carolina at Greensboro, 1994.

PHAEDRA

Beard-Stradley, Cloyce. “A Performer's Analysis of Benjamin Britten's Phaedra, Dramatic Cantata for Mezzo-soprano and Small Orchestra, op. 93: A Lecture Recital, Together with Three Recitals of Selected Works of H. Purcell, R. Schumann, R. Vaughan Williams, P. Tchaikovsky, G. Faure, K. Lowe, G. Menotti, S. Barber and others.” DMA thesis, University of North Texas, 1999.

Shelton, Margaret Meier. "The ABC of Phaedra: Word Painting as Structure in Britten's Phaedra; and The Spanish Gypsy: for Mezzo-soprano and Chamber Orchestra." PhD diss, University of California, Los Angeles, 1983.

QUATRE CHANSONS FRANCAISES

Mark, Christopher. "Britten's Quatre chansons francaises.” Soundings UK X (Summer 1983): 23-35.

\section{SECHS HÖLDERLIN-FRAGMENTE}

Wood, Hugh. "Britten's Hölderlin Songs." The Musical Times CIV, no 1449 (November 1963): 781-783.

\section{SERENADE FOR TENOR, HORN AND STRINGS}

Falling, Timothy J. "The Horn Mastery of Dennis Brain: A Study of the Serenade for Tenor, Horn and Strings by Benjamin Britten.” MM thesis, Ball State University, 1991.

Foster, Michael Stephen. "A Biographical Delineation of Edward Benjamin Britten and an Analytical Synopsis of His Composition Serenade for Tenor, Horn and Strings, Op. 31." MA thesis, New Mexico Highlands University, 1982. 
Lickey, Eugene Harold. "I: An Analysis of Samuel Barber's Knoxville, Summer of 1915. II: An Analysis of Benjamin Britten's Serenade, opus 31.” DM diss., Indiana University, 1969.

Oosting, Stephen. "Text-music Relationships in Benjamin Britten's Serenade for Tenor, Horn, and Strings." DMA thesis, University of Rochester, 1985.

Rodriguez, Daniel. “A Melodic Analysis of Benjamin Britten's Serenade for Tenor, Horn and Strings, op. 31." MM thesis, University of Texas at El Paso, 1992.

Truscott, Harold. "Benjamin Britten's Serenade, Op. 31" Music-Survey 1, no. 5 (1949): 162-163.

Turner, Robert Forren. "An Examination of Benjamin Britten's opus 31, Serenade for Tenor (Solo), Horn and Strings." MA thesis, Claremont College, 1958.

SEVEN SONNETS OF MICHELANGELO

*Bolin, Douglas Wayne. "Pictorial and Poetic Influences in Benjamin Britten's Seven Sonnets of Michelangelo: A Magical Journey Through Associations." DMA diss., Ohio State University, 1996.

*Goeke, Christopher Leo. "A Discussion of the Relationship Between the Words and Music in Benjamin Britten's Seven Sonnets of Michelangelo." DMA diss., University of Iowa, 1994.

Orr, C. W. "Benjamin Britten's Seven Sonnets of Michelangelo, Op. 22" The Music Review IV, no. 4 (August 1943): 206.

Speranza, Ennio. "'Inglese italianato, diavolo incarnato': Brevi note, con alcune licenze, su Britten e Michelangelo." In Esotismo e scuole nazionali: Itinerari musicali tra l'Europa e le Americhe, ed. Armando Menicacci and Johannes Streicher, 83-107. Roma: Logos, 1992.

\section{SONGS AND PROVERBS OF WILLIAM BLAKE}

Barker, Jon Albert. "A Musical Analysis of Songs and Proverbs of William Blake, opus 74 by Edward Benjamin Britten.” DMA diss., Louisiana State University, 1977.

Ladell, Madeleine. "Some Analytical Observations on Britten's Songs and Proverbs of William Blake" MM thesis, University of London, King's College, 1988.

Meister, Babara. "The Interaction of Music and Poetry: A Study of the Poems of Paul Verlaine as Set to Music by Claude Debussy and the of the Song Cycle Songs and Proverbs of William Blake by Benjamin Britten.” PhD diss., City University of New York, 1987.

Walsh, Stephen. "Songs and Proverbs of William Blake." Tempo 74 (Autumn 1965): 23-24. 
SONGS FROM THE CHINESE

Moon, Kyung Soo. "Balinese Influences in Benjamin Britten's Songs from the Chinese, op. 58." DMA diss., University of Texas at Austin, 1993.

Noble, Jeremy. "Britten's Songs from the Chinese." Tempo 52 (Autumn 1959): 25-29.

WHO ARE THESE CHILDREN?

*Douglas, Earl Bruce. “A History and Analysis of Benjamin Britten's Who Are These Children?, opus 84.” DMA diss., University of Texas at Austin, 1987.

*Gasser, Alan. "Performing Benjamin Britten's Who Are These Children?, opus 84." NATS Bulletin XLIII, no. 5 (May/June 1987): 5-11.

\section{WINTER WORDS}

Benser, Jerry Ray. “A Singer's Commentary on the Winter Words of Benjamin Britten.” DMA diss., University of Iowa, 1990.

*Bonney, Georgia Ypma. "A Study of the Music and Text of Benjamin Britten's Winter Words, op.52: Lyrics and Ballads of Thomas Hardy." NATS Journal 49 (November/December 1992): 4-6.

*Brashear, Ann. "Winter Words, op. 52, by Benjamin Britten: An Analysis." MM thesis, Northern Illinois University, 1986.

Mason, Colin. "New Music: Winter Words" The Musical Times 96 (April 1955): 202.

*Paetsch, Annabelle. "Aspects of Narrativity and Temporality in Britten's Winter Words." Music \& Letters 79, no. 4 (November 1998): 538-554.

Prictor, Megan. "The Poems of Thomas Hardy as Song.” Context VI (Summer 1993): 34-42.

Sabin, Robert. "New Music: Benjamin Britten Sets Poems by Hardy." Musical America LXXV (December 1, 1955): 22.

Skelley, Barbara J. "'Before Life and After’ from Winter Words: A Song Cycle for High Voice and Piano, by Benjamin Britten.” MM thesis, Bowling Green State University, 1976.

*Whitmire, Mark Alexander. "Songs by John Ireland and Benjamin Britten to Poems by Thomas Hardy.” DMA diss., University of Maryland, College Park, 1991. 


\section{OPERAS}

GENERAL

Aldrich Moodie, James D. "Toward a Sociology of Opera and Literature: Three Case Studies." $\mathrm{PhD}$ diss., Stanford University, 1998.

Bermbach, Udo. Oper in 20. Jahrhundert: Entwicklungstendenzen und Komponisten. Stuttgart: J.B. Metzler, 2000.

Brendel, Ronald Scott. "Singing the Tenor Arias in the Chamber Operas of Benjamin Britten: An Analysis of the Technical Demands." DMA diss., Temple University, 2001.

Brett, Philip. "Eros and Orientalism in Britten's Operas.” In Queering the Pitch: The New Gay and Lesbian Musicology, 235-256. New York: Routledge, 1994.

Britten, Benjamin. "On Writing English Opera." Opera XII (January 1961): 7-8.

Corse, Sandra. Opera and the Uses of Language: Mozart, Verdi, and Britten. Rutherford, NJ: Fairleigh Dickinson University, 1987.

Couderc, Gilles. "Des heros au singulier: Les operas de Benjamin Britten.” PhD diss., Universite de Paris, 1999.

Dean, Winton. “A Note on Opera.” The Musical Times, UK CXV (January 1974): 34-35.

Dellamora, Richard; Ed. By Fischlin, Daniel T. The Work of Opera: Genre, Nationhood, and Sexual Difference. New York, NY: Columbia University Press, 1997.

Elliott, Graham. "The Operas of Benjamin Britten: A Spiritual View." The Opera Quarterly, USA IV, no. 3 (Fall 1986): 28-44.

Fischer, Jens Malte, ed. Oper und Opertext. Reihe Siegen: Beitrage zur Literatur-und Sprachwissenschaft, vol. 60. Heidelburg: C. Winter, 1985.

Herbert, David, ed. The Operas of Benjamin Britten: The Complete Librettos. Columbia University Press, 1979.

Hindley, Clifford. "Homosexual Self-affirmation and Self-oppression in Two Britten Operas." The Musical Quarterly 76, no. 2 (Summer 1992): 143-168.

Holland, Victoria. "Hearing the Female Voice in Benjamin Britten's Operas.” DM diss., Northwestern University, 2003.

Hoover, Jean Marie. "Constructions of National Identities: Opera and Nationalism in the British Isles.” PhD diss., Indiana University, 1999. 
Howard, Patricia. The Operas of Benjamin Britten: An Introduction. London: Barrie \& Rockcliff the Cresset, 1969.

Hutcheon, Linda; Michael Hutcheon. Opera: Desire, Disease, Death. Texts and Contexts, no. 17. Lincoln: University of Nebraska, 1996.

Kennedy, Michael. “Britten's Operas; 20 Years On.” Opera United Kingdom 47, no. 9 (September 1996): 1004-1011.

Klein, J. "Britten and the English Opera." Musical Opinion LXXII (July 1949): 517-518.

Konold, Wulf. "Natur in der Oper: Vorlaufige Bemerkungen zu einem neuen Thema.” In Gesungene Welten: Aspekte der Opera, 223-246. Berlin, Germany: Reimer, 1992.

Krolzig, Gunter. "Benjamin Brittens Kirchenoper". Der Kirchenmusiker, Germany XX, no. 3 (May-June 1969): 73-84.

Kuhnel, J. "Die Novelle als Opernvorwurf: zur Dramaturgie einiger Opern Benjamin Brittens." Oper und Operntext (Winter 1985): 227-60.

Latham, Edward David. "Linear-Dramatic Analysis: An Analytical Approach to TwentiethCentury Opera.” PhD diss., Yale University, 2000.

Law, Joe Keith. "The Dialogics of Operatic Adaptation: Reading Benjamin Britten." Yearbook of Interdisciplinary Studies in the Fine Arts I (1989): 407-427.

Lindenberga, Vita. "Features of the Dramatic Technique in Benjamin Britten's Opera." MA diss., Leningradskaja Gosudarstvennaja Konservatorija, 1973.

Littlejohn, David. The Ultimate Art: Essays Around and About Opera. Berkeley: University of California, 1992.

Maria, Isabella. "L'opera da camera di Benjamin Britten.” Tesi di laurea, Universite degli Studi di Torino, 1989.

Martin, George. "Benjamin Britten: Twenty-Five Years of Opera." Yale Review, USA LX, no. 1 (October 1970): 24-44.

. The Opera Companion to Twentieth-century Opera. New York: Dodd, Mead \& Company, 1979.

McKellar, Shannon Colwyn. "Institutional Voices: Five Britten Operas.” Dphi diss., University of Oxford, 1998.

Pears, Peter. Benjamin Britten: das Opernwerk. Bonn: Boosey \& Hawkes, 1955. 
Rambo, Carol Sue Piskac. "Benjamin Britten: Three Representative Operas.” MM thesis, University of Nebraska, 1974.

Redlich, H.F. “The Significance of Britten's Operatic Style.” Music Survey II, no. 4 (Spring 1950): 240-245.

Rinkel, Lawrence Stuart. "The Forms of English Opera: Literary and Musical Responses to a Continental Genre.” PhD diss., Rutgers University, 1977.

Sanderson, Gillian Mary. "The Dramatic Role of Percussion in Selected Operas of Benjamin Britten.” MM thesis, University of Alberta, 1980.

Schmidgall, Gary. Literature as Opera. Oxford: Oxford University Press, 1977. . Shakespeare and Opera. Oxford: Oxford University Press, 1990.

Scott, Richard O. "Two Operas of Benjamin Britten: An Analysis of Style.” MA thesis, Eastern Illinois University. 1967.

Seymour, Claire. The Operas of Benjamin Britten. Woodbridge, Suffolk: Boydell Press, 2004.

Simons, Harriet Rose. "The Use of the Chorus in the Operas of Benjamin Britten." DM diss., Indiana University., 1971.

Smedley, Bruce Robert. "Contemporary Sacred Chamber Opera: A Medieval Form in the Twentieth Century.” PhD diss., George Peabody College For Teachers, 1977.

Smith, Robert Ludwig. "An Analysis of Two Operas by Benjamin Britten.” MM thesis, University of Mississippi, 1959.

Stein, E. “Benjamin Britten's Operas.” Opera I (1950): 16-21.

Swantston, Hamish F. In Defense of Opera. London: Allen Lane, 1978.

Tambling, Jeremy. Opera, Ideology, and Film. Manchester: Manchester University, 1987.

Thiemann, Susan. "Contemporary Chamber Opera: A Representative Study in the Works of Stravinsky, Menotti, and Britten.” Honors Thesis, Smith College, 1956.

Tuchowski, Andrzej. "The Music Theatre in Relation to Socio-ethical Problems: The Devils of Loudun by Krzysztof Penerecki as Seen in Contrast to Peter Grimes and Other Operas by Benjamin Britten.” In Krzysztof Penderecki's Music in the Context of 20th-century Theatre, 109-116. Krakow: Akademia Muzyczna, 1999. 
. "Symbolika oper Benjamina Brittena.” PhD diss., Uniwersytet Warszawski, Instytut Muzykologii, 1988.

Varany, Guillermo. “La Opera de Benjamin Britten.” Scherzo: Revista de musica, no. 16 (June 1987): 78-80.

White, Eric Walter. Benjamin Britten, His Life and Operas. London: Faber \& Faber, 1970.

. The Rise of English Opera. London, J. Lehmann, 1951.

Whittall, Arnold. "A War and a Wedding: Two Modern British Operas.” Music \& Letters, UK LV, no. 3 (July 1974): 299-306.

*Wilcox, Michael. Benjamin Britten's Operas. Bath, Somerset: Absolute Press, 1997.

Wolf, Muriel Hebert; Keill, Stuart. “Opera as a Forum for the Insanity Defense.” The Opera Quarterly, USA III, no. 2 (Summer 1985): 14-24.

Worbs, Hans Christoph. Welterfolge der modernen Oper. Berlin: Rembrandt, 1967.

\section{ALBERT HERRING}

Bledsoe, Robert. "Chastity and Darkness in Albert Herring." Mosaic XVIII, no. 4 (Fall 1985): 125-133.

Crozier, Eric. "AAlbert the Good!'” In Physic Meet \& Metaphysic: A Celebration on Edward Lowbury's 80th Birthday, 114-117. Salzburg: Universitat Salzburg, 1993.

Crozier, Eric; Nancy Evans. "After Long Pursuit: The English Opera Group and Albert Herring," The Opera Quarterly 11, no. 3 (1995): 3-16.

Hindley, Clifford. "Not the Marrying Kind: Britten's Albert Herring." Cambridge Opera Journal 6, no. 2 (July 1994): 159-174.

Keller, Hans. Benjamin Britten: "Albert Herring": Analytical Notes. London, New York: Boosey \& Hawkes, 1949.

Law, Joe. "Daring to Eat a Peach: Literary Allusion in Albert Herring" The Opera Quarterly, USA V, no. 1 (Spring 1987): 1-10.

Mitchell, Donald. "The Serious Comedy of Albert Herring." The Opera Quarterly, USA IV, no. 3 (Fall 1986): 45-59.

Zottos, Ion. "Benjamin Britten's 'Albert Herring': Ena melodrama eparchiakes katapises." Moussicologihia, Greece I, no. 2 (1985):125-156. 
Snyder, Richard Dale. "The Use of the Comic Idea in Selected Works of Contemporary Opera." PhD diss., Indiana University, 1968. (Albert Herring, A Midsummer Night's Dream)

\section{BEGGAR'S OPERA}

Clark, Nancy Louise. “The Scenography for John Gay's The Beggar's Opera by Benjamin Britten." MA thesis, California State University, Northridge, 1980.

Holloway, R. "Gloriana and The Beggar's Opera." Tempo 189 (June 1994): 39-41.

\section{BILLY BUDD}

Boubel, Karen Brandser. "The Conflict of Good and Evil: A Musical and Dramatic Study of Britten's Billy Budd." PhD diss., University of Wisconsin, Madison, 1985.

Cescotti, Diego. "Britten e la favola del 'Bel Marinaio."” Rivista italiana di musicologia, Italy XXI, no. 1 (1986): 170-193.

Cooke, Mervyn; Reed, Philip. Benjamin Britten, "Billy Budd." Cambridge: Cambridge University Press, 1993.

Crozier, Eric. “L'ecriture d'un opera.”' L'avant-scene opera 158 (March-April 1994): 94-97. . "The Writing of Billy Budd." The Opera Quarterly, USA IV, no. 3 (Fall 1986): 11-27.

Driscoll, F. Paul. "Full Sail.” Opera News 61, no. 12 (Mar 8, 1997): 26-31.

Emslie, Barry. "Billy Budd and the Fear of Words." Cambridge Opera Journal 4, no. 1 (March 1992): 43-59.

Fernandez, Dominique. “Un opera sans femmes.” L'avant-scene opera 158 (March-April 1994): 110-113.

Fougerousse, James. "Billy Budd from Novel to Opera. A Comparative Study of Herman Melville's Billy Budd, Sailor, and Benjamin Britten's Opera, Billy Budd." PhD diss., University of Innsbruck, 1975.

Geyer, Helen. "Billy Budd, ein moderner Mythos: Uberlegungen zu Brittens Allegorie von Gut und Bose." In Festschrift fur Winfried Kirsch zum 65. Geburtstag, 511-527. Tutzing, Germany: Scheider, 1996.

Griffiths, Wendy. "Motive and Meaning in Benjamin Britten's Billy Budd." PhD diss., City University of New York, 1999. 
Hardwick, Elizabeth. "The Eternal Heartbreak: Billy Budd, from Story to Stage." Opera News 56, no. 14 (March 1992): 8-11.

Hindley, Clifford. "Britten's Billy Budd: The 'Interview Chords' Again.” The Musical Quarterly 78, no. 1 (Spring 1994): 99-126.

. "Love and Salvation in Britten's Billy Budd." Music \& Letters 70, no. 3 (August 1989): 363-381.

Labie, Jean-Francois. "Les beautes symetriques: Melville retouche par Britten." L'avant-scene opera 158 (March-April 1994): 100-104.

Lang, Sarah. A Guide to "Billy Budd." New York, NY: Metropolitan Opera Guild, Education Dept., 1979.

Lascelles, George Henry. "Voir grandir l'ouevre." L'avant-scene opera 158 (March-April 1994): 98-99.

McKee, David. "Navy Blues.” Opera News 61, no. 12 (March 8, 1997): 22-24.

McKellar, Shannon. "Re-visioning the 'Missing' Scene: Critical and Tonal Trajectories in Britten's Billy Budd." Journal of the Royal Musical Association 122, no. 2 (December 1997): 258-280.

Michot, Pierre. "Billy le begue." L'avant-scene opera 158 (March-April 1994): 105-109.

Mitchell, Donald. "More Off than On 'Billy Budd."” Music-Survey 4, no. 2 (February 1952): 386-408.

Pitt, Charles. "Billy Budd and the Royal Navy in the 18th Century." L'avant-scene opera 158 (March-April 1994): 114-116.

Reed, Philip. "On the Sketches for Billy Budd." In On Mahler and Britten: Essays in Honour of Donald Mitchell on His Seventieth Birthday, ed. Philip Reed and Donald Mitchell, 231252. Woodbridge, United Kingdom: Boydell \& Brewer, 1995.

Sicuro, P. Il "Billy Budd di Benjamin Britten.” Tesi di laurea, Universita degli Studi di Palermo, 1991.

Wagner, Klaus. "Billy Budd in Hamburg." Tempo, UK 103 (December 1972): 51-52.

Whittall, Arnold. "'Twisted Relations': Method and Meaning in Britten's Billy Budd." Cambridge Opera Journal 2, no. 2 (July 1990): 145-171. 
Gibson, Caroline G. “An Investigation into Benjamin Britten's Church Parable The Burning Fiery Furnace." DMA diss., University of Iowa, 1996.

Schneyder, Peter. "Brittens Kirchenoper Die Junglinge im Feuerofen." Osterreichische Musikzeitschrift Austria XXXII, no. 5-6 (1977): 256-258.

\section{CHURCH PARABLES}

Hindley, Clifford. "Britten's Parable Art: A Gay Reading.” History Workshop Journal XL ( 1995): 63-90.

Narboni, Francois. Les Paraboles for Church Performance de Benjamin Britten. Maitrise, Université de Paris IV, 1992.

Page, Gordon Keith. "The Leitmotif in the Parables for Church Performance by Benjamin Britten.” MM thesis, Southwestern Baptist Theological Seminary, 1978.

Sheppard, W. Anthony. Britten's Parables. Revealing Masks: Exotic Influences and Ritualized Performance in Modernist Music Theater. Berkeley: University of California Press, 2001.

Waddell, Brent. "The Parables for Church Performance of Benjamin Britten.” MA thesis, University of Calgary, 1983.

\section{CURLEW RIVER}

Alexander, Peter. "A Study of the Origins of Britten's Curlew River" Music \& Letters, UK LXIX, no. 2 (April 1988): 229-243.

Banks, Paul; Reed, Philip. "Curlew River": An Exhibition of Documents and Other Material. Aldeburgh: Britten-Pears Library, 1991.

Graham, Colin. Production Notes and Remarks on the Style of Performing "Curlew River" by Benjamin Britten \& William Plomer. London: Faber and Faber, 1965.

Laade, Wolfgang. "Benjamin Brittens Mysterienspiel Curlew River und die japanischen Vorbilder." Musik und Bildung, Germany I, no. 12 (December 1969): 562-565.

Mayer, Mark. "A Structural and Stylistic Analysis of the Benjamin Britten Curlew River." EdD diss., Columbia University Teachers College, 1983.

Vermeulen, E. Höhepunkt des Holland-Festivals: "Curlew River von Britten." Melos XXXI (October 1964): 313-314. 


\section{DEATH IN VENICE}

Carnegy, Patrick. "The Novella Transformed: Thomas Mann as Opera." In Benjamin Britten:

"Death in Venice," ed. Donald Mitchell, 168-177. Cambridge: Cambrdige University Press, 1987.

Cooke, Mervyn. "Britten and the Gamelan: Balinese Influences in Death in Venice." In Benjamin Britten: "Death in Venice," ed. Donald Mitchell, 115-128. Cambridge: Cambridge University Press, 1987.

Corse, Sandra; Corse, Larry. "Britten's Death in Venice: Literary and Musical Structures." The Musical Quarterly 73, no. 3 (1989): 344-363.

Diana, Barbara. Il sapore della conoscenza; Benjamin Britten e "Death in Venice." Torino: De Sono, 1997.

Dickinson, A “Current Chronicle: Britten's New Opera.” The Musical Quarterly, USA LX, no. 3, (July 1974): 470-478.

Evans, John. "Britten's Venice Workshop. I: The Sketch Book.” Soundings, UK 12 (Winter 1984-1985): 7-24.

. "Britten's Venice Workshop.II: The Composition Sketch and Revisions." Soundings, UK 12 (Summer 1985): 51-75.

. "Death in Venice: The Appollonian/Dionysian Conflict." The Opera Quarterly, USA IV, no. 3 (Fall 1986): 102-115.

. "Twelve-Note Structures and Tonal Polarity." In Benjamin Britten: "Death in Venice," ed. Donald Mitchell, 99-114. Cambridge: Cambridge University Press, 1987.

. "Benjamin Britten, Death in Venice: Perspectives on an Opera. PhD diss., University of Wales, 1984.

Evans, Peter. "Britten's Death in Venice." Opera XXIV, no. 6 (June 1973): 490-496.

. "Synopsis: The Story, the Music Not Excluded." In Benjamin Britten: "Death in Venice," ed. Donald Mitchell, 76-85. Cambridge: Cambridge University Press, 1987.

Feldman, James Allen. "The Musical Portayal of Gustav von Aschenbach in Benjamin Britten's Death in Venice." PhD diss., Kent State University, 1987.

. "Part I. The Intruder: A Chamber Opera in One Act. (Original Composition). Part II. The Musical Portrayal of Gustav von Aschenbach in Benjamin Britten's Death in Venice." PhD diss., Kent State University, 1987. 
Graham, Colin. “The First Production." In Benjamin Britten: "Death in Venice," ed. Donald Mitchell, 67-71. Cambridge: Cambridge University Press, 1987.

Hindley, Clifford. "Contemplation and Reality: A Study in Britten's Death in Venice." Music \& Letters 71, no. 4 (November 1990): 511-523.

. "Platonic Elements in Britten's Death in Venice." Music \& Letters 73, no. 3 (August 1992): 407-429.

Matthews, Colin. “The Venice Sketchbook." In Benjamin Britten: "Death in Venice," ed. Donald Mitchell, 55-66. Cambridge: Cambridge University Press, 1987.

Matthews, David. "Death in Venice and the Third String Quartet." In Benjamin Britten: "Death in Venice," ed. Donald Mitchell, 154-161. Cambridge: Cambridge University Press, 1987.

Milliman, Joan Ann. "Benjamin Britten's Symbolic Treatment of Sleep, Dream, and Death as Manifest in His Opera Death in Venice." PhD diss., University of Southern California, 1977.

Mitchell, Donald. "An Introduction in the Shape of a Memoir." In Benjamin Britten: "Death in Venice," 1-25. Cambridge: Cambridge University Press, 1987.

Mitchell, Donald, ed. Benjamin Britten, "Death in Venice." Cambridge: Cambridge University Press, 1987.

Palmer, Christopher. "Britten's Venice Orchestra." In Benjamin Britten: "Death in Venice," ed. Donald Mitchell, 129-153. Cambridge: Cambridge University Press, 1987.

. "Towards a Genealogy of Death in Venice." In On Mahler and Britten: Essays in Honour of Donald Mitchell on His Seventieth Birthday, ed. Philip Reed and Donald Mitchell, 213-227. Woodbridge, United Kingdom: Boydell \& Brewer, 1995.

Piper, Myfanwy. “The Libretto.” In Benjamin Britten: “Death in Venice,” ed. Donald Mitchell, 45-54. Cambridge: Cambridge University Press, 1987.

Reed, Philip. “Aschenbach becomes Mahler: Thomas Mann as Film.” In Benjamin Britten: "Death in Venice," ed. Donald Mitchell, 178-183. Cambridge: Cambridge University Press, 1987.

Reed, T.J. "Mann and His Novella Death in Venice." In Benjamin Britten: "Death in Venice," ed. Donald Mitchell, 163-167. Cambridge: Cambridge University Press, 1987.

Remme, Anneli. "Musical Signs in Death in Venice by Benjamin Britten.” In Musical Semiotics in Growth, 473-482. Imatra: International Semiotics Institute, 1996. 
Rorem, Ned, et al. "Critical Reception: Britten's Venice." In Benjamin Britten: "Death in Venice," ed. Donald Mitchell, 186-204. Cambridge: Cambridge University Press, 1987.

Roseberry, Eric. "Tonal Ambiguity in Death in Venice: A Symphonic View." In Benjamin Britten: "Death in Venice," ed. Donald Mitchell, 86-98. Cambridge: Cambridge University Press, 1987.

Said, Edward W. "Not All the Way to the Tigers: Britten's Death in Venice." In On Mahler and Britten: Essays in Honour of Donald Mitchell on His Seventieth Birthday, ed. Philip Reed and Donald Mitchell, 267-274. Woodbridge, United Kingdom: Boydell \& Brewer, 1995.

South Australia; Dept. of Education., Corp Author. "Death in Venice": An Introduction to Benjamin Britten's Last Opera. Adelaide: Education Dept. of South Australia, 1980.

Strode, Rosamund. “A Death in Venice Chronicle." In Benjamin Britten: "Death in Venice," ed. Donald Mitchell, 26-44. Cambridge: Cambridge University Press, 1987.

Travis, Roy. "The Recurrent Figure in the Britten/Piper Opera Death in Venice." Music Forum, USA VI, no. 1 (1987): 129-246.

Vaughan, David. "Death in Venice" Ballet Review, New York.22, no.3 (Fall 1994): 11-12.

\section{GLORIANA}

Alexander, Peter. "The Process of Composition of the Libretto of Britten's Gloriana." Music \& Letters, UK LXVII, no. 2 (April 1986): 147-158.

Banks, Paul. Britten's "Gloriana": Essays and Sources. Woodbridge, United Kingdom: Boydell \& Brewer Press, 1993.

Banks, Paul; Strode, Rosamund. "Gloriana: A List of Sources." In Britten's "Gloriana": Essays and Sources, ed. Paul Banks, 95-170. Woodbridge, United Kingdom: Boydell \& Brewer Press, 1993.

Evans, Peter A. "The Number Principle and Dramatic Momentum in Gloriana." In Britten's "Gloriana": Essays and Sources, ed. Paul Banks, 77-93. Woodbridge, United Kingdom: Boydell \& Brewer Press, 1993.

Hewison, Robert. “'Happy Were He': Benjamin Britten and the Gloriana story.” In Britten's "Gloriana": Essays and Sources, ed. Paul Banks, 1-16. Woodbridge, United Kingdom: Boydell \& Brewer Press, 1993.

Keller, Hans. "Two Interpretations of Gloriana as Music Drama. I: A Re-affirmation." Tempo no. 79 (Winter 1967): 2-5.

Klein, J. “Britten's Major Setback.” Musical Opinion XC (October 1966): 13-14. 
. "Some Reflections on Gloriana." Tempo 29 (Autumn 1953): 16-21.

Malloy, Antonia. "Britten's Major Set-Back? Aspects of the First Critical Response to Gloriana." In Britten's "Gloriana": Essays and Sources, ed. Paul Banks, 49-65. Woodbridge, United Kingdom: Boydell \& Brewer Press, 1993.

. "Gloriana: A Bibliography." In Britten's "Gloriana": Essays and Sources, ed. Paul Banks, 171-181. Woodbridge, United Kingdom: Boydell \& Brewer Press, 1993.

Mitchell, Donald. "The Paradox of Gloriana: Simple and Difficult." In Britten's "Gloriana": Essays and Sources, ed. Paul Banks, 67-75. Woodbridge, United Kingdom: Boydell \& Brewer Press, 1993.

Plomer, William. “The Gloriana Libretto.” Sadler's Wells Magazine IV, (1968): 8-9.

. “Let's Crab an Opera.” London Magazine III, no. 7 (1963): 101-104.

Porter, A. Britten's "Gloriana." Music \& Letters XXXIV, no. 4 (October 1953): 277-287.

Reed, Philip. "The Creative Evolution of Gloriana." In Britten's "Gloriana": Essays and Sources, ed. Paul Banks, 17-47. Woodbridge, United Kingdom: Boydell \& Brewer Press, 1993.

Walsh, Stephan. "Two Interpretations of Gloriana as Music Drama. II: A New Impression." Teтpo 79 (Winter 1966): 2-9.

\section{LET'S MAKE AN OPERA}

Crozier, Eric; Benjamin Britten; William Blake; Edward Ardizzone. The Story of "Let's Make an Opera." London: Oxford University Press, 1962.

Jonson, Joanne M. “A Production Thesis of Benjamin Britten's Let's Make an Opera." MA thesis, University of Minnesota, 1976.

THE LITTLE SWEEP

Crozier, Eric; Benjamin Britten. “The Little Sweep.” London: Boosey \& Hawkes, 1978

A MIDSUMMER'S NIGHT DREAM

Allen, Debra Kaye. "Drama and Characterization in Opera Settings of A Midsummer Night's

Dream by Britten and Siegmeister." MA diss., North Texas State University, 1982

Bach, Jan Morris. "An Analysis of Britten's A Midsummer Night's Dream." DMA diss., University of Illinois, 1971. 
Bellingardi, Luigi. "Su certi caratteri peculiari del teatro di Benjamin Britten e sull'originalita di A Midsummer Night's Dream." In Novecento: Studi in onore di Adriana Panni, 93-111. Torino:Edizioni di Torina, 1996.

Berger, Rudolf; Anne-France Boissenin. A Midsummer Night's Dream. Paris: Bleu Nuit, 2000.

Breque, Jean-Michel. "De Shakespeare a Britten: La primaute de la feerie." L'avant-scene opera 146 (May-June 1992): 11-16.

Brett, Philip. "Britten's Dream." In: Musicology and Difference: Gender and Sexuality in Music Scholarship, ed. Ruth A. Solie, 259-280. Berkeley: University of California, 1993.

Britten, Benjamin; Sir Peter Pears; William Shakespeare. "Britten, Le songe d'une nuit d'ete." Paris: Editions Premières Loges, 1992.

Collins, Dennis. "Britten, Le songe d'une nuit d'ete." L'avant-scene opera 146 (May-June 1992): $1-16$.

Cooke, Mervyn. "Britten and Shakespeare: Dramatic and Musical Cohesion in A Midsummer Night's Dream." Music \& Letters LXXIV, no. 2 (May 1993): 246-268.

Dervan, Michael. “Midsummer Magic.” Opera News 61, no. 6 (December 14, 1996): 35-38.

Evans, P. “Britten's New Opera: A Preview.” Tempo 53/54 (Spring/Summer 1960): 34-38.

Godsalve, William H.L. Britten's “A Midsummer's Night Dream”: Making an Opera from Shakespeare's Comedy. London: Associated University Press, 1995.

. "Opera from Comedy: Britten Remakes Shakespeare's Dream." PhD diss., University of Saskatchewan, 1990.

Iowa Center for the Arts. Shakespeare and Britten at Iowa: Interpretive Essays. Iowa City, IA: The Iowa Center for the Arts, The University of Iowa, 1991.

Johnson, Jennifer. "The Metadramatic Dimensions of Benjamin Britten's A Midsummer Night's Dream.” MA thesis, Louisiana State University, 1987.

Machart, Renaud. "Chanter Oberon: entretien avec James Bowman.” L'avant-scene opera 146 (May-June 1992): 96-98.

Mitchell, D. “In and Out of Britten's Dream.” Opera XI (1960): 797-801.

Riehle, Wolfgang. "Benjamin Brittens Oper A Midsummer Night's Dream aus heutiger Sicht." Jahrbuch Deutsche Shakespeare-Gesellschaft (1984): 149-163. 
Roseberry, Eric. "A Note on the Four Chords in Act II of A Midsummer Night's Dream." Tempo 66/67 (Autumn/Winter 1963): 36-37.

Shaw, Billy Wayne. "Creating Art: Adapting Shakespeare's Othello and A Midsummer Night's Dream to the Operatic Stage." MA thesis, University of Houston- Clear Lake, 2000.

Teachout, Terry. "A Little Night Music: Britten's A Midsummer Night's Dream Marked as a Rare Departure into Comedy for the Composer." Opera News 61, no. 6 (December 14, 1996): 20-22.

Timan, Paul. "Form and Style in Benjamin Britten's A Midsummer Night's Dream: A Study in Interpretation." Mus. D. diss., Indiana University, 1967.

Viebrock, Helmut. "A Midsummer Night's Dream": Shakespeares Lustspieltext und seine Verwendung als Libretto in Benjamin Brittens glecihnamiger Oper. Stuttgart: F. Steiner, 1991.

Warren, Roger. "A Midsummer Night's Dream": Text and Performance. London, Macmillan, 1983.

NOYE'S FLUDDE

Graham, Colin. "Noye's Fludde": The Chester Miracle Play Set to Music by Benjamin Britten: Notes on the Production. New York: Boosey \& Hawkes, 1958.

Martin, Phillip R. "An Analysis of Benjamin Britten's Noye's Fludde." MCM thesis, Southern Baptist Theological Seminary, 1969.

Robison, Clayne Wilcox. "Part I. The Departure: A Theatre-Oriented Theory of Opera Translation Including an English Version of Die Abreise by Eugen D'albert. Part II. Documentation of Two Opera Productions: Slow Dusk by Carlisle Floyd and Noye's Fludde by Benjamin Britten.” DMA diss., University of Washington, 1973.

Winter, Jerome Lynn. "An Analysis and Perspective of Noye's Fludde by Benjamin Britten." DMA diss., University of Iowa, 1990.

OWEN WINGRAVE

Barnes, Jennifer. Television Opera: The Fall of Opera Commissioned for Television. Woodbridge: Boydell \& Brewer, 2002

Britten, Benjamin; Myfanwy Piper. Britten, Le tour d'écrou: "Owen Wingrave." Paris: Editions Premières Loges, 1996.

Cescotti, Diego. "Pacifismo in musica: Il caso di Owen Wingrave di Benjamin Britten." In Ottocento e oltre: Scritti in onore di Raoul Meloncelli, 591-601. Roma: Pantheon, 1993. 
Evans, Peter. "Britten's Television Opera.” TheMusical Times, UK CXII, no. 1539 (May 1971): 425-428.

McClatchie, Stephen C. "Benjamin Britten, Owen Wingrave and the Politics of the Closet; or, 'He Shall Be Straightened Out at Paramore.'" Cambridge Opera Journal 8, no. 1 (March 1996): 59-75.

McKellar, S. "Music, Image and Ideology in Britten's Owen Wingrave: Conflict in a Fissured Text." Music \& Letters LXXX, no. 3 (August 1999): 390-410.

Raynor, Henry. "Owen Wingrave." The Music Review XXXII, no. 3 (August 1971): 271-273.

Sadie, Stanley. "Owen Wingrave." The Musical Times CXII (July 1971): 663-666.

Schiffer, B. “Benjamin Brittens neue Fersehoper.” Melos 7/8 (July/August 1971): 313-314.

Warrack, John. “Britten's Television Opera.” Opera XXII, no. 5 (May 1971): 371-378.

Whittall, Arnold. "Breaking the Balance." The Musical Times CXXXVII (September 1996): 4-7.

PAUL BUNYAN

Auden, W.H. and Benjamin Britten. Paul Bunyan: An Operetta in Two Acts and a Prologue. London: Faber Music Ltd., 1976.

Frayne, John. "Paul Bunyan's Second Chances: Revisions and Revivals." American Music, USA III, no. 1 (Spring 1985): 1-15.

Ketukaenchan, Somsak. "A (Far Eastern) Note on Paul Bunyan." In On Mahler and Britten: Essays in Honour of Donald Mitchell on His Seventieth Birthday, ed. Philip Reed and Donald Mithcell, 275-279. Woodbridge, United Kingdom: Boydell \& Brewer Press, 1995.

Reed, Philip. “A Rejected Love Song from Paul Bunyan.” The Musical Times 129, no. 1744 (June 1998): 283-288.

\section{PETER GRIMES}

Abbiati, Franco. Benjamin Britten: "Peter Grimes.” Milan: Istituto d'altra cultura, 1946.

Banks, Paul. The Making of “Peter Grimes.” Woodbridge:Boydell \& Brewer Press, 1996.

Brett, Philip. Benjamin Britten, “Peter Grimes." Cambridge Opera Handbooks. Cambridge: Cambridge University Press, 1983. 
. "Britten and Grimes." TheMusical Times, UK CXVIII, no. 1618 (December 1977): 995-1000.

Brett, Philip. "Peter Grimes: The Growth of the Libretto." In The Making of "Peter Grimes," ed. Paul Banks, 53-78. Woodbridge, United Kingdom: Boydell \& Brewer Press, 1996.

Brett, Philip, ed. "Peter Grimes.” Cambridge: Cambridge University Press, 1983.

Cescotti, Diego. "Sui 40 anni di Peter Grimes." Eunomio: Parole di musica, no. 1 (Spring 1986): 20.

Crozier, Eric. "Notes on the Production of Peter Grimes." In The Making of "Peter Grimes," ed. Paul Banks, 7-20. Woodbridge, United Kingdom: Boydell \& Brewer Press, 1996.

Crozier, Eric, ed. "Peter Grimes." Sadler Wells Opera Book, no. 3. London: John the Bodley Head, 1945.

Crozier, Eric; Nancy Evans. "Il sapore della conoscenza; Benjamin Britten e Death in Venice. The Opera Quarterly 10, no. 4 (Summer 1994): 7-20.

Freisinger, Peter. "Three Operatic Madmen in Twentieth-century Opera: A Comparison and Analysis of Wozzeck, Peter Grimes and The Rake's Progress." DMA diss., University of Cincinnati, 1999.

Garbutt, J.W. "Music and Motive in Peter Grimes." Music \& Letters XLIV, no. 4 (October 1963): 334-342.

Garvie, Peter. "Plausible Darkness - Peter Grimes after a Quarter of a Century." Tempo, UK 100 (June 1972): 9-14.

Harris, Dale. "In That Dawn." Opera News 60, no. 1 (July 1995): 18-21.

Keller, Hans. Britten: "Thematic Relations and the 'Mad' Interlude's Fifth Motif." Music Survey IV, no. 1 (October 1951): 332-334.

Keller, Hans and Christopher Wintle. Three Psychoanalytic Notes on "Peter Grimes." King's College London Institute of Advanced Musical Studies, 1995.

Kovenatskaja, Ljudmilla; trans. By Nick Winter. "Notes on a Theme from Peter Grimes." In On Mahler and Britten: Essays in Honour of Donald Mitchell on His Seventieth Birthday, ed. Philip Reed and Donald Mitchell, 172-185. Woodbridge, United Kingdom: Boydell \& Brewer Press, 1995.

Lange, Wolfgang. "Held ohne Zukunft: Peter Grimes von Benjamin Britten in der Komischen oper." Theater der Zeit, Germany XXXVI, no. 3 (1981): $42-43$. 
Mandel, Marc. "Peter Grimes:" Tanglewood 1946,1996. Lenox, Massachusettes: Tanglewood Music Center, 1996.

McGiffert, Genevieve White. "The Musico-Dramatic Techniques of Benjamin Britten: A Detailed Study of Peter Grimes.” PhD diss., University of Denver, 1970.

McGregor, Cynthia Annmarie. "The Musical Language of Dramatic Monologues: A Study of Wotan, Tristan, Salome, Boris and Grimes (Richard Wagner, Germany, Richard Strauss, Modest Petrovich Mussorgsky, Benjamin Britten, England, Russia).” PhD diss., Northwestern University, 2001.

Mitchell, Donald. “Peter Grimes: Fifty Years On.” In The Making of "Peter Grimes, ” ed. Paul Banks, 167-228. Woodbridge, United Kingdom: Boydell \& Brewer Press, 1996.

Mitchell, Michael. "Peter Grimes." Seattle Opera Guild Study Guide for Understanding. Seattle: Seattle Opera Guild, 1983.

Packales, Joseph. "String Quartet: Benjamin Britten's Peter Grimes: An Analysis.” PhD diss., Kent State University, 1984.

Payne, A. "Dramatic Use of Tonality in "Peter Grimes." Tempo 66/67 (Autumn/Winter 1963): 22-26.

Pears, Peter. “Peter Grimes. ” In The Making of "Peter Grimes, ” ed. Paul Banks, 5-6. Woodbridge, United Kindgdom: Boydell \& Brewer Press, 1996.

Reed, Philip. "Finding the Right Notes." In The Making of "Peter Grimes, " ed. Paul Banks, 79114. Woodbridge, United Kingdom: Boydell \& Brewer Press, 1996.

. "Personalia.” In The Making of "Peter Grimes," ed. Paul Banks, 229-238.

Woodbridge, United Kingdom: Boydell \& Brewer Press, 1996.

. “A Peter Grimes Chronology, 1941-1945.” In The Making of "Peter Grimes,” ed. Paul Banks, 21-52. Woodbridge, United Kingdom: Boydell \& Brewer Press, 1996.

Richmond, Joy Diane. "Peter Grimes: An Annotated Bibliography of the First Fifty Years (1945-1995).” MS thesis, Texas A\&M University-Commerce, 1999.

Shawe-Taylor, Desmond. "Peter Grimes in Stockholm." In The Arts, ed. Desmond ShaweTaylor, 49-53. New York: Arno, 1968.

Slater, Montagu; George Crabbe, Benjamin Britten. Peter Grimes, Britten. Paris: L'Avant-scène opera, 1995.

Stein, E. "Opera and Peter Grimes." Tempo 12 (September 1945): 2-6. 
Strode, Rosamund. "The Later History of the Composition Draft." In The Making of "Peter Grimes, ” ed. Paul Banks, 115-124. Woodbridge, United Kingdom: Boydell \& Brewer Press, 1996.

Stuart, Charles. Benjamin Britten: “Peter Grimes.” London: Boosey \& Hawkes, 1948.

Tibbs, Scot Alan; William MacDuff. "Volume I, Motivic Tranformation in the Benjamin Britten Opera Peter Grimes; Volume II, No Man's Land: An Opera.” PhD diss., UCLA, 1998.

Williams, Jeannie. “Grappling with Grimes.” Opera News 64, no. 5 (November 1999): 36-45.

\section{PETER GRIMES/GLORIANA}

John, Nicholas, ed. Benjamin Britten: "Peter Grimes" and "Gloriana." Opera Guide, vol. 24. London: Calder, 1983.

Slater, Montagu and George Crabbe. "Peter Grimes;” "Gloriana." London: J Calder, 1983.

\section{PETER GRIMES/THE RAPE OF LUCRETIA}

Brett, Philip. "Grimes and Lucretia." In Music and Theatre: Essays in Honor of Winton Dean, ed. Andrew Porter, David Rosen, and Claire Brook, 353-366. Cambridge: Cambridge University Press, 1987.

\section{PETER GRIMES/THE RAPE OF LUCRETIA/GLORIANA}

Davis, Dolores Su. "Treatment of the Leading Soprano Roles in Selected Operas of Benjamin Britten: Peter Grimes, The Rape of Lucretia, Albert Herring, and Gloriana. MM thesis, North Texas State College, 1956.

\section{PETER GRIMES/THE TURN OF THE SCREW}

Deavel, R. Gary. "A Study of Two Operas by Benjamin Britten: Peter Grimes and The Turn of the Screw." PhD diss., University of Rochester, Eastman School of Music, 1970.

\section{THE PRODIGAL SON}

Cooke, M. "Eastern Influences on Britten's The Prodigal Son." Melos 19-20 (1997): 37-45.

Matthews, David. "Britten's The Prodigal Son." Tempo no. 85 (Summer 1968): 28-30.

THE RAPE OF LUCRETIA

Britten, Benjamin; Ronald Frederick Henry Duncan, André Obey. "The Rape of Lucretia," Opera in Two Acts. New York: Boosey \& Hawkes, 1946. 
Crozier, Eric. "The Rape of Lucretia, Benjamin Britten's Second Opera." In The Arts, ed. Desmond Shawe-Taylor, 54-60. New York: Arno, 1946.

Duncan, Ronald Frederick Henry; Eric Crozier. "The Rape of Lucretia:” A Symposium. London: Bodley Head, 1948.

Greco, Antonia M. "Musical Symbolism and the Functional Use of the Orchestra in Benjamin Britten's The Rape of Lucretia." MA thesis, Hofstra University, 1976.

Keller, Hans Heinrich. Benjamin Britten: "The Rape of Lucretia." London: Boosey \& Hawkes, 1947.

Mertz, Margaret Stover. "History, Criticism, and the Sources of Benjamin Britten's Opera The Rape of Lucretia." PhD diss., Harvard University, 1990.

Power, Tushaar. Opera as literature: The Rape of Lucretia. Irish musical studies 4 (1996): 232246.

\section{THE TURN OF THE SCREW}

Brauneiss, Leopold. Benjamin Britten: "The Turn of the Screw - - Von die Schrauben der Bosen, der Erziehung und der Geschichte." Osterreichische Musikzeitschrift, Austria 57, no. 5 (May 2002): 9-16.

Brett, Philip. "Britten's Bad Boys: Male Relations in The Turn of the Screw." Repercussions 1, no. 2 (Fall 1992): 5-25.

Brown, Monika. "Film Music as Sister Art: Adaptations of The Turn of the Screw." Mosaic: A Journal for the Interdisciplinary Study of Literature 31, no. 1 (March 1998): 61-81.

Coolidge, Sandra Ann. "A Director's Study and Prompt Book of The Turn of the Screw by Benjamin Britten. MA thesis, Texas Woman's University, 1970.

De Simone, Robert. "The University of Washington's Productions of The Turn of the Screw and Rusalka and a New English Translation of L'Enfant Prodigue." DMA diss. University of Washington, 1981.

Evans, John. "The Sketches: Chronology and Analysis." In Benjamin Britten: "The Turn of the Screw, " ed. Patricia Howard, 63-70. Cambridge: Cambridge University Press, 1985.

Harshman, Thomas. "Two Turns of the Screw: Henry James \& Benjamin Britten.” MA thesis, Brown University, 1987.

Hindley, Clifford. "Why Does Miles Die? A Study of Britten's The Turn of the Screw." The Musical Quarterly 74, no. 1 (1990): 1-17. 
Howard, Patricia. "The Climax: Act II, scene 8, Miles." In Benjamin Britten: "The Turn of the Screw," 90-100. Cambridge: Cambridge University Press, 1985.

. "Myfanwy Piper's The Turn of the Screw: Libretto and Synopsis." In Benjamin Britten: "The Turn of the Screw," 23-62. Cambridge: Cambridge University Press, 1985.

. "Structures: An Overall View." In Benjamin Britten: "The Turn of the Screw," 71-89. Cambridge: Cambridge University Press, 1985.

. "The Turn of the Screw in the Theatre." In Benjamin Britten: "The Turn of the Screw," 126-149. Cambridge: Cambridge University Press, 1985.

Howard, Patricia, ed. Benjamin Britten, "The Turn of the Screw." Cambridge: Cambridge University Press, 1985.

Landgraf, Ludwig. “Bemerkungen des Übersetzers.” Neues Forum VII, (1957-1958): 119-123.

Marsh, Malcolm Herbert. "The Turn of the Screw: Britten and Piper's Operatic Fulfillment of Henry James's Novella." PhD diss., University of London, 1983.

Marshall, Richard. Benjamin Britten's "The Turn of the Screw; A Structural Analysis." Mus.D. diss., Indiana University, 1963.

Mitt, Charles. "L'histoire scenique." L'avant-scene opera 173 (September-October 1996):151153.

Paduano, Guido. Il giro di vite: Percorsi dell'opera lirica. Firenze: La nuova Italia, 1992.

Palmer, Christopher. "The Colour of Music." In Benjamin Britten: "The Turn of the Screw," ed. Patricia Howard, 101-125. Cambridge: Cambridge University Press, 1985.

Reininghaus, Frieder. "Wie ein spannender Kriminalfilm. Benjamin Britten's The Turn of the Screw." Neue Zeitschrift fur Musik, Germany XCLIV, no. 12 (1983): 28-29.

Schulz, Max F. "An Unending Horror: Henry James's and Benjamin Britten's Turn(ings) of the Screw." A Yearbook of Interdisciplinary Studies in the Fine Arts. 2 (1990): 37-48.

Shuffield, Joseph N. "Nattiez's Tripartition as an Analytical Strategy for Britten's The Turn of the Screw." MM thesis, Baylor University, 1995.

Smith, Sara Elizabeth. "A Study and Analysis of the Instrumental Theme and Variations in Benjamin Britten's The Turn of the Screw." MA thesis, University of Rochester, 1983.

Stein, E. "The Turn of the Screw and its Musical Idiom." Tempo 34 (Winter 1955): 6-14. 
Stimpson, Mansel. "Drama and Meaning in The Turn of the Screw." The Opera Quarterly, USA IV, no. 3 (Fall 1986): 75-82.

Whitesell, Lloyd. "Doubt and Failure in Britten's The Turn of the Screw." Indiana Theory Review 13, no. 2 (Fall 1992): 41-87. 


\section{CHORAL WORKS}

GENERAL

Arthur, William N. "A Stylistic Analysis of Four Choral Compositions in Four Periods of Music History." MA thesis, Arizona State College, 1956.

Auden, W.H. Litany and Anthem for S. Matthew's Day. Northampton, England: Stanton and Son, 1946.

Boos, Kenneth. "The Study of the Relationship Between Text and Music in Five Selected Choral Works of Benjamin Britten.” DMA doc., University of Miami, 1986.

Calabrese, Alfred James. "Benjamin Britten's Hymn to St. Cecilia, op. 27, A Ceremony of Carols, op. 28, and Rejoice in the Lamb, op. 30: An Analysis." DM doc, Indiana University, 1992.

Capps, Mary Clyde. "The Sacred Choral Music of Benjamin Britten.” MM thesis, University of Texas at Austin, 1960.

Corse, Larry B. "The A Cappella Choral Music of Benjamin Britten.” MM thesis, North Texas State University, 1963.

Cowman, Karen Sue. "Symbolism in the Textual Treatment of the Choral Works of Benjamin Britten." MA thesis, University of Missouri, 1975.

Davis, Charles Rockwell. "A Conductor's Analysis of Laudes organi, and Te Deum by Zoltan Kodaly and Cantata Misericordium by Benjamin Britten.” MCM thesis, Southwestern Baptist Theological Seminary, 1975.

Dawney, Michael. “Some Notes on Britten's Church Music.” Tempo no. 82 (Fall 1967): 13-21.

Dundore, Mary Margaret. "I. The Choral Music of Benjamin Britten; II. The Russian Grand Opera Company in the Pacific Northwest; III. Documentation for Choral Concert Given on June 10, 1969.” DMA thesis, University of Washington, 1988, 1969.

Goetz, Thomas E. "Britten's Church Music: The Short Choral Works and A.M.D.G.” DMA diss., Northwestern University, 1990.

Hall, Nelson. "The Use of Text in Three Twentieth-Century Settings of Psalm 150: Implications for the Conductor." DMA diss., University of Miami, 1998.

Hansler, George E. "Stylistic Characteristics and Trends in the Choral Music of Five TwentiethCentury British Composers: A Study of the Choral Work of Benjamin Britten, Gerald Finzi, Costant Lambert, Michael Tippett, and William Walton.” PhD diss., New York University, 1957. 
Hart, Ralph Eugene. "Compositional Techniques in Choral Works of Stravinsky, Hindemith, Honegger, and Britten.” PhD diss., Northwestern University Library, 1953.

Hill, Kevin Howard. "A Musical Analysis of Rejoice in the Lamb with Performance Suggestions and Historical Background on the Work and the Composer." MM thesis, Georgia State Univesrity, 2003.

Hurstad, Linda. "Benjamin Britten's Sacred Works for Voices and Organ: An Analysis with Performance Suggestion for Choral Conductors." DMA diss., Univeristy of Texas at Austin, 1987.

Jones, Douglas Loyd. “Aspects of Textual Treatment in Benjamin Britten's Unaccompanied Choral Music; With Commentary on the History and Meaning of the Text." DMA diss., University of Houston, 2000.

Kirby, Claude O'Donald. "A Conductor's Analysis of Selected Choral Works by Orlandus Lassus, Claudio Monteverdi, Heinrich Schutz, Benjamin Britten, and Jean Berger.” MM thesis, Southwestern Baptist Theological Seminary, 1980.

Lamb, Gordon Howard. "A Study of Choral Techniques in the Sacred Works of Benjamin Britten.” MM thesis, University of Nebraska, 1962.

Lathan, Mark J. "Emotional Progression in Sacred Choral Music: How Three Twentieth-Century Masterworks Depict Grief in Time of War and Song of Hope, a Cantata for Chorus and Orchestra." PhD diss., University of California, Los Angeles, 2001.

MacPherson, Scott A. "The Posthumously Published Choral Works of Benjamin Britten." DMA diss., University of Southern California, 192.

Maddox, Donald Paul. "Benjamin Britten: A Conductor's Analysis of Saint Nicolas." MCM thesis, Southwestern Baptist Theological Seminary, 1970.

Maes, Lloyd R. "Rejoice in the Lamb and Cantata Misericordium: A Study of Benjamin Britten's Earlier and Later Choral Styles.” DMA diss., Stanford University, 1973.

Manalili, Rachel S. "Reverent Cadence and Subtle Psalm: Benjamin Britten's Wartime Choral Settings of English Christian Poetry.” AB honors thesis, Harvard University, 1994.

Marcades, Michael. “Benjamin Britten's Ad Majorem Dei Gloriam (A.M.D.G.): A MusicoPoetic Analysis and Performance Guide for the Choral Conductor." PhD diss., Texas Tech, 1999.

McKercher, Gary Conn. "Romaniticism in Music as Seen in the Choral Works of Johannes Brahams (sic), Benjamin Britten, and William Schuman.” MA thesis, California State University, Fullerton, 1976. 
Mendelson, Edward. "The Making of Auden's Hymn for St. Cecilia's Day." In On Mahler and Britten: Essays in Honour of Donald Mitchell on His Seventieth Birthday, ed. Philip Reed and Donald Mitchell, 186-192. Woodbridge, United Kingdom: Boydell \& Brewer Press, 1995.

Mitchell, Deneen K. "A Ceremony of Carols: An Advent Celebration." MM. thesis, St. Cloud State University, 1996.

Nitschke, Brad. "Benjamin Britten's A Ceremony of Carols: A Study and Analysis." MM thesis, Bowling Green State University, 1985.

Osborn, Lawrence David. "Benjamin Britten's Cantata Misericordium, opus 69: A Theoretical Analysis and a Conductor's Guide to Gestural Analysis." AMusD diss., University of Arizona, 1993.

Pfeifer, Kristin Ann. "A Historical Analysis of Three Works for Trebles by Benjamin Britten." MA thesis, San Jose State University, 2002.

Schiavone, Suzanne C. "Aspects of Style in Benjamin Britten's Choral Music with Particular Reference to Word-Setting and to the Practical Aspects of His Composition." MA thesis, University College of Wales, Aberystwyth, 1981.

Willy, Kenneth Roget. "The Liturgical Choral Works of Benjamin Britten.” Mmus thesis, University of East Anglia, 1992.

A BOY WAS BORN

Fancher, Joseph E. "A Musico-Dramatic Analysis of A Boy was Born, op. 3 of Benjamin Britten.” MA thesis, San Francisco State University, 1989.

Lambert, Penelope. "The Symbolic Use of the Boys' Chorus in Benjamin Britten's A Boy was Born." MM thesis, University of London, Goldsmiths' College, 1991.

CHILDREN'S CRUSADE

Nolan, Sir Sidney. “Children's Crusade”. Kinderkreuzzug, op. 82. A Ballad for Children's Voices and Orchestra. London: Faber Music, 1973.

THE COMPANY OF HEAVEN

Weber, Michael James. "Benjamin Britten's The Company of Heaven." AMusD diss., University of Arizona, 1990. 
Aston, Peter. "Benjamin Britten's Hymn to St. Cecilia." In Chormusik und Analyse: Beitrage zur Formanalyse und Interpretation mehrstimmiger Vokalmusik, ed. Heinrich Poos, 259-27. Mainz, Germany: Schott, 1997.

Unger, Melvin. "Britten's Hymn to St. Cecilia: An Exegesis.” Choral Journal XXII, no. 8 (April 1982): 17-21.

MISSA BREVIS IN D

Leavens, Kenneth S. "The Preparation and Performance of Britten's Missa brevis in D for Boys' Voices and Organ, opus 63.” MA thesis, California State University, Fullerton, 1976.

REJOICE IN THE LAMB

Chiles, Harvey M. “An Analysis of Benjamin Britten's Rejoice in the Lamb, Text by Christopher Smart.” MM thesis, Bowling Green State University, 1980.

Greuling, Corinne Marcia. “A Stylistic Analysis of Benjamin Britten's A Ceremony of Carols for Purposes of Interpretation and Choral Performance Practice.” MA thesis, University of Connecticut, 1978,

Hatfield, Lawson Gerald. A Conductor's Study of "Rejoice in the Lamb" by Benjamin Britten. Louisville: Hatfield, 1977.

Nelson, David Paul. "Benjamin Britten's Rejoice in the Lamb, Historical Perspectives and Performance Practices.” MM.thesis, Hardin-Simmons University, 1987.

Nickels, Samuel Vance. "The Influence of Text and Harmony on the Formation of Melody in Benjamin Britten's Rejoice in the Lamb." MM thesis, Florida State University, 1985.

Preble, Deborah J. "Benjamin Britten's Rejoice in the Lamb." MA thesis, California State University, Fullerton, 1980.

Szombatfalvy, Csilla. "Benjamin Britten: Rejoice in the Lamb, op. 30. Unnepi cantata." Magyar egyhazzene 6, no. 3 (1998): 349-354.

Wilcauskas, Sherri L. "Rejoice in the Lamb: Text-Music Relationships.” Honors paper, Mount Holyoke College, 1991.

\section{SAINT NICHOLAS}

Jones, Keith W. “Benjamin Britten's Saint Nicolas, op. 42: A Conductor's Analysis and Discussion.” D. Mus., Indiana University, 1999. 
Weese, Becky L. 'Benjamin Britten's Saint Nicholas: A Conductor's Analysis for Performance." DMA doc., University of Miami, 1998.

\section{TE DEUM}

Pooler, Marie. "Part I: Analyses of Choral Settings of the Te Deum by the Contemporary Composers Benjamin Britten, Leo Sowersby, Halsey Stevens, and Vincent Persichetti." MA thesis, California State University, Fullerton, 1971.

\section{WAR REQUIEM}

Ashby, Bonnie. "'My Subject is Way': Benjamin Britten's War Requiem as an Intersection of Historical, Musical, and Literary Perspectives.” University Scholar Project: Brigham Young University, 2001.

Bagley, Peter Belvy Eugene. "Benjamin Britten's War Requiem: A Structural Analysis.” DM diss.,Indiana University, 1972.

Bauer, Hans-Gunther. "Die Fehler im System' als Sinngebung in Neuer Musik: Die Funktion des Tritonus in Benjamin Brittens War Requiem." Musik und Bildung, Germany XVIII, no. 5 (May 1986): 459-464.

Bernard, Andrew. "Two Musical Perspectives of Twentieth-Century Pacifism: An Analytical and Historical View of Britten's War Requiem and Bernstein's Kaddish Symphony." DMA doc., University of Washington, 1990.

Boyd, Malcolm. "Britten, Verdi, and the Requiem.” Tempo no. 96 (Autumn 1968): 2-6.

Brace, Patricia Lynne. "A Rhetorical Study of Coventry Cathedral and Benjamin Britten's War Requiem Revealing the Tropes of Metonymy, Metaphor and Irony." PhD diss., Ohio University, 1993.

Buccheri, John Stephen. "Aspects of Form, Melody, and Harmony in the War Requiem by Benjamin Britten.” MA thesis, University of Rochester, 1965.

Chance, Jr., Von Darnell. "The Use of Borrowed Musical Materials in Benjamin Britten's War Requiem and Igor Stravinsky's Requiem Canticles." MA thesis, University of Tennessee, Knoxville, 1978.

Cooke, Mervyn; Reed, Philip. Britten: “War Requiem.” Cambridge Music Handbooks. Cambridge, Cambridge University Press, 1996.

De Villiers, Bernadette. "Benjamin Britten: War Requiem." MM thesis, University of the Witwatersrand, Johannesburg, 1979. 
Ellis, Jim. "Strange Meeting: Wilfred Owen, Benjamin Britten, Derek Jarman, and the War Requiem." In The Work of Opera: Genre, Nationhood, and Sexual Difference, 277-296. New York, NY: Columbia University Press, 1997.

Hall, William Dawson. "The Requiem Mass: A Study of Performance Practices from the Baroque Era to the Present Day as Related to Four Requiem Settings by Gilles, Mozart, Verdi, and Britten.” DMA diss., University of Southern California, 1970.

Hepworth, Mindy Marie. "Wilfred Owen and the Text of Benjamin Britten's War Requiem." Honors thesis, University of Utah, 2001.

Juul-Hansen, Anette. "Benjamin Britten's War Requiem and Wilfred Owen's Text." Musik \& Forskning, Denmark III (1977): 180.

Lundergan, Edward Joseph. "Benjamin Britten's War Requiem: Stylistic and Technical Sources." DMA diss., University of Texas at Austin, 1991.

Matonti, Charles J. “A Prayer for Peace Now: Britten's War Requiem Revisited.” Choral Journal, USA. XXIV, no. 2 (October 1983): 21-30.

Nickson, John Arthur. "Benjamin Britten's War Requiem." DMA diss., University of Southern California, 1990.

Page, Gordon Keith. "Melodic Unification in Benjamin Britten's War Requiem." DMA diss., Southwestern Baptist Theological Seminary, 1991.

Rooney, Thomas Francis. "Benjamin Britten's War Requiem: Parody and the Transmutation of Myth.” PhD diss., Boston University, 1997.

Shaw, Robert. "The Text of Britten's War Requiem." In Five Centuries of Choral Music: Essays in Honor of Howard Swan Stuyvesant, ed. Gordon Paine and Howard Swan, 357-383. Stuyvesant, NY: Pendragon, 1988.

Strader, Nikola Dale. "The Stylistic Placement of War Requiem in Benjamin Britten's Oeuvre." $\mathrm{PhD}$ diss., Ohio State University, 1996.

Vouga, Francois. Resonances theologiques de la musique. L'evangile dans la vie, vol. 9. Geneve: Labor et Fides, 1983

Ward, Brian Edward. "The New Sounds of Mourning: The Changing Role of the Requiem in the Late Nineteenth and Twentieth Centuries as Demonstrated by the Works of Giuseppe Verdi, Johannes Brahms, Paul Hindemith, and Benjamin Britten.” MA thesis, University of Montana, 2001. 


\section{ADDITIONAL WORKS CONSULTED}

Cyrus Meher-Homji, "Noel Mewton-Wood," Grove Music Online. L. Macy, ed. [online]; available from http;//www.grovemusic.com; Internet: accessed 27 August 2005.

Hamburger, Michael, ed. Hölderlin Selected Verse. Dover, New Hampshire: Anvil Press Poetry Limited, 1961.

Hyde, H. Montgomery. The Love That Dared Not Speak Its Name: A Candid History of Homosexuality in Britain. Boston: Little, Brown and Company, 1970.

Jivani, Alkarim. It's Not Unusual: A History of Lesbian and Gay Britain in the Twentieth Century. Indianapolis: Indiana University Press, 1997.

Sieburth, Richard. Friedrich Hölderlin Hymns and Fragments. Princeton, New Jersey: Princeton University Press, 1984. 


\section{SCORES CONSULTED}

Britten, Benjamin. Folksong Arrangements, Volume 1: British Isles. New York: Boosey \& Hawkes, 1943.

. The Holy Sonnets of John Donne, opus 35. New York: Boosey \& Hawkes, 1946.

. Sechs Hölderin-Fragmente, opus 61. New York: Boosey \& Hawkes, 1962.

. Seven Sonnets of Michelangelo, opus 22. New York: Boosey \& Hawkes, 1943.

. Who Are These Children?, opus 84. London: Faber Music Ltd., 1972.

. Winter Words, opus 52. New York: Boosey \& Hawkes, 1954.

Larsen, Robert, ed. Arias for Tenor. New York: G. Schirmer, 1991.

Parisotti, Alessandro, ed. Italian Songs and Arias of the Seventeenth and Eighteenth Centuries. New York: G. Schirmer, 1926.

Purcell, Henry. 40 Songs for Voice and Piano. New York: International Music Company, 1958.

Schubert, Franz. 200 Songs in Three Volumes, Volume 1: 100 Songs. New York: International Music Company, 1961. 


\section{SELECTED DISCOGRAPHY}

Britten, Benjamin. Benjamin Britten. Contains Seven Sonnets of Michelangelo recorded in 1942, performed by Peter Pears and Benjamin Britten. Pavilion Records Ltd. GEMM CD 9177. Compact Disc.

- Benjamin Britten, Archive Series. Contains Seven Sonnets of Michelangelo recorded in 1941, performed by Peter Pears and Benjamin Britten. MNC Recordings Ltd. MNC D030, 1995. Compact Disc.

. Billy Budd. Contains The Holy Sonnets of John Donne recorded in 1967, performed by Peter Pears and Benjamin Britten. London 417 428-2, 1989. Compact Disc.

. Britten: The Performer, Volume 14. Contains Who Are These Children? recorded in 1971, performed by Peter Pears and Benjamin Britten. BBC Music BBCB 8014-2, 1999. Compact Disc.

. Britten Serenade. Contains Seven Sonnets of Michelangelo and Winter Words recorded in 1954, performed by Peter Pears and Benjamin Britten. London 425 996-2, 1992. Compact Disc.

. Owen Wingrave. Contains Sechs Hölderlin-Fragmente recorded in 1961, performed by Peter Pears and Benjamin Britten. London 433 200-2, 1993. Compact Disc. 


\section{Dr. Robert Strauss}

50 Penbrooke Drive

Penfield, New York 14526

(716) 909-9236

StraussRobert@msn.com

\section{Education}

Doctor of Musical Arts in Vocal Performance and Literature

May 2006

West Virginia University

Morgantown, West Virginia

Vocal Study: Peter Lightfoot, Robert Thieme

Private Vocal Study

2005-present

Carol Webber, Eastman School of Music

Oberlin in Italy

June 2003, 2004, 2005

Opera Apprentice Program

Centro Studi Italiani, Urbania, Italy

Vocal Study: Marlene Rosen (Oberlin), Ruth Golden (Academy of Vocal Arts)

Private Vocal Study

1996-2001

Carla LeFevre, University of North Carolina at Greensboro

Master of Music in Vocal Performance

December 1994

University of North Carolina at Greensboro

Greensboro, North Carolina

Vocal Study: Charles Lynam, Benton Hess

Bachelor of Music in Vocal Performance

State University of New York College at Fredonia

May 1992

Fredonia, New York

Vocal Study: David Evans

\section{Professional Experience}

Nazareth College - Pittsford, New York

2004 - present

Lecturer

Applied Voice

Opera Workshop, stage director

Private Vocal Studio - Penfield, New York

1990 - present 
Washington \& Jefferson College - Washington, Pennsylvania

March 2003 - May 2004 Instructor

Applied Voice

Radford University - Radford, Virginia

August 1998 - May 2001

Visiting Full-Time Instructor

Applied Voice

Assistant to Opera Workshop Director (1998-1999)

Conductor, Women's Choir (1998-1999)

Greensboro Music Academy - Greensboro, North Carolina

June 1997 - August 1999

Voice Lessons

Voice Classes

Director, Musical Theatre Workshop

Guilford College - Greensboro, North Carolina

January 1997 - May 1998

Lecturer

Applied Voice

\section{Professional Performances}

Recital, Genesee Community College - Batavia, New York

February 2006

Works by Britten, Caccini, Donaudy, Gluck, and Mozart

December 2005

Canandaigua Messiah Sing - Canandaigua, New York

Tenor soloist for Messiah

Coro San Carlo di Pesaro - Pesaro, Italy

June 2005

Tenor Soloist for Rossini's Messa di Gloria

Mohawk Valley Choral Society - Illion, New York

May 2005

Tenor Soloist for Mozart's Requiem

Recital, Trinity Episcopal Church - Buffalo, New York

April 2005

Italian Songs and Arias

Camerata di Sant'Antonio - Buffalo, New York

December 2004

Tenor Soloist for Albinoni Magnificat

Washington \& Jefferson Chorale - Washington, Pennsylvania

November 2003

Tenor Soloist for Buxtehude's Jesu, meine Freude

Blacksburg Master Chorale - Blacksburg, Virginia

April 2001

Tenor Soloist for Rossini's Petite messe solennelle 
Guest Artsist, Annual Rebecca Orr Memorial Concert - Blacksburg, Virginia Works by Strauss and Vaughan Williams

Guilford College Choir

Tenor Soloist for Bach's Christmas Oratorio, Part V

December 2000

Floyd Community Choir - Floyd, Virginia

December 2000

Tenor Soloists for Messiah

Kathryn G. Obenshain Concert Series - Christiansburg, Virginia

Works by Britten, Fauré, Quilter, and Schubert

Blacksburg Master Chorale

November 1999

Tenor Soloist for Mozart's Vesperae solennes de confessore

West Market Street United Methodist Church -Greensboro, North Carolina

December 1997

Tenor Soloist for Messiah

Greensboro Opera Company - Greensboro, North Carolina

Registrar in Madama Butterfly

November 1997

Greensboro Choral Society - Greensboro, North Carolina

April 1997

Tenor Soloist for Mozart's Requiem

Greensboro Choral Society

Tenor Soloists for Charpentier's Te Deum

February 1997

West Market Street United Methodist Church

December 1995

Evangelist in Schütz's The Christmas Story

Greensboro Choral Society

October 1995

Tenor Soloist for Handel's Ütrecht Te Deum

West Market Street United Methodist Church

February 1995

Tenor Soloist for Claussen's A New Creation

Chapel Hill Messiah Sing - Chapel Hill, North Carolina

December 1994

Tenor Soloist for Messiah

Greensboro Opera Company

November 1994

Slave in Die Zauberflöte

Elon Choral Singers - Elon, North Carolina

March 1993

Tenor Soloist for Saint-Saens's Christmas Oratorio 


\section{Faculty Performances}

Mozart Birthday Recital - Nazareth College

January 2006

Arias and Scenes from Le nozze di Figaro,

Don Giovanni, Die Entführung aus dem Serail

Opera Performances - Nazareth College

November 2005

Abbé in Benton Hess's Felice

Voice Faculty Recital - Nazareth College

January 2005

Britten Songs, Scenes from La traviata, L'elisir d'amore

Guest Artist, Faculty Recital - Radford University

April 2001

Britten Songs from the Chinese

Faculty Recital - Radford University

Robert Schumann Duets and Dichterliebe

February 2001

Faculty Recital - Radford University

Vaughan Williams Songs of Travel, Strauss Lieder, opus 10,

November 2000

Ravel Cinq mélodies poulaires grecques, Jean Berger Villanescas

Faculty Recital - Radford University

Britten Seven Sonnets of Michelangelo, Schubert Lieder,

February 2000

Fauré Mélodies, Quilter Songs

Opera Scenes Program featuring Greensboro Music Academy Voice Faculty

May 1999

Scene from La Bohème

Faculty Recital - Radford University

January 1999

Brahms Lieder, Britten Canticle II: Abraham and Isaac,

Duparc and Turina Songs, Arias from Eugene Onegin and The Rake's Progress

Music Department Recital - Guilford College

November 1997

Ravel's Cinq mélodies populaires grecques, aria from Manon

\section{Directing Experience}

Nazareth College

2004 - present

Felice (Benton Hess), stage director (2005)

Dido and Aeneas, stage director (2004-2005)

Trial by Jury, stage director (2004-2005) 
West Virginia University (scenes)

Carmen (Act III trio), stage director (2003)

Die Fledermaus (Act I, Introduction, Duet, and Trio), stage director (2003)

Fidelio (Jaquino/Marzelline duet), stage director (2003)

Die Entführung aus dem Serail (Act II), stage director (2003)

Die Zauberflöte (Pamina's suicide), stage director (2003)

Die Lustigen Weibern von Windsor (Act I finale), stage director (2001)

St. Paul Lutheran Church - Morgantown, West Virginia

2002

Godspell, stage / music director

Greensboro Music Academy (scenes)

Le Nozze di Figaro (Act II, opening to Count/Countess duet), stage/music director

Hansel and Gretel (Sandman scene/Evening Prayer), stage/music director

La Boheme (Act I, Rodolfo's aria to end of act), stage/music director

Radford University (scenes)

1999

Le Nozze di Figaro (Act II, opening to Susanna/Cherubino duet), stage director

Guilford College (scenes)

1998

Die Zauberflöte (Act I, Trio, Pamina/Papageno duet), stage/music director

Die Fledermaus (Act I, Adele/Rosalinda/Eisenstein trio), stage/music director

Dido and Aeneas (Dido's Lament), stage/music director

Guilford College - Greensboro, North Carolina

1998

The Fantasticks, music director

Randolph Summer Vacation Playhouse - Asheboro, North Carolina

1998

Oklahoma!, music director

Stained Glass Playhouse - Winston-Salem, North Carolina

1996-1997

Man of La Mancha, music director (1997)

Godspell, music director (1996)

Occasional Dinner Theater - Burlington, North Carolina

1996

It's a Wonderful Life-The Musical, music director

\section{Other Opera/musical Theatre Roles Performed}

West Virginia University

2001-2004

Baron Zeta, The Merry Widow (2004)

Prologue/Peter Quint, The Turn of the Screw (2004)

Count Belfiore, La finta giardiniera (2003)

Le Petit Vieille, L'Enfant et les sortileges (2002)

Jack Point, The Yeomen of the Guard (2002)

Nemorino, L'elisir d'amore (2002) 
Act II Theatre Company

Anthony Hope, Sweeney Todd, the Demon Barber of Fleet Street

West Virginia University Division of Music Gala

Man, Side by Side by Sondheim

University of North Carolina at Greensboro, Guest Artist

Mayor Upfold, Albert Herring

High Point Theatre

1996

Tony, West Side Story

University of North Carolina at Greensboro

1992-1994

Daniel Buchanan, Street Scene (1995)

Don Ottavio, Don Giovanni (1994)

Gherardo, Gianni Schicchi (1993)

Rinuccio (cover), Gianni Schicchi (1993)

Sage, Hin und Zurück (Hindemith) (1992)

Fredonia Opera Theatre

1989-1992

Magician, The Consul (1992)

Lover, Amelia Goes to the Ball (1992)

Tamino, Die Zauberflöte (1991)

Alfred, Die Fledermaus (1990)

Parpignol, La Bohème (1989)

\title{
Professional Associations
}

National Association of Teachers of Singing Member

1997 - present

Virginia Chapter Board of Directors (2000-2001)

College Music Society

2000 - present

\author{
Member
}

